
ir in

lic $<1$.

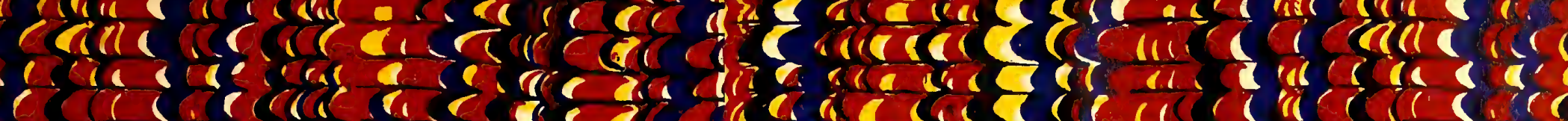

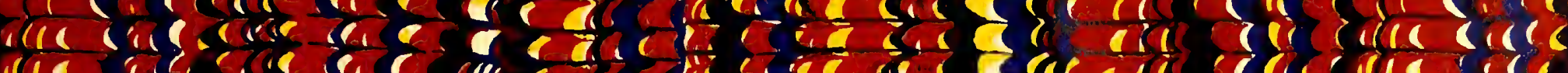

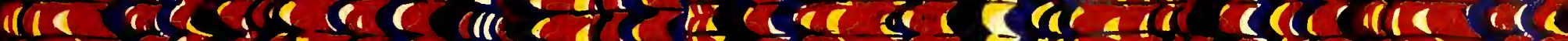

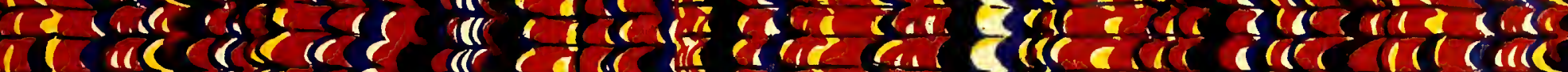

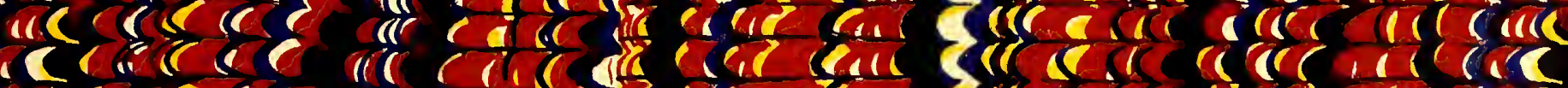

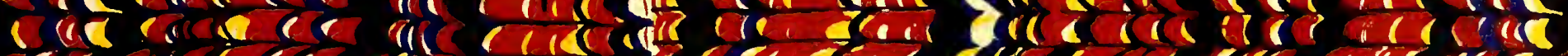

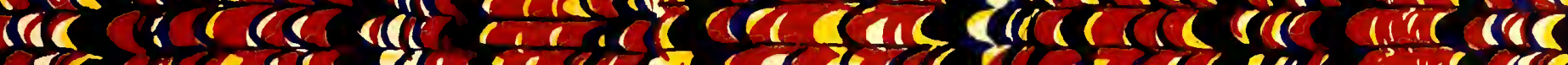

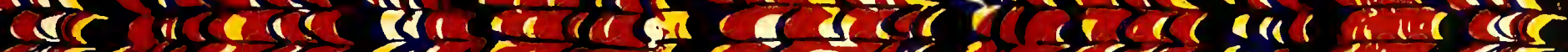

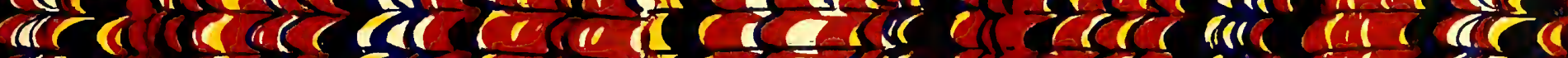

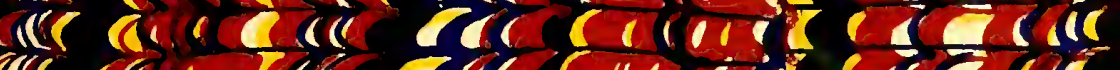

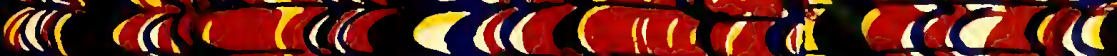

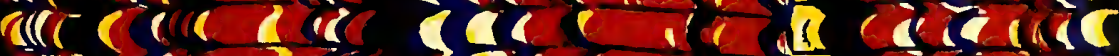

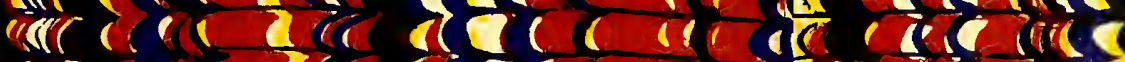

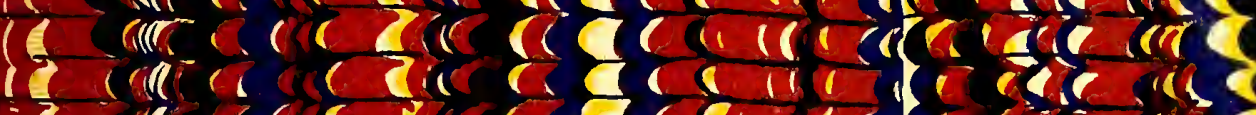

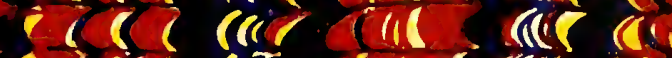
clic

ie rescer

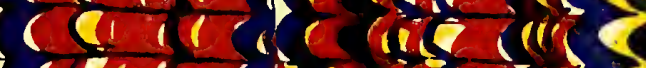

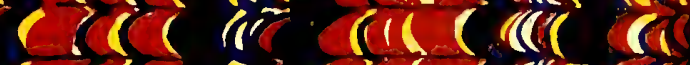

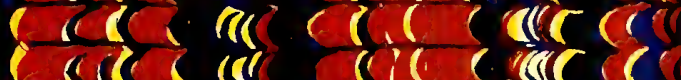

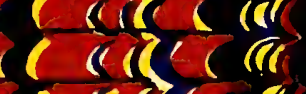
(c)

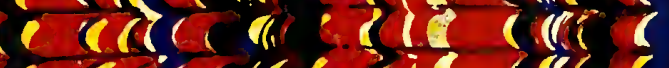

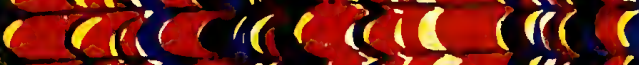

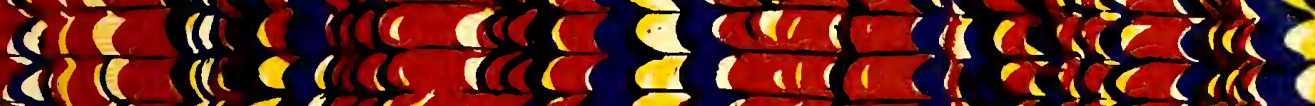
mel

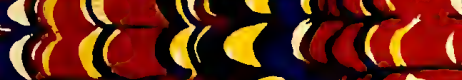

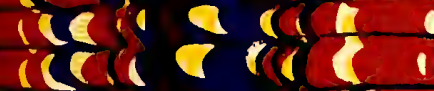

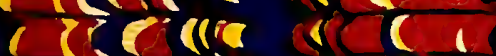

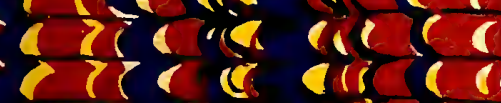
c)

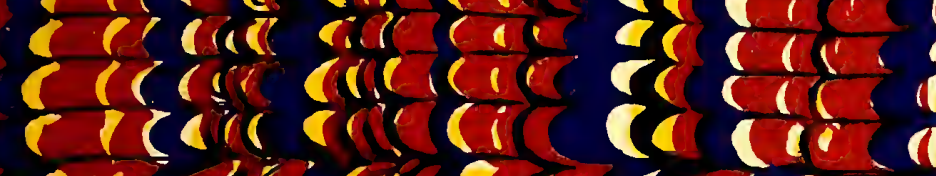

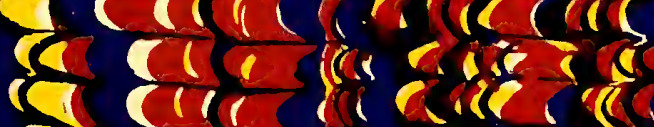

$\operatorname{sic} x)$ $c(1$

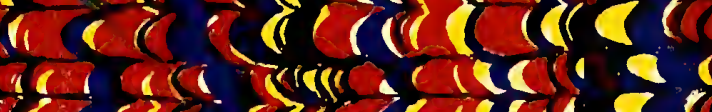
s)

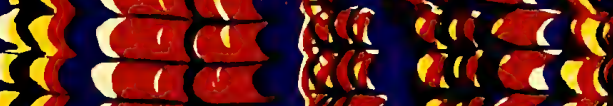
$\sec \left\{\begin{array}{l}1 \\ 1\end{array}\right.$ this eres $\sec (2)<\cos$

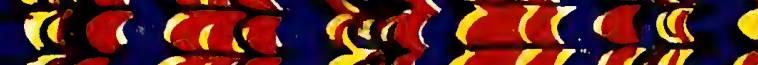

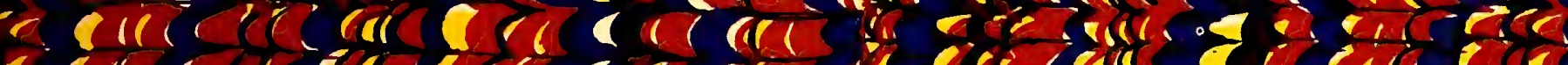
$\int C_{1} C$

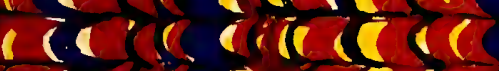
eir cere.

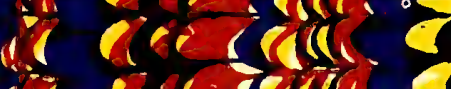
$r$

$140.8 \cos 2$

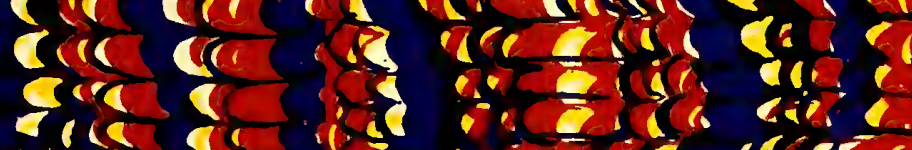
$\cos \theta \cos$ $\operatorname{lic}(\mathrm{c})$ $\operatorname{sic}<द<(\pi)$

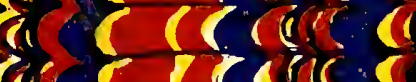

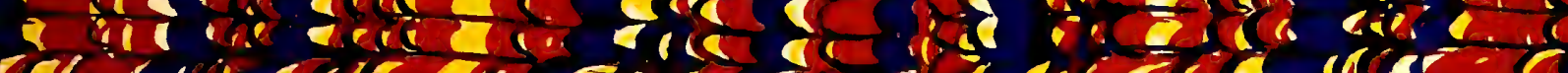

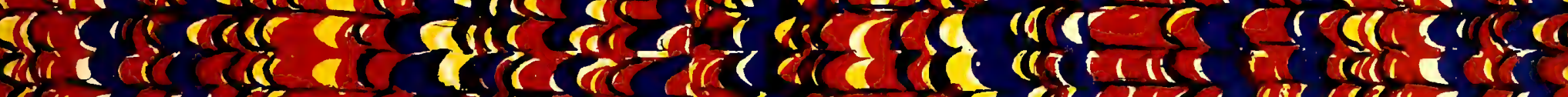

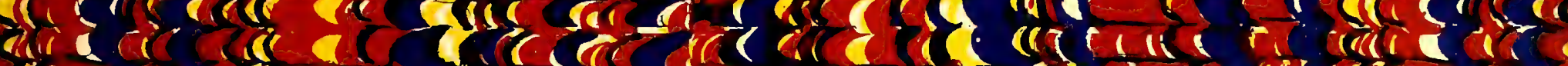

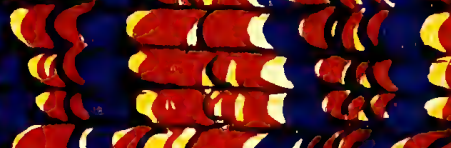

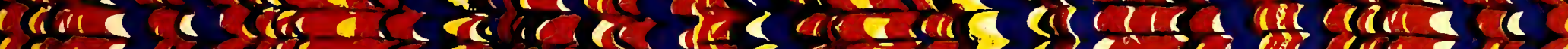
rene

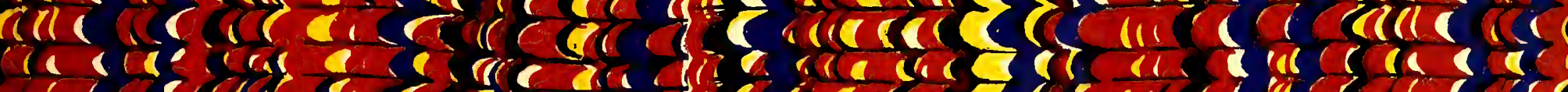

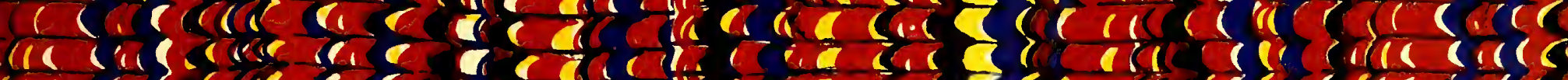

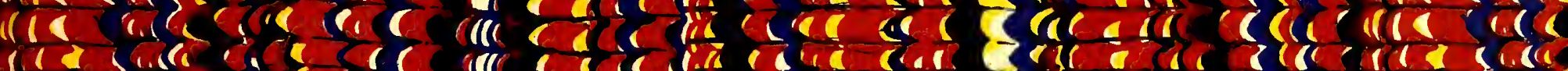

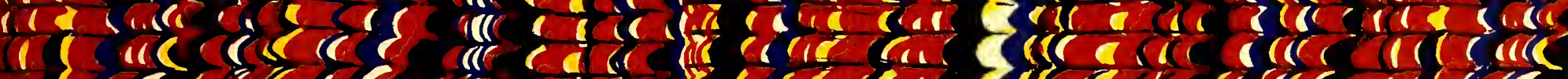

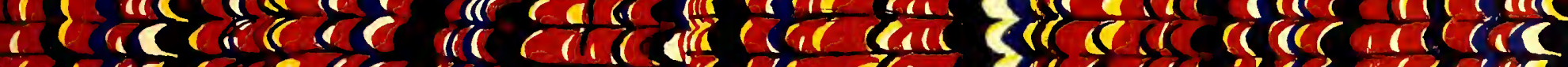

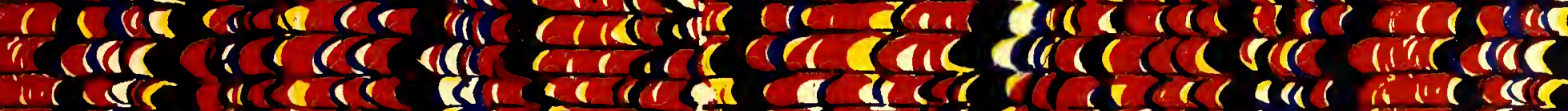

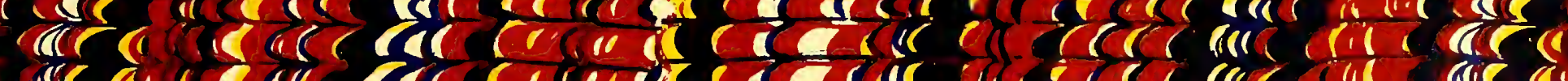

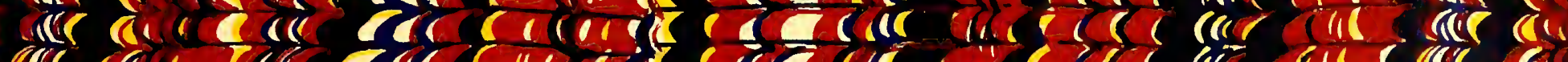

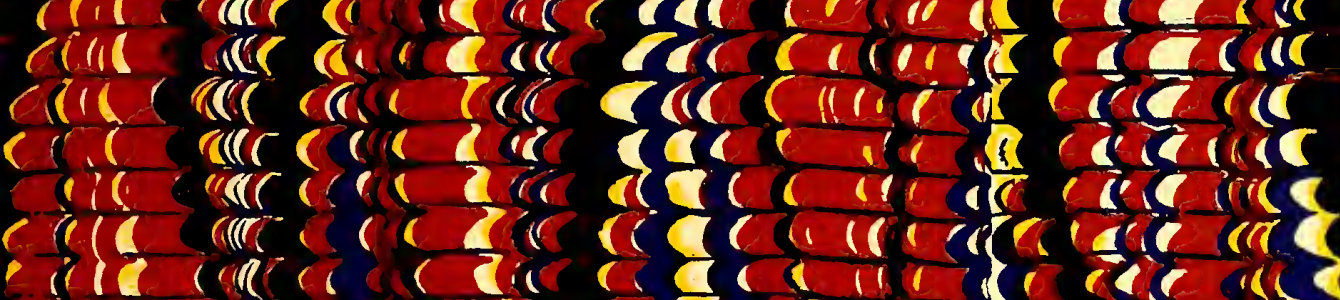

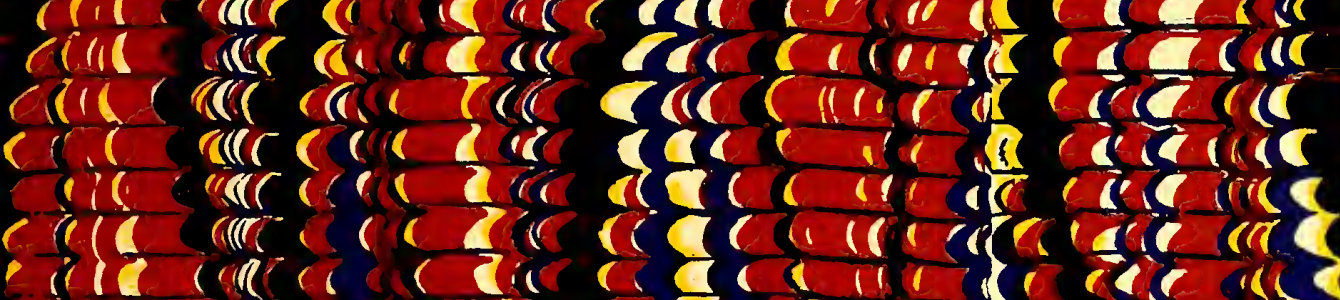

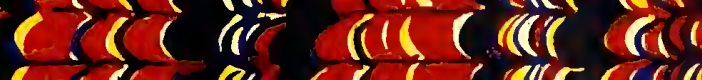

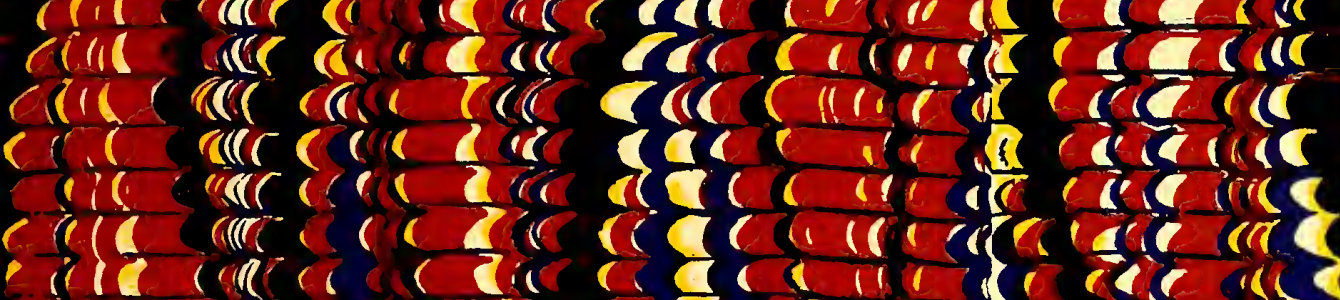

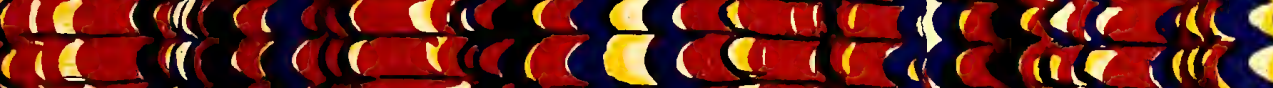

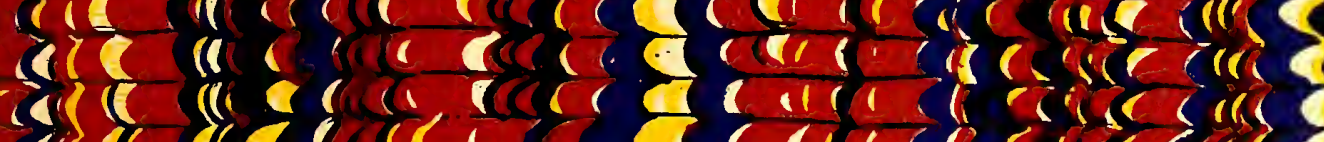

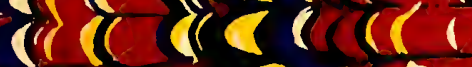

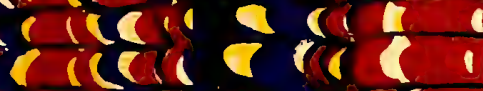

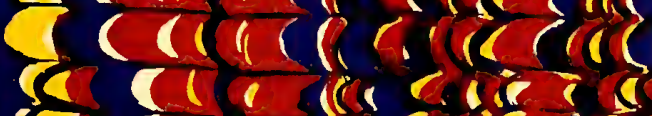

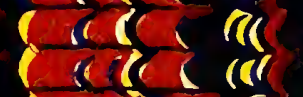

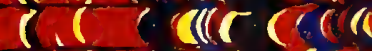

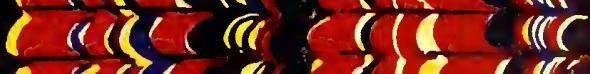

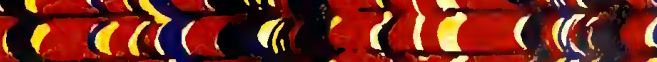

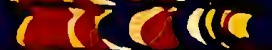

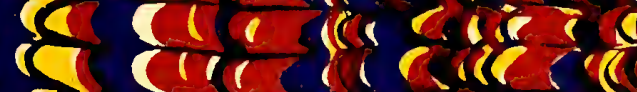

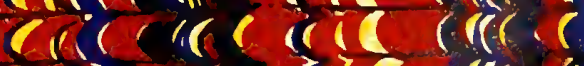

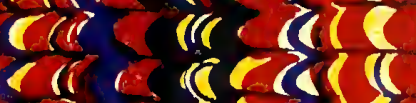
(c)

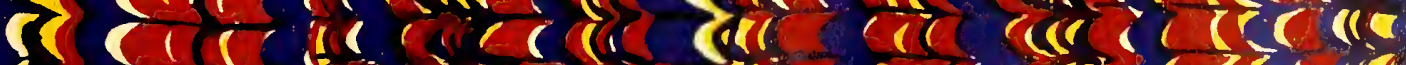


Cons oncest 



SMITHSONIAN CONTRIBUTIONS TO KNOWLEDGE VOLUME 35, NUMBER 3

\title{
A CONTRIBUTION TO THE COMPARATIVE HISTOLOGY OF THE FEMUR
}

\author{
BY \\ J. S. FOOTE, M. D. \\ Professor of Pathology, Creighton Medical College, Omaha, Nebraska
}

EDITED BY ALEŠ HRDLIČKA
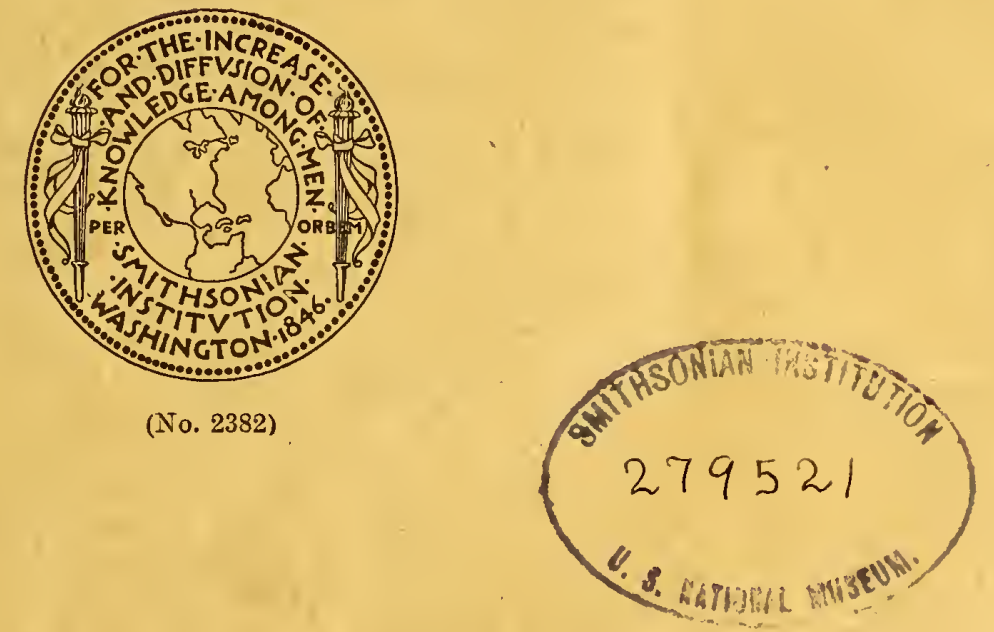

CITY OF WASHINGTON

PUBLISHED BY THE SMITHSONIAN INSTITUTION 



\title{
A CONTRIBUTION TO THE COMPARATIVE HISTOLOGY OF THE FEMUR
}

\author{
BY \\ J. S. FOOTE, M. D. \\ Professor of Pathology, Creighton Medical College, Omaha, Nebraska \\ EDITED BY ALEŠ HRDLIČKA
}

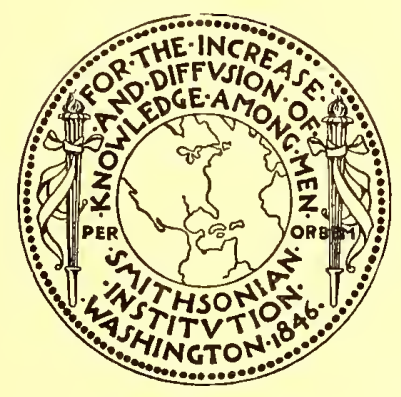

(No. 2382)

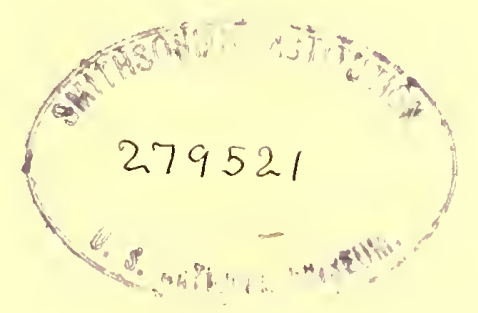

CITY OF WASHINGTON

PUBLISHED BY THE SMITHSONIAN INSTITUTION

1916 
Commission to whom this memoir has been referred:

Aleš Hrduličía

Frank Baker

George Arthur Piersol

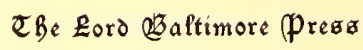
BALTISURE, MD., U. S. A. 


\section{ADVERTISEMENT}

The present memoir by J. S. Foote, M. D., Professor of Pathology at Creighton Medical College, entitled "A Contribution to the Comparative Histology of the Femur," records original observations begun by the author in 1909 in a study of cross-sections of the femora of about six hundred different animals, including amphibians, reptiles, birds, mammals, and man, with a view to determine what variations of bone structure may exist and their signification.

In accordance with the rule adopted by the Smithsonian Institution, the work has been submitted for examination to a commission consisting of Dr. Aleš Hrdlička, of the United States National Museum; Dr. Frank Baker, of the National Zoological Park; and Dr. George Arthur Piersol, of the University of Pennsylvania, who recommended its publication in the present series.

The work is published in cooperation with the Creighton University, Omaha, Nebraska.

Charles D. Walcott, Secretary.

Smithsonian Institution, Washington, December, 1915. 



\section{CON'TENTS}

ii

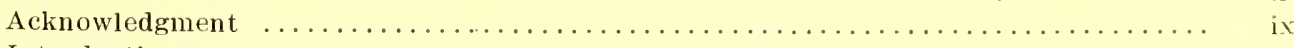

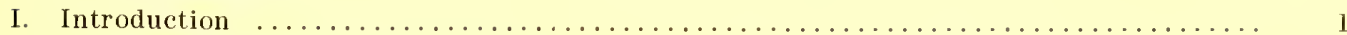

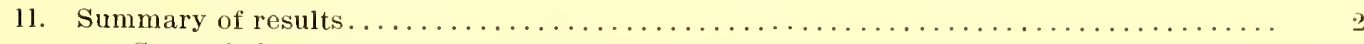

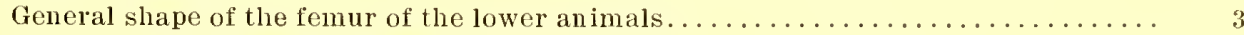

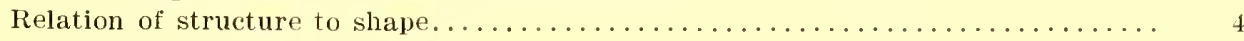

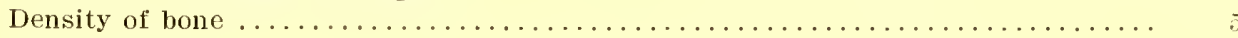

Measurements .....................................

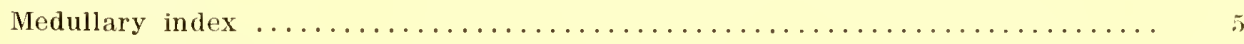

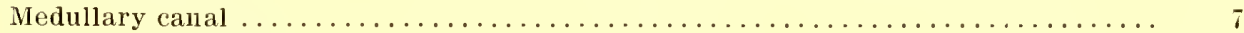

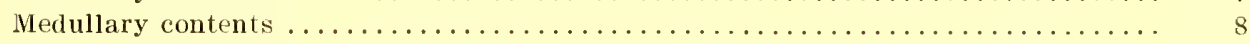

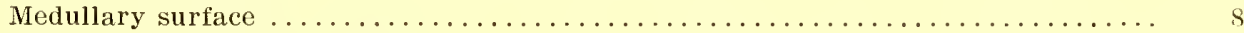

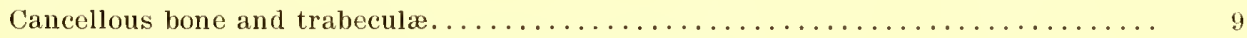

Variety of minute structure of the wall of the fem $u r \ldots \ldots \ldots \ldots \ldots \ldots \ldots \ldots \ldots \ldots \ldots$

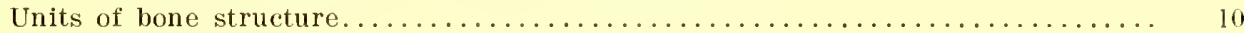

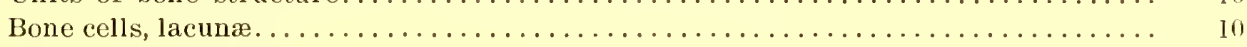

Dendrites, canaliculi .................................. 10

Differentiated bone units-lamella........................ 10

Uniformly lamellated bone structure....................... 11

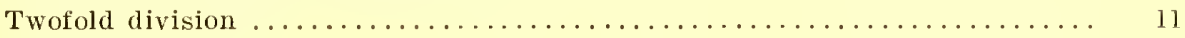

Threefold division $\ldots \ldots \ldots \ldots \ldots \ldots \ldots \ldots \ldots \ldots \ldots \ldots \ldots \ldots \ldots \ldots \ldots \ldots \ldots$

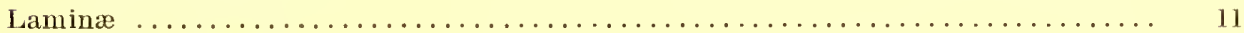

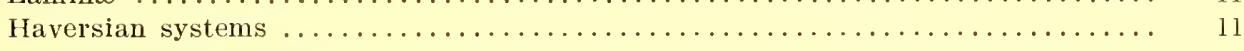

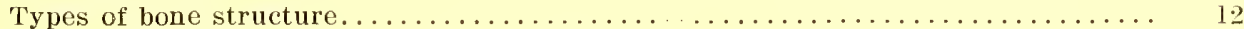

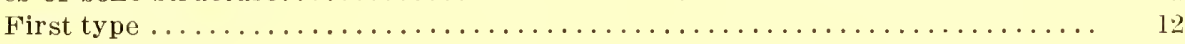

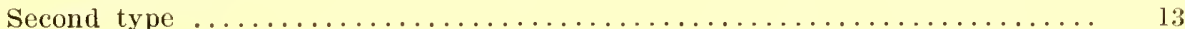

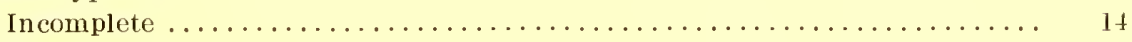

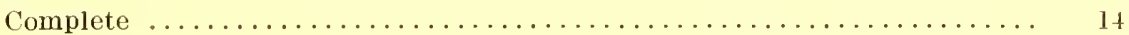

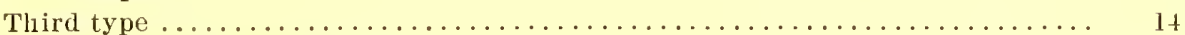

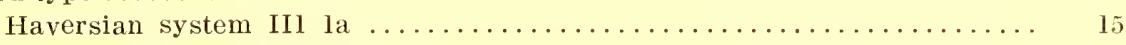

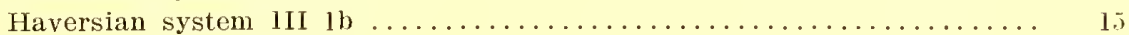

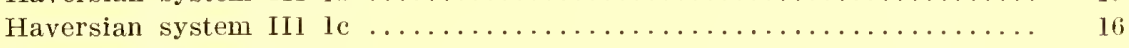

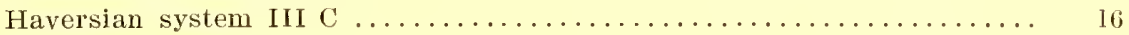

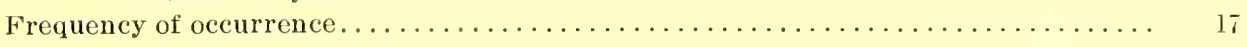

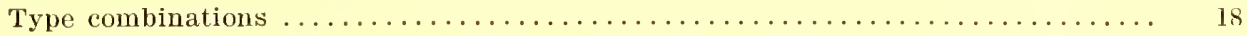

Type of bone structure according to classes of animals.............. 18

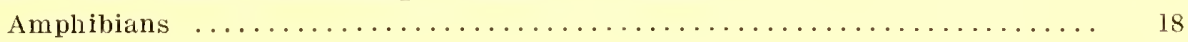

leptiles $\ldots \ldots \ldots \ldots \ldots \ldots \ldots \ldots \ldots \ldots \ldots \ldots \ldots \ldots \ldots \ldots \ldots \ldots \ldots \ldots \ldots \ldots$

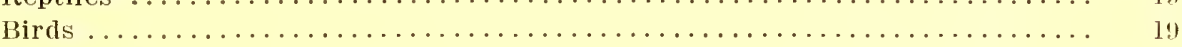

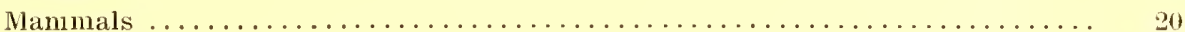

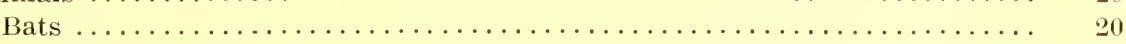

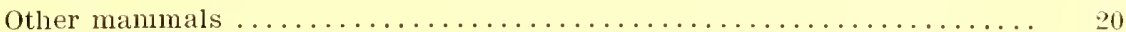

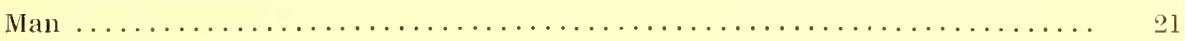

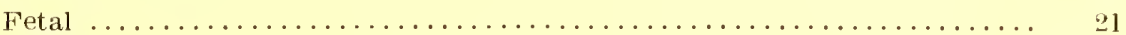

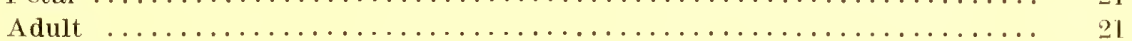

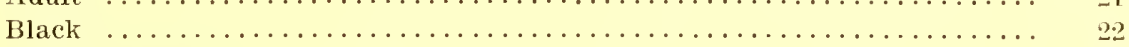

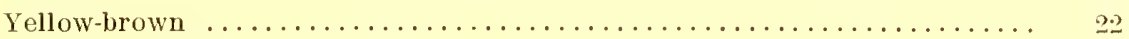

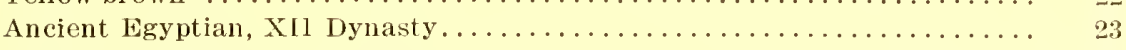

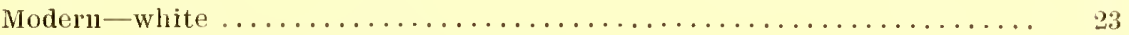

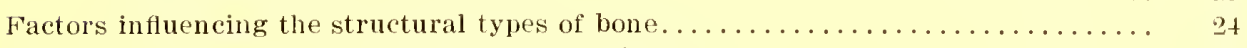

1. Grade of aninal in biological classification.................. 24

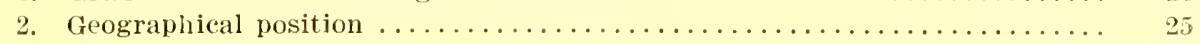

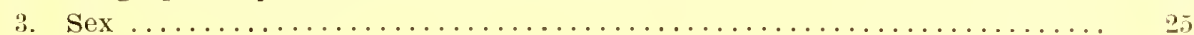

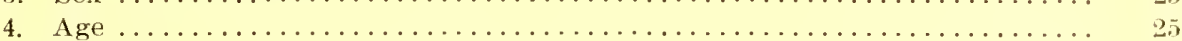

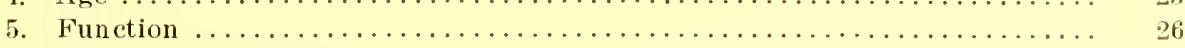

6. Individual variations . . . . . . . . . . . . . . . . . . . . .

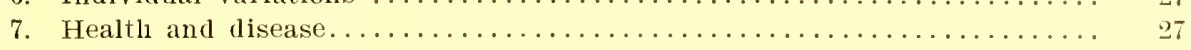

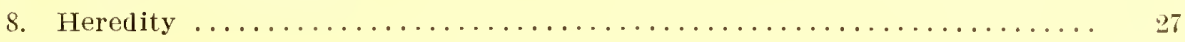

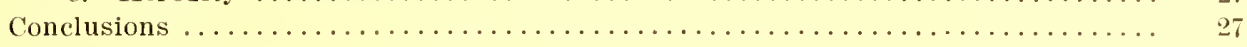


IV. Histological examination of two entire human femora-general description . . . . . . . 32

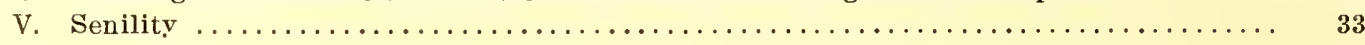

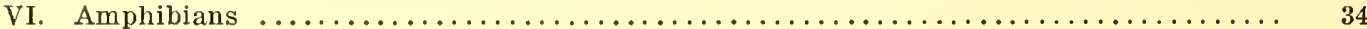

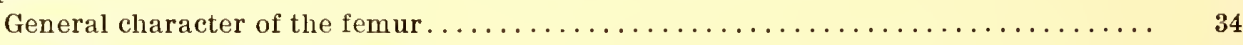

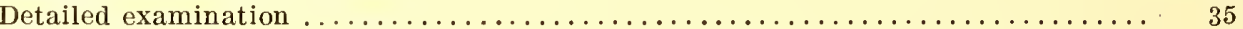

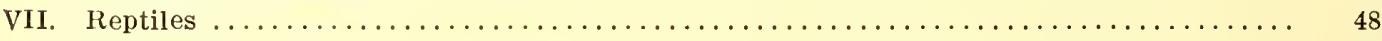

General character of the femur........................... 48

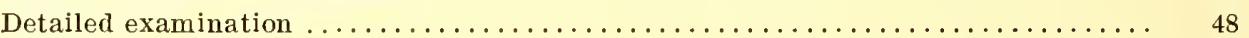

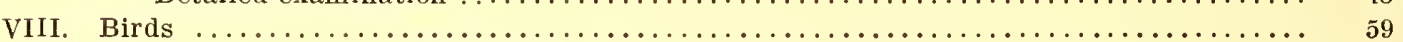

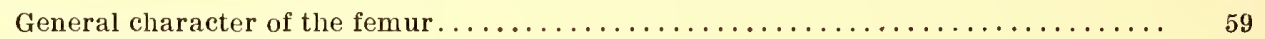

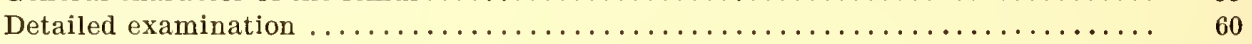

IX. Mammals-bats ............................................ 75

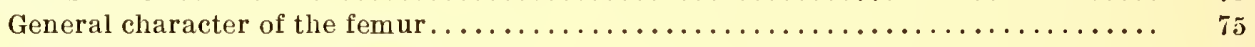

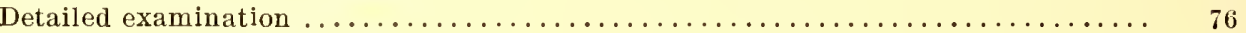

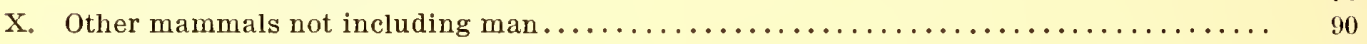

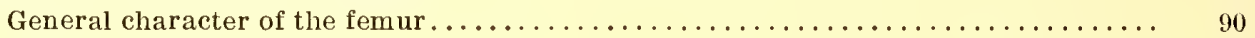

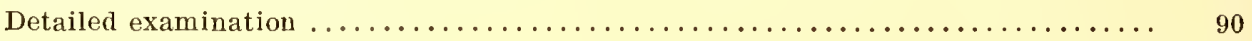

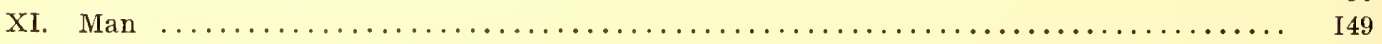

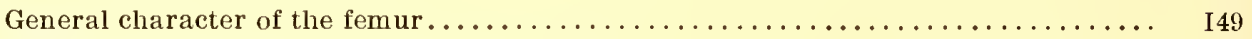

Detailed examination of fetal liuman femora..................... 149

XII. Man-black race ............................................ 153

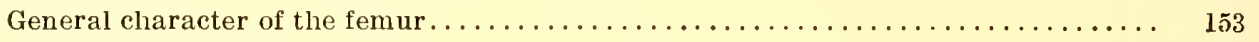

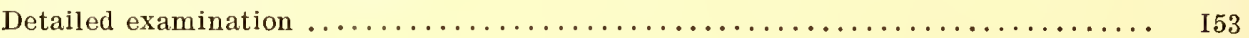

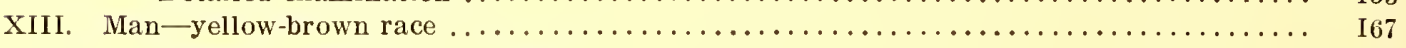

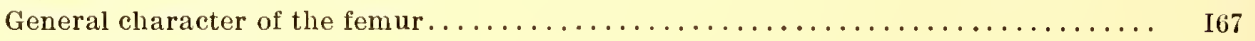

Detailed examination .............................. I67

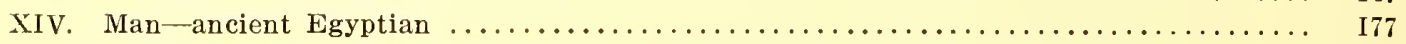

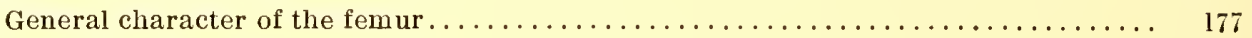

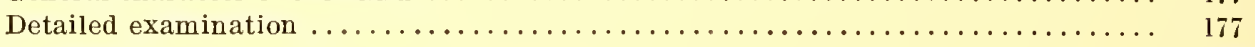

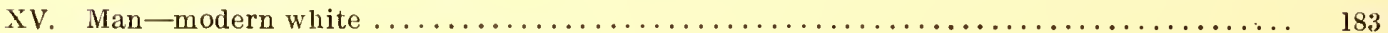

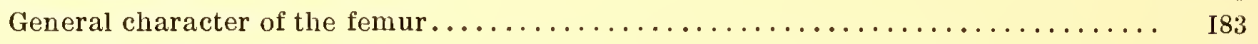

Detailed examination . . . . . . . . . . . . . . 183

XVI. Histological examination of two entire human femora-detailed description.......... 2I3

SYNOPTIC TABLES

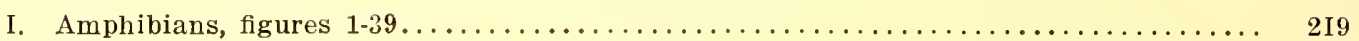

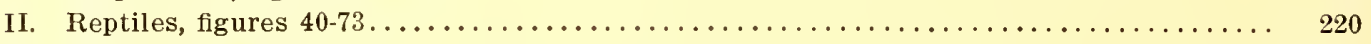

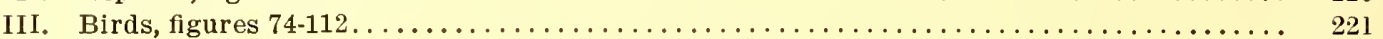

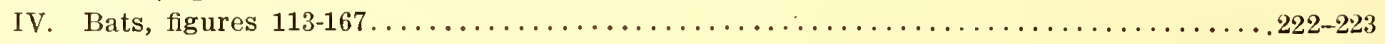

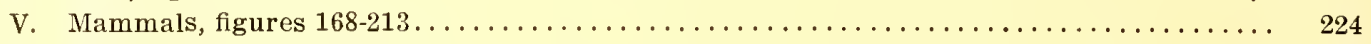

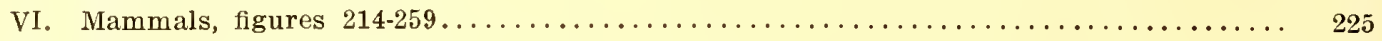

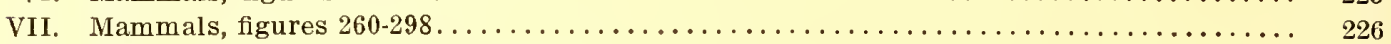

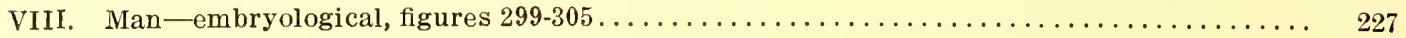

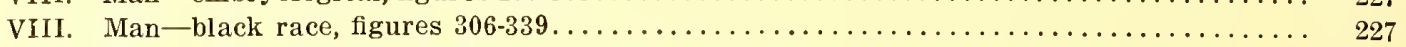

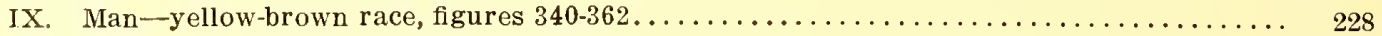

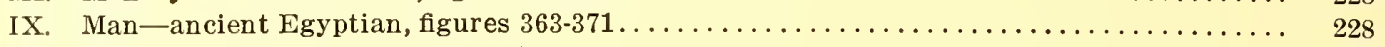

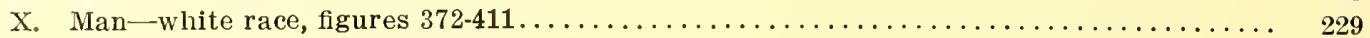

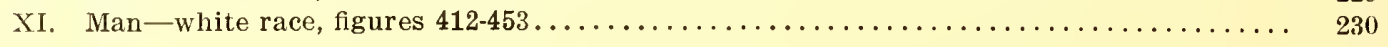

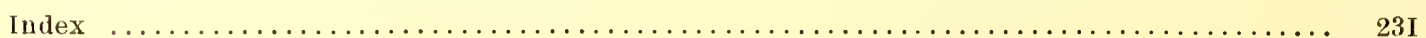




\section{ILLUSTRATIONS}

\section{PLATES}

A. Three stages in the differentiation of lacunæ.

Basic bone substance and differentiated first type bone.

Differentiations of second type bone.

Incomplete and complete differentiations of the third type bone.

The three types of bone.

B. Cross and longitudinal sections of bone types and the reconstruction of bone types and combinations.

C. Type combinations.

1. Femora of amphibians and a repaired femur.

2. Femora of amphibians.

3. Femora of amphibians and reptiles.

4. Femora of reptiles.

$5-7$. Femora of birds.

8. Femora of fifty genera of bats.

9-20. Femora of mammals.

21. Femora of man-embryological.

22-24. Femora of man-negro.

25. Femora of Pueblo Indian.

26. Femora of Chicama and Pachacamac Indians.

27. Femora of Chicama and Egyptian.

28. Femora of Egyptian.

29-33. Femora of white race.

34. Femora of white race and senile Haversian systems.

35. Femora of white race.

35. Femur of a male white-idiopathic epileptic. 



\section{ACKNOWLEDGMEN'T}

This work has been largely of a pioneer' nature. The zoological classification of animals has furnished the principal guide in the selection of bones and in the general plan of study. Beginning with the amphibians and closing with man, one femur after another has been examined until sufficient data have been accumulated to establish, to a reasonable degree, definite bone types and type combinations which were then employed as a structural basis for comparative study.

In an investigation of this character, covering a period of more than five years and involving many details, it will not be surprising if imperfections are found; but all possible effort was made to eliminate those that could be detected.

The study has brought to light a number of important new facts. Among other conclusions the author finds that three types of minute structure form the basis of all bones. The first and second types predominate in amphibians, reptiles, and birds, the third in mammals and man. The first type, composed of lanella, appears as a uniform structure or in a twofold or threefold division, and characterizes the amphibians, lizards, and bats. The second type (laminar) appears first in the amphibians and in an early or late form of differentiation in birds and lower mammals. The third type (Haversian system) is first ontlined in the amphibians and reaches its highest development in the higher manmals and especially in man.

For valuable material, facilities for sturly and courtesies extended, the writer is especially indebted to the Division of Physical Anthropology of the United States National Museum, to the Divisions of Mammals and Reptiles of the same institution, to the Departments of Reptiles, Birds, and Mammals of the American Musem of Natural History, to the Nebraska State Hospital, and to the Departments of Anatomy of the Northwestern, the Tulane, the Nebraska, and Creighton Universities.

Furthermore, he desires to express his deep sense of obligation to those who have assisted him: to Dr. Aleš Hrdlička for his encomraging interest and most valuable suggestions in the pursuance of the study, without his clearinghouse advice the tedions details would have fallen into a nseless mass; to Creighton University for apparatus and material assistance in the publication of this report; to Professor William F'. Rigge for the calculation of the medullary indices; and to the many sturlents and lormels who have rentered assistance in every possible manmer.

J. S. FoOTE. 



\title{
A CONTRIBUTION TO THE COMPARATIVE HISTOLOGY OF THE FEMUR
}

\author{
BY J. S. FOOTE, M. D.
}

\section{INTRODUCTION}

The investigations in the Comparative Histology of the Femur were begun by the writer in 1909, and were suggested by a section of the turkey's femur which he had casually prepared and which seemed to show a type of bone structure quite unlike that usually described. Before long, other peculiarities were noticed and it was then decided to extend the study to various animals for the purpose of determining what variations of bone structure may exist, and, if possible, what is their significance. Accordingly, the femora of 46 different animals, including amphibians, reptiles, birds, mammals, and man, were examined as they could be obtained and described, the report being published in the Transactions of the American Miscroscopical Society of April, 1911. The number of femora examined up to that time was small, nevertheless the results of the work were so new and interesting as to warrant further study.

Following the report and upon the suggestion of Dr. Aleš Hrdlička, curator of the Division of Physical Anthropology in the United States National Museum, the writer extended his investigations to a much greater number of orders, genera, and species of the lower animals, and finally also to the three main races of man-black, yellow-brown, and white-the latter including the ancient Egyptian. An abstract of the results of the advanced investigations was published in 1913 by the Smithsonian Institution." The studies, however, were still continued as long as material was available and finally have been combined in this memoir which presents a comprehensive view of the whole work thus far accomplished. In all, 600 sections have been examined; of these 440 are described.

The present report includes, besides the text, 467 drawings. They were made, for the most part, directly from the slides with the help of the Edinger Drawing Apparatus, and are illustrations of the structural bone units, of the types and combinations of bone types in their various stages of differentiation,

${ }^{1}$ Foote, J. S. The comparative histology of femoral bones. Trans. Amer. Micros. Soc., 30. 1911, pp. 87-140, 9 plates.

${ }^{2}$ Foote, J, S. The comparative histology of the femur. Smithsonian Miscellaneous Collections, Vol. 61, No. 8 (Publication 2232), Washington, 1913, pp. 1-9, 3 plates. 
and of the arrangements of types as they would appear in reconstructed femora. The exact number of listologic bone units of any section does not, and obviously could not, appear in the drawings. 'The writer's endeavor has been to represent, in a comprehensive way, the development, proportions, and arrangements of these units, rather than their exact number.

It was also found impracticable to make the drawings of the various bone sections to a definite, uniform scale, the femora ranging from $0.5 \mathrm{~mm}$. to $13 \mathrm{~cm}$. in diameter. Microphotographs were essayed, but were found unsatisfactory.

The various diameters of the examined femora, their medullary canals, and medullary indices are given in the synoptic tables and also in the text at the beginning of each detailed description. The sections and measurements were made invariably at the middle of the shaft of the bone.

The femur was selected for these studies rather than any other bone of the body, because it is of good size, because it is in fairly constant use, and on account of its being the sole bone of an important segment of the body. It is, in other words, a good representative bone and perhaps the best adapted to the investigations of this nature.

The illustrations have, generally, been grouped according to the structural relations of the bones.

The type or combination of types of structure which any bone was observed to present will be found noted in the tables, so that by a glance at these there may be readily obtained a comprehensive view of the grouping of the femora of the various animals.

The femora examined and included in this report are those of amphibians, reptiles, birds, mammals, and man. Fetal, young, adolescent, adult, and senile femora of the same species were examined whenever possible, and, when circumstances allowed, observations were also made on other bones of the borly. All sections were carefully ground to proper thinness and mounted in hard balsam.

\section{SUMMARY OF RESULTS}

As the mass of detailed observations which follow will be consulted in special instances only, it may be convenient to the reader to have a general summary of the principal results of the stndy presented at this place instead of at the end of the work.

The microscopic structure of a long bone deseribed by the early histologists happened to be that of a third or Haversian system type, and it has been assuned, perhaps without a more definite reason, that all long bones have the sane structure. From an examination of a large number of femora it is evident that they have not.

If there is any one distinctive characteristic of bone structure shown by the present investigation, it is that of extensive variation, variation due to heredity, 
to age, size and strength of the bone, and possibly to other conditions. It is certainly safe to say that few long bones, and particularly femora, have preeisely the same structure, and yet, through all their diversity, there can be perceived certain definite, readily recognizable strains, which are found not only peculiar to separate groups of animals, but also to definite stages of differentiation.

The summary which follows will be treated under the following headings:

General shape.

Relation of structure to shape.

Density of bone.

Measurements.

Medullary index.

Mednllary canal.

Medullary contents.

Medullary surface.

Cancellous bone and trabeculæ.

Variety of minute structure of the wall of the femur.

Units of bone strueture.

Bone cells-lacunæ.

Dendrites and canaliculi.

Differentiated bone units-Lamella.

Uniformly lamellated bone.

T'wofold division.

Threefold division.

laminæ.

Haversian system.

Types of bone structure.

Frequency of the oceurrence of types.

Type combinations.

Type of bone structure accorling to classes of amimals.

The factors influencing types of bone structure as could be determined from the grade of the animal.

Geographic position.

Sex, age, function, individuality, health and disease, heredity.

Senility.

General Shape of the Femora of the Lower Anmalas

By the shape of the femur is understool the shape of the cross-section of the bone at its middle. That this shape of the shaft of the femur varied con- 
siderably in man was long since shown by Hrdlička. ${ }^{1}$ The present studies demonstrate that it differs also in animals. In general it is represented by the same geometrical types as in man, being triangular, elliptical, round, quadrangular, and plano-convex. Also, as in man, besides the femora which are fairly true to a type, there are other's which are irregular or indeterminate in shape and do not admit of any definite classification.

Generally speaking, however, there was one particular shape which was more prominent than any other, and that was the elliptical. This was found to be true of the majority of adults among amphibians, reptiles, birds, bats, and other manmals, and, therefore, was the most common shape of femur below man as far as these examinations were concerned. The differences in the lengths of the two main diameter's were usually small, the lateral diameter being generally the longest; in only a few specimens-as in the femur of the seal-were the lateral diameters greatly in excess of the antero-posterior. The femora of the Hyla cinerea, Erinaceus europeus, Tatu novemcinctus, Castor canadensis, and Rhinoceros bicornis had very long posterior, lateral, curved or straight ridges and differed very materially from other femora. The variations from the circular and elliptical shapes were in a measure dependent upon the development of the linea aspera. In some femora this was absent; in others it was fairly well developed; and in still other's its development was extreme. In the table which follows will be found the various shapes of the femora of the lower animals expressed in percentages:

SHAPE OF THE SHAFT OF THE LOWER ANIMAL FEMUR AT THE MIDDLE

\begin{tabular}{|c|c|c|c|c|c|c|c|}
\hline & $\begin{array}{l}\text { No. of } \\
\text { femora } \\
\text { examined }\end{array}$ & $\begin{array}{c}\text { I } \\
\text { Triangular } \\
\text { Per cent }\end{array}$ & $\begin{array}{c}\text { II } \\
\text { Elliptical } \\
\text { Per cent }\end{array}$ & $\begin{array}{c}\text { III } \\
\text { Round } \\
\text { Per cent }\end{array}$ & $\begin{array}{c}\text { IV } \\
\text { Quad. } \\
\text { rangular } \\
\text { Per cent }\end{array}$ & $\begin{array}{c}\mathrm{V} \\
\text { Indeter. } \\
\text { minate } \\
\text { Per cent }\end{array}$ & $\begin{array}{c}\text { VI } \\
\text { Plano- } \\
\text { Convex } \\
\text { Per cent }\end{array}$ \\
\hline 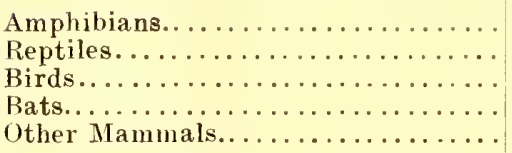 & $\begin{array}{r}39 \\
34 \\
40 \\
55 \\
133\end{array}$ & $\begin{array}{r}26 \\
29 \\
12 \\
0 \\
21\end{array}$ & $\begin{array}{l}41 \\
53 \\
52 \\
72 \\
53\end{array}$ & $\begin{array}{r}28 \\
9 \\
18 \\
25 \\
15\end{array}$ & $\begin{array}{l}0 \\
3 \\
3 \\
0 \\
0\end{array}$ & $\begin{array}{l}5 \\
0 \\
0 \\
0 \\
5\end{array}$ & $\begin{array}{r}0 \\
6 \\
15 \\
3 \\
6\end{array}$ \\
\hline 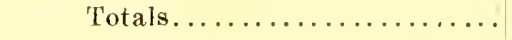 & $30 l$ & 17 & 50 & 25 & 0.7 & 3 & 5 \\
\hline
\end{tabular}

\section{Relation of Structure to Shape}

As far as present investigations are concerned, no special relation of the histologic structure of the femur to the shape of its shaft has been determined. The prolonged posterior ridge of the triangular sections is due to the linea aspera, and wherever the latter is well developed macroscopically it is composed of Haversian systems regardless of the type of the rest of the bone.

As will be seen later, the linea aspera seems to have a development quite distinct from the rest of the femur.

\footnotetext{
${ }^{1}$ See in this connection, Hrdlička, A.--Typical forms of shaft of long bones. Proc. Amer. Assoc. Anatomists, 14th Sess., 1900 (Washington, 1901), pp. 55-69.
} 


\section{Density of Bone}

This quality of bone was estimated by its weight and the subjective feeling experienced during the process of grinding, and was found to be far from uniform. Hardly any two bones were the same in this respect. Some were heavy and others were light; some were hard and others were soft. In some, one portion of the wall was hard and another was soft, and in still others there were soft and hard spots. The femur of the hippopotamus was extremely heavy and exhibited a stone-like quality in grinding, while that of the peahen, tnrkeybuzzard, or eagle was light and had a flint-like character. Many mammalian and human femora were found to vary greatly in the densities of the different portions of their wall. The outer was soft and the inner hard, or vice versa. This was noticed more especially in human femora. Many liuman bones also had small areas of unequal hardness which were sometimes accounted for by senile changes. Finally, sections of some femora-as those of the elk-seemed to show an extremely brittle character.

In some cases these inequalities could be explained by histological variations; while in others the chemical character of the inorganic compound seemer to govern the hardness. As a rule, first and second type bones (lamellar and laminar) ground more easily than third (Haversian system), as might be expected. But the femur of the peahen had flinty hardness and yet showed an incomplete second type of structure. This could only be explained by some peculiarity of its inorganic composition.

\section{Measurements}

The following measurements of each cross-section were taken: the anteroposterior and lateral diameters of the bone and the same diameters of the merlullary canal. All measurements were recorded in millimeters. The results will be found in the synoptic tables and also at the begimning of each detailed description. The measurements will give a correct impression of the relative diameters of the shafts of the various femora, and upon them are based the calculated ratios of the medullary canals to their respective bones.

\section{Medullary Index}

The ratio of the square of the mean diameter of the medullary canal to that of the surrounding bone, as determined from cross-sections of the middle portions of the various femora, is referred to as the medullary index. It has been calculated from the formula below. 'The individnal indices will be found

$$
\left(\frac{\left(\frac{a+b}{2}\right)^{2} \times 100}{\left(\frac{A+B}{2}\right)^{2}-\left(\frac{a+b}{2}\right)^{2}}\right)=R .
$$

$a$ and $b$ are the long and short diameters of the medullary canal respectively. $A$ and $B$ are the long and short diameters of the bone respectively. $R$ is the ratio of the medullary canal to the bone.

The calculations were made by William F. Rigge, S. J., Professor of Astronomy, Creighton University, Omaha, Nebraska. 
in percentages in the synoptic tables and text. By an examination of these indices it will be seen that the medullary canals of the various femora do not bear a constant relation to the bones, but present very important variations. In some bones the canals are relatively large and in other's they are relatively small. The larger the canal in a given species the thimner the wall of bone, and vice versa. There are also some individual variations within each species, and quite noticeable differences in this respect between the young, adult, and senile bones.

The averages given below show that the medullary indices of the different classes of animals and even in man vary considerably:

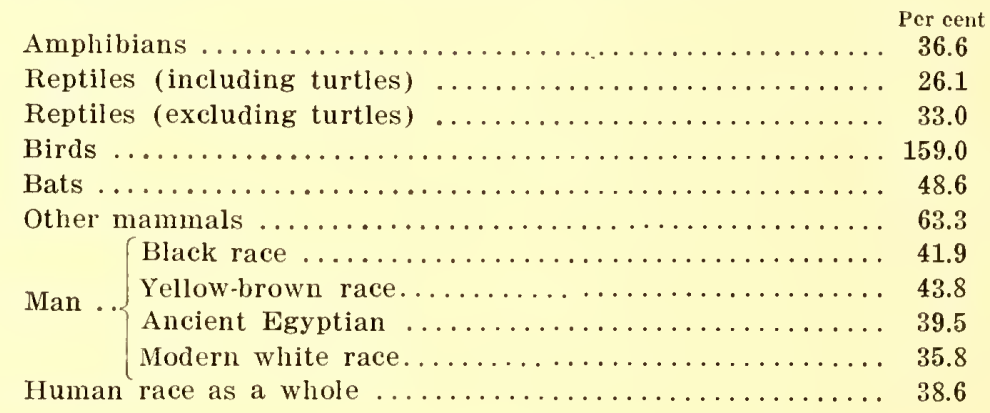

Looking over the above averages it will be noticed:

First.-That the lowest index is foumd in the reptiles where it is $26.1 \%$. The average index of the class of reptiles is lowered by the turtles, in most of which the index is zero. In the turtle femora the medullary canals are occupied by heavy cancellous bone with very small meshes filled with marrow. Observed with the naked eye these bones appear to be solid. If the turtles are exchuted the average reptile index is $33 \%$ instead of $26.1 \%$. As far as the medulary canals are concerned, both in regard to their contents and indices, those of the turtles do not resemble those of other reptilian genera in any respect. Comparing the indices of the amphibians with those of the reptiles, it will be seen that the index falls quite sharply or that the medullary canal diminishes and the mass of bone increases markedly from amphibian to reptile.

The highest average index is found in birds, where it is $159 \%$. From this it will be seen that the medullary canal increases relatively in size and the bone decreases in mass enormously from reptile to bird. In proportion to their weight, the birds have less bone than amphibians or reptiles. The index is higher in those birds which have empty medullary canals $(226.4 \%)$ than in those which have full canals $(149.7 \%)$. That is, the femora with empty canals have thinner walls in relation to the size of the bone than those with full canals.

Second.-The mean index falls, to a marked degree, from birds to mammals, or from $159 \%$ to $63.3 \%$. The index in bats is $48.6 \%$, and in mammals without the bats $63.3 \%$. That is, the canal is smaller and the walls of the bone are 
thicker in mammals than in birds, and the canal is smaller and the walls are thicker in bats than in other mammals.

Third.-The medullary index in the human race, as a whole, is $38.6 \%$ and, therefore, much lower than in other manmals, in which it averages $63.3 \%$; that is, the medullary canal is relatively smaller and the wall of the bone thicker in bipeds which earry the weight of the body on two legs than in quadrupeds which carry the weight on four. The three races, however, show slight rariations. In all, 139 hnman femora were examined-34 black, 23 Indian (preColumbian), 9 ancient Egyptian, and 73 modern white. Their respective indices were $41.9 \%, 43.8 \%, 39.5 \%$, and $35.8 \%$. From these it will be seen that the index is higher in the ancient than in the morlern white femora (comting the Egyptian as of white race), and lower in the modern white $(35.8 \%)$ than in the modern black $(41.9 \%)$ or the pre-Columbian Indian $(43.8 \%)$. That is, the canal is larger and the mass of bone smaller in ancient (Egyptian) than in the modern white femur, and the canal is relatively smaller and the bone larger in the modern white than in the modern black race or the pre-Columbian Indian. The smallest canal and thickest wall were found in the modern white, and the relatively largest canal and thinnest wall in the Indian. Some of these detailed differences may, of course, be purely accidental, due to the insufficient number of specimens, or other conditions; but they are of sufficient interest to warrant further observations.

\section{Medullary Canal}

The canal presents many peculiarities in position, shape, size, surface, and contents.

In some femora it is situated eccentrically. This is more especially true of human fetal bones, where the canal occupies the anterior half of the crosssection. It is also true in many adult femora of the triangular shape and third (or Haversian) type. In femora of the first type of structure (the lamellar), the canal is situaterl almost centrally, as such femora do not often have a welldefined linea aspera. In still other cases it is situated obliquely, as in some human femora.

The shape of the canal seldom corresponds with the peripheral outline of the bone, and the wall of the femur, therefore, is not of uniform thickness excepting in round bones with central canals, and these are generally limiter to small femora, to those of the yomg, and to simple types. In adult bones, the canal varies considerably in shape. In some hones it is nearly circular with fairly regular outlines, as may be seen in the small first type (lamellar) femora like those of the bats. In others it is elliptical or irregular, regardless of the shape of the bone, as in some human specimens. 
In size the canal presents several peculiarities. Some femora have relatively very small, and others very large canals. In some cases it is reduced to extremely small dimensions, as in the amblystoma, turtles, yellow-hammer, and some embryonic mammals. It reaches its greatest relative size in birds and its smallest in amphibians and reptiles.

\section{Medullari Contents}

The contents vary. Some medullary canals are full of marrow, as those of amphibians, of reptiles, and of hats; some contain cancellous bone and marrow, as those of man; some have trabeculie, as those of the peahen, eagle, and turkey-buzzard. In birds an important variation is found. About one-half of their femora have canals full of màrow, while the remaining half are either empty or contain trabecule only. The full or empty condition of the canal seems to bear no relation to the flight of the bird. T'he peahen is a poor flier and has an empty canal, and the eagle is a good fiier and has an empty canal. The wild goose is a good flier and has a full canal, and the domestic turkey ${ }^{1}$ is a poor flier and has a full canal. The peahen and domestic turkey may be thought to exhibit the flying habits of domestieation; but these birds show two opposite conditions of medullary contents-the peahen has an empty canal and the turkey a full canal. Similar results are also observed in the wild and domestic turkeys. Both have full canals although they differ greatly in their abilities to fly. Again, in some birds, as the yellow-hammer, pigeon, and white pelican, the medullary canals are occupied by a heavy cancellous bone with small meshes and present the appearances of nearly solid bones, and yet these birds are good fliers. Generally speaking, the medullary canals of amphibians, reptiles, mammals, and man are full, while those of the birds examined are about equally divided. In most cases the canals were filled with yellow narrow. A few, however, were full of red marrow.

\section{Medullary Surface}

The medullary canals present a variety of surface. In some instances, as in the peacock and eagle, there is seen extending inward from the wall of the femur an intricate network of trabeculæ, which increases in complexity toward the epiphyses. The surfaces in the larger mammals and in man are generally irregular, from the presence of ridge-like projeetions.

In many instances the medullary surface is smooth, as in the whole class of amphibians, in lizards, and in bats; while in other cases it is rough, uneven, or irregularly corrugated. This is especially true of the larger mammalian femora.

${ }^{1}$ The humerus has an empty canal crossed by trabeculæ. 


\section{Cancellous Bone and Trabeculze}

Cancellous bone is a special form of first type hone characterized by an arrangement of lamella enclosing more or less irregularly shaped meshes filled with marrow. The character of the framework varies in the different femora. In some, as in the turtle, it forms a thick, heary framework with very small meshes (pl. 4, fig. 67). In others, as in some birds, mammals, and in man, it is found as a delicate interwoven lacework with large meshes. In fetal human femora and in the bone of repair there is a channeled bone substance in which irregularly shaped meshes are present.

Cancellous bone, filling the medullary canal, has a wide distribution in the femora of animals. It is found in all classes from amphibian to man, but does not oceur in the majority of the species. It was present in only one amphibian, absent in the lizards, present in the turtles, present in a few birds-yellowhammer, pelican, and domestic pigeon-in many mammals, and in nearly all human femora. It was not found in the order of hats.

Trabecula.-Bone trabeculæ are composed of a few lamella with long narrow lacune and branching canaliculi, with or withont Haversian systems.

In those bones which have marrowless medullary canals, trabeculie form an interlacing network, as in the peahen and tnrkey-bnzzard. The trabeculæ extend transversely from wall to wall, or more or less up and down toward the epiphyses of the bone. Near the extremities they generally form a labyrinth, as in man. The femora having trabecule are generally thin-wallerl.

The medullary eanals which do not contain marrow have networks of trabecula, while those with marrow have cancellons bone or not, according to the animal.

Trabeculæ are very infrequent in amphibians, reptiles, mammals, or man, and reach their greatest degree of frequency in birds.

\section{Variety of Minute S'tructure of the Wall of the Femur}

We may now approach the minute strueture of the wall of the femur. There is no one type of structure which characterizes all the femora of any single species of animal. Some individuals in each species will show single, pure-type bones, while others, and these are generally in the majority, present combinations of types. A great variety of combinations occurs. 111 bones consist of the same fundamental structural units, but these are combined and arranged in many ways and in different proportions. Three pure types and several combinations of types, in some stage of differentiation, are more clearly distingnishable and will be defined below. 


\section{The Units of Bone Structure}

The units of bone structure are divisible into the basic and the differentiated. The basic units are the bone substance proper and in a measure also the individual bone cell with its dendrites or the lacuna with its canaliculi. The differentiated units are the lamella, the lamina, and the Haversian system.

But little needs to be said in this place about the basic units. The bone substance behaves passively and is wholly subject to the activity of the cells. While the cells with their processes are the all-important, living, constructive, and destructive parts of the bone, they change and act in ways that are, as yet, largely obseure. Certain modifications in their characteristics have, however, been observed in the course of the present work and will be mentioned in the proper place.

\section{Bone Celus-Lacune}

Bone cells or osteocytes have formed, and in fresh bone occupy the small spaces called lacune. The latter vary in shape from round and oval to long and narrow. Many femora have both. 'The round lacme characterize especially the young bone, while the long prevail in bone which is fully formed. The denser the bone, the more probability there is that it will present the long, narrow lacunx, while in the rarer, but not senile bone substance, the round and oval forms are more abundant (pl. A, figs. A, B, C).

\section{Dendrites and Canaliculi}

The dendrites are processes which extend outwardly from the bone cells, the canaliculi being minnte canals in the bone substance for the accommodation of the dendrites. In a cross-section of the femur, the exposed canaliculi are seen to vary considerably. In some cases they are short, branching, and bushy in appearance, while in others they are long and but slightly branched. The former belong to the round or oval, the latter to the long and narrow lacuna (pl. A, figs. A, B, C).

\section{Differentiated Bone Units--Lamella}

Although bone first appears as a basic or undifferentiated substance in very young embryos and possibly in the more primitive forms of the lower classes of animals, in the course of time it manifests a tendency towards differentiation. Perhaps the earliest sign of such tendency is indicated by the concentricity of the lacuna and next by the formation of what are known to the histologist as lamellæe (pl. A, fig. F).

A lamella can, at present, only be defined as a simple, separate layer of bone. The exact mode of its formation is not as yet known, but it must, of course, be the product of the progressive activity of the bone-forming elements. The 
lamella themselves follow several lines of differentiation. Three distinct forms may be distinguished. They are as follows:

\section{TNIFORMLY LAMELLATED BONE}

Bones of this character, after their development has reached its limits, are composed entirely of concentric lamella. The structure is uniform in all parts of the section. The lacune are oval or long and narrow (pl. A, fig. E; pl. 2, fig. 7).

TWOFOLD DIVISION

A further stage of differentiation is found in many femora in which a twofold division has occurred; that is, the section is composed of wide external and very narrow internal lamellar rings in contact with each other (pl. 2, fig. 9).

\section{THREEFOLD DIVISION}

In some femora the lamelle are separated into three concentric rings. The external ring is narrow, the central wide, and the internal again narrow (pl. 2, fig. 27).

Lamellæ appear as the most prominent structures in amphibians, reptiles, bats, and in early fetal human femora.

\section{LAMIN 2}

The lamina, as used in this memoir, is a larger and more complex bone layer than the lamella. It is composed of a variable number of concentric sheaths of lamelle surrounding the bone or its medullary canal, but the characteristic feature is that it is separated from adjacent structures by systems or plexuses of vascular canals extending in a direction parallel with the medullary and external surfaces of the bones. It ocenrs in birds, mammals, late fetal, and early eliildhood, and is often, though not invariably, a stage in the differentiation of bone from the first to the third. It reaches its highest degree of development in mammals (pl. A, fig. J ; pl. B, figs. 2, 5).

\section{Maversian Sistems}

The Haversian systems are more or less eylindrical shaped complexes of varying diameters composed of concentric lamellæ enclosing a central or Haversian canal. They extend in a direction parallel with the long axis of the bone, and in sections ent at right angles are circular in outline. Tn many cases, however, and perhaps in the majority, their directions are considerably modified and instead of extending in directions parallel with the long axis they rum tortuous courses (pl. A, fig. F; pl. B, figs. 3, 6). 
Haversian systems, foreshadowed in a few amphibians, somewhat advanced in some reptiles and birds, much more completely differentiated in the lower mammals, become fully developed in man.

\section{Types of Bone Structure}

The most interesting and unexpected fact which has been brought out by the investigations herein reported is the existence, in the femur as well as in other bones of the body, of three distinct, easily separable types of minute bone structure, corresponding, respectively, to the lamellar, laminar, and Haversian system stages of differentiation. These may occur alone, but are very frequently found in various though in general readily analyzable combinations.

The types may be called the primary, intermediate, and advanced; or simply the lamellar, laminar, and Haversian system types. More conveniently than either, perhaps, they may be designated as the first, second, and third types respectively. They are shown in plate $A$, figures $1,2,3$; plate $B$, figures $1, .2,3$; microscopically and grossly in plate B, figures $4,5,6$.

These types of bone structure are, in the main, nothing but various stages of osseous development. They do not represent radically distinct varieties of bone, but rather consecutive stages of differentiation of one and the same fundamental variety which underlies bone structure in all the terrestrial vertebrates. The bone structure advances from simple to more complex in conformity with definite laws which affect all the organisms possessing a skeleton, and the process is never reversed. The main types of bone structure that were determined may be defined briefly, as follows:

THE FIRST TYPE

This is composed of basic, or but moderately differentiated, bone substance, enclosing more or less numerous lacune, from which radiate seant to numerous minute canaliculi. The lacune are generally round or oval in shape, and their canaliculi are mostly short and bushy. The lacune may or may not occupy a definitely concentric position ( $\mathrm{pl}$. A, fig. D). In the more advanced stage the lacune assume a concentric arrangement, change in shape to a longer and narrower form, their canaliculi become longer and straighter, and the basic bone substance becomes separable into parallel layers, which are the lamellæ. Here development in many species stops (pl. A, figs. E, F). The first type of bone, therefore, is one varying from wholly basic, unorganized bone substance with no perceivable systematic arrangement of the cells, to that showing distinct lamellation with varying lacunæ and canaliculi. The most advanced and characteristic bone unit is the lamella (pl. A, fig. F; pl. B, figs. 1, 4).

The arrangement of the lamellæ is mostly concentric about a larger or smaller canal (pl. A, fig. E), but in some localities in a bone-as in the areas 
among the Haversian systems-the lamella are fragmentary-like and short, and may be straight or curved. On cross-section the individual lamellæ are seen to be, generally, of uniform thickness. Their ventral and dorsal surfaces, on the whole, are regularly shaped, and the edges of the cross-sections are finely serrated. The separate lamella are joined by cement. They may constitute the whole bone structure in a given specimen (pl. A, fig. E), or only a part of it; they may surround the Haversian canal and form the basis of the Haversian system, being then known as Maversian lamella (pl. A, fig. F); they may enclose the whole medullary canal, in which case they are known as internal circumferential lamella; or, finally, they may form the external boundary of the bone, where they are known as external circumferential lamella. The lamella, therefore, may be considered as the primary differentiated unit of bone structure-the first to appear in progressive development. Bone cells, represented by lacuna, may oceur within the lamella or between them (pl. A, fig. F; pl. B, figs. 1, 4).

It is interesting to notice that the first type bone unit (lamella) is found, in some form, in all femora from amphibians to man, and, as already pointed out, it may vary in its degree of differentiation. According to such differentiation, the lamellx may become the foundation of the second and third type bones. The differentiation gives rise to three subtypes of lamellated bone: The wniformly lamellated, found in many of the amphibians, reptiles, birds, and bats, but not in the higher mammals or $\operatorname{man}^{1}$ (pl. 2, fig. 7) ; the trofold, which was seen in amphibians, reptiles, birds, bats, and in a few mammals, but not in adult man (pl. 2, fig. 9) ; and the threefold, which occurs in amphibians, reptiles, birds, and bats, but not in the ligher mammals or man (pl. 2, fig. 27).

The principal interest in these secondary differentiations of a first type bone lies in the fact that they indicate the manner of origin of divisions which are so frequently present in the higher and later third type or Haversian system bones. In these the outer and imner lamellar rings are known as the external circumferential and internal circumferential lamelle, while the central broad ring has differentiated into Haversian systems. In some stage of differentiation, the first type bone is found in all femora as an important structure, and, therefore, may be considered as universal.

THE SECOND TYPE

This is composed of lamine in some stage of differentiation, arranged concentrically around the medullary canal. While Haversian systems may be present here and there, the lamina dominate and characterize the bone structure. The degree of differentiation present varies. In some cases it is only a

${ }^{1}$ Of the total 440 femora examined, 19 per cent were composed entirely of uniformly lamellated bone and were limited to amphibians, reptiles, and bats. (See table, p. 17.) 
little in advance of the lamellar type; in others the advancement is more pronounced; while in still others the type appears to have reached its limits of development (pl. A, figs. H, I, J ; pl. B, figs. 르, 5).

The exact mode of development of the lamina, as in the case of the lamella, has not yet been traced. Laminæ show incomplete and complete stages of differentiation.

Incomplete: In some cases, as in birds, basic bone substance is partially separated into indistinct laminæ by a few, short, vascular canals having general concentric positions. The lacune are round or oval and the canaliculi are short and bushy and rather infrequent (pl. A, fig. H). In other cases the concentric canals are lengthened and arranged in the form of a more or less complete plexus, in the elongated meshes of which lamina are more clearly seen. The lacunæ are oval and the canaliculi are very numerous and reticular in arrangement (pl. A, figs. I or ?2).

Complete: In still other cases the vascular canals form more or less complete circuits, and the laminæ are well defined in clearly differentiated sheaths, with completely developed lamellæ and long lacune with straight canaliculi, and are pierced quite regularly by rascular canals extending transversely ( $p l . \Lambda$, fig. J ; pl. B, figs. ㄹ, 5 ).

The laminæ have more individuality than the lamellæ, and in a dried femmr of the second type they can be sealed off one after another. They are fairly uniform in thickness, but in the incomplete stage rary considerably in the length of their segments. The lamina were first observed in two amphibians, occurring singly in the femora of the Bufo americana and IIyla gratiosa (pl. 2, fig. 14; pl. 3, lig. 36). In both of these bones they were only fairly well developed and oceupied irregular positions in reference to the medullary and external surfaces. In the alligator and some turtles they alternated with concentric rings of crude Haversian systems. But it is in birds that laminæ first become prominent as units of bone structure. In these animals the structure of the femora examined presented stages of differentiation varying from a very incomplete to an advanced, but not complete, character. It is not until the lamina reach the class of mammals that they show their highest development, so that in birds they appear to occupy a transitional position. In fact it is not difficult to distinguish between these units of the bird and the mammal by the incomplete character of the concentric canals and the early differentiations of the lacume which are present in birds, and the complete concentric canals and higher grade lacunar differentiations which are present in mammals.

THE THIRD TYPE

This type is composed of Harersian systems as the main units of structure. These systems form the whole bone or a larger proportion of the same. Nar- 
row external and internal sheaths of circumferential lamella often surround the bone and its mednllary cavity, but the characteristic strnctural units are the Haversian systems. The type presents two stages of differentiation-the incomplete (I) (pl. A, figs. K, L, M), and the complete (C) (pl. A, figs. $\mathrm{N}$ or 3 ; pl. B, figs. 3, 6). The incomplete differentiation is further divisible into three sub-stages which are indicated in the synoptic tables and text as the la, lb, and Ic stages (pl. A, figs. K, L, M). These stages can be readily distinguished microscopically, and may all ocemr in a single bone. As a matter of fact, it is often impossible to include all llaversian systems of a bone nnder any one stage of differentiation. Term (Ia) signifies early, (Ib) intermediate, and (Ic) the late stage of incomplete differentiation. When the process of differentiation is completed, the Haversian system is referred to as (C) (pl. A, fig. N).

III, Ia.-This was first observed in a few of the amplibians. In the femora of these animals the system was merely a minute, more or less irregularly shaped, canal, extending in a direction parallel with the long axis of the bone. In cross-section the canal was round, oval, or irregular in shape and surrounded by a small, clear, more or less circular area of bone substance, across which were seen a few canaliculi on their way from neighboring lacmno. That is, they were not concentrically arranged and appeared to be independent of the canal with the exception of a slight connection by means of the canaliculi. The figure presented merely a suggestion of an Haversian system. 'This stage of development was found in all classes of animals from amphibians to man. Its characteristic structure may be seen by referring to plate $\Lambda$, figure $K$.

As one studies the many sections in which this stage is found it is clearly evident that it is associated with the earlier periods of development both phyloand ontogenetically, since the Haversian canal alone is present, and this ocems in the lamellar areas of the bone. There seems to be no particular relation of the canal to adjacent lacume.

$I I I, I b$.-This stage represents a morphological advancement characterized by a more definite relation of neighboring lacunse to the Haversian ('anal, and by more extensive communication of the bone cells of the lacuna with the Haversian cinculation. The result is that the Haversian system is fairly well ontlined. As this stage is but a step in advance of (Ia) it might be expected to appear in any femur in which (Ia) is present, and to a certain extent this is true. It was observed in all classes of animals except ing amphibians and birds (pl. A, fig. L). It was first seen in some of the reptiles, such as the turtles. In these femora the canal was smromnded by a clear, circular area of bone substance, and the lacuna were arranged concentrically around the circumference of the area. There was a noticeable increase of the canaliculi passing' from the lacunx to the canal. The whole figme presented a circular form and the Haversian system could be clearly distinguished. 
III, Ic.--This stage of Haversian development may possibly occupy a transitional position between the early and late differentiations, although it does not resemble either one very closely. It differs from both in the intricate character of the canaliculi, and in some respects sngests as early a development as that seen in ( $\mathrm{Ia}$ ) or ( $\mathrm{Ib}$ ). The Haversian canal is regnlar in shape and small in size. 'The lacune have assumed a definite concentric arrangement around the ranal, and, with their bushy, branching eanaliculi forming a delicate network, ocenpy the clear area of bone substance referred to under (Ia) and (Ib). 'The structure has taken on the definite form of an Haversian system and presents a peculiar dull character by which it may be identified anywhere (pl. A, fig. M). This stage was observed in birds only and is easily recognized.

$I I I, C$.-This is the completely differentiated Haversian system and belongs to the higher mammals and man. In this stage the dim characters of the incompletely differentiated systems have disappeared. The outlines and structural units of the Haversian systems are clearly distinct. 'The canaliculi are slightly wavy and parallel (pl. A, fig. N).

Such systems were not found below the mammals nor in the lower manmals, such as the monotremes, marsupials, and some of the edentates and Chiroptera, but were always present in the higher mammals and adult man. Therefore it seems safe to regard this form as the Haversian system of the latest differentiation.

The Haversian system in early or late stages of differentiation, appears also in all classes of aninals; but there are wide and often characteristic differences in the variety and extent of such bone. In the amphibians it is merely an outline, but in its extension through the reptiles, birds, and mammals to man, it presents pliases of an advancing differentiation. The lower the class the earlier the stage, and the higher the class of anmals the more complete the stage of development of the Haversian systems. 'The development seems to be one of a transformation of the first bone type into a third by some plan of arrangement, since a complete Haversian system is composed of concentric lamellae enclosing an Haversian canal. 'The earlier stages are generally found in all classes of animals in which the first type bone is present as a characteristic structure, and the later stages are found more especially in those classes in which the first type is disappearing or has disappeared.'

${ }^{1}$ In addition to the ordinary method of Haversian system development one or two other peculiar forms were observed. In a fractured femur of a frog the upper and lower fragments were united by new bone formed around them. The new bone was cancellous or channeled in character and in some of the meshes lamella were concentrically deposited until the meshes were filled with the exception of small canals in their centers. The results, at least in appearance, were Haversian systems (pl. A, fig. O; pl. I, figs. 5, C, E, F). Such results were rather unexpected since there was no structure in the original fenur which in the least resembled an Haversian system or even cancellous bone.

Another peculiarity was observed in some second type (laminar) femora, as those of the domestic pig and wild boar. In these bones small, circular enlargements of the concentric canals between the 


\section{Frequency of Occurrence}

The distribution of the three types of bone, their stages of development, and divisions may be seen in the following table:

DISTRIBUTION OF THE THREE BONE TYPES AND THEIR DIFFERENTIATIONS

\begin{tabular}{|c|c|c|c|c|c|c|c|c|c|}
\hline Type & & $\underset{\text { ians }}{\text { Amplib- }}$ & Reptiles & Birds & Bats & $\begin{array}{l}\text { Other } \\
\text { mam'ls }\end{array}$ & $\begin{array}{l}\text { Adult } \\
\text { man }\end{array}$ & $\begin{array}{l}\text { Fetal } \\
\text { man }\end{array}$ & Total \\
\hline \multirow{6}{*}{ I. } & Number of femora examined.. & 39 & 34 & 40 & 55 & 133 & 139 & 7 & 440 \\
\hline & & Per cent & Perecnt & Percent & Percent & Pet cent & Per rent & Percent & Percent \\
\hline & Lamelle, uniform throughout. . & 26 & 60 & 30 & 73 & 0 & 0 & 0 & 19 \\
\hline & $\begin{array}{l}\text { Lamella, twotold division..... } \\
\text { Lamella, threefold division... }\end{array}$ & 20 & $\begin{array}{r}16 \\
6\end{array}$ & $\dot{5}^{6}$ & $\begin{array}{r}16 \\
9\end{array}$ & $\begin{array}{l}2 \\
0\end{array}$ & $\begin{array}{l}0 \\
0\end{array}$ & $\begin{array}{l}0 \\
0\end{array}$ & $\begin{array}{r}14 \\
4\end{array}$ \\
\hline & Lamellae as cancellous bone... & 3 & 17 & 5 & 0 & 46 & 92 & 100 & 46 \\
\hline & $\begin{array}{l}\text { Lainelle as important bone } \\
\text { structure................. }\end{array}$ & 100 & 100 & 47 & 100 & 48 & 92 & 100 & 79 \\
\hline \multirow[t]{3}{*}{ II. } & 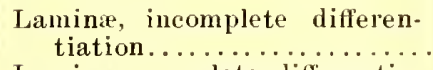 & 5 & 9 & 25 & 0 & 10 & 0 & 100 & 18 \\
\hline & $\begin{array}{l}\text { Laminx, complete differentia- } \\
\text { tion................................... }\end{array}$ & 0 & 0 & 0 & 0 & 40 & 8 & 0 & 1.4 \\
\hline & 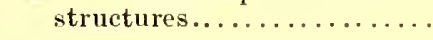 & 5 & 9 & 25 & 0 & 50 & 8 & 100 & 21 \\
\hline \multirow[t]{6}{*}{ III. } & Haversian system, Гa.. & 21 & 21 & 5 & 5 & 39 & 32 & 14 & 27 \\
\hline & Haversian system, Ib.. & 0 & 23 & 7 & 7 & 28 & 6 & 71 & 15 \\
\hline & Haversian system, Ic........ & 0 & 0 & 82 & 0 & 0 & 0 & 0 & 7 \\
\hline & Haversian system, C........... & 0 & 0 & 0 & 0 & 82 & 100 & 0 & 54 \\
\hline & $\begin{array}{l}\text { differentiation.............. } \\
\text { Haversian system, complete }\end{array}$ & 21 & 52 & 89 & 12 & 67 & 38 & 18 & 46 \\
\hline & differentiation............. & 0 & 0 & 0 & 0 & 82 & 100 & 0 & 54 \\
\hline
\end{tabular}

Looking over the above table it will be noticed that lamella, in some stage of differentiation, form an important part of the majority of all femora, and, therefore, may be considered as the simplest, oldest, and most universal bone units; that the first type of bone, without concentric divisions, has a wider range than it has with concentric divisions, and that cancellous bone-which is first type with a special arrangement of lamella-is found in all classes of animals; that lamina-ineomplete or complete-are found in the smallest number of femora, and that Haversian systems, in some stages of dilferentiation, are found in the largest number of femora and to the greatest extent in man. The early differentiations of the Haversian systems are found in $46 \%$ and the late in $54 \%$ of all femora examimed. There are more early differentiations in the lower animals and more late differentiations in man than in the lower animals. Early and late differentiations may oceur in the same bone and more especially in mammals and man, as may be seen in such femora as represented in plate 31 , figure 399 .

two laminæ occurred at intervals. Around these enlargements two to four concentric lamellæ were arranged, the whole figure presenting the appearance of a small Haversian system (pl. A, fig. P).

These are referred to in the detailed description as aberrant forms of the Haversian system. 


\section{Type Combinations ${ }^{1}$}

In a large number of femora the three structural types-first, second, and third-are seen represented simultaneously in various proportions and form what may be called type combinations. Is a rule, in these combinations, the rarious types occupy similar positions in all the adult femora that present such combinations. Usually first and second type constituents surround the femur peripherally and encircle also the medullary canal, while the third type bone forms the central portion of the sections. The bone units in these cases show varying stages of development.

While the single types occur as the sole structures in the femora of some amplibians, reptiles, birds, mammals, and man, a large number, perhaps the majority, are composed of various combinations of these types. There may be a marked difference in the degrees of differentiation present in the several structural units in the same bone.

About $60 \%$ of the whole number of femora examined presented combinations of bone types. The first and third were found in association in the largest number.

\section{Type of Bone Structure According to Classes of Amimals}

\section{AMPHIBIANS}

In these animals the trpe of bone present in the rarious species showed generally evidences of a progressive character in the structural units. There was observed a change in the shape of the lacume from round to long and narrow, in the canaliculi from short and bushy to long and straight, and in the arrangement of the lacume from diffuse to concentric. There was also noticed

${ }^{1}$ The most common type combinations are as follows:

$I-I I$. This combination is composed of lamellæ and laminæ. It is seen more especially in fetal femora. In young bones the lamellæ generally occupy the peripheral portion of the bone, and become separated into laminæ nearer the medullary canal. As differentiation advances, much of the first type (lamellar) structure changes gradually into that of the second type (laminar) (pl. C, fig. 1).

I-III. This is a combination of lamellæ and Haversian systems. The lamellæ form a sheath of varying thickness around the bone and enclose either wholly or partly a ring of Haversian systems, also of varying thickness. The Haversian systems may be of any grade of differentiation (pl. B, fig. 7; pl. C, fig. 2).

II-III. This is a combination of laminæ and Haversian systems. The laminæ, generally, form thin, concentric sheaths around a stout ring of Haversian systems (pl. B, fig. 8; pl. C, fig. 3). Here again the Haversian system may be of various grades of differentiation. If the laminar structure is of advanced type, the Haversian system is also; but if it is not, the Haversian system appears in some of its earlier forms.

$I-I I-I I I . \quad$ This is a combination of lamellæ, laminæ, and Haversian systems. The simple lamellæ are generally located exterually, the laminæ more internally, and the Haversian systems form the central portions of the bone. The Haversian systems may be of any grade of development. As a rule, the lamellæ and laminæ are well developed or fairly well developed in these forms of bone, while the Haversian systems vary considerably in their degree of differentiation (pl. B, fig. 9; pl. C, fig. 4). 
the separation of the uniformly lamellar wall into two and three concentrie divisions, the presence of lamine in Bufo americana and Hyla gratiosa, and the appearance of Haversian canals of the (Ta) differentiation in the Surinam and other toads (pls. 2-3, figs. 6-39).

REPTILES

The reptiles seem to be divided in the matter of bone differentiation into two groups-the division occurring between the lizards and the turtles. The first group, which includes the lizards, is characterized by the first type bone structure and the second, including the turtles, by the first and third. Belonging to the lizard group in their type of bone were the femora of the Python regius, which were composed of erude first type structure with a twofold division. The femur of the alligator represents a later differentiation than that of the lizards and snakes, inasmuch as the second and third types have appeared. Both of these units have reached a later degree of development than they have in any femur preceding them in the zoological scale, while they are not as far advanced as they are in the turtles which follow them. Comparing the class of reptiles with that of amphibians the chief evidences of type advancement are seen in the more complete differentiations of the third type units (pls. 3, 4, figs. 40-73).

\section{BIRDS}

The study of the femora of birds is, to some extent, unsatisfactory. While the three types of bone structure are present, either alone or in combination, they generally bear more or less of a transitional character. The several units -lamelle, laminæ, and Haversian systems-show, usually, incompleteness of development. In some instances, it is difficult to recognize any distinct type. On the whole, however, eridences of advancing differentiation are prominent in birds, since all three units have appeared and generally in a more complete form than in the femora of reptiles or amplibians.

The first type of bone (lamellar) is present in some species, as in the robin, and is of a very simple form. The second (laminar) appears in a larger number of species, as in the turkey, grouse, and ostrich, and is, perhaps, the most representative type among birds. The laminx, generally, show an incomplete differentiation. The third type (Haversian systems) is found in several species, and presents distinct characters by which they can be distinguished from the Haversian systems of other animals.

In some cases Haversian systems are present in the posterior ridges, in others, of larger size, in the posterior ridges and anterior walls, and in still others they form the entire central ring (pls. 5, 6, 7, figs. 7t-112). 
The femora of mammals, not inchuding man, present the first, second, and third type units and most of their combinations. As far as can be determined microscopically, these units are the same as were present in the amphibians, reptiles, and birds; but on the whole, they show a more advanced differentiation.

Since the complete Haversian system does not appear in amphibians nor in reptiles nor clearly in birds, and does appear in mammals as a predominating structure and often in a high degree of differentiation, its general presence to such an extent and to such a degree of advancement points to the age of mammals as the most important period in the history of bone development.

For convenience in description the bats are treated separately since they do not resemble other mammals as closely as they do some of the lizards.

Bats.-Practically the whole order has been covered, and from the drawings, descriptions, and tables it will be seen that the bat femora are generally true to the first type bone. The sections are composed of lamellæ with round, oval, or long and narrow lacune, arranged concentrically around the medullary canal.

The sections are uniform in structure with the exception of a small number in which we find the twofold or threefold lamellar division. Very few structural variations have occurred in the whole order. In the genus Pteropus, which included the largest bats, Haversian canals of the early differentiation are present, and, generally speaking, the femora of the larger species have more of these canals than those of the smaller (pl. 8, figs. 113-166).

Other mammals.-The femora of the fetal sheep, calf, and pig of half-time development and also those of many adult mammals were examined.

In the fetal sheep the type of bone was an incomplete second with short, wide, irregular communicating canals. In the femur of the adult sheep the type was also second; but the laminx had become regular and concentric and the canals between them much narrower and more regular. In the fetal calf the type of bone was very indistinctly second, with numerous bizarre-shaped canals. In the adult ox the type had become a well developed second and third.

Tn the fetal pig the type was second and, with the addition of a few Haversian systems in the posterior wall, remained second in the adult (pl. 11, fig's. 199, 200, 201).

The most pronounced developmental change was observed in the femur of the calf.

The whole range of differentiation in minute bone structure reaches, generally speaking, the greatest advance in the mammals exclusive of bats.

The often more or less vague character of the structure in lower animals clears up to a marked degree, and the bone units stand out as finished products. Types and type combinations are now distinct. Pure types are found in many 
instances, though combinations of types are the most numerous and characteristic of mammalian bone. The Haversian systems have differentiated into their later stages, to reach their highest degree of perfection and prominence in man (pls. 9-20, figs. 168-298).

Man.-In human femora the bone structure, as already mentioned in part, reaches, in many respects, the climax of its differentiation. The hmman femora examined were the fetal and adult. The fetal bones belonged to the black and white races, the adult to the black, yellow-brown, and white including the ancient Egyptian. The number of fetal fomora examined is small, but the results indicate that the study of the comparative histology of a larger number of fetal bones, not only of man but also of other animals, would clear up many interesting points in the differentiations which are found in the adult (pls. 21-35, figs. 306-453).

Fetal human femora.-These femora, representing the whole period of intra-uterine life, showed basic bone substance in the early, and differentiated lamellæ and laminx in the later months; also there was observed the horseshoeshaped band forming the anterior and lateral wall and the separate formation of the posterior ridge (pl. 21, figs. 299-305). (For details see section III.)

Adult femora.-Generally speaking, the adult human femur is characterized by the predominance of completely differentiated third type units. An exclusive first type was not found in the adult hone. The most primitive form was a first and third combination. The proportions of the structural units (lamellx, laminæ, and Haversian systems) vary greafly. In some femora first type bone amounted to more than half of the sections; in others it was reduced to a small fraction; in still other's there was a second and third instead of a first and third; and, finally, some femora showed the first, second, and third type bone in various combinations.

When first type bone is present in the human femur it is found in the form of a horseshoe-shaped band situated underneath the periosteum. The inter-Haversian lamella, frequently present in sections of human femora, are apparently the remains of the disappearing horseshoe band just described. In a fully differentiated hmman bone, Haversian systems form the whole structure.

The three races, black, yellow-brown, Egyptian, and white, exhibit similar types and combinations of types of bone structure. In eacll there is a first and third, second and third, and complete third type, with or without senile changes. As a race the white presents more third type femora than the black or yellowbrown race. Early (primitive) and late (advanced) differentiations have been found in the different femora of the negro, Pueblo, and Peruvian Indians, the ancient Egyptian, and modern white. The linea aspera in the adult human femur is always composed of Haversian systems. Senile changes, absent or rare in other animals, are mexpectedly frequent in human femora. 
The best type of human femur is composed wholly of Haversian systems of the complete differentiation. The systems have long, narrow lacunæ, with long, straight canaliculi situated between or within concentric lamellæ which enclose the Haversian canal. External and internal circumferential lamellæ form in some instances very narrow rings around the bone and medullary canal, or they may be fragmentary. Such femora are not very common.

Black race.-The femora of the black race exhibit types and combinations of types ranging from a first and third to a complete third. The majority of bones examined are type combinations. In some femora a wide horseshoeshaped band of lamellæ, enclosing Harersian canals of the early incomplete differentiation and a few, scattered, small Haversian systems, is found partly surrounding a narrow, central ring of completely developed Haversian systems. In other's the horseshoe is narrower, and the central ring of Haversian systems is wider; that is, the proportion of the horseshoe band to the Haversian ring is a variable quantity. In still other femora the horseshoe forms a fragmentary background which can be distinguished, but which has been mostly displaced by fully developed Haversian systems (pls. 21-23, figs. 306-324; pl. 25, figs. 335-340).

The negro fenur has a higher medullary index than the white or Egyptian race.

During the examination of the right femur of negro No. 248674 , U. S. Nat. Mus., it was observed that considerably more than half of the section was first type bone, in which were many Haversian canals of the primitive and incomplete differentiation. It was then decirled to examine all of the long bones of that negro in order to ascertain, if possible, whether or not the structure was basic in character. Accorlingly, the left femmr, tibia, fibula, radius, ulna, humerus, clavicle, and metatarsal hone of the great toe were examined. The result was they were all found to conform closely to what was found in the right femur. It was therefore concluder that the type combination found in the femur was a representative type of the whole long bone formation of that particular negro, and that one type or type combination would probably not be found in one bone of an individnal and a different one in another (pl. 24, figs. 325-333).

The yellow-brown race.-With one exception these femora were pre-Columbian. They were a little smaller than those of the blacks. The majority were composed of second and third, and first, second, and third type combinations. Only three or four were pure third type. In the femora, composed of type combinations, there was a greater average proportion of first type bone than was present in the other races examined.

The medullary canals were relatively larger than in the other races, as may be seen from their medullary indices-yellow-brown $43.8 \%$, blacks $41.9 \%$, Egyptians $39.5 \%$, and whites $38.5 \%$. Therefore the yellow-brown femur has 
proportionately a smaller percentage of bone substance than the femora of other races (pls. 25-27, figs. 341-361).

Egyptian femora of the twelfth dynasty.-This series ineludes the femora of children, youth, and adults. The bones are interesting on account of thein antiquity. They show the structure of the femur of four thousand years ago. By comparing them with modern femora it will be seen that the bone types which were promment then are still prominent now.

One of the most interesting femora examined was that of a young child, figures 363 and 363-a. It showed the formation of an Haversian system from the eirculation, an accomnt of which will be fonnd elsewhere (p. 177). Two or three femora from adolescents showed gradually diminishing first and second and inereasing third type units. The adult bones showed two main types of differentiation. One was composed of lamellæ enclosing Haversian systems, and the other of Haversian systems alone, figures 369 and 370. Femur 369 bears the stamp of a much lower degree of development than femur 370. Femur 369 was much more than half lamellæ, while 370 was composed entirely of Haversian systems (pls. 27-28, figs. 363-371).

The white race.-The femora of the modern white race showed a variety of type combinations as well as single types. On the whole, the complete Haversian system type predominated. A larger percentage of the bones examined than in any other race showed the third type structure and senile changes. Individual differences in structure were quite extensive.

The average medullary index, as already seen, was $35.8 \%$. That is, the femur of the white race had a smaller medullary canal and thicker wall of bone than the femur of the other races. In the III, C type of femora the Haversian systems varied considerably in size. Some were small with a few, while others were large with many, concentric lamella. 'The communicating canals hetween the systems also varied greatly. In some femora they were very numerons and provided a rieh blood supply for the whole bone; in other femora they were few in number, comparatively, and the Haversian circulation was very much diminished. Differences in the extent of the circulation in different parts of the bone were observed. The inner wall generally had more inter-Haversian canals than the outer, while the posterior ridge (linea aspera) had a much richer blood supply than the anterior wall (pls. 28-35, figs. 372-453).

In those femora which showed combinations of types, the proportions of the units were found to vary greatly. In some the proportion of lamellie was considerably over $50 \%$ of the whole bone, and in others varying percentages of lamellæ and laminæ from $50 \%$ to $0 \%$ were observed. In only a few cases the femora composed of Haversian systems alone were withont senilé evidences. From an examination of two entire human femora of the white race at intervals 
of $2.5 \mathrm{~cm}$, it was further determined that sections through the middle of the shaft represented the entire structure of the bone with the exception of the extremities.

\section{Factors Influencing Types of Bone Structure}

1. Grade of the animal in biological classification.

2. Geographical location.

3. Sex.

4. Age.

5. Function.

6. Individuality.

7. Health arrd disease.

8. Heredity.

The results of the investigations in these rlirections are here briefly sumnilarized.

1. THE GRADE OF THE ANIMAL IN BIOLOGICAL CLASSIFICATION

It is, perhaps, impossible to decide just how much is evidence in regard to the relation of grade to structure. In the specimens of the different femora examined there were found many variations which, doubtless, have some significance. On the one hand, there are evidences which tend to show that the grade of an animal has an influence in limiting the structural bone type present; but on the other, there are counter evidences which indicate that the whole matter is not so simple. In support of the first view is the fact that the position which the animal occupies in the scale of life is generally in hamony with the type of bone present in its femur. That is, the lowest class of femoral vertebrates, the lowest order of any class, the lowest genus of any order, and the lowest species of any genus, all show the simplest and most primitive types of bone structure. The converse is also equally true-that the highest class, older, genus, and species shows the most advanced or highly dereloped type of bone. This may be seen from the specimens, tables, and drawings. While each class, order, genus, and species seems to have a bone cycle of its own, the varions cycles are bound together by some factor of an advancing differentiation and the high ${ }^{1}$ bone units in one class, order, genus, or species become higher in the next in succession.

But there are exceptional features which remain to be explained. Each class of animal-amphibian, reptile, birl, mammal-has some first type bone species. Eacll class, order, genus, and species shows an early and late differentiation of bone mints. While each class of animal seems to be complete in itself,

${ }^{1}$ The terms high and low do not refer to exact states, but to relative distinctions in differentiation 
there is apparently some underlying determinant which gives to the higher group a more complete differentiation than is found in a preceding or lower class. That is, the late differentiation in mammals is more complete than it is in birds, in birds than it is in reptiles, and in reptiles than in amphibians; while the early differentiation in each class secms to remain practically the same. As the animal rises in the scale of differentiation, the grade of the adnut bone type also rises. As far as the microscopic appearances are concerned it is difficult, if not impossible, to tell when bone units of structure have become complete, but it is not difficult to observe that they have arlvanced as we go from one class to another.

\section{GEOGRAPHICAL POSITION}

The effect of geographical position upon bone variation is not yet reducible to exact deductions. The majority of the femora of amphibians liave the first type of bone structure and this, too, regardless of their geographical location. The same is true of the lizards and hats. Perhaps the bats furnish the most important example. Is saicl already, practically the whole order was examined. The individuals came from all parts of the world where bats abound, and they all showed the same type of strueture with very little variation. Some mammals of different locations are alike in structure and some are unlike.

In respect to man, the femora of the ancient Egyptians differed from one another greatly, althongh they were taken from the same cemetery. The same is true of the pre-Colmmbian Chicama and Pachacamac Indians. In the modern races variations in type are very common and they cannot, in the writer's experience, in any way be associated with geographical position.

As far as the present observations are concemed, therefore, there is no reason to suppose that geography has had any marked influence upon bone type.

$$
\text { 3. } \mathrm{SEX}
$$

In reference to sex, it may be briefly stated that the femora examined shower no conchisive evidence that sex was an important factor in the minute structural variation of bone.

4. $\mathrm{AGE}$

Unlike the previons factors, age influences the type of bone very considerably. In the higher mammals and man the femora invariably change in structure with the advaneing age of each individnal. Some femora arrive at completion earlier than others. In the formation of the luman bone from early fetal types there were to be seen distinct evidences of progressive changes from the first through the second to the third type. In some cases this course of development was completed much earlier than it was in others, and senility 
appeared to a greater or less degree in the Haversian systems of such femora; in one instance senile changes were manifest although the individual was not over 35 years of age.

\section{FUNCTION}

The effect of function upon variation in bone structure can scarcely be doubted in some instances, while in others there seems to be little or no evidence of it. In amplibians the largest bones have the most Haversian canals. This, however, is only true as a gencral rule. For example, the frog has no Haversian canals or lamine, while the toad, which may be smaller than the frog, shows both laminæ and Haversian canals. In reptiles, the small lizards do not have the Haversian canals, while the larger ones have many. On the other hand, a large alligator lias very incomplete Haversian systems, while a small turtle has more advanced third type units. Again, small turtles have few, while the large ones lave many, Haversian systems. In birds, some of the larger varieties, as the ostrich, have predominating second types and not the third, while many small birds have predominating third type units.

A turkey of 16 pounds weight has the second type of structure with a few Haversian systems, while a turkey of 32 pounds has the same type with a noticeable increase in the number of Haversian systems. That is, size or weight seems to have a decided influence upon third type bone development in some cases, and little, if any, in others.

In mammals of the same species, provided the species has Haversian systems, there will be more of these systems in the larger than in the smaller rarieties. But in animals of different classes the larger species may have, on the average, no more Haversian systems than those of the smaller species. For example, a domestic pig, weigling 500 pounds, has a second type bone with some Haversian systems, while a tomestic turkey, weighing 32 pounds, has also a second type bone and nearly as many Haversian systems. The two bones of different classes differ from one another very materially in differentiation of both types, but not in the types themselves. In bipedal mammals of considerable weight like man, in which the weight of the animal is borne by two legs instead of four, there is a greater tendency towards the third type bone, and ret there are many exceptions. Furthermore, the os penis of the raceoon is an Haversian system bone, and conforms, generally, to the femoral type of that animal. In this case it is evident that function has had no effect on bone structure (pl. 20, fig. 288).

A cessation of function in an adult bone favors the appearance of marks of senility. There is a difference between a rudimentary femur without function and a normal bone which has lost its function by accident. The rudimentary femora of the python are first type bones like those of the lizards, 
and althongh the femora are useless, their bone mits are apparently sound; while in human femora amputated several years before examination the structure is well differentiated, but shows premature senile changes.

\section{INDIVIDUAL VARIATIONS}

Individual variations are by no means as common in the lower femoral vertebrates as they are in the higher forms. They are found to increase in the frequency of occurrence from birds to man. As far as the higher vertebrates are concerned, hardly any two individuals are exactly alike. They conform to a general type of structure which is fundamental, and exhibit special variations which are peculiar to the individual. This was found to be the case even with cats of the same litter. The individuals varied in structure.

\section{HEALTH AND DISEASE}

Variations due to health and disease remain very largely for studies in the future. However, the right femur of an adult white male who liad congenital epilepsy shows an extremely thin wall ( $1 \mathrm{~mm}$. to $2 \mathrm{~nm}$. in thickness), and an index of $277 \%$. See plate 35 , figure 453 , for hrawing and text for description.

\section{HEREDITY}

The influence of heredity on bone variation requires a greater amount of selected material of known genetic relationship than the writer has been able to gather. Most of the femora utilized are those of individuals with no obtainable family history. However, the femur of the mule resembles structurally the jackass more than the horse, and the femora of a litter of kittens showed quite marked differences. Exchnding other causative factors which do not sufficiently account for the variations observed, heredity offers a most attractive field. The further stndy of bones of the descendants of known ancestors, and of selecterl crossings, is especially desirable.

\section{Conchusions}

If we survey the whole field of bone histology, as it was observed during the present investigation, the following salient points stand out with suffieient clearness :

1. The predominant shape of cross-sections of the femora of the animals below man is elliptical.

2. Generally speaking, first and seeond type femora are circular or elliptical and third types are triangular or related shapes.

3. Mednllary canals are situated centrally, eccentrically, or obliquely, and may be circular, elliptical, or irregular in shape. 
t. The medullary surfares may be smootli, romghened by depressions, or corrugated.

5. Medullary contents are composed of marrow and its blood vessels, of marrow and cancellous bone, of trabecula alone, or the contents may be entirely absent. About half of the bird femora have full medullary canals, while the remainimg half have no contents.

6. The medullary index (relative thickness of bone compared with the medullary ranal) is lowest in reptiles and highest in birds. It falls from anphibian to reptile, rises from reptile to bird, falls rapidly from bird to mammal, and is about the same in man as in the lower mammals. The reptiles have the lighest percentage of bone, the amphibians next, the mammals next, the modern white race of man next, and the bird the lowest pereentage. Of the human race the modern white has the most bone, the Egyptian next, the negro next, and the American Indian the least.

7. The femora of the different animals and in man, even those of different inclividuals, vary in density, and the single femmr varies in the density of the different parts of its wall.

8. Lacruna and analiculi present various stages of differentiation, the rharacter of the differentiation being harmonions with, and indicative of, the degree of bone derelopment.

9. Lamellax, lamina, and Haversian systems appear in bone in the order given, and become the basis of the types and type combinations of bone structure which enter into the formation of the different femora.

10. Basic bone substance is differentiated into lamella when the diffuse arrangement of lacuna becomes concentrie.

11. Cancellous bone is present in all classes of animals, and is more frequently observed in large than in small bones.

12. Three types of structure form the basis of all femora. They may occur singly or in combination. The first and second predominate in anphibians, reptiles, and birds, the third in manmals and man.

13. The first type, composed of lamella, appears as a uniform structure, or in a twofold or threefold division, and characterizes the amphibians, lizards, and bats.

14. The second type (lamina) appears first in the amphibian, and in an early or late form of differentiation in birds and lower mammals.

15. The thirl type (Haversian system) is first outlined in the amphibians. It is the result, primarily, of a series of differentiations begimning with the amphibians and emding in man.

16. Combinations of types are of frequent occurrence.

17. In fetal and young femora the differentiation of first into second and serom into third types of bone structure was observable. 
18. The presence of the early differentiations of type in some black, yellow-brown, white, and Egyptian femora, and of the late or complete differentiations in other femora of the same races was observed.

The following evidences of type advancement appear in the different classes of animals :

Amphibians. - A change of round to oval and long lacuna, and from their diffuse to their concentric arrangements, a transformation of basic to lamellated bone, the separation of the uniformly lamellated bone structure into a twofold or threefold division, and the formation of distinct lanina and Haversian canals in the walls of the femora, were all observod in the amphibians.

Reptiles.-The extension of lamellie and the further development of lamina and Haversian systems were seen in the femora of reptiles.

Birds.-The extension of lamellx, prominent development of lamine, and advancement of Haversian systems were observed in these animals.

Mammals.-Extension of lamella, completion of lamina, and a much better development of Haversian strstems were observed in mammals.

Man.-Extension of lamella, lamine, and the completion of the Haversian systems were seen in hmman femora.

\section{FETAL HUMAN FEMORA AND THEIR FURTHER DEVELOPMENT}

Type differentiations, changes in the medullary index, and position of the medullary canal, development of the linea aspera, and changes in the shape of the shaft of the femur, are shown very interestingly in these bones, as may le seen from the following descriptive observations.

The fetal bones examined, mostly of the white race, varied in age from two and one-half to nine months. The soung bones of two and a half months were composed of a crude, undifferentiated bone substance, with round lacunx and short, bushy canaliculi, enclosing large irregularly shaped meshes. The medullary canal was very small and irregular in shape, and together with the meshes was filled with marrow. It was situated in the center of the section, and immediately surrounded by a narrow ring of lamella, thus showing the twofold division observed in some of the lower animals. The diameters of the bone were, the antero-posterior $1.8 \mathrm{~mm}$., the lateral $1.5 \mathrm{~mm}$., and of the canal $0.5 \mathrm{~mm}$. $\times 0.4 \mathrm{~mm}$. (pl. 21, fig. 299). The antero-posterior diameter at this stage of life was longer than the lateral. A little later (three to three and one-half months) the same liameters were respectively $2.5 \mathrm{~mm}$. $\times \stackrel{2}{-}$ mml, while those of the medullary canal were $0.5 \mathrm{~mm} . \times 0.5 \mathrm{~mm}$. The canal was sitnated eecentrically in the anterior laalf of the section, was only a trifle larger than the canal of the younger bone, and was surrounded by a narrow ring of lanella, also showing the twofold division (pl. 21, fig. 300). Comparing this section with the 
preceding it was noticed that a structural variation had already appeared in the latter bone. The irregular meshes seen in the former were considerably elongated. They had assumed canal shapes and were arranged concentrically. Basic bone substance, with round lacunæ and bushy canaliculi, formed the reticulum between the elongated meshes or canals. Furthermore, a difference in structure was noticed between the posterior and remaining wall. In the posterior wall the concentric arrangement of the canals, described above, was absent, and a general direction of the canals from the medullary canal toward the external surface of the posterior wall was assumed. Here and there in the bone substance between the canals an Haversian canal of the ( $\mathrm{Ia}$ ) differentiation appeared. This whole posterior structure was the beginning of the linea aspera, and seemed to be a distinct bone formation.

In still later femora (four or five months) the diameters of the shaft were $3.5 \mathrm{~mm} . \times 2.5 \mathrm{~mm}$, and those of the medullary canal were $0.6 \mathrm{~mm} . \times 0.5 \mathrm{~mm}$. The medullary canal was situated eccentrically. The section was composed of basic bone substance, enclosing wide, branching, concentric canals, giving the appearance of a very primitive second type formation. The posterior wall was more proninent, and composed of bone substance with round and oval lacunæ, enclosing long, wide, branching canals, directed toward the external surface and at right angles to the structures of the lateral wall. The distinction between the posterior and lateral walls was more pronounced than in the specimens of earlier femora (pl. 21, fig. 301).

In still older femora (five to seven months) a distinct difference between the posterior wall, which now appears as a ridge, and the remaining walls was observed. The diameters of the bone were $3.5 \mathrm{~mm} . \times 3 \mathrm{~mm}$., and those of the medullary canal $0.5 \mathrm{~mm} . \times 0.5 \mathrm{~mm}$. The canal was situated eccentrically. The bone was composed of concentric lamina arranged in the shape of a horseshoe, enclosing, in part, the medullary canal. The toe of the shoe formed the anterior wall and the heel embraced the posterior ridge. The posterior ridge was composed of elongated Haversian systems, as they appeared in cross-section, with large, wide Haversian canals extending outward toward the external posterior surface and at right angles to the laminx of the remaining wall. In crosssection the posterior ridge was wedge-shaped and clearly distinct. The laminæ of the remaining wall were incompletely differentiated. They were wide, and composed of bone substance with round and oval lacunæ and bushy canahiculi (pl. 21, fig. 302).

In the femora of the final stages of fetal development (eight to nime months) the diameters of the bone were $4.5 \mathrm{~mm} . \times 5 \mathrm{~mm}$., of the canal $1 \mathrm{~mm}$. $\times 1 \mathrm{~mm}$. In these bones the lateral diameter was longest. The medullary canal was irregular in shape, larger, and situated eccentrically. The bone was composed of elongated, concentric Haversian systems (in cross-section) arranged in horse- 
shoe shape around the medullary canal. The systems were composed of bone substance with oval and long lacunæ and with bushy and straight canaliculi. They gave one the impression of Haversian systems very much flattened by pressure. The posterior ridge or linea aspera, clearly distinct and wider than in the foregoing sections, was composed of elongated Haversian systems, and was divided into two lateral halves by a narrow radiating space, which is the last part of the linea aspera to become bone (pl. 21, fig. 303).

In a series of five Pueblo Indian femora of different ages, from one year to adult age, various further developmental stages were shown (pl. 9, figs. 341344). The child's femur was composed of incompletely developed laminæ and Haversian systems, the systems ranging from the (Ia) to the (C) differentiation. The posterior ridge, only partly formed in the femur of one year, was much further advanced in the femur of six years. In the femur of early youth the laminæ were, to a considerable degree, displaced by imcompletely developed Haversian systems, and the posterior ridge could not be distinguished from the lateral wall. In the femur of later youth the Haversian systems have increased in proportion and advanced markedly in development, and in the adult bone the lamellæ and laminæ were almost entirely displaced by fully developed Haversian systems. While these femora were from different individuals and probably from individuals of unlike types; yet they showed, in a general way, the differentiating changes in bone development. The Chicama and Pachacamac Indians showed similar changes.

Reviewing the above differentiations chronologically, evidences of advancement were strikingly apparent with inerease in age. The femur of the human fetus begins its osseous history as a bone of crude first type, and then gradually advances through the second to the pure third type, or to some combination of the first and third, second and third, or first, second, and third types. Haversian systems begin with the most primitive, incomplete, and advance to the fully developed stage, gradually increasing at the same time in number. An early twofold division of the femoral wall increases to a threefold division.

It may also be seen that the linea aspera of the human femur is the product of a distinct bone formation which occurs in the posterior wall. It was noticed at the early age of three and one-half months, and was observed in the different femora until birth. Therefore, in the formation of the shaft of the human femur, two distinct bone forming processes seem to be evident, one the formation of the horseshoe-shaped band of the anterior and lateral walls, and the other of the posterior ridge or linea aspera. They appear to go on independently of each other for a white, and fuse together some time after birth.

The development of the linea aspera-the last part of the shaft to be completed-is especially interesting from the viewpoint of its function and the growth of bone. 


\section{HISTOLOGICAL EXAMINATION OF TWO ENTIRE HUMAN FENIORA-GENERAL DESCRIPTION}

As all of the sections were made through the middle of the shaft, and the deseriptions given applied only to the structure of one location, it was desirable to examine sections of entire femora of different types in order to determine to what extent the structure of the middle of the shaft represented the whole femmr. With this object in view, two entire femora have been examined. In each bone the first section was made transversely through the middle of the head, and the remaining seetions at intervals of $2.5 \mathrm{~cm}$. The two femora represented two types of differentiation-one, I-III, C, senile, and the other, III, C, senile.

The first femur (length $41 \mathrm{~cm}$, No. 300, Cr. Medl. Coll.).-This was composed of a predominating proportion of lamelle interrupter by Haversian systems of the (Ta) and (C) differentiation, enclosing a narrow ring of Haversian systems of the (C) differentiation, many of which were senile. This femur, therefore, represented a human bone with incomplete development.

The structural type remained the same throughout the entire femur, but the different sections showed variations in medullary indices, proportions of lamellæ, cancellous bone, and senile changes. The medullary indices diminished from the extremities of the medullary canal toward the middle of the shaft, and were lowest 15 to $20 \mathrm{~cm}$. below the section of the head.

The proportion of the lamellar to the enclosed Haversian systems increased gradually from the head to the lower extremity. The eancellous bone diminished from the extremities toward the middle of the shaft. The senile changes were most numerous in the middle of the shaft and in the anterior wall.

On the whole, the bone was composed of an external, thick sheath of lamelle enclosing a thin, shorter sheath of Haversian systems, and a section through the middle of the shaft gave a fair representation of the whole bone structure, excepting that of the two extremities.

It was noticed during the grinding of the middle sections that the lamellar and Haversian system rings were easily separated from one another, and that they were readily fractured in the anterior wall in which senility was most marked.

Second femm. (length $38 \mathrm{~cm}$., No. 301, Cr. Med. Coll.).-The upper portion of this femur was composed almost entirely of well developed Haversian systens and the lower portion of lamella and Haversian systems. The lamella formed a wille external band situated in the anterior wall, and were frequently interrupted by Haversian systems, some of which were senile.

The bone represented a human femur of a much later differentiation than No. 300, although it was not entirely a pure third type bone. The principal variation from the third type was limited to the lower portion. 
The merlullary indices diminished from the extremities toward the middle of the shaft, and were lowest 15 to 17 am. below the section of the head. The band of lamelle began 20 to $22.2 \mathrm{~cm}$. below the head, and was most pronouncerl in the anterior wall. It extended downward toward the lower extremity, and, gradually diminishing in thickness, finally merged into the thin envelope of lamella surrounding the condyles. Cancellous bone diminished from the extremities toward the middle of the shaft, and was entirely absent from the middle third of the bone. Senile changes, not very marked, were most frequent in the middle portion and the anterior wall.

A section through the middle of this femur, compared with the remaining sections, did not give as fair a representation of the whole bone structure as the corresponding section of femur No. 300 gave to that bone. However, it did show plainly the type of bone to which this femur belonged. Notwithstanding, the lamellar band in the anterior wall of the lower portion, the characteristic unit of the whole bone was the Ilaversian system.

The heads and condyles of both femora were composerl almost entirely of lamellix.

\section{SENHLITY}

After reaching its highest degree of development, as indicated by the character of its lacune and canaliculi, the Haversian system may remain in this condition for a time, but sooner or later the dissoeiation of the organic and inorganic constituents begins to appear, and the srstem gradually becomes granular, opaque, and black. The sum total of the processes by which these results are obtained is age or senility.

An examination of the various sections shows that this eondition is more common than would be expected, and that, too, regardless of age in years. A human femur may be more or less senile at 35 or any subseqnent age.

Adult human femora in general show a much larger pereentage of senility than the femora of the lower animals. From a review of the various sections it may be seen that senility does not seem to appear at all in the amphibians, reptiles, birds, or bats, and was seen in only five or six of all the remaining manmalian femora; while it is found in the majority of femora of the white human race. Just when the amphibian, reptile, bird, or mammal becomes adult, just how long this period of life lasts, or when old age sets in, are not known.

The fact that senile changes are so prominent in the lamellix of Haversian systems and so infrequent in the lamelle of other situations snggests a difference either in the variations of the hood supply or in the chemical stability of the bone snbstance, or in botlı. The cirenlation is more complicaterl in a third type bone than it is in a first or second, and therefore more subject to structmral deviations. 
In a senile Haversian system, at the beginning of the proeess, the lamella aromd the Haversian canal becomes dark from a deposit of inorganic granules. This deposit intensifies the clearness of the serrated edges and cement. The granules increase as the process goes on, involving lamella after lamella, until the whole system is opaque and black. After the lamellæ have reached this stage they are gradually broken down into amorphous particles which drop into the Haversian canal and are removed by the blood vessels. The lamellæ of adjoining systems pass through similar processes. The inter-Haversian lamellæ follow and a cavity is formed, which in the section appears as a space. This process continues with a greater or lesser rapidity until the bone, reduced in dimensions and weight, remains as a mere shell of its normal condition (pl. 34, figs. 423-426).

In plate 29, figure 381, these ehanges may be observed. Haversian systems in different stages of senility are most numerous in the anterior and outer walls and in the middle portion of the shaft of the bone. The systems may be in pretty good condition elsewhere or, in extreme cases, granular deposits of different degrees of intensity may be present in most of them. The internal circumferential lamella remain in a fragmentary form. The essential change, therefore, is primarily in the Haversian system.

The changes which occur in senility may be summarized, as follows:

1. Dissociation of the organic and inorganic constituents of the lamella aromnd the Haversian canals.

2. Deposit of inorganic granules in the lamellæ around the Haversian canals.

3. Gradual extension of the inorganic deposit toward the periphery of the Haversian systems and opacity of the lamellæ.

4. Absorption and disappearance of the granular lamellæ from the Haversian canal outward.

5. Widening of the Haversian eanals and thimning of the walls of the Haversian system.

6. Disappearance of the Haversian systems and formation of irregular spaces. (Deposit of salts in the walls of degenerating vessels.)

7. Decrease in the weight of the bone.

\section{AMPHIBIANS}

The study begins with the amphibians. Thinty-nine femora were examined.

\section{General Character of the Femur}

The femora of these animals are generally small. They vary to a considerable degree in shape. Some sections are triangular, some elliptical, some 
round, and a few are indeterminate. In the elliptical sections the lateral diameters are longest. The medullary canals are full of marrow, and in one femur, Amblystoma tigrinum, the canal is occupied by cancellous bone. The medullary index varies from zero to $129 \%$, with an average of $36.6 \%$. The type of structure is principally first; the basic or undifferentiated bone substance is found in Amblystoma tigrimum, the most primitive of amphibians, the lamellated or differentiated bone in the majority of the remaining species; while the II and III, Ia differentiations oreur in the toads. 'The lacune are round, oval, or long, and the canaliculi are short and bushy or long and straight. The structure may be uniform throughout the whole section, or it may present a twofold division, as seen in Hyla arenicolor; or a threefold division, as seen in Necturus.

On the whole, then, the amphibian femora show the first type bone, and also mark the beginning of the second and third types.

\section{Detailed Examination}

FEMORA OF RANA CATESBIANA. BULL FROG

The femora of four bull frogs were examined, the first musually large, the second of medium size, the third and fourth small.

They showed different developments of the same type of bone (pl. 1, figs. 1-4).

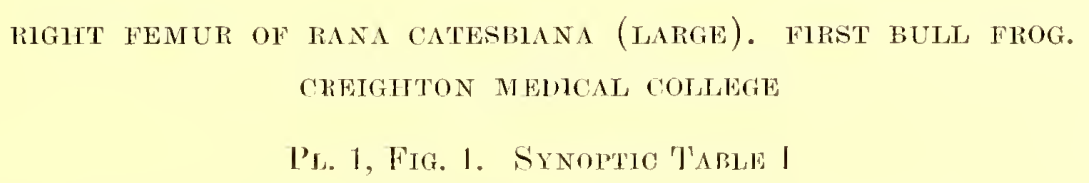

Antero-posterior liameter of bone, $3.5 \mathrm{nmm}$; lateral, $4.5 \mathrm{~mm}$.

Antero-posterior diameter of medullary canal, $1 \mathrm{~mm}$.; lateral, $2 \mathrm{~mm}$.

The medullary canal is full. Medullary index, $16 \%$.

The section is surrounded by a narrow ring of external circumferential lamellæ. Their lacune are round and oval, their canaliculi are short and bushy, and all are poorly developed. The central ring, situated between the external and internal lamellx, is interrupted ly many large, bush-like, radiating canals. The lamella are indistinet, their lacune are round and oval, and the canalienli commmnicate with the radiating canals.

The canals are just visible to the naked eye. Some of them extend from the internal to the external circumferential lamelle, some about two-thirds of that distance, and some are interrupted at various points along the way. The central ring forms about four-fifths of the thickness of the bone, is thicker in the posterior half than in the anterior, and presents a low development. 
The internal circumferential lanrelle surround the medullary canal. They are clearer than those of the external lamellæ, their lacuna are oval, their canaliculi are short and partly in the central ring, and there is a large vascular canal on its way to the medullary canal. The internal lamelle are poorly developed. The section shows a threefold division.

Type I.

RIGHT FEMUR OF RANA CATESBIANA (MEDIUM SIZED). SECOND BULL FROG. CR. MED. COLL.

1'L, 1, FIG. 2. S'YN. 'TAB. I

Antero-posterior diameter of bone, $2.5 \mathrm{~mm}$.; lateral, $3 \mathrm{~mm}$.

Antero-posterior diameter of medullary canal, $1.4 \mathrm{~mm}$. ; lateral, $1.6 \mathrm{~mm}$.

The medullary canal is full. Mednllary index, $42 \%$.

structure.-Around the bone is a very narrow ring of dense lamella containing a few, long, narrow lacunir and long eanaliculi.

In the center of the anterior wall is a notch, which is part of the nutrient ("anal. Beginning a little to the onter side of the posterior mid-line and extending around the outer wall, anterior, and about one-fourth of the inner wall, the entire thickness of the bone is composed of concentric lamella with oval lacuna and bushy canaliculi. The remaining portion of the bone is composed of concentric lamella, which are crossed by short eanals, arranged radially in twos and threes. The canals are surrounded by clear areas of bone substance, and extending from them in all directions are very fine canaliculi. The internal cireumferential lamellax are not distinet from the remaining strueture. Its peculiar feature is the gradual disappearance of the rarliating canals.

Type I.

RIGHT FEMUR OF RANA CATESBANA (SMALL). THHRD BULL FROG. CR. MED. COLL.

Pl. 1. Fig. 3. SYN. TAB. I

Antero-posterior diameter of the bone, $1 \mathrm{~mm}$; lateral, $1.3 \mathrm{~mm}$.

Antero-posterior diameter of the medullary canal, $0.5 \mathrm{~mm}$. ; lateral, $0.6 \mathrm{~mm}$.

The medullary canal is full. Nedullary index, $29 \%$.

Structure.-The section is composed of lamella, concentrically arranged around the medullary canal. There are no radiating canals. The lamella are clear, their lacunæ oval, long and narrow, and their canaliculi are long and numerous. The section has a uniform structure.

The peculiar feature is the complete disappearance of the radiating canals.

These fignres show drawings of femora taken from the same species of frogs, but of different sizes and weights. The largest (fig. 1) is lowest in development; the second in size (fig. 2) is next, and the third (fig. 3) is last 
and most complete. They are all of the first type, though of different developments. In figure 1 the radiating canals with poorly developed intervening lamellæ indicate an early stage of development. In figure 2 more than half of the canals have disappeared and better developed lamella are formed. In figure 3 all of the canals have disappeared and the whole bone is composed of concentric lamellæ.

Type I.

RIGHT FEMUR OF raNA CATESBIANA (SMALL), FOURTH BULl Frog. Cl. MEd. COLI.

Pl. 1, Fig. 4. Sin. Tab. I

Antero-posterior diameter of bone, $1 \mathrm{~mm}$.; lateral, $1.5 \mathrm{~mm}$.

Antero-posterior diameter of medullary canal, $0.5 \mathrm{~mm}$.; lateral, $0.6 \mathrm{~mm}$.

Medullary index, $24 \%$.

Structure.-The section is composed of concentric lamella with long lacma and long, straight canaliculi surrounding the medullary canal. The section has a uniform structure.

Type I.

FRACTURED AND REPAIRED FEMUR OF A FROG. CR. MED. COLl.

Pl. 1, Fig. 5. Sinn. Tha. I

Antero-posterior diameter of bone, $1.5 \mathrm{~mm}$; lateral, $1.7 \mathrm{~mm}$.

Antero-posterior diameter of medullary canal, $0.6 \mathrm{~mm}$.; lateral, $0.7 \mathrm{~mm}$.

The medullary canal is full. Medullary index, $20 \%$.

Structure.-One of the femora had been fractnred abont the mirldle of the shaft. The ends of the bone had slipped by each other, and new bone had formed around the fragments. In section (fig. 5) which was taken from the middle of the new bone, two cuts of the femur appear situated eccentrically. The sections are eomposed of concentric lamellie with oval and straight lacunx surrounding the medullary canals.

The upper fragment, H, proximal, shows cell growths bursting through the wall of the bone (pl. 1, fig. 5, A, B). In the lower fragment, D, distal, no cell outbursts appear.

Around the two fragments and extending between them is a formation of cancellous or channeled bone which is the new bone of repair. Some of the meshes of this bone are occmpied by newly deposited lamella, and resemble Haversian systems, although there are no Haversian systems or cancellons bone in the femur of the frog $(p l .1$, fig. 5 C, E). This fact suggests a genetic relationship between cancellous bone and Haversian systems.

Type I. 
RIGHT FEMUR OF AMBLYSTOMA TIGRINUM. AMER, MUS. NAT. HIS.

$$
\text { PL. 2, Fig. 6. Syn. TAB. I }
$$

Artero-posterior diameter of bone, $2 \mathrm{~mm}$. ; lateral, $2.5 \mathrm{~mm}$.

Antero-posterior diameter of medullary canal, cancellons meshes.

Medullary index, 0 .

Structure.-The section has no distinet medullary caral. It is composed of a narrow external ring of bone substance, with a few oval lacunæ and bushy ('analiculi, from the under portion of which a cancellous center is derived. The meshes are filled with structureless material, and their walls have the same structure as the walls of the bone.

Type I.

RIGHT FENUR OF HYLA VERSICOLOR. TREE FROG. AMER. MUS. NAT. HIST.

$$
\text { PL. 2, Fig. \%. SYN. 'TAB. I }
$$

Antero-posterior diameter of bone, $0.8 \mathrm{~mm}$; lateral, $0.8 \mathrm{~mm}$.

Antero-posterior diameter of medullary canal, $0.2 \mathrm{~mm}$. ; lateral, $0.2 \mathrm{~mm}$.

The medullary eanal is full. Medullary index, $7 \%$.

Structure.-The entire section is composed of lamellæ with round and oval lacuns and bushy canaliculi enclosing the medullary canal. The section has a uniform structure.

Type I.

RIGHT FEMUR OF HYLA ARENICOLOR. NO. E 50 30, U. S. NAT. MUS.

$$
\text { PL. 2, Frg. 8. SYм. T'AB. I }
$$

Antero-posterior diameter of bone, $0.5 \mathrm{~mm}$. ; lateral, $0.5 \mathrm{~mm}$.

Antero-posterior dianeter of medullary canal, $0.2 \mathrm{~mm}$.; Jateral, $0.2 \mathrm{~mm}$.

The medullary canal is full. Medullary index, $19 \%$.

Structure. - The section is composed of concentric Jamella with oval Jacuna and long, straight canaliculi, divided into wide external and narrow internal rings which surround its medullary canal, thus showing a twofold division.

Type I.

Right FEMUR OF HILA FEMORALIS. NO. E 60 23, U. S. NAT. MUS.

$$
\text { Pi. 2, Fig. 9. Srn. Tab. I }
$$

Antero-posterior diameter of bone, $0.5 \mathrm{~mm}$.; lateral, $0.4 \mathrm{~mm}$.

Antero-posterior diameter of medullary canal, $0.2 \mathrm{~mm}$.; lateral, $0.2 \mathrm{~mm}$.

The medullary canal is full. Medullary index, $24 \%$.

Structure.-The section is composed of concentric lamellæ with oval lacunæ and long canaliculi, divided into wide external and narrow internal rings which surround the medullary canal, a twofold division.

Type I. 
RIGHT FEMUR OF HYLA EVITIATA. NO. E 5517 , U. S. NAT. MUS.

Pl. 2, Fig. 10. Syx. This. I

Antero-posterior diameter of bone, $0.5 \mathrm{~mm}$.; lateral, $0.2 \mathrm{~mm}$.

Antero-posterior diameter of medullary canal, $0.4 \mathrm{~mm}$.; lateral, $0.1 \mathrm{~mm}$.

The medullary canal is full. Medullary index, $104 \%$.

Structure.-The section is composed of concentric lamelle with oval lacunir and long canaliculi, divided into wirle external and narrow internal concentric rings which surround the medullary canal, a twofold division.

Type I.

$$
\begin{aligned}
& \text { RIGHT EEMUR OF HYTA CINEREA. NO. 13095, U. S. NAT. MUS. } \\
& \text { PL. 2, Fig. } 11 \text {. SYN, TAB. I }
\end{aligned}
$$

Antero-posterior diameter of bone, $1.5 \mathrm{~mm}$.; lateral, $1 \mathrm{~mm}$.

Antero-posterior diameter of medullary canal, $0.5 \mathrm{~mm}$; ] lateral, $0.4 \mathrm{~mm}$.

The medullary canal is full. Medullary index, $14 \%$.

Structure.-The section has a long posterior process, the central position of which, from the medullary canal to the tip, is occupied by bone substance with a few oval lacunæ and branching canaliculi. The body of the section is composed of lamellæ with oval lacunæ and straiglit canaliculi. A narrow ring of internal circumferential lamelle surrounds the mednllary canal. The section shows a twofold division.

Type I.

RIGHT FEMUR OF HYLA REglLLA. NO. E 6239 , U. S. NAT. MUS.

PL. 2, Fig. 12. Syn. Taß. I

Antero-posterior diameter of bone, $1 \mathrm{~mm}$.; lateral, $0.9 \mathrm{~mm}$.

Antero-posterior diameter of medullary canal, $0.5 \mathrm{~mm}$. ; lateral, $0.5 \mathrm{~mm}$.

The medullary canal is full. Medullary index, $38 \%$.

Structure.-The section is composed of lamellæ with oval lacme and long canaliculi, divided into wide external and narrow internal rings. The internal ring forms the internal circumferential lamella. Twofold division.

Type I.

RIGHT FEMUR OF HYLA SQU1RELLA. NO. E 51 2, U. S. NAT. MUS.

PL. 2, Fig. 13. SYN. 'TAB. I

Antero-posterior diameter of bone, $0.8 \mathrm{~mm}$, lateral, $0.5 \mathrm{~mm}$.

Antero-posterior diameter of medullary canal, $0.5 \mathrm{~mm}$. ; lateral, $0.4 \mathrm{~mm}$.

The medullary canal is full. Medullary index, $92 \%$. 
Structure.-The section is triangular in shape and composed of lamellæ with round and oval lacuna and long canaliculi, divided into wide external and narrow internal rings. A vascular canal is seen in the posterior wall. The internal ring forms the internal circumferential lamellæ. Twofold division.

Type I.

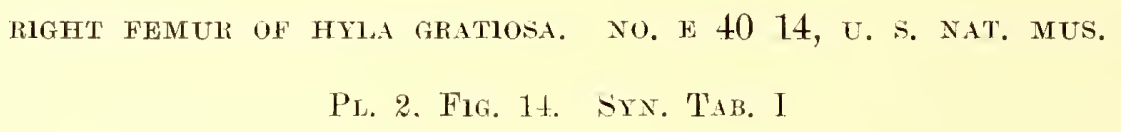

Antero-posteriox diameter of bone, $1 \mathrm{~mm}$; lateral, $0.8 \mathrm{~mm}$.

Antero-posterior diameter of medullary canal, $0.5 \mathrm{~mm}$; lateral, $0.5 \mathrm{~mm}$.

The medullary canal is full. Medullary index, $44 \%$.

Structure.-The section is composed of concentric lamella with oval lacunæ and bushy canaliculi sur'ounding the medullary canal. A narrow lamina, not parallel with the external $\omega^{*}$ medullary surfaces, forms a complete ring around the section. It approaches the medullary surface in the lateral wall and departs from it in the anterior and posterior wall.

Type I-II

RIGHT FEMUR OF DENDROBATES TINCTORIUS. NO. E 1436 , U. S. NAT. MUS.

$$
\text { PL. 2. Fug. 15. SyN. TAB. I }
$$

Antero-posterior diameter of bone, $0.6 \mathrm{~mm}$.; lateral, $0.5 \mathrm{~mm}$.

Antero-posterior diameter of medullary canal, $0.2 \mathrm{~mm}$.; lateral, $0.2 \mathrm{~mm}$.

The medullary canal is full. Medullary index, $15 \%$.

Structure. The section is composed of lamellæ with long, narrow lacunæ and long, straight canaliculi, divided into wide external and narrow internal rings. The internal ring forms the internal circumferential lamellæ. Twofold division.

Type I.

RIGHT FEMUR OF IEPTODACTYLUS ALBILABRIS. G 13 11, U. S. NAT. MUS.

$$
\text { PL. 2, FIG. 16. SYN. TAB. I }
$$

Antero-posterior diameter of bone, $1 \mathrm{~mm}$; lateral, $0.8 \mathrm{~mm}$.

Antero-posterior diameter of medullary canal, $0.8 \mathrm{~mm}$; lateral, $0.3 \mathrm{~mm}$.

The medullary canal is full. Medullary index, 59\%.

Structure.-The section is composed of lamellæ with oval lacunæ and straight canaliculi, divided into wide external and narrow internal rings. 'The internal ring forms the intermal circumferential lamellæ. Twofold division.

Type I. 
RIGHT FEMUR OF CHOROPHILUS FERIARUM. NO. E 5247 , U. S. NAT. MUS.

$$
\text { PL. 2, FIG. 1\%. SYN. TAB. I }
$$

Antero-posterior diameter of bone, $0.5 \mathrm{~mm}$; lateral, $0.4 \mathrm{~mm}$.

Antero-posterior diameter of medullary canal, $0.2 \mathrm{~mm}$; lateral, $0.2 \mathrm{~mm}$.

The medullary canal is full. Medullary index, $24 \%$.

Structure.-The section is composed of lamella with oval lacumx and straight canaliculi, divided into wide external and narrow internal rings. The internal ring forms the internal circumferential lamellæ. Twofold division.

Type I.

RIGHT FEMUR OF ACRIS GRYLLUS, U. S. NAT. MUS.

Pl. 2, FIG. 18. SYN, TaB. I

Antero-posterior diameter of bone, $0.5 \mathrm{~mm}$; lateral, $0.3 \mathrm{~mm}$.

Antero-posterior diameter of medullary canal, $0.2 \mathrm{~mm}$.; lateral, $0.1 \mathrm{~mm}$.

The medullary canal is full. Medullary index, $16 \%$.

Structure.-The section is composed of lamellæ with oval lacunx and straight canaliculi, divided into wide extemal and narow internal rings. 'The internal ring forms the internal circumferential lamellæ. 'Twofold division.

Type I.

Right FEMUR OF RANA CATESBIANA. BUll FrUg. AMER, MUS. NAT, hist.

PL. 2, Fig. 19. Sir. 'T.B. I

Antero-posterior diameter of bone, $2.5 \mathrm{~mm}$; lateral, $2.5 \mathrm{~mm}$.

Antero-posterior diameter of medullary canal, $1.5 \mathrm{~mm}$, lateral, $1.5 \mathrm{~mm}$.

The medullary canal is full. Medullary index, $56 \%$.

Structure.-The section is composed of lamella with round, oval, and long lacunæ and straight, long, thickly set canaliculi, arranged concentrically around the medullary canal. The bone is uniform.

Type I.

RIGHT FEMUR OF RANA PALUSTRIS. NO. F 52 2.2, U. S. NAT, MUS,

$$
\text { P1. 2, Fis. 20. SYx. TAR. I }
$$

Antero-posterior diameter of bone, $1 \mathrm{~mm}$; lateral, $0.8 \mathrm{~mm}$.

Antero-posterior diameter of medullary canal, $0.5 \mathrm{~mm}$.; lateral, $0.5 \mathrm{~mm}$.

The medullary canal is full. Medullary index, $44 \%$.

Structure.-The section is composed of concentric lamella with round and oval lacunæ and bushy canaliculi, separated into two concentric rings. The positions of the lacums and canaliculi give a radiating effect. The internal ring forms the internal circumferential lamellæ. Twofold division.

Type I. 
Right FeMUr of rana areolata circulosa. No. F 72 3, U. S. NAT. MUS.

$$
\text { Pl. 2, Fig. 21. Syn. TAB. I }
$$

Antero-posterior diameter of bone, $2 \mathrm{~mm}$; lateral, $2 \mathrm{~mm}$.

Antero-posterior diameter of medullary canal, $1.5 \mathrm{~mm}$.; lateral, $1.4 \mathrm{~mm}$.

The medullary canal is full. Medullary index, $110 \%$.

Structure.-The section is composed of concentric lamellæ with oval lacunæ and bushy canaliculi surrounding the medullary canal. The bone is uniform in structure. A portion of the nutrient canal is seen.

Type I.

Right remut of rana agilis aUrora. No. F 50 10, t. s. Nat. mus.

$$
\text { Pl, 2, Fig, 22. Syn. Thi, I }
$$

Antero-posterior diameter of bone, $1.5 \mathrm{~mm}$. ; lateral, $1 \mathrm{~mm}$.

Antero-posterior diameter of medullary canal, $0.5 \mathrm{~mm}$.; lateral, $0.5 \mathrm{~mm}$.

The medullary canal is full. Medullary index, $19 \%$.

Structure.-The section is composed of lamellie with oval lacunie and straight canaliculi smrounding the medullary canal, and divided into dim, wide external and narrow internal rings. Twofold division.

Type I.

$$
\begin{aligned}
& \text { hight fenur of raxa pretiosa. xo. y } 7511 \text {, l. s. Nat. mets. } \\
& \text { Pe. 2, Fig. 23. Syx. Tab. I }
\end{aligned}
$$

Antero-posterior diameter of bone, $2 \mathrm{~mm}$; lateral, $1.5 \mathrm{~mm}$.

Antero-posterior diameter of medullary canal, $1 \mathrm{~mm}$.; lateral, $0.8 \mathrm{~mm}$.

The medullary canal is full. Medullary index, $41 \%$.

Structure.-The section is composed of lamelle with round and oval lacune and bushy canaliculi, dimly separated into four or five concentric divisions. In some portions of the section a few radiating canals are seen.

Type I.

RIGHT FEMUT OF RANA DRAYTONII. NO. F 70 14, U. S. NAT. MUS.

$$
\text { Pl. 2, Fig. 24. Syn. Tab. I }
$$

Antero-posterior diameter of bone, $3 \mathrm{~mm}$; lateral, $3 \mathrm{~mm}$.

Antero-posterior diameter of medullary canal, $1.5 \mathrm{~mm}$; lateral, $1.5 \mathrm{~mm}$.

The medullary canal is full and eccentrically situated. Medullary index, $33 \%$.

Structure.-The section is composed of lamellæ with round and oval lacunæ and bushy canaliculi surrounding the medullary canal. The lacunæ are generally arranged in concentric rows and their bushy canaliculi extend outward 
from them. The canaliculi frequently unite and form a fine network. In some parts of the section there are large radiating canals extending the whole width of the walls of the bone. These canals communicate with adjacent lacunæ by fine canaliculi. The section as a whole has a bushy appearance. The large radiating canals seem to be found only in the frogs of large size.

Type I.

RIGHT FEMUR OF sPELERPES PUBER. RED SALAMANDER. AMER. MUS. NAT. HIST.

$$
\text { P'L. 2, FIG. 25. SYX. 'T'Bв. I }
$$

Antero-posterior diameter of bone, $1 \mathrm{~mm}$.; lateral, $1.5 \mathrm{~mm}$.

Antero-posterior diameter of medullary canal, $0.3 \mathrm{~mm}$; ; lateral, $0.2 \mathrm{~mm}$.

The medullary anal is full. Medullary index, $4 \%$.

Structure--The entire section is composed of lamelle witl elongated lacunx and bushy canaliculi enclosing the medullary canal. The bone has a uniform structure.

Type $\mathrm{I}$.

RIGHT FEMUR OF CRLPTOBRANCHUS ALIEGHENIENSIS. HELLBENDER.

AMER, MUS, NAT. HIST.

Pt. 2, Fig. 26. Srn. Taß. I

Antero-posterior diameter of bone, $2.5 \mathrm{~mm}$.; lateral, $1.5 \mathrm{~mm}$.

Antero-posterior diameter of medullary canal, $0.5 \mathrm{~mm}$.; lateral, $0.5 \mathrm{~mm}$.

The medullary canal is full. Medullary index, $7 \%$.

Structure.-Witl the exception of a few lamella around the medullary canal the entire section is composed of round and oval lacunæ witl bushy canaliculi embedded in bone substance and arranged concentrically around the medullary canal. The medullary canal is relatively small. A slight structural differentiation appears in the lamella around the medullary calnal. Twofold division.

Type I.

Right FEMUR OF NECTURUS MACUlates. AMER. MUS. NAT. HIST,

$$
\text { PL, 2, FIG. 2\%. SYN. T.Mr. I }
$$

Antero-posterior diameter of bone, $2 \mathrm{~mm}$.; lateral, $1.5 \mathrm{~mm}$.

Antero-posterior diameter of medullary canal, $0.5 \mathrm{~mm}$.; lateral, $0.5 \mathrm{~mm}$.

The medullary canal is full. Medullary index, $9 \%$.

Structure--Around the section are a few enclosing lamella with rather long lacunx. Nearly the entire section is composed of large, oval, round, and elongated lacunæ with bushy canaliculi arranged radially between enclosing lamellæ. The arrangement of the lacunæ is such as to give a radiating appear- 
ance. Around the medullary canal are a few lamellæ with long lacunæ and long and straight canaliculi. Threefold division.

Type $\mathrm{I}$.

RIGHT FEMUR OF SCAPIIOPLS HOLBROOKII. SPADEFOOT TOAD. AMER. MUS. NAT. HIST,

$$
\text { P'L. 2, FIG. 28. SYX. TAB. I }
$$

Antero-posterior diameter of bone, $1.5 \mathrm{~mm}$.; lateral, $1 \mathrm{~mm}$.

Antero-posterior diameter of medullary canal, $0.5 \mathrm{~mm}$. ; lateral, $0.5 \mathrm{~mm}$.

The medullary canal is full. Medullary index, $11 \%$.

structure.-The section is composed of two divisions, one, external, composed of concentric lamelle with round and oval lacume and long, straight canaliculi, and the other, internal, composed of circumferential lamellæ with long, narrow lacunæ and long, straight canaliculi. Twofold division.

Type $\mathrm{I}$.

RIGHT FEMUR OF SCAPHIOPUS COUCIIII. NO. F 50 20, U. S. NAT. MUS.

$$
\text { Pu. 2. Fri. 29. SrN. Tab. I }
$$

Antero-posierior diameter of bone, $1 \mathrm{~mm}$.; lateral, $1.5 \mathrm{~mm}$.

Antero-posterior diameter of medullary canal, $0.5 \mathrm{~mm}$.; lateral, $0.6 \mathrm{~mm}$.

Medullary canal is full. Medullary index, $24 \%$.

Structure.-The section is composed of lamellæ with long lacunæ and bushy canaliculi, indistinctly divided into concentric rings which surround the medullary canal.

Type I.

RIGHT FEMUR OF SCAPHIOPUS HAHMONDH. NO. F 20 6, U. S. NAT. MUS.

$$
\text { PL. 2. Fig. } 30 \text {. Sin. Tab. I }
$$

Antero-posterior diameter of bone, $1 \mathrm{~mm}$.; lateral, $0.8 \mathrm{~mm}$.

Antero-posterior diameter of medullary eanal, $0.5 \mathrm{~mm}$.; lateral, $0.4 \mathrm{~mm}$.

The medullary canal is full. Medullary index, $33 \%$.

Structure.-The section is composed of concentric rings of lamellæ surrounding a central medullary canal. The lacune are oval and the canaliculi are long.

Type 1 .

RIGHT FEMUR OF PIPA AMERICANA. SURINAM TOAD. AMER. MUS. NAT. HIST.

PL. 3, Fig. 31. SyN. TAB. I

Antero-posterior diameter of bone, $3.5 \mathrm{~mm}$; lateral, $5.5 \mathrm{~mm}$.

Antero-posterior diameter of medullary canal, $0.8 \mathrm{~mm}$.; lateral, $0.8 \mathrm{~mm}$.

'The medullary canal is full. Medullary index, $3 \%$. 
Structure.-The section is surrounded by a wide ring of lamella with long lacunæ and rather infrequent bushy canaliculi, interrupted by Haversian canals of the (Ia) differentiation. The ring is widest in the lateral walls. The canals appear in eross and oblique sections. Underneath this ring is a wide, central ring composed of crude lamellix with oval lacume and relatively few canaliculi, enclosing large, irregularly shaped canals with surrounding, clear areas and presenting a general conrentric arrangement. A few internal circunferential lamellæ with long lacunæ surround the medullary canal. Two large, open, round spaces appear, one in the inner posterior wall and the other in the outer lateral wall. The femur shows the three usual divisions-external cireumferential lamellie, central ring, internal circumferential lamellæ and primitive Haversian canals-all of which indicate slight advancement. Structural differentiation is shown by the three divisions and primitive Haversian canals.

Type I-III, Ia.

Right femur of bUfo agua. Bermuda toAd. NO. 1113, amer. mus. nat. hist.

$$
\text { PL. 3, Fig. 32. SYN. TAB. I }
$$

Antero-posterior diameter of bone, $5 \mathrm{~mm}$; lateral, $3.5 \mathrm{~mm}$.

Antero-posterior diameter of medullary canal, $2.5 \mathrm{~mm}$; lateral, $2 \mathrm{~mm}$.

The medullary canal is full. Medullary index, $39 \%$.

Structure.-The section is surrounded by a wide band of bone substance with long, obliquely arranged lacunæ and straight canaliculi, interrupted by round, oval, and elongated filled canals around which are clear areas ( $\mathrm{Ta}$, differentiation). Underneath this band is a wide central ring of lamellæ with oval lacunæ and bushy canaliculi, interrupted by elongated and oval-filled canals surrounded by clear areas of bone substance (Ia, differentiation). Fine canaliculi pass from these canals to adjacent lacune. The canals mark the beginning of Haversian systems. Around the medullary canal is a narrow ring of lamella with oval lacuna and bushy canaliculi. Threefold division.

Type I-III, Ia.

Right FEMUR OF BUFO IIALOPIHLUS. NO. E 35 8, U. S. NAT. MUS.

$$
\text { PL. 3, Fig. 33. Syn. TAB. I }
$$

Antero-posterior diameter of bone, $2 \mathrm{~mm}$, lateral, $2 \mathrm{~mm}$.

Antero-posterior diameter of medullary canal, $1.5 \mathrm{~mm}$.; lateral, $1.5 \mathrm{~mm}$.

The medullary canal is full. Medullary index, $129 \%$.

Structure.-The strurture shows the three divisions. The external circumferential lamella form a narrow boundary ring. The central ring constitutes most all of the section, and is composed of lamelle with oval lacune and bushy canaliculi. In the anterior and posterior walls the ring is traversed by 
Haversian canals of the (Ta) differentiation. Internal cireumferential lamellæ form a narrow ring around the medullary canal.

Type I-III, Ia.

RIGITT FEMUR OF BUFO COLUMBIENSIA. NO. E 40, U. S. NAT. MUS.

$$
\text { PL. 3, Fig. 3t. Syn. 'TAB. I }
$$

Antero-posterior diameter of bone, $2 \mathrm{~mm}$; lateral, $2 \mathrm{~mm}$.

Antero-posterior diameter of medullary canal, $1.4 \mathrm{~mm}$.; lateral, $1.5 \mathrm{~mm}$.

The medullary canal is full. Medullary index, $111 \%$.

Structure.-The section shows the three divisions, external circumferential lamellæ very thin, central ring of lamellæ, and internal circunferential lamellæ. The external lamelle are little more than a condensation of the external portion of the central ring. The central ring consists of concentric lamellæ with oval lacunæ. In the posterior and part of the lateral walls, oval laeunæ with bushy canaliculi are crowded together between the central ring and internal lamellæ. A few canals appear in the inner wall. The internal circumferential lamella form a narrow ring around the medullary canal.

Type I-III, Ta.

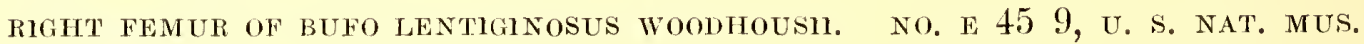

$$
\text { PL. 3, F1G. 35. Syx. 'TAB. I }
$$

Antero-posterior diameter of bone, $2.5 \mathrm{~mm}$; lateral, $2 \mathrm{~mm}$.

Antero-posterior diameter of medullary canal, $1.5 \mathrm{~mm}$; lateral, $1 \mathrm{~mm}$.

The medullary canal is full. Medullary index, $45 \%$.

Structure.-The section is composed of a thick ring of concentric lamellæ with oval lacunx, erossed by numerous radiating canals and perforated by a few Haversian canals ( Ia). Internal circumferential lamella form a narrow ling around the medullary canal. Twofold division.

Type I-III, Ia.

RIGHT FEMUR OF BUFO AMERICANUS. AMERICAN TOAD. AMER. MUS. NAT. HIST.

$$
\text { Ph. 3, Frg. 36. Srn. TAls. I }
$$

Antero-posterior diameter of bone, $2.5 \mathrm{~mm}$; ] lateral, $2 \mathrm{~mm}$.

Antero-posterior diameter of medullary canal, $1 \mathrm{~mm}$. ; lateral, $0.6 \mathrm{~mm}$.

The medullary canal is full. Medullary index, $15 \%$.

Structure.-The section is surrounded by a wide band of lamellæe with oral lacuna and bushy canaliculi, interrupted by frequent Haversian canals of the (Ia) differentiation. The band is widest in the anterior and inner walls. 
Underneath this band is a single lamina with long, well-developed lacunæ and straight canaliculi, parallel with neither surface of the bone, but occupying an irregular position.

Underneath the lamina is a wide central ring of lamellæ with oval lacunæ and bushy canaliculi, interrupted by frequent Haversian canals of the (Ia) differentiation. A narrow ring of internal circumferential lamellie surrounds the medullary canal. Threefold division.

Type I-II-III, Ia.

RIGHT FEMUR OF BUFO LENTIGINOSUS COGNATUS, No, 13 11, U. S. NAT, MUS,

PL. 3, Fig. 3\%. Syn. TAB. I

Antero-posterior diameter of bone, $2 \mathrm{~mm}$; lateral, $1.5 \mathrm{~mm}$.

Antero-posterior diameter of medullary canal, $1 \mathrm{~mm}$.; lateral, $0.9 \mathrm{~mm}$.

The medullary canal is full. Medullary index, $42 \%$.

Structure.-The three divisions are evident. The external circumferential lamella, with long lacunæ and straight canaliculi, surround the section. The central ring is composed of lamellæ with oval lacunæ perforated by Haversian canals of the ( $\mathrm{Ia}$ ) differentiation. The internal circunferential lamella form a narrow ring around the medullary canal.

Type I-III, Ia.

RIGHT FEMUR OF BUFO VALLICEPS. NO. E 21 5, U. S. NAT. MUS.

Pl. 3, Frg. 38. Syn. Tab. I

Antero-posterior diameter of bone, $2 \mathrm{~mm}$; lateral, $1.5 \mathrm{~mm}$.

Antero-posterior diameter of medullary canal, $0.9 \mathrm{~mm}$. ateral, $0.8 \mathrm{~mm}$.

The medullary canal is full. Medullary index, $31 \%$.

Structure.--The section is surrounded by a thick band of lamelle witlı oval lacune and bushy canaliculi. It is perforated by numerous Haversian canals of the (Ia) differentiation. In the inner wall many radiating eanals appear. The canaliculi from adjacent lacune extend into both the circular and radiating canals. A narrow ring of internal circumferential lamellæ encloses the medullary canal. Twofold division.

Type T-III, Ia.

$$
\begin{gathered}
\text { RIGHT FEMUP OF RANA BOYLII. NO. F } 61 \text { 20, U. S. NAT, MUS. } \\
\text { PL. 3, FIG. 39. NYN. TAB. } 1
\end{gathered}
$$

Antero-posterior diameter of bone, $1 \mathrm{~mm}$; lateral, $0.6 \mathrm{~mm}$.

Antero-posterior diameter of medullary canal, $0.5 \mathrm{~mm}$.; lateral, $0.4 \mathrm{~mm}$.

The medullary canal is full. Medullary index, $47 \%$. 
Structure.-The section is composed of two parts, viz.: A wide ring of external lamellæ with oval lacunæ and bushy canaliculi, and a narrow ring of internal lamellæ with long, narrow lacunæ and straight canaliculi around the medullary canal. Twofold division.

Type I.

\section{REPTILES}

Thirty-four femora were examined.

\section{General Chalacter of the Femur}

The general shape of the reptilian femur varies considerably. The triangular, elliptical, round, and indeterminate forms are present. The majority are elliptical. In some sections the antero-posterior diameters are longest, as in many of the lizards, and in others the lateral diameter's are longest, as in the turtles.

The contents of the medullary canals are variable in character. In the lizards they are filled with marrow and in the turtle with cancellous bone, the meshes of which are filled with marrow.

The medullary surfaces are smooth in the small, and rough in the large, femora.

The medullary index varies from 0 to $88 \%$ with an average of $26.1 \%$. Excluding the turtles, in most of which the index is zero, the average is $33 \%$.

The reptilian femora follow about the same kind of development as was seen in the amphibians, but the development is carried further.

The first type of bone predominates in both amphibians and reptiles. Haversian canals, (Ia) stage, appear in the amphibians, while a better developed form of Haversian system, ( $\mathrm{Ib}$ ) stage, is found in some of the reptiles. In the amphibians the external, internal circumferential lamellæ, and central ring appear, while in the reptiles these divisions are not prominent. Cancellous bone was found in one amphibian, the Amblystoma. It does not appear in the lizards, and is a characteristic structure of turtles.

\section{Detailed Examination}

Right FEMUR of SPHENOdon PUNCTATA (MOST Primitive of reptiles).

AMER. MUS. NAT. HIST.

Pu. 3, Fig. 40. Syn. Tal. II

Antero-posterior diameter of bone, $3 \mathrm{~mm}$.; lateral, $2.5 \mathrm{~mm}$.

Antero-posterior diameter of medullary (anal, $1.5 \mathrm{~mm}$.; lateral, $1 \mathrm{~mm}$.

The medullary canal is full. Medullary index, $26 \%$.

Structure.-The section is composed entirely of concentric lamella with oval lacunæe and bushy canaliculi surrounding the medullary canal. A large 
vascular canal appears in the imner and posterior wall. There is very little differentiation of structme. The bone is uniform.

Type I.

RIGHT FENUR OH PHRTNOSOMA CORNUTUM. TEXAS HORNED TOAD. NO. 1:200, AMER. MUS. NAT. HIST.

$$
\text { Pe. 3, Fiti. +1. Srx. T'Al. } 11
$$

Antero-posterior diameter of bone, ‥8 $\mathrm{mmm}$; lateral, $1.5 \mathrm{~mm}$.

Antero-posterior diameter of medullary canal, $0.8 \mathrm{~mm}$.; lateral, $0.5 \mathrm{~mm}$.

The medullary canal is full. Medullary index, $10 \%$.

Structure. -The section is composed of concentric lanellie with long and oval lacune and straight and bushy canaliculi surrounding the medullary canal. 'The lacune of the external portion are long and narrow with straight canaliculi, and those of the medullary portion are oval with bushy canaliculi. There is very little differentiation of structure. The seetion shows an indistinct twofold division.

Type 1.

Left femur of Chameleo vulgaris. CHAMeleon. No. 135, amer. MUts. Nat. hist.

$$
\text { P'L. 3, Fitr. 42. Stx. TAB. II }
$$

Antero-posterior diameter of bone, $1.8 \mathrm{~mm}$; lateral, $1.5 \mathrm{~mm}$.

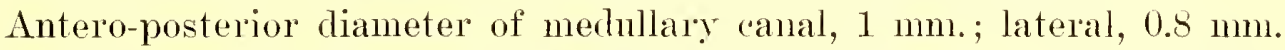

The medullary canal is full. Merlullary index, $42 \%$.

Structure.-The section is composed of an external ring of lamella with oval lacunæ and bushy canaliculi. The lacunæ tend to flatten as they reach the external surface. In the posterior wall the lacune are large and nearly round. Underneath this ring is another of lamellæ with oval lacunæ and bushy canaliculi. The two rings are separated by concentric, central lacune closely packed together. The bone shows an indistinet twofold division.

Type 1.

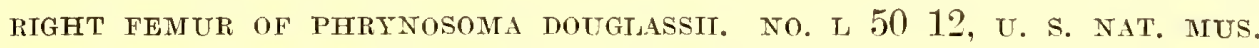

$$
\text { Pt. 3, Fig. 43. Syx. TАв. II }
$$

Antero-posterior diameter of bone, $2 \mathrm{~mm}$.; lateral, $1 \mathrm{~mm}$.

Antero-posterior diameter of medullary canal, $0.5 \mathrm{~mm}$. ; lateral, $0.5 \mathrm{~mm}$.

The medullary canal is full. Medullary index, $12 \%$.

Structure.-The section is composed of concentric lamelli with oval lacunæ and long canaliculi surrounding the medullary canal. Little or no differentiation has occurrer. The section has a nniform structure.

Type I. 
RIGHT FEMUR OF PTYCHOZOON HOMALOCEPHALUM-GECKO. NO. 684 AMER, MUS. NAT. HIST.

$$
\text { PL. 3, FIg. 1t. SYN. 'TAB. } 11
$$

Antero-posterior diameter of bone, $1 \mathrm{~mm}$.; lateral, $0.8 \mathrm{~mm}$.

Antero-posterior diameter of mednllary canal, $0.5 \mathrm{~mm}$; lateral, $0.4 \mathrm{~mm}$. The mednllary canal is full. Medullary index, $33 \%$.

Structure.-The section is composed of concentric lamella with long lacumæ and long, straight canaliculi surrounding the medullary caual. Very little differentiation appears. The section is miform.

Type I.

RIGTT FEMUR OF IGUANA TUBERCULATA. AMER. MUS. NAT. HIST.

$$
\text { PI. 3. FIf. 15. SYN. TML, II }
$$

Antero-posterior diameter of bone, $3.5 \mathrm{~mm}$.; lateral, $3 \mathrm{~mm}$.

Antero-posterior diameter of medullary canal, ¿ mm.; lateral, 2 mm.

The medullary anal is full. Medullary index, $61 \%$.

Structure.-The section is composed of concentric lamella with long lacuna and long, straight canaliculi surrounding the medullary canal. The posterior wall is thickest and shows a column of oval lacunæ and their lamellæ extending from the medullary canal toward the external posterior surface. Very little differentiation of structure appears. The section is uniform.

Type I.

$$
\begin{aligned}
& \text { IEFT FEMUR OF VARANUS SALFATOR. AMER. MLS. NAT. HIST. } \\
& \text { PL. 3, FIG. HG. STA. TAB. II }
\end{aligned}
$$

Antero-posterior diameter of bone, $11 \mathrm{~mm}$; lateral, $10 \mathrm{~mm}$.

Antero-posterior diameter of medullary canal, $7 \mathrm{~mm}$; lateral, $6 \mathrm{~mm}$.

The medullary canal is full. Medullary index, $51 \%$.

Structure.-The section is composed of concentric lamella with long and oval lacunx and bushy canaliculi surrounding the bone, with the exception of the posterior wall. The lamellæe are partially separated into lamina by concentric rows of long lacuns placed end to end. Numerous short canals, parallel to each other and radiating from the medullary canal, cross the lamellæ. Around the canals are clear areas of bone substance crossed in many instances by fine canaliculi. In the posterior and imner wall the concentric lamellæ are displaced by canals and oval lacuna with bushy canaliculi extending from the external surface to the medullary canal. The canals mark the locations of future Haversian systems. Fragments of lamellæ surround the medullary canal. In the 
posterior wall a little cancellous bone appears. The bone shows an early differentiation by its traces of laminx and Haversian canals.

Type I-III, Ia.

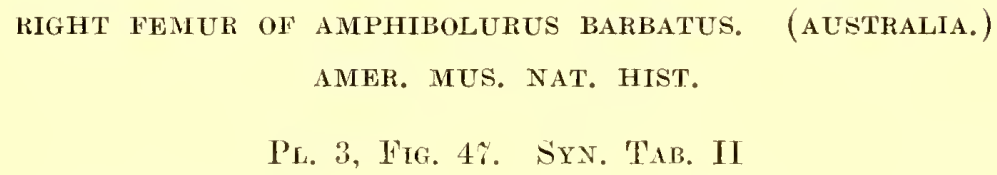

Antero-posterior diameter of bone, $3 \mathrm{~mm}$.; lateral, $4 \mathrm{~mm}$.

Antero-posterior diameter of medullary canal, $1.5 \mathrm{~mm}$.; lateral, $2.5 \mathrm{~mm}$.

The medullary canal is full. Medullary index, $49 \%$.

Structure.-The section is composed of concentric lamellæ with long and oval lacunæ and long, straight canaliculi surrounding the medullary canal. No differentiation of structure is present. A large, vascular canal appears in the inner wall. The section is uniform.

Type I.

LEFT FEMUR OF VARANUS ARENARIUS. AMER. MUS. NAT, HIST,

PL. 3, Fig. 48. SYN. TAB. II

Antero-posterior diameter of bone, $4.5 \mathrm{~mm}$.; lateral, $3 \mathrm{~mm}$.

Antero-posterior diameter of medullary canal, $3 \mathrm{~mm}$.; lateral, $2 \mathrm{~mm}$.

The medullary canal is full. Medullary index, $45 \%$.

Structure.-The section is composed of concentric lamellæ with oval lacunæ and bushy canaliculi arranged around the medullary canal. Many small canals traverse the walls of the bone radially from the medullary canal outward and from the external surface inward. There is very little differentiation of structure. The section is uniform.

Type I.

RIGHT FEMUR OF VARANUS NUCHALIS. MONITOR. AMER, MUS. NAT, HIST.

$$
\text { PL. 3, Frg. 49. S'YN. T.'АB. II }
$$

Antero-posterior diameter of bone, $4.5 \mathrm{~mm}$. ; lateral, $3.5 \mathrm{~mm}$.

Antero-posterior diameter of medullary canal, $3 \mathrm{~mm}$. ; lateral, $2.5 \mathrm{~mm}$.

The medullary canal is full. Medullary index, $88 \%$.

Structure. - With the exception of a small area of lamelle along the medullary surface of the posterior wall, the section is composed of concentrie lamella with oval lacunæ and bushy canaliculi, interrupted by a large number of short. radiating canals around which are clear areas of bone substance. In the pos- 
terior wall the canals are circular in cross-section, elsewhere they are long. The bone shows a little differentiation of structure.

Type I-III, Ia.

RIGHT FEMUR OF HELODERMA SUSPECTUM. GILA MONSTER. NO. 583, AMER, MUS. NAT. HIST.

PL. 4, Fig. 50. Syn. Tab. II

Antero-posterior diameter of bone, $3 \mathrm{~mm}$.; lateral, $3 \mathrm{~mm}$.

Antero-posterior diameter of medullary canal, $0.7 \mathrm{~mm}$; lateral, $0.7 \mathrm{~mm}$.

The medullary canal is full. Medullary index, $5 \%$.

Structure.-The section is composed of concentric lamellæ having oval and long lacunæ with bushy and straight canaliculi indistinctly outlined in laminæ. 'The external lamellæ show long lacunæ and rather straight canaliculi, the remaining lamellæ, oval lacunæ and bushy canaliculi. Around the medullary canal is an enclosing ring of lamellæe with lacune and long, straight canaliculi. The bone shows traces of differentiation into the three main divisions - external, a central ring, and internal circumferential lamellæ. There is no trace of an Haversian system.

Type I.

RIGHT FEMUR OF SCELOPORUS CLARKI1. NO. 161 17, U. S. NAT. MUS,

PL. 4, Fig. jl. Srx. TAr. II

Antero-posterior diameter of bone, $1.5 \mathrm{~mm}$.; lateral, $1.5 \mathrm{~mm}$.

Antero-posterior diameter of medullary canal, $0.5 \mathrm{~mm}$.; lateral, $0.5 \mathrm{~mm}$.

The medullary canal is full. Medullary index, $12 \%$.

Structure.-The section is composed of concentric lamellæ with oval lacunx and bushy canaliculi surrounding the medullary canal. There is no differentia tion of structure. The section is uniform.

Type I.

RIGHT FEMUR OF SCELOPORUS SPINOSUS FLORIDANUS. No. 173 12,

U. S. NAT. MUS.

PL, 4, FIG. 52. SYN. 'TA3. II

Antero-posterior diameter of bone, $1.5 \mathrm{~mm}$; lateral, $1.5 \mathrm{~mm}$.

Antero-posterior diameter of medullary canal, $0.5 \mathrm{~mm}$; lateral, $0.5 \mathrm{~mm}$.

The medullary canal is full. Medullary index, $12 \%$.

Structure.-The section is composed of concentric lamellæ with long lacunæ and straight canaliculi surrounding the medullary canal. There is no differentiation of structure. The section is uniform.

Type I. 
RIGHT FEMUR OE SCELOPORUS OCCIDENTALIS, NO. 1743 , 4 . S. NAT, MUS.

$$
\text { PL. 4. F'G. 53. SYX. 'TAB. II }
$$

Antero-posterior diameter of bone, $1.5 \mathrm{~mm}$.; lateral, $1 \mathrm{~mm}$.

Antero-posterior diameter of medullary canal, $0.6 \mathrm{~mm}$; lateral, $0.5 \mathrm{~mm}$.

'The medullary canal is full. Medullary index, $24 \%$.

Structure.-The section is composed of lamella with oval and long lacumx and straight canalicnli snrrounding the medullary ranal. There is no differentiation of structure.

Type I.

Right FEMUR OF SCELOPORUS MAGRTER. NO. J 71 2, U. S. NAT. MUS.

$$
\text { PL. +, FIa. 5t. Syx, 1'A3. II }
$$

Antero-posterior diameter of bone, $1.5 \mathrm{~mm}$; lateral, $1 \mathrm{~mm}$.

Antero-posterior diameter of mednllary canal, $0.5 \mathrm{mmm}$; lateral, $0.5 \mathrm{~mm}$.

The mednllary canal is full. Medullary index, $19 \%$.

Structure.-The section is composed of concentric lamella with oral lacuma and bushy camaliculi surromuding the medullary canal. 'There is no differentiation of structure.

Type I.

BIGHT FEMUR OF CYClITH CARINATA. I'. S. NAT. MUS.

$$
\text { Pe. 1. Fur. in. Sras. Tak. } 11
$$

Antero-posterior diameter of bone, $5 \mathrm{~mm}$; lateral, $5 \mathrm{~mm}$.

Antero-posterior diameter of medullary canal, $3 \mathrm{~mm}$.; lateral, $3 \mathrm{~mm}$.

The medullary canal is full. Medullary index, $56 \%$.

Structure.-The section is composed of concentric lamellæ with oval lacunæ and straight canaliculi surrounding the medullary caulal. There is very little differentiation of structure. The section is uniform.

\section{Type I.}

RIGHT FEMUR OF ANOLTS CRISTATELlUS. NO. L 1513 , U. S. NAT. MUS.

$$
\text { PL. 4. Fic. j6. SYN. TAв. II }
$$

Antero-posterior diameter of bone, $1 \mathrm{~mm}$; lateral, $1 \mathrm{~mm}$.

Antero-posterior diameter of medullary canal, $0.5 \mathrm{~mm}$; lateral, $0.5 \mathrm{~mm}$.

The medullary canal is full. Medullary index, $33 \%$.

Structure.-The section is composed of two rings of lamellæ, external and internal. The external has long lacunæ with straight canalicnli and the internal, oval and round lacunre with bushy canaliculi. They are of nearly equal width. There is very little differentiation of structure. The section shows the twofold division.

Type I. 
RIGHT FEMUR OF CROTAPHYTUS COLlaris. NO. J 2112 , U. S. NAT. MUS.

$$
\text { PL. 4, Fig. 5\%. SxN. TAB. II }
$$

Antero-posterior diameter of bone, $1.5 \mathrm{~mm}$. ; lateral, $1.5 \mathrm{~mm}$.

Antero-posterior diameter of medullary canal, $1 \mathrm{~mm}$.; lateral, $1 \mathrm{~mm}$.

The medullary canal is full. Medullary index, $80 \%$.

Structure.-The section is composed of two concentric rings of lamellæ surrounding the medullary canal. The external ring has long lacunæ and straight canaliculi, the internal, oval lacuna and bushy canaliculi. The section shows the twofold division.

Type I.

LEFT FEMUR OF CROTAPHYTUS COLLARIS, NO. J 32 9, T. S. NAT, MUS.

$$
\text { Pl. 4. Fig. 58. Sir. 'TAB. II }
$$

Antero-posterior diameter of bone, $1.5 \mathrm{~mm}$.; lateral, $1.5 \mathrm{~mm}$.

Antero-posterior diameter of medullary canal, $0.8 \mathrm{~mm}$. ; lateral, $0.8 \mathrm{~mm}$.

The medullary canal is full. Medullary index, $40 \%$.

Structure.-The section is composed of two concentric rings of lamellæ surrounding the medullary canal. The external has long lacunæ and straight canaliculi, the internal, oval lacunæ and bushy canaliculi. The section shows the twofold division.

Type I.

right femur of ameiva exul. (CAya de santiago, porto rico.) No. L 2111. U. S. NAT, MUS.

Pr. 4, Fig. 59. Syn. Tab. II

Antero-posterior diameter of bone, $2 \mathrm{~mm}$. ; lateral, $2 \mathrm{~mm}$.

Antero-posterior diameter of medullary canal, $0.5 \mathrm{~mm}$.; lateral, $0.5 \mathrm{~mm}$.

The medullary canal is full. Medullary index. $33 \%$.

Structure.-The section is composed of concentric lamellæ with oval and long lacune and straight canaliculi surrounding the medullary canal. There is very little differentiation of structure. The section is uniform.

Type I.

RlGHT FEMUR OE EUMECES FASCIATUS. NO. H 31 4, U. S. NAT. MUS.

$$
\text { Pr. t, Fig. 60. Sin. TAв. II }
$$

Antero-posterior diameter of bone, $1.5 \mathrm{~mm}$.; lateral, $1 \mathrm{~mm}$.

Antero-posterior diameter of medullary canal, $0.6 \mathrm{~mm}$. ; lateral, $0.5 \mathrm{~mm}$.

The medullary canal is full. Medullary index, $24 \%$.

Structure.-The section is composed of lamellæ with oval lacunæ and bushy canaliculi dimly outlined in lamine. There is little differentiation of structure.

Type I. 
RIGHT FEMUR OF SAUROMALUS. NO. J 406 , U. S. NAT. MUS.

PL. 4, FIg. 61. Syn. 'T'AB. II

Antero-posterior diameter of bone, $3 \mathrm{~mm}$.; lateral, $2.5 \mathrm{~mm}$.

Antero-posterior diameter of medullary canal, $1.5 \mathrm{~mm}$; lateral, $1.2 \mathrm{~mm}$.

The medullary canal is full. Medullary index, $32 \%$.

Structure.-The section is composed of concentric lanells with oval lacunæ and straight canaliculi partially divided into concentric rings. A vascular canal is seen in the posterior inner wall. A narrow ring of lamella with long lacunxe and straight canaliculi surrounds the medullary canal.

Type I.

RIGHT FEMUR OF GERRHONOTUS GRANDIS. NO. 122 4, U. S. NAT. MUS,

PL. 4, Fig. 62. Syn. Tab. II

Antero-posterior diameter of bone, $1.5 \mathrm{~mm}$.; lateral, $1 \mathrm{~mm}$.

Antero-posterior diameter of medullary canal, $0.4 \mathrm{~mm}$; lateral, $0.4 \mathrm{~mm}$.

The medullary canal is full. Medullary index, $11 \%$.

Structure.-The section is composed of concentric lamellæ with oval and long lacunx and straight and bushy canaliculi. Around the posterior and lateral medullary surface is a crescent of basic bone substance with round lacune and bushy canaliculi.

Type I.

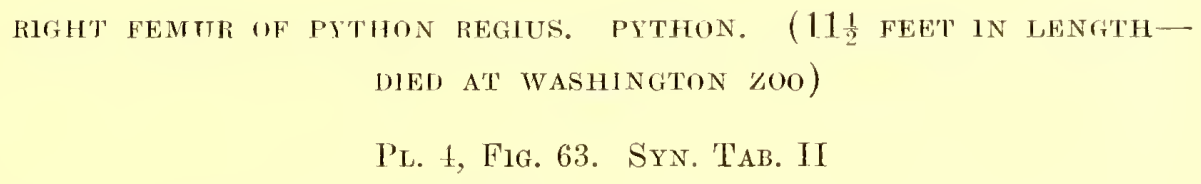

Antero-posterior diameter of bone, $1 \mathrm{~mm}$; lateral, $0.6 \mathrm{~mm}$.

Antero-posterior diameter of medullary canal, 0.4 mun.; lateral, $0.3 \mathrm{~mm}$.

The medullary canal is full. Medullary index, $24 \%$.

Structure.-The femmr is rudimentary. The section is composed of lamella arranged in a peculiar manner. In the anterior wall they are arranged concentrically around a semicircle with a short radius. In the lateral and posterior wall the lamella take a long curve from the medullary surface of the anterior wall. The lacunx are round and the canalicnli are bushy. The anterior wall is best developed. A narrow ring of internal lamellæ with long lacmna and straight canaliculi surrounds the medullary canal.

Type I. 
LEFT FEMUR OF TIE SAME PYTHON REGIUS. U. S. NAT. MUS.

Pl. 4, Fig. 64. Syn. TAB. II

Antero-posterior diameter of bone, $1 \mathrm{~mm}$; lateral, $1 \mathrm{~mm}$.

Antero-posterior diameter of medullary canal, $0.5 \mathrm{mmm}$; lateral, $0.4 \mathrm{~mm}$.

The medullary canal is full. Medullary index, $28 \%$.

Structure.-The section is composed of two rings of lamellæ, viz.: external and internal. The external is thickest and is composed of lamelle with a few romnd and oval lacunx and bushy canaliculi. The canaliculi of the posterior wall are long and straight and, in the anterior wall, infrequent and bushy. A narrow ring of internal lamella with long lacune and straight canaliculi surrounds the medullary canal.

Type $\mathrm{I}$.

LEFT FEMUR OF ALLIGATOR MISSISSIPPIENSIS. ALLIGATOR. CR. MED. COLL.

$$
\text { PL. 4, FIr. 65. Syn. 'T'Ав. II }
$$

Antero-posterior diameter of bone, $17 \mathrm{~mm}$; lateral, 1511111.

Antero-posterior diameter of medullary canal, $7 \mathrm{~mm}$.; lateral, $6 \mathrm{inm}$.

The medullary canal is full. Medullary index, $20 \%$.

Structure.-A thin cross-section of this femur held up to the light presents a ringed appearance like that of a cross-section of the trunk of a tree.

The section is composed of three concentric rings of laminæ with long, narrow lacune and straight canaliculi, alternating with four concentric rings of bone substance enclosing crude Haversian canals. The Haversian canals are l'ound, oval, or irregular in shape, are large and small in size, and very numerons. They are surrounded by clear areas of bone substance and many fine canaliculi from concentric adjacent oval lacuna pass radially across the areas of bone substance into the canals. The $(\mathrm{Ib})$ stage of the Haversian system is represented. The laminæ are fairly well developed.

Týpe I-II-III, Ia, Ib.

FEMUR OF CHELYDRA SERPEN'INA. SNAPPING TURTLE. CR. MED. COLL.

$$
\text { Pl. 4, Fig. 66. Syn. TAB. II }
$$

Antero-posterior diameter of bone, $8 \mathrm{~mm}$; lateral, $8.5 \mathrm{~mm}$.

Antero-posterior diameter of medullary canal, $1 \mathrm{~mm}$; lateral, $1 \mathrm{~mm}$.

The medullary canal is full. Medullary index, $1.5 \%$.

Structure.--The wall of the shaft is very thick, proportionately, and the medullary canal is very small. The femur is nearly solid. The section has four concentric rings of laminæ alternating with three concentric rings of bone substance in which are many Haversian canals. The canals are much more regular in shape than they were in the alligator and are surrounded by smaller, 
clear arcas of bone substance. Oval lacune are arranged concentrically around the boundaries of these areas and bushy canaliculi pass from the lacune to the canals. The lamine are much better developed than the Haversian systems which have reached the ( $\mathrm{Ib}$ ) differentiation. The posterior wall is composed of bone substance with round lacune and bushy canaliculi arranged as a crude cancellous bone and merges into the cancellous bone of the medullary canal.

Type I-II-III, Ia, Ib.

RIGHT FEMUR OF TRIONYX SPINIFER, SOFT-SHELLED TURTLE. NO. 2325,

AMER. MUS. NAT. HIST.

PL. 4, Fig. 6\%. Syn. 'T'AB. II

Antero-posterior diametcr of bone, $3.5 \mathrm{~mm}$. ; lateral, $5.5 \mathrm{~mm}$.

Antero-posterior diameter of medullary canal—cancellous bone.

The medullary canal is full. Mednllary index, 0 .

Structure.-The section is surrounded by a ring of lamelle with oval lacunæ and bushy canaliculi. It is interrupted by Haversian eanals of the (Ta) differentiation. In the postcrior wall here and there an Haversian system appears in the $(\mathrm{Ib})$ stage of advancement. Cancellous bone occupies the central eanal of the bone and is derived, by extension, from the enclosing lamellar ring. The walls of the cancellous meshes are composed of lamcllæ with oval and long lacunæ and straight canaliculi. There is no individual medullary canal.

Type I-III, Ia, Ib.

Right FEMUR OF CINOSTERnUm PenNSylvanicum. MUd TURTLE.

AMER. MUS. NAT. HIST.

PL. 4, Fig. 68. Syn. 'Tab. II

Antero-posterior diameter of bone, $3 \mathrm{~mm}$; lateral, $3.5 \mathrm{~mm}$.

Antcro-posterior diameter of medullary canal-cancellous bone.

The medullary canal is full. Medullary index, 0 .

Structure.-The section is surrounded by a narrow ring of lamellæ with oval lacunæ and bushy canaliculi, from which is derived the canccllous bone which fills the medullary canal. A few Haversian systems of the ( $\mathrm{Ib}$ ) differentiation are found in the posterior wall.

Type I-III, Ib.

RIGHT FEMUR OF CHelopus gutTatus. SPOTTED TURTLE. AMER, MUS. NAT. Hist.

PL. 4, Fig. 69. Syn. TAB. II

Antero-posterior diameter of bone, $2.5 \mathrm{~mm}$; lateral, $4 \mathrm{~mm}$.

Antero-posterior diameter of medullary canal-cancellous bone.

The medullary canal is full. Medullary index, 0 . 
Structure.-The section is surrounded by a narrow ring of lamella with oval lacunx and bushy canaliculi, interrupted by a few Haversian canals of the (Ia) differentiation. From the under surface of this ring is derived a cancellous bone which entirely fills the medullary canal. The walls of the meshes are composed of lamellæ with oval lacunæ and bushy canaliculi. In the posterior wall are a few Haversian systems of the ( $\mathrm{Ib})$ stage of development.

Type I-III, Ia, Ib.

LEFT FEMUR OF CHRYSEMYS PICTA. PAINTED TURTLE. AMER. MUS. NAT. Hist.

$$
\text { Pe. 4, Fig. ro. Syn. Tab. II }
$$

Antero-posterior diameter of bone, $2.5 \mathrm{~mm}$.; lateral, $4 \mathrm{~mm}$.

Antero-posterior diameter of medullary canal-cancellous bone.

The medullary canal is full. Medullary index, 0 .

Structure.-The section is surrounded by a ring of lamella with oval lacunx and bushy canaliculi, interrupted by a few Haversian canals of the (la) differentiation. Haversian systems of the ( $\mathrm{Ib}$ ) stage of development are found in the posterior wall. From the lamellar ring is derived the cancellons bone which occupies the whole medullary canal.

Type I-III, Ia, Ib.

RIGHT FEMUR OF AROMOCHELYS ODORATUS. MUSK TURTLE. AMER. MUS. NAT. HIST.

$$
\text { Pl. 4, Fig. 71. Syn. TAB. II }
$$

Antero-posterior diameter of bone, $1.8 \mathrm{~mm}$; lateral, $1.4 \mathrm{~mm}$.

Antero-posterior diameter of medullary canal, $0.3 \mathrm{~mm}$; lateral, $0.3 \mathrm{~mm}$.

The medullary eanal is full. Medullary index, $4 \%$.

Structure.-The section is surrounded by a band of lamellæ of various widths. The lacune are long and their canalicnli are long and straight. Underneath this is a central ring of lamellæ with oval lacunæ and bushy canaliculi. In this ring are several Haversian systems of the ( $\mathrm{Ib}$ ) differentiation forming a circular row around the medullary canal.

Around the medullary canal is a ring of internal circumferential lamellix with long lacune and straight canaliculi. The bone shows the outlines of the three divisions-external and internal dircumferential lamellæ and the central ring of lamella with Haversian systems.

'Type I-III, Ib.

RIGHT FEMIUR OF PSEUdEMIS FLORIDANA. NO. 28417, U. S. NAT. MUS.

PL. 4, Fig. \%2. Syn. TAB. II

Antero-posterior diameter of bone, $4 \mathrm{~mm}$; lateral, $3 \mathrm{~mm}$.

Antero-posterior diameter of medullary canal-cancellous bone.

Medullary index, 0 . 
Structure.-The section is composed of lamellæ with oval lacunæ and bushy canaliculi, incompletely separated into lanine which surround the medullary canal. In the posterior wall the crude laminæ are frequently interrupted by Haversian canals of the $(\mathrm{Ib})$ differentiation. In the internal laminæ of the anterior wall are several crude undeveloped and a few fairly well developed Haversian systems. The medullary canal is occupied by cancellous bone.

Type I-II-III, Ib.

Right FeMU OF testudo (GOpherus) POLYPhenus. No. 7555, U. S. NAT. MUS.

$$
\text { Pl. 4, Fia. } 73 \text {. Six. TAB. II }
$$

Antero-posterior diameter of bone, $8.5 \mathrm{~mm}$; lateral, $6 \mathrm{~mm}$.

Antero-posterior diameter of medullary canal-cancellous bone.

The medullary canal is full. Medullary index, 0 .

Structure.-The section is composed of incompletely formed, concentric laminæ which constitute the anterior, outer, and posterior wall. The laminæ are crossed by short, radiating canals and interrupted by Haversian systems of the (Ia) differentiation. Beneath the laminæ of the anterior and outer wall are Haversian systems of the $(\mathrm{Ib})$ stage of development and the posterior' ridge is made up almost entirely of Haversian systems of the same development. The inner wall is composed of lamellæ.

Type I-III, Ta, Ib.

\section{BIRDS}

Forty femora were examined.

\section{General Character of the Femur}

The femora of birds vary considerably in shape. A few are triangular, many are elliptical, and some are circular. The majority of them are elliptical and their antero-posterior diameters are longest. The medullary contents present a variable character. In some femora the medullary canals are full of marrow; in some, of cancellous bone, the meshes of which are filled with marrow; while in others, the canals are empty or oceupied by trabeculæ only. About half of the femora examined have no contents.

The medullary surfaces also vary somewhat in character. In those canals filled with marrow and blood vessels the surface is uneven, while in those which have no contents the surface is smooth. In these bones the walls are thin, the canals large, and the trabeculæ are numerous. The medullary index varies from 0 to $327 \%$, with an average of $159 \%$.

The bone structures show considerable variation. The three single types and many combinations of types, in an incomplete or complete differentiation, 
are found. None of these, with the possible exception of the first, have reached their full development. The second is found in a very incomplete and an advanced stage and forms the structure of a large number of femora; while the third has assumed a more complex form than that found in reptiles. The Haversian systems are comparatively large, the Haversian canals are small and around them are concentrically arranged round or oval lacunæ with intricate networks of canaliculi. This is the ( $\left.\mathrm{I}_{\mathrm{c}}\right)$ stage of Haversian differentiation and is characteristic of birds.

\section{Detailed Examination}

RIGHT FEMUR OF CYANocitTA STELleRI AZTECA. AZTEC JAY. No. 2874, AMER. MUS. NAT. HIST.

$$
\text { PL. 5, FIG. 74. Syn. TAB. III }
$$

Antero-posterior diameter of bone, $3 \mathrm{~mm}$; lateral, $2.5 \mathrm{~mm}$.

Antero-posterior diameter of medullary canal, $2 \mathrm{~mm}$.; lateral, $1.5 \mathrm{~mm}$.

The medullary canal is full. Medullary index, 68\%.

Structure.-The section is composed of bone substance with oval lacunæ and bushy canaliculi surrounding the medullary canal. The bone substance is partially separated into laminæ by short canals. The bone shows but little differentiation of structure.

Type I-II.

LEFT FEMUR OF MERGUS SERrator. RED-BrEASTED MERGanser. NO. 3117, AMER, MUS. NAT. HIST.

Pl. 5, Fig. 75. Syn. Tab. III

Antero-posterior diameter of bone, $6.5 \mathrm{~mm}$; lateral, $4.5 \mathrm{~mm}$.

Antero-posterior diameter of medullary canal, $4.5 \mathrm{~mm}$.; lateral, $2.5 \mathrm{~mm}$.

The medullary canal is full. Medullary index, $68 \%$.

Structure.-The section is composed of bone substance with oval lacunæ and bushy canaliculi, separated into incomplete laminæ by short, concentric, branching canals. A few vascular canals running longitudinally appear in the posterior inner and anterior wall. In the bone substance are a few Haversian systems of the (Ic) stage of development, and a single better differentiated system occurs in the tip of the posterior ridge. The lacunæ are oval. A narrow ring of internal circumferential lamellæ with long lacunæ and straight canaliculi surrounds the medullary canal.

Type I-II-III, Ic. 
RigHT FEMUR OF AJAIA AJAJA. ROSEATE SPOONBILL. NO. 2858, AMER. MUS. NAT. Hist.

Pl. 5, FIg. \%6. Syn. TAB. III

Antero-posterior diameter of bone, $7 \mathrm{~mm}$; lateral, $6 \mathrm{~mm}$.

Antero-posterior diameter of medullary canal, $5 \mathrm{~mm}$.; lateral, $4.5 \mathrm{~mm}$.

Medullary index, $114 \%$.

Structure.-With the exception of two rather crude Haversian systems in the posterior ridge the section is composed of lamellæ with oval lacunæ and bushy canaliculi, separated by canals of a branching character into crude laminæ. The general direction of the canals is concentric. The bone shows very little differentiation of structure.

Type I-II.

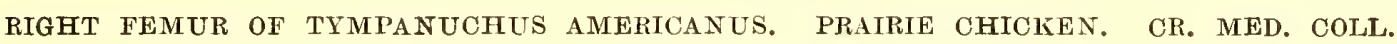

$$
\text { Pl. 5, F1G. } 7 \% \text {. Syx. TAb. III }
$$

Antero-posterior diameter of bone, $5 \mathrm{~mm}$. ; lateral $6 \mathrm{~mm}$.

Antero-posterior diameter of medullary canal, $4 \mathrm{~mm}$; lateral, $4.5 \mathrm{~mm}$.

The medullary canal is empty. Medullary index, 148\%.

Structure.-The bone is composed of lamellæ, crossed at all angles by short canals, some of which extend inward from the external surface. In the posterior and outer wall they unite and form a coarse network, while in the anterior and inner wall they do not. Their lacunæ are oval or narrow and their canaliculi are bushy or long and branching.

A very few Haversian systems of the (Ic) stage are found interrupting the lamellæ of the anterior and inner wall. In the posterior wall are two ridges separated by a concave intermediate wall of bone. Two or three undeveloped Haversian systems are found in each ridge.

The internal circumferential lamellæ surround the medullary canal. They are well developed. Their lacunæ are long and narrow and their canaliculi are long and branching.

Type I.

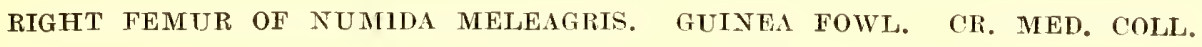

$$
\text { PL. 5, Fig. 7\% } \frac{1}{2} \text {. Sxn. TAB. III }
$$

Antero-posterior diameter of bone, $7 \mathrm{~mm}$; lateral, $8 \mathrm{~mm}$.

Antero-posterior diameter of medullary canal, $5 \mathrm{~mm}$. ; lateral, $6 \mathrm{~mm}$.

The medullary canal is full. Medullary index, $116 \%$.

Structure.-The section is composed of crude laminæ with oval lacunæ and bushy canaliculi, interrupted by Haversian systems of the (Ic) differentiation. In the anterior and posterior wall the lamine have a radial direction. The 
internal circumferential lamellæ with long lacunæ and straight canaliculi form a narrow ring around the medullary canal.

Type II-III, Ic.

Right Femur of Cyanocitta cristata. blue JAY. CR. MED. COLL.

PL. 5, Fig. 78. Syn. Tab. III

Antero-posterior diameter of bone, $2.5 \mathrm{~mm}$; lateral, $2.5 \mathrm{~mm}$.

Antero-posterior diameter of medullary canal, $1.5 \mathrm{~mm}$. ; lateral, $1.5 \mathrm{~mm}$.

The bone is nearly round. The medullary canal is full. Medullary index, $56 \%$.

Structure.-The section is composed of bone substance separated into crude laminæ by short, branching, more or less concentric canals. A few Haversian systems of the (Ic) stage of differentiation appear here and there. The lacunæ are oval and the canalicnli are short and bushy.

Type II-III, Ic.

JeEt FeMtur of Pteroglossus torquatus. BANDEd toUCAN. No. 2854, AMER. MUS. NAT. HIST.

Pl. 5, Fig. 79. Syn. TAB. III

Antero-posterior diameter of bone, $3 \mathrm{~mm}$. ; lateral, $3 \mathrm{~mm}$.

Antero-posterior diameter of medullary canal, $2 \mathrm{~mm}$.; lateral, $2 \mathrm{~mm}$.

The medullary canal is full. Medullary index, $80 \%$.

Structure.-The section is composed of concentric lamellæ with oval lacunæ and bushy canaliculi, crossed by a few short canals surrounding the medullary canal.

Type I.

LEFT FEMUR OF CHARAdRIUS PLUVIALIS. GOLdEN PLOVER. NO. 3356, AMER, MUS, NAT, HIST.

Pl. 5, Fig. 80. Syn. TAB. III

Antero-posterior diameter of bone, $2.5 \mathrm{~mm}$; lateral, $2.5 \mathrm{~mm}$.

Antero-posterior diameter of medullary canal, $1.5 \mathrm{~mm}$. ; lateral, $1.5 \mathrm{~mm}$.

The medullary canal is full. Medullary index, $56 \%$.

Structure:-The section is composed of concentric lamellæ witlı oval lacunæ and bushy canaliculi, interrupted by a few crude Haversian systems. The lamellæ are partially separated into laminæ by short concentric canals. The bone shows little differentiation.

Type II. 
LEFT FEMUR OF AMAZONA ORATRIX. MEXTCAN YELLOW-HEADED PARROT. NO. 3025,

AMER, MUS, NAT, HIST,

J's. J. Fig. 81. Syn, Tab, IlI

Antero-posterior diameter of bone, $4 \mathrm{~mm}$.; lateral, $3.5 \mathrm{~mm}$.

Antero-posterior diameter of medullary canal, $3 \mathrm{~mm}$.; lateral, $3 \mathrm{~mm}$.

The medullary canal is full. Medullary index, $177 \%$.

Structure.-The section is composed of lamellæe with oval lacunæ and bushy canaliculi, incompletely separated into dim lamine by short, concentric canals and interrupted by Haversian canals of the (Ia) differentiation. In the central portion of the section, and extending nearly around it, is a concentric row of Haversian systems of the ( $\mathrm{Ic}$ ) differentiation. In the posterior wall oval lacunæ are crowded together along the medullary surface.

Type II-III, Ia, Ic.

Right FEMUR OF tURdes MigratoriUs. robiN. CR. MED. COLl.

Pl. 5. Fig. 82. Sin. Tab. III

Antero-posterior diameter of bone, $2 \mathrm{~mm}$; lateral, $2 \mathrm{~mm}$.

Antero-posterior diameter of medullary canal, $1.5 \mathrm{~mm}$.; lateral, $1.5 \mathrm{~mm}$.

The medullary canal is full. Medullary index, $129 \%$.

Structure.-The section is composed of concentric lamella with oval and long lacunæ and straight and bushy canaliculi surrounding the medullary canal. A concentric row of small Haversian systems of the (Ic) stage is found in the central portion of the wall of the bone. A few canals cross the bone in different directions.

Type I-III, Ie.

Femur of pelecanus erithrorhynchus. White Pelican, Cr, med. Coll.

$$
\text { Pl. 5, Fig. 83. S'r. T.ı. III }
$$

Antero-posterior diameter of bone, $12 \mathrm{~mm}$.; lateral, $10 \mathrm{~mm}$.

Antero-posterior diameter of medullary canal, 0 ; lateral, 0.

The central portion of the bone is cancellous. Medullary index, 0 .

Structure.-The external cireumferential lamellæ form a narrow enclosing ring. Underneath this is a central ring of Haversian systems of the (Ic) differentiation with canals rmming at all angles. Beneath this is a narrow ring of internal circumferential lamella from the inside of which is derived a cancellous structure occupying the whole medullary region of the bone. The meshes are filled with insolnble matter. A very small medullary canal is situated in the posterior half of the section.

Type T-IIT, Tr. 
right Femur of ara maCao. macaw. Cr. med. Coll.

Pl. 5, Fig. 84. SYn. 'TAB. III

Antero-posterior diameter of bone, $5.5 \mathrm{~mm}$; lateral, $4.5 \mathrm{~mm}$.

Antero-posterior diameter of medullary canal, $4.5 \mathrm{~mm}$.; lateral, $3.5 \mathrm{~mm}$.

The medullary canal is full. Medullary index, $178 \%$.

Structure.-The bone is composed of rather crude laminx, separated and crossed at various angles by numerous canals and interrupted here and there by a few Haversian systems of the (Ic) differentiation. In the posterior ridge the systems form a considerable portion of the thickness of the wall. The laminæ are composed of a few lamellæ with oval and round lacunæ and short, bushy canaliculi.

Type II-III, Ic.

RIGHT FEMUR OF NYCTHEhodiUs VIOLACEUS. NIGHT HERON. CR. MED. COLL.

Pu. 5, Fig. 85. Syn. Tab. III

Antero-posterior diameter of bone, $5 \mathrm{~mm}$; lateral, $6 \mathrm{~mm}$.

Antero-posterior diameter of medullary eanal, $4 \mathrm{~mm}$. ; lateral, $4.5 \mathrm{~mm}$.

The medullary canal is full. Medullary index, $148 \%$.

Structure.-The external circumferential lamellæ are not distinct. The bone is composed, for the most part, of short, irregular, and incomplete laminæ, marked off by short, concentric canals. The laminæ are interrupted by small Haversian systems of the (Ic) differentiation which form nearly the whole of the posterior ridge. Each lamina consists of a few lamellæ with oval lacunæ and bushy canaliculi. The canals separating the laminæ are wide and short, and not often uniting. Internal circumferential lamellæ with long lacunæ and straight canaliculi surround the medullary canal.

Type II-III, Ic.

FEMUR OF PAVO CRISTAtus. PEAFOWL. CR. MED. COLL.

Pl. 5, Fig. 86. Syn. Tab. III

Antero-posterior diameter of bone, $10 \mathrm{~mm}$; lateral, $11 \mathrm{~mm}$.

Antero-posterior diameter of medullary canal, $8 \mathrm{~mm}$.; lateral, $10 \mathrm{~mm}$.

The walls of the bone are thin. The medullary canal is large, empty, and has a network of trabeculæ which extends from one wall in a downward direction to the opposite wall.

Medullary index, $277 \%$.

Structure.-The section is composed of a concentric network of canals enclosing short laminæ. The canals intersect at all angles. The laminæ, composed of bone substance with oval lacunæ and relatively few rather short, 
bushy canaliculi, are interrupted by a few Haversian systems of the (Ic) differentiation.

Type II-III, Ic.

FEMUR OF HALIETUS LEUCOCEPHALUS. EAGLE. CR. MED. COLL.

PL. 5, Fig. 8\%. Syn. TAB. III

Antero-posterior diameter of the bone, $13 \mathrm{~mm}$; lateral, $14 \mathrm{~mm}$.

Antero-posterior diameter of the medullary canal, $11 \mathrm{~mm}$. ; lateral, $11.5 \mathrm{~mm}$.

The medullary canal is empty. Medullary index, $227 \%$.

Structure.-External circumferential lamellæ surround the bone, excepting the posterior ridge where they are interrupted by tendon attachments. Their lacunæ are long, narrow, and concentrically arranged and their canaliculi are rather short and branching.

The central ring of bone is composed of concentric laminx, interrupted by Haversian systems of the (Ic) differentiation. The canals which separate the laminæ are relatively wide and, on account of their frequent communications with neighboring canals, they present the appearance of a coarse network.

Internal circumferential lamellæ surround the medullary eanal. They are fairly well developed and are frequently crossed by canals extending inward from the medullary canal. Their lacunæ are long and narrow and their canaliculi are long and branching.

On the posterior surface are two ridges, one central and one on the pos. terior inner lateral border. The bone at these points consist of Haversian systems of the (Ic) stage, separated by frequent wide canals which pass to an apex at the outer surface of the ridges. The external circumferential laminx are absent at these points and tendon insertions, interspersed with many canals, occupy the posterior ridges.

Type II-III, Ic.

LEFT FEMUR OF ARAMUS VOCTFERUS. COURLAN. No. 2859, AMER. MUS. NAT. Hist.

$$
\text { PL. 5, Fig. 88. Syn. TAB. III }
$$

Antero-posterior diameter of bone, $6.5 \mathrm{~mm}$.; lateral, $6 \mathrm{~mm}$.

Antero-posterior diameter of medullary canal, $5.5 \mathrm{~mm}$.; lateral, $5 \mathrm{~mm}$.

The medullary canal is empty. Medullary index, $239 \%$.

Structure.-The section is composed of concentric laminæ with oval lacunæ and bushy canaliculi. In the anterior and posterior walls a single Haversian system of the (Ic) stage is seen. Around the medullary canal is a narrow ring of lamellæ with long lacunæ and straight canaliculi. The bone shows very little variation of structure.

Type II. 
LEFT FEMUR OF CENTROCERCUS UROPHASIANUS. SAGE GROUSE OR SAGE HEN.

$$
\text { CR. MED. COLL. }
$$

$$
\text { PL. 5, Fig. 89. Syn. Tab. III }
$$

Intero-posterior diameter of bone, $7 \mathrm{~mm}$; lateral, $6 \mathrm{~mm}$.

Antero-posterior diameter of medullary canal, $6 \mathrm{~mm}$.; lateral, $5 \mathrm{~mm}$.

The medullary canal is empty. Medullary index, 252\%.

Structure. The bone is composed of short, concentric lamina, with the exception of a short, narrow crescent of poorly developed Haversian systems in the posterior imner wall. The laminæ are frequently crossed by canals. Each lamina is composed of a few lamellæ with long, narrow lacunæ and long canaliculi. In the posterior wall on both sides of the mid-line are two tendon insertions which mark the attachment of muscles.

Type II.

FEMORA OF MEteagris gatdipaVo. WILD AND DOMESTIC TURKEYS. CR. MED. COLL.

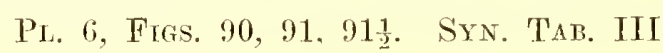

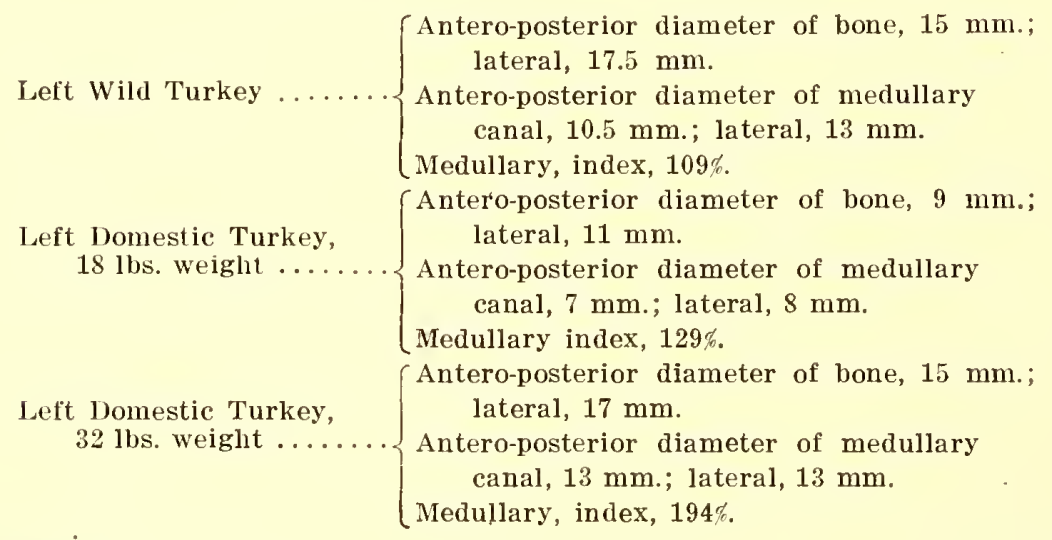

Simce the three bones resemble each other closely, one description will. answer for all. The medullary canals are full and relatively large. 'The walls of the bone are thin. The index is higher in the domestic than in the wild turkey.

Structure.-External circumferential lamellx, with long, narrow lacunx and many bushy canaliculi, surround the sections. Along the posterior vidges of the femora are small areas of Haversian systems of the (Ic) differentiation which occupy nearly the entire thickness of the posterior walls of the bones. In the anterior walls are small areas of similar Haversian systems. The Haversian canals are large, the lacunæ are oval, and their canaliculi are numerous and bushy.

The lateral walls of the bones are composed of rather crude concentric laminæ, interrmpted by a few Haversian systems of the ( $\mathrm{Ia}, \mathrm{Ic}$ ) differentiations, separated by prominent concentric canals and crossed at frequent intervals by 
smaller canals extending from both surfaces of the bone. The laminx are composed of lamellæ, between which are oval lacunæ with short, bushy canaliculi. Around the medullary canal the internal circumferential lamellæ are not distinet from the adjoining laminæ.

As the femur of the domestic turkey was the first bone to suggest variation in bone type, a number of turkey femora were examined. It was found that they were all second type with Haversian systems of the (Ia) and (Ic) stages of development. The turkeys of greatest weight had the most Haversian sys-

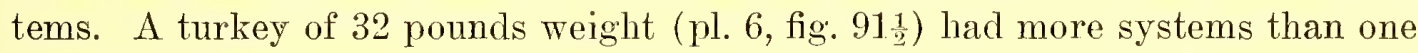
of 14,16 , or 18 pounds, and the systems were distributed over a greater area in the different walls of the bone.

Type II-III, Ia, Ic.

LEFT FEMUR OF DENDRAGAPUS OBSCURUS. GROUSE. CR. MED. COLT.

PL. 6, Fig. 92. Syn. 'T'AB. III

Antero-posterior diameter of bone, $5 \mathrm{~mm}$.; lateral, $5.5 \mathrm{~mm}$.

Antero-posterior diameter of medullary eanal, $4 \mathrm{~mm}$.; lateral, $5 \mathrm{~mm}$.

The medullary canal is empty. Medullary index, $277 \%$.

Structure.-The bone, with the exception of a narrow ring of internal circumferential lamellie, is composed of short, concentric laminæ, separated by wide canals. Each lamina is composed of lamellæ, with long, narrow or oval lacune and long, branching or bushy canaliculi. The canals freely communicate with each other across the laminæ. In the anterior wall (middle portion) is a slight prominence or ridge, consisting of poorly developed Haversian systems, situated close to the external surface. In the posterior wall are two ridges separated by a concave intermediate wall of bone. A single, poorly developed Haversian system is found at the apex of each ridge, around which are collections of oval lacunæ, with short, bushy canaliculi. Close to the internal cireumferential lamellæ are a few Haversian systems of a crude type.

Internal circumferential lamellæ surround the medullary canal. Their lacunæ are long and narrow.

Type II.

LEFT FEMUR OF RHEA AMERICANA. RHEA. NO. 2875, AMER. MUS. NAT. HIST.

PL. 6, FIg. 93. Syn. TAB. III

Antero-posterior diameter of bone, $25.5 \mathrm{~mm}$; lateral, $20.5 \mathrm{~mm}$.

Antero-posterior diameter of medullary canal, $19 \mathrm{~mm}$. lateral, $15 \mathrm{~mm}$.

The medullary canal is full. Medullary index, $120 \%$.

Structure.-The section is composed of concentric laminæ, separated and crossed by numerous canals, and, here and there, interrupted by small Haversian systems of the (Ic) differentiation.

Type II-III, Ic. 
LEFT FEMUR OF STRUTH1O. OSTRICH. AMER. MUS. NAT. HIST.

Pl. 6, Fig. 94. Syn. Tab. III

Antero-posterior diameter of bone, $54 \mathrm{~mm}$; lateral, $40 \mathrm{~mm}$.

Antero-posterior diameter of medullary canal, $47 \mathrm{~mm}$.; lateral, $32 \mathrm{~mm}$.

The medullary canal is empty. Medullary index, $240 \%$.

Structure.-The bone is large, thin-walled, and light. The section is composed of incomplete, concentric, short and long laminæ, crossed by numerous canals, and interrupted by many Haversian systems of the (Ic) stage of differentiation. The posterior ridges are composed mostly of similar Haversian systems. The central zones of these systems are composed of lamellæ with round lacuna and short, bushy canaliculi, while their external zones, much narrower, consist of lamellie with long, narrow lacune and straight canaliculi.

Type II-III, Ic.

\section{HAVERSTAN SYSTEM OH THE OSTRICH \\ Pu. 6, FIG. 95. SYN. 'T'A в. III}

An Haversian system from the posterior wall of the femur of an ostrich (fig. 94) is enlarged in order to show developmental stages.

The system consists of a central and peripheral portion. The central portion is composed of bone substance with round lacunæ and branching canaliculi forming a delicate canalicular network around the Haversian canal. The peripheral portion is composed of long, narrow lacunæ with straight canaliculi situated in and between lamellæ and arranged concentrically around the central portion. The central portion suggests an early development by its round lacunæ and close proximity to the circulation of the Haversian canal, while the peripheral portion suggests a later and more complete development by its long, narrow lacune and removal from the Haversian canal.

left femur of phasiands torquatus. chinese pheasant. Cr. med. Coll.

PL. 6, FIG. 95 $\frac{1}{2}$. Syn. TAB. III

Antero-posterior diameter of bone, $6 \mathrm{~mm}$; lateral, $6 \mathrm{~mm}$.

Antero-posterior diameter of medullary canal, $4.5 \mathrm{~mm}$; lateral, $4.5 \mathrm{~mm}$.

The medullary canal is empty. Medullary index, $129 \%$.

Structure.-The section is composed of crude, short laminæ interrupted by a few Haversian systems of the (Ic) differentiation. The lacunæ are oval and the canaliculi are short and bushy. Internal circumferential lamellæ partly surround the medullary canal.

Type II, Ic. 
RIGHT FEMUR OF DROM AUS NOVA HOLLANDIE. EMU. NO. 2916, AMER, MUS. NAT. HIST.

$$
\text { PL. 6, Fig. 96. Sin. Tab. III }
$$

Antero-posterior diameter of bone, $30 \mathrm{~mm}$; lateral, $26 \mathrm{~mm}$.

Antero-posterior diameter of medullary canal, $22 \mathrm{~mm}$; lateral, $19.5 \mathrm{~mm}$.

Medullary index, $122 \%$.

Structure.-The section is composed, for the most part, of a background of short laminæ separated by short concentric canals in which are seattering Haversian systems of the ( $\mathrm{C}$ ) differentiation. In the outer wall a threefold division is present-external circumferential lamins, central ring, and internal circumferential lamellæ.

The central ring is composed of Haversian systems, many of which are arranged in a peculiar manner'. 'They occur in groups of two to eight, enclosed within an envelope of lamina resembling cross-sections of cables. The systems are of the (Ic) differentiation. 'This is the only bone in which this arrangement has been seen.

Type II-III, Ic.

FEMUR OF ANAS BOSCAS. MALLARD DUCK. CR. MED. COLL.

$$
\text { PL. 6, Fic. 9\%. Syn. TAb. III }
$$

Antero-posterior diameter of bone, $4.5 \mathrm{~mm}$.; lateral, $6.5 \mathrm{~mm}$.

Antero-posterior diameter of medullary canal, $3.5 \mathrm{~mm}$; lateral, $5 \mathrm{~mm}$.

The medullary canal is empty. Medullary index, $141 \%$.

Structure.-The section is composed of crude lamina arranged concentrically and interrupted by rather small and poorly developed Haversian systems. The two posterior ridges have groups of the (Ic) differentiation.

Type II-III, Ic.

Femur of emberiza Citrinella, yellow-hammer. Cr. med, Coll.

$$
\text { PL. 6, Fig. 98. Six. TAB. III }
$$

Antero-posterior diameter of bone, $2.5 \mathrm{~mm}$; lateral, $3 \mathrm{~mm}$.

Antero-posterior and lateral diameters of medullary canals, 0.

The medullary canal is full and situated close to the posterior wall. Medullary index, 0 .

Structure.-The section is surrounded by external circumferential lamella, within which are a few Haversian systems of the $(\mathrm{Ic})$ differentiation. Large canals extend transversely across the walls of the bone, communicating with the meshes of the central bone structure.

The central portion of the bone, usually occupied by the medullary canal, is composed of a fine cancellous bone with the exception of a small medullary 
canal, about the size of a fine sewing needle, situated near the posterior wall. The femur is therefore nearly solid bone. The cancellous center is composed of fine lamellw forming a meshwork extended from the internal circumferential lamellæ. The meshes are filled with granular material, insoluble in ether or chloroform. The lacunæ are small, round, or oval and their canaliculi are short, bushy, and infrequent. Although the bird is a good flier its femur is practically a solid bone.

Type I-III, Ic.

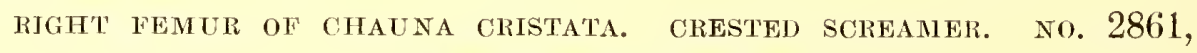

AMER. MUS. NAT, HIST.

Pl. 6, Fig. 99. Syn. Tab. III

Antero-posterior diameter of bone, $12.5 \mathrm{~mm}$; lateral, $12 \mathrm{~mm}$.

Antero-posterior diameter of medullary canal, $10.5 \mathrm{~mm}$. lateral, $10.5 \mathrm{~mm}$.

The inedullary canal is empty. Medullary index, $277 \%$.

Structure.-The section has the three divisions well marked. The external circumferential lamellæ form a narrow, distinct ring around the section. Their lacunæ are long and the canaliculi are straight. The central ring is composed of Haversian systems of the (Ic) stage and of canals and fragments of lamellæ. The internal circumferential lamellæ form a distinet ring around the medullary ranal. Their lacunæ are long.

'Type III, Ic.

LEFT FEMUR OF PANDION CAROLINENSIS. AMERICAN OSPREY. NO. 55, CR. MED. COLL.

$$
\text { PL. 6, FIg. 100. Syn. TAB. III }
$$

Antero-posterior diameter of bone, $7.5 \mathrm{~mm}$; lateral, $8 \mathrm{~mm}$.

Antero-posterior diameter of medullary canal, $6 \mathrm{~mm}$. ; lateral, $6.5 \mathrm{~mm}$.

The medullary canal is full. Medullary index, $188 \%$.

Structure.-The external circumferential lamellæ are not distinct from the underlying structure. The bone is composed of crude lamina which are frequently interrupted by Haversian systems of the (Ic) differentiation, and crossed at differing angles by vascular canals. In the posterior wall near the mid-line is a cluster of small Haversian systems with which tendon intersections are blended. The lacunæ of the laminæ are round and oval.

Concentric laminæ surround the medullary canal. They are frequently crossed by short canals from the medullary canal.

Type II-III, Ic. 
RIGHT FEMUR OF SARCORHAMPHUS GRYPHUS. ANDEAN CONDOR. NO. 1276, AMER, MUS. NAT, HIST.

Pl. \%, Fig. 101. SYN. '1'גB. III

Antero-posterior diameter of bone, $18.5 \mathrm{~mm}$. ; lateral, $17.5 \mathrm{~mm}$.

Antero-posterior diameter of medullary canal, $15 \mathrm{~mm}$.; lateral, $14.5 \mathrm{mmm}$.

The medullary canal is full. Medullary index, $204 \%$.

Structure.-The bone has three divisions. The external circunferential lamella form a narrow enclosing ring. Their lacuna are long and their cana lieuli are straight. The central ring is composed of round and elongated Ha versian systems of the $(\mathrm{Ic})$ differentiation. Internal cireunferential lamella form an uneven ring around the medullary canal. Their lacuna are long.

Type I-III, Ic.

RIGHT FEMUR OF OLOR SP. SWAN. NO. 1681, AMER. MUS. NAT. HIST.

$$
\text { PL. } \% \text {, F1G. 102. SYN. TAB. III }
$$

Antero-posterior diameter of bone, $11.5 \mathrm{~mm}$.; lateral, $10.5 \mathrm{~mm}$.

Antero-posterior diameter of medullary canal, $7 \mathrm{~mm}$.; lateral, $8 \mathrm{~mm}$.

Medullary index, $87 \%$.

Structure.-The bone has the three divisions. The external cireumferential lamellæ form a narrow enclosing ring. Their lacunæ are long and their canaliculi are straight. The central ring is composed of crude laminæ with oval lacunæ, partly displaced by Haversian systems of the (Ic) differentiation. In the anterior imner wall indistinct laminæ appear. A wide ring of lamelle, partly separated into laminæ, surrounds the medullary canal. The lamellæ have long lacunæ and are crossed by numerous canals.

Type II-III, Ic.

LeFT FEMUR OF GAViA STEllata. RED-THROATED LOON. NO. 2801, AMER. MUS. NAT. IHIST.

Pu. \%, Fig. 103. Syx. 'Tıв. III

Antero-posterior diameter of bone, $8.5 \mathrm{~mm}$. lateral, $6.5 \mathrm{~mm}$.

Antero-posterior diameter of medullary canal, $5 \mathrm{~mm}$.; lateral, $4 \mathrm{~mm}$.

The medullary canal is divided into two equal parts, antero-posteriorly by a partition of bone. Medullary index, $184 \%$.

Structure.-The section has the three divisions. The external cireumferential lamella form a narrow enclosing ring. The lacune are long and oval and their canaliculi are long and bushy. The rentral ring is composed of lamellæ and Haversian systems of the (Tc) differentiation. The internal circumferential lamella with long lacme and straight canaliculi snrround the 
medullary canal and form the dividing partition. Four large vaseular canals appear in the anterior wall and two or three in the posterior. Their lacunæ are long and oval with long and straight canaliculi.

Type I-III, Ic.

FEMUR OF Gallus, DOMESTIC CHICKEN. CR. MED. COLL.

PL. \%, Fig. 104. SYN, TAB. III

Antero-posterior diameter of bone, $9 \mathrm{~mm}$; lateral, $9 \mathrm{~mm}$.

Antero-posterior diameter of medullary canal, $7 \mathrm{~mm}$.; lateral, $7 \mathrm{~mm}$.

The medullary canal is full. Medullary index, $153 \%$.

Structure.-Well marked external circumferential lamellax with long, narrow lacunæ and branching canaliculi surround the section. The central ring is composed of irregularly shaped Haversian systems of the (Ic) differentiation. At the posterior ridge they occupy the entire thickness of the wall of the bone as far as the internal circumferential lamellæ. Interspersed between the systems are short lamellæ.

Internal circumferential lamellæ completely surround the medullary canal. Their lacunæ are long and narrow and their canaliculi are bushy.

Type I-III, Ic.

HEMUR OF CORVUS AMERICANUS, CROW. CR. MED. COLL.

Pl. 7, Fig. 105. Syn. Tab. IJI

Antero-posterior diameter of bone, $4 \mathrm{~mm}$. ; lateral, $3 \mathrm{~mm}$.

Antero-posterior diameter of medullary canal, $2.5 \mathrm{~mm}$.; lateral, $2 \mathrm{~mm}$.

The medullary canal is full. Medullary index, $70 \%$.

Structure.-External circumferential lamellæ form a wide ring around the bone. The lacunæ are oval with bushy, connecting canaliculi.

The central ring is composed of lamellæ and irregular Haversian systems of the (Ic) stage of development. There is very little difference in the structure of the various parts of the bone.

Internal circumferential lamellæ form a narrow ring around the medullary canal. Their lacunæ are narrow and long and their canaliculi are long and branching.

Type I-III, Ic.

FEMUR OF ASIO WILSONIANUS. LONG-EARED OWL

$$
\text { Pu. \%, Fig. 106. Stn. Tab. III }
$$

Antero-posterior diameter of bone, $8 \mathrm{~mm}$; lateral, $7 \mathrm{~mm}$.

Antero-posterior diameter of medullary canal, $6 \mathrm{~mm}$. ; lateral, $6 \mathrm{~mm}$.

The medullary canal is full. Medullary index, $178 \%$. 
Structure.-The external circumferential lamellæ surround the section. Their lacunæ are long, numerous, and have very fine, long canaliculi. Here and there canals traverse the entire thickness of them all.

The central ring is composed of irregularly shaped Haversian system of the $(\mathrm{Ic})$ stage of development, extending between which are numerous short canals. The lacunæ are oval, numerons, and have bushy canaliculi.

The internal circumferential lamellæ form a thick, heavy ring around the medullary canal. In the outer wall of the bone they tend to separate into laminæ. The whole ring of internal circumferential lamellæ forms about onethird of the thickness of the wall of the bone. It is traversed by many canals extending from the medullary canal into the canals of the Haversian systems. Their lacunæ are long and numerous and their canaliculi are bushy.

Type I-II-III, Ic.

RIGHT FEMUR OF BERNICLA CANADENSIS. WILD GOOSE

PL. \%, FTG. 10\%. SYN. TAB. III

Antero-posterior diameter of bone, $9 \mathrm{~mm}$; lateral, $8.5 \mathrm{~mm}$.

Antero-posterior diameter of medullary canal. $7 \mathrm{~mm}$.; lateral, $7 \mathrm{~nm}$.

The medullary canal is full. Medullary index, $178 \%$.

Structure.-The external cireumferential lamelle surround the section. Their lacunæ are long and narrow and their canaliculi are rather few in number. At the posterior ridge are found many Haversian systems of the (Ic) differentiation. The anterior wall of the bone is composed of similar Haversian systems occupying the whole thickness of the wall between the external and internal circumferential lamellæ. The remainder of the bone shows quite different structures and arrangements in the different portions of the wall. Laminæ occupy the inner half of the wall, while Haversian systems of the (Ic) stage of development occupy the onter half and are situated under the external circumferential lamellæ.

The two halves are well marked and distinct from each other. The lacunx of the systems and laminx are oval and their canaliculi are few and short. The canals between the lamine are irregular and branching. The internal circumferential lamellæ are well developed. In the imner wall of the bone quite large canals extend from the medullary canal through the laminæ to the Haversian canals between the laminæ.

Type II-III, Ic.

LEFT FEMUR OF LEPTOPTllos sP. STORK. NO. 2827, AMER. MUS. NAT. HiST.

$$
\text { PL. 7, Fig. 108. Syn. Tib. III }
$$

Antero-posterior diameter of bone, $17 \mathrm{~mm}$. ; lateral, $15 \mathrm{~mm}$.

Antero-posterior diameter of medullary canal, $14.5 \mathrm{~mm}$; lateral, $13.5 \mathrm{~mm}$.

The medullary canal is empty. Medullary index, $327 \%$. 
Structure.-The section has the three divisions; the external circumferential lamellæ form a narrow ring around the section and have long lacunæ and straight canaliculi. The central ring is composed of Haversian systems of the (Ic) differentiation between which are canals and short fragments of lamellæ with oval lacunæ and bushy canaliculi. The internal circumferential lamellæ form a distinct, narrow ring around the medullary canal. Their lacunæ are long and canaliculi are straight.

Type I-III, Ic.

Right FEMUR OF ANTHRACOCERos MALABARICUS. HORN BILL. NO. 2887, AMER, MUS, NAT. HIST.

PL. \%, Fig. 109. Syn. TAB. III

Antero-posterior diameter of bone, $6.5 \mathrm{~mm}$.; lateral, $6 \mathrm{~mm}$.

Antero-posterior diameter of medullary canal, $5.5 \mathrm{~mm}$. ; lateral, $5 \mathrm{~mm}$.

The medullary canal is empty. Medullary index, $240 \%$.

Structure.-The section has three divisions. The external circumferential lamellæ with long lacunæ and straight canaliculi form a distinct, narrow ring around the bone. The central ring is composed of lamellæ with round and oval lacunæ, interrupted by many canals and Haversian systems of the (Ic) stage. The internal circumferential lamellæ with long lacunæ form a narrow distinct ring around the medullary canal.

Type I-III, Ic.

FEMUR OF ASTUR ATRICAPILlUS. GOSHAWK. CR. MED. COLL.

$$
\text { Pl. \%, Fig. 110. Syn. Tab. III }
$$

Antero-posterior diameter of bone, $4 \mathrm{~mm}$.; lateral, $4.3 \mathrm{~mm}$.

Antero-posterior diameter of medullary canal, $3 \mathrm{~mm}$. ; lateral, $3.3 \mathrm{~mm}$.

The medullary canal is empty. Medullary index, $139 \%$.

Structure.-The section is surrounded by external circumferential lamellæ, fairly well developed. Their lacunæ are more frequently oval than long. The canaliculi are bushy.

In the inner lateral posterior wall is a slight ridge to which are attached muscle tendons penetrating the external lamellæ. Underneath the external circumferential lamellæ is a thick ring of Haversian systems of the (Ic) stage of development. The ring is crossed at all angles by wide, irregular canals.

The medullary canal is enclosed by internal circumferential lamellæ with long lacunæ and canaliculi.

Type I-III, Ic. 
LEFT FEMUR OF INOCOTIS PAPILLOSUS. 1BIS. NO. 3178, AMER. MUS. NAT. HIST.

$$
\text { PL. \%, FIG. 111. STI. 'TAB. III }
$$

Antero-posterior diameter of bone, $7 \mathrm{~mm}$.; lateral, $6.5 \mathrm{~mm}$.

Antero-posterior diameter of medullary canal, $6 \mathrm{~mm}$; lateral, $5.5 \mathrm{~mm}$.

Medullary index, $264 \%$.

Structure.-The section shows the three divisions. External circumferential lamellix form a narrow ring around the section. 'Their lacuna are long' and narrow. Underneath this ring is a wide central ring of lamellæ, Haversian systems, and canals. The lamellæ have oval lacunæ and bushy canaliculi. The Haversian systems are of the (Ic) stage of development. Around the medullary canal is a ring of lamellæ with long and narrow lacunæ.

Type I-III, Ic.

Right Femur of CAthartes aURa. TURKey-BUZzard. No. 70, CR, med, Coll.

$$
\text { PI. \%, FIG. 112. SYN. TAB. III }
$$

Antero-posterior diameter of bone, $9.5 \mathrm{~mm}$; lateral, $8 \mathrm{~mm}$.

Antero-posterior diameter of medullary canal, $7.5 \mathrm{~mm}$; lateral, $7 \mathrm{~mm}$.

The medullary canal is empty. Medullary index, $219 \%$.

Structure.-The walls are very thim and hard. The usual three structural divisions are present. The external circumferential lamellæ form a narrow ring around the section excepting in the posterior ridge where a few tendon insertions displace them. Their lacunæ are long, narrow, and well developed. The central ring is composed of Haversian systems of the (Ic) differentiation. The lacune are some distance apart and their canaliculi are rather infrequent. The ring is crossed at all angles by canals. The internal circumferential lamellæ constitute a narrow ring around the medullary canal. Their lacunx are well developed.

Type I-III, Ic.

\section{MAMMALS-BATS}

Fifty-five femora were examined.

\section{General Character of the Femur}

The prevailing shape of the femm is elliptical. Several are romul, and a few are plano-convex. The medullary canals are all full of marrow and one, Desmodus rotundus, is full of red marrow. No cancellous bone and no trabecula are found. The medullary surfaces are smooth or very slightly corrugated.

The medullary index varies from $12 \%$ to $178 \%$ with an average of $48.6 \%$. 
The type of structure is first. The bone substance is lamellated, the lacuna are round, oval or long, and the canaliculi are bushy, short, or long. In some of the large bats of the Pteropus genus, Haversian canals of the (Ia) differentiation are present.

\section{Detalled Examination}

RIGHT FEMUR OF MORMOOPS. NO. 102231 , U. S. NAT. MUS.

PL. 8, Fig. 113. SYN. 'I'AB. IV

Antero-posterior diameter of bone, $1 \mathrm{~mm}$.; lateral, $0.8 \mathrm{~mm}$.

Antero-posterior diameter of medullary canal, $0.6 \mathrm{~mm}$. ; lateral, $0.5 \mathrm{~mm}$.

The medullary canal is full. Medullary index, $59 \%$.

Structure.-The section is composed of concentric lamellæ with oval lacunæ and bushy canaliculi surrounding the medullary canal. The bone is uniform.

Type I.

RIGHT FEMUR OF RIINOLOPHUS MEHELY1. NO. 84768 , U. S. NAT. MUS.

P. 8, Fig. 114. SyN. TAB. IV

Antero-posterior diameter of bone, $0.8 \mathrm{~mm}$; lateral, $0.8 \mathrm{~mm}$.

Antero-posterior diameter of medullary canal, $0.5 \mathrm{~mm}$.; lateral, $0.5 \mathrm{~mm}$.

The medullary canal is full. Mednllary index, $64 \%$.

Structure.-The section is composed of concentric lamellæ with oval lacunæ and bushy canaliculi surrounding the medullary canal. The bone is uniform.

Type I.

LEFT FEMUR OF STURNIRA LILIUN. NO. 115053, U. S. NAT. MUS.

Pl. 8, Fig. 115. Siyn. Tab. IV

Anter o-posterior diameter of bone, $1 \mathrm{~mm}$. ; lateral, $0.9 \mathrm{~mm}$.

Antero-posterior diameter of medullary canal, $0.5 \mathrm{~mm}$; lateral, $0.4 \mathrm{~mm}$.

The medullary canal is full. Medullary index, $29 \%$.

Structure.-The section is composed of concentric lamellæ with long, narlow lacunæ and long, straight canaliculi surrounding the medullary canal. The bone is uniform.

Type I.

RIGITT FEMUR OF LONCHORHINA. NO. 173849 , U. S. NAT. MUS.

Pl. 8, Fig. 116. Syn. Tab. IV

Antero-posterior diameter of bone, $0.9 \mathrm{~mm}$; lateral, $0.8 \mathrm{~mm}$.

Antero-posterior diameter of medullary canal, $0.5 \mathrm{~mm}$; lateral, $0.5 \mathrm{~mm}$.

The medullary canal is full. Medullary index, $55 \%$. 
Structure.-The section is composed of concentric lamellæ with oval lacunx and straight canaliculi surrounding the medullary canal. The bone is uniform.

Type I.

LEFT FEMUR OF ROUSETtUS AMPLEXICAUdATUS. NO. 175844, U. S. NAT. MUS.

$$
\text { Pl. 8, Fig. 11\%. Syn. Tab. IV }
$$

Antero-posterior diameter of bone, $2.5 \mathrm{~mm}$; lateral, $2 \mathrm{~mm}$.

Antero-posterior diameter of medullary canal, $1.5 \mathrm{~mm}$.; lateral, $1 \mathrm{~mm}$.

The medullary canal is full. Medullary index, $44 \%$.

Structure.-The section is dimly separated into three concentric divisions, external, central, and internal. The external and central divisions have lamellæ with long, narrow lacunæ and straight canaliculi, while the internal division has lamellæ with oval lacuna and bushy canaliculi. The bone shows the threefold division.

Type I.

RIGHT FEMUR OF HIPPosideros LaRVATUS. No. 152076 , U. S. NAT. MUS.

$$
\text { PL. 8, Fig. 118. Syn. Tab, IV }
$$

Antero-posterior diameter of bone, $1 \mathrm{~mm}$; lateral, $1 \mathrm{~mm}$.

Antero-posterior diameter of medullary canal, $0.5 \mathrm{~mm}$. ; lateral, $0.5 \mathrm{~mm}$.

The medullary canal is full. Medullary index, $33 \%$.

Structure.-The section is composed of concentric lamellæ with oval lacunæ and straight canaliculi separated into external, central, and internal rings which surround the medullary canal. The bone is uniform.

Type I.

LEFT FEMUR OF HEMIDERMA. NO. 123744 , U. S. NAT. MUS.

$$
\text { PL. 8, Fig. 119. SYN. TAB. IV }
$$

Antero-posterior diameter of bone, $1 \mathrm{~mm}$.; lateral, $1 \mathrm{~mm}$.

Antero-posterior diameter of medullary canal, $0.5 \mathrm{~mm}$. ; lateral, $0.5 \mathrm{~mm}$.

The medullary canal is full. Medullary index, $33 \%$.

Structure.-The section is composed of concentric lamellæ with oval lacuna and bushy canaliculi surrounding the medullary canal. The bone is uniform.

Type I.

LEFT FEMUR OF DESMODUS ROTUNDUS. NO. 114977, U. S. NAT. MUS.

$$
\text { PL. 8, Fig. 120. SYN. TAB. IV }
$$

Antero-posterior diameter of bone, $1.5 \mathrm{~mm}$; lateral, $2.5 \mathrm{~mm}$.

Antero-posterior diameter of medullary canal, $1 \mathrm{~mm}$.; lateral, $2 \mathrm{~mm}$.

The medullary canal is full of red marrow. Medullary index, $129 \%$. 
Structure.-The section is flattened antero-posteriorly and is surrounded bexternal riremuferential lamellie. The central ring is widest and is composed of oval lacunæe with very delicate bushy canaliculi. The posterior wall has two ridges. In the outer ridge is a vascnlar canal. The bone shows the threefold division.

Type I.

LEFT FEMUR OF LEPTONYCTERIS. NO. 105129 , U. S. NAT. MUS.

Pl. 8, Fig. 121. Syn. TAB. IV

Antero-posterior diameter of bone, $1 \mathrm{~mm}$; lateral, $0.8 \mathrm{~mm}$.

Antero-posterior diameter of medullary canal, $0.5 \mathrm{~mm}$. ; lateral, $0.4 \mathrm{~mm}$.

The medullary canal is full. Medullary index, $33 \%$.

Structure.-The section is composed of concentric lamellæ divided into wide external and narrow internal rings. The external is composed of lamellæ with oval lacmnæ and bushy canaliculi, and the internal, of lamellæ with long, narrow lacunæ and straight canaliculi. The bone has the twofold division.

Type I.

RIGHT FEMUR OF RHINOPOMA. (PALESTINE.) No. 120140, U, S. NAT. MUS.

PL. 8, F1G. 122. SYN. TAв. IV

Antero-posterior diameter of bone, $1 \mathrm{~mm}$.; lateral, $0.9 \mathrm{~mm}$.

Antero-posterior diameter of medullary canal, $0.5 \mathrm{~mm}$. ; lateral, $0.4 \mathrm{~mm}$.

The medullary canal is full. Medullary index, $29 \%$.

Structure.-The section is composed of concentric lamellæ with oval lacunx and straight canaliculi surrounding the medullary canal. The bone is uniform.

Type I.

LEFT FEMUR OF EROPHYILA BOMBIFRONS. NO. 86262 , U. S. NAT. MUS.

$$
\text { PL. 8, FTG. 123. SYN. TAB. IV }
$$

Antero-posterior diameter of bone, $1 \mathrm{~mm}$.; lateral, $0.8 \mathrm{~mm}$.

Antero-posterior diameter of medullary canal, $0.5 \mathrm{~mm}$.; lateral, $0.4 \mathrm{~mm}$.

The medullary canal is full. Medullary index, $33 \%$.

Structure.-The section is composed of concentric lamellæ with oval lacunæ and straight canaliculi surrounding the medullary canal. The bone is uniform.

Type I.

LeFt feMUR OF PHYllostoma Hastatum. No. 102906, U. S. NAT. MUS.

PL. 8, Fig. 124. SYn. Tab. IV

Antero-posterior diameter of bone, $2.5 \mathrm{~mm}$; lateral, $1.5 \mathrm{~mm}$.

Antero-posterior diameter of medullary canal, $1.5 \mathrm{~mm}$.; lateral, $1 \mathrm{~mm}$.

The medullary canal is full. Mednllary index, $64 \%$. 
Structure.-The section is composed of concentric lamellæ with oval lacunæ and straight canaliculi surrounding the medullary canal. The lamellæ are dimly separated into wide external and narrow internal rings by a condensation of the lacunæ around the medullary canal. Twofold division.

Type I.

LEFT FEMUR OF EPOMOPHORUS WAHLBERGII. NO. 113451, U. S. NAT. MUS.

PL. 8, FIG. 125. SYN. TAB. IV

Antero-posterior diameter of bone, $2 \mathrm{~mm}$.; lateral, $1 \mathrm{~mm}$.

Antero-posterior diameter of medullary canal, $1 \mathrm{~mm}$.; lateral, $0.5 \mathrm{~mm}$.

The medullary canal is full. Medullary index, $33 \%$.

Structure.-The section is composed of lamellæ divided into three concentric rings. The external is narrow and composed of lamellæ with long lacunæ and straight canaliculi; the central is wide and consists of lamellæ with oval lacunæ and bushy canaliculi; and the internal is narrow and composed of lamellæ with long lacune and straight canaliculi. The bone shows the threefold division.

Type I.

LEFT FEMUR OF GLOSSOPHAGA ELONGATA. NO. 102107, U. S. NAT, MUS.

PL. 8, FIG. 126. SYN. TAB. IV

Antero-posterior diameter of bone, $0.9 \mathrm{~mm}$.; lateral, $0.8 \mathrm{~mm}$.

Antero-posterior diameter of medullary canal, $0.4 \mathrm{~mm}$.; lateral, $0.4 \mathrm{~mm}$.

The medullary canal is full. Medullary index, $28 \%$.

Structure.-The section is composed of concentric lamellæ with oval lacunæ and straight canaliculi surrounding the medullary canal. The bone is uniform.

Type I.

LEFT FEMUR OF NYCTALUS AVIATOR. NO. 102098, U. S. NAT. MUS.

Pu. 8, Fig. 12\%. SxN. Tab. IV

Antero-posterior diameter of bone, $1.5 \mathrm{~mm}$. ; lateral, $1.5 \mathrm{~mm}$.

Antero-posterior diameter of medullary canal, $0.5 \mathrm{~mm}$.; lateral, $0.5 \mathrm{~mm}$.

The medullary canal is full. Medullary index, $12 \%$.

Structure.-The section is composed of concentric lamellæ with oval lacunx and straight canaliculi surrounding the medullary canal. The bone is uniform.

Type I.

LEFT FFMUR OF SCOTOPHILUS HEATHII. No. 13692, U. S. NAT. MUS.

PL. 8, Fit. 128. SYN. TAB. IV

Antero-posterior diameter of bone, $2 \mathrm{~mm}$.; lateral, $1.5 \mathrm{~mm}$.

Antero-posterior diameter of medullary canal, $1.2 \mathrm{~mm}$; lateral, $1 \mathrm{~nm}$.

The medullary canal is full. Medullary index, $65 \%$. 
Structure.-The section is divided into two rings, an extermal composed of lamellæ with oval lacunæ and bushy canaliculi, and an internal composed of lamellæ with long lacunæ and straight canaliculi. Twofold division.

Type I.

RIGHT FEMUR OF MINIOPTERUS SCHREIBERSII. No. 152610 , U. S. NAT. MUS.

$$
\text { Pl. 8, Fig. 129. \$ум. TAB. IV }
$$

Antero-posterior diameter of bone, $0.8 \mathrm{~mm}$; lateral, $0.7 \mathrm{~mm}$.

Antero-posterior diameter of medullary canal, $0.3 \mathrm{~mm}$.; lateral, $0.4 \mathrm{~mm}$.

The medullary canal is full. Medullary index, $64 \%$.

Structure.-The section is composed of concentric lamellæ with oval lacunæ and straight canaliculi surrounding the mednllary canal. The bone is uniform.

Type I.

LEFT FEMUR OF PROMOPS FOSTERI. NO. 105676, U. S. NAT. MUS.

$$
\text { PL. 8, Fig. 130. SYN. TAB. IV }
$$

Antero-posterior diameter of bone, $1 \mathrm{~mm}$.; lateral, $0.8 \mathrm{~mm}$.

Antero-posterior diameter of medullary canal, $0.5 \mathrm{~mm}$; lateral, $0.4 \mathrm{~mm}$.

The medullary canal is full. Medullary index, $33 \%$.

Structure.-The section is composed of concentric lamellæ with oval lacunæ and straight canaliculi surromding the medullary canal. The bone is uniform.

Type I.

LEFT FEMUR OF VESPERTILIO MURINUS. No. 5333, U. S. NAT. MUS.

$$
\text { PL. 8, FIG. 131. SYN. TAB. IV }
$$

Antero-posterior diameter of bone, $1.5 \mathrm{~mm}$; lateral, $1.5 \mathrm{~mm}$.

Antero-posterior diameter of medullary canal, $0.5 \mathrm{~mm}$; lateral, $0.5 \mathrm{~mm}$.

The medullary canal is full. Medullary index, $12 \%$.

Structure.-The section is composed of concentric lamella with oval lacuna and straight canaliculi surrounding the medullary canal. The bone is uniform.

Type I.

RIGHT. FEMUR OF MOLOSSUS NIGRICANS. NO. 8268, U. S. NAT. MUS.

$$
\text { PL. 8, Fig. 132. SYN. T'AB. IV }
$$

Antero-posterior diameter of bone, $1.5 \mathrm{~mm}$; lateral, $1 \mathrm{~mm}$.

Antero-posterior diameter of medullary canal, $0.7 \mathrm{~mm}$.; lateral, $0.8 \mathrm{~mm}$.

The medullary canal is full. Medullary index, $56 \%$.

Structure.-The section is composed of concentric lamellæ with long lacunæ and straight canaliculi surrounding the medullary canal. The bone is uniform.

Type I. 
RIGHT FEMUR OF DASIPTERUS INTERMEDIUS. NO. 22408, U. S. NAT. MUS.

PL, 8, Fig. 133. Syn. TAB. IV

Antero-posterior diameter of bone, $1 \mathrm{~mm}$. ; lateral, $0.9 \mathrm{~mm}$.

Antero-posterior diameter of medullary canal, $0.5 \mathrm{~mm}$; lateral, $0.4 \mathrm{~mm}$.

The medullary canal is full. Medullary index, $29 \%$.

Structure.-The section is composed of lamellæ divided into wide externa! and narrow internal rings. The external consists of lamellæ with oval lacunæ and straight canaliculi, and the internal, of lamellæ with long lacunæ and straight canaliculi. The bone has the twofold division.

Type I.

LEFT FEMUR OE MOLOSSUS MAJOR. NO. 101893, U. S. NAT, MUS.

PL. 8, FIG. 134. SYN. TAB. IV

Antero-posterior diameter of bone, $0.6 \mathrm{~mm}$. ; lateral, $0.6 \mathrm{~mm}$.

Antero-posterior diameter of medullary canal, $0.4 \mathrm{~mm}$.; lateral, $0.4 \mathrm{~mm}$.

The medullary canal is full. Medullary index, $80 \%$.

Structure.-The section is composed of concentric lamellæ with oval lacuna and straight canaliculi. Two divisions appear, external and internal. The external is wide and the internal is narrow. The concentric divisions surround the medullary canal. The bone shows a twofold division.

Type I.

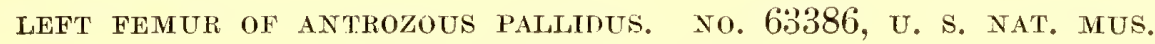

PL. 8, Fig. 135. SYN. Tab. IV

Antero-posterior diameter of bone, $1 \mathrm{~mm}$. ; lateral, $1 \mathrm{~mm}$.

Antero-posterior diameter of medullary canal, $0.8 \mathrm{~mm}$.; lateral, $0.8 \mathrm{~mm}$.

The medullary canal is full. Medullary index, $178 \%$.

Structure.-The section is thin-walled and composed of concentric lamellæ with oval and round lacunæ with bushy canaliculi surrounding the medullary canal. The bone is uniform.

Type I.

LEFT FEMUR OF EUMOPS CALIFORNICUS. NO. 61387, U. S. NAT, MUS.

Pu. 8, FIg. 136. Syn. TAB. IV

Antero-posterior diameter of bone, $1.5 \mathrm{~mm}$; lateral, $1.5 \mathrm{~mm}$.

Antero-posterior diameter of medullary canal, $0.9 \mathrm{~mm}$. ; lateral, $0.9 \mathrm{~mm}$.

The medullary canal is full. Medullary index, $56 \%$.

Structure.-The section is composed of concentric lamellæ with oval lacunæ and straight canaliculi, divided into wide external and narrow internal rings. Twofold division.

Type $\mathrm{I}$. 
Right FEMUR OF Plecotus aURITUS, No. 152597, U. S. NAT. MUS.

$$
\text { Pl. 8, Fig. 13\%. Syn. Tab. IV }
$$

Antero-posterior diameter of bone, $0.8 \mathrm{~mm}$; lateral, $0.7 \mathrm{~mm}$.

Antero-posterior diameter of medullary canal, $0.5 \mathrm{~mm}$.; lateral, $0.4 \mathrm{~mm}$.

The medullary canal is full. Medullary index, $56 \%$.

Structure.-The section is composed of concentric lamellæ with oval lacuna and straight canaliculi surrounding the medullary canal. The bone is uniform.

Type I.

LEFT FEMUR OF NiCticeiUs HuMeralis. No. 115141, U. S. NAT. MUS.

$$
\text { Pl. 8, Fig. 138. Syn. Tab. IV }
$$

Antero-posterior diameter of bone, $0.8 \mathrm{~mm}$; lateral, $0.7 \mathrm{~mm}$.

Antero-posterior diameter of medullary canal, $0.6 \mathrm{~mm}$. ; lateral, $0.5 \mathrm{~mm}$.

The medullary canal is full. Medullary index, $116 \%$.

Structure.-The section is composed of a few concentric lamellæ with oval lacunæ and straight canaliculi surrounding the medullary anal. The bone is uniform.

Type I.

RIGHT FEMUR OF MYOTIS MYOTIS. NO. 86500 , U. S. NAT. MUS.

PL. 8. Frg. 139. Syn. TAB. IV

Antero-posterior diameter of bone, $1 \mathrm{~mm}$.; lateral, $1 \mathrm{~mm}$.

Antero-posterior diameter of medullary canal, $0.5 \mathrm{~mm}$. lateral, $0.5 \mathrm{~mm}$.

The medullary canal is full. Medullary index, $33 \%$.

Structure.-The section is composed of concentric lamellæ with oval lacunæ and straight canaliculi surrounding the medullary canal. The bone is uniform.

Type I.

IEFT HEMUR OF EPTESICUS BAHAMENSIS. NO. 121929, U. S. NAT. MUS.

$$
\text { PL. 8. Fig. 140. SYN. TAB. IV }
$$

Antero-posterior diameter of bone, $0.8 \mathrm{~mm}$. ; lateral, $0.7 \mathrm{~mm}$.

Antero-posterior diameter of medullary canal, $0.5 \mathrm{~mm}$. ; lateral, $0.4 \mathrm{~mm}$.

The medullary canal is full. Medullary index, $56 \%$.

Structure.-The section is composed of concentric lamellæ with oval lacunæ and straight canalieuli surrounding the medullary canal. The bone is uniform. Type I. 
LEFT FEMUR OF NYCTERIS BOREALIS. NO. 101945, U. S. NAT. MUS.

PL. 8, FIG. 141. SYN. TAB. IV

Antero-posterior diameter of bone, $0.8 \mathrm{~mm}$. ; lateral, $0.8 \mathrm{~mm}$.

Antero-posterior diameter of medullary canal, $0.4 \mathrm{~mm}$. ; lateral, $0.4 \mathrm{~mm}$.

The medullary canal is full. Medullary index, $33 \%$.

Structure.-The section is composed of concentric lamellæ with oval lacunæ and straight canaliculi surrounding the medullary canal. The bone is uniform.

Type I.

RIGHT FEMUR OF GLTSCHROPUS TNLOPUS. No. 142385 , U. S. NAT. MUS.

PL. 8. Fig. 142. Syn. TAB. IV

Antero-posterior diameter of bone, $0.5 \mathrm{~mm}$; lateral, $0.4 \mathrm{~mm}$.

Antero-posterior diameter of medullary canal, $0.3 \mathrm{~mm}$. ; lateral, $0.2 \mathrm{~mm}$.

The medullary canal is full. Medullary index, $45 \%$.

Structure.-The section is composed of lamellæ with round lacunæ and bushy canaliculi surrounding the medullary canal. The bone is uniform.

Type I.

Right FEMUR OF NYCTERIS CINEREA. NO NUMBER, U. S. NAT. MUS.

PL. 8, Fig. 143. SyN. TAB. IV

Antero-posterior diameter of bore, $1 \mathrm{~mm}$.; lateral, $1 \mathrm{~mm}$.

Antero-posterior diameter of medullary canal, $0.5 \mathrm{~mm}$; ; lateral, $0.5 \mathrm{~mm}$.

The medullary canal is full. Medullary index, $33 \%$.

Structure.-The section is composed of concentric lamellæ with oval lacunæ and straight canaliculi, divided into wide external and narrow internal rings which surround the medullary canal. The bone shows a twofold division.

Type I.

LEF' FEMUR OF PHYLLONYCTERTS. NO. 103501, U. S. NAT. MUS.

Pr. 8, Fig. 144. SYN. 'I'AB. IV

Antero-posterior diameter of bone, $1 \mathrm{~mm}$. ; lateral, $0.8 \mathrm{~mm}$.

Antero-posterior diameter of medullary canal, $0.5 \mathrm{~mm}$. ; lateral, $0.4 \mathrm{~mm}$.

The medullary ranal is full. Medullary index, $33 \%$.

Structure.-The section is composed of concentric lamellæ with oval lacunæ and straight canaliculi surrounding the medullary canal. The bone is uniform.

Type I. 
RIGHT FEMUR OF MEgaderma SPASMA. NO. 114272, U. S. NAT. MUS.

$$
\text { PL. 8, Fig. 145. Syn. Tab. IV }
$$

Antero-posterior diameter of bone, $1 \mathrm{~mm}$.; lateral, $1 \mathrm{~mm}$.

Antero-posterior diameter of medullary canal, $0.5 \mathrm{~mm}$; lateral, $0.5 \mathrm{~mm}$.

The medullary canal is full. Medullary index, $33 \%$.

Structure.-The section is composed of concentric lamellæ with oval lacunæ and bushy canaliculi. The lamella are dividerl into wide external and narrow internal rings which partly surround the medullary canal. The internal ring is limited to the lateral walls. The bone slows a partial twofold division.

Type 1 .

$$
\begin{gathered}
\text { RIGHT FEMLR OF PTERONOTUA. No. 113570, U. S. NAT. MUS. } \\
\text { PL. 8, FIG. 146. SYN. 'TAB. IV }
\end{gathered}
$$

Antero-posterior diameter of bone, $1 \mathrm{~mm}$.; lateral, $0.8 \mathrm{~mm}$.

Antero-posterior diameter of medullary canal, $0.5 \mathrm{~mm}$.; lateral, $0.4 \mathrm{~mm}$.

The medullary canal is full. Medullary index, $33 \%$.

Structure.-The section is composed of concentric lamella with oval lacunæ and straight canaliculi surromding the medullary canal. 'The bone is uniform.

Type $\mathrm{I}$.

LEFT FEMUR OF BALANTIOPTERIX PLICATA. XO. 142606, U. S. NAT. MUS.

$$
\text { PL. 8, FIG. 14\%. SrN. TAB. IV }
$$

Antero-posterior diameter of bone, $0.5 \mathrm{~mm}$; lateral, $0.5 \mathrm{~mm}$.

Antero-posterior diameter of medullary canal, $0.3 \mathrm{~mm}$.; lateral, $0.3 \mathrm{~mm}$.

The medullary canal is full. Medullary index, $56 \%$.

Structure.-The section is composed of a few concentric lamellæ with round and oval lacunæ and bushy canaliculi surrounding the medullary canal. The bone is uniform.

Type I.

$$
\begin{gathered}
\text { Right FeMUR OF SACCOPTeryx. No. 123800, U. S. NAT. MUS. } \\
\text { PL. 8, Fig. 148. SyN. Tab. IV }
\end{gathered}
$$

Antero-posterior diameter of bone, $1 \mathrm{~mm}$; lateral, $0.8 \mathrm{~mm}$.

Antero-posterior diameter of medullary canal, $0.4 \mathrm{~mm}$.; lateral, $0.3 \mathrm{~mm}$.

The medullary canal is full. Medullary index, $18 \%$.

The bone is flat on the posterior side.

Structure.-The section is composed of concentric lamellæ with oval lacunæ and bushy canaliculi surrounding the medullary canal. The bone is uniform.

Type I. 
LEFT FEMUR OF PETAliA. No. 154866 , U. S. NAT. MUS.

Pi. 8, FIg. 149. SYx. TAB, IV

Antero-posterior diameter of bone, $1 \mathrm{~mm}$.; lateral, $0.9 \mathrm{~mm}$.

Antero-posterior diameter of medullary canal, $0.5 \mathrm{~mm}$. ; lateral, $0.5 \mathrm{~mm}$.

The medullary canal is full. Medullary index, $38 \%$.

Structure.-The section is composed of concentric lamellæ with oval lacumx and straight canaliculi surrounding the medullary anal. The bone is uniform.

Type I.

LEFT FEMUR OF MONOPHYLLUS. NO. 113677 , U. S. NAT. MUS,

PL. 8. Fig. 150. Sxx. Tab. IV

Antero-posterior diameter of bone, $1 \mathrm{~mm}$; lateral, $1 \mathrm{~mm}$.

Antero-posterior diameter of medullary canal, $0.5 \mathrm{~mm}$.; lateral, $0.5 \mathrm{~mm}$.

The medullary canal is full. Medullary index, $33 \%$.

Structure.-The section is composed of concentric lamella with oval lacun: and straight canaliculi surrounding the medullary ranal. The bone is uniform.

Type T.

LEFT FEMUR OF VAMPYROPS LINEATIS. U. S. NAT. MUS.

Pu. 8, Fig. 151. SYro. Tha, IV

Antero-posterior diameter of bone, $1 \mathrm{~mm}$. ; lateral, $0.8 \mathrm{~nm}$.

Antero-posterior diameter of medullary canal, $0.5 \mathrm{~mm}$.; lateral, $0.4 \mathrm{~mm}$.

The medullary canal is full. Nedullary index, $33 \%$.

Structure.-The section is composed of concentric lamellæ with oval lacunæ and straight canaliculi surrounding the medullary canal. The bone is uniform.

Type I.

RIGHT FEMUR OF CHILONYCTERIS. NO. 173842, U. S. NAT. MUS.

Pl. 8, Fig. 152. Syn. TAB. IV

Antero-posterior diameter of bone, $1 \mathrm{~mm}$; lateral, $1 \mathrm{~mm}$.

Antero-posterior diameter of medullary canal, $0.5 \mathrm{~mm}$.; lateral, $0.5 \mathrm{~mm}$.

The medullary canal is full. Medullary index, $33 \%$.

Structure.-The section is composed of concentric lamellæ with oval lacuna and straight canaliculi surrounding the medullary canal. The bone is uniform.

Type I. 
RIGHT FEMUR OF CYNOPTERUS. NO. 141241, U. S. NAT. MUS.

$$
\text { PL. 8. Fig. 153. Syn. 'TAB. IV }
$$

Antero-posterior diameter of bone, $1 \mathrm{~mm}$; ; lateral, $0.8 \mathrm{~mm}$.

Antero-posterior diameter of medullary canal, $0.5 \mathrm{~mm}$.; lateral, $0.4 \mathrm{~mm}$.

The medullary canal is full. Medullary index, $33 \%$.

Structure.-The section is composed of concentric lamellæ with oval lacunæ and straight canaliculi surrounding the medullary canal. The bone is uniform.

Type I.

LEF'T FEMUR OF ARTIBELS PALMARUM. No. 102866, U. S. NAT. MUS.

$$
\text { PL. 8, FIG. 154. SYN. TAB. IV }
$$

Antero-posterior diameter of bone, $1 \mathrm{~mm}$; lateral, $1 \mathrm{~mm}$.

Antero-posterior diameter of medullary anal, $0.5 \mathrm{~mm}$. ; lateral, $0.5 \mathrm{~mm}$.

The medullary canal is full. Medullary index, $33 \%$.

Structure.-The section is composed of concentric lamellæ with oval lacunæ and straight canaliculi surrounding the medullary canal. The bone is uniform.

Type I.

LEFT FEMUR OF BRACITPHYLA. No. 103251, U. S. NAT, MUS.

Pl. 8, Fig. 155. Sra. Tab. IV

Antero-posterior diameter of bone, $1.5 \mathrm{~mm}$.; lateral, $1 \mathrm{~mm}$.

Antero-posterior diameter of medullary canal, $1 \mathrm{~mm}$; lateral, $0.5 \mathrm{~mm}$.

The medullary canal is full. Nedullary index, $56 \%$.

Structure.-The section is composed of concentric lamellæ with oval lacuna and straight canaliculi surrounding the medullary canal. The bone is uniform.

Type I.

RTGHT FEMUR OF MACRoglossus MiNimus. No. 171695, U. S. NAT. MUS.

$$
\text { PL. 8, Fig. 156. Syn. TAB. IV }
$$

Antero-posterior diameter of bone, $1 \mathrm{~mm}$; ; lateral, $0.8 \mathrm{~mm}$.

Antero-posterior diameter of medullary canal, $0.5 \mathrm{~mm}$. ; lateral, $0.4 \mathrm{~mm}$.

The medullary canal is full. Medullary index, $33 \%$.

Structure.-The section is composed of concentric lamellæ with oval lacunæ and straight canaliculi surrounding the medullary canal. The bone is uniforn.

Type I. 
LEFT FEMUR OF TAPHOZOUS PHILPPINENSIS. NO. 144851, U. S. NAT. MUS.

$$
\text { PL. 8, Fig. 15\%. SYx. The. IV }
$$

Antero-posterior diameter of bone, $1 \mathrm{~mm}$.; lateral, $1 \mathrm{~mm}$.

Antero-posterior diameter of mednllary canal, $0.5 \mathrm{~mm}$. ; lateral, $0.5 \mathrm{~mm}$.

The medullary canal is full. Mednllary index, $33 \%$.

Structure.-The sertion is composed of concentrie lamellas with oval lacuna and straight canalienli smronnding the mednllary canal. The lamella are dimly separated into external and internal rings. Incomplete twofold division.

Type I.

R1GHT FEMUR OF CHEIROMELEA TORQUATUS. NO. 102462 , U. S, NAT, MTS.

$$
\text { PL. 8, Fig. 158. Srn. ThB. IV }
$$

Antero-posterior diameter of hone, $3.5 \mathrm{~mm}$. ; lateral, $2 \mathrm{~mm}$.

Antero-posterior diameter of mednllary canal, $1.5 \mathrm{~mm}$. ; lateral, $1 \mathrm{~mm}$.

The medullary canal is full. Medullary index, $27 \%$.

Structure.-The section is composed of concentric lamella with narrow lacnnæ and long, straight canalienli, divided into two distinct rings-external wide and internal narrow-which snrronnd the medullary canal. The internal ring laas very few lacmnx. 'Twofold division.

'Туре I.

RIGHT FEMUR OF xOCTILIO. xO. 49545, U. S. NAT. MUS.

Pr. 8, Fig. 159. Sin. Tab. IV

Antero-posterior diameter of bone, $2 \mathrm{~mm}$.; lateral, $1.5 \mathrm{~mm}$.

Antero-posterior diameter of mednllary canal, $1.5 \mathrm{~mm}$.; lateral, $0.9 \mathrm{~mm}$.

The medullary canal is full. Mednllary index, $82 \%$.

Structure.-The section is composed of concentric lamella with oval lacune. In the onter wall there are a few minnte canals smrronnded by clear areas of bone snbstance, around which oral lacnne with bnsliy canaliculi are assmming a partial concentric arrangement.

Type I-III, Ia.

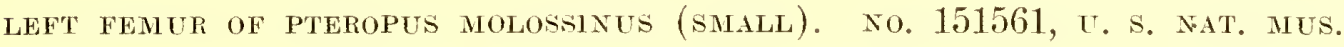

$$
\text { PL. 8, Fig. 160. SYx. Tab. IV }
$$

Antero-posterior diameter of hone, $2.5 \mathrm{~mm}$.; lateral, $2.5 \mathrm{~mm}$.

Antero-posterior diameter of medullary canal, $1.5 \mathrm{~mm}$. ; lateral, $1.5 \mathrm{~mm}$.

The mednllary canal is full. Nerlnllary index, $56 \%$. 
Structure.-The section is composed of lamella with oval lacumæ and straight canalienli indistinctly separated into three concentric rings. Incomplete threefold division.

Type I.

Righ't FeMUR OF pteropes molosinus (LARGe). U. S. NAT. MUS.

Pl. 8, Fig. 161. Syn. Tab. IV

Antero-posterior diameter of bone, $3 \mathrm{~nm}$.; lateral, $3.5 \mathrm{~mm}$.

Antero-posterior diameter of medullary canal, $2.5 \mathrm{~mm}$; lateral, $2.5 \mathrm{~mm}$.

The medullary canal is full. Medullary index, $147 \%$.

Structure.-The section is composed of lamellæ with long, narrow lacunæ and straight canaliculi enclosing the medullary canal. The lamellæ are divided into two rings, a narrow external and wide internal. In the inner wall the lamella are interrupted by a few canals of the (Ia) differentiation. The femur shows a little advancement. T'wofold division.

Type I-III, Ia.

Right FEMUL OF PTERolus ALDABRENSIS. No. 20989, U. S. NAT. MUS.

PL. 8, FIG. 162. SYN. 'Tab. IV

Antero-posterior diameter of bone, $2 \mathrm{~mm}$; lateral, $2.5 \mathrm{~mm}$.

Antero-posterior diameter of medullary canal, $1 \mathrm{~mm}$; lateral, $1.5 \mathrm{~mm}$.

The medullary canal is full. Medullary index, $43 \%$.

Structure.-The section is composed of concentric lamellae with oval and long lacune and straight canaliculi inter'upted by a few crude, undeveloped Haversian systems of the (Ia) differentiation.

Type I-III, Ia.

RIGHT FEMUR OF PTEROPUS. (CELEBEs.) No. 172460 , U. S. NAT. MUS.

Pl. 8, Fig. 163. SyN. Tab. IV

Antero-posterior diameter of bone, $4 \mathrm{~mm}$.; lateral, $3.5 \mathrm{~mm}$.

Antero-posterior diameter of medullary canal, $2.5 \mathrm{~mm}$; lateral, $2 \mathrm{~nm}$.

The medullary canal is full. Medullary index, $55 \%$.

Structure.-The section is composed of a wide external band of lamellæ divided into two nearly equal concentric lings by longitudinal canals of the (Ia) differentiation. The lacumæ are oval and narrow and the canaliculi are straight. Internal circumferential lamellæ with long lacunæ and straight canaliculi surround the medullary canal.

Type I-III, Ia. 
Right FEMUR of Pteropus. (JAYA.) No. 12616, U. S. NAT. MUS.

PL. 8, Fig. 164. Syn. Tab. IV

Antero-posterior diameter of bone, $3 \mathrm{~mm}$.; lateral, $3.5 \mathrm{~mm}$.

Antero-posterior diameter of medullary canal, $2.5 \mathrm{~mm}$.; lateral, $2 \mathrm{Imm}$.

The medullary canal is full. Medullary index, $91 \%$.

Structure.-The section is composed of concentric lamella with oval and long lacune and straight manaliculi, interrupted by many very crude Haversian systems of the (Ia) differentiation.

Type I-III, Ia.

RIGHT FEMUR OH PTEROPUS LEPICOS. No. 112404, U. S. NAT. MUS.

Pl. 8, Fig. 165. SyN. TAB. IV

Antero-posterior diameter of bone, $2.5 \mathrm{~mm}$.; lateral, $2 \mathrm{~nm}$.

Antero-posterior diameter of medullary canal, $1.5 \mathrm{~mm}$.; lateral, $1 \mathrm{~mm}$.

The medullary canal is full. Medullary index, $45 \%$.

Structure.-The section is composed of concentric lamellw with oval and long lacune and straight canaliculi crossed by numerous radiating canals. Here and there a few very crude Haversian systems of the (Ta) differentiation are seen. The bone is uniform.

Type I-III, Ia.

might femur of pteropus. (Tongatabu.) no. 173884 , U. S. Nat. mus.

PL. 8, Fig. 166. Sry. Tab. IV

Antero-posterior diameter of bone, $3 \mathrm{~mm}$; lateral, $3 \mathrm{~mm}$.

Antero-posterior diameter of medullary canal, $1.5 \mathrm{~mm}$. ; lateral, $1.5 \mathrm{~mm}$.

The medullary canal is full. Medullary index, $33 \%$.

Structure.-The section is composed of concentric lamellæ with oval lacunæ and straight canaliculi, partially separated by undeveloped Haversian systems of the (Ia) differentiation into two laminæ. The systems occupy a central concentric position. The bone has a twofold division.

Type I-III, Ia.

RIGHT FEMUR OF PTERopus POLIOCEPHALUS. U. S. NAT. MUS.

Pl. 9, Fig. 16\%. Syn. TAa. IV

Antero-posterior diameter of bone, $3.5 \mathrm{~mm}$.; lateral, $3.5 \mathrm{~mm}$.

Antero-posterior diameter of medullary canal, $2 \mathrm{~mm}$. ; lateral, $2 \mathrm{~mm}$.

The medullary canal is full. Medullary index, $49 \%$.

Structure.-The section has the three concentric divisions, external, central, and internal. The lacuna are oval and the canaliculi are straight. In the cen- 
tral division or ring are found numerous Haversian canals situated nearer to the internal than to the external division. The canals run parallel with the' medullary canal. They are surrounded by clear areas of bone substance which are crossed radially by very fine camaliculi from adjacent lacune. The canals witl: their canaliculi and lacune are crude outlines of Haversian systems of the (Ia) differentiation. The bone has the threefold division.

Type I-III, Га.

\section{O'THER MAMMALS NO'T INCLUDING MAN}

One hundred and thirty-three femora were examined.

\section{General Characteli of the Femul}

The general shape of the femur varies very considerably. Some bones are triangnlar, many elliptical, some round, some indeterminate, and a few are plano-convex. The majority of them are elliptical.

The medullary canals, with one or two exceptions, are full of marrow, and a large number have cancellous bone, the meshes of which are filled with marrow. The medullary surfaces are generally rough or irregularly corrugated. The medullary index varies from $9 \%$ to $289 \%$ with an average of $63.3 \%$.

The type of structure varies greatly. Nearly all types and type combinations in their various stages of differentiation are found. The bone units of monotremes and marsupials present an earlier differentiation than the higher mammals.

The first type bone is present in many genera and may be associated with the undeveloped third type of the (Ia) differentiation. A number of mammalian femora present a well marked second trpe structure. The lamina are much better developed than in birds. In most of these bones Haversian systems are found to the greatest extent in the posterior ridges. The pure third type of the (C) differentiation occurs only in a few mammals. Of these the African elephant is the best example. The majority of mammalian femora exhibit type combinations. These may be first and third, second and third, or first, second, and third in some form of differentiation. The majority are composed of the first and third types.

Detailed Examination

LEFT FEMUR OF TUPAIA. TREE-SHREW. AMER. MUS, NAT. HIST.

$$
\text { Ph. 9, Fig. 168. Srx. Tab. V }
$$

Antero-posterior diameter of bone, $3 \mathrm{~mm}$. ; lateral, $2.5 \mathrm{~mm}$.

Antero-posterior diameter of medullary canal, $2 \mathrm{~mm}$.; lateral, 1.5 $\mathrm{mm}$. 
The medullary canal is full. Medullary index, $67 \%$.

Structure.-With the exception of a few small and poorly developed Haversian systems of the (Ib) differentiation in the posterior and inner walls, the section is composed of lamellæ with oval lacune and straight canaliculi. The specimen shows very little differentiation of structure. The bone is uniform.

Type I.

RIGHT FEMUR OF ECHIDNA. EGG-LAYING MAMMAL. NO. 17355, AMER, MUS. NAT. HIST.

$$
\text { PL. 9, Fig. 169. Syn. TAв. V }
$$

Antero-posterior diameter of bone, $6 \mathrm{~mm}$.; lateral, $11.5 \mathrm{~mm}$.

Antero-posterior diameter of medullary canal, $3.5 \mathrm{~mm}$. ; lateral, $6.5 \mathrm{~mm}$.

The medullary canal is full. Medullary index, $49 \%$.

Structure.-A few primitive Haversian systems of the (Ib) differentiation are found in the inner and outer walls. The section, for the most part, is composed of basic bone substance with round and oval lacune and bushy canalieuli, crossed at various angles by branching canals. Around the medullary canal the lacunæ are longer and the lamellæ denser than clsewhere. In the outer wal! of the medullary canal cancellous bone occurs. The bone shows some departure from the first type by its crude Haversian systems.

Type I.

LEFT FEMUR OF ORNTITORHYNCHUS. DUCK BILL. EGG-LAITNG MAMMAL.

$$
\begin{aligned}
& \text { xo. } 13854 \text { U. S. NAT. MUS. } \\
& \text { PL. 9, FIG. } 170 . \text { SxN. TAB. V }
\end{aligned}
$$

Antero-posterior diameter of the bone, $4 \mathrm{~mm}$.; lateral, $5 \mathrm{~mm}$.

Antero-posterior diameter of the medullary canal, $2.5 \mathrm{~mm}$.; lateral, $3.5 \mathrm{~mm}$. The medullary canal is full. Medullary index, $79 \%$.

Structure.--The section is divided about equally into two concentric parts or rings not separated by any well marked boundary. The external half is composed of basic bone substance with a great many oval and round lacune and short, bushy canaliculi. In some places, as in the outer and inner ridges, crude Haversian systems appear. Wide canals arranged transversely, obliquely, anc? concentrically occur at frequent intervals. The internal half consists of lamellic with long lacuna and canaliculi, interrupted in the outer wall by Haversian systems of the (Ib) differentiation. The lamellie are crossed by canals, and in the anterior wall the canals rum concentrically.

Type I-III, Ib. 
LEFT FEMUR OF CAVIA CUTLERI. gUINEA PIG. AMER. MUS. NAT. Hist.

$$
\text { Pl, 9, Fig. 171. Syn. Tab. V }
$$

Antero-posterior diameter of bone, $6 \mathrm{~mm}$. ; lateral, $4 \mathrm{~mm}$.

Antero-posterior diameter of medullary canal, $4 \mathrm{~mm}$.; lateral, $3 \mathrm{~mm}$.

The medullary canal is full. Medullary index, $100 \%$.

Structure.-The three divisions are plainly marked. The external circumferential lamelle with long lacune and straight canaliculi form a narrow ring around the bone. The central ring consists of basic bone substance with round and oval lacunæ and bushy canaliculi, interrupted by poorly developed Haversian systems of the (Ia) differentiation and crossed by radiating canals. In the posterior wall the ring consists of crude Haversian systems between which is bone substance with oval lacunæ and bushy canaliculi.

The internal circumferential lamellæ form a narrow ring around the medullary canal. The bone shows a threefold division.

Type I-III, Ia.

LEHT FEMIR OF SCALOPUS AQUATICUS. MOLE. AMER. MUS. NAT. HIST.

$$
\text { P.u. 9, Fig. 1\%2. Syn. TAB. V }
$$

Antero-posterior diameter of bone, $1.5 \mathrm{~mm}$. ; lateral, $1.5 \mathrm{~mm}$.

Antero-posterior diameter of medullary canal, $1 \mathrm{~mm}$. ; lateral, $1 \mathrm{~mm}$.

The medullary canal is full. Medullary index, $80 \%$.

Structure.-The section is composed of lamellæ with long and oval lacunæ and straight canaliculi, partially separated into two equal, concentric rings by concentric, branching canals and crossed at various angles by radiating canals. In the posterior wall the lamellæ are crude Haversian systems of the (Ib) differentiation.

Type I-III, Ib.

RIGHT FEMUR OF SOREX. SHREW. AMER. MUS. NAT. HIST.

$$
\text { Pu. 9, Fig. 173. Syn. Tав. V }
$$

Antero-posterior diameter of bone, $3 \mathrm{~mm}$.; lateral, $3.3 \mathrm{~mm}$.

Antero-posterior diameter of medullary canal, $1.2 \mathrm{~mm}$. ; lateral, $1.5 \mathrm{~mm}$.

The medullary canal is full. Medullary index, $22 \%$.

Structure.-The section is composed of bone substance with oval lacunæ and bushy canaliculi, frequently interrupted by primitive Haversian systems of the $(\mathrm{Ib})$ differentiation and crossed by canals. In some places fragments of external circumferential lamellæ appear. In the posterior wall is a group of oval lacunæ with short, bushy canaliculi.

The bone shows but little differentiation of structure. It is uniformly of an early differentiation.

Type I-III, Ib. 
RIGHT FEMUR OF MACROPIS. WALLABI. NO. 22810, AMER. MUS. NAT. HIST.

$$
\text { PL. 9, Fia. 1\%4. SYN. 'J' I }
$$

Antero-posterior diameter of bone, $14 \mathrm{~mm}$; lateral, $14 \mathrm{~mm}$.

Antero-posterior diameter of medullary canal, $10 \mathrm{~mm}$; lateral, $10.5 \mathrm{~mm}$.

The medullary caual is full. Medullary iudex, $115 \%$.

Structure.-The section is composed of lamella with oval long lacuna and straight canaliculi, interrupted in the posterior wall by vascular canals and crude Haversian systems, and elsewhere by frequent radiating canals and Haversian systems of the ( $\mathrm{Ia}$ ) differentiation. It is indistinctly laminated.

Type I-III, Ia.

LEFT FEMUR OF SOLENODON PARADOXUS (YOUNG). AMER, MUS. NAT. HIST.

$$
\text { Pl. 9, Fig. 175. SYN. TAB. V }
$$

Antero-posterior diameter of bone, $5 \mathrm{~mm}$. ; lateral, $4.5 \mathrm{~mm}$.

Antero-posterior diameter of medullary canal, $4 \mathrm{~mm}$; lateral, $3.5 \mathrm{~mm}$.

The medullary canal is full. Medullary index, $165 \%$.

Structure.-The section is composed of lamella with round and oval lacumx and bushy canaliculi, frequently inter'upted by Haversian systems of the (Ta) and (Ib) differentiation and crossed by many oblique and radiating canals which take their origin in the medullary canal. 'The boue shows a very inconplete differentiation.

Type I-III, Ia, Ib.

RIGHT FEMUL OF SOLENODON PARADOXIS (ADULT). AMER. MUS. NAT. HIST.

$$
\text { PL. 9, Fig. 186. SYN. TAB. V }
$$

Antero-posterior diameter of bone, $6.5 \mathrm{~mm}$; lateral, $5 \mathrm{~mm}$.

Antero-posterior diameter of medullary canal, $4.5 \mathrm{~mm}$; lateral, $3.5 \mathrm{~mm}$.

The medullary canal is full. Medullary index, $94 \%$.

Structure.-The section shows the three divisions. The external cireumferential lamella form a distinct ring around the section. It is widest in the imner' wall. 'The lacunce are long' and the canaliculi are bushy and straight. 'Tlte central ring is composed of lamella with oval lacume and bushy caualiculi, interrupted by crude Haversian systems of the (Ia) and (Ib) differentiations. 'The section is nearly all lamella. 'The internal circumferential lamellae form a fragmentary ring around the medullary canal. Their lacume are oval aud straight and the canalieuli are straight.

Type I-III, Ta, Tb. 
FEMUR OF LEMUR MONGOZ. NO. 86849, U. S. NAT. MUS.

$$
\text { Pl. 9, Fig. 17\%. Srn. Tiв. V }
$$

Antero-posterior diameter of bone, $9 \mathrm{~mm}$; lateral, $7 \mathrm{~mm}$.

Antero-posterior diameter of medullary canal, $7 \mathrm{~mm}$. ; lateral, $4.5 \mathrm{~mm}$.

The medullary canal is full. Medullary index, $100 \%$.

Structure.-The section is composed of lamellæ with long lacunæ and straight canaliculi, divided into wide external and narrow internal rings. The lamelle of the external ring are interrupted by small and rather crude Haversian systems of the $(\mathrm{Ib})$ differentiation and by vascular canals which occupy a concentric position in the wall of the bone. The internal ring of lamellæ with long lacunæ and straight canaliculi surrounds the medullary canal. The bone has the twofold division.

Type I-III, Ib.

LEFT FEMUR OF COLOBUS Abysinicus CAUdATUS. NO. 27711, AMER. MUS. NAT. Hist.

$$
\text { PL. 9, Fig. 178. SrN. TAB. V }
$$

Intero-posterior diameter of bone, $12.5 \mathrm{~mm}$; lateral, $13 \mathrm{~mm}$.

Antero-posterior diameter of medullary canal, $7 \mathrm{~mm}$. ; lateral, $7 \mathrm{~mm}$.

The medullary (anal is full. Medullary index, $43 \%$.

Structure.-The section is composed of a very wide band of external circumferential lamellæ, interrupted by numerous very crude Haversian systems of the (Ia) and ( $\mathrm{Ib}$ ) differentiations. The band forms nearly the whole width of the wall of the bone. In the posterior wall the lamellie are displaced by small undeveloped Haversian systems and in the outer wall a narrow crescent of Haversian systems of the (C) stage appears just external to the internal circumferential lamellæ.

Internal circumferential lamella surround the medullary canal. Generally the lacunie are long and narrow and the canaliculi are straight, but in the posterior wall the lacuna are oval. The bone shows the twofold division.

Type I-III, Ia, Ib, C.

FEMUR OF PUTORIUS VULGARIS. WEASEl. CR. MED. COLI.

$$
\text { Pl. 9, Fig. 179. SYN. Tab. V }
$$

Antero-posterior diameter of the bone, $1.5 \mathrm{~mm}$.; lateral, $2 \mathrm{~mm}$.

Antero-posterior diameter of the medullary canal, $1 \mathrm{~nm}$. ; lateral, $1.5 \mathrm{~mm}$.

The medullary canal contains a very thin layer of marrow around the walls of the bone. Medullary index, $62 \%$. 
Structure.-The section is composed of lamclla with long and narrow lacunæ and long, straight canaliculi. In the outer wall the lamellæ are interrupted by irregularly shaped whorls of oval and round lacuna closely packed together in the bone substance. The canaliculi are short and bushy. In one of these whorls a central canal appears and the whole figure resembles slightly a crude Haversian system. A few large canals cross the section radially on their way from the medullary canal to the external surface. The bone is uniform.

Type I.

FEMUR OF MUS RATTUS. RAT. CR. MEN. COLL.

PI. 9. FIG. 180. SYN. TAB. V

Antero-posterior diameter of bone, 2.5 mm.; lateral, $3.5 \mathrm{~mm}$.

Antero-posterior diameter of the medullary canal, $1.5 \mathrm{~mm}$; lateral, $2.5 \mathrm{~mm}$.

The medullary canal is full. Medullary index, $75 \%$.

Structure.-The section is composed of two concentric rings of about equal width surrounding the medullary canal. The external ring is composed of lamellæ with long lacunæe and long, branching canaliculi. Here and there cross canals appear. The internal ring is romposed of short lamelle, lamina, and a few incomplete Haversian systems of the (Ib) differentiation, separated by a network of canals. The lacunxe are oval and round and the canaliculi are bushy. The internal circumferential lamelle are so blended with the ofler structures of the internal ring that they are poorly defined.

'Type I-III, Ib.

LEFT FEMUR OF HETEROMTS. SPINY POCKET RAT. AMER. MUS. NAT, HIST.

$$
\text { PL. 9. Fig. 181. SYx. ThB. V }
$$

Antero-posterior diameter of bone, 4.5 mm.; lateral, $2.5 \mathrm{~mm}$.

Antero-posterior diameter of medullary canal, $3.5 \mathrm{~mm}$. ; lateral, 22 $\mathrm{mm}$.

The medullary canal is full. Medullary index, $153 \%$.

Structure.-The anterior and imer walls are composed of lamella witl long and oval lacuma and straight canaliculi, clossed radially by freqnent canals. The posterior wall is composed of rather crude Haversian systems with oval lacuna and bushy canaliculi, and the outer wall of lamella with oval lacuna and bushy canaliculi, interrupted by crurle Haversian systems of the (Ia) and ( $\mathrm{Ib}$ ) differentiations and crossed by canals. The internal rircumferential lamelle are not distinct. The bone shows but little rifferentiation of structure.

Type I-III, Тa, Ib. 
RIGHT FEMUR OF MYOGALE MOSCHATA. DESMAN. CR. MED. COLL.

$$
\text { Pl. 9, Fig. 182. STN. T'Ав. V }
$$

Antero-posterior diameter of bone, $5 \mathrm{~mm}$.; lateral, $6.5 \mathrm{~mm}$.

Antero-posterior diameter of medullary canal, $2.5 \mathrm{~nm}$.; lateral, $3 \mathrm{~mm}$.

Medullary canal has no contents. Medullary index, $30 \%$.

Structure.-The immer wall of the bone is extended in the form of a ridge, which is composed of a network of laminæ and canals running transversely and occupying the outer four-fifths of the ridge. Each lamina is composed of lamellæ with long or oval lacunæ and long branching or bushy canaliculi. The inner one-fifth of the ridge wall is composed of a network of lamina running from the medullary canal to the outer network. The remainder of the bone (anterior, outer, and posterior wall) is composed of a very irregular, wide internal ring of lamellæ surrounding the medullary canal and having an outer wavy border, in some places distinct and in other places fused with an external network of laminæ. Many canals cross the lamellæ on their way from the medullary canal to the middle of the wall. Within the lamellar ring are several round or elliptical bodies composed of lamelle running lengthwise of the cross-section. These bodies are such as would result from a transverse section of solid pillars. In the outer wall of the bone lamellæ form the entire thickness. Here and there occur a few incomplete Haversian systems consisting of a central canal and radiating canaliculi. Twofold division.

Type I-II-III, Ib.

FeMUR OF CINOMTS LUDOVICTANUS, PRAIRIE DOg. CR. MED. COLL.

$$
\text { PL. 9, Frg. 183. SYr. Tab. V }
$$

Antero-posterior diameter of bone, $4.5 \mathrm{~mm}$. ; lateral, $5 \mathrm{~mm}$.

Antero-posterior diameter of medullary canal, $2.5 \mathrm{~mm}$.; lateral, $3 \mathrm{~mm}$.

The medullary canal is empty. Medullary index, $50 \%$.

Structure.-The section is composed of external circumferential lamella forming an irregular ring which reaches its greatest width in the inner wall. The lacunæ are long and narrow and the canaliculi are long.

The central ring is composed of incomplete Haversian systems of the ( $\mathrm{Ib}$ ) differentiation. Their lamelle are indistinct, their lacume are oval, and their canaliculi are bushy.

A very wide ring of internal circumferential lamelle surrounds the medullary canal. The ring is widest in the anterior wall. 'Their lacune are long and narrow and their canaliculi are long. Numerous canals pass from the medulJary canal across the lamellæ into the interior of the bone.

Type I-III, Ib. 
LEFT FEMUR OF Trichosurus Vulpecula. PHALANGER. No. 22804, AMER, MUS. NAT. HIST.

PL. 9, Fig. 184. Syn. Tab. V

Antero-posterior diameter of bone, $7 \mathrm{~mm}$; lateral, $7.5 \mathrm{~mm}$.

Antero-posterior diameter of medullary canal, $4 \mathrm{~mm}$.; lateral, $5 \mathrm{~mm}$.

The medullary canal is full. Medullary index, $61 \%$.

Structure.-The section is composed of lamellæ with long lacunæ and straight canaliculi, interrupted by a few Haversian systems of the (Ia) and (Ib) differentiations and crossed radially by vascular canals.

The bone shows very little differentiation of structure. The bone is uniform.

Type I-III, Ia, Ib.

LEFT FEMUR OF PHASCOLOMYS URSiNUS. WOMBAT. AMER. MUS. NAT. Hist.

$$
\text { Pl. 9, Fig. 185. Syn. Tab. V }
$$

Antero-posterior diameter of bone, $11.5 \mathrm{~mm}$. ; lateral, $13 \mathrm{~mm}$.

Antero-posterior diameter of medullary canal, $4 \mathrm{~mm}$. ; lateral, $6 \mathrm{~mm}$.

The medullary canal is full. Medullary index, $11 \%$.

Structure.-The section is composed of several concentric rings of lamell $x$ with long lacunæ and straight canaliculi surrounding the medullary canal.

The rings of lamellæ are separated by small, crude Haversian systems of the $(\mathrm{Ia})$ and $(\mathrm{Ib})$ differentiations and crossed radially by many canals. The posterior ridge is double. The two ridges are composed of very crude Haversian systems and inter-Haversian lamellæ. Between them and forming the posterior wall the structure is the same as elsewhere.

The lacunæ are long and oval and the canaliculi are long, straight, or bushy. The bone shows but little differentiation of structure.

Type I-III, Ia, Ib.

RIGHT FEMUR OF LASIOPYGA KOLBI. AFRICAN MONKEY. NO. 27719, AMER, MUS. NAT. HIST.

$$
\text { PI. 9, FIG. 186. SYN. TAB. V }
$$

Antero-posterior diameter of bone, $8.5 \mathrm{~mm}$. ; lateral, $10 \mathrm{~mm}$.

Antero-posterior diameter of medullary canal, $6 \mathrm{~mm}$. ; lateral, $7 \mathrm{~mm}$.

The medullary canal is full. Medullary index, $98 \%$.

Structure.-The section is composed of concentric lanella with oval lacune and bushy canaliculi, interrupted by small crude Haversian systems of the (Ia) and $(\mathrm{Ib})$ differentiation enclosing the medullary canal. A few fairly well de- 
veloped Haversian systems appear in the immer wall and several are found in the posterior wall. The bone is uniform.

Type I-III, Ia, Ib.

RIGHT FEMUR OF TRAGrl, JAYANICUS. JAVA MOUSE-DEER. No, 14128,

AMER. MUS. NAT. IHST.

Pt. 10. Fig. 18\%. Syx. Tab. V

Antero-posterior diameter of hone, 7.5 mm.; lateral, $7 \mathrm{~mm}$.

Antero-posterior diameter of medullary anal, $6.5 \mathrm{~mm}$.; lateral, $6 \mathrm{~mm}$.

The medullary canal is full. Medullary index, $289 \%$.

Structure.-The section is composed of lamellie with long lacunæ and straight canalicnli incompletely separated into laminx, interrupted by a few Haversian systems of the (Ta) and (C) differentiations and crossed by canals. In the posterior wall Harersian systems are most numerous. The lacunæ are long and oval. The bone shows but little differentiation of strueture.

Type II-TII, Til, C.

RIGTT FEMUR OF MUS SYLYATICUS. WOOD MOUSE. CR. MED, COLT.

PL. 10. Fig. 188. Sิrx. 'TiB. T

Antero-posterior liameter of hone, $2 \mathrm{~mm}$; lateral, $3 \mathrm{~mm}$.

Antero-posterior dianeter of medullary canal, $1 \mathrm{~mm}$.; lateral, $2 \mathrm{~mm}$.

The medullary canal is full. Medullary index, $50 \%$.

Structure.-The section is composed of lamella with round, oval, and long lacunæe and bushy analicnli, separated into short bands which extend spirally, concentrically, and radially along the walls. Here and there a few crude Haversian systems appear.

Type I-III, Ib.

LEFT FEMUR OF ERINACEUS EUROPAES. HEDGEHOG. AMER. MUS. NAT. Hist.

PL. 10, Fig. 189. Six. 'Tib. V

Antero-posterior diameter of bone, $3 \mathrm{~mm}$. ; lateral, $6 \mathrm{~mm}$.

Antero-posterior dianeter of medullary canal, $2 \mathrm{~mm}$. ; lateral, $2.5 \mathrm{~mm}$.

The medullary canal is full. Medullary index, $38 \%$.

Structure.-With the exception of the anterior wall, the section is surronnded by bone substance with oral lacunæ and bushy canaliculi.

The body of the section is composed of bone substance with oval lacme and bushy canaliculi in which are Haversian systems of the (Ib) differentiation. In the anterior wall is a narrow concentric lamina. The posterior wall is very much extended and composed of cancellous bone substance with oval lacunx. The internal eireumferential lamellæ are absent.

Type I-III, Ib. 
RIGHT FEMUR OF VIVERRA. CIVET. AMER. MUS. NA'T. HISTI.

Pl. 10. Fig. 190. Syx. Tab. V

Antero-posterior diameter of bone, $\&$ mm.; lateral, $7 \mathrm{~mm}$.

Antero-posterior diameter of mednllary canal, $5 \mathrm{~mm}$.; lateral, $4 \mathrm{~mm}$.

The mednllary canal is full. Medullary index, $55 \%$.

Structure.-The section has three divisions. A wide ring of lamellax, dimly separated into concentric parts and freqnently intermpted by Haversian systems of the (Ta) differentiation, forms the greater part of the bone. The lacune are oval and the canalionli are bushy and straight. Underneath this is a long erescent of Haversian systems of the ( $\mathrm{Tb}$ ) differentiation surrounding the section with the exception of the imner wall. The systems are separated by bone substance with romol lacune and bushy caualiculi.

A narrow ring of lamella with long lacune and straight canalienli surromnds the medulary canal.

Type I-III, Ia, Ib.

RIGHT FEMUR OF RATCA MAXIMA. GINT SQUTREL. No. 20839,

AMER, MUS. NAT, HIST,

PL. 10, Fig. 191. Sra. Tad. V

Antero-posterior diameter of bone, $5.5 \mathrm{~mm}$.; lateral, $6.5 \mathrm{~mm}$.

Antero-posterior diameter of medullary canal, $3.5 \mathrm{~mm}$. ; lateral, $4.5 \mathrm{~mm}$.

The medullary canal is full. Medullary index, $80 \%$.

Structure.-The section is surromed by a wide ring of lamellæ with long lacunæ and straiglit canalicnli, interrupted by Haversian systems of the (Ta) differentiation. In the posterior and onter wall is a narrow ring of small Harersian systems of the (Ib) differentiation. The internal circumferential lamellæ are not distinet.

Type I-IГT, Ta, Tl.

FEMUR OF GALEOPTHECUS. FLTING LEMUR. NO. 49640, U. S. NAT, MUS.

PL. 10, Fig. 192. Six. T.IB. V

Antero-posterior diameter of bone, $6.5 \mathrm{~mm}$; lateral, $5.5 \mathrm{~mm}$.

Antero-posterior dianeter of medullary canal, 4 mm.; lateral, $3.5 \mathrm{~mm}$.

The mednllary eanal is full. Mednllary intex, $64 \%$.

Structure.-The section is composed of a wide ring of extermal rircom ferential lamelle with long lacme and straight canalicnli, frequently inter rupted by small, crute Harersian srstems of the (la) differentiation. The 
lamellæ form the whole thickness of the anterior wall with the exception of the internal circumferential lamellæ.

The internal circumferential lamelle, with a long, narrow crescent of $\mathrm{Ha}$ versian systems of the $(\mathrm{Ib})$ differentiation, especially in the posterior and adjacent lateral wall, surround the medullary canal.

Type I-III, Ia, Ib.

LEFT FEMUR OF MANIS. SCALY ANT-EATER, AMER, MUS, NAT, HIST.

PL. 10, Fig. 193. Syn. Tab. V

Antero-posterior diameter of bone, $7.5 \mathrm{~mm}$; lateral, $11 \mathrm{~mm}$.

Antero-posterior diameter of medullary canal, $5 \mathrm{~mm}$.; lateral, $7 \mathrm{~mm}$.

The medullary canal is full. Medullary index, $74 \%$.

Structure.-The three divisions appear indistinctly marked. The external circumferential lamellæ with long lacunæ and straight canaliculi form a wide band around the section. They are interrupted by crude Haversian systems of the (Ia) differentiation and crossed by canals which assume a radial direction. Under this band is a narrow ring of lamellæ with oval lacunæ and bushy canaliculi. Beneath this again is a narrow ring of Haversian systems of the (Ib) differentiation. The lacunæ are oval and long and the canaliculi are bushy.

Internal circumferential lamellæ form a narrow ring around the medullary canal. Their lacunæ are oval. In the outer wall tendon insertions and crude systems are found. Threefold division.

Type I-III, Ia, Ib.

RIGHT FEMUR OF PROCAVIA CAPENSIS. CONEY. No. 35326, AMER. MUS. NAT. Hist,

PL. 10, Fig. 194. Syn. Tab. V

Antero-posterior diameter of bone, $7.5 \mathrm{~mm}$. ; lateral, $5 \mathrm{~mm}$.

Antero-posterior diameter of medullary canal, $3 \mathrm{~mm}$. ; lateral, $2.5 \mathrm{~mm}$.

The medullary canal is full. Medullary index, $25 \%$.

Structure.-The external circumferential lamellæ form a narrow boundary of the posterior wall and then gradually widen to form the whole of the anterior wall. They are interrupted by Haversian systems of the (Ia) differentiation.

Their lacune are long' and their canaliculi are straight. In the posterior half of the section the central ring borders the medullary surface of the posterior and inner wall and is discontinued as it reaches the anterior wall. It is 'omposed of well developed Haversian systems. Internal circumferential lamellæ form a broken ring around the medullary canal.

Type I-III Ta, C. 
LEFT FEMUR OF HELICTIS ORIEN'JALS. ASIATIC BADGER. NO. 31806 ,

AMER. MUS. NAT. TISTT.

PL. 10, FIG. 195. SYN. 'TLU. V

Antero-posterior diameter of bone, $5.5 \mathrm{~mm}$; lateral, $4.5 \mathrm{~mm}$.

Antero-posterior diameter of medullary canal, $3.2 \mathrm{~mm}$.; lateral, $2.5 \mathrm{~mm}$.

The medullary canal is full. Medullary index, $129 \%$.

Structure.-The section is composed of lamella frequently intermpted by Haversian systems and crossed by amals. The lamella have oval and long lacunæ and straight and bushy canaliculi.

Type I-III, C.

RIGHT FEMUR OF CYNOCEPIIALUS. BABOON. NO. 35120, AMER. MUS. NAT. HIST.

Pr. 10, Fig. 196. SYn. T'AB. V

Antero-posterior diameter of bone, $16 \mathrm{~mm}$.; lateral, $16 \mathrm{~mm}$.

Antero-posterior diameter of medullary canal, $10 \mathrm{~mm}$. ; lateral, $10 \mathrm{~mm}$.

The medullary canal is full. Medullary index, $64 \%$.

Structure.-The section is composed of a wide ring of external lamelle, interrupted by small, crude Haversian systems of the (Ia) differentiation and by large spaces. The lacunx are long and oval with long eanaliculi. The ring forms nearly the whole width of the wall. Around the medullary canal the internal circumferential lamellæ form an enclosing ring which is partly cancellous. A few Haversian systems occur between the internal and external lamellæ. In the posterior ridge Haversian systems, separated by lamellæ with oral lacunx, constitute the structure.

Type I-III, Ia, Ib.

RIGHT FEMUR OF CYNOCEPHALUS MAMION. MANDRILL. NO. 22817, AMER. MUS. NAT. HTST.

PL. 10, Fig. 19\%. SYN. TAB. V

Antero-posterior diameter of bone, $13 \mathrm{~mm}$. ; lateral, $11.5 \mathrm{~mm}$.

Antero-posterior diameter of medullary canal, $8 \mathrm{~mm}$. ; lateral, $8 \mathrm{~mm}$.

The medullary canal is full. Medullary index, $75 \%$.

Structure.-The section is composed of two parts: a wide external circomferential ring of lamella, interrupted by a few erude Haversian systems of the (Ia) and ( Ib) differentiations, and a narrower internal ring of cancellons bone. The lacune are long and oval and their canaliculi are straight. The bone shows but little differentiation of structure.

Type I-III, Ta, Ib. 
RIGHT FEMUR OF HYDROCHCRUS CAP'TBAR, NO, 35325, AMER, MUS, NAT, HIST.

Pl. 10, Fig. 198. Syn. TAB. V

Antero-posterior diameter of bone, $22 \mathrm{~mm}$. ; lateral, $20 \mathrm{~mm}$.

Antero-posterior diameter of medullary canal, $13 \mathrm{~mm}$.; lateral, $11 \mathrm{~mm}$.

The medullary canal is full. Medullary index, $48 \%$.

Structure.-The section is surrounder! by a narrow ring of Haversian systems and inter-IJaversian lamella. The central ring, confined to the outer wall, is composed of crude Haversian systems of the (Ib) differentiation, between which are lamelle with large, oval lacuna and bushy canaliculi in the outer wall, and lamellie witlı oval lacune and bushy canaliculi interrupted by canals of the (Ia) differentiation in the imer and anterior wall. The internal eircunferential lamelle form a narrow ring round the medullary canal. The lacunæ are oval.

Type I-III, Ia, Ib.

$$
\begin{aligned}
& \text { Fenomia of Femal Sheep, Calf, and Pig-Half Thme } \\
& \text { RIGHT TEMUR OF FETAl SHELP, } 11 \text { WEERS. NO. 93, CR. MED. COLL. }
\end{aligned}
$$$$
\text { PL. 11, Fifi, 199. Sin, TaB, V }
$$

Antero-posterior diameter of bone, $3.5 \mathrm{~mm}$; lateral, $4 \mathrm{~mm}$.

Antero-posterior diameter of medullary canal, $1 \mathrm{~mm}$.; lateral, $1 \mathrm{~mm}$.

The medullary canal is full. Medullary index, $8 \%$.

Structure.-The section is composed of short, wide, irregular lamine witlı oval lacunæe and bushy canaliculi, between which are short, wide, irregular communicating canals. The section is pretty uniform in structure. A few Haversian systems of the $(\mathrm{Ib})$ differentiation are present in the posterior wall. This femur is about one-half of the full fetal term and may be compared with the human femur of 4 to 5 months.

Type II-III, Ib.

RIGHT FEMUR OF EETAL CALF, 18 WEEKS, No. 94, Cr. MEd, COLl.

$$
\text { PL. 11, Fig. 200. SYN. TAB. V }
$$

Antero-posterior diameter of bone, $12 \mathrm{~mm}$; lateral, $11 \mathrm{~mm}$.

Antero-posterior diameter of medullary canal, $5 \mathrm{~mm}$.; lateral, $4 \mathrm{~mm}$.

The medullary canal is full. Medullary index, $18 \%$.

Structure.-The bone is half fetal development. It is composed of small, very irregular areas of laminæ separated by many canals of bizarre shapes. Aromd the circumferential fourth of the bone the canals are elongated and the lamine have assuned a general concentric arrangement. In the medullary three-fourths there is no definite plan of arrangement. The laminæ are 
composed of oral and long lacune with rather infrequent wanticnli. Here and there, and especially in the posterior ridge, some lamina have widenerl, shortened, and assmmed in part the shape of Haversian systems.

Type HI-III, Ib.

RIGHT FEMUR OF A FETAL PIG, HALF FETAL PERIOD-8 $\frac{1}{2}$ WEEKS.

I'L. 11, Fig. 201. SYN. TAB. V

Antero-posterior diameter of bone, $3.5 \mathrm{~mm}$. ; lateral, $3 \mathrm{~mm}$.

Antero-posterior diameter of medullary canal, $1.5 \mathrm{~mm}$.; lateral, $1 \mathrm{~mm}$.

The medullary canal is situated eccentrically. The anterior wall is thinnest, the posterior thickest.

The medullary canal is full. Medullary index, $17 \%$.

Structure.-The section is composed of concentric lamina separated and crossed by wide canals. In the anterior wall the lamine are short, in the lateral wall, long, and in the posterior wall, irregular. There are no Haversian systems, although in the posterior wall the lamina are very short and inclined to a circular' bend. 'The lacune are oval and the canaliculi are bushy.

Type II.

FEMUR OF CARLACUS MACROTIS. DEER. CR. MEL, COLI.

P'. 11, Fig. 20\%. Sin. Tab. V

Antero-posterior diameter of bone, $25 \mathrm{~mm}$; lateral, $24 \mathrm{~mm}$.

Antero-posterior diameter of the medullary canal, $17 \mathrm{~mm}$.; lateral, $16.5 \mathrm{~mm}$.

The medullary canal is full. Medullary index, $88 \%$.

Structure.-The bone is composed almost entirely of lamina. They are well developed, separated, and "rossed by wide eanals. Their larma are long, narrow, and completely developed and the canaliculi are long and branching. Here and there are found a few aberrant Haversian systems, produced by a eircular widening of the concentric eanals and the bending of a few lamellæ around the circular openings. The lamine form the entire section, excepting the posterior ridge and a small area near the anterior wall which are composed of Haversian systems with many oval lacune. There are no distinct external cireumferential lamellx. The canals between the lamine cross them at right angles and communicate frecly with each other.

The internal eireumferential lamine form an irregularly shaped boundary of the medullary anal. They are fresuently crossed by canals extending outward from the medullary anal. The surface of the posterior ridge shows the tendon attachments of muscles. Fxtending from this surface to the internal circumferential lamina, and for a short distance on either side of the posterior mid-line, is an area of Haversian systems. They are irregular in shape, well 
leveloped for the most part, separated by bone substance with oval lacunæ and bushy canaliculi, and surrounded by a coarse network of canals. T'heir lacune are long and narrow, generally. A few, however, show round or oval lacune with short, bushy canaliculi. The bone is uniform.

Type II-III, C.

FEMUR OF SUS. DOMESTIC PlG. CR. MED. COLL.

PL. 11, Fig. 203. Syn. T'ab. V

Antero-posterior diameter of hone, $21.5 \mathrm{~mm}$; lateral, $18.5 \mathrm{~mm}$.

Antero-posterior diameter of medullary canal, $16.5 \mathrm{~mm}$; lateral, $12.5 \mathrm{~mm}$.

The medullary canal is full. Medullary index, $108 \%$.

Structure.-The bone, with the exception of the posterior wall, is composed of concentric laminæ. The laminæ are separated and crossed by wide canals which frequently communicate with each other. The separating canals, here and there, widen into circular areas which are surrounded by incompletely developed concentric lamelle and form aberrant Haversian systems. The laminæ are long or short and strongly developed. They have long, narrow lacunæ and branching canaliculi. In the posterior wall are two areas of well developed Haversian systems separated by an intermediate wall of laminæ. These are the only regular systems of the section.

The femur of the adult pig is second type with two areas of Haversian systems in the posterior wall. This bone, therefore, is essentially second in type as it emerges from the fetal stage, and, for the most part, remains second in the adult.

Type II-III, C.

RIGHT-FEMUR OF SUS SCROFA. WILD BOAR. (ARKANSAS.) CR. MED. COLL.

PL. 11, Fig. 201. Syn. Tab. V

Antero-posterior diameter of bone, $23 \mathrm{~mm}$; lateral, $20 \mathrm{~mm}$.

Antero-posterior diameter of medullary canal, $15 \mathrm{~mm}$; lateral, $13 \mathrm{~mm}$.

The medullary eanal is full. Medullary index, $74 \%$.

Structure.-The bone is composed of concentric laminæ crossed and divided into short segments by canals. The laminæ are composed of lamelle with long narrow lacunæ and straight canaliculi.

In the posterior wall are two ridges separated by the intervening portion of the posterior wall. These ridges are composed of well developed Haversian systems which occupy the whole thickness of the wall from the external laminæ to the internal. Between the ridges the posterior wall is composed of laminæ alternating with Haversian systems in concentric rows. About the middle of the lateral walls on both sides of the two ridges, crude Haversian systems are 
extended for some distance between the lamine. The lacme of all units are well developed.

Type II-III, C.

FEMUR OF ALCES MACHLIS. ELK. CR. MED. COLL.

Pl. 11, Fig. 205. Syn. Tib. V

Antero-posterior diameter of bone, $35 \mathrm{~mm}$. ; lateral, $33 \mathrm{~mm}$.

Antero-posterior diameter of medullary canal, $23 \mathrm{~mm}$. ; lateral, $20 \mathrm{~mm}$.

The medullary canal is full. Medullary index, $66 \%$.

Structure.-A ring of external cirenmferential lamellæ surrounds the bone. Their lacunæ are long and narrow and their canaliculi are long and branching. The central ring, constituting the greater part of the bone, is composed of fully developed laminæ separated by concentric canals and interrupted at short intervals by completely developed Haversian systems. The laminæ are frequently transected by the canals, which freely communicate with each other: They are composed of lamellæ with long, narrow lacunæ and branching canaliculi. They have the appearance of a strong derelopment. The canals are wide and in some places have widened into Haversian canals.

The Haversian systems have long, narrow lacunæ and long branching canaliculi. The Haversian eanals are large, round or oval in shape, and freely communicate with each other. Beginning in the posterior wall, and extending around the outer wall, nearly to the anterior mid-line, and oceupying a position next to the interual cireumferential lamellæ, is a narrow zone of Haversian systems. Another group is found near the surface of the anterior wall, and near the medullary canal are several large vascular eanals surrounded by lamellæ.

Type II-III, C.

RIGHT FEMUR OF CAMELUS. CAMEL, NO. 35379, AMER, MUS. NAT, HIST.

PL. 11, Fig. 206. Syn. TAB. V

Antero-posterior diameter of bone, $51 \mathrm{~mm}$.; lateral, $50 \mathrm{~mm}$.

Antero-posterior diameter of medullary canal, $35 \mathrm{~mm}$.; lateral, $35 \mathrm{~mm}$.

The medullary canal is full. Medullary index, $93 \%$.

Structure.-The section is composed of concentric laminæ crossed by numerous canals. Their lacunie are oval and long and their canaliculi are bushy and straight. Near the medullary border the laminæ are interrupted by numerous irregularly shaped spaces. The posterior ridge is composed of Haversian systems of the $(\mathrm{Ib})$ differentiation. Around the medullary surface these are separated by large, irregularly shaped spaces.

Type II-III, Ib. 
Right Femur of AUCHENia glama. Llama. No. 36363, AMER. MUS. Nat. Hist.

PL. 11, FIG. 20\%. SYN. TAB. V

Antero-posterior diameter of bone, $25 \mathrm{~mm}$; lateral, $25 \mathrm{~mm}$.

Antero-posterior diameter of medullary canal. $17 \mathrm{~mm}$. ; lateral, $15 \mathrm{~mm}$.

The medullary canal is full. Medullary index. $69 \%$.

Structure.-The section is composed of short and long concentric laminæ with long lacunæ and straight canaliculi, separated and crossed by canals and frequently interrupted by small Haversian systems of the $(\mathrm{Ib})$ differentiation. The posterior ridge is composed of Haversian systems. Around the medullary canal are many irregularly shaped spaces.

Type II-III, Ib.

Right FEMUR OF RANGIFER. REINDEer. NO. 4176, U. S. NAT. MUS.

Pl. 11, Fig. 208. Syn. TAB. V

Antero-posterior diameter of bone, $26 \mathrm{~mm}$.; lateral, $23 \mathrm{~mm}$.

Antero-posterior diameter of medullary canal, $16 \mathrm{~mm}$.; lateral, $14 \mathrm{~mm}$.

The medullary canal is full. Medullary index, $60 \%$.

Structure.-Begimning on both sides of the posterior ridge and extending around the section is a hor'seshoe band of laminæ with long lacunæ and straight canaliculi, frequently interrupted by small, crude Haversian systems of the (Ia) differentiation. The band constitutes the whole width of the wall with the exception of the narrow internal circumferential lamellæ. The posterior ridge is composed of Haversian systems-( $\mathrm{Ib}$ differentiation). The medullary eanal is surrounded by a ring of lamellæ.

Type II-III, Ia, Ib.

LEFT FEMUR OF URSUS AMERICANUS. BLACK BEAR. CR. MED. COLL.

PL. 12, FIG. 209. Syn. TAB. V

Antero-posterior diameter of bone, $31 \mathrm{~mm}$. ; lateral, $29 \mathrm{~mm}$.

Antero-posterior diameter of medullary canal, $22 \mathrm{~mm}$.; lateral, $21 \mathrm{~mm}$.

The medullary canal is full. Medullary index, $105 \%$.

Structure.-The bone is nearly round and has thin walls. The anterior wall is thickest. The bone is composed of short and long laminæ having a general concentric arrangement, but presenting a variety of positions in the different portions of the wall. In the anterior and outer wall they are short and long, having the curvature of the bone, or present short angular curves and run transversely. The laminæ are quite uniform in width and are separated by distinctly wide canals. The lacunæ are long and the canaliculi are straight. 
In the posterior wall the laminæ are interrupted by a few Haversian systems well developed. In the inner wall the laminæ are more uniformly concentric.

Type II.

right femur of taurotragus oryx. eland. No. 27891, amer. mus. nat. hist.

PL. 12, Fig. 210. Syn. Tab. V

Antero-posterior diameter of bone, $55 \mathrm{~mm}$. ; lateral, $44 \mathrm{~mm}$.

Antero-posterior diameter of medullary canal, $35 \mathrm{~mm}$.; lateral, $30 \mathrm{~mm}$.

The medullary canal is full. Medullary index, $73 \%$.

Structure.-The section is composed entirely of laminæ with the exception of the posterior ridge. They are short in the anterior wall and of varying lengths in the lateral wall. Their lacunæ are generally oval and their canaliculi are straight. The posterior ridge is composed of irregular Haversian systems, separated by bone substance with oval lacunæ and bushy canaliculi.

Type II.

IEFT FEMUR OF CONNOCH AMER, MUS. NAT. HIST.

Pl. 12, Fig. 211. SYN. 'TAB. V

Antero-posterior diameter of bone, $33.5 \mathrm{~mm}$. ; lateral, $30 \mathrm{~mm}$.

Antero-posterior diameter of medullary canal, $20 \mathrm{~mm}$.; lateral, $17.5 \mathrm{~mm}$. The medullary canal is full. Medullary index, $53 \%$.

Structure.-With the exception of the posterior ridge the section is composed of short and long laminæ. The laminæ are composed of lamellæ with oval lacunæ and straight canaliculi and are separated and crossed by canals.

The ridge is composed of fairly well developed Haversian systems, separated by short lamellæ with oval lacunæ and bushy canaliculi.

Type II.

RIGHT FemUr OF ovibos Moschatus WARd. MUSK OX. AMER. MUS. NAT. Hist.

PL. 12, Fig. 212. Sre. Tab. V

Antero-posterior diameter of bone, $36 \mathrm{~mm}$. lateral, $34 \mathrm{~mm}$.

Antero-posterior diameter of medullary canal, $30 \mathrm{~mm}$.; lateral, $28 \mathrm{~mm}$.

The medullary canal is full. Medullary index, $219 \%$.

Structure.-The section is composed of laminæ with oval lacunæ and straight canaliculi, separated by concentric canals. The laminæ are short and long, and interrupted here and there by small Haversian systems of the ( $\mathrm{Ib}$ ) differentiation. The posterior ridge is composed of small Haversian systems. 
In the inner lateral wall is another aggregation of the same type of Haversian systems.

Type II-III, Th.

RIGHT FEMUR OF MEXICAN BURRO. CR. MED. COLL.

PL. 12, FIG. 213. SyN. TAB. V

Antero-posterior diameter of bone, $30 \mathrm{~mm}$. lateral, $23 \mathrm{~mm}$.

Antero-posterior diameter of medullary canal, $15 \mathrm{~mm}$.; lateral, $11 \mathrm{~mm}$.

The medullary canal is full. Medullary index, $31 \%$.

Structure.-The section is composed of concentric laminæ, separated and crossed by canals, and interrupted by crude and fairly well developed Haversian systems. Several laminæ extend from the anterior to the posterior wall along the medullary surface of the inner wall. The internal circumferential lamellæ with long lacunæ and straight canaliculi form a narrow boundary of the medullary canal. Haversian systems occupy the mid-line of the posterior ridge.

'Type II.

RIGHT FEMUR OF TAPIRUS. TAPIR. NO. 35181, AMER, MUUS. NAT. HIST,

$$
\text { PL. 12, FIG. 214. SYN. TAB. VI }
$$

Antero-posterior diameter of bone, $32 \mathrm{~mm}$; lateral, $35 \mathrm{~mm}$.

Antero-posterior diameter of medullary canal, $21 \mathrm{~mm}$. ; lateral, $25 \mathrm{~mm}$.

The medullary canal is full. Medullary index, $98 \%$.

Structure.-The section is composed of laminæ interrupted by two groups of Haversian systems, one in the posterior outer ridge and the other in the posterior inner ridge. In the anterior wall a few systems also appear. The lacunæ are oval, the canaliculi bushy, and cross canals are infrequent. A little cancellous bone is seen in the anterior wall. The Haversian systems of the posterior wall are separated by considerable inter-Haversian lamellæ.

Type II-IIT, C.

LEFT FEMUR OF EQUUS HEMIONUS. WILD ASS OF ASIA. NO. 49493, U. S. NAT. MUS.

$$
\text { PL. 12, FIG. 215. SYN. TAB. VI }
$$

Antero-posterior diameter of bone, $46 \mathrm{~mm}$; lateral, $31 \mathrm{~mm}$.

Antero-posterior diameter of medullary canal, $26 \mathrm{~mm}$. ; lateral, $19 \mathrm{~mm}$.

The medullary canal is full. Medullary index, $55 \%$.

Structure--Beginning on both sides of the posterior ridge and constituting the entire thickness of the wall of the bone are laminæ which are interrupted by small Haversian systems, and also alternate with Haversian systems. The systems are most numerous in the posterior wall. There is nearly an equal concentric division of the laminæ. In the external portion they follow a regular 
concentric course; while in the internal they form two wide crescent-shaped bands around the medullary canal. In the mid-hine of the anterior wall the systems are arranged in a narrow columm from one surface to the other.

The posterior ridge is composed of Haversian systems, large, small, and irregnlar in shape. Internal circumferential lamella in a narrow ring enclose the medullary canal.

Type II-TII, C.

Right FEMUR OF ELEPIAAS AFricanus. AFRICAN ELEPHANT. NO. 35185 ,

AMER. MUS. NAT. HIST.

Pl. 12, Fig. 216. Syn. Tab. VI

Antero-posterior diameter of bone, $108 \mathrm{~mm}$; lateral, $83 \mathrm{~mm}$.

Antero-posterior diameter of medullary canal, $65 \mathrm{~mm}$; lateral, $49 \mathrm{~mm}$.

The medullary canal is full. Medullary index, $55 \%$.

Structure.-With the exception of a very narrow fragmentary ring of external circumferential lamella with long lacuma and straight canaliculi, the section is composed almost entirely of Haversian systems of the (C) differentiation. Inter-Haversian lamella are present in some portions of the bone. The systems form the external boundary of the inner anterior wall where the lamella are deficient. Numerous cross canals unite the systems. The lacune of the whole section are long and narrow and their wandiculi are long', straight, and thickly set. The internal circumferential lamellae are fragmentary.

Type III, C.

FEMUR OF CHOLEPUS DIDACTYlus. TWO-TOED SLOTH. NO. 104593, U. S. NAT. MUS.

PL. 12, Fig. 21\%. SYN. T'Ab. VI

Antero-posterior diameter of bone, $16 \mathrm{~mm}$; lateral, $11 \mathrm{~mm}$.

Antero-posterior diameter of medullary canal, $4 \mathrm{~mm}$; ; lateral, $4 \mathrm{~mm}$.

The medullary canal is cancellous. Medullary index, 9\%.

Structure.-The section has a long posterior ridge and exhibits the three structural divisions. The external circumferential lamella form a nar'ow ring around the bone excepting at the posterior ridge. The lacunæ are long with straight canaliculi in some places and oval with bushy canaliculi in others.

The central ring is composed of very distinct Haversian systems with litte inter-Haversian lamella. They are of a high structural type. Their lar.unx are long and their canaliculi are long and straight. Some of the Haversian systems are mited by cross canals, but not many. The systems are well leveloped but many, especially around the mednllary canal, show senile dianges.

The internal ciremuferential lamella take the form of a thick ring of rancellons bone. The lacuna are well developed.

Type III, C, senile. 
RIGHT FEMUR OF POTOS CAUDIVOlvUlus. KINKAJOU. AMER. MUS. NAT. HIST.

PL. 12, Fig. 218. Syn. 'Tab. VI

Antero-posterior diameter of bone, $7 \mathrm{~mm}$; lateral, $8 \mathrm{~mm}$.

Antero-posterior diameter of medullary canal, $4.5 \mathrm{~mm}$; lateral, $5.5 \mathrm{~mm}$.

The medullary canal is full. Medullary index, $80 \%$.

Structure.-The section has three divisions. The external circumferential lamellæ form a narrow band around the anterior and lateral wall. Their lacunæ are oval and their canaliculi are straight. The central ring is composed of Haversian systems and inter-Haversian lamellæ with oval lacunæ and bushy canaliculi. The ring forms the inner wall with the exception of the internal lamellæ. The internal circumferential lamellæ form a ring around the medullary canal.

Type III, C.

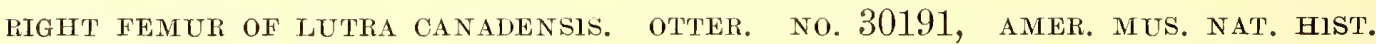

PL. 12, Fig. 219. SYr. TAB. VI

Antero-posterior diameter of bone, $14.5 \mathrm{~mm}$.; lateral, $11 \mathrm{~mm}$.

Antero-posterior diameter of medullary canal, $7 \mathrm{~mm}$.; lateral, $5 \mathrm{~mm}$.

The medullary canal is full. Medullary index, $28 \%$.

Structure.-The external circumferential lamellæ appear in fragments. The central ring constitutes nearly the whole section and is composed of well developed Haversian systems. In the posterior wall the systems are separated by lamellæ with oval lacunæ and straight canaliculi. The internal circumferential lamellæ surround the medullary canal and form a wide band in the outer wall.

Type III, C.

Right Femur OF SIMia satyrus. orang-Utan. (Borneo.) No. 154304, U. S. NAT. MUS.

Pl. 13, Fig. 220. Syx. TAB. VI

Antero-posterior diameter of bone, $20 \mathrm{~mm}$; lateral, $30 \mathrm{~mm}$.

Antero-posterior diameter of medullary canal, $11 \mathrm{~mm}$; lateral, $16 \mathrm{~mm}$.

The medullary canal is full. Medullary index, $41 \%$.

Structure.-The external circumferential lamellæ are deficient in a portion of the anterior wall, the Haversian systems of the central ring reaching the surfince at this point. The lamellæ begin to increase in thickness as they pass around the inner wall where they form nearly one-third of its width. They then diminish in thickness as they reach the posterior wall, then slightly increase in the outer wall, and finally disappear as they approach the anterior wall. In 
this manner they form a complete ring with the exception of a small anterior portion of the circumference. They are interrupted by vascular canals and Haversian canals of the (Ia) differentiation.

The central ring is composed of well developed Haversian systems separated here and there by short lamellix. The systems are small and large, but well developed. Their lacunæ are long and narrow. The systems are frequently united by cross canals. The internal circumferential lamellæ form a complete ring of varying widths around the medullary canal.

The femur of the orang-utan resembles the human femur more closely than those of other apes or monkeys.

Type I-III, Ia, C.

LEFT FEMUR OF FELIS TIGRIS. TIGER. NO. 174981, U. S. NAT. MUS.

Pr. 13, F1G. 221. STN. TAB. VI

Antero-posterior diameter of bone, $28 \mathrm{~mm}$; lateral, $22 \mathrm{~mm}$.

Antero-posterior diameter of medullary canal, $15 \mathrm{~mm}$. ; lateral, $12 \mathrm{~mm}$.

The medullary canal is full. Medullary index, $41 \%$.

Structure.-The posterior ridge is composed of well developed Haversian systems. Beginning on both sides of the ridge and extending around the section is a horseshoe band of lamellx with long lacune and straight canaliculi, interrupted by Haversian systems of the (Ia) differentiation. The central ring is composed of well developed Haversian systems. The internal circumferential lamellæ with long lacunæ and straight canaliculi form a wide irregular ring around the medullary canal. The ring is crossed by numerous radiating canals.

Type I-III, Ia, C.

RIGHT FEMUR OF HEMIGALUS HARDWICKI. CIVET CAT. NO. 32358, AMER. MUS. NAT. HIST.

PL. 13, Fig. 222. Syn. Tab. VI

Antero-posterior diameter of bone, $7 \mathrm{~mm}$.; lateral, $5.5 \mathrm{~mm}$.

Antero-posterior diameter of medullary canal, $4.5 \mathrm{~mm}$; lateral, $3 \mathrm{~mm}$.

The medullary canal is full. Nedullary index, $54 \%$.

Structure.-The three divisions are well marked. The external circumferential lamella form a wide ring around the bone. It is crossed by canals and interrupted by a few crude Haversian systems of the (La) differentiation. Its lacune are long and the "analiouli are straight. The rentral ring is composed of well developed Haversian systems with very little inter-Jlaversian lamellæ. The internal circumferential lamellie form a narrow ring aromot the medullary eanal. The lacune are long and the canalienli are straight.

Type I-III, Ia, C. 
Right FEMUR OF tatu NOVEMCINCTUS. ARMAdillo. NO. 357, AMER. MUS. NAT. Hist.

Pi. 13, Fig. 223. Syn. Tab. VI

Antero-posterior diameter of bone, $7.5 \mathrm{nmm}$; lateral, $16 \mathrm{~mm}$.

Antero-posterior diameter of medullary canal, $5 \mathrm{~mm}$.; lateral, $6 \mathrm{~mm}$.

The medullary canal is full. Medullary index, 33\%.

Structure.-The section has a long lateral diameter by extension of its outer wall. It is composed of lamellæ with oval and round lacunæ and bushy canaliculi, crossed in all directions by canals and interrupted by a few undeveloped Haversian systems of the ( $\mathrm{Ib}$ ) differentiation. The outer process has central cancellous bone.

Type I-III, Ib.

RIGHT FEMUR OF TAMANDUA TETRADACTYLA. ANT-EATER. NO. 14866, AMER. MUS. NAT. HIST.

Pi. 13, Fig. 224. Syn. 'TAB. VI

Antero-posterior diameter of bone, $7 \mathrm{~mm}$; lateral, $12 \mathrm{~mm}$.

Antero-posterior diameter of medullary canal, $3 \mathrm{~mm}$. ; lateral, $4 \mathrm{~mm}$.

The medullary canal is full. Medullary index, $17 \%$.

Structure.-The longest diameter of the bone is its lateral diameter. The outer wall is projected outward into a prominent ridge. Begimning on both sides of the mid-line of the inner wall and extending around the section is a band of external circumferential lamellix, interrupted in the anterior wall by concentrically arranged small, crude Haversian systems of the (Ia) differentiation, and in the posterior wall by a few fairly well developed Haversian systems. The band is widest in the anterior wall and narrowest in the outer wall. The lacunæ are oval and long and the canaliculi are bushy and straight.

Under this band is a central ring of Haversian systems of the ( $\mathrm{Ib}$ ) differentiation, between which is bone substance with oval and large lacunæ and bushy canaliculi. The ring nearly reaches the external surface at the mid-line of the inner wall. The systems are united by cross canals. Internal circumferential lamellæ form a rather narrow ring around the medullary canal. In the outer and inner wall it assumes a cancellous form.

Type I-III, Ia, Ib.

LEFT FEMUR OF GORILla. GORlLIA. NO. 22832, AMER. MUS. NAT. Hist.

PL. 13, Fig. 225. SYN. T'AB. VI

Antero-posterior diameter of bone, $16.5 \mathrm{~mm}$; lateral, $19.5 \mathrm{~mm}$.

Antero-posterior diameter of medullary canal, $7.5 \mathrm{~mm}$. lateral, $9 \mathrm{~mm}$.

The medullary canal is full. Medullary index, $15 \%$. 
Structure.-Beginning on both sides of the posterior ridge and extending around the external aspect of the bone is a wide horseshoe-shaped band of lamellæ with long and oval lacunæ and straight and bushy canalieuli. The lamellæ are interrupted by erude Haversian systems of the (La) differentiation and crossed at various angles by numerous canals.

The central ring is composed of well developed Haversian systems and inter-Haversian lamellæ. Their lacunæ are long and canaliculi are straight. The ring is narrow in the anterior wall and widens as it encircles the lateral and posterior wall. In the posterior ridge the systems form the whole thickness of the wall and are embraced by the heel of the horseshoe band. The internal circumferential lamellæ form a narrow ring around the medullary canal.

More than half of the section is lamellar. In this respect it differs from the orang-utan in the femur of which the external lamellw form a narrower ring.

Type I-III, Ta, C.

FEMUR OF PRESBYTTS RUBICUNDA. MONKEY. NO. 153793, U. S. NAT, MUS,

$$
\text { Pl. 13, Fig. 226. Syn. Tab. VI }
$$

Antero-posterior diameter of bone, $11 \mathrm{~mm}$.; lateral, $11 \mathrm{~mm}$.

Antero-posterior diameter of medullary canal, $6 \mathrm{~mm}$. ; lateral, $6.5 \mathrm{~mm}$.

The medullary canal is full. Medullary index, $48 \%$.

Structure-- I wide irregularly shaped horseshoe of lamellæ surrounds the section. The lamellæ form about one-half of the thickness of the inner and anterior wall and practically the whole thickness of the outer wall. They are well developed with narrow lacunæ and long canaliculi and are frequently interrupted by Haversian canals of the (Ia) differentiation.

The central ring is interrupted by the external lamella of the outer wall. It is narrow and composed of fairly well developed Haversian systems with considerable inter-lamellar structure. The posterior ridge is composed of lamellæ and Haversian systems mixed. The systems have oval and nar'row lacuna and rather infrequent canaliculi. The internal circumferential lamellæ form a narrow ring around the medullary canal.

Type I-IIT, Ta, C.

RIGHT FEMUR OF HYLOBATES. GIBBON. NO. 111988, U. S. NAT. MUS,

$$
\text { PL. 13, Fig. 22\%. STN. ThB. VI }
$$

Antero-posterior diameter of bone, $11 \mathrm{~mm}$.; lateral, $11.5 \mathrm{~mm}$.

Antero-posterior diameter of medullary canal, $6 \mathrm{~mm}$. ; lateral, $6.5 \mathrm{~mm}$.

The medullary canal is full. Medullary index, $44 \%$.

Structure.-The section of the bone is composed of a wide external ring of lamellæ, frequently interrupted by very incomplete Haversian systems of the (Ta) differentiation. The lamellar ring surrounds the bone with the exception 
of the posterior ridge, where a few Haversian systems reach the external surface and blend with a few tendon insertions.

The central ring is composed of Haversian systems of the (C) differentiation which displace the internal circumferential lamellæ in the outer lateral wall and border on the medullary canal. Their lacunæ and canaliculi are well developed. The internal circumferential lamellæ surround the medullary canal excepting a small part of the outer lateral wall.

Type I-III, Ia, C.

LEFT FEMUR OF ANTHROPOPITHECUS TROGLODYTES. CHIMPANZEE. NO. 18010, AMER. MUS. NAT. HIST.

Pu. 13, Fig. 228. Srn. Tab. VI

Antero-posterior diameter of bone, $13 \mathrm{~mm}$; lateral, $16 \mathrm{~mm}$.

Antero-posterior diameter of medullary canal, $6 \mathrm{~mm}$.; lateral, $8 \mathrm{~mm}$.

'The medullary canal is full. Medullary index, $30 \%$.

Structure.-The external circumferential lamellæ surround the section. This lamellar ring is widest in the antero-inner lateral wall where it constitutes nearly the whole thickness of the wall. It is narrowest in the posterior wall. Its lamellæ have long lacunæ with straight canaliculi. 'The ring is interrupted by crude Haversian systems of the (Ia) differentiation and crossed by canals.

The central ring, irregular in width, is composed of well developed Haversian systems.

The internal circumferential lamellæ form a narrow ring around the medullary canal. Just external to this ring is a concentric row of vascular spaces. 'The lacunæ are long.

The bone is, however, more than half lamellæ.

Type I-III, Ia, C.

RIGHT FEMUR OF MACACUS RHESUS. INDIAN MONKEY. R. I.

PL. 14, Fig. 229. Syn. TAB. VI

Antero-posterior diameter of bone, $8 \mathrm{~mm}$. ; lateral, $8.5 \mathrm{~mm}$.

Antero-posterior diameter of medullary canal, $5 \mathrm{~mm}$.; lateral, $5.5 \mathrm{~mm}$.

The medullary canal is full. Medullary index, $68 \%$.

Structure.-There are no external and internal circumferential lamellæ distinct from the central ring of the bone.

A crescent of well developed Haversian systems, bordering upon the inner wall of the medullary canal, begins in the posterior region and extends around the inner and anterior to the outer wall, where it merges into the lamellar structure. The widest part of the crescent forms about one-third of the entire thickness of the inner wall. 
The systems are well developed. In several places a half system borders the medullary canal. The lacunæ are long and narrow and their canaliculi are long and branching. The Haversian systems are frequently united by short inter-Haversian lamellæ. A second crescent of Haversian systems borders the medullary canal extending from the posterior prominence around the posterior and outer to about the middle portion of the anterior wall. The systems of the two crescents are the only fully developed systems present. The second crescent is narlower than the first. Its widest part is in the posterior region of the outer wall. The lacunæ are long and narrow and the canaliculi are straight.

The main structure of the inner, anterior, and outer wall is lamellar. It is composed of irregularly concentric lamellæ, interrupted by rudimentary Haversian systems of the $(\mathrm{Ib})$ differentiation. This laniellar structure makes up practically the whole bone. The lacunæ are generally long, and have long, branching, and numerous canaliculi. In some places the lacunæ are curved and quite irregular in shape. The posterior wall and ridge is composed of Haversian systems, poorly developed. They are separated by lamellæ. Their outlines are not sharply defined, but appear to merge into the surrounding lamellæ.

Type I-III, Ib, C.

Right Femur of Sciurus SP. (LARge Red SQUiRrel.) CR. Med. COLL.

Pl. 14, Fig. 230. SYN. TAB. VI

Antero-posterior diameter of bone, $4.5 \mathrm{~mm}$.; lateral, $6 \mathrm{~mm}$.

Antero-posterior diameter of the medullary canal, $3.5 \mathrm{~mm}$.; lateral, $5 \mathrm{~mm}$.

The medullary canal is full. Medullary index, $18 \%$.

Structure.-A ring of external circumferential lamellæ of varying widths surrounds the bone. Their lacunæ are mostly long and narrow and their canaliculi are numerous, long, and branching. A central, irregularly shaped ring of complete and incomplete Haversian systems is situated under the external lamellæ. It increases in thickness around the inner, posterior, and outer wall, and reaches the surface in the outer wall. In many places in the inner wall the systems are composed of oval lacunæ with short, bushy canaliculi arranged in a circular manner.

Internal circumferential lamellæ form an uneven, thick ring around the medullary canal. Their lacunæ are long and narrow and their canaliculi are long, numerous, and branching. The bone, therefore, is composed of three very uneven and irregularly shaped rings of structural units.

Type I-III, Ib, C. 
RIGHT FEMUR OF FELIS, DOMESTIC CAT. CR. MED. COLL.

PL. 14, Fig. 231. Syn. TAB. VI

Antero-posterior diameter of bone, $7.5 \mathrm{~mm}$; lateral, $9.5 \mathrm{~mm}$.

Antero-posterior diameter of medullary canal, $4 \mathrm{~mm}$.; lateral, $5.5 \mathrm{~mm}$.

The medullary canal is full. Medullary index, $45 \%$.

Structure.--External circumferential lamellæ form more than one-half of the thickness of the wall of the bone. A few Haversian systems appear in the middle portion of the lamellar ring. They are well developed and without apparent signification. A short distance from the mid-line in the inner wall the lamellar ring divides into a wide outer and a narrow inner part which encloses a crescent shaped area of Haversian systems. About the middle of the inner wall is quite a sharp lateral ridge. The lamellar ring is widest at this point and narrowest in the outer wall. The lacune are long and narrow and the canaliculi are thickly set, long, and branching.

The central ring is composed of well developed, large and small Haversian systems, widest in the inner wall and nar'rowest in the outer wall. The systems are generally strongly developed, and are round, elliptical, or irregular in crosssection.

'T'he internal circumferential lamellæ are in the form of laminæ. Their lacune are long or oval and their canaliculi are bushy. Numerous canals pass through the lamine on their way from the medullary canal. Four femora of the domestic cat were examined and in each one there was a different development, structure, and arrangement of bone units.

Type I-II-III, C.

$$
\begin{aligned}
& \text { LEFT TEMTR OF FELIS CATUS. WILD CAT. CR. MED. COLL. } \\
& \text { PL. 1t, FIG. 232. SYA. TAB. VI }
\end{aligned}
$$

Antero-posterior diameter of bone, $13.5 \mathrm{~mm}$; lateral, $11 \mathrm{~mm}$.

Antero-posterior diameter of the medullary canal, $8 \mathrm{~mm}$.; lateral, $5.5 \mathrm{~mm}$.

The medullary canal is full. Medullary index, $42 \%$.

Structure.-Around the outside of the bone is a ring of lamellæ, interrupted very frequently by incomplete Haversian systems of the (Ib) differentiation. The ring forms a greater part of the thickness of the wall of the bone excepting in the posterior wall, where the Haversian systems occupy the whole width from the internal circumferential lamellæ outward to the circumference. Many canals traverse the ring. For the most part, all of the structural units are rather indistinct. Around the anterior and a portion of the inner wall is a narrow rim of external lamellæ. The lacunæ of the lamellar ring are long or oval and their canaliculi are long and branching or bushy. 
The central ring is incomplete, occupying the posterior, inner, and anterior walls. It is composed of well developed Haversian systems, crossed in the anterior wall by an extension from the external lamellæ. It is wide in the posterior wall and gradually narrows as it passes around the lateral into the anterior wall.

Around the medullary canal is a well defined ring of internal circumferential lamellæ. Numerous large canals cross the ring to communicate with canals within the center of the bone. The lacunæ are long and canaliculi long. and branched.

Type I-III, Ib, C.

FEMUR OF MEPHITIS MEPHITICA. SKUNK. CR. MED. COLL.

Pl. 14, Fig. 233. Syn. TAB. VI

Antero-posterior diameter of bone, $5 \mathrm{~mm}$.; lateral, $5 \mathrm{~mm}$.

Antero-posterior diameter of medullary canal, $3.5 \mathrm{~mm}$.; lateral, $4 \mathrm{~mm}$.

The medullary canal is full. Medullary index, $127 \%$.

Structure.-The section is composed of lamellæ with long lacunæ and straight and bushy canaliculi, frequently interrupted by irregularly shaped Haversian systems and canals. Some of the systems are round, some oval, and some have long, wide, straight, or curved canals. In some situations they are concentric. As a whole, they are well developed. There is no well defined central ring nor internal circumferential lamellæ.

Type I-III, C.

FEMUR OF PUTORIUS VISON. MINK.

PL. 14, Fig. 234. Syn. TAB. VI

Antero-posterior diameter of bone, $3.5 \mathrm{~mm}$.; lateral, $4.5 \mathrm{~mm}$.

Antero-posterior diameter of medullary canal, $1.5 \mathrm{~mm}$; lateral, $2 \mathrm{~mm}$.

The medullary canal is full. Medullary index, $23 \%$.

Structure.-The anterior wall is composed of lamellæ which form its entire thickness. The lamellæ then form an irregularly shaped, complete ring around the medullary canal. Numerous canals pass across this ring, incompletely or completely, on their way from the medullary canal to small canals of the interior. The lacunæ are long and narrow and their canaliculi are long and branching.

The Haversian systems are absent at the widest lamellar point of the anterior wall. They then begin to appear in single file, gradually increase in thickness to the posterior wall, and diminish again as they approach the anterior wall. In this manner they form an irregular long crescent enclosed within 
lamellax. The crescent nearly eneircles the bone. The Haversian systems are well developed, their lacuna are oral, and their canaliculi are relatively few. Their canals frequently unite. In some places bands of lamella cross the crescent extending from the outer to the inmer lamella. Numerous canals traverse the crescent. The internal circumferential lamellæ form a wide, irregular ring, fusing with the external lamella in the anterior wall. The lacunæ are long and narrow and their canaliculi are long and branching.

Type I-III, C.

LEFT FEMUR OF CRYPTOPROCTA FEROX. CAT-LIKE CIVET. AMER. MUS. NAT. HIST.

$$
\text { PL. 14, Fit. 235. SYN. TAB. VI }
$$

Antero-posterior diameter of bone, $8.5 \mathrm{~mm}$.; lateral, $8 \mathrm{~mm}$.

Antero-posterior diameter of medullary canal, $4.5 \mathrm{~mm}$.; lateral, $4.5 \mathrm{mmn}$.

The medullary canal is full. Medullary index, $42 \%$.

Structure.-The section is surrounded by a ring of external lamella of varying widths. It is interrupted by numerous canals of the (Ia) differentiation. The lacune are long and the canaliculi are straight. The ring is distinet from the underlying central ring of Haversian systems, which are well developed. The medullary canal is surrounded by internal circumferential lamellæ of varying widths.

Type I-III, Ia, C.

RIGHT FEMUR OE HYENA CROCUTA. IIYENA. NO. 35431, AMER. MUS. NAT. HIST.

$$
\text { Pl. 11, Fri. 236. Six. T'AB. YI }
$$

Antero-posterior diameter of bone, $14 \mathrm{~mm}$; lateral, $18 \mathrm{~mm}$.

Antero-posterior diameter of medullary canal, $9 \mathrm{~mm}$.; lateral, $13.5 \mathrm{~mm}$.

The medullary canal is full. Medullary index, $98 \%$.

Structure.-External lamelle form a wide ring around the section with the exception of the outer ridge. The lamella are crossed by canals, interrupted by crude Haversian systems of the (Ia) differentiation, and have long laeunæ and straight canaliculi.

The central ring is composed of well developed Haversian systems with some inter-Haversian lamellæ. The systems form the whole of the outer ridge, where they are separated by bone substance with many oval lacune and bushy ranaliculi.

A narrow ring of internal circumferential lamella surrounds the medullary canal. The lacme are long.

Type I-III, Ia, C. 
RIGUT FEMUR OF THYLACINEA GNOCEPHALUS. TASMANIAN WOLF

PL. 11, Fir. 2836 SYx. 'Tib. VI

Antero-posterior lianeter of bone, $19.5 \mathrm{~mm}$; lateral, $1.5 \mathrm{~mm}$.

Antero-posterior diameter of medullary canal, 8 mm.; lateral, $8.5 \mathrm{~mm}$.

The merlullary canal is full. Merlullary inclex, $28 \%$.

Structure.-The sertion is surromuled by a narrew ring of external lamellax, interrupted here and there by crude Haversian systems of the (Ta) differentiation. Enderneath this ring is a wide horseshoe of lamellae, interoupted by many crude Haversian systems of the (La) differentiation arranged concentrically. The outer wall is all lamellae.

Underneath this band is a central, incomplete ring of well developed Haversian systems with inter-Haversian lamella. In the posterior wall the systems form nearly the whole of the wall. Here the oval large lacune with bushy canaliculi are pronounced.

Internal ciremuferential lamelax form a narow ring around the medullary canal. 'Their lacumæ are long.

Type I-III, Ia, C.

RIGHT FEMUR OF DASYPROCTA AGOUTl. NO. 15669, AMER. MUS. NAT. HIST,

$$
\text { PL. 14, Fig. 238. Sxx. Tab. VI }
$$

Antero-posterior diameter of bone, $10 \mathrm{~mm}$. ; lateral, $8 \mathrm{~mm}$.

Antero-posterior tiameter of merlullary aanal, 6.5 $\mathrm{mm}$; lateral. $5 \mathrm{~mm}$.

The medullary canal is full. Merlullary index, $93 \%$.

Structure.-The three divisions are well marked. I wide ring of external circumferential lamella, interupted by arude Haversian systems of the (Ia) differentiation and crossed by canals, smrounds the section with the exception of the posterior ridge. The lamellar ring forms more than laalf of the section. The central ring is composed of well developed Haversian systems with interHaversian lamella.

The systems of the rentral ring reach the surface at the posterior ridge where they are separated by bone subsiance with oval lacuna. The internal eiremuferential lamella form a narow ring around the medullary canal. The lacuna are long in the external and internal lamellar; elsewhere they are oval.

Type I-III, Ia, C.

LEFT FEMUR OF LASIOPYGA CENTRALIS JOHXSTONI. AFRICAN MONKEY. NO. 2̈T0. ANER. MUS. NAT. HIST.

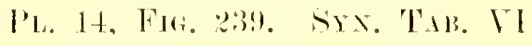

Antero-posterior diameter of bone, $9 \mathrm{~mm}$. ; lateral, $8 \mathrm{~mm}$.

Antero-posterior diameter of medullary canal, $5.5 \mathrm{~mm}$. ; lateral, 5 $\mathrm{mm}$. 
The medullary canal is full. Meslullary index, $62 \%$.

Structure.-The section has three divisions. A wide ring of extermal circumferential lamella, inter'upted by Haversian system:s of the (Ta) differentiation, surrounds the bone. In the posterior wall it is interrupted by irregularly shaped Haversian systems: Canals cross the ring at various intervals. The lacunæ are long and narrow and the canaliculi are straight.

The central ring is very narrow and composed of a few well developed Haversian systems with inter-Haversian lamell:e.

The internal circumferential lamella form a narrow ring around the medullary canal.

Type I-III, Ia, C.

RIGIIT FEMUR OF FELIS CANADENSIS. CANADA LYNX. CR. MED. COLL.

$$
\text { Pl. 15, Fif. 240. Srx. Tab. VI }
$$

Antero-posterior diameter of bone, $13 \mathrm{~mm}$. ; lateral, $12 \mathrm{~nm}$.

Antero-posterior diameter of medullary canal, $9.5 \mathrm{~mm}$. ; lateral, $9 \mathrm{~mm}$.

The medullary canal is full. Medullary index, $121 \%$.

Structure.--The usual three structural rings are distinct. The external circumferential lamella form a wide ring around the section excepting at the ridges of the inner and posterior wall where they are deficient. They are interrupted by small, crude Haversian systems of the (Ta) differentiation; while in the posterior wall much better developed systems form an important part of the whole lamellar ring.

The central ring is composed of well developed Haversian systems with very little inter-Haversian structure. At the ridges the systems break through the external circumferential lamellæ and form the external surface of the bone at these points.

The internal circumferential lamellæ form a narrow ring around the meduilary canal excepting a small portion of the posterior and inner wall. The lacunæ in all parts are well developed.

Type I-III, Ia, C.

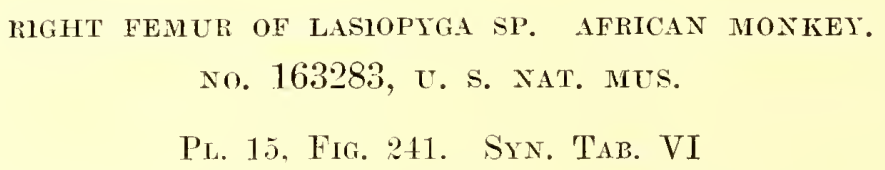

Antero-posterior diameter of bone, $5.5 \mathrm{~mm}$. ; lateral, $5 \mathrm{~mm}$.

Antero-posterior dianeter of medullary canal, $3 \mathrm{~mm}$. ; lateral, $2.5 \mathrm{~mm}$.

The medullary canal is full. Merlullary index, $38 \%$.

Structure.-External circumferential lamellæ of varying widths surround the bone. In the anterior and inner wall they form two-thirds of the thickness 
of the section and in the posterior and outer wall about one-fometh of the entire thickness. They are frequently interrupted by crnde Haversian systems of the (Ta) differentiation and crossed at various angles by short canals. Their lacuma and canaliculi are well developed. The central ring is romposed of well developed Haversian systems and lamella with systems of the (Ia) differentiation. The ring is widest in the onter lateral wall.

In the lamellar portion of the ring are one or two concentric rows of small Haversian canals which gradually change into the more completely developed Haversian systems of the outer wall. The internal circumferential lamella surround the medullary canal excepting in the outer wall. The lamellar and Haversian portions of the section are about equal.

Type I-III, Ia, C.

RIGHT FEMUR OF MDAS RUTONIGER. SOUTH AMERTCAN MONREY (UPPER AMAZON). No. 14548, U. S. NAT. MUS.

Pl. 15, Fig. 242. Srn. Tab. VI

Antero-posterior diameter of bone, $4.5 \mathrm{~mm}$.; lateral, $4 \mathrm{~mm}$.

Antero-posterior diameter of medullary canal, $3 \mathrm{~mm}$; lateral, 2.5 1111.

The medullary canal is full. Medullary index, $74 \%$.

Structure. - The three structural rings are distinctly marked. The external circumferential lamella form a thick enclosing ring of one-third to one-half the thickness of the wall of the bone. The lamella of the imner wall are very frequently dotted with small, clear, romd spaces which are not present in the outer wall. The lacme are well developed.

The central ring is composed of rather irogularly shaped but well de veloped Haversian systems, separated by inter-llaversian lamelle. They are frequently united hy canals. The internal cirenmferential lamella form a nar. row ring around the medullary canal, excepting in the onter wall where they are reficient.

'Type I-III, Ia, C.

LEFT FEMUR OF LEMUR. NO. 84383 , U. S. NAT. MUS.

PL. 15, Fig. 213. STN. 'Tab. VI

Antero-posterior diameter of bone, $10 \mathrm{~mm}$; lateral, $8.5 \mathrm{~mm}$.

Antero-posterior diameter of medullary canal, $5.5 \mathrm{~mm}$; lateral, $4.5 \mathrm{~mm}$.

The medullary canal is lull. Merlullary index, $41 \%$.

Structure. - The section is smounded by a lamellar rimg which is widest in the anterior and posterior wall. Tn the inner wall it is divided into laminæ, and frequently interrupted by canals and rery crude Haversian systems of the (Ta) differentiation. 'The lacme are generally well developed. The central 
ring, of varying widths, is conposed of fairly well developed Haversian systems, small, large, and irregular in shape, and frequently united by canals. Their lacme are well developed. In the anterior wall the ring is divided into two nearly equal parts by a narrow, crescent-shaped lamina, the horns of which begin about the middle of the lateral walls. The intermal circumferential lamelle surround the medullary canal. It is widest in the inner wall and well developed.

Type I-III, Ia, C.

RIGHT FEMUR OF LEMUR CATTA. RING-TAlled LEMUR. U. S. NAT. MUS.

Pi. 15, Fig. 244. Syn. TAB. VI

Antero-posterior diameter of bone, $8.5 \mathrm{~mm}$.; lateral, $7 \mathrm{~mm}$.

Antero-posterior diameter of medullary canal, $7 \mathrm{~mm}$.; lateral, $4.5 \mathrm{~mm}$.

The medullary canal is full. Medullary intex, $122 \%$.

Structure.-The section is surrounded by a heavy, dark ring of varying widths romposed of mesher bone work. The meshes are irregular in shape and size. The ring is narrowest in the outer wall, widest in the inner and anterolateral, and of intermediate thickness in other situations. The meshes are filled with dense material which adheres to the mesh walls even in extremely thin places. The mesh walls are extensions of the external circumferential lamellæ.

Underneath this ring is a wide lamellar ring, interrupted by cross and longitudinal canals and crude Haversian systems of the ( $\mathrm{Ia}$ ) and ( $\mathrm{Ib}$ ) differentiations. In the posterior wall the ring is wide and coarsely lamellar and frequently interrupted by large, irregular spaces. Underneath this is an irregularly shaped ring of fairly well developed Haversian systems with numerous spaces. The internal cireumferential lamella surround the medullary canal. It is widest in the anterior and lateral walls.

Type I-III, Ia, Ib, C.

LEFT FEMUR OF ATELES. SPIDER-MONKEy. (TEHUANTEPEC.) No. 11842,

$$
\text { U. S. NAT. MUS. }
$$

Pl. 15, Fig. 245. Syn. Tab. VI

Antero-posterior diameter of bone, $12.5 \mathrm{~mm}$; lateral, $10.5 \mathrm{~mm}$.

Antero-posterior diameter of medullary canal, $7 \mathrm{~mm}$; lateral, $5.5 \mathrm{~mm}$.

The medullary canal is full. Medullary index, $42 \%$.

Structure.-The external circumferential lamellæ form a wide ring surrounding the section, excepting a small portion of the inner wall. The lamellæ are frequently interrupted by Haversian canals of the (Ia) differentiation and small Haversian systems. The ring is widest in the posterior wall. The cen- 
tral ring is composed of well developed Haversian systems with some interHaversian lamellæ. The systems displace the external circumferential lamellæ in the anterior portion of the inner wall where they form the external boundary of the bone.

The internal circnmferential lamellæ surround the medullary canal. They are most prominent in the inner wall. The lacune of the three rings are well developed.

Type I-III, Ta, C.

right feMur of Calltcebts torquatus. SqutrRel-Monkey. No. 105539,

U. S. NAT. MUS.

PL. 15, Fig. 246. Syn. TAB. VI

Antero-posterior diameter of bone, $5.5 \mathrm{~mm}$.; lateral, $5 \mathrm{~mm}$.

Antero-posterior diameter of medullary canal, $4 \mathrm{~mm}$.; lateral, $3.5 \mathrm{~mm}$.

The medullary canal is full. Medullary index, 104\%.

Structure.-The anterior and outer half of the section is surrounded by a wide band of external circumferential lamellæ, interrupted by Haversian canals of the ( $\mathrm{Ta}$ ) differentiation, underneath which is a narrow half ring of Haversian systems bordering upon the medullary canal. The lacunæ of the lamellæ and Haversian systems are oval and long and the canaliculi are generally long and straight.

The posterior and inner half of the section is composed of irregularly shaped Haversian systems forming the whole thickness of the posterior and inner wall. The external and internal circumferential lamellæ are not distinct from the remaining structure.

Type I-III, Ia, C.

LEFT FEMUR OF GENETTA. GENET. NO. 163294, U. S. NAT, MUS.

PL. 15, Fig. 24\%. Syn. TAB. VI

Antero-posterior diameter of bone, $9 \mathrm{~mm}$; lateral, $7 \mathrm{~mm}$.

Antero-posterior diameter of medullary canal, $6.5 \mathrm{~mm}$.; lateral, $5 \mathrm{~mm}$.

The medullary canal is full. Nedullary index, $107 \%$.

Structure.-A ring of external circumferential lamella of varying widths surrounds the section. In the anterior wall it forms nearly the whole thickness: it then becomes narrow in the outer wall, remains about the same width in the posterior wall, and again widens in the inner anterior wall. It is interrupted by crude Haversian systems of the (Ia) differentiation in the anterior, inner, and posterior wall. The lacunæ are oval and long, and the canaliculi are long and straight. Underneath the lamellar ring is an irregular ring of Haversian systems weil developed. The ring is widest in the lateral and posterior wall. The systems are irregular in shape in the onter wall. Their lacunæ are oval 
and the canaliculi are straight. An incomplete ring of internal circumferential lamellæ surrounds the medullary canal.

Type I-III, Ia, C.

LEFT FEMUR OF PEDETES. JUMPING HARE. U. S. NAT. MUS.

PI. 15, Fig. 248. SYN. TAB. VI

Antero-posterior diameter of bone, $10.9 \mathrm{~mm}$; lateral, $9 \mathrm{~mm}$.

Antero-posterior diameter of medullary canal, $7.5 \mathrm{~mm}$.; lateral, $6 \mathrm{~mm}$.

The medullary canal is full. Medullary index, $85 \%$.

Structure.-The bone is surrounded by a lamellar ring of varying widths. The lamellæ are frequently interrupted by small, crude Haversian systems of the (Ia) differentiation and crossed by a few canals. The lacunæ are oval and narrow and the canaliculi are bushy and straight. Underneath the lamellax is an irregular ring of Haversian systems separated by lamelle and canals. The systems are fairly well developed. In the inner wall the systems are interrupted by a few laminæ. The internal circumferential lamellæ form a ring of varying widths around the medullary canal. Their lacunæ are narrow and the canaliculi are straight.

Type I-III, Ia, C.

RIGHT FEMU OF BRADYPUS TRIDACTILUS. THREE-TOED SLOTH. NO. 16871 , AMER, MUS. NAT, HIST.

Pl. 15, Fig. 2.49. Sys. Tab. VI

Antero-posterior diameter of bone, $8.5 \mathrm{~mm}$.; lateral, $13 \mathrm{~mm}$.

Antero-posterior diameter of medullary canal, $3 \mathrm{~mm}$. ; lateral, $4 \mathrm{~mm}$.

The medullary canal is full. Medullary index, $12 \%$.

Structure.-The section has three divisions. The external circumferential lamella form a wide rim around the bone. It is crossed radially by numerous canals and interrupted frequently by normal and senile Haversian systems and by Haversian canals of the (Ia) differentiation. The band of lamella constitutes half of the wall. The lacunæ are oval and long and the canaliculi are straight.

The central ring is composed of complete and semile Haversian systems. Various stages and degrees of senility are found. Some systems are entirely gone; some occur in narrow rings; some show precipitation of inorganic material around the Haversian canal; and some show the whole systems involved but still in position. Their lacunæ are long and oval. The internal circumferential lamellæ assume a cancellous form around the medullary canal. Their lacuns are long and the canaliculi are straight. 
The bone exhibits a much greater lamellar structure than the femur of the two-toed sloth. It is quite different in shape. Senility is marked.

Type I-III, Ia, C, senile.

Right FEMUR OF CASTOR CaNADENSIS. BeAVEr. No. 10005, U. S. NAT. MUS.

$$
\text { PL. 16, Fig. 250. Syn. T'AB. VI }
$$

Antero-posterior diameter of bone, $25 \mathrm{~mm}$.; lateral, $11 \mathrm{~mm}$.

Antero-posterior diameter of medullary canal, $6 \mathrm{~mm}$.; lateral, $4 \mathrm{~mm}$.

The medullary canal is full. Medullary index, $10 \%$.

Structure.--The section has a long posterior ridge, which accounts for the long antero-posterior and short lateral measurements. The section is surrounded by a lamellar and lamimar band of varying widths, interrupted by Haversian canals of the (Ia) differentiation and crossed by frequent vascular canals. The lacunæ are oval and long and the canaliculi are straight.

Underneath the lamelle is a narrow band of irregular Haversian systenıs. The systems are large and small, but very well developed. They are quite irregular in shape. Their canals frequently mite. The central part of the ridge is composed of large Haversian systems, poorly developed and united by vascular canals. The internal circumferential lamella assume the form of cancellous bone around the medullary canal.

Type I-II-III, Ia, Ib, C.

LEFT FEMUR OF FELIS. LEOPARD. NO. 35349, AMER. MUS. NAT. Hist.

PL. 16, Fig. 251. SYN. TAB. VI

Antero-posterior diameter of bone, $18 \mathrm{~mm}$. ; lateral, $17 \mathrm{~mm}$.

Antero-posterior diameter of medullary canal, $10 \mathrm{~nm}$.; lateral, $9 \mathrm{~mm}$.

The medullary canal is full. Medullary index, $37 \%$.

Structure.-The seetion has three divisions. A wide band of lamellæ and Haversian systems surrounds the bone. It is widest in the inner wall. The systems are numerous and do not appear to have any definite plan of arrangement. The lacuna are long and the canaliculi are straight. The central ring, irregular in width, is composed of well developed Haversian systems with little inter-Haversian lamella. 'The internal rircumferential hamelle torm a fragmentary ring around the medullary anal. Many sparess oceur which alpear to be the result of the disappealanere of llaversian systems. Senile changes are frequent.

T'ype I-III, C, senile. 
LEFT FEMUR OF BOS. DOMESTIC OX. CR. MED. COLL.

PL. 16, F'IG. 252. SYN. T'AB. VI

Antero-posterior diameter of bone, $44 \mathrm{~mm}$. ; lateral, $39 \mathrm{~mm}$.

Antero-posterior diameter of medullary canal, $23 \mathrm{~mm}$; lateral, $21 \mathrm{~mm}$.

The medullary canal is full. Medullary index, $40 \%$.

Structure.-The bone is eomposed of three wide concentric rings with irregular boundaries, separated by canals containing chains of black lacunarlike bodies with connecting and very irregular canalicular extensions. In thin seetions there appear to be no miting struetures in the canals of sufficient importance to hold the rings together.

The canals have an undulating course and communicate with other canals of the rings.

External or first ring: This ring is composed of concentrie lamine divided into short lengths. Occasionally a few Haversian systems interrupt the laminæ. In the anterior wall the lamine are transformed into irregular Haversian systems which have their best development in the middle portion of the walls. The lamine have long or oval lacume and branching or bushy canaliculi. Some lamine are solid; some have central canals; and some show these canals enlarged at intervals with the lamelle bending around the enlargements, forming aberrant Haversian systems.

Middle or second ring: The border's of the separating canals are composed of clear lanellie with no visible canaliculi. The second ring is composed of short and long lamina arranged vertically to the outer ring, especially in the inner wall. Along the outer border of the separating canal the lamina is concentric. As it approaches the anterior projecting wall it merges into the irregular Haversian systems of that region. In the outer wall the laminæ are much more concentric. The lamine of this ring are folded around canalicular expansions into elliptical or elongated angular Haversian systems. As they approach the thind ring they are more circular. Their lacunæ and canaliculi are like those of the outer ring.

Internal or third ring: This is composed of vertical and concentric laminæ of an Haversian system character intermixed. There are more systems in the posterior wall, and it is here that they are best developed. The lamina of this ring run in various directions and form complex arrangements of structural mits. The anterior wall of the bone is composed of irregularly shaped, large, crute Haversian systems united by short lamellie. Around the medullary canal is an irregular ring of internal circumferential lanellic having long, narrow lacune with branchine canalieuli.

Type II-III, C. 
LEFT FEMUR OF EQUUS CABALLUS. DOMESTIC HORSE. CR, MED, COLL.

$$
\text { PL. 16, Fig. 253. S'N. T'A3. VI }
$$

Antero-posterior diameter of bone, $57.5 \mathrm{~mm}$; lateral, $41.5 \mathrm{~mm}$.

Antero-posterior diameter of medullary canal, $32 \mathrm{~mm}$; lateral, $22.5 \mathrm{~mm}$.

The medullary canal is full. Medullary index, $43 \%$.

Structure.-The section is composed of rings of well developed Haversian systems alternating with lamina. It lıas more Haversian systems than laminæ. The external circumferential lamello are fragmentary. The Haversian systems reach the external bounclary, and in some places half-systems are present with their Haversian canals directly underneath the periostemm. The Haversian systems vary in diameter and are well developed. Their lacuna are long and their canaliculi are long and branching. Commencing in the outer posterior region a few lamine appear, which increase in number as they approach the posterior wall. The lamine are well developed and are separated by Haversian systems. Internal cirrumferential lamella form a narrow ring around the medullary canal and become cancellous in the posterior wall.

Type II-III, C.

RIGITT FEMUR OF OVIS. DOMESTIC SHEEP, CR, MEL, COLL.

PL. 16, Fig. 254. Sxn. TAB. VI

Antero-posterior diameter of bone, $18 \mathrm{~mm}$; lateral, $14 \mathrm{~mm}$.

Antero-posterior diameter of merlullary canal, $10.7 \mathrm{~mm}$.; lateral, $7 \mathrm{~mm}$.

The medullary canal is full. Medullary index, $44 \%$.

Structure.-External circumferential lamine surround the section. The lacunx are long and narrow with long, branching canaliculi. Between the external lamine and internal cireumferential lamella are small and large Haversian systems, arranged in the form of a crescent and situated in the outer, posterior, and inner lateral wall. The thickest portion of the crescent is in the outer wall. 'The systems are, for the most part, small, close together, and their Haversian canals frequently mite. They lave few lacunæ and few bushy canaliculi. The inner wall of the bone is composed ahmost entirely of laminx, there being a few Haversian systems rlose to the internal circumferential lamellax. The lamina are separated by wide canals which frequently cross and unite with other canals. Each lamina is composed of lamella with oval lacuma and bushy analiculi. The inner wall of the bone has oblique lamina. Internal rircumferential lamelle surround the medullary anal.

Type II-III, C. 
RIGHT FEMUR OF BISON AMERICANUS. BISON. NO. 22914, AMER. MUS. NAT. HiSt.

$$
\text { Pl. 16, Fig. 255. Syn. TAB. VI }
$$

Antcro-posterior diameter of bone, $56 \mathrm{~mm}$; lateral, $46 \mathrm{nIm}$.

Antero-posterior diameter of medullary canal, $39 \mathrm{~mm}$.; lateral, $33 \mathrm{~mm}$.

The medullary canal is full. Medullary index, $100 \%$.

Structure.-The bone is chiefly composed of laminæ. There are two aggregations of Haversian systems, one in the posterior ridge and the other in the angle of the inner wall. They are fairly well developed and occupy nearly the whole thickness of the wall. Their lacune are oval. The remainder of the section is composed of laminæ, interrupted by small Haversian systems. The lacumæ are oval and the canaliculi are straight.

Type II-III, C.

Right FEMUR OF A MULe. No. 227, Cr. Med. COLl.

PL. 16, Fig. 256. Syn. Tab. VI

Antcro-posterior diameter of bone, $60 \mathrm{~mm}$; lateral, $55 \mathrm{~mm}$.

Antero-posterior diameter of medullary canal, $47 \mathrm{~mm}$; lateral, $45 \mathrm{~mm}$.

The medullary canal is full. Medullary index, $179 \%$.

Structure.-The section shows a posterior and outer ridge. The posterior ridge is composed of small Haversian systems and inter-Haversian lamellix with oval lacunæ and bushy canaliculi. Many spaces oceur and the laminæ are crossed by numerous short canals. The outer ridge consists of Haversian systems and laminæ and shows a large number of spaces. Between these two ridges the wall is composed of Haversian systems and laminx: The remainder of the section is composed of laminæ, interrupted by Haversian systems and crossed by canals. Half of the anterior and inner walls is composed of laminæ perforated with spaces. The spaces have no walls but those of adjoining laminx. They appear to be the result of senile changes. The bone is thin and fragile.

Type II-III, C, senile.

LENT FEMUR OF A MULE. NO, 229, CR. MED. COLL.

PL. 16, FIG. 25\%. Syn. TAB. VI

Antero-posterior diameter of bone, $68 \mathrm{~mm}$.; lateral, $50 \mathrm{~mm}$.

Antero-posterior diameter of medullary canal, $40 \mathrm{~mm}$.; lateral, $37 \mathrm{~mm}$.

The medullary canal is full. Medullary index, $77 \%$.

Structure.-The section has three ridges, a posterior ridge and one on either side of the anterior wall. The posterior ridge is composed of short lamellæ with branching canals, laving a direction toward the point of the ridge. 
Between the lamella are some Haversian systems. The lacmne are oval and the canaliculi are straight. The anterior and inner ridges are composed of a few crude Haversian systems, laminx, and branching canals. The anterior and outer ridges have many more Haversian systems and relatively fewer canals than the inner ridge. Between the three ridges the walls are composed of laminæ, interrupted by a few Haversian systems. The laminxe are frequently crossed by canals. Some cancellous bone appears on the medtullary surfaces of the anterior and posterior walls.

Type II-III, C.

LEFT FEMUR OF A MULE. NO. 235, CR. MED. COLI.

PL. 16. FIG. 258. SYN. T'AB, VI

Intero-posterior diameter of bone, $65 \mathrm{mmm}$; lateral, $51 \mathrm{~mm}$.

Antero-posterior diameter of medullary canal, $38 \mathrm{~mm}$; lateral, $40 \mathrm{~mm}$.

The medullary canal is full. Medullary index, $85 \%$.

Structure.-The posterior wall is over half cancellous. The posterior ridge is composed of Haversian systems, inter-Harersian lamella with oval lacum and many branching canals, having a direction toward the external snrface of the ridge. The remaining wall is composed of lamina, interrupted by Haversian systems and crossed by nmmerous cands. In the outer wall near the mid-line is a collection of Haversian systems forming a slight ridge. Around the medullary canal in the anterior and lateral walls there are many spaces of irregular shape whirh appear to be the result of senile changes. The lacuna are generally oval.

Type II-III, C, senile.

IEFT FEMUR OF A MULE. NO. 236, CR. MED. COLL.

$$
\text { Pu. 16, Fig. 259. Syx. 'T'AB. VI }
$$

Antero-posterior diameter of bone, $61 \mathrm{~mm}$.; lateral, $50 \mathrm{~mm}$.

Antero-posterior diameter of mednllary canal, $40 \mathrm{~mm}$; lateral, $38 \mathrm{~mm}$.

The medullary canal is full. Medullary index, $100 \%$.

Structure.-The posterior ridge is composed of Haversian systems and inter-Haversian lamellæ with oval lacunæ. There are many short, branching canals having a direction toward the external surface. About one-third of the medullary portion of the wall is cancellous bone. The inner and anterior wall is composed of laminæ, interrupted by many Haversian systems. The systems are more numerous around the medullary canal. Many cross canals appear between the systems and extend across the laminx. The anterior half of the outer wall is nearly all laminæ which are interrupted by Haversian systems. The posterior half is composed of irregular elongated Haversian systems and 
of laminæ. The femur of the mule differ's from the horse in its predominating proportion of lamine and in the frequent senile changes present in its scattering Haversian systems. The difference between the horse and the mule is found in the jackass.

Type II-III, C.

LEFT FEMUR OF Elephas 1NDICUS. ASIATIC ELEPHANT. AMER, MUS, NAT, hist.

$$
\text { PL. 1\%, Fig. 260. SYN. TAB. VII }
$$

Antero-posterior diameter of bore, $121 \mathrm{~mm}$; lateral, $77 \mathrm{~mm}$.

Antero-posterior diameter of medullary canal, $50 \mathrm{~mm}$; lateral, $38 \mathrm{~mm}$.

The medullary canal is full. Medullary index, $25 \%$.

Structure.-The section is composed of lamellæ, laminæ, and Haversian systems, the laminæ predominating. The posterior ridge is composed of Haversian systems with inter-Haversian lamellæ. Beginning in the inner side of the ridge and extending around the external surface of the posterior inner wall is a wide band of lamellie, frequently interrupted by Haversian systems. The lamellæ soon separate into laminæ as they extend around the section. The lamine, frequently interrupted by Haversian systems and crossed by canals, complete the circumference of the bone to the posterior ridge. In the anterior wall they constitute two-thirds, in the inner wall one-third, and in the outer and posterior wall over half the width of the wall. As they approach the ridge they shorten and widen into elongated Haversian systems. Thus a wide horseshoe of lanella and laminæ surrounds the bone. In the anterior wall the toe of this shoe is very narrow, having been displaced by Haversian systems. The lacunæ and canaliculi are well developed. Underneath the laminar shoe is an irregularly shaped central ring of well developed Haversian systems with some senile changes around the medullary canal. The lacunæ are well developed. Around the medullary canal is an enclosing ring of lamellæ in the form of cancellous bone.

The bone is over laalf laminæ and lamellæ, and exhibits a different type of structure from that seen in the African elephant.

Type IL-III, C, senile.

RIGHT FEMUR OF HIPPOPOTAMUS AMPHIBUS. HIPPOPOTAMUS

$$
\text { Pl. 12, Fig. 261. SYn. Tab. VII }
$$

Antero-posterior diameter of bone, $70 \mathrm{~mm}$. ; lateral, $70 \mathrm{~mm}$.

Antero-posterior diameter of medullary canal, $26 \mathrm{~mm}$.; lateral, $30 \mathrm{~mm}$.

The medullary canal is full. Medullary index, $19 \%$.

Structure.-Beginning on the outer side of the posterior ridge and extend ing around the bone to the inner wall is a wide band of laming, interrupted by 
Haversian systems of the ( $\mathrm{Ia}$ ) and (C) differentiations. The laminx, separated and crossed by canals, form nearly the whole width of the outer, about onethird of the anterior, and terminate somewhat abruptly at the junction of the anterior and inner wall. The lacunx are oval and the canaliculi are straight.

Underneatl the laminar band is a central, irregularly shaped ring of Haversian systems, very narrow in the outer, wider in the anterior, and forming the whole of the inner and posterior wall. The systems are united by cross canals and exhibit some senile changes. Their lacunæ are oval and the canaliculi are straight.

Around the medullary canal is a cancellous ring of lamellæ. The bone is composed of about equal parts of Haversian systems and laminæ. The bone is unusually hard.

Type II-III, Ia, C.

LEFT FEMUR OF GRAFFA CAMELOPARDALIS. GIRAFFE. NO. 27752, AMER. MUS. NAT. Hist.

PL. 17, FIG. 262. Syn. TAB. VII

Antero-posterior diameter of bone, $72 \mathrm{~mm}$; lateral, $59 \mathrm{~mm}$.

Antero-posterior diameter of medullary canal, $35 \mathrm{~mm}$; lateral, $30 \mathrm{~mm}$.

The medullary canal is full. Medullary index, $33 \%$.

Structure.-Beginning in the outer wall, close to the posterior ridge and extending around the section to about the middle of the inner wall, is a wide band of laminæ, interrupted frequently by Haversian systems. The band forms the external half of the posterior, all of the outer, and two-thirds of the anterior and inner wall. The lamina are separated and crossed by canals. Their lacunæ are well developed.

The whole posterior, imer lateral, and medullary portions of the anterior and posterior lateral wall are composed of Haversian systems with the exception of the internal circumferential lamelle. The systems vary somewhat in size and are well developed. In the posterior wall they are separated by aggregations of oval lacunæ closely packed together.

Internal circumferential lamella with long lacuna and straight canaliculi, widest in the outer wall, surround the medullary canal.

Type II-III, C.

LEFT FEMUR OF RHINOCEROS BICORNIS. RHINOCEROS. NO. 27757, AMER, MUS. NAT. HIST.

PL. 17, Fig. 263. Sxn. TAI. VII

Antero-posterior diameter of bone, $47.5 \mathrm{~mm}$; lateral, $130 \mathrm{~mm}$.

Antero-posterior diameter of medullary canal, $14 \mathrm{~mm}$; lateral, $23 \mathrm{~nm}$.

The medullary canal is full. Medullary index, $55 \%$. 
Structure.-The bone is extended laterally and outwardly by a very prominent, wile, curved process, oceupying the middle portion of the femur. Only a few femora have such a process. For convenience in description the section may be divided into a body containing the medullary canal and adjoining middle portion and a curved cancellous process.

The body is composed of Haversian systems which form the entire inner wall and of Haversian systems and lamine which form the anterior and posterior wall. The systems vary in size, eommunicate by cross canals, and have oval lacuna with straight canaliculi. Around the medullary region they show senile changes and greater irregularity. Laminæ begin to appear in the anterior and posterior wall and rapidly displace the systems as they reach the middle portion. The niddle portion is composed of long lamina separated by wide canals. In the center, crude Haversian systems and short lamine are found. The canals communicate with the medullary canal and with the cancellous spaces of the eurved process. The larune are oval and the canaliculi are bushy. The curved process is composed of narrow, bordering lamella with small Haversian systems, enclosing a wide central portion of eancellous bone, the spaces of which are relatively large. The spaces communicate with the long canals of the middle portion and also with the medullary canal. Internal circumferential lamellæ form an irregularly shaped ring around the medullary canal. Their lacunæ are oval. The bone exlibits predominating lamine and Haversian systems with oval lacunx and bushy and straight canaliculi. Haversian systems are found only in the inner half of the body.

Type II-III, C, senile.

RRGIT FEMUR OF EQUUS BURCHELLI GRANTI. ZEBRA. NO. 27749, AMER. MUS. NAT. HIST.

$$
\text { PL. 17, FIG. 264. SYN. 'I'AB. VII }
$$

Antero-posterior diameter of bone, $43 \mathrm{~mm}$.; lateral, $37 \mathrm{~mm}$.

Antero-posterior diameter of medullary canal, $20 \mathrm{~mm}$; lateral, $22 \mathrm{~mm}$.

The medullary canal is full. Medullary index, $38 \%$.

Structure.-Three divisions are present. External circumferential lamellæ, frequently interrupted by Haversian systems, extend from the lateral boundaries of the posterior wall around the section. The lacunæ are oval and long. The systems are well developed.

The central ring is composed of a wide, horseshoe-shaped band of laminæ, interrupted in the anterior wall by groups of well developed Haversian systems. The lacune are oval and long and the canaliculi are straight.

The internal cireumferential lamellæ form an enclosing ring around the medullary canal. In the anterior and posterior wall it takes the form of cancellous bone. The lacunæ are oval and long. 
The posterior wall is composed entirely of Haversian systems of the (C) differentiation.

Type II-III, C.

LEFT FEMUR OF URSUS MARTTIMUS. POLAR BEAR. NO. 35085, AMER. MUS. NAT. HIST.

$$
\text { Pu. 1\%, Fig. 265. SYN. TAB. VII }
$$

Antero-posterior diameter of bone, $31 \mathrm{~mm}$. lateral, $38 \mathrm{~mm}$.

Antero-posterior cliameter of medullary canal, $18 \mathrm{~mm}$. ; lateral, $22 \mathrm{~mm}$.

The medullary canal is full. Medullary index, $51 \%$.

Structure.-The section has a rather peculiar shape. With the exception of the posterior ridge it is surrounded by lamina, which, in the anterior wall, merge into lamellæ and are interrupted by Haversian systems. The central ring is composed of concentric rows of well developed Haversian systems alternating with laminæ, excepting in the posterior ridge which is all Haversian systems.

Internal circumferential lamellæ form a narrow ring around the medullary canal. The bone is more lighly differentiated than the femur of the black bear.

Type II-III, C.

RIGHT FEMUR OF BUBALIS JACKSONI. HARTEBEEST. NO. 37815, AMER. MUS. NAT. Hist.

$$
\text { PL. 1\%, Fig. 266. Syn. Tab. VII }
$$

Antero-posterior diameter of bone, $32.5 \mathrm{~mm}$. ; lateral, $30 \mathrm{~mm}$.

Antero-posterior diameter of medullary canal, $17 \mathrm{~mm}$.; lateral, $16 \mathrm{~mm}$.

The medullary canal is full. Medullary index, $39 \%$.

Structure.-The section is composed mostly of laminæ. Around the bone is a wide horseshoe band of laminæ, interrupted bv Haversian systems. The band forms the whole of the outer and anterior walls. Underneath the band in the inner wall is a narrow crescent of well developed Haversian systems. The posterior wall is composed of Haversian systems and short laminæ, between which are several vascular canals. A narrow ring of internal circumferential lamellæ, slightly wider in the inner wall, surrounds the medullary canal. The lacunæ are long and oval.

Type II-III, C.

LEFT FEMUR OF PHACOCHCERS AFRICANUS. WARTHOG. No. 2776., AMER, MUS. NAT, HIST.

PL. 1\%, FIG. 26\%. SYN. TAB. VII

Antero-posterior dianeter of bone, $24 \mathrm{~mm}$.; lateral, $20.5 \mathrm{~mm}$.

Antero-posterior diameter of medullary canal, $14 \mathrm{~mm}$.; lateral, $12 \mathrm{~mm}$.

The medullary canal is full. Medullary index, $52 \%$. 
Structure.- - w wide horseshoe band of lamina surrounds the bone with the exception of the posterior ridge. The inner and outer portions of the posterior wall are composed entirely of lamima. The anterior' and lateral walls are about one lualf laminx. The laminx are long and short, liave oval lacunx and bushy canaliculi. The rentral ring is incomplete. It is composed of a crescent of well developed Haversian systems in the anterior and lateral wall. The systems are separated by short, oblique lanella. The posterior ridge is romposed of Haversian systems of the (Ib) differentiation, between which lamella with oval lacuna are prominent.

The internal circumferential lamelle are framentary. The bone shows differentiation of structure in its lamina and systems.

Type II-III, Ib, C.

LEFT FEMUR OF FELIS CONCOLOR. PANTHER. NO. 1492, AMER. MUS. NAT. HIST.

$$
\text { PL. 18, Fra. 268. Six. Tib. TII }
$$

Antero-posterior diameter of bone, $16 \mathrm{~mm}$; lateral, $19 \mathrm{~mm}$.

Intero-posterior diameter of medullary canal, $11 \mathrm{~mm}$; lateral, $12 \mathrm{~mm}$.

The medullary canal is full. Mednllary index, $76 \%$.

Structure.-The external circumferential lamella appear only in the posterior and in the inner lateral wall. The central ring constitutes the principal part of the section. In the inner anterior wall the ring is divided into two equal portions by a narrow concentric lamina. The ring is composed of well de-. veloped Harelsian strstems. The internal rircumferential lamella form a ring of varying widths around the medullary anal. It is widest in the outer wall.

Type I-II-III, C.

LEWT FEMUR OF GULO LUSCUS. WOLVERENE. NO. 20884, AMER. MUS. NAT. HIST.

$$
\text { Pu. 18. Fig. 269. Six. Tab. VII }
$$

Antero-posterior diameter of bone, $10 \mathrm{~mm}$; ; lateral, $11.5 \mathrm{~mm}$.

Antero-posterior diameter of medullary canal, 5.5 mm.; lateral, $6 \mathrm{~mm}$.

The medullary caul is full. Nedullary index, $31 \%$.

Structure.-A wide ring of lamella and crurle lamine interrupted by Haversian systems surrounds the section with the exception of a small portion of the onter wall. It is frequently crossed by canals. The lacunre are long and the ranaliculi are straight.

The central ring is somewhat incomplete and composed of well dereloped Haversian systems. It reaches the surface in the outer wall. A ring of laminx interupted by a few Haversian systems surroumds the medullary canal.

Type I-II-TIT, C. 
LEFT FEMUR OF ERIGNATIIUA BARBATLS. SEAL. NO. 19347, AMER. MUS. NAT. HIST.

$$
\text { P'L, 18, FIG. 220. SYX. 'THB. VII }
$$

Antero-posterior diameter of bone, 19.5 $\mathrm{mm}$. ; lateral, $39 \mathrm{~mm}$.

Antero-posterior dianeter of medullary amal, $10 \mathrm{~mm}$. ; lateral, $2.5 \mathrm{~mm}$.

The medullary canal is full. Mednllary index, $50 \%$

Structure.-Three divisions are present. The external circumferential lanella form a narrow enclosing ring. 'The lacme are oval.

'The central ring is composed of well developed Haversian systems, short laminx, and lamellxe with cross canals intermixed. It shows no plan of arrangement, but a confusing mixture of units. The lacune are oval and lone and the canaliculi are straight. The ring constitutes nearly all of the section. The internal circumferential lamelle form an incomplete ring around the medullary canal. In the lateral walls the lamelle take the cancellons form. The planless arrangement of its throe muts is somewhat simnicant.

Type II-III, C.

LEFT FEMUR OF BOS BUBALIS. WATER BUFFALO. NO. 27770, AMER. MUS. NAT. HIST.

$$
\text { PL. 18, FIt: 2:1. SYx. TMB. VII }
$$

Antero-posterior diameter of hone, 48 mm.; lateral, 451111.

Antero-posterior diameter of medullany ranal, $2 \pm$ mm.; lateral, $2510 m$.

The medullary canal is full. Medullary imlex, $38 \%$

Structure.-Beginning on the immer side of the posterior and extending around the imner, anterior, and a portion of the outer wall is a wide band of laminx, short and long, crossed by a great number of branching canals and interrupted in the anterior and outer wall by a few Haversian systems. Underneatl this band in the immer and anterior wall is a rescent of Havesian systems and lamelle with oval lacumx and bushy canaliculi. The crescent is rossed by numerous canals. The outer wall is composed of Haversian systems and short lamine and the posterior wall of Haversian systems and inter-Harersian lamella with oval lacume and bushy canaliculi. The medullary canal is surrounded by a narrow ring of internal circumferential lanclla.

Type II-III, Ib, C.

LEFT FEMUR OF OVIS MONTANA. MOUNTAIN SHEEP. CR. MED. COLL.

$$
\text { Pl. 18, Fig. 2:. NYx. Tha. VII }
$$

Antero-posterior diameter of bone, 200 $\mathrm{mm}$. ; lateral, $25 \mathrm{~mm}$.

Antero-posterior diameter of medullary ranal, 12.5 mm.; lateral, 15 mm.

'The medullary canal is full. Medullary index, $60 \%$.

Structure.-The bone is composed of short concentric lamine enclosing the medullary canal, with the exception of the resesent of Haversian systems in 
the anterior and an area of Haversian systems in the posterior wall. A single concentric lamina diviles the section into two parts. Each lamina is composed of a few lamellie with well developed lacunæ and canaliculi. There is a crescent of well developed Haversian systems in the anterior wall bordering upon the internal circumferential lamella. The posterior wall is composed of well dereloped Haversian systems extending from the external surface of the bone to the internal circumferential lamellx. A narrow ring of internal circumferential lannellæ with long lacum and straight canaliculi surrounds the medullary canal.

Type II-III, C.

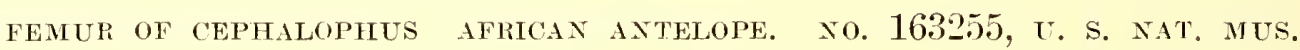

PL. 18, Fig. 273. SYN. TAB. VII

Antero-posterior diameter of bone, $15 \mathrm{~mm}$. ; lateral, $13.5 \mathrm{~mm}$.

Antero-posterior diameter of medullary canal, $9 \mathrm{~mm}$.; lateral, $9 \mathrm{~mm}$.

The medullary canal is full. Medullary index, $67 \%$.

Structure.-The bone is composed of a wide horseshoe band of laminæ embracing the posterior ridge. The lamina are long and short and are interrupted by a few Haversian canals in the external lamina. They are crossed by numerous canals from the medullary anal. Their lacuna are long and their canalieuli are straight. Underneath the laminas and adjacent to the internal circumferential lamella is a narrow ring of Haversian systems. The systems form nearly the whole posterior ridge, and elsewhere are situated between the "anals extending outward from the medullary canal. They are well developed. The medullary canal is surrounded by a narrow ring of internal cireumferential lamellæ well developerl.

Trpe II-III, C.

EEMUR OF RAPHICEROS. STETNBOK. NO. 164801, U. S. NAT. MUS.

PI. 18, FIG. 2it. SYN. Tub, VII

Antero-posterior diameter of bone, $12 \mathrm{~mm}$. ; lateral, $12.5 \mathrm{~mm}$.

Antero-posterior dianeter of medullary canal, $6.5 \mathrm{~mm}$; lateral, $7 \mathrm{~mm}$.

The medullary canal is full. Medullary index, $43 \%$.

Structure.-The section is surrounded by a narrow ring of lamellæ and Haversian systems. In the posterior lateral wall is a group of Haversian systems which forms nearly the whole wall. The lacunæ are long and their canaliculi bushy and straight. The remainder of the bone is composed of laminæ, crossed at rarious angles by canals and interrupted here and there by very crude Haversian systems of the (Ia) differentiation. 'The lacunie are long. and narrow.

Type II-III, Ia, C. 
LEFT FEMUR OF GAZELLA GRANTl. GRANT'S GAZELLE. NO, 27762, AMER. MIS. NAT. HiST.

Pi. 18, Fig. 275. SyN. 'T'AB. VII

Antero-posterior diameter of bone, $19 \mathrm{~mm}$; lateral, $19.5 \mathrm{~mm}$.

Antero-posterior diameter of medullary canal, $10.5 \mathrm{~mm}$; lateral, $11 \mathrm{~mm}$.

The medullary anal is full. Medullary index, $45 \%$.

Structure.-The section is composed of a wide horseshoe haml of laminæ embracing the posterior ridge. In the anterior wall they are interrupted by Haversian systems, especially near the circumference. They are long and short and their lacuma are round and oval with bushy and straight canaliculi. Underneath the lamine of the outer lateral, the anterior, and inner lateral wall is a crescent of Haversian systems well developed. The posterior ridge is composed mostly of Haversian systems. Internal circumferential lamellæ with narrow lacunx and straight canaliculi surround the medullary canal.

Type II-III, C.

LEFT FEMUR OF KOBUS ELLAPSIPRYMNOS. WATER BUCK. NO. 27669,

AMER, MUS. NAT, HIST.

P'L. 18, Fig. 2:6. SYx. 'T'AB. VII

Antero-posterior diameter of bone, $28 \mathrm{~mm}$; lateral, $25 \mathrm{mmn}$.

Antero-posterior diameter of medullary canal, $18 \mathrm{~mm}$.; lateral, $16 \mathrm{~mm}$.

The medullary canal is full. Medullary index, $70 \%$.

Structure.-Begimning on the outer side of the posterior ridge and extending around the outer and anterior wall is an external band of lamella, interrupted by Haversian systems of the ( $\mathrm{Ia}$ ) differentiation and by canals. Their lacuna are long and their canaliculi are straight. The imner wall of the section is composed of lamina which are continued around the section to the posterior ridge under the lamellar band of the anterior and outer wall. The lamina are frequently interrupted by Haversian systems. Their larama are long and their analiculi are straight. The posterior ridge is composed of Haversian systems which are extended around the outer and anterior wall and borter upon the medullary canal. Their lacunæ are long.

Type I-II-TII, Ia, C.

Right FEMUR OF ARCTOMYS MONAX. WOODCHUCK OR GROUND HOG. CR. MED. COLL.

Pi. 19, Fig. 27\%. Syn. TAB. VII

Antero-posterior diameter of bone, $6 \mathrm{~mm}$; lateral, $7 \mathrm{~mm}$.

Antero-posterior diameter of medullary canal, $4 \mathrm{~mm}$.; lateral, $4.5 \mathrm{~mm}$.

The medullary canal is full. Medullary index, $74 \%$.

Structure.-Two lamina with long lacunæ and straight canaliculi, interrupted here and there by Haversian systems of the (Ia) differentiation, surround the section with the exception of the posterior ridge. 
The central ring is composed of Haversian systems, irregular in shape and of the (C) differentiation, between which are groups of lamellæ extending in different directions. A wide ring of lamellæ, separated into laminæ, surrounds the medullary canal. The lacunæ are long and the canaliculi are straight.

Type II-III, Ia, C.

RIGHT FEMUR OF CANIS LATRANS. COYOTE. CR. MED. COLL.

Pl. 19, Fig. 2ir. Sin. Tab. VII

Antero-posterior diameter of bone, $12 \mathrm{~mm}$. ; lateral, $11.5 \mathrm{~mm}$.

Antero-posterior diameter of medullary canal, $8 \mathrm{~mm}$; lateral, $7 \mathrm{~mm}$.

The medullary canal is full. Medullary index, $68 \%$.

Structure.-The section is surrounded by external circumferential lamellæ excepting its posterior rilge and anterior wall. Beginning on the outer lateral side of the posterior ridge the lamellæ separate into laminæ. As they pass around the outer lateral to the anterior wall the laminæ decrease in number until they are reduced to a few lamellæ. The lamellæ then pass around the inner wall as a narrow band.

Their lacunæ and canaliculi are well developed. Underneath the lamello and lamina is a wide ring of well developed Haversian systems, widest in the posterior wall where they form nearly the whole thickness of the posterior ridge. The systems frequently unite by cross canals and have long, narrow lacunæ. The medullary canal is enclosed by a ring of lamellæ. In the lateral wall the lamella gradually thicken and separate into several laminæ which form half the thickness of the wall. They are well developed.

Type II-III, C.

RIGHT FEMUR OF CAPRA. GOAT. CR, MED. COLL.

Pl. 19, Fig. 279. Syn. Tab. VII

Antero-posterior diameter of bone, $4.5 \mathrm{~mm}$; ; lateral, $5 \mathrm{~mm}$.

Antero-posterior diameter of medullary canal, $2.5 \mathrm{~mm}$. ; lateral, $3 \mathrm{~nm}$.

The medullary canal is full. Medullary index, $50 \%$.

Structure.-The section is surrounded by a ring of laminæ, divided into short, long, and irregular segments by transverse canals and interrupted by small Haversian systems of the ( $\mathrm{Ib}$ ) differentiation. Underneath this is a wide central ring of laminæ arranged concentrically and obliquely and interrupted frequently by Haversian systems of the (Ib) and (C) differentiations. In the anterior and posterior wall are two crescents of Haversian systems, and in the outer portion of the posterior wall a group of Haversian systems.

A narrow ring of lamellæ surrounds the medullary canal. The lacunæ are generally oval and the canaliculi are straight.

Type II-III, Ib, C. 
RIGHT FEMUR OF A BULL DOG (NOT A PURE BLOOD). NO. 292, CR. MED. COLL.

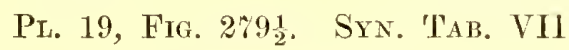

Antero-posterior diameter of bone, $14.5 \mathrm{~mm}$.; lateral, $12.5 \mathrm{~mm}$.

Antero-posterior diameter of medullary canal, $10.5 \mathrm{~mm}$.; lateral, $9 \mathrm{~mm}$.

The medullary canal is full. Medullary index, $109 \%$.

Structure.-The section is composed of a horseshoe of lamina and lamellix, separated into two bands by a central band of Haversian systems. The lamina constitute the whole of the inner wall, and as they reach the anterior wall they become lamellæ, which are then separated into extermal and internal bands by a central band of Haversian systems. The three bands, external lamellar, central Haversian system, and internal lamellar form the outer wall. The internal lamellæ are frequently crossed by radiating canals. The posterior ridge is composed of Haversian systems with comparatively few lacuna. Their bone substance is in excess of that usually seen. In the anterior wall near the medullary canal are four quite large openings.

Type I-II-III, C.

LEFT FEMUR OF A SHEPIERD DOG (NOT A PURE BLOOD). NO. 201, Cr. MEl. COLI.

$$
\text { Pl. 19, Fig. 280. Six. TAв. VII }
$$

Antero-posterior diameter of bone, $11 \mathrm{~mm}$.; lateral, $10.5 \mathrm{~mm}$.

Antero-posterior diameter of medullary canal, $6.5 \mathrm{~mm}$.; lateral, $5.5 \mathrm{~mm}$.

The medullary canal is full. Medullary index, $45 \%$.

Structure.-The section is surrounded by a horseshoe band of lamine which constitutes the principal part of the bone. Between the laminie are canals which widen into circular areas at intervals. The lacme are oval and long. The central ring is reduced to a long, narrow crescent of Haversian systems extending around the anterior, outer, and posterior' wall. 'The posterior ridge is almost entirely composed of Haversian systens. The internal rireumferential lamelle form a narrow ring around the medullary canal.

Type II-III, C.

RIGHT HEMUR OF A DOG. NO. 291, CR. MEL. COLL.

Pl. 19, F1G. 2801. Syn. Tab. VII

Antero-posterior diameter of bone, $16 \mathrm{~mm}$. ; lateral, $17 \mathrm{~mm}$.

Antero-posterior diameter of medullary canal, $11 \mathrm{~mm}$.; lateral, $10 \mathrm{~mm}$.

The medullary canal is full. Medullary index, $68 \%$.

Structure.-The section is composed of a horseshoe band of lamella and laminæ, interrupted by Haversian systems of the (Ia) differentiation. In the outer wall the lamellæ are separated into two nearly equal concentric bands by a middle band of Haversian systems. The lamellar bands are frequently 
crossed by radiating canals and interrupted by crude Haversian canals. The lamellæ on reaching the anterior wall separate into laminæ, which constitute the whole inner wall. Here and there the canals between the laminæ widen into circular openings. The posterior ridge is composed of Haversian systems, between which are short lamellæ with round lacunæ. The internal circumferential lamellæ surround the medullary canal.

Type I-II-III, Ia, C.

FEMUR OF A FOX TERrier (NOT A PURE BLOOD). NO. 202, CR. MED. COLl.

PL. 19, F1G. 281. Syn. Tab. VII

Antero-posterior diameter of bone, $11 \mathrm{~mm}$.; lateral, $9.5 \mathrm{~mm}$.

Antero-posterior diameter of medullary canal, $6.5 \mathrm{~mm}$.; lateral, $6 \mathrm{~mm}$.

The medullary canal is full. Medullary index, $59 \%$.

Structure.-The section is surrounded by a wide horseshoe of laminæ which forms three-fourths of the thickness of the wall of the bone. The ranals between the laminæ widen at intervals into circular areas. The laminæe are frequently crossed by irregular canals. The lacunæ are oval. The central ring is a narrow crescent and is composed of well developed Haversian systems. The ring reaches the surface of the posterior ridge where it is composed of vascular canals surrounded by concentric lamellæ. Between the canals are long, minute, tendon insertions. The internal circumferential lamella form a narrow ring around the medullary canal. Just behind the ring are several large vascular spaces.

Type II-III, C.

Right FEMUR OF A MONGRel DOG (NO CHARACTERISTIC FEATURES).

NO. 200, CR. MED, COLL.

PL. 19, Fig. 282. SYN. T'AB. VII

Antero-posterior diameter of bone, $12.5 \mathrm{~mm}$. lateral, $13 \mathrm{~mm}$.

Antero-posterior diameter of medullary canal, $8.5 \mathrm{~mm}$.; lateral, $9 \mathrm{~mm}$.

The medullary canal is full. Medullary index, $90 \%$.

Structure.-The section is surrounded by a horseshoe band of laminæ and lamellæ. The laminæ form the whole width of the inner wall. They then become fewer in number as they reach the anterior wall, where they are reduced to a narrow lamellar band. The lamellæ then widen and separate into laminæ as the band reaches the posterior ridge. The central ring is reduced to a long, narrow crescent of Haversian systems which nearly encircles the section. The systems reach the surface of the posterior ridge and form nearly the whole width of the posterior wall. They are well developed. The internal circumferential lamellæ do not form an enclosing ring. In the posterior wall they form a narrow band, in the outer wall the band widens into laminæ, and in the 
anterior outer lateral wall the lamine form three-fourths of the wall. In the anterior inner lateral wall the lamellæ and lamine disappear altogether and Haversian systems form the boundary of the medullary canal.

Type II-III, C.

RIGHT FEMUR OF A BULL dOG (NOT A PURE BLOOD). NO. 204, Cr. MED. COLL.

Pl. 19, Fig. 283. Syn. TAB. VII

Antero-posterior diameter of bone, $13 \mathrm{~mm}$. ; lateral, $12 \mathrm{~mm}$.

Antero-posterior diameter of medullary canal, $7 \mathrm{~mm}$. ; lateral, $6.5 \mathrm{~mm}$.

The medullary eanal is full. Medullary index, $41 \%$.

Structure.-The section is surrounded by a wide horseshoe of crude laminæ intermixed with Haversian systems. The shoe is widest in the outer wall where it forms half the width of the wall. In the inner wall the systems are irregular and more numerous than elsewhere. The central ring is composed of Ilaversian systems. It reaches the surface of the posterior ridge. Between the systems near the posterior surface and extending along the external boundary on either side of the ridge are oblique tendon insertions. The ring is narrowest in the outer wall. The internal circumferential lamellæ enclose the medullary ranal. They form a thick band along the inner and anterior walls. The thick band is crossed frequently by cross canals.

Type II-III, C.

Right FeMur of a COLlie dog ( xot a PURe blood). No. 203, Cr. Med. COll.

$$
\text { Pl. 19, Fig. 284. Syn. TAb. VII }
$$

Antero-posterior diameter of bone, $13.5 \mathrm{~mm}$.; lateral, $13 \mathrm{~mm}$.

Antero-posterior diameter of medullary canal, $8 \mathrm{~mm}$.; lateral, $7.5 \mathrm{~mm}$.

The medullary canal is full. Mednllary index, $50 \%$.

Structure.-The section is enclosed by a horseshoe of lamella, interrupted by small Haversian systems and partially separated by canals. The lamellæe form nearly half of the width of the wall of the bone. The rentral ring is composed of well developed Haversian systems which constitute the entire posterior ridge with the exception of the internal lamellw. The internal circumferential lamellæ form a ring of varying widths surrounding the medullary cantal.

Type I-II-III, C.

RIGITT FEMLTR OF A SPANIEL, (NOT A PURE BLOOD). NO. 205, CR. MED, (OIA,

$$
\text { PL. 19, Fig. 285. SrN. 'TAb. VII }
$$

Antero-posterior diameter of bone, $13 \mathrm{~mm}$. ; lateral, $13.5 \mathrm{~mm}$.

Antero-posterior liameter of mednllary canal, $8.5 \mathrm{~mm}$. ; lateral, $8.5 \mathrm{~mm}$.

The mednllary canal is full. Medullary intex, $70 \%$. 
Structure.-The section is surrounded by a narrow horseshoe of lamellæ, widest in the immer wall. The central ring forms the greater portion of the width of the wall. It reaches the surface of the posterior ridge and constitutes nearly all of the posterior wall. The ring is composed of well developed Haversian systems. The internal circumferential lamellæ form a ring of lamellæ and lamine extending in various directions.

Type II-III, C.

The femora of ten dogs were examined and no two of them showed the same structure. They ranged from a second to a second and third combination. In the combinations the proportions, of the units varied greatly.

LEFT FEMUR OF ILPUS CUNICULUS. RABBIT. CR. MED. COLL.

PL. 19, Fig. 286. Syn. 'TAB. VII

Antero-posterior diameter of bone, $5.5 \mathrm{~mm}$.; lateral, $7.5 \mathrm{~mm}$.

Antero-posterior diameter of medullary canal, $3.5 \mathrm{~mm}$. ; lateral, $5 \mathrm{~mm}$.

The medullary canal is full. Medullary index, $74 \%$.

Structure.-Around the bone is a ring of lamellæ of varying thicknesses. As a whole, it is narrow, and, in the posterior wall, merges into oblique laminæ which join the internal eircumferential lamellæ. The lacunæ are long and narrow and the canaliculi are long and branching.

There is a central ring of incomplete Haversian systems and short, irregular laninæ occupying the anterior and inner wall. In the posterior wall this ring is interrupted by oblique, well developed Haversian systems and laminæ extending from the internal to the external circumferential lamellæ. In the outer wall there are wide, oblique canals separating irregular laminx extending from the internal to the external lamellæ and interdigitating with extensions from the periosteum. These two oblique arrangements enclose a small crescent of irregular systems and lamellx. The lacunæ are oval or long and the canaliculi are bushy.

Internal circumferential lamellæ of varying thickness and well developed surround the medullary canal. In the inner and posterior wall it merges into oblique, wide laminæ, separated by an oblique row of complete Haversian systems. To the outer side of this row of systems are three or four wide, oblique laminæ which appear to be extensions of the internal lamellæ.

Type I-II-III, C.

RIGHT FEMUR OF PROCYON LOTOR. RACCOON

PL. 20, Fig. 28\%. Syn. TAB. VII

Antero-posterior diameter of bone, $9 \mathrm{~mm}$; lateral, $10 \mathrm{~mm}$.

Antero-posterior diameter of medullary canal, $6.5 \mathrm{~mm}$. ; lateral, $7 \mathrm{~mm}$.

The medullary canal is full. Medullary index, $100 \%$. 
Structure.-The section is surrounded by external circumferential lamellæ. In the anteriox and posterior inner wall the ring is thick and interrupted by Haversian systems of the (Ia) differentiation. The lacunæ are long and narrow and the canaliculi are long.

The central ring is composed of irregularly shaped Haversian systems well developed. It gradually increases in thickness in the inner wall until it reaches about the middle, where it forms two-thirds of the width of the wall. From this point it continues to increase to the middle of the anterior wall, where it forms four-fifths of the bone. The systems are strongly developed, their lacuna are long and narrow, and their canaliculi are long and branching. Between the systems are short lamellæ. The Haversian canals frequently unite.

A ring of internal circumferential lamina of varying thickness surrounds the medullary canal. In the inner wall and extending around the posterior region are short, oblique lamine, forming, in some places, nearly one-half of the thickness of the bone. In the outer wall two or three lamina form the medullary boundary. The lacunæ are long and narrow and the canaliculi are long and branching.

Type I-II-III, Ia, C.

OS PENIS OF THE RACCOON

Pl. 20, Fig. 288. Syn. Tab. VII

The os penis is introduced here because of its relation to the general bone structure of the animal and its relation of structure to function.

The antero-posterior diameter of the bone is $4 \mathrm{~mm}$.; lateral, $4 \mathrm{~mm}$.

The antero-posterior diameter of the central canal is $0.8 \mathrm{~mm}$.; lateral, 0.8 $\mathrm{mm}$.

The canal is very irregular in shape. The bone is of medium hardness.

The medullary canal is full. Medullary index, $4 \%$.

Structure.-External circumferential lamella, rather incompletely developed, surround the bone. They are not equally distinct in all parts. In some places they are fairly well developed, while in others they are indistinct and interrupted by small, incomplete Haversian systems. The lacune are large, few in number, oval in shape, and have branching canaliculi.

A wide ring of large and small Haversian systems constitutes the central ring. The large systems occupy the inner portion of the ring, the small ones the outer portion. They are all fairly well developed. Their Haversian canals frequently communicate with each other; their cross-sections are circular; their lacunæ are few, long, and narrow; their canaliculi are long and branching; and their lamellæ are not clearly defined. Here and there short inter-Haversian lamellæ appear. 
Internal circumferential lamellæ form a very irregular boundary of the medullary canal. The lacunx are long and their canaliculi are very numerous and branching.

Type I-III, C.

FEMUR OF CANIS LUPUS. WOLF

Pl. 20, Fig. 289. Syn. Tab. VII

Antero-posterior diameter of bone, $16.5 \mathrm{~mm}$; lateral, $7 \mathrm{~mm}$.

Antero-posterior diameter of medullary canal, $10 \mathrm{~mm}$. ; lateral, $5 \mathrm{~mm}$.

The medullary canal is full. Medullary index, $77 \%$.

Structure.-Beginning on both sides of the posterior ridge and extending around the two latcral portions of the wall of the bone are two wide bands of lamina, interrupted by Haversian systems of the (Ia) and (C) differentiations. As the bands reach the anterior wall the lamine are reduced to a narrow rim of external circumfercntial lamellæ. Beginning on both sides of the posterior wall, directly underneatl the internal circumferential lamellæ and extending around the anterior wall, is a central crescent of well developed Haversian systems. Bordering the medullary surface of the anterior wall is an area of laminæ. The postcrior ridge is composed of well developed Haversian systems. A narrow lamina surrounds the medullary canal.

Type II-III, Ia, C.

RIGHT FEMUR OF FELIS LEO. LION. AMER. MUS. NAT. HiST.

PL. 20, Fig. 290. Syn. TAB. VII

Antero-posterior diameter of bone, $26 \mathrm{~mm}$.; lateral, $25.5 \mathrm{~mm}$.

Antero-posterior diameter of medullary canal, $13 \mathrm{~mm}$; lateral, $11.5 \mathrm{~mm}$.

The medullary canal is full. Medullary index, $28 \%$.

Structure.-The section is partly surrounded by a band of lamellæ and crude lamina, interrupted by Haversian systems of the (Ia) and (C) differentiations. The band is broken at the posterior ridge and outer antero-lateral wall by Haversian systems of the central ring.

The central ring occupies the posterior wall and the remainder of the section excepting that part immediately surrounding the medullary canal. It is composed of well developed Haversian systems, which are separated into two nearly equal portions by a narrow laminar extension of the wide band of the inner lateral wall.

The intenal cincumferential lamellæ form a narrow ring around the medullary canal. Immediately behind this, in the outer anterior wall, are a number of spaces.

Type I-II-III, Ia, C. 
FEMUR OF CANIS. SMALL GREY FOX. CR, MEN, COLL.

PL. 20, FIG. 291. SYN, TAB. VII

Antero-posterior diameter of bone, $8 \mathrm{~mm}$.; lateral, $9 \mathrm{~mm}$.

Antero-posterior diameter of medullary canal, $5 \mathrm{~mm}$.; lateral, $6.5 \mathrm{~mm}$.

The medullary canal is full. Medullary index, $80 \%$.

Structure.-A ring of external circumferential lamellæe and laminæ, interrupted by Haversian systems of the (Ia) differentiation, surrounds the bone. In the outer wall the lamellar ring is distinct, but in the inner wall it widens and separates into laminæ which occupy the whole thickness of the wall. The laminæ are short and are separated and crossed by intercommunicating canals. On the inner lateral side of the posterior wall is a ridge and the lamine from the inner wall reach the surface at this point and appear to interdigitate with inward extensions from the periosteum. The lacune are long and narrow; the eanaliculi are long and branching.

The central ring is composed of a wide crescent of well developed Haversian systems, the horns of which begin a short distance apart in the inner wall, while the widest part of the body occupies the outer wall. The systems are small and large, regular and irregular in shape. Their lamellæ are well defined; their lacunæ are long and narrow; and their canaliculi are branching. Their Haversian canals frequently communicate.

Around a portion of the medullary canal is a border of Haversian systems. The internal circumferential lamellæ form an incomplete ring around the medullary canal.

Type I-II-III, Ia, C.

LEFT FEMUR OF TAXIDEA AMERICANA. AMERICAN BADGER, AMER. MUS. NAT. HIST.

Pl. 20, Fig. 292. Syn. 'TAB. VII

Antero-posterior diameter of bone, $7 \mathrm{~mm}$; ; lateral, $8 \mathrm{~mm}$.

Antero-posterior diameter of medullary canal, $4 \mathrm{~mm}$.; lateral, $4 \mathrm{~mm}$.

The medullary canal is full. Medullary index, $40 \%$.

Structure.-The section is surrounded in the anterior and lateral wall by external circumferential lamella. In the posterior wall the lanelle are arranged obliquely. Under the lamelle is a narrow crescent of small, well developed Haversian systems. Under the ring of systems is a wille ring of laminæ which in the posterior wall are arranged obliquely from the medullary canal. The canals between the lamina are wide and branching. The lacunæ are oval and long.

Type I-II-III, C. 
RIGHT FEMUR OF MELURSUS LABIATUS. SLOTH BEAR, NO. 22720, AMER, MUS, NAT, HIST.

Pr. 20, Fig. 293. Syn. Tab. VII

Antero-posterior diameter of bone, $24 \mathrm{~mm}$.; lateral, $24 \mathrm{~mm}$.

Antero-posterior diameter of medullary canal, $10 \mathrm{~mm}$.; lateral, $10 \mathrm{~mm}$.

The medullary canal is full. Medullary index, $21 \%$.

Structure.-A horseshoe band of lamellæ, laminx, and Haversian systems of the (Ia) differentiation embraces the posterior ridge. The band is widest in the inner wall, where it is composed of lamelle and laminæ alternating with Haversian systems. The lacunæ are oval and long.

The central ring is composed of lamelle, lamine, and Haversian systems intermixed and alternating with each other. The systems are well developed. The posterior ridge is composed of Haversian systems and lamellæ having a direction from the external to the medullary surface.

The internal circumferential lamellæ form a narrow ring around the medullary canal. The lacunæ are long.

The bone is peculiar in the mixture of its units.

Type I-II-III, Ia, C.

LEFT FEMUR OE CANIS AUREES. JACKAL. NO. 163293, U. S, NAT MUS.

Pr. 20, Frg. 294. SYY. 'TAB. VII

Antero-posterior diameter of bone, $10 \mathrm{~mm}$. ; lateral, $8.5 \mathrm{~mm}$.

Antero-posterior diameter of medullary canal, $6.5 \mathrm{~mm}$.; lateral, $6 \mathrm{~mm}$.

The medullary canal is full. Medullary index, $85 \%$.

Structure.-An irregular horseshoe of lamellæ and lanimæ surrounds the section. On the outer side of the posterior ridge the lamellæ are wide, as they extend around the outer lateral wall they become very narrow, then widen again in the anterior wall to more than half the width, and as they pass around the inner wall they separate into laminæ, diminish in width, and terminate in the inner posterior region. The lamellæ are interrupted by Haversian systems of the (Ia) differentiation. They are frequently crossed by canals. Undemeath the lamellæ and laminæ is an irregularly shaped central ring of Haversian systems. It forms the whole width of the posterior and adjacent inner wall. The systems are large and small and well developed. In the outer wall they are elongated in cross-section, especially in the anterior region. A narrow ring of internal circumferential lamellæ surrounds the medullary canal.

Type I-II-III, Ia, C. 
Right FEMUR OF DIDElPhys virgintana. OPOSSUM. CR. MEd. COLL.

$$
\text { PL. 20, Fia. 295. Syx. T'AB. VII }
$$

Antero-posterior diameter of bone, $7 \mathrm{~mm}$. ; lateral, $8.5 \mathrm{~mm}$.

Antero-posterior diameter of medullary canal, $3.5 \mathrm{~mm}$.; lateral, $5 \mathrm{~mm}$.

The medullary canal is full. Medullary index, $42 \%$.

Structure.-The bone presents a rudimentary appearance. It is composed of two wide external lamellar bands of incomplete formation, separated by a very narrow band of imperfectly developed Haversian systems, the whole occupying two-thirds of the posterior, onter, and anterior wall. The lamellar bands are composed of bone substance with large, oval lacunæ and extensive, bushy canalieuli forming an intricate network. At short intervals radiating canals appear, giving a bush-like appearance to the band. Just internal to this lamellar band is a narrow crescent of very incomplete Haversian systems oceupying the anterior, outer, and posterior wall. The systems are of the (Ib) differentiation. Around the medullary canal of the anterior, outer, and posterior wall, internal circumferential lamella are well developed, reaching their greatest thickness in the outer wall. Their lacunæ are long and narrow and their canaliculi are long, straight, and branching.

The inner wall of the bone is extended in the form of a heavy ridge. It is composed of bone substance with heavy, oblique canals, from which are sent off dense networks of large canaliculi. This peculiar arrangement forms the external half of the ridge. The internal half is composed of incomplete Haversian systems, arranged in oblique rows, converging to a central point in the middle of the ridge. No internal cireumferential lamella are found in this region.

Type I-III, Ib.

LEFT FEMUR OF MANIS. ANT-EATER. NO. 8351, U. S. NAT. MUS.

$$
\text { PL. 20, Fig. 296. Syn. TAb. VII }
$$

Antero-posterior diameter of bone, $9 \mathrm{~mm}$.; lateral, $12.5 \mathrm{~mm}$.

Antero-posterior diameter of medullary canal, $4 \mathrm{~mm}$; lateral, $5.5 \mathrm{~mm}$.

The medullary canal is full. Medullary index, $24 \%$.

Structure.-The three structural divisions appear in a somewhat modified form. A thick, incomplete ring of crude circumferential lamine surrounds the section, excepting the posterior ridge. The laminæ are wide and composed of lamellæ having round and oval lacunæ with bushy canaliculi. They are separated by irregularly shaped canals which appear fragmentary in the section. In some situations the canals are branching and arranged in plexus form. The laminæ are frequently interrupted by Haversian canals of the (Ta) differentiation. 
The central ring is composed of Haversian systems of the (Ib) differentiation. Their lacune are generally oval or round, in a few places long and narrow, and are at some distance from the Haversian canals. Their canaliculi are long. The rings break through the external circumferential laminæ at the inner ridge and form the whole width of the ridge, from the internal circumferential lamella to the external surface. The internal circumferential lamellæ of the different widths surround the medullary canal and in some places form cancellous structure. Their lacunæ are long, narrow, and well developed.

Type II-III, Ia, Ib.

RIGITT FEMUR OF HAPLODONTIA OLYMPICA. SEWELLEL, MOUNTAIN BEAVER, OR FARMER PL. 20, Fig. 29\%. SYN. TAB. VII

Intero-posterior diameter of bone, $5.5 \mathrm{~mm}$.; lateral, $4 \mathrm{~mm}$.

Antero-posterior diameter of medullary canal, $3 \mathrm{~mm}$.; lateral, $1.5 \mathrm{~mm}$.

The medullary canal is full. Medullary index, $26 \%$.

Structure.-The section is composed of a confusing mixture of lamellæ, laminæ, and Haversian systems of various differentiations. A narrow ring of lamellæ and crude Haversian systems surrounds the bone. The central ring is composed of crude Haversian systems, following no definite plan of arrangement and representing no definite state of development. The ring is crossed obliquely by a few laminæ and separated into two parts by concentric lamellæ. The internal circumferential lamellæ are incomplete.

Type I-II-III, Ia, Ib.

LEFT FEMUR OF ERETHIZON. PORCUPINE. CR. MED. COLL.

PL. 20, Fig. 298. Syn. Tab. VII

Antero-posterior diameter of bone, $9.5 \mathrm{~mm}$. ; lateral, $7.5 \mathrm{~mm}$.

Antero-posterior diameter of medullary canal, $3 \mathrm{~mm}$. ; lateral, $2.5 \mathrm{~mm}$.

The medullary canal is full. Medullary index, $12 \%$.

Structure.-With the exception of the posterior wall the section is surlounded by a narrow band of external circumferential lamellæ. The posterior wall is composed of crude Haversian systems and inter-Haversian bone substance with oval lacunæ and bushy canaliculi.

The central ring is composed of Haversian systems and inter-Haversian bone substance with oval lacunæ and bushy canaliculi.

Internal circumferential lamellæ, crossed by many radiating canals and interrupted by Haversian systems of the (Ia) and (Ib) differentiation, surround the medullary canal.

Type I-III, Ia, Ib, C. 


\section{MAN}

One hundred and thirty-nine femora were examined.

\section{General Character of the Femur}

The femur of man presents a variety of shapes:

The medullary canals are generaliy full of cancellous bone, the meshes of which are filled with marrow. The medullary surfaces are almost always rough, but in some round sections the surfaces are smooth and cancellous bone is absent.

The average medullary index of the adult is $38.6 \%$. Comparing the average index of man with that of other mammals, which is $63.3 \%$, it will be noticed that the medullary canal is proportionately smaller and the wall of the bone thicker in man than in other mammals, or in bipeds than in quadrupeds.

The following types and combinations of types are found: the third, first and third, second and third, and first, second, and third. The third type oceurs in the (Ta), (Ib), and (C) forms of differentiation. The pure third type bone without senile changes is rather infrequent. The lumman series consists of the fetal, infantile, adolescent, and adult femora. The fetal series includes the white and black races; the infantile, the yellow-brown, ancient Egyptian, and modern white races; the adolescent, the yellow-brown, ancient Egyptian, and white races; and the adult, all races.

\section{Fetal Humay Femora}

Seven femora were examined.

In the very young fetus of two to three monthe, hasir home substance is present and is marked off into regular areas by ande, branching canals. As fetal life advances the canals become less branching and more concentric. Grad nally the basic bone becomes lamellated and then develops into the second type and remains so until birth. Throughout childhood and youth the lamina tend to disappear and to be replaced by Haversian systems, until the bone develop ment is completed.

In the formation of lomman fetal temora the following plan was ohserved. A horseshoe-shaped band of lamelle or lamina with oval lar'mae and bushy canaliculi is formed aromd the medullary canal, with the exreption of the posterior ridge which appears to have an independent formation at a later date. As the bone develops the ridge fuses with the lateral wall.

RIGHT FEMUR OE I WIITE FETUS, TWO IND ONE-HALF MONTHS OLD

$$
\text { PL. 21, Fig. 299. Sxx. TAв. TIII }
$$

Antero-posterior diameter of bone, 1.8. ; lateral, $1.5 \mathrm{~mm}$.

Antero-posterior diameter of medullary canal, $0.5 \mathrm{~mm}$.; lateral, $0.4 \mathrm{~mm}$.

The medullary canal is full. Merlullary index, $8 \%$. 
Structure.--The section is amposed of two concentric rings of bone substance, external and internal. The external-much the wider-forms most of the wall of the bone, and is composed of chamelled bone substance with round lacune and relatively few canaliculi. In some portions the elongated meshes assume the character of laminar formation.

The internal circunferential lamellæ with long lacunæ and bushy canaliculi form a narrow ring around the medullary canal.

Trpe I.

RIGHT FEMUR OF A WHITE FETTS, THREE AND ONE-HALF MONTHS OLD.

$$
\begin{aligned}
& \text { No. 89, ('R. MED. COIL. }
\end{aligned}
$$

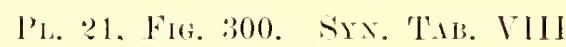

Antero-posterior dianeter of bone, 2..5 mml.; lateral, 2 mm.

Antero-posterior diameter of merlullary canal, $0.5 \mathrm{~mm}$; lateral, $0.5 \mathrm{~mm}$.

The medullary canal is full. Medullary index, $5 \%$.

Structure.-The anterior wall is much thimner than the posterior. The section is composed of bone substance within which are irregularly shaped canals. Between the canals the bone substance, with oval lacune and short, bushy canaliculi, is arranged concentrically around the medullary canal. In some situations the canals with their adjacent lacuna have the formations of Haversian systems of the (Ia) differentiation. The posterior ridge forms the whole posterior wall, and is conposed of bone snbstance with wide canals haring a direction from the external to the medullary surface and presenting the appearance of long canals divided into shorter ones until erude Haversian eanals are formed. The bone substance has oval lacme and busliy canaliculi. The medullary canal is small and concentrically sitnated.

Type II-III, Ia.

RIGHT FEMLR OF A WEITE FETUA, NOUR MONTHS. NU. 90, CR. MED. COLL.

$$
\text { PL. 21, Fig. 301. SYr. TAB. VIII }
$$

Antero-posterior diameter of bone, $3.5 \mathrm{~mm}$. ; lateral, $2.5 \mathrm{~mm}$.

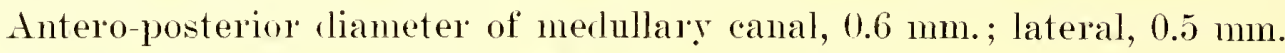

The medullary canal is full. Medullary index, $3 \%$.

Structure.-The anterior wall is much thinner than the posterior. The section is composed of bone substance with oval lacunx and bushy canaliculi, interrupted by wide, irregular canals bent around the medullary canal in the shape of a horseshoe. A few erude, elongated Haversian systems are found in the posterior wall. The posterior ridge is composed of a few undereloped Haversian systems of the $(\mathrm{Ib})$ differentiation and inter-Haversian bone substance with wide canals, extending from the external to the medullary surface. The 
Haversian systems of the ridge are somewhat better developed than in the three months' fetus.

Type II-III, Ib.

RIGHT FEMUR OF A WHITE FETUS, FIVE TO SEVEN MONTIIS. NO. 248045, U. S. NAT. MUS.

$$
\text { PL. 21, Fig. 302. Sin. TAB. VIII }
$$

Antero-posterior diameter of bone, $3.5 \mathrm{~mm}$; lateral, $3 \mathrm{~mm}$.

Antero-posterior diameter of medullary canal, $0.5 \mathrm{~mm}$; lateral, $0.5 \mathrm{~mm}$.

The medullary canal is very small and occupies a very eccentric position. Medullary index, $2 \%$.

Structure.-The section is composed of a wide horseshoe band of long and short lamina arranged around the medullary canal. The toe forms the very narrow anterior wall and the heel embraces the very wide posterior ridge. 'The laminæ have central canals and are composed of lamellæ with oval lacunæ and bushy canaliculi. They widen and shorten as they approach the posterior' ridge and on either side of it they have become Haversian systems of the (Ib) differentiation. The posterior ridge is composed of long' and short spaces surrounded by lamella extending from the external to the medullary surface. The section exhibits the early formation of laminx, the horseshoe arrangement, the formation of Haversian systems, and the later formation of the posterior ridge. Two laminæ with round and oval lacunæ and short bushy canaliculi surround the medullary canal.

Type II-III, Ib.

RIGHT FEMUR OF A WHITE FETUS, EIGHT TO NINE MONTHS. No. 228842,

$$
\text { U. S. NAT. MUS. }
$$

PL. 21, Fig. 303. Syn. TAB. VIII

Antero-posterior diameter of bone, $4.5 \mathrm{~mm}$; lateral, $5 \mathrm{~mm}$.

Antero-posterior diameter of medullary canal, $1 \mathrm{~mm}$; lateral, $1 \mathrm{~mm}$.

The medullary canal is irregular in shape and is situated in the anterior half of the microsection. Nedullary index, $4 \%$.

Structure.-Around the outside of the section-posterior ridge excepted-. is a narrow band of incompletely developed lamella with oval lacuna and short, bushy canaliculi. The remainder of the anterior and lateral wall is composed of a wide, horseshoe-shaped band enclosing the medullary canal. It is composed of long laminæ with central canals gradually shortening and widening as they pass around the lateral wall until they are transformed into oval Haversian systems close to the posterior ridge. 'The posterior ridge is composed of elongated, crude Haversian systems of the (Ib) differentiation, and short laminæ extending from the external to the medullary surface and at right angles to the laminæ of the lateral wall. In the center of the ridge is a narrow space 
where the wall of the bone has united or is about to unite. Many large oval lacunæ are found in the bone substance between the systems. The bone shows the formation of Haversian systems, the filling of the posterior ridge by laminæ at right angles to the lateral walls, and the line of union as the walls fuse together in the posterior ridge. A wide band of lamellæ with oval lacunæ and bushy canaliculi surrounds the medullary canal.

Type II-III, Ib.

RIGHT FEMUR OF AMERICAN NEgRo FETUS, NINE MONTHS. NO. 228801, U. S. NAT. MUS.

PL. 21, FIG. 304. SYN. 'TAB. VIII

Antero-posterior diameter of bone, $4.5 \mathrm{~mm}$; ; lateral, $5.5 \mathrm{~mm}$.

Antero-posterior diameter of medullary canal, $1.5 \mathrm{~mm}$; lateral, $2.5 \mathrm{~mm}$.

The medullary canal is full. Medullary index, $15 \%$.

Structure.-The anterior wall is composed of a few external circumferential lamellæ, which, as they leave the mid-line, soon spread out and enclose elongated, crude Haversian systems of the $(\mathrm{Ib})$ differentiation. The systems, which appear to be laminæ crudely bent around and along' wide, short canals, assume a concentric arrangement and enclose the medullary canal in the form of a horseshoe. The posterior ridge is then formed and fuses with the lateral wall. The lacunæ are oval; the canaliculi are comparatively few and bushy. In the mid-line of the anterior wall the external circumferential lamellæ are distinctly separated from the crude Haversian systems, but this line of separation soon becomes indistinct. The Haversian systems vary in shape and completeness in the different portions of the wall. In the anterior portion they are round or oval, especially just beneath the external circumferential lamellæ where they are most complete. The Haversian canals are relatively wide. The lacunæ of the systems form single concentric rings around the Haversian canals and at some distance from them. They are oval with short, bushy canaliculi. The Haversian systems gradually elongate and become extremely elliptical as they approach the posterior ridge. Here the Haversian canals are long, wide, and generally parallel. They occupy nearly the whole thickness of the posterior wall and extend from the external to the medullary surface. The Haversian canals of the lateral wall are wide, irregular, and long, but are generally parallel with the external surface of the bone. The lacunæ are oval, few, and confined to a single concentric row situated at some distance from the canal. The posterior ridge appears to be formed at a later date than the anterior and lateral walls. The internal circumferential lamellæ with long lacunæ and straight canaliculi are present in the anterior wall, but not elsewhere.

Type II-III, Ib. 
RIGHT FEMUR OF CRANIORRHACHISCHISIS-WIHITE FETUS. NO. 91, CR. MED. COLL.

PL. 21, Fig. 305. SyN. TAB. VIII

Antero-posterior diameter of bone, $6 \mathrm{~mm}$.; lateral, $6 \mathrm{~mm}$.

Antero-posterior diameter of medullary canal, $3 \mathrm{~mm}$.; lateral, $2.5 \mathrm{~mm}$.

The medullary canal is full. Medullary index, $26 \%$.

Structure.-The bone has no distinct divisions. The anterior wall is thinnest; the posterior is thickest. The bone is composed of a wide horseshoe of irregular, concentric laminæ with wide canals surrounding the medullary canal. The laminæ of the posterior ridge with their wide canals shorten, widen, and become crude, elongated Haversian systems, ruming from the external to the medullary surface and at right angles to the laminæ of the lateral wall. The lacunæ are oval and the canaliculi are bushy. The femur is larger than that of the normal fetus of the same age.

Type II-III, Ib.

In the development of human fetal femora some of the Haversian systems appear to be produced by the aberrant method of formation; that is, by the transformation of laminæ into Haversian systems.

\section{MAN-BLACK RACE \\ General Character of the Femur}

The bones vary in shape. The medullary canals are full and cancellous bone is prominent. The medullary surfaces are very much corrugated and irregular in character. The mednllary index varies from $17 \%$ to $92 \%$, with an average of $41.9 \%$. The type of structure ranges from a first and third to a complete third, and the majority are type combinations rather than single types. The first and third and first, second and third are the most frequent combinations. Senile changes are found in many femora. The bone units are incompletely and completely differentiated.

\section{Detalled Examination}

LEFT FEMUR OF NEGRO. NO. 228481, U. S. NAT. MUS.

PL. 21, FIG. 306. SYn. TAB. VIII.

Antero-posterior diameter of bone, $29 \mathrm{~mm}$; lateral, $30 \mathrm{~mm}$.

Antero-posterior diameter of medullary canal, $16 \mathrm{~mm}$.; lateral, $15 \mathrm{~mm}$.

The medullary canal is full. Medullary index, $38 \%$.

Structure.-The external circumferential lamellæ, in fragments, surround the bone. The lacunæ are long and narrow and the canaliculi are straight. 
The central ring, forming nearly the whole thickness of the wall of the bone, is composed of well developed Haversian systems with little or no inter-Haversian lamellx. The horseshoe areas have been displaced entirely by well developed Haversian systems. The internal circumferential lamellæ with long lacunæ and straight canaliculi surround the medullary canal.

Type III, C.

The degree of development of a human femur is proportionate to the degree of displacement of its lamellæ or laminæ by Haversian systems.

FEMUR OF WHITE AND NEgro MIXED, AT LEAST ONE-HALF WHITE.

No. 247368 , U. S. NAT. MUS.

PL. 21, Fig. 30\%. Syn. Tab. VIII

Antero-posterior diameter of bone, $22 \mathrm{~mm}$.; lateral, $27 \mathrm{~mm}$.

Antero-posterior diameter of medullary canal, $12 \mathrm{~mm}$.; lateral, $11 \mathrm{~mm}$.

The medullary canal is full. Medullary index, $30 \%$.

Structure.-The external circumferential lamellw, in fragments, surround the bone. Their lacunx and canaliculi are well developed. There is little evidence of the horseshoe band of lamellæ. The central ring is composed of Haversian systems and forms nearly the whole width of the wall. The systems are of unequal sizes, some are small and other's are large relatively, but generally they are rather small. There is also a corresponding variation in the diameters of the Haversian canals. The lacunæ and canaliculi of the Haversian systems are of the fully developed variety. Many Haversian systems are senile.

The internal circumferential lamellæe with long lacunæ and straight canaliculi surround the medullary canal.

Type III, C, senile.

LEFT FeMUR OF a Negro. NO. 3, Med. DePt. TUlane Univ.

PL. 21, FIg. 308. SyN. TAB. VIII

Antero-posterior diameter of bone, $30 \mathrm{~mm}$.; lateral, $24 \mathrm{~mm}$.

Antero-posterior diameter of medullary canal, $15 \mathrm{~mm}$; lateral, $14 \mathrm{~mm}$.

The medullary canal is full. Medullary index, $41 \%$.

Structure.-External circumferential lamellæ with long lacunæ and straight canaliculi are fragmentary. The central ring forms most of the bone and is composed of Haversian systems of the (C) differentiation. Many show senile changes. A narrow ring of internal circumferential lamella surrounds the medullary canal.

Type III, C, senile. 
LEFT FEMUR OF A NEGRo. NO. 87, MED. DEPT. TULANE UNIV.

PL. 22, Fig. 309. Syn. Tab. VIII

Antero-posterior diameter of bone, $27.5 \mathrm{~mm}$; lateral, $30 \mathrm{~mm}$.

Antero-posterior diameter of medullary canal, $17 \mathrm{~mm}$; lateral, $17 \mathrm{~mm}$.

The medullary canal is full. Medullary index, $54 \%$.

Structure.-The external circumferential lamellæ are fragmentary. The central ring is composed of large, small, and irregular Haversian systems, which show marked senile changes. The internal lamellæ form a fragmentary ring around the medullary canal.

Type III, C, senile.

Right FEMUR OF A NEGRo. NO. 7, MEd. DEPt. TULANE UNiV.

PL. 22, Fig. 310. Syn. Tab. VIII

Antero-posterior diameter of bone, $27 \mathrm{~mm}$.; lateral, $30 \mathrm{~mm}$.

Antero-posterior diameter of medullary canal, $19 \mathrm{~mm}$.; lateral, $18 \mathrm{~mm}$.

The medullary canal is full. Medullary index, $74 \%$.

Structure.-The external lamellæ are fragmentary. The central ring is composed of Haversian systems with few senile changes. The internal lamellæ form a narrow ring around the medullary canal.

Type III, C, senile.

LEFT FEMUR OF A NEGRo. No. 4, MED. DEPT. TULANE UNIV.

Pu. 22, Fig. 311. Syn. Tab. VIII

Antero-posterior diameter of bone, $30 \mathrm{~mm}$; lateral, $23 \mathrm{~mm}$.

Antero-posterior diameter of medullary canal, $21 \mathrm{~mm}$.; lateral, $13 \mathrm{~mm}$.

The medullary canal is full. Medullary index, $65 \%$.

Structure.-The external circumferential lamellæ form a narrow enclosing ring, excepting in the posterior ridge where it is absent. The central ring forms most of the section and is composed of regular, well developed Haversian systems, excepting in the immer wall where the systems are much elongated.

The internal circumferential lamellæ are fragmentary.

Type III, C.

LEFT FEMUR OF A NEGRo. NO. 84, MED. DEPT. TULANE UNIV.

PL. 22, FIG. 312. SYn. TAB. VIII

Antero-posterior diameter of bone, $24 \mathrm{~mm}$; lateral, $25 \mathrm{~mm}$.

Antero-posterior diameter of medullary canal, $15 \mathrm{~mm}$; lateral, $13 \mathrm{~mm}$.

The medullary canal is full. Medullary index, $48 \%$. 
Structure.-The external circumferential lamellæ are fragmentary. The central ring is composed of well developed Haversian systems. A narrow ring of internal circumferential lamellæ surrounds the medullary canal.

Type III, C.

LEFT FEMUR OF A NEGRo. NO. 10, MED. DEPT. TULANE UNIV.

PL. 22, FIG. 313. SYN. TAB. VIII

Antero-posterior diameter of bone, $26 \mathrm{~mm}$; lateral, $29 \mathrm{~mm}$.

Antero-posterior diameter of medullary canal, $14 \mathrm{~mm}$; lateral, $15 \mathrm{~mm}$.

The medullary canal is full. Medullary index, $38 \%$.

Structure.-The section is composed of a wide background of the lamellar horseshoe occupying the lateral wall. The lamella are frequently interrupted by Haversian systems of the (C) differentiation. In the anterior wall the lamellæ are replaced by Haversian systems.

The remainder of the section is composed of well developed Haversian systems. Cancellous bone surrounds the medullary canal.

Type I-III, C.

Right femur of a female Negro. age 40. No. 123, med. Dept. tulane univ.

$$
\text { PL. 22, Fig. 314. Syn. TAB. VIII }
$$

Antero-posterior diameter of bone, $28 \mathrm{~mm}$; lateral, $27 \mathrm{~mm}$.

Antero-posterior diameter of medullary canal, $14 \mathrm{~mm}$; lateral, $11 \mathrm{~mm}$.

The medullary canal is full. Medullary index, $25 \%$.

Structure.-The external circumferential lamellæ appear only in fragments. The central ring, which constitutes most of the bone, is composed of Haversian systems, many of which are senile. The internal circumferential lamellæ form a narrow ring around the medullary canal. The lacunæ of all units are oval and long and the canaliculi are straight.

Type III, C, senile.

LEFT FEMUR OF A NEGRo. AGE 40. NO. 79, MED. DEPT. TULANE UNIV.

$$
\text { PL. 22, Fig. 315. SYN. TAB. VIII }
$$

Antero-posterior diameter of bone, $30.5 \mathrm{~mm}$; lateral, $26.5 \mathrm{~mm}$.

Antero-posterior diameter of medullary canal, $17 \mathrm{~mm}$; lateral, $15 \mathrm{~mm}$.

The medullary canal is full. Medullary index, $46 \%$.

Structure.-The external circumferential lamellæ appear only in fragments. The central ring forms most of the section and is composed of Haversian systems. Around the medullary region nearly half of the wall of the bone is composed of Haversian systems in an extremely senile condition. The systems of 
the peripheral portion are in pretty good condition, although senile changes are present to some extent.

The internal circumferential lamellæ form a narrow ring around the medullary canal.

Type III, C, senile.

IEFT FEMUR OF A NEGRO. NO. 224714, U. S. NAT. MUS.

Pu. 22, Fig. 316. Syn. TAB. VIII

Antero-posterior diameter of bone, $34 \mathrm{~mm}$. lateral, $36 \mathrm{~mm}$.

Antero-posterior diameter of medullary canal, $21 \mathrm{~mm}$.; lateral, $21 \mathrm{~mm}$.

The medullary canal is full. Medullary index, $56 \%$.

Structure.-Beginning on the inner side of the posterior ridge and extending around the lateral to the anterior wall is one-half of the lamellar horseshoe described in the foregoing femora. The lamellar shoe is studded with many Haversian systems. The central ring is narrow and composed of Haversian systems, many of which are senile. The posterior ridge and adjoining outer wall are composed entirely of Haversian systems. Internal circumferential lamellæ form a narrow ring around the medullary canal.

Type I-III, C, senile.

LEFT FEMUR OF A NEGRo. NO. 11, MED. DEPT. TULANE UNIV.

PL. 22, Fig. 31\%. Syn. TAB. VIII

Antero-posterior diameter of bone, $32 \mathrm{~mm}$. ; lateral, $26.5 \mathrm{~mm}$.

Antero-posterior diameter of medullary canal, $13 \mathrm{~mm}$.; lateral, $12 \mathrm{~mm}$.

The medullary canal is full. Medullary index, $22 \%$.

Structure.-The remains of the lamellar horseshoe band are evident. It is narrow in the outer posterior, widens to one-third the width of the anterior, and extends along the inner wall as a wide band. The band is inter'upted by Haversian systems in the lateral wall and by Haversian canals of the (Ia) differentiation in the anterior wall. The central ring is composed of well developed Haversian systems. The internal lamellæ form a wide ring around the medullary canal.

Type I-III, Ia, C.

RIGHT FEMUR OF A NEGro. NO. 2, MED. DEPT. TUlane UNiv.

Pl. 23, Fig. 318. Syn. Tab. VIII

Antero-posterior diameter of bone, $30 \mathrm{~mm}$; lateral, $29 \mathrm{~mm}$.

Antero-posterior diameter of medullary canal, $16 \mathrm{~mm}$.; lateral, $14 \mathrm{~mm}$.

The medullary canal is full. Medullary index, $36 \%$. 
Structure.-The external circumferential lamellæ are fragmentary. Beginning on the outer side of the posterior ridge and extending around the external half of the outer wall is a wide band of alternating laminæ and Haversian systems. Underneath the band is a central ring of Haversian systems. The anterior, inner, and posterior wall is composed almost entirely of Haversian systems. The internal circumferential lamellæ form a narrow, enclosing ring around the medullary canal.

Type I-II-III, C.

LEFT FEMUR OF A NEGRo. No 56, MED. DEPT. TULANE UNIV.

PL. 23, Fig. 319. Syn. TAB. VIII

Antero-posterior diameter of bone, $27.5 \mathrm{~mm}$; lateral, $27 \mathrm{~mm}$.

Antero-posterior diameter of medullary canal, $16 \mathrm{~mm}$. ; lateral, $14 \mathrm{~mm}$.

The medullary canal is full. Nedullary index, $43 \%$.

Structure.-The external cireumferential lamellæ are fragmentary. The central ring is composed of a wide band of lamellæe with Haversian systems in the outer and anterior wall and of IIaversian systems with some interHaversian lamellæ in the inner and posterior wall. The systems are well developed but senile to a great extent. The internal circumferential lamellæ are fragmentary.

Type I-III, C, senile.

LEFT FEMUR OF A Negress. No. 220, CR. MEd. COLl.

Pl. 23, Fig. 320. Syn. Tab. VIII

Antero-posterior diameter of bone, $30 \mathrm{~mm}$; lateral, $25 \mathrm{~mm}$.

Antero-posterior diameter of medullary canal, $18 \mathrm{~mm}$. lateral, $14 \mathrm{~mm}$.

The medullary canal is full. Medullary index, $50 \%$.

Structure.-A wide circumferential horseshoe band of lamellæ forms the background of the section. It is narrowest in the inner, forms two-thirds of the anterior, and over half of the outer wall. In these situations the lamellæ are to some extent displaced by Haversian systems of the ( Ia) and (C) differentiations. The central ring is narrow and is composed of Haversian systems, many of which are senile. There are relatively few cross canals. The internal circumferential lamellæ form a narrow ring which becomes cancellous.

Type I-III, Ia, C, senile.

Right AMPUtATEd FEMUR OF A NEgREss. NO. 220, CR. MED. COLl.

PL. 23, Fig. 321. Syn. Tab. VIII

The femur is amputated at lower third.

Antero-posterior diameter of bone, $30 \mathrm{~mm}$; lateral, $25 \mathrm{~mm}$. 
Antero-posterior diameter of medullary canal, $24 \mathrm{~mm}$; lateral, $15 \mathrm{~mm}$.

The medullary canal is full. Medullary index, $92 \%$.

Structure.-A wide circumferential horseshoe of lamellæ surrounds the section. It gradually increases in width in the imner and outer, and constitutes nearly the whole of the anterior wall. It is interrupted by Haversian systems of the (Ia) and (C) differentiations. The central ring is composed of Haversian systems of varying sizes. The communicating canals between the systems are few. There seems to be great variation in the different femora in this respect, and their variation affords a possible explanation of senile changes in bone. Near the medullary canal the senility is marked. The Haversian systems here are practically gone. The wall of the bone, including the posterior ridge, is very thin. The internal circumferential lamellæ are fragmentary. The senile changes are much more pronounced than in the left femur and may be the result of disuse.

Type I-III, Ia, C, senile.

$$
\begin{aligned}
& \text { LEFT FEMUR OF A NEgRess. AGE 14. NO. 226, CR. MED. COLL. } \\
& \text { PL. 23, Fig. 322. SYN. TAB. VIII }
\end{aligned}
$$

The mother is white and the father is not a pure black. The child died from the effects of carbolic acid taken for suicidal purposes. The upper third of the femur has a very small medullary canal.

Antero-posterior diameter of bone, $24 \mathrm{~mm}$. ; lateral, $18 \mathrm{~mm}$.

Antero-posterior diameter of medullary canal, $12 \mathrm{~mm}$.; lateral, $9 \mathrm{~mm}$.

The medullary canal is full. Medullary index, $34 \%$.

Structure.-The posterior ridge is thick and composed of irregularly shaped Haversian systems, separated in the circumferential portion by bone substance with round and oval lacunæ and bushy canaliculi. Numerous canals surrounded by clear areas appear. The external circumferential lamellæ form an enclosing ring. The central ring is composed of Haversian systems, which are oval and round in cross-section and separated in places by short laminx. Their lacunæ are generally oval; otherwise the systems are fairly well developed. The internal circumferential lamellæ are fragmentary, excepting in the inner wall where they form a wide crescent. The bone is not quite complete.

Type I-III, C.

FEMUR OF A NEGRo. NO. 1, MED. DEPT. TULANE UNIV.

PL. 23, FIG. 323. SYN. TAB. VIII

Antero-posterior diameter of bone, $23 \mathrm{~mm}$. lateral, $25 \mathrm{~mm}$.

Antero-posterior diameter of medullary canal, $11 \mathrm{~mm}$.; lateral, $10 \mathrm{~mm}$.

The medullary canal is full. Medullary index, $24 \%$. 
Structure.-Beginning on both sides of the posterior ridge and extending around the section is a horseshoe of lamellæ, laminæ, and Haversian systems of the (Ia) and (C) differentiations. The shoe is crossed by frequent canals. Under the horseshoe is a middle ring of well developed Haversian systems which reaches the external surface of the posterior ridge.

Internal circumferential lamellæ form a narrow ring around the medullary canal. The section is nearly half lamellæ.

Type I-II-III, Ia, C.

RIGHT FEMUR OF A KAFFIR NEGRo. NO. 263196, U. S. NAT. MUS.

PL. 23, Fig. 324. Syn. TAB. VIII

Antero-posterior diameter of bone, $27 \mathrm{~mm}$; lateral, $23 \mathrm{~mm}$.

Antero-posterior diameter of medullary canal, $14 \mathrm{~mm}$.; lateral, $11.5 \mathrm{~mm}$.

The medullary canal is partly surrounded by cancellous bone and is full. Medullary index, $32 \%$.

Structure.-The external circumferential lamellæ are fragmentary. Beginning on the outer side of the posterior ridge and extending around the outer lateral wall is a wide external band of elongated Haversian systems in a background of lamellæ. This band, one-half the width of the wall, bends inward toward the internal circumferential lamellæ as it approaches the anterior wall and then merges into the Haversian systems of that wall. In the inner wall is a similar, narrower external band beginning near the posterior ridge, extending around the lateral, widening, curving inward toward the medullary canal, and merging into the Haversian systems of the anterior wall. 'These bands are the remains of the lamellar horseshoe. Their lacunæ are oval and narrow. Underneath these bands is an irregularly shaped ring of well developed Haversian systems forming nearly the whole width of the anterior and posterior wall. They communicate freely by cross canals and their lacunæ are well developed. The internal circumferential lamellæ surround the medullary canal as cancellous bone. In the lateral inner wall they widen and separate into laminæ, which spread toward the external surface and occupy half of the width of the wall in the widest place. The lacunæ are oval and narrow.

Type I-III, C.

RIGHT FEMUR OF A NEGRO. NO. 248674, U. S. NAT. MUS.

PL. 23, FIG. 325. Syn. TAB. VIII

Antero-posterior diameter of bone, $30 \mathrm{~mm}$. ; lateral, $26 \mathrm{~mm}$.

Antero-posterior diameter of medullary canal, $15 \mathrm{~mm}$.; lateral, $12.5 \mathrm{~mm}$.

There is little cancellous bone around the medullary canal. The bone is a little larger than the left femur.

The medullary canal is full. Medullary index, $32 \%$. 
Structure.-The external circumferential lamella are not distinct from the underlying structures. Beginning on both sides of the posterior ridge and extending around the section is a wide horseshoe-shaped band of laminæ and lamellx. The toe of the shoe forms nearly the whole of the anterior wall and the heel nearly one-third of the posterior wall. In the outer lateral wall the heel of the shoe is composed of laminx, separated by canals and crude Haversian systems. The laminx gradually widen and increase in number and bend inwards nearly to the medullary canal as they reach the anterior wall. Here the laminar structure spreads out into a wide band of lamellæ which forms nearly all of the anterior wall. In this band are a great number of crude Haversian systems of the ( $\mathrm{Ia}$ ) differentiation arranged in concentric lines. After leaving the anterior, the lamellæ gradually become narrow until they form about one-third the width of the posterior wall. Underneath the horseshoe band is an irregularly shaped ring of Haversian systems which widens and forms nearly the whole posterior ridge. The systems are often separated by lamellæ. The internal circumferential lamellæ surround the medullary canal and are widest in the outer wall. The lacunæ are oval and narrow.

Type I-II-III, Ia, C.

LEFT FEMUR OF A NEGRO. NO. 248674, U. S. NAT. MUS.

Pu. 24, Fig. 326. Syn. Tab. VIII

Antero-posterior diameter of bone, $29 \mathrm{~mm}$; lateral, $27 \mathrm{~mm}$.

Antero-posterior diameter of medullary canal, $17 \mathrm{~mm}$; lateral, $14 \mathrm{~mm}$.

The medullary canal is full. Medullary index, $42 \%$.

Structure.-Beginning on both sides of the posterior ridge and extending around the external portion of the section is a wide horseshoe-shaped band of laminæ, lamellæ, and Haversian systems. In the outer wall the heel is composed of a wide band of lamellæ, interrupted by a few Haversian systems of the (Ia) differentiation, and in the inner wall of lamina with many systems of the same grade. The lamellar and laminar bands rapidly widen about the midlateral wall and bend inward nearly to the medullary canal as they reach the anterior and form the whole width of the anterior wall, excepting the internal circumferential lamellæ. In the anterior wall the lamellæ form a background which is thickly set with crude Haversian systems of the (Ia) differentiation. Underneath the horseshoe and between it and the medullary canal the following structures are found: In the inner wall short, wide, irregular bands appear, interrupted by Haversian systems, well developed. In the outer wall the systems are much more closely set and better developed. The posterior ridge is composed entirely of systems, well developed. The lacunæ are well developed. 
The internal circumferential lamellæ surround the medullary canal, widest in the outer wall.

Type I-II-III, Ia, C.

Since the lamellar and laminar structures constitute such an important part of the femora of the negro, No. 248674, it was thought best to examine sections of all of the long bones of this negro in order to ascertain, if possible, whether or not the lamellar and laminar structures are accidental or characteristic of all the long bones of that individual. The following long bones have, therefore, been examined: Tibia and fibula, radius and ulna, humerus, clavicle and metatarsal bone of the great toe.

TIBIA OF NEGRO, NO. 248674, U. S. NAT. MUS.

PL. 24, FIG. 32\%. SYN. TAB. VIII

Structure.-Beginning with the inner ridge and extending laterally in both directions is a wide external band of lamellæ and laminæ, interrupted by Haversian systems of the (Ia) differentiation. A wide external band of lamellæ and laminæ also forms the boundary of the outer wall. The anterior and posterior walls are mostly Haversian systems. Underneath the horseshoe is an irregular central ring of Haversian systems, well developed. The internal circumferential lamellæ are arranged in places in the form of cancellous bone. The lacunæ are oval and long and the canaliculi are bushy. The tibia has practically the same type combination as the femur.

Type I-II-III, Ia, C.

FIBULA OF NEGRO, NO. 248674, U. S. NAT. MUS.

PL. 24, Fig. 328. Syn. TAB. VIII

Structure.-A wide lamellar and laminar band, interrupted in places by Haversian systems of the (Ia) and (C) differentiations, surrounds the bone, excepting the anterior wall where the Haversian systems form the circumference. The band is widest in the posterior wall. Underneath the band is an irregular ring of Haversian systems well developed. The lacunæ are oval and long. The internal circumferential lamellæ form the boundary of the medullary canal and are thickest in the posterior wall. The bone shows the same structure as the femur.

Type I-II-III, Ia, C.

ULNA OF NEGRO, NO. 248674, U. S. NAT. MUS.

PL. 24, Fig. 329. Syn. Tab. VIII

Structure.-The section is surrounded-posterior ridge excepted-by a wide horseshoe of lamellæ, interrupted by Haversian systems of the (Ia) and 
(C) differentiation. The central ring is composed of well developed Haversian systems, separated in some places by laminæ. Internal circumferential lamellæ, wide in some places and interrupted by Haversian systems of the (Ia) differentiation, surround the central canal.

Type I-II-III, Ia, C.

RADIUS OF NEGRO, NO. 248674, U. S. NAT. MUS

PL. 24, Fig. 330. Syn. TAB. VIII

Structure.-The section is surrounded by a wide horseshoe band of lamellæ, interrupted by scattering Haversian systems of the ( $\mathrm{Ta}$ ) and (C) differentiations. The central ring, narrow and irregular, is composed of Haversian systems and inter-Haversian lamellæ. The systems are well developed. Internal circumferential lamellæ of varying widths surround the central canal.

Type I-III, Ia, C.

HUMERUS OF NEGRo, No. 248674, U. S. NAT. MUS.

Pl. 24, Fig. 331. Syn. Tab. VIII

Structure.-About half of the section is composed of lamellæ, interrupted by scattering, well developed Haversian systems and Haversian systems of the (Ia) differentiation, and the remaining half of well developed Haversian systems. Internal circumferential lamellæ form a ring of varying widths around the medullary canal.

Type I-III, Ia, C.

CLAVTCLE OF NEGRO, NO. 248674, U. S. NAT. MUS.

PI. 24, Fig. 332. Syn. TAB. VIII

Structure.-The section is about half surrounded by a wide band of lamellæ and laminæ, which alternate with concentric rows of Haversian systems. The remaining half is composed of well developed Haversian systems, separated in some places by short laminæ. External and internal circumferential lamellæ form narrow rings around the bone and central canal.

Type I-II-III, C.

Metatarsal bONE OF the GREat toE. NEGRo, No. 248674, U. S. NAT. MUS.

PL. 24, Fig. 333. Syn. TAb. VIII

Structure.-The inner one-half of the wall of the bone is composed of lamellæ with a few crude Haversian systems of the (Ta) differentiation. The 
outer half is composed of well developed Haversian systems between narrow external and internal circumferential lamellæ.

Type I-III, Ia, C.

Reviewing the long bones of this negro, No. 248674, it may be observed that they all conform to the first and third or first, second, and third types of structure, which types must be considered basic for this individual. .

LEFT FEMUR OF A NEGRO. NO. 224713, U. S. NAT. MUS.

PL. 24, FIG. 33t. Syn. TAB. VIII

Antero-posterior diameter of bone, $35 \mathrm{~mm}$.; lateral, $24 \mathrm{~mm}$.

Antero-posterior diameter of medullary canal, $20 \mathrm{~mm}$; ] lateral, $12 \mathrm{~mm}$.

The medullary canal is full; cancellous bone is prominent in the posterior wall. Medullary index, $40 \%$.

Structure.-The section is surrounded by a more or less fragmentary ring of lamellæ, lamina, and Haversian systems. The ring is wide and broken by Haversian systems of the central ring in the posterior and inner wall. The central ring is composed of wel] developed Haversian systems and inter-Haversian lamellæ. Internal circumferential lamellæ form a narrow ring around the medullary canal.

Type I-II-III, Iá, C.

RIGHT FEMUR OF A NEGRO. NO. 83, MED. DEPT. TULANE UNIV.

$$
\text { Pl. 25, Fig. 335. SYN. TAB. VIII }
$$

Antero-posterior diameter of bone, $30 \mathrm{~mm}$. ; lateral, $25 \mathrm{~mm}$.

Antero-posterior diameter of medullary canal, $12 \mathrm{~mm}$; lateral, $10 \mathrm{~mm}$.

The medullary canal is full. Medullary index, $19 \%$.

Structure.-Beginning on both sides of the posterior ridge and extending around the section is a horseshoe of lamellæ, laminæ, and Haversian systems of the (Ia) and (C) differentiations. It is thin in the outer and thick in the remaining wall. The central ring is irregular and incomplete and composed of well developed Haversian systems with long, narrow lacunæ and straight canaliculi. The internal circumferential lamellæ form a very irregular ring, which, in the outer wall, spreads out into a curved, fan-shaped area of laminæ occupying most of that wall. The leaves of the fan then merge into a wide band of lamellæ, which bends inward to the medullary surface of the anterior wall. The fan encloses several complete Haversian systems and short canals.

Type I-II-III, Ia, C. 
RIGHT FEMUR OF A NEgro. No 6, MED. DEPT. TUlane UNiv.

PL. 25, Fig. 336. Syn. Tab. VIII

Antero-posterior diameter of bone, $33.5 \mathrm{~mm}$; lateral, $27 \mathrm{~mm}$.

Antero-posterior diameter of medullary canal, $13 \mathrm{~mm}$; lateral, $10 \mathrm{~mm}$.

The medullary canal is full. Medullary index, $17 \%$.

Structure.-With the exception of the posterior ridge, the section is surrounded by a band of lamellæ of varying widths, interrupted by Haversian systems of the (Ia) and (C) differentiations. On both sides of the ridge the lamellæ are separated into crude laminæ by short concentric canals. The lamellæ occupy nearly the whole of the anterior wall. The central ring is very irregular and limited to the posterior and inner wall. It is composed of well developed Haversian systems and inter-Haversian lamellæ.

Internal circumferential lamellæ form a very irregular ring around the medullary canal. In the outer wall it expands into a wide semicircular area of laminæ, interrupted by Haversian systems of the (Ia) and (C) differentiations.

Type I-II-III, Ia, C.

RIGHT FEMUR OF A NEgro. NO. 63, MED. NEPT. TUlANE UNIV.

PL. 25, FIg. 33\%. Syn. TAB. VIII

Antero posterior diameter of bone, $32 \mathrm{~mm}$; lateral, $28 \mathrm{~mm}$.

Antero-posterior diameter of medullary canal, $20 \mathrm{~mm}$.; lateral, $14 \mathrm{~mm}$.

The medullary canal is full. Medullary index, $45 \%$.

Structure.-A narrow ring of external circumferential lamellæ surrounds the bone. Beginning on the outer side of the posterior ridge and extending around the outer lateral and anterior wall is a wide band of lamellæ, laminæ, and Haversian systems. After leaving the anterior wall the lamellar band is displaced by Haversian systems and as the posterior wall is approached the lamellar band again appears. These interrupted bands are the remains of the horseshoe. Underneath the band is an incomplete central ring of well developed Haversian systems.

The internal circumferential lamellæ form an enclosing ring around the medullary canal. It is widest in the inner wall.

Type I-II-III, Ia, C.

LEFT FEMUR OF a Negro. No. 5, Med. DePt. TUlane UNiv.

PL. 25, Fig. 338. SYN. TAB. VIII

Antero-posterior diameter of bone, $25 \mathrm{~mm}$.; lateral, $24 \mathrm{~mm}$.

Antero-posterior diameter of medullary canal, $16 \mathrm{~mm}$; lateral, $15 \mathrm{~mm}$.

The medullary canal is full. Medullary index, $67 \%$. 
Structure.-A wide horseshoe band of lamellæ and laminæ, interrupted by Haversian systems of the (Ta) and (C) differentiations, surrounds the section. The band is narrow in the inner wall. The central ring is narrow and irregular and composed of Haversian systems and inter-Haversian lamellæ.

Internal circumferential lamellæ form an irregular ring around the medullary canal. In the inner wall they extend outward in an oblique direction and are separated by canals having the same direction.

Type I-II-III, Ia, C.

Right Femur of a Negro. No. 8, Med. Dept. tulane Univ.

Pu. 25, Fig. 339. Syn. TAB. VIII

Antero-posterior diameter of bone, $27 \mathrm{~mm}$.; lateral, $25 \mathrm{~mm}$.

Antero-posterior diameter of medullary canal, $12.5 \mathrm{~mm}$. lateral, $9 \mathrm{~mm}$.

The bone is small. The medullary canal is full. Medullary index, $20 \%$.

Structure.-On both sides of the posterior ridge are two wide external bands of lamellæ of unequal length. They are interrupted by small, crude Haversian canals of the (Ia) differentiation. The band of the inner increases in width as it reaches the anterior wall where it forms nearly the whole wall. It is then displaced by Haversian systems. The band of the outer wall is much shorter and is displaced by Haversian systems about the middle of the wall. The lacunæ are generally long. The Haversian systems of the section occupy irregularly shaped areas. The internal circumferential lamellæ form a wide ring around the medullary canal and it is crossed by frequent canals.

Type I-III, Ia, C.

LEFT FEMUR OF A NEGRO. NO. 7, MED. DEPT. TULANE UNIV.

PL. 25, FIg. 340. SYN, 'ТАв. IX

Antero-posterior diameter of bone, $30 \mathrm{~mm}$; lateral, $26 \mathrm{~mm}$.

Antero-posterior diameter of medullary canal, $17 \mathrm{~mm}$. ; lateral, $15 \mathrm{~mm}$.

The medullary canal is full. Medullary index, $50 \%$.

Structure.-The external circumferential lamellæ are fragmentary. The central ring constitutes practically the whole bone, and is composed of Haversian systems which show extensive senility. Around the medullary canal many systems have entirely disappeared, leaving irregularly shaped spaces.

The internal circumferential lamellæ form a narrow ring around the medullary canal.

Type III, C, senile. 


\title{
XIII. MAN-YELLOW-BROWN RACE
}

\author{
General Character of the Femur
}

With one exception the femora of the yellow-brown race are pre-Columbian. The series includes infantile, adolescent, and adult bones from the Pueblo, Chicama, and Pachacamac Indians.

The general shape of these femora is nearer circular than it is in the black or white races. The medullary canals were filled with marrow and cancellous bone. The medullary surfaces are irregular and corrugated. The medullary index varies from $19 \%$ to $100 \%$, with an average of $43.8 \%$.

Nearly all of the femora are composed of type combinations. The proportion of first type units is larger than it is in other races.

\section{Detailed Fxamination}

RIGHT FEMUR OF A PUEBLO INDIAN CHILD, ONE YEAR OLD. NO. 258675(z), U. S. NAT. MUUS.

PL. 25, Fig. 341. Syn. TAB. IX

Antero-posterior diameter of bone, $8 \mathrm{~mm}$; lateral, $7.5 \mathrm{~mm}$.

Antero-posterior diameter of medullary canal, $4.5 \mathrm{~mm}$.; lateral, $4 \mathrm{~mm}$.

The medullary eanal is full. Medullary index, $43 \%$.

Structure-Around the external portion of the section is a horseshoeshaped band of crude Haversian systems in various stages of differentiation. Some are round, some elongated, and many are irregular in shape. Their Haversian canals of the (Ib) differentiation are relatively large and surrounder by lamellæ with oval larmme and rather infrequent "analiculi. The toe of the shoe is hest developed and widest.

Underneath the Haversian band is a wider horseshoe band, forming the remainder of the section, and composed of lamina, between which are concentric canals. In the anterior and outer wall the laminae are assuming the shape of very much elongated Haversian systems. The posterior ridge is composed of crude, elongated Haversian systems, which extend from the external to the medullary surface and at right angles to the lamine of the lateral wall. The systems have wide Haversian canals, surrounded by lamellie with oval lacunæ and bushy canaliculi. A large vascular canal is seen in the imner posterior wall.

The internal circumferential lamellæ surround the medullary canal in the form of cancellous bone.

Type II-III, Ib. 
RIGHT FEMUR OF A PUEBLO 1NDIAN CHILD, SIX YEARS OLD. NO. 258675(I/),

$$
\text { U. S. NAT. MUS. }
$$

PL. 25, Fig. 342. Syn. 'Taв. IX

Antero-posterior diameter of bone, $12 \mathrm{~mm}$; lateral, $10.5 \mathrm{~mm}$.

Antero-posterior diameter of medullary canal, $8 \mathrm{~mm}$. ; lateral, $6 \mathrm{~mm}$.

The medullary canal is full. Medullary index, $61 \%$.

Structure.-Beginning on both sides of the posterior ridge and extending around the section is a lorseshoe-shaped band of laminæ and lamellæ, interrupted by Haversian systems of the (Ia) differentiation. In the inner wall the band is composed of laminæ, separated by rather short, wide canals. 'The lamine gradually merge into a narrow band of lamellæ as they pass around the inner lateral into the anterior wall. The band of lamella then widens in the outer wall and separates into laminæ, which form the whole width of the wall just before reaching the posterior ridge. The lacunæ are oval.

Underneath this band is a central ring of large, small, and irregularly shaped Haversian systems with inter-Haversian lamellæ. Many large canals occur which are irregular in shape and surrounded by clear areas of bone substance with few oval lacunæ. The systems communicate by canals which, in some portions, assume the form of a network. The ring reaches the external surface of the posterior ridge.

The internal circumferential lamellæ surround the medullary canal, excepting in the outer posterior wall where the systems form the border of the canal.

Type I-II-III, Ia, C.

LEFT FEMUR OF A PUEBLO INIIAN, TWELVE IEARS OLD. NO. 258675(S2),

$$
\text { U. S. NAT. MUS. }
$$

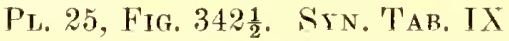

Antero-posterior diameter of hone, $17 \mathrm{~mm}$. ; lateral, $16 \mathrm{~mm}$.

Antero-posterior diameter of medullary canal, $9 \mathrm{~mm}$.; lateral, $9 \mathrm{~mm}$.

The medullary canal is full. Medullary index, $42 \%$.

Structure.-Around the outside of the section is a horseshoe-shaped band of lamellæ, separated into fragmentary laminæ by short concentric canals. The toe of the shoe is the widest part of the band and the heel of the inner is wider than that of the outer wall. The band is frequently interrupted by spaces of various sizes and shapes, the significance of which is not clear, and by Haversian systems of the (Ia) differentiation. The spaces are generally visible to the naked eye, and some of them are surrounded by clear areas crossed by a few canaliculi.

Underneath the horseshoe band is a central ring of incomplete Haversian systems with intervening lamellw. The ring is also frequently interrupted 
by spaces similar to those mentioned above. The systems are round, oval, and irregular in shape with oval lacme and straight canaliculi. They communicate by cross canals. The posterior ridge is nearly all Haversian systems.

A ring of internal circumferential lamellæ of varying widtlis surrounds the medullary canal. In the lateral wall it spreads out into a fan-shaped area, which occnpies abont half the wall and is interrupted by a few canals.

Type I-II-III, Ia, C.

FEMUR OF a PUEBlo INDIAN, NO. $258675(\mathrm{x})$, U. S. NAT. MUS.

PL. 26, Fig. 343. Syn. TAB. IX

Antero-posterior diameter of bone, $20 \mathrm{~mm}$. lateral, $20 \mathrm{~mm}$.

Antero-posterior diameter of medullary canal, $8 \mathrm{~mm}$.; lateral, $9 \mathrm{~mm}$.

'The medullary canal is full. Medullary index, $22 \%$.

Structure.-The posterior ridge, not prominent, is composed of Haversian systems which are well developed. Beginning on both sides of the ridge and extending completely around the bone is a wide horseshoe of lamellæ, separating in places into laminæ, which are interrupted by Haversian systems of the (Ia) differentiation. The horseshoe varies in thickness. The toe constitutes two-thirds the width of the anterior wall, while the heel is considerably narrower. In the anterior wall the lamellæ are very frequently interrupted by elongated Haversian systems arranged concentrically. These systems are crnde and of a low development.

Underneath the lamellar horseshoe is a central ring of complete Haversian systems. They are well developed with long, narrow lacunæ and straight canalicnli. Internal circumferential lamelle enclose the medullary canal. In the posterior wall they form a wide band. In other situations they are reduced to a narrow ring.

'Type I-II-III, la, C.

RIGHT FEMUR OE A PUEBL, INDJAN, ADULT, NO. 227339, U. S. NAT. MUS.

P'L. 26, FiG. 344. Syn. 'T'AB. IX

Antero-posterior diameter of bone, $25 \mathrm{~mm}$; lateral, $2.3 \mathrm{~mm}$.

Antero-posterior diameter of medullary canal, $14 \mathrm{~mm}$.; lateral, $11 \mathrm{~mm}$.

The medullary canal is full. Medullary index, $37 \%$.

Structure.-The external circumferential lamellie appear in scattered fragments around the section, and whole or half Haversian systems occupy the intervals between the fragments. The lacunæ are oval and long. A thick central ring of Haversian systems forms the chief part of the wall of the bone. The systems are well developed, their lacunæ are long and narrow. Extending across the prominence of the inner wall and forming its external boundary the Haversian systems are somewhat elongated and arranged in a direction parallel 
with the external surface of the bone. The internal circumferential lamellæ surround the medullary canal. Their lacune are long.

Type III, C.

LEFT FEMUR OF A PERUVIAN INDIAN. No. 266469(b), U. S. NAT. MUS.

Pl. 26, Fig. 345. Syn. TAв. IX

Antero-posterior diameter of bone, $27 \mathrm{~mm}$.; lateral, $31 \mathrm{~mm}$.

Antero-posterior diameter of medullary canal, $21 \mathrm{~mm}$; lateral, $19 \mathrm{~mm}$.

The medullary canal is full. Medullary index, $91 \%$.

Structure.-The section is surrounded by a narrow ring of external lamellæ. The inner wall is extended in the form of a ridge and is composed of lamine parallel with the ridge surface. The laminæ are perforated by irregularly shaped spaces. The central ring is wide and composed of well developed Haversian systems, many of which are senile, especially those of the outer wall.

The internal circumferential lamellæ form an irregular ring around the medullary canal. In some places the lamellæ are indistinctly separated into laminæ.

Type I-II-III, C, senile.

Left femur of a PerUVian indian. No. 266469(a), U. S. Nat. MUS.

Pl. 26, Fig. 346. SYN. TAB. IX

Antero-posterior diameter of bone, $22 \mathrm{~mm}$; lateral, $27 \mathrm{~mm}$.

Antero-posterior diameter of medullary eanal, $13 \mathrm{~mm}$.; lateral, $12 \mathrm{~mm}$.

The posterior ridge is small, while a very prominent heavy ridge occurs in the inner wall. This gives to the bone a peculiar shape.

The medullary canal is full. Medullary index, $36 \%$.

Structure.-The external circumferential lamellæ are fragmentary. 'The section is composed almost entirely of well developed Haversian systems with some inter-Haversian lamellæ.

The internal circumferential lamella are fragmentary.

Type III, C.

Left femur of a chicama indian. No 2, U. S. nat. mus.

Pl. 26, Fig. 34\%. Syn. T'AB. IX

Antero-posterior diameter of bone, $31 \mathrm{~mm}$; lateral, $30 \mathrm{~mm}$.

Antero-posterior diameter of medullary canal, $13 \mathrm{~mm}$.; lateral, $13 \mathrm{~mm}$.

The walls of the bone are thick. Medullary index, $22 \%$.

Structure.-A wide horseshoe of lamellæ, interrupted by Haversian systems of the (Ia) differentiation surrounds the section. The central ring, composed of large, small, and irregularly shaped Haversian systems, constitutes nearly 
all of the bone. $A$ few senile systems appear. In the outer posterior wall elongated systems occur. The Haversian systems generally are separated by short lamellæ with oval lacunæ. The internal cireumferential lamellæ, of varying widths and irregularities, crossed by radiating canals and interrupted by Haversian systems, surround the medullary canal.

Type I-III, Ia, C.

Right femur of a Chicama Valtey indtan of peru. No. 3, U. S. nat, mus.

$$
\text { Pu. 26, Fig. 348. Syn. Tab. IX }
$$

Antero-posterior diameter of bone, $27 \mathrm{~mm}$; lateral, $25 \mathrm{~mm}$.

Antero-posterior diameter of medullary canal, $16 \mathrm{~mm}$. ; lateral, $11 \mathrm{~mm}$.

Medullary index, $35 \%$.

Structure.-The external circumferential lamellæ are incomplete. The central ring constitutes most all of the section and is composed of large, small, and irregularly shaped Haversian systems, between which are some inter-Haversian lamellæ with oval lacunx. The lamellie are most prominent in the anterior wall, and here the systems are somewhat elongated in cross-section.

The internal circumferential lamella are fragmentary.

Type I-IIT, C.

RIGHT FEMUR OF A CHICAMA INDIAN. NO. 1, U. S. NAT. MUS.

PL. 26, Fig. 349. Syn. 'T'Ab. IX

Antero-posterior diameter of bone, $26.5 \mathrm{~mm}$.; lateral, $31 \mathrm{~mm}$.

Antero-posterior diameter of medullary canal, $11 \mathrm{~mm}$. ; lateral, $16 \mathrm{~mm}$.

Medullary index, $27 \%$.

Structure.-The external circumferential lamellæ are fragmentary. The central ring constitutes nearly all of the section and is composed of Haversian systems, large, small, and irregular. In the outer wall they have a more or less elongated shape arranged concentrically and separated hy short lamella with oval lacunæ.

The posterior ridge is composed of Haversian systems with inter-Haversian bone substance and oval lacunæ.

A ring of internal circmmferential lamelle surrounds the medullary anal.

Type III, C.

$$
\begin{aligned}
& \text { LEFT FEMUR OF A (IHICAMA INDTAN. NU. 4, U. S. NAT. MUS. } \\
& \text { PL. 26, FIG. 350. NYN. 'TAB. IX }
\end{aligned}
$$

Antero-posterior diameter of bone, $30 \mathrm{~mm}$. lateral, $28 \mathrm{~mm}$.

Antero-posterior diameter of medullary canal, $18 \mathrm{~mm}$; ; lateral, $16 \mathrm{~mm}$.

Medullary index, 52\%. 
Structure-Beginning on the outer side of the posterior ridge is a wide band of lamelle in which are many Haversian systems. The band occupies about one-half of the wall and is gradually displaced by Haversian systems in the anterior wall. In the inner wall the continuation of the band is indicated by concentric rows of elongated systems. Underneath the band is a central ring of Haversian systems with senile changes. Many canals extend in all directions in the two bands. The two bands taken together are the remains of the horseshoe of lamellæ so often present in the lower types of bone. The posterior ridge is composed of sinall, irlegularly shaped Haversian systems with inter-Haversian lamellæ.

A narrow band of internal circumferential lamellæ surrounds the medullary canal.

Type I-III, C, senile.

LEFT FEMUR OF AN ADOLESCENT CHICAMA INDIAN. NO. 7, U. S. NAT. MUS.

PL. 27, Fig. 351. Sin. TAB. IX

Antero-posterior diameter of bone, $18.5 \mathrm{~mm}$; lateral, $19 \mathrm{~mm}$.

Antero-posterior diameter of medullary canal, $10.5 \mathrm{~mm}$.; lateral, $9 \mathrm{~mm}$.

Medullary index, $37 \%$.

Structure.-The external circumferential lamella, interrupted by Haversian systems surround the section. The central ring is composed of lamellæ and Haversian systems. In the anterior wall the toe of the shoe is for the most part displaced by Haversian systems. A wide ring of internal circumferential lamellæ surrounds the medullary canal. In the inner wall the lamellæ become lamina. The posterior ridge is composed of elongated Haversian systems.

Type I-II-III, C.

* LefF femur of a chicama indian. No. 9, U. S. nat. mus. ${ }^{1}$

SYN. TAB. IX

Antero-posterior diameter of bone, $22 \mathrm{~mm}$; lateral, $23.5 \mathrm{~mm}$.

Antero-posterior diameter of medullary canal, $11 \mathrm{~mm}$; lateral, $11 \mathrm{~mm}$.

Medullary index, $30 \%$.

Structure.-A horseshoe of lamellæ, laminæ, and crnde Haversian systems surrounds the section. The toe of the shoe is narrow and the heel wide.

The central ring is wide and composed of small and large irregularly shaped Haversian systems with short inter-Haversian lamellæ, numerous canals, and spaces.

${ }^{1}$ The femora marked (*) have been described, but not drawn. 
The internal circumferential lamella enclose the medullary canal. It is a fairly wide band in the lateral walls. The lacunæ of the section are generally oval.

Type I-II-III, Ia, C.

* right femur of an adulte pachacamac indian. no. 14, u. s. nat. mus.

SYN. T'AB. IX

Antero-posterior diameter of bone, $24 \mathrm{~mm}$.; lateral, $21 \mathrm{~mm}$.

Antero-posterior diameter of medullary canal, $14 \mathrm{~mm}$.; lateral, $10 \mathrm{~mm}$.

Medullary index, $38 \%$.

Structure.-Slight evidences of the horseshoe band are present. The lamellæ are most pronounced in the anterior wall where they form a fairly wide band. In the lateral wall the lamellæ are separated into lamine, between which are small Haversian systems of the (Ia) differentiation.

The central ring is composed of Haversian systems. In the outer and inner wall inter-Haversian lamellæ are present. The internal circumferential lamellæ enclose the medullary canal. In the outer wall they expand into a wide crescent, which is broken into irregularly shaped fragments by interrupting Haversian systems. The lacune are long, narrow, and oval.

Type I-II-III, Ia, C.

* right lemur of a pachacamac indian. no. 13, u. s. nat. mus.

$$
\text { Syn. TAB. IX }
$$

Antero-posterior diameter of bone, $16 \mathrm{~mm}$. ; lateral, $15 \mathrm{~mm}$.

Antero-posterior diameter of mednllary canal, $8 \mathrm{~mm}$.; lateral, $7 \mathrm{~mm}$.

Medullary index, $30 \%$.

Structure.-The section is surrounded, with the exception of the posterior ridge, by a horseshoe band of lamina in the outer and anterior wall and of Haversian systems of the (Ia) differentiation in the imner wall. The lamina are frequently perforated hy small anals and in the anterior wall they suddenly widen and ocempy the whole wall. As they approach the inner wall they bend around the immer anterior angle and are then displaced by very arude Haversian systems.

The central ring is reduced to a creseent in the outer wall. It is romposer of crude Haversian systems and lamellar.

The posterior ridge is not distingmishable from the lateral wall and consists of Haversian systems and short lamine having a direction parallel with the external surface. 
The internal circumferential lamellæ surround the medullary canal. They expand in both lateral walls into two wide crescents composed of wide lamellar bands and crossed by numerous canals from the medullary surfaces. The lacunæ of all parts are oval.

Type II-III, Ia, C.

* Left femur of an adolescent pachacamac 1ndan. no. 8, U. S. Nat. mus.

SyN. T'AB. IX

Antero-posterior diameter of bone, $22.5 \mathrm{~mm}$; lateral, $18 \mathrm{~mm}$.

Antero-posterior diameter of medullary canal, $9 \mathrm{~mm}$.; lateral, $7 \mathrm{~mm}$.

Medullary index, $19 \%$.

Structure.-The remains of the external horseshoe of lamellæ are evident. In this section the lamellæ are separated into laminæ which are interrupted by frequent Haversian systems.

The central ring is wide and composed of well developed Haversian systems with very little inter-Haversian lamellæ. There are many canals running in various directions.

A narrow ring of internal circumferential lanella encloses the medullary canal. The lacunæ are oval and round.

Type II-III, C.

* Right femur of a PaChacamaC indian Child. No. 11, U. S. NAT. MUS. Syn. Tab. IX

Antero-posterior diameter of bone, $10 \mathrm{~mm}$; lateral, $9 \mathrm{~mm}$.

Antero-posterior diameter of medullary canal, $7 \mathrm{~mm}$.; lateral, $6.5 \mathrm{~mm}$.

Medullary index, $100 \%$.

Structure.-The section is composed of lamellæ and laminæ in the form of a horseshoe embracing the posterior ridge. The shoe is crossed by canals and interrupted by Haversian systems which are developing from the vascular canals. The lacune are oval and round. The posterior ridge is composed of developing Haversian systems, between which are coarse canaliculi and large, round lacunæ embedded in bone substance. The ridge is distinctly marked off from the enclosing laminæ.

Type II-III, Ia, Ib.

LEFT FEMUR OF A PACHACAMAC INDIAN CHU.D. NO. 12, U. S. NAT. MUS.

PL. 27, Fig. 35\%. SYN. 'T'AB. IX

Antero-posterior diameter of bone, $10 \mathrm{~mm}$.; lateral, $12.5 \mathrm{~mm}$.

Antero-posterior diameter of medullary canal, $7 \mathrm{~mm}$; lateral, $7.5 \mathrm{~mm}$.

Medullary index, $72 \%$. 
Structure.-With the exception of the posterior ridge the section is surrounded by a band of laminæ and Haversian systems. In the outer wall the laminæ are perforated by small longitudinal canals.

The central ring forms nearly all of the imner wall and little or none of the outer wall. It is composed of crude Haversian systems. The systems are irregular in shape with oval lacunæ.

The posterior ridge has blended with the lateral walls and is composed of crude Haversian systems. The lacume are oval.

The internal circumferential lamellæ enclose the medullary canal.

Type II-III, Ib.

* right femur of an adult pachacamac indian. No. 10, u. S. nat. mus.

$$
\text { Srn. TAB. IX }
$$

Antero-posterior diameter of bone, $21.5 \mathrm{~mm}$; lateral, $20 \mathrm{~mm}$.

Antero-posterior diameter of medullary canal, $10.5 \mathrm{~mm}$.; lateral, $8.5 \mathrm{~mm}$.

Medullary index, 23\%.

Structure.-The horseshoe band around the section is evident. It is composed of a lamellar background, most pronounced in the inner and anterior wall, interrupted by numerous irregularly shaped Haversian systems.

The central ring is composed of Haversian systems.

The medullary canal is enclosed by internal circumferential lamellæ which expand into a crescent in the inner wall. It is crossed by radiating canals and interrupted by scattering Haversian systems. The lacunæ are oval.

Type I-III, Ia, C.

* Ieft femur of a PaChacamac indian. No. 5, U. S. Nat. mus.

Syn. TAB. IX

Antero-posterior diameter of bone, $20 \mathrm{~mm}$; lateral, $21 \mathrm{~mm}$.

Antero-posterior diameter of merhllary canal, $11 \mathrm{~mm}$.; lateral, $9 \mathrm{~mm}$.

Medullary index, $31 \%$.

The bone is adolescent.

Structure.-The section is surromnted by external circumferential lamella. Many canals enter the section from the external surfare. Here and there an Haversian system appears. The lacmire are oval and romnl.

The central ring is composed of short lamellax and irregularly shaped Haversian systems which are still undeveloped. Their lacunir are oral and round. 
The internal circumferential lamellæ surround the medullary canal. In the outer wall the lamellæ take the form of a crescent which occupies half of the width of the wall. Near the anterior wall the lamellæ of the erescent cross the medullary canal as a narrow band. The crescent is interrupted by a few Haversian systems. The lacunæ are long and narrow.

Type I-III, Ia, C.

RIGHT FEMUR OF A PACHACAMAC INDIAN, NO. 15, U. S. NAT. MUS.

PL. 2\%, Fig. 360. Syn. TAB. IX

Antero-posterior diameter of bone, $24 \mathrm{~mm}$; lateral, $20 \mathrm{~mm}$.

Antero-posterior diameter of medullary canal, $12 \mathrm{~mm}$; lateral, $9 \mathrm{~mm}$.

Medullary index, $27 \%$.

Structure.-The section is surrounded, with the exception of the posterior ridge, by a horseshoe of lamella and Haversian systems of the (Ia) and (C) differentiations. The shoe becomes narrowest at the junction of the anterior and outer wall where it is displaced by a wide expansion of the internal lamellæ.

The central ring, irregular in width, is composed of Haversian systems and inter-Haversian lamellæ.

The internal circumferential lamellæ form a wide, irregular ring around the medullary canal.

In the outer wall it expands into a wide crescent composed of lamellæ indistinctly separated into lamine.

The lacunæ are oval.

Type I-III, Ia, C.

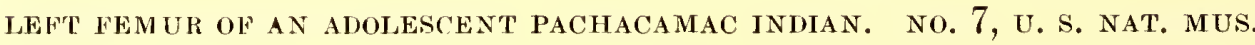

Pl. 2\%, Fig. 361. Syn. 'TAB. IX

Antero-posterior diameter of bone, $20.5 \mathrm{~mm}$.; lateral, $18.5 \mathrm{~mm}$.

Antero-posterior diameter of medullary canal, $9 \mathrm{~mm}$.; lateral, $7 \mathrm{~mm}$.

The bone is adolescent. Medullary index, 20\%.

Structure.-The section is surrounded by external circumferential lamellæ, which are very frequently interrupted by small, rrude Haversian systems. In the posterior ridge the lamellæ are deficient.

The central ring is wide and composed of irregularly shaped Haversian systems, cross canals, and short inter-Haversian lamellæ with oval lacunæ. The internal eircunferential lamellæ enclose the medullary canal. In the outer wall they assume the form of a erescent and are erossed by frequent radiating canals.

Type I-III, C. 
RIGHT FEMUR OF A JAPANESE MALE. NO. 245, CR. MED. COLL.

Pe. 27, Fig. 36\%. Syn. TAB. IX

Antero-posterior diameter of bone, $30 \mathrm{~mm}$; lateral, $30 \mathrm{~mm}$.

Antero-posterior diameter of medullary canal, $20 \mathrm{~mm}$. ; lateral, $18 \mathrm{~mm}$.

The medullary canal is full. Medullary index, $65 \%$.

Structure.-The external circumferential lamellæ form an enclosing ring of various widths. It is widest in the anterior and inner wall, and is interrupted by Haversian canals of the (Ia) differentiation. The central ring is composed of Haversian systems, large and small, interrupted by irregularly shaped areas of lamellæ. Numerous vascular canals occur, and some senile systems appear. The internal circumferential lamellæ form a fragmentary ring around the medullary canal.

Type I-III, Ia, C, senile.

\section{MAN-ANCIENT EGYPTIAN}

Nine femora were examined.

\section{General Character of the Femur}

The Egrptian femora were taken from the cemeteries of Egypt of the Twelfth Dynasty (2000 B. C.). The series includes the femora of the child, adolescent, and adult.

The femora are rather small in size and variable in shape.

The medullary surface is less corrugated than it is in modern white bones.

The medullary index varies from $27 \%$ to $111 \%$, with an average of $39.5 \%$.

The type varies from a third to a second and third, or first and third, depending upon the age in years. The femur of a child about one year old shows the formation of Haversian systems directly from the circulation. It is the only fenmr examined which shows such an origin (figs. 363 and 363a, pl. 27). This formation of the Haversian system is especially interesting.

Detalled Fixamination

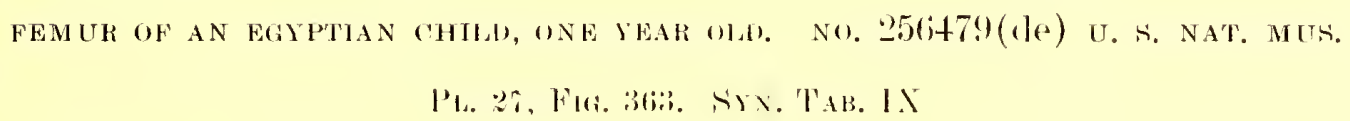

Antero-posterior dianteter of hone, 9 $\mathrm{mm}$; ; lateral, $11.5 \mathrm{~mm}$.

Antero-posterior diameter of medullary camal, $7 \mathrm{~mm}$; ; lateral, $8 \mathrm{~mm}$.

The medullary anal is full. Medullary intex, $111 \%$.

Structure.-The section shows three concentrice, parallel grroups of blood vessels. One group is near the external surface (fig. 363D), a second ocenpies 
the middle of the wall (fig. $363 \mathrm{E}$ ), and the third is near the medullary canal (fig. $363 \mathrm{k}$ ). From these groups of vessels small branches originate, and from the branches intricate plexuses of minute vessels are formed and occupy the intervals between the groups of large vessels. The posterior wall is composed, almost entirely, of plexuses of blood vessels and a little bone substance with a few oval lacunæ between them. Figure 363a is an enlarged drawing of figure 363A. In this bone may be seen an Haversian system formation unlike any noticed in other femora. A short branch is given off from one of the large concentric vessels (figs. 363-1 and 363a1) and divides into small branches, which assume a circular arrangement (fig. 363a2). The small branches send off numerous twigs which break into capillaries and surround a central opening (fig. 363a3). This gives the whole figure a circular form. Slight enlargements of the peripheral capillaries are nipped off at intervals, from which arise many minute canals (fig. 363a4). The enlargements become lacunæ and the minute canals canaliculi (fig. 363a5). The lacune are round and the eanaliculi are long and straight.

From this it would appear that the foundations of Haversian systems are laid in the vascular system. Osteoblasts either lodge in the capillaries or are produced by endothelium, and by growth and obstruction to the circulation, separate, throw ont processes, and secrete bone substance in which they are enclosed. In this manner an Haversian system seems to be formed. These developments take place in the concentric intervals or rings between the concentric groups of vessels and transform then into bone (fig. 363B). In this femur the intervals between the three vascular groups are occupied by Haversian systems. At quite regular intervals large, irregularly shaped spaces occur, the significance of which does not appear (fig. 363C). Although this bone presents great vascularity, yet it is lard enough to be sawed. Around the external and medullary surfaces the bone formation is farther arlvanced. Lamellæ are begimning to be evirlent in these regions.

'T'ype III, Ia, Tb.

FEMUR OF AN EGYPTIAN CHILD. No. $256479(d)$, U. S. NAT. MUS.

PL. 27, Fig. 364. Srn. Tab. IX

Antero-posterior diameter of bone, $9.5 \mathrm{~mm}$. ; lateral, $10 \mathrm{~mm}$.

Autero-posterior diameter of mednllary canal, $4 \mathrm{~mm}$.; lateral, $5 \mathrm{~mm}$.

The medullary canal is full. Medullary index, $27 \%$.

Structure.-The bone is nearly rouml. The posterior ridge is coarsely serrated on its external surface. The serrations consist of projecting loops of lamellæ, enclosing long, elliptical canals and presenting the appearance of rather crude Haversian systems. Underneath the serrated border the ridge is composed of bone substance enclosing more or less circularly shaped spaces. Some 
of these spaces and lamellæ present outlines of crude Haversian systems. The lacunæ are round and oval and the canaliculi are short and bushy. Beginning on one side of the posterior ridge and extending around the external surface of the bone to the opposite side are a few rather coarse lanine witl undulating borders, frequently interrupted by small Haversian systems formed by bending lamellæ of the laminæ around the central canals. The systems are elliptical. Under the external laminæ the bone is composed of channelled bone substance, with large meshes visible to the naked eye and having a concentric horseshoe arrangement. Underneath this is a narrow coneentric lamina with long lacunæ, and under this again is a wide ring of channelled bone substance resembling the external one, but rather more advanced. Around the medullary canal is a very narrow ring of lamellæ. The arrangement of the several rings of thin bone correspond to the groups of vessels and inter-vascular structures seen in figure 363 , and appears to be a more complete formation.

Type I-II-III, Ia, Ib.

RIGHT FEMUR OF AN EGYPTIAN. NO. 256479 (a3), U. S. NAT. MUS.

PL. 27, Fig. 365. Syn. T'AB. IX

Antero-posterior diameter of bone, $12 \mathrm{~mm}$; lateral, $12.5 \mathrm{~mm}$.

Antero-posterior diameter of medullary canal, $5.5 \mathrm{~mm}$. ; lateral, $7 \mathrm{~mm}$.

The medullary canal is full. Medullary index, $35 \%$.

This femur belongs to the same series and shows a further advancement, since the cancellous structure has disappeared and a compact bone has taken its place.

Structure.-The posterior ridge is composed of Haversian systems and vascular canals. Their lacme are narrow and their canalicnli are long.

Beginning on one side of the posterior ridge and extending around the section to the other side is a horseshoe hand of lamella of varying widths. It is widest in the posterior wall and remains of uniform wirth in other situations. The lamellæ are interrupted by Haversian systems of the (Ia) differentiation. Underneath the lamellar band is the middle ring of Haversian systems and inter-Haversian lamellæ. Around the medullary canal is a wide band of lamellæ with long lacunæ and straight canaliculi. This bone is more lamellar than Haversian system, but it shows a much more advanced stage of formation than those preceding. The completed units have appeared.

Type I-III, Ia, C.

FEMUR OF AN EGYPTIAN. NO. 258675 (a), U. S. NAT. MUS.

PL. 27, Fig. 366. Srn. TAB. IX

Antero-posterior diameter of bone, $18 \mathrm{~mm}$. ; lateral, $16.5 \mathrm{~mm}$.

Antero-posterior diameter of medullary canal, $10 \mathrm{~mm}$.; lateral, $9 \mathrm{~mm}$. 
The bone belongs to the same series as the foregoing.

The medullary canal is full. Medullary index, $44 \%$.

Structure.-The section is composed of wide external and internal lanellæ with a central ring of Haversian systems. 'The enclosing horseshoe-shaped band of lamellx is clearly marked. It is fairly uniform in width, and interrupted by crude Haversian systems of the (Ia) differentiation. Around the medullary canal is a wide ring of lamella of varying widtls. It is widest in the inner wall and interrupted by a few incomplete Haversian systems. Between these two bands of lamellæ is a narrow middle ring of Haversian systems and inter-Haversian lamellæ. The lacunæe are oval and long and their canaliculi are long.

'Type I-III, Ia, C.

Right FEMUR OF AN ADULT EgTPTIAN. No. $256481(d)$, U. S. NAT. MUS.

Pl. 28, Fig. 36\%. Syn. T'AB. IX

Antero-posterior diameter of bone, $18.5 \mathrm{~mm}$.; lateral, $17.5 \mathrm{~mm}$.

Antero-posterior diameter of medullary canal, $9 \mathrm{~mm}$.; lateral, $8 \mathrm{~mm}$.

The medullary canal is full. Medullary index, $28 \%$.

Structure.--The bone is surrounded by a lamellar ring, within which are a few Haversian systems of the (la) and (C) differentiations. The ring is separated by concentric canals into laminæ.

The medullary canal is surrounded by a wide band of lamellæ with long lacuna and straight canaliculi, which in the inner wall rather abruptly widens into a semicircular area of lamina occupring nearly the whole thickness of the wall. The lamina are interrupted by mmerons Haversian systems of the (Ia) differentiation. Between these two bands is an irregularly shaped central ring of Haversian systems and inter-Haversian lamella. The lacunæ are long and narrow and their canaliculi are long.

'Type I-II-III, La, C.

LEFT FEMUR OF AN ADULT EGYPTIAN. NO. 256481 (a), U. S. NAT. MUS.

PL. 28, Fig. 368. Syn. TAB. IX

Antero-posterior diameter of bone, $18 \mathrm{~mm}$; lateral, $16 \mathrm{~mm}$.

Antero-posterior diameter of medullary canal, $8 \mathrm{~mm}$; lateral, $7 \mathrm{~mm}$.

The medullary canal is full. Medullary index, $24 \%$.

The bone is very hard and brittle instead of chalky like the other femora described. It is small and nearly round.

Structure.-The posterior ridge, which is not very prominent, is composed of well developed Haversian systems. 
Beginning on either side of this ridge and extending completely around the bone is a very wide horseshoe-shaped band of lamellæ with long lacunæ and straight canaliculi. It forms more than half the thickness of the wall of the bone. It is perforated at frequent intervals by irregularly shaped spaces or openings, surrounded by very narrow rims of lamellæ. The openings are more numerous in the inner wall where they take a concentric arrangement. Between the openings are Haversian systems which are wide apart in the inner and close together in the outer wall. The lamellæ are clearly marked, their lacunæ are long and oval and the canaliculi are very numerous, long, and branching. The Haversian systems are well developed.

This wide lamellar band is distinctly distinguished from the narrow, central ring of Haversian systems underneath. The systems are somewhat irregular in shape, but well developed. In all of them the canaliculi are extremely numerous. The internal circumferential lamella surround the medullary canal. They form a thick band in the inner wall, a narrower band in the outer, and a narrow rim in the anterior and posterior wall.

The bone, therefore, has three concentric rings in section, an extremely wide lamellar ring over half the thickness, a narrow central Haversian ring one-fourth the thickness, and an irregular ring of internal circumferential lamellæ.

Type I-III, Ib, C, senile.

RIGHT FEMUR OF AN ANCIENT EGYPTIAN. NO. $258675(\mathrm{e})$, U. S. NAT. MUS.

PL. 28, Fig. 369. Syn. 'Tab. IX

Antero-posterior dianeter of bonc, $26 \mathrm{~mm}$. ; lateral, $21.5 \mathrm{~mm}$.

Antero-posterior diameter of medullary canal, $14 \mathrm{~mm}$.; lateral, $10 \mathrm{~mm}$.

The medullary canal is full. Medullary index, $44 \%$.

The bone is chalky. The femur is pear-shaped in cross-section.

Structure.-The posterior ridge is composed of large, uniformly developed Haversian systems and large, vaseular canals surrounded by a few concentric lamellæ.

Beginning on both sides of the ridge and extending aronnd the section is a wide horseshoe of lamelle with long laeme and straight canaliculi, frequently interrupted by Haversian systems. The toe of the shoe forms nearly all of the anterior, and the heel, half of the posterior wall. The lacuna are long, narrow and oval and their canaliculi are long and closely branching. . Underneath the horseshoe, between it and the internal circumferential lamella, is an irregularly shaped crescent of Haversian systems situated eccentrically.

The internal circumferential lamella surround the medullary canal.

In the inner wall the internal lamellx widen abruptly and occupy one. third of the width of the wall. In the anterior, outer, and posterior wall they 
form a narrow band around the medullary canal. The lacunæ and canaliculi are well developed.

Type I-III, C.

FEMUR OF AN ADULT EGYPTIAN. NO. 256478(23), U. S. NAT. MUS.

Pl. 28, Fig. 370. Syn. Tab. IX

Antero-posterior diameter of bone, $24 \mathrm{~mm}$.; lateral, $30 \mathrm{~mm}$.

Antero-posterior diameter of medullary canal, $10 \mathrm{~mm}$.; lateral, $10 \mathrm{~mm}$.

The bone is chalky.

The medullary canal is full. Medullary index, $16 \%$.

Structure.-The external circumferential lamelle surround the bone. Their lacunæ are long and narrow and their canaliculi are long and branching.

The central ring, of well developed Haversian systems, forms nearly the whole thickness of the wall of the bone. The systems are close together, which means that there are little or no inter-Haversian lamellæ, and they are generally' large and uniform in size and shape. Their lacuna are long and narrow and their canaliculi are long and branching, or the lacunæ may be oval and their canaliculi short and busliy.

The internal circumferential lamellæ surround the medullary canal. The ling varies in thickness.

Type III, C.

RIGHT FEMUR OF AN ADUlT EgIPTIAN. NO. $256478(x)$, U. S. NAT. MUS.

P'L. 28, Fig. 3\%1. Syn. Tab. IX

Antero-posterior diameter of hone, $23 \mathrm{~mm}$; ; lateral, $27 \mathrm{~mm}$.

Antero-posterion diameter of medullary (anal, 12 $\mathrm{mm}$. ; lateral, $11 \mathrm{~mm}$.

The femur is small. The medullary canal is full. Merlullary index, $27 \%$.

Structure.-The external aircunferential lamella are fragmentary. Beginning on the inner side of the posterior ridge and extending around the external surface of the immer lateral wall is a hand of lamellæ enclosing Haversian systems. As the band reaches the mid-lateral wall it is displaced by Haversian systems. In the immer anterior wall concentric systems and lamellx alternate. The remaining portion of the section is composed of Haversian systems somewhat irregular in shape and size. The lacunæ are oval in some places and narrow in others, the oval predominating. The external part of the posterior ridge is composed of large, oval lacunæ with bushy canaliculi.

The internal circumferential lamellæ are fragmentary. The evidence of the lamellar horseshoe is present to a small extent as a background in the inner wall, while the section is nearly all Haversian systems.

Type I-III, C. 


\title{
XV. MAN-MODERN WHITE
}

\author{
Generat Character of the Femur
}

The femora of the white race vary in shape to a marked degree. The medullary canals occupy rentral, eccentric, and oblique positions. They are filled witlı cancellons bone and marrow. The medullary surfaces are very uneven. The average medullary index is $35.8 \%$.

The type of structure varies from the third to the first and third. A great many first and third type combinations are found in the various femora, and the proportions of the first to the third type vary greatly. In some, it forms a narrow surrounding band; in others, the band increases in thickness until it forms a quarter, third, half, or more than half of the whole section; in still others, it remains as a background of inter-Haversian lamellæ.

\section{Detatled Examination}

FEMUK OF A WHITE MALE, NO. 1629, U. S. NAT. MUS.

Pu. 28, Fig. 372. Syn. Tab. X

Antero-posterior diameter of bone, $28 \mathrm{~mm}$; lateral, $28 \mathrm{~mm}$.

Antero-posterior diameter of medullary canal, $18 \mathrm{~mm}$. lateral, $17 \mathrm{~mm}$.

The medullary canal is full. Nedullary index, $64 \%$.

Structure.-The external circumferential lanella form a very narrow ring around the section. Beginning a little to the inner side of the posterior ridge and extending around the immer wall, beneath the external eireumferential lamelle, is a narrow band of elliptical Haversian systems in eross-section. They disappear as they approach the anterior wall. These structures are the remains of the lamella and lanina seen so frequently in lower bones in the same situation. The middle ling of the section is romposed of well developed Haversian systems with many conmuniogting ands. The medullary canal is surrounded by a narrow ring of internal circumferential lamelle. The lacune and canaliculi are generally well developed.

Type III, C.

Right FEMUR of a White Female. No. 147, Med. Dept. Northwestern univ.

Pl. 28, Fig. 373. Syn. Tab. X

Antero-posterior diameter of bone, $33.5 \mathrm{~mm}$.; lateral, $32 \mathrm{~mm}$.

Antero-posterior diameter of medullary canal, $19 \mathrm{~mm}$.; lateral, $18.5 \mathrm{~mm}$.

The medullary canal is surrounded by cancellous bone and is full. Medul lary index, $49 \%$. 
Structure.-External circumferential lamella appear only in scattered frayments. They are most pronounced in the posterior inner wall. The central ring of well developed Haversian systems constitutes practically the whole bone. In most parts they form the external border directly under the periostem, and here and there a half system bounds the section. The systems are fairly uniform in size and cireular in cross-section. Many of these have relatively large Haversian canals and show slight senile changes. The Haversian canals fre quently communicate by cross canals. On the two sides of the posterior ridge, near the circumference, they are a little elongated and show faint traces of a former laminar condition.

The internal circumferential lamella form a narrow ring around the medullary canal. For the most part the lamellie assume the form of cancellous bone. All bone units are well developed.

Type III, C, senile.

RIGHT FEMUR OF A WHITE CHILD, LESS THAN ONE IEAR OLD. NO. 249588,

$$
\text { U. S. NAT. MUS. }
$$

PL. 29, Fig. 3\%4. SyN. TAB. X

Antero-posterior diameter of bone, $6.5 \mathrm{~mm}$; lateral, $7.5 \mathrm{~mm}$.

Antero-posterior diameter of medullary canal, $4 \mathrm{~mm}$; lateral, $5 \mathrm{~mm}$.

The mednllary canal is full. Nedullary index, $70 \%$.

Structure.-Extending around the circimference of the section-posterior ridge excepter-is a narrow ring of lamella with oval lacme and bushy canaliculi. The lamella are frequently interrupted by canals running longitudinally.

Beginning on both sides of the posterior ridge and extending around the section underneath the external lamelle is a horseshoe band of lamine and Haversian systems forming the remainder of the bone. The inner wall is almost entirely lamine. As the lamine reach the anterior wall they are mostly displaced by rather arule, elongated Haversian systems, which, however, generally maintain concentric arrangements. In the outer wall the Haversian systems occupy the medullary half and the lamine the circumferential half of the section. The lacmin are oval. The Haversian canals are irregular in shape and extend in various directions. The internal circumferential lamellæ are fragmentary.

The posterior ridge is incompletely formed and is composed of large canals, surrounded by oval lacune with infrequent bordering canaliculi. Here and there an Haversian system appears. The ridge is obviously a later formation than the remaining walls.

Type II-III, Ia, Ib. 
FEMUR OF A WIITTE MALE, NO, 53, CR, MED. COLL.

PL. 29, Fig. 375. STN. 'TAB. X

Antero-posterior diameter of bone, 28 mm.; lateral, $30 \mathrm{~mm}$.

Antero-posterior dianneter of medullary canal, $16 \mathrm{~mm}$; lateral, $17 \mathrm{~mm}$.

Cancellous bone surlounds the medullary anal and is most prominent in the anterior wall. The medullary canal is full. Medullary index, $48 \%$.

Structure.-The external circumferential lamella surround the bone at scattered intervals. Their lacunx are long and narow and their canaliculi are long. 'The central ring, constituting nearly the entire thickness of the wall of the bone, is composed of Haversian systems, which, in places, form the external boundary of the bone. At some points in the periphery, only half or three-quarter systems appear directly under the periosteum. The systems vary in size, but are highly developed. Their lacunde are long and narrow and their canaliculi are long. The Haversian canals intercommunicate. The internal circumferential lamelle surround the medullary canal in the form of cancellous bone.

Type III, C.

RIGHT FEMUR OF A IVHITE MALE. NO. 171, MED. DEPT, NORTHWESTERN UNIV.

$$
\text { PL. 29, Fig. 3\%6. S'YN. T'AB. X }
$$

Antero-posterior diameter of bone, $30 \mathrm{~mm}$. ; lateral, $33 \mathrm{~mm}$.

Antelo-posterior diameter of medullary anal, $17 \mathrm{~mm}$; lateral, $15 \mathrm{~mm}$.

The medullary canal is full. Medmllary index, $35 \%$.

structure.-The external circumferential lamella aplear in franguents.

The section is composed almost entirely of Haversian systems with very little inter-Haversian lamellar structure. The systems vary in size and some of them show senile changes.

The internal circumferential lamella form a very narow ring around the medullary canal. The bone is high in development, since practically all lamella! and laminar formations have disappeared and IIaversian systems lave taken their places. It shows, however, senile changes.

'Type III, C, senile.

LEFT FEMUR OF A IVHITE MAN, NO. 95, CR. MEU. COLL.

$$
\text { PL. 29, Fig. 3\%r. Syn. Tab. X }
$$

Antero-posterior diameter of bone, $30 \mathrm{~mm}$.; lateral, $27.5 \mathrm{~mm}$.

Antero-posterior diameter of mednllary canal, $17 \mathrm{~mm}$; lateral, $16 \mathrm{~mm}$.

The medullary canal is full. Medullary index, $42 \%$. 
Structure.-The external circumferential lamellæ appear in fragments. The central ring is composed of Haversian systems and constitntes almost the entire wall of the bone. Many systems are senile. They reach the external surface between the lamellar fragments and form the posterior ridge. They are large, small, and irregular in shape and frequently commumicate by canals. Their lacme are narrow and oval. Around the internal circumferential lamellie the systems show senile changes. There is very little inter-Haversian structure.

The internal circumferential lamelli form a very narrow ring around the medullary eanal.

Type III, C, senile.

LEFT FEMUR OF A White MALE. NO. 96, CR. MED. COLL.

Pl. 29, Frg. 3\%8. Syn. 'I'Ab. X

Antero-posterior diameter of bone, $29.5 \mathrm{~mm}$; lateral, $30 \mathrm{~mm}$.

Antero-posterior diameter of medullary canal, $14.5 \mathrm{~mm}$. ; lateral, $12 \mathrm{~mm}$.

The medullary canal is full. Medullary index, $24 \%$.

Structure.-A few fragments of the external circumferential lamella appear here and there around the surface of the bone. The central ring of Ha versian systems constitutes almost entirely the whole section.

There are some inter-Haversian lamellæ which are the remains of the laminar and lamellar structures seen in lower bones. The systems are large, small, and irregular in shape and frequently communicate by canals. Some of them show senile changes. On the whole, they are well developed.

The internal circumferential lamellæ form a very narrow, irregular ring around the medullary eanal. It is displaced at intervals by Haversian systems of the central ring.

Trpe III, C, senile.

IAET FEMUR OF A WHITE MALE, AgE 45. NO. 168, MED. DEPT. NORTHWESTERN UNiV. PL. 29, HIG. 3\%9. SYN. TAB. X

Antero-posterior liameter of bone, $30 \mathrm{~mm}$; lateral, $30 \mathrm{~mm}$.

Antero-posterior diameter of medullary canal, $15 \mathrm{~mm}$; lateral, $17 \mathrm{~mm}$.

The medullary canal is full. Medullary index, $40 \%$.

Structure.-The external circumferential lamellæ are fragmentary. The central ring is composed of large, small, and irregularly shaped Haversian systems, many of which show senile changes. The internal circumferential lamellæ form a narrow fragmentary ring around the medullary canal.

Type III, C, senile. 
LEFT FEMUR OF A WHITE MALE, AGE 50. NO. 10, MED. DEPT. NORTHWESTERN UNIV.

$$
\text { Pl. 29, Fig. 380. Srn. 'Tab. X }
$$

Antero-posterior diameter of bone, $30 \mathrm{~mm}$; lateral, $31.5 \mathrm{~mm}$.

Antero-posterior diameter of medullary canal, $13 \mathrm{~mm}$; lateral, $12 \mathrm{~mm}$.

The medullary canal is full. Medullary index, $20 \%$.

Structure.-The external circumferential lamellæ appear only in short fragments. The central ring is composed of large, small, and irregular Haversian systems with many senile changes. The internal ciremnferential lamella form a narrow ring around the medullary canal.

Type III, C, senile.

FEMUR OF A SENILE WHITE AMERICAN FEMALE, AGE 52. NO. 227876, U. S. NAT. MUS.

$$
\text { PL. 29, Fig. 381. Syn. Tab. X }
$$

Antero-posterior diameter of bone, $22 \mathrm{~mm}$. ; lateral, $25 \mathrm{~mm}$.

Antero-posterior diameter of medullary canal, $13.5 \mathrm{~mm}$. ; lateral, $12 \mathrm{~mm}$.

The medullary canal is full. Medullary index, $42 \%$.

There is a difference of eight years between the senile femora of fig'ures .381 and 382. The two femora have about the same external diameter, bnt figure 381 has an index of $42 \%$, and figme $382,7+\%$.

Structure.-Femmr (fig. 381) is of a slightly lower type of structure than fig'ure 382. 'This may be seen by the concentric arrangement of the oblong' Haversian systems of the inmer wall. 'The external circumferential lamella are fragmentary. The central ring is composer of large and small Haversian systems in different stages of senility. A few are normal; that is, their Haversian canals are about the usnal size. Some have large Haversian canals and crescentshaped lamella; some have large canals and narrow rings of granular lamellx; some have large canals and perfectly black, opaque rings or crescents aromind them; and some are entirely gone.

The internal circumferential lamellar are framentary.

Type IIT, C, senile.

FEMITR OF A SENIIE WHITE FEMALE, MGE (i). NO. 207880, U. S. NAT. MUS.

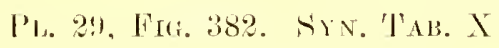

Antero-posterior diamotor of bone, 나 $\mathrm{mm}$; ;ateral, 25 $\mathrm{mm}$.

Antero-posterior diameter of medullary anal, $16 \mathrm{~mm}$; lateral, $16 \mathrm{~mm}$.

cancellons hone is present in places. 'l'he bone is extrenely soft, light, and thin-walled. The mednllary canal is relatively large. Tn the wall of the bone are large, irregularly shaped spaces.

The mednllary canal is full. Mednllary index, 74\%. 
Structure.-The external circumferential lamellæ are fragmentary. The central ring is composed of large, small, and irregularly shaped Haversian systems, most of which show marked degrees of senility. Some are black and partly gone and others have entirely disappeared, leaving spaces. The internal circumferential lamelli are fragmentary, appearing only here and there.

Type III, C, senile.

LEFT FEMUR OF A WHTte MALE. NO. 162, MED. DEPT. NORTHWESTERN UNIV.

$$
\text { Pl. 30, Fig. 384. SyN. Tab. X }
$$

Antero-posterior diameter of bone, $25 \mathrm{~mm}$; lateral, $29 \mathrm{~mm}$.

Antero-posterior diameter of medullary canal, $13 \mathrm{~mm}$; lateral, $15 \mathrm{~mm}$.

The medullary canal is full. Medullary index, $35 \%$.

Structure.-The external circumferential lamellæ are fragmentary.

The central ring is composed of Haversian systems of various shapes and sizes with round and oval lacume and bushy and straight canaliculi, many of which are senile.

The internal circumferential lamella with long, narrow lacune and straight canaliculi surround the medullary canal.

Type III, C, senile.

RIGHT FEMUR OF A WHITE MALE. NO. 244, CR. MED. COLL.

Pu. 30, Fig. 385. Syn. Tab. X

Antero-posterior dianeter of bone, $35 \mathrm{~mm}$. ; lateral, $30 \mathrm{~mm}$.

Antero-posterior diameter of medullary canal, $17 \mathrm{~mm}$.; lateral, $15 \mathrm{~mm}$.

The medullary canal is full. Nedullary index, $32 \%$.

Structure.-Slight remains of the lamellar horseshoe are found on both sides of the posterior ridge.

The external circumferential lamelle are fragmentary.

The central ring constitutes most all of the section, and is composed of Haversian systems with many senile changes.

The internal circumferential lamella form a narrow fragmentary ring around the medullary canal.

Type III, C, senile.

RIGHT FEMUR OF AN EAST INDTAN. NO. 223, (R. MED. COLL.

PL. 30, Fiti. 386. SYN. 'I'AB. X

Antero-posterior diameter of bone, $29 \mathrm{~mm}$; lateral, $24 \mathrm{~mm}$.

Antero-posterior diameter of medullary canal, $16 \mathrm{~mm}$.; lateral, $12 \mathrm{~mm}$.

The medullary canal is full. Medullary index, $38 \%$. 
Structure.-External circmmferential lamellax suround the section. In the inner and anterior wall they are intermpted by crucle Haversian systems of the (Ia) differentiation.

The central ring is composed of large, small, and irregularly shaped, well developed Haversian systems. Here and there a lew, short, inter-Haversian lamellæ appear. Some of the systems are senile. But, on the whole, the Haversian systems are strong and well developed.

The internal circmmferential lamellac form a narrow ring around the medullarry canal.

Type III, Ia, C.

LEFT FEMUR OF AN EAST 1NDLAN. No. 223, CR. MED. COLL.

Pl. 30, Fig. 38\%. SYN. TAB. X

The leg had been amputated below the knee and the femm har not exerciser its normal function for years.

Antero-posterior diameter of bone, $28 \mathrm{~mm}$; lateral, $22 \mathrm{~mm}$.

Antero-posterior diameter of medullary canal, $17 \mathrm{~mm}$. ; lateral, $12 \mathrm{~mm}$.

The mednllary canal is full. Medullary index, $49 \%$.

Structure.-The section is smrounded by external rircmmferential lamellæ, thinnest in the anterior wall. The lamella are inter'mpted by crnde Haversian systems of the ( $\mathrm{Ia}$ ) differentiation.

The central ring is composed of large, small, and irregularly shaped Harersian systems, showing senile changes which are most numerons around the medullary canal.

Internal circumferential lamellae form a narrow ring aromnd the medullary canal.

Type III, Ia, C, senile.

A comparison of the two foregoing femora shows that the femur of the amputated leg is smaller than the other, the index is higher, the wall of the bone is thimer, and senile changes are more marked.

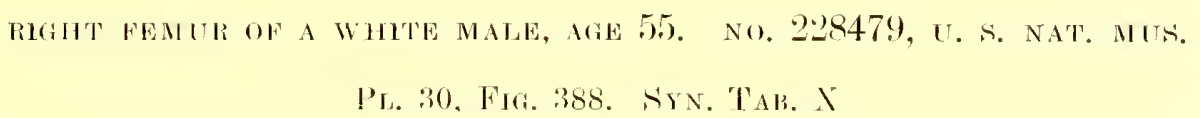

Antero-posterior diameter of bone, :20 nm. ; lateral, 28 mm.

Antero-posterior diamoter of meshullary anal, 14 mm. ; lateral, 17 mm.

The mednllary canal is foll. Melullary index, $36 \%$. There is onsiderable ancellous bone.

Structure.-The external rincumforential lamellas are fragmentary and show the remains of the lamellar or laminar horseshoe. 
The central ring constitutes almost the whole thickness of the walls and is composed of Haversian systems with some inter-Haversian lamellæ. The systems are large, small, and irregular, and show some senile changes. There are very few cross canals. Their lacune are oral and narrow.

The internal circumferential lamellæ form a narrow ring around the medullary canal and in the anterior wall assume the form of cancellous bone.

Type III, C, senile.

Right Femur of a white mate, age 45. No. 154, Med. DePT. NorthWestern univ.

$$
\text { Ph. 30, Fig. 389. Sin. Tab. X }
$$

Antero-posterior diameter of bone, $30 \mathrm{~mm}$; lateral, $29 \mathrm{~mm}$.

Antero-posterior diameter of medullary canal, $15 \mathrm{~mm}$; lateral, $14 \mathrm{~mm}$.

The medullary canal is full. Medullary index, $26 \%$.

Structure.-The external circumferential lamellæ are fragmentary. The central ring is composed of Haversian systems, which, in the inner wall, alternate with concentric laminæ. Many systems are senile.

The internal circumferential lamellæ form a narrow ring around the medullary canal.

Type III, C, senile.

Left femur of a WHite Male. No. 146, med. Dept. Northwestern univ.

Pl. 30, Fig. 390. Syn. Tab. X

Antero-posterior diameter of bone, $28 \mathrm{~mm}$.; lateral, $24 \mathrm{~mm}$.

Antero-posterior diameter of medullary canal, $13 \mathrm{~mm}$. ; lateral, $10 \mathrm{~mm}$.

The medullary canal is full. Medullary index, $24 \%$.

Structure.--The extemal cireumferential lamellæ are fragmentary. Half systems frequently occur on the external border of the section. The central ring forms practically all of the bone and is composed of irregularly shaped Haversian systems. Senile changes are marked. The lacunæ are oval and long and the canaliculi are bushy and straight. The internal circumferential lamellæ are fragmentary.

Type III, C, senile.

LEFT FEMUR OF A WHITE MALE, AGE 60. NO. 159, MED, DEPT. NORTHWESTERN UNIV.

$$
\text { [’c. 30, Fig. 391. SYN. 'TAB, X }
$$

Antero-posterior diameter of hone, $32 \mathrm{~mm}$.; lateral, $31.5 \mathrm{~mm}$.

Antero-posterior diameter of medullary (anal, $17.5 \mathrm{~mm}$.; lateral, $18 \mathrm{~mm}$.

The medullary canal is full. Medullary index, $45 \%$.

Structure.-The external circmuferential lamellæ are fragmentary. The central ring is composed of Haversian systems showing many senile changes. 
The internal cireumferential lamellæ form a narrow ring around the medullary eanal.

Type III, C, senile.

RIGHT FEMUR OF A WHITE MALE. NO. 167, MED. DEPT. NORTHWESTERN UNIV.

Pl. 30, Fig. 392. Siyn. Tab. X

Antero-posterior diameter of bone, $27 \mathrm{~mm}$; lateral, $2.5 \mathrm{~mm}$.

Antero-posterior diameter of medullary canal, $14 \mathrm{~mm}$.; lateral, $11 \mathrm{~mm}$.

The medullary canal is full. Medullary index, $30 \%$.

Structure.-The external cireumferential lamellæ are fragmentary. For the most part, Haversian systems form the external boundary of the section. The central ring is composed of Haversian systems and inter-Haversian lamellæ in the inner wall and of Haversian systems elsewhere. The internal circumferential lamellæ are fragmentary.

Type III, C, senile.

RIGHT FEMUR OF A IVHITE MALE. NO. 172, MED. DEPT. NORTHWESTERN UNIV.

$$
\text { PL. 30, Fig. 393. Syn. TAB. X }
$$

Antero-posterior diameter of bone, $32 \mathrm{~mm}$; lateral, $31.5 \mathrm{~mm}$.

Antero-posterior diameter of medullary canal, $17.5 \mathrm{~mm}$.; lateral, $18 \mathrm{~mm}$.

The medullary canal is full. Medullary index, $45 \%$.

Structure.-A narrow band of external circumferential lamelli, somewhat fragmentary, forms the external boundary of the section. The central ring is composed of Haversian systems, well developed and of varying sizes. In the anterior and imner wall, the systems are separated by a little inter-Haversian structure. Many senile systems appear. Few cross canals are seen. The internal circumferential lamellie are fragmentary.

Type III, C, senile.

RIGHT FEMUR OF A WHITE MALF. NO. 242, CR. MED. COLL.

PL. 31, Fig. 394. Syn. 'I'AB. X

Antero-posterior diameter of bone, $32 \mathrm{~mm}$; ; lateral, $27 \mathrm{~mm}$.

Antero-posterior diameter of medullary anal, $19 \mathrm{~mm}$; lateral, $15 \mathrm{~mm}$.

The medullary anal is full. Medullary index, $49 \%$.

Structure.-The external airmmferential lanellas are fragmentary. Remains of the lamellar horseshoe are foum in the imner wall.

The central ring forms nearly the whele of the sertion and is composed of Haversian systems, many of which show senile changes.

The internal cireumferential lamella form a narow ring aroum the merlullary canal.

Type III, C, senile. 


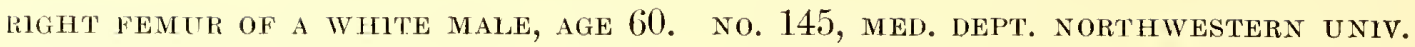
Pl. 31, Fig. 395. Srn. Tab. X

Intero-posterior diameter of bone, $30 \mathrm{~mm}$. ; lateral, $29 \mathrm{~mm}$.

Antero-posterior diameter of medullary canal, 16 mml.; lateral, $18 \mathrm{~mm}$.

The medullary canal is full. Medullary index, $49 \%$.

Structure.-The external circumferential lamella are fragmentary and half systems occur on the external boundary of the section. The central ring is composed of well developed, large and small Haversian systems. Many senile changes occur in the anterior and posterior wall. Few cross canals are seen. 'The internal circumferential lamella form a narrow ring around the medullary eanal and in the anterior and posterior wall cancellous bone.

Type III, C, senile.

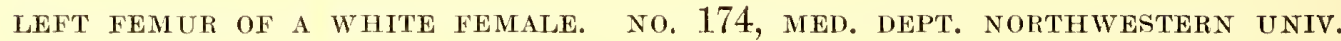

Pl. 31, Fig. 396. SrN. Tab. X

Antero-posterior diameter of bone, $27 \mathrm{~mm}$; lateral, $26 \mathrm{~mm}$.

Antero-posterior diameter of medullary canal, $14 \mathrm{~mm}$.; lateral, $13 \mathrm{~mm}$.

'The medullary canal is full. Medullary index, $35 \%$.

Structure.-The external circumferential lamella surround the section. Tu the outer wall they form a wide background of about lalf the wirlth of the wall in which are numerous Haversian systems. The background gradually disappears in the anterior wall and the lamella are reduced to a very narrow rim. In the inner wall the narrow rim gradually widens again as it approaches the posterior ridge. The central l'ing is composed of large and small Haversian systems, many of which are senile. Near the external surface of the posterior ridge groups of round and oval lacune appear between the systems. The internal circumferential lamella are fragmentary.

Type I-IIT, C, senile.

RlGFT FEMUR OF A WHITE MALE. NO. 157, MEO. DEPT. NORTHWESTERN ITNIV.

PL. 31, Fig. 39\%. Sry. TAB. X

Antero-posterior diameter of bone, $30 \mathrm{~mm}$. lateral, $29 \mathrm{~mm}$.

Antero-posterior diameter of medullary canal, $16.5 \mathrm{~mm}$; lateral, $16 \mathrm{~mm}$.

'The medullary canal is fill. Medullary index, $44 \%$.

Structure.-The external cin'umferential lamellar, separated into laminx in the lateral wall, surround the section. 'The central ring is romposed of Haversian systems, and senile changes are abundant. Tn the immer wall may be seen distinct remains of the lamellar horseshoe. The internal circumferential lamella are fragmentary.

Type I-IT-III, C, senile. 
LEFT FEMUR OF A WHITE MALE. NO. 161, MED. DEPT. NORTHWESTERN UNIV.

$$
\text { Pl. 31, Fig. 398. Syn. TAr. X }
$$

Antero-posterior diameter of bone, $28 \mathrm{~mm}$.; lateral, $31 \mathrm{~mm}$.

Antero-posterior diameter of medullary canal, $12 \mathrm{~mm}$; lateral, $15 \mathrm{~mm}$.

The medullary canal is full. Medullary index, $26 \%$.

Structure.-The external lamella are practically absent. The central ring is composed of various forms of Haversian systems with considerable interHaversian lamella, especially in the imner wall. This is the remains of the horseshoe. Many senile changes are present. Near the posterior ridge the systems are oval and assume a concentric arrangement. The internal lamellæ form a narrow ring around the medullary canal.

Type III, C, senile.

RIGHT FEMUR OF A WHITE MALE. NO. 153, MED, DEPT. NORTHWESTERN UNIV.

$$
\text { PL. 31, Fig. 399. Syn. Tab. X }
$$

Antero-posterior diameter of bone, $27.5 \mathrm{~mm}$.; lateral, $26 \mathrm{~mm}$.

Antero-posterior diameter of medullary canal, $14 \mathrm{~mm}$.; lateral, $11 \mathrm{~mm}$.

The medullary canal is full. Medullary index, $27 \%$.

Structure.-A wide horseshoe band of lamella extends around the external border of the section and is interrupted by numerous crude Haversian systems of the (Ia) differentiation and crossed by canals. The central ring is composed of large, small, and irregular Haversian systems, some of which are senile. The internal lamella form a broken ring around the medullary canal.

Type I-III, Ia, C, senile.

Right femer of A WHite MALe. No. 243, CR. MED. COLL.

$$
\text { Pu. 31, Fig. 400. Syn. Tab. X }
$$

Antero-posterior diameter of bone, $30 \mathrm{mmm}$; lateral, $27 \mathrm{~mm}$.

Antero-posterior cliameter of medullary canal, $16 \mathrm{~mm}$; lateral, $14 \mathrm{~mm}$.

The medullary canal is full. Merlnllary index, $23 \%$.

Structure.-C'The section is surroumled for the most part by a wide horse shoe band of lamellar, intermpted frequently hy Haversian systems of the ([a) differentiation.

The central ring is composenl of Haversian systems with fragments of lamella ruming between them in all directions. This is especially true in the onter wall. A few senile systems appear. Lntermal circmoferential lannella form a narrow ring aromme the medullary canal.

Type I-III, Ia, C, senile. 
LEFT FEMUR OF a WHite MaLe. No. 148, Med. DEPT. NORTHWESTERN UNiv.

Pl. 31, Fig. 401. Syn. TAB. X

Antero-posterior diameter of bone, $24 \mathrm{~mm}$. ; lateral, $33 \mathrm{~mm}$.

Antero-posterior diameter of medullary canal, $13.5 \mathrm{~mm}$.; lateral, $14 \mathrm{~mm}$.

The medullary canal is full. Medullary index, $30 \%$.

Structure.-Remains of the lamellar horseshoe band are seen as a background in the lateral and anterior wall. The band is interrupted by numerous Haversian systems. The central ring is incomplete and composed of large, small, and irregular Haversian systems. Senile changes are frequent in the anterior and posterior wall. The internal lamellæ form a narrow ring around the medullary canal.

Type I-III, C, senile.

LEFT FEMUR OF A WHITE MALE. NO. 230, CR, MED. COLL.

PL. 31, FIG. 402. SYN. TAB. X

Antero-posterior diameter of bone, $31 \mathrm{~mm}$.; lateral, $29 \mathrm{~mm}$.

Antero-posterior diameter of medullary canal, $17 \mathrm{~mm}$.; lateral, $14 \mathrm{~mm}$.

The medullary canal is full. Medullary index, $33 \%$.

Structure.-The horseshoe band of lamella, widest in the outer and absent in the anterior wall, remains as a background. It forms half of the outer and one-third of the posterior immer wall. In the lamellar background are oval and round Haversian systems. The central ring is composed of large, small, and irregular Haversian systems. Senile changes are frequent. The lacunæ are generally oval. The internal circumferential lamellæ appear in fragments and as cancellous bone in the anterior wall.

Type I-III, C, senile.

LEFT FEMUR OF A WHITE MALE. NO. 97, CR. MED. COLI.

Pl. 32, Fig. 403. Syn. Tab, X

Antero-posterior diameter of bone, $28.5 \mathrm{~mm}$.; lateral, $27 \mathrm{~mm}$.

Antero-posterior diameter of medullary canal, $16 \mathrm{~mm}$. ; lateral, $15 \mathrm{~mm}$.

The medullary canal is full. Medullary index, $45 \%$.

Structure.-A wide horseshoe hand of lamine and lamellie surrounds the section. On both sides of the ridge the heel of the shoe constitutes nearly the whole thickness of the wall, while the toe constitutes more than one-half of the anterior wall. In the inner wall the band is narrow and in the outer wall, wide. On both sides of the posterior ridge the heel of the shoe is composed of 
laminæ with inter-laminar Haversian systems and canals. The laminæ merge together to some extent as they reach the anterior. wall, but are still evident in that region. The Haversian systems of the horseshoe band are of the (Ia) and (C) differentiations, the former predominating. Their locations between adjacent laminæ produce irregular borders of the lamina. In the anterior wall the systems are all poorly developed, being little more than Haversian canals. The lacunæ of the lamellæ are long and narrow; of the laminæ, somewhat oval.

The central ring is narrow and composed of well developed Haversian systems in the outer, a wide band of lamelle and Haversian systems in the anterior, lamellæ and Haversian systems in the imner wall, and Haversian systems in the posterior ridge. No senile changes appear. The posterior ridge is composed of Haversian systems and inter-Haversian lamellæ with many oval lacunæ. The internal circumferential lamellæ form an irregular ring of varying widths around the medullary canal. The bone is more than one-half lamina and lamellæ.

Type I-II-III, Ia, C.

LEFT FEMUR OF A WHITE MALE. NO. 99, CR. MED. COLL

Pl. 32, Fig. 404. Syn. TaB. X

Antero-posterior diameter of bone, $30 \mathrm{~mm}$. lateral, $27.5 \mathrm{~mm}$.

Antero-posterior diameter of medullary canal, $14 \mathrm{~mm}$. ; lateral, $10 \mathrm{~mm}$.

The medullary canal is full. Medullary index, $20 \%$.

Structure.-Beginning on the onter side of the posterior ridge and extending around the lateral wall are coarse lamime, interrupted hy a few Haversian systems of the (C) differentiation and by many of the (Ia) differentiation. As the laminæ reach the anterior wall they merge into lamellæ, which terminate in the anterior inner wall, and are then completely displaced by well devcloped Haversian systems. The lamina again appear in the posterior wall. The lacunæ are generally oval and their canaliculi straight. In the outer wall is a wide semicircular area of lamina, which, with those of the extemal band, constitute the whole wall. These laminæ are also interrupted by Haversian systems similar to those of the external band.

The central ring is incomplete, since it is limited to a narrow portion of the anterior, nearly the whole of the inner anterior and posterior wall. It is composed of well developed Haversian systems without senile changes.

The medullary canal is surrounded by laminæ, interrupted by Haversian systems of the (Ia) differentiation. The section is more than half lamellæ and laminæ.

Type I-II-III, Ia, C. 
RIGHT FEMUR OF A WHITE MALE. NO. 160, MED. DEPT. NORTHWESTERN UNIV.

$$
\text { PL. 32, F1G. 405. STN. TAB. X }
$$

Antero-posterior diameter of bone, $28 \mathrm{~mm}$; lateral, $28.5 \mathrm{~mm}$.

Antero-posterior diameter of medullary canal, 15 mmı.; lateral, $15 \mathrm{~mm}$.

The medullary canal is full. Medullary index, $38 \%$.

Structure.-Beginning on the inner side of the posterior ridge and extending around the inner and a part of the anterior wall is a wide band of lamellæ in which are many well developed Haversian systems. The band forms the entire thickness of the inner posterior wall. In the anterior outer wall the band has been displaced by Haversian systems, and in the outer posterior wail the lamellar band again appears.

The central ring is composed of Haversian systems of the (C) differentiation, many of which show senile changes.

The internal circumferential lamellæ are fragmentary. The section is about half lamellæ.

Type I-III, C, senile.

LEFT FEMUR OF A WHITE MALE. NO. 163, MED. DEPT. NORTHWESTERN UNiV.

PL. 32, Fig. 406. Sin. Tab. X

Antero-posterior diameter of bone, $28 \mathrm{~mm}$; lateral, $25 \mathrm{~mm}$.

Antero-posterior diameter of medullary canal, $15 \mathrm{~mm}$.; lateral, $11.5 \mathrm{~mm}$.

'The medullary canal is full. Medullary index, $32 \%$.

structure.-Beginning on the inner side of the posterior ridge and extenting around the external border of the inner and anterior wall is a wide band of lamellax, interrupted by Haversian systems. The band forms about half of the inner and the whole of the anterior wall, and is then displaced by Haversian systems. The lacuna are oval and long. Around the external surface of the outer wall is a narrower band of lamellax, interrupted by canals of the (Ia) differentiation. The central ring of the inner and outer wall is composed of Haversian systems, some of which exhibit senile changes. In the posterior ridge the systems are separated by lamella with oval lacunx. The medullary canal is enclosed by a narrow ring of lamellæ.

Type I-III, Ia, C, senile.

RIGHT FEMUR OF A WHITE MALE. NO. 156, MED. DEPT. NORTHWESTERN UNIV.

$$
\text { PL. 32, Fig. 40\%. Srn. TAB. X }
$$

Antero-posterior diameter of bone, $31 \mathrm{~mm}$; lateral, $23.5 \mathrm{~mm}$.

Antero-posterior diameter of medullary canal, $11 \mathrm{~mm}$; lateral, $11 \mathrm{~mm}$.

The medullary canal is full. Medullary index, $20 \%$. 
Structure.-The external circumferential lamella are fragnentary. The central ring constitutes nearly all of the section and is composed of large, small, and irregularly shaped Haversian systems in a wide band of lamella, especially in the inner and posterior wall. The band is nearly displaced by Haversian systems in the outer wall. Senile changes are frequent. The internal circumferential lamellæ are fragmentary. The section shows an unusually large, inner posterior ridge.

Type I-III, C, senile.

LEFT FEMUR OF A WHITE MALE. NO. 169, MED. DEP'T. NORTHWESTERN UNIV.

PL. 32, Fig. 408. Syn. Thв. X

Antero-posterior diameter of bone, $31 \mathrm{~mm}$; lateral, $29 \mathrm{~mm}$.

Antero-posterior diameter of medullary canal, $16 \mathrm{~mm}$.; lateral, $15 \mathrm{~mm}$.

The medullary canal is full. Medullary index, $37 \%$.

Structure.-Beginning on the inner side of the posterior ridge and extending around the inner lateral wall is a wide lamellar background in which are numerous Haversian systems. In the anterior wall the band narrows to an interrupted rim and widens again to a background in the onter wall.

The central ring is composed of Haversian systems, large and small, with some senile changes. Along the external surface of the posterior ridge the systems are separated by lamella with oval and round lacuna. The internal circumferential lannella form a narrow ring around the medullary canal. Senile ehanges are numerous in the systems in close proximity to the medullary canal.

'Type I-III, C, senile.

RIGH'L FEMUR OF A WIITE MALE, AGE 35. NO. 151, MEI. DEPT. NORTHWESTERN UNIV.

PL. 32, Fig. 409. SrN. 'T'AB. X

Antero-posterior diameter of bone, $28 \mathrm{~mm}$; lateral, $31 \mathrm{~mm}$.

Antero-posterior diameter of medullary anal, $11.5 \mathrm{~mm}$; lateral, $12 \mathrm{~m}$ m.

The medullary canal is full. Medullary index, $19 \%$.

Structure.-The external circumferential lamella surround the bone. They form thin bands in the lateral wall and are displaced by bone substance with large oval lacune and bushy canaliculi in the posterior ridge. The anterior wall is over half lamellæ, in which are parallel rows of crude Haversian systems of the (Ia) differentiation, arranged concentrically. The lamellæe and systems form the external part of the wall, and, as they approach and pass into the lateral wall, they are replaced by wide bands of irregularly shaped Haversian systems. Senile elianges are frequent in the inner lateral wall. Underneath 
the lamellar and Haversian system band is a central ring of regular Haversian systems, well developed.

The internal circumferential lamelle form a wide band in the lateral and posterior wall. In the posterior, outer lateral wall several laminæ extend obliquely from the interior of the wall to the medullary surface. The external half of the posterior ridge is composed of Haversian systems, between which is bone substance with many oval lacune, while the medullary half is composed of Haversian systems with a little inter-Haversian lamellæ.

Type I-II-III, Ia, C, senile.

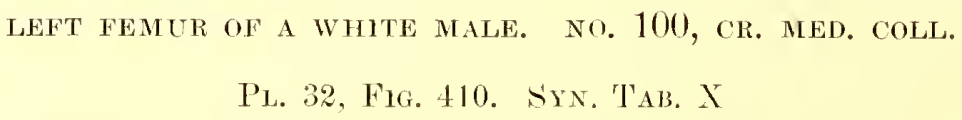

Antero-posterior diameter of bone, $24 \mathrm{~mm}$; lateral, $31 \mathrm{~mm}$.

Antero-posterior diameter of medullary canal, $17.5 \mathrm{~mm}$; lateral, $13.5 \mathrm{~mm}$.

The medullary canal is full. Medullary index, $46 \%$.

Structure.-The external circumferential lamellæ form the boundary of a part of the outer wall. In some places, however, Haversian systems form the external boundary. In the outer wall lamine separate the Haversian systems of the central ring. Their lacune are well developed.

The central ring constitutes the greater part of the section, and especially is this true of the outer wall.

In the inner wall is a wide external band of lamina and oblong Haversian systems extending from the posterior ridge around to the outer antero-lateral junction. In the anterior wall is a wide hand of lannella. 'The systems are large, small, and irregnlar in shape. In those aroum the medullary canal, senile changes appear. 'The internal circumferential lamelle form an extremely narrow ring around the mednllary canal.

Type I-II-LII, C, senile.

RIGH'T FEMUR OF A WHITE FEMALE. NO. 150, MED, NEPT. NORTHWESTERN UNIV.

PL. 32, Fig. 411. Syn. TAB. X

Antero-posterior diameter of bone, $26 \mathrm{~mm}$; lateral, $26 \mathrm{~mm}$.

Antero-posterior diameter of medullary canal, $20 \mathrm{~mm}$.; lateral, $21 \mathrm{~mm}$.

The medullary canal is full. Nedullary index, $16 \%$.

Structure.-The section is inregular in shape and is composed of a background of lamellæ, in which are irregularly shaped Haversian systems with senile changes.

Type I-III, C, senile. 
LEFT FEMUR OF A WHITE MALE. NO. 152, MED. DEPT. NORTHWESTERN UNIV.

PL. 33, Fig. 412. Syn. Tab. XI

Antero-posterior diameter of bone, $26 \mathrm{~mm}$. ; lateral, $37 \mathrm{~mm}$.

Antero-posterior diameter of medullary canal, $14 \mathrm{~mm}$.; lateral, $16 \mathrm{~mm}$.

The medullary canal is full. Medullary index, $30 \%$.

Structure.-The section is the first portion of a double femur. The original femur (fig. 412B) is composed of Haversian systems almost entirely. In the posterior wall they are separated by short lamellæ with oval lacunæ. Many senile changes occur. In some systems the Haversian canals have increased in diameter to such an extent that only a narrow rim of bone remains. Around the medullary canal are large spaces. The lacunæ of the systems are of the oval type and not very numerous. The external and internal circumferential lamellæ appear in fragments. Between the original and accessory growth is a concentric series of spaces partly surrounded by enclosing lamellæ. A sharp line appears between the two bones (fig. 412C). The accessory bone is composed of a background of lamella in which are Haversian systems of the ( $\mathrm{Ib}$ ) differentiation and numerous radiating canals. The inter-Haversian lamellæ with oval lacunæ predominate. Many of the systems are senile. The external circumferential lamellæ are fragmentary. The accessory portion shows an earlier development than the original bone by its predominating lamellæ and relatively few Haversian systems.

Type I-III, Ib, C, senile.

LEFT FEMUR OF A WHTTE MALE. NO. 152, MED. DEPT. NORTHWESTERN UNIV.

Pl. 33, Flg. 413. Syn. Tab. XI

Antero-posterior diameter of original bone, $27 \mathrm{~mm}$.; lateral, $25 \mathrm{~mm}$.

Antero-posterior diameter of medullary canal of original bone, $16 \mathrm{~mm}$; lateral, $17 \mathrm{~mm}$.

The medullary canal is full. Medullary index, $67 \%$.

Antero-posterior diameter of accessory bone, $23 \mathrm{~mm}$; lateral, $18 \mathrm{~mm}$.

Antero-posterior diameter of accessory medullary canal, $10 \mathrm{~mm}$; lateral, $10 \mathrm{~mm}$.

The medullary canal is full. Medullary index, $31 \%$.

Antero-posterior diameter of the whole bone, $25 \mathrm{~mm}$. ; lateral, $45 \mathrm{~mm}$.

The section was taken $33 \mathrm{~mm}$. below figure 412 .

Structure.-In this section the accessory development has formed an additional femur. The original bone is composed of Haversian systems for the most part, but their senile changes are markedly increased (fig. 413B). The accessory bone is composed of lamellæ with oval lacunæ, interrupted by numer- 
ous Haversian systems of the ( $\mathrm{Ib}$ ) differentiation. The two bones are separated by a narrow partition of cancellous bone (fig. 413C). Internal and external circumferential lamellæ in both bones are fragmentary.

Type I-III, Ib, C, senile.

LEFT FEMUR OF A WHITE FEMALE. No. 164, MED. DEPT. NORTHWESTERN UNIV.

Pl. 33, Fig. 414. Syn. Tab. XI

Antero-posterior diameter of bone, $28 \mathrm{~mm}$; lateral, $27.5 \mathrm{~mm}$.

Antero-posterior diameter of medullary canal, $20 \mathrm{~mm}$; lateral, $20 \mathrm{~mm}$.

The medullary canal is full. Medullary index, $55 \%$.

Structure.-The external circumferential lamellæ appear only in short fragments. The central ring is composed of large and small, irregularly shaped Haversian systems in a background of lamellæ which extends around the bone. The systems are generally senile. The wall of the bone is thin. The anterior and inner wall is nearly half destroyed by senile losses.

Internal circumferential lamellæ occur in fragments.

Type I-III, C, senile.

LEFT FEMUR OF A WHITE FEMALE. NO. 166, MED. DEPT. NORTHWESTERN UNIV.

PL. 33, Fig. 415. Syn. Tab. XI

Antero-posterior diameter of bone, $26.5 \mathrm{~mm}$; lateral, $26 \mathrm{~mm}$.

Antero-posterior diameter of medullary canal, $14 \mathrm{~mm}$; lateral, $13 \mathrm{~mm}$.

The medullary canal is full. Medullary index, $34 \%$.

Structure.-Beginning on both sides of the posterior ridge and extending around the lateral wall are two bands of lamellæ, incompletely separated into laminæ and interrupted by Haversian systems. The band disappears entirely in the anterior and antero-lateral wall. The external surface of the posterior ridge shows many large, oval lacunæ between the Haversian systems. The central ring is composed of Haversian systems, large and small, with considerable inter-Haversian lamellæ. The systems show many senile changes. The internal circumferential lamellæ are fragmentary.

Type I-III, C, senile.

Right femur of a white male (Suicide), age 22. No. 175, CR. Med. Coll.

$$
\text { PL. 33, Fig. 416. Syn. Tab. XI }
$$

Antero-posterior diameter of bone, $27 \mathrm{~mm}$. lateral, $29 \mathrm{~mm}$.

Antero-posterior diameter of medullary canal, $14 \mathrm{~mm}$. ; lateral, $19 \mathrm{~mm}$.

The medullary canal is full. Medullary index, 53\%. 
Structure.-The section is surrounded by a band of lamellæ and laminæ. In the anterior and inner wall the band is lamellar and perforated by numerous canals of the (Ia) differentiation. In the outer and posterior wall the band is laminar and interrupted by elongated Haversian systems of the (Ib) formation.

The central ring is irregular. In the outer wall it is thick and composed of well developed Haversian systems; in the antero-inner lateral wall it is thin; and in the posterior inner lateral it is almost entirely absent.

Internal circumferential lamellæ form a narrow cancellous ring around the medullary canal. The lamellæ are separated into laminæ in the inner wall.

Type I-II-III, Ta, Ib, C.

LefT FeMUR OF A White MALe. No. 98, CR. Med. COLL.

PL. 33, FIG. 41\%. SYN. TAB. XI

Antero-posterior diameter of bone, $30 \mathrm{~mm}$.; lateral, $30 \mathrm{~mm}$.

Antero-posterior diameter of medullary canal, $17 \mathrm{~mm}$.; lateral, $15 \mathrm{~mm}$.

The medullary canal is full. Medullary index, $39 \%$.

Structure.-External circumferential lamellæ and laminæ surround the section. In the inner wall are two rows of elongated Haversian systems extending in a concentric direction from the external laminæ to the medullary surface of the anterior wall. The central ring of Haversian systems constitutes almost the entire thickness of the wall of the bone. The inner wall shows the borders of a wide external crescent composed of very much flattened Haversian systems.

The Haversian systems are large, small, and irregular in shape. Nearly one-half of them in the outer and a few in the inner wall show senile changes. The various stages of senility are well marked in this bone. In the early stage the lamellæ of the Haversian systems are prominent. The organic portion of the lamellæ seems to separate from the inorganic and the mineral salts begin to appear as granules in the lamellæ around the Haversian canals. In this stage the systems appear brown with sharply defined lamelle. In the next stage the mineral deposit is heavy and the systems are black. Here and there a system can be seen in the last stage. The lamellæ around the Haversian canal are absorbed and little by little the Haversian canal widens until a narrow black ring is all that remains of the system, or the entire system disappears. The inorganic salts are deposited in the Haversian canals (pl. 34, figs. 424-426). After this manner the bone becomes light and the walls become thin as the process extends outward from the medullary canal. The internal circumferential lamellæ appear in fragments.

Type I-II-III, C, senile. 
LEFT FEMUR OF A WHITE MALE. NO. 91, CR. MED. COLL,

PL. 33, Fig. 418. Syn. TAB. XI

Antero-posterior diameter of bone, $30 \mathrm{~mm}$; lateral, $27 \mathrm{~mm}$.

Antero-posterior diameter of medullary canal, $17 \mathrm{~mm}$; lateral, $13 \mathrm{~mm}$.

The medullary canal is full. Medullary index, $39 \%$.

Structure.-External circumferential lamellæ surround the section, excepting the posterior ridge. The central ring is composed of Haversian systems with the remains of a laminar horseshoe in the posterior lateral wall. No senile changes are found.

The internal circumferential lamellæ form a narrow ring around the medullary canal.

Type I-II-III, C.

FEMUR OF AN AUSTRALian. NO. 227420, U. S. NAT. MUS.

PL. 34, Fig. 419. SxN. TAB. XI

Antero-posterior diameter of bone, $28 \mathrm{~mm}$.; lateral, $23 \mathrm{~mm}$.

Antero-posterior diameter of medullary canal, $12 \mathrm{~mm}$; lateral, $11 \mathrm{~mm}$.

The medullary canal is full. Medullary index, $25 \%$.

Structure.-The external circumferential lamella enclose the bone, excepting the anterior wall and posterior ridge. Beginning on either side of the posterior ridge and extending around the lateral to the anterior wall are two wide bands composed of lamellæ and elongated Haversian systems, arranged in concentric rows. Their long diameters are parallel to the external surface of the bone. As the bands approach the anterior wall they are displaced by Haversian systems, which form the whole width of the wall. These bands are the remains of the horseshoe.

The anterior wall and posterior ridge are composed entirely of Haversian systems. The lacunæ are oval and narrow. The internal circumferential lamellæ form a broken narrow ring around the medullary canal.

Type I-III, C.

LEFT FEMUR OF A WHite MALE. NO. 94, CR. MED. COLL.

PL. 34, Fig. 420. SYN. TAB. XI

Antero-posterior diameter of bone, $30 \mathrm{~mm}$; lateral, $29 \mathrm{~mm}$.

Antero-posterior diameter of medullary canal, $17 \mathrm{~mm}$; lateral, $14 \mathrm{~mm}$.

The medullary canal is full. Medullary index, $38 \%$.

Structure.--External circumferential lamellæ form a narrow ring around the section. Beginning on both sides of the posterior ridge and extending around the lateral wall are wide bands of elongated and well developed Ha- 
versian systems with considerable inter-Haversian lamellæ. As the band of the inner wall approaches the anterior it is entirely displaced by Haversian systems, while the band of the outer wall is displaced about the mid-lateral region. The central ring, therefore, is irregular in shape and position. It is composed of well developed Haversian systems.

The internal eircumferential lamellæ form a narrow ring around the medullary canal.

Type I-III, C.

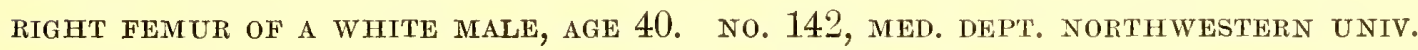

$$
\text { PL. 34, Fig. 421. Syn. Tab. XI }
$$

Antero-posterior diameter of bone, $30 \mathrm{~mm}$; lateral, $27.5 \mathrm{~mm}$.

Antero-posterior diameter of medullary canal, $13 \mathrm{~mm}$.; lateral, $11.5 \mathrm{~mm}$.

The medullary canal is full. Medullary index, $22 \%$.

Structure.-Beginning on both sides of the posterior ridge and extending around the section is an enclosing band of varying widths composed of lamellæ, interrupted by small Haversian systems of the (Ia) differentiation. The band is widest in the outer and anterior wall.

Underneath this band is a wide central ring of well developed Haversian systems. They vary in size and present some senile changes around the medullary canal.

The internal circumferential lamellæ form a narrow ring around the medullary canal. The bone units are well developed.

Type I-III, Ia, C, senile.

FIAVERSIAN SYSTEMS SHOWING STAGES OF SENILITY

PL. 34, FIGS. 423-24-25-26

These systems were taken from figure 417 and enlarged. Figure 423 shows an Haversian system before senile changes are visible. It is composed of a number of concentric lamellæ with serrated edges united by cement. The lacunx are long and narrow and are situated either between the lamellæ or within them. There does not seem to be any regularity in the arrangement.

Figure 424 shows an early stage of senility. In this Haversian system there is a deposit of opaque granules in the lamellæ around the Haversian canal. The density of the granules diminishes from the eanal toward the periphery.

Figure 425 shows a later stage. The density has inereased and expanded. The central lamellæ have dropped out and the Haversian canal is larger. The whole system is more or less involved. In the external portion the granules are brown and the lamellæ are somewhat dim. The central ring is black. 
Figure 426 shows the last stage. The lamellæ have nearly all disappeared, and a narrow black ring only remains. The Haversian canal is large and irregular in shape. The medullary canal is very much increased in size and the bone is light in weight.

Senile changes are more frequent around the medullary canal than elsewhere, although they may occur in any part of the bone.

As the lamellæ around the Haversian canals become more and more opaque with inorganic salts they gradually disintegrate, the inorganic matter enters the blood vessels and is carried into the general circulation to be removed from the body or deposited in the degenerating wall of blood vessels.

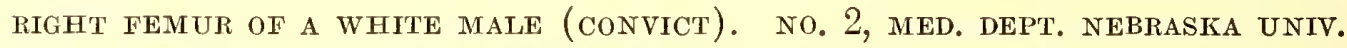

PL. 35, Fig. 428. Syn. Tab. XI

Antero-posterior diameter of bone, $32 \mathrm{~mm}$. ; lateral, $27.5 \mathrm{~mm}$.

Antero-posterior diameter of medullary canal, $15 \mathrm{~mm}$; lateral, $10 \mathrm{~mm}$.

The medullary canal is full. Medullary index, $21 \%$.

Structure.-A narrow band of external circumferential lamellæ surrounds the section.

The central ring is composed of large, small, and variously shaped Haversian systems with relatively small Haversian canals. On account of the small canals the Haversian systems have thick walls. Many of the canals are situated eccentrically. Scattered throughout the wall of the section are many Haversian systems in various stages of senility. In some, the two or three lamellæ around the Haversian canal are involved; in others, half of the system is senile; and in others, the whole system is black with mineral precipitation. In the posterior inner wall a few elliptical Haversian systems occur.

Internal circumferential lamellæ surround the medullary canal. The lacunæ of the section are generally oval.

Type III, C, senile.

right femur of a white male (CONvict). No. 3, med. Dept. nebraska univ.

PL. 35, FIG. 429. Syn. TAB. XI

Antero-posterior diameter of bone, $26.5 \mathrm{~mm}$; lateral, $25 \mathrm{~mm}$.

Antero-posterior diameter of medullary canal, $15 \mathrm{~mm}$; lateral, $12 \mathrm{~mm}$.

The medullary canal is full. Medullary index, $39 \%$.

Structure.-The external circumferential lamellæ are fragmentary. The central ring is composed of variously shaped, large and small Haversian systems with no inter-Haversian lamellæ. Some of the systems are well developed; some have small Haversian canals; some show early stages of senility; some 
later; and some the latest. The lacunæ are generally oval. A narrow ring of internal circumferential lamellæ surrounds the medullary canal.

Type III, C, senile.

* Left femur of a iWhite male, age 50. No. 268, Cr. Med. Coll.

SYN. TAB. XI

Antero-posterior diameter of bone, $30 \mathrm{~mm}$. lateral, $30 \mathrm{~mm}$.

Antero-posterior diameter of medullary canal, $13 \mathrm{~mm}$.; lateral, $12 \mathrm{~mm}$.

Medullary index, $21 \%$.

Structure.-The external circumferential lamellæ are fragmentary. The section is composed almost entirely of small, large, and irregularly shaped Haversian systems and a small amount of inter-Haversian lamellæ. In the vicinity of the medullary canal many of the systems are senile. The internal circumferential lamellæ are fragmentary.

Type III, C, senile.

* right femur of a white male. No. 269, CR. med. Coll.

SyN. TAB. XI

Antero-posterior diameter of bone, $29 \mathrm{~mm}$. ; lateral, $33.5 \mathrm{~mm}$.

Antero-posterior diameter of medullary eanal, $17 \mathrm{~mm}$; lateral, $20 \mathrm{~mm}$.

Medullary index, $54 \%$.

Structure.-A wide background of lamellæ, enclosing Haversian canals and small Haversian systems, forms the external half of the anterior wall and is mostly displaced by Haversian systems as it extends around the lateral wall to the posterior ridge. The systems vary in size and shape and many show senile changes. There is a scarcity of communicating cross canals.

In the inner wall a short, fan-shaped band of laminæ, interrupted by small Haversian systems, extends from the medullary surface of the posterior ridge outward. This has been observed in a number of femora, but not in all. Its significance is not clear.

The internal circumferential lamellæ form a very narrow fragmentary ring around the medullary canal.

Type I-II-III, Ia, C, senile.

* right femur of a white male. No. 270, Cr. med. Coll.

Syn. Tab. XI

Antero-posterior diameter of bone, $31 \mathrm{~mm}$; lateral, $25 \mathrm{~mm}$.

Antero-posterior diameter of medullary canal, $14 \mathrm{~mm}$. ; lateral, $13 \mathrm{~mm}$.

Medullary index, 29\%. The section is almost quadrangular in shape. 
Structure.-The external circumferential lamellæ are fragmentary. The section is composed, for the most part, of well developed Haversian systems with very little inter-Haversian bone substance. Many of the systems are senile. The cross canals are fairly numerous.

The internal circumferential lamellæ form a very narrow ring around the medullary canal.

Type III, C, senile.

* right femur of a white male. No. 271, Cr. med. coll.

Syn. TAB. XI

Antero-posterior diameter of bone, $31 \mathrm{~mm}$; lateral, $32 \mathrm{~mm}$.

Antero-posterior diameter of medullary canal, $17 \mathrm{~mm}$; lateral, $15 \mathrm{~mm}$.

Medullary index, $35 \%$.

Structure.-The external circumferential lamellæ form a narrow ring around the bone.

The section is composed almost entirely of large, small, and irregularly shaped Haversian systems. Their lacunæ are generally oval. The cross canals are not numerous. Senile changes are few.

The internal circumferential lamellæ form a narrow ring around the medullary canal.

Type III, C.

* right femur of a white male. No. 272, cr. med. coll.

SYN. TAB. XI

Antero-posterior diameter of bone, $33 \mathrm{~mm}$; lateral, $28 \mathrm{~mm}$.

Antero-posterior diameter of medullary canal, $27 \mathrm{~mm}$; lateral, $25 \mathrm{~mm}$.

Medullary index, 26\%.

Structure.-The external circumferential lamellæ appear as rather wide bands on both sides of the posterior ridge. These bands are interrupted by small Haversian systems and become narrower as they approach the anterior wall where they are fragmentary. The remainder of the section is composed of Haversian systems with oval and long lacunæ.

The internal circumferential lamellæ form a narrow ring around the medullary canal.

Type III, C.

* Right femur of a white male. No. 273, Cr. med. coll.

Str. TAв. XI

Antero-posterior diameter of bone, $28 \mathrm{~mm}$; lateral, $29 \mathrm{~mm}$.

Antero-posterior diameter of medullary canal, $15 \mathrm{~mm}$; lateral, $12 \mathrm{~mm}$.

Medullary index, 29\%. 
Structure.-The external circumferential lamellæ form a complete narrow ring around the bone. The section is composed of well developed Haversian systems closely packed together. Some are large, some small, and some are irregular. Senile changes are frequent.

The internal circumferential lamella enclose the medullary canal.

Type III, C, senile.

Right FeMUR OF A WHITE MALE. No. 274, CR. MEd. COLL.

Pl. 35, Fig. 436. Syn. Tab. XI

Antero-posterior diameter of bone, $30 \mathrm{~mm}$.; lateral, $35 \mathrm{~mm}$.

Antero-posterior diameter of medullary canal, $15 \mathrm{~nm}$.; lateral, $16 \mathrm{~mm}$.

Medullary index, $30 \%$.

Structure.-The external circumferential lamellæ are fragmentary. The rest of the section is composed almost entirely of Haversian systems, many of which are large in size and have large, irregularly shaped Haversian canals. They are more numerous around the medullary canal than elsewhere. They give to the section a general porous appearance when observed with the naked eye.

The internal circumferential lamellie form a narrow ring around the medullary canal.

Type III, C, senile.

RIGHT FEMUR OF A WHITE MALE. NO. 275, CR. MED. COLL.

PL. 35, Fig. 43\%. SYn. TAB. XI

Antero-posterior diameter of bone, $30 \mathrm{~mm}$.; lateral, $27 \mathrm{~mm}$.

Antero-posterior diameter of medullary canal, $19 \mathrm{~nm}$.; lateral, $14 \mathrm{~mm}$.

The medullary canal is full. Medullary index, $50 \%$.

Structure.-The section is surrounded by a wide band of lamellæ, interrupted by numerous Haversian systems of the (Ta) and (C) differentiations. The central ring, about equal in width to the external lamellar band, is composed of well developed Haversian systems, many of which are senile.

A narrow ring of internal lamellæ surrounds the medullary canal.

Type I-III, Ia, C, senile.

* LEFT FEMUR OF A WHITE MALE. NO. 276, CR. MED. COLL.

$$
\text { SYN. TAB. XI }
$$

Antero-posterior diameter of bone, $28 \mathrm{~mm}$; lateral, $33.5 \mathrm{~mm}$.

Antero-posterior diameter of medullary canal, $26 \mathrm{~mm}$; ; lateral, $17.5 \mathrm{~mm}$.

Medullary index, $100 \%$. 
Structure.-The external circumferential lamellæ form a narrow ring around the bone.

The section is composed of Haversian systems, which, in the anterior wall, are separated by the fragments of a lamellar horseshoe band described elsewhere. Many systems are senile.

The internal circumferential lamellæ form a narrow ring around the medullary canal.

Type III, C, senile.

RIGHT FEMUR OF A WHite MALE. NO. 277, CR. MED. COLL.

Pl. 35, FIG. 439. Srn. Tab. XI

Antero-posterior diameter of bone, $32 \mathrm{~mm}$; lateral, $28 \mathrm{~mm}$.

Antero-posterior diameter of medullary canal, $17 \mathrm{~mm}$.; lateral, $11 \mathrm{~mm}$.

The medullary canal is full. Medullary index, $28 \%$.

Structure--External circumferential lamellæ, interrupted by many Haversian systems, surround the section. The central ring, irregular in widtl, is composed of Haversian systems, somewhat irregular in shape, but well developed. The internal circumferential lamellæ, expanded into a wide semicircular area in the inner wall, surround the medullary canal.

Type I-III, C.

* right femur of a white male. No. 278, Cr. med. coll.

$$
\text { Syn. TAB. XI }
$$

Antero-posterior diameter of bone, $29 \mathrm{~mm}$; lateral, $34 \mathrm{~mm}$.

Antero-posterior diameter of medullary canal, $17 \mathrm{~mm}$.; lateral, $15 \mathrm{~mm}$.

Medullary index, $35 \%$.

Structure.-The external circumferential lamellæ are fragmentary. The section is composed almost entirely of large, small, and irregularly shaped Haversian systems.

The internal circumferential lamellæ form a narrow enclosing ring around the medullary canal.

Type III, C.

* Right FEMUr OF A White MaLe. NO. 279, CR. MEd. COLL.

SYN. TAB. XI

Antero-posterior diameter of bone, $30 \mathrm{~mm}$.; lateral, $27 \mathrm{~mm}$.

Antero-posterior diameter of medullary canal, $16 \mathrm{~mm}$; lateral, $14 \mathrm{~mm}$.

Medullary index, 38\%.

Structure.--The external circumferential lamellæ are fragmentary. The section is composed almost entirely of large, small, and irregular Haversian 
systems, between which are some areas of short lamellæ. The lacunæ are oval; senile changes are frequent. The internal circumferential lamellæ are fragmentary.

Type III, C, senile.

* right femur of a white male. No. 280, Cr. med. Coll.

SYN. TAB. XI

Antero-posterior diameter of bone, $30 \mathrm{~mm}$. ; lateral, $24.5 \mathrm{~mm}$.

Antero-posterior diameter of medullary canal, $15 \mathrm{~mm}$.; lateral, $11 \mathrm{~mm}$.

Medullary index, 29\%.

Structure.-The external circumferential lamellæ form a narrow ring around the bone. The section is mostly composed of well developed Haversian systems with little inter-Haversian bone substance.

The internal circumferential lamellæ surround the medullary canal.

Type III, C.

* Left femur of a white male. No. 281, Cr. med. Coll.

SYN. TAB. XI

Antero-posterior diameter of bone, $31 \mathrm{~mm}$; lateral, $27 \mathrm{~mm}$.

Antero-posterior diameter of medullary canal, $13 \mathrm{~mm}$; lateral, $10 \mathrm{~mm}$.

Medullary index, $19 \%$.

Structure.-The external circumferential lamellæ are fragmentary. The section is composed of large, small, and irregularly shaped Haversian systems, some of which show senile changes.

The internal circumferential lamellæ form a narrow ring around the medullary canal.

Type III, C, senile.

* Right fEMUR of a WHite maLe. No. 282, CR. MEd. COLL.

SyN. TAB. XI

Antero-posterior diameter of bone, $30 \mathrm{~mm}$. ; lateral, $31.5 \mathrm{~mm}$.

Antero-posterior diameter of medullary canal, $16 \mathrm{~mm}$; lateral, $13.5 \mathrm{~mm}$.

Medullary index, $30 \%$.

Structure.-The external circumferential lamellæ are fragmentary. The section is composed of well developed, closely arranged Haversian systems. As a rule, they are clearly distinct, but some of them are senile and obscure.

The internal circumferential lamellæ are fragmentary.

Type III, C, senile. 
RIGHT FEMUR OF A WHITE MALE. NO. 284, CR. MED. COLL.

Pl. 35, Fig. 445. Syn. Tab. XI

Antero-posterior diameter of bone, $26.5 \mathrm{~mm}$; lateral, $26 \mathrm{~mm}$.

Antero-posterior diameter of medullary canal, $13 \mathrm{~mm}$. ; lateral, $12.5 \mathrm{~mm}$.

The medullary canal is full. Medullary index, $31 \%$.

Structure.-Beginning on both sides of the posterior ridge and surrounding the section is a wide horseshoe of crude laminæ and lamellæ, frequently interrupted by Haversian systems of the (Ia) and (C) differentiations. The horseshoe forms half of the outer, nearly all of the anterior, and a third of the inner wall. The Haversian systems have, generally, concentric positions. The canals separating the laminæ are short. In the inner posterior wall is a fanshaped area of laminæ, interrupted by a few Haversian systems. The remainder of the central ring, of which the fan is a part, is composed of Haversian systems with some senile changes. In the outer wall it has some inter-Haversian lamellæ. The posterior ridge is composed of Haversian systems.

A narrow ring of internal circumferential lamellæ surrounds the medullary canal.

Type I-II-III, Ia, C, senile.

This femur is characterized by units of low differentiations. Only a small portion of it is composed of well developed Haversian systems.

* Right hemur of a white male. No. 285, CR. Med. Coll.

Syn. TAB, XI

Antero-posterior diameter of bone, $29 \mathrm{~mm}$.; lateral, $28 \mathrm{~mm}$.

Antero-posterior diameter of medullary canal, $15 \mathrm{~mm}$.; lateral, $14 \mathrm{~mm}$.

The medullary canal is full. Medullary index, $35 \%$.

Structure.-The external circumferential lamellæ are fragmentary. The central ring constitutes nearly all of the section and is composed of Haversian systems with some inter-Haversian lamellæ. Many senile changes occur around the medullary canal. Internal circumferential lamellæ surround the medullary canal.

Type III, C, senile.

* Right FEMUr of a White MALE. No. 286, CR. MEd. COLL.

SYN. TAB. XI

Antero-posterior diameter of bone, $32 \mathrm{~mm}$. ; lateral, $27.5 \mathrm{~mm}$.

Antero-posterior diameter of medullary canal, $17 \mathrm{~mm}$; lateral, $14 \mathrm{~mm}$.

The medullary canal is full. Medullary index, $36 \%$. 
Structure.-The external circumferential lamellæ are fragmentary. The central ring constitutes nearly all of the section and is composed of Haversian systems exhibiting many senile changes.

Internal circumferential lamellæ surround the medullary canal.

Type III, C, senile.

* Right feMur of a WHite male. No. 287, CR. MEd. Coll.

Syn. TAB. XI

Antero-posterior diameter of bone, $25 \mathrm{~mm}$.; lateral, $25 \mathrm{~mm}$.

Antero-posterior diameter of medullary canal, $12 \mathrm{~mm}$; lateral, $9 \mathrm{~mm}$.

The medullary canal is full. Medullary index, $21 \%$.

Structure.-Around the outer and anterior wall is a wide band of lamellæ, interrupted by Haversian systems of the (Ta) differentiation. The band is displaced in the inner wall by Haversian systems. The central ring constitutes all of the inner wall, the posterior ridge, two-thirds of the outer and one-third of the anterior wall. It is composed of Haversian systems of the (C) differentiation, large and small, separated in the outer wall by wide inter-Haversian lamellæ. Some senile changes ocur. The internal circumferential lamellæ form a narrow ring around the medullary canal.

Type I-III, Ia, C, senile.

* Right femur of a white male. No. 288, CR. MEd. Coll.

$$
\text { Syn. TAB. XI }
$$

Antero-posterior diameter of bone, $30 \mathrm{~mm}$; lateral, $31 \mathrm{~mm}$.

Antero-posterior diameter of medullary canal, $17 \mathrm{~mm}$.; lateral, $15 \mathrm{~mm}$.

The medullary canal is full. Medullary index, $38 \%$.

Structure.-A narrow ring of external circumferential lamellæ surrounds the section.

The central ring constitutes nearly all of the bone and is composed of $\mathrm{Ha}$ versian systems, many of which are senile. The systems are united by cross canals.

A narrow ring of internal circumferential lamellæ surrounds the medullary canal.

Type III, C, senile.

RIGHT FEMUR OF A WHITE MALE. NO. 289, CR. MEd. COLL.

Pl. 35, FIg. 451. Syn. Tab. XI

Antero-posterior diameter of bone, $30 \mathrm{~mm}$; lateral, $33 \mathrm{~mm}$.

Antero-posterior diameter of medullary canal, $14 \mathrm{~mm}$; lateral, $15 \mathrm{~mm}$.

The medullary canal is full. Medullary index, $27 \%$. 
Structure.-The external circumferential lamellæ, separated into short laminæ and interrupted by many Haversian systems, surround the section. The central ring blends with the external and internal rings and is composed of Haversian systems and lamellæ.

The internal circumferential lamellæ, expanding into a semicircular laminar area in the inner wall, surround the medullary canal.

Type I-II-III, C.

LEFT FEMUR OF A WHITE MALE. NO. 296, CR. MED. COLL.

PL. 35, Fig. 452. Syn. Tab. XI

Antero-posterior diameter of bone, $27.5 \mathrm{~mm}$; lateral, $23 \mathrm{~mm}$.

Antero-posterior diameter of medullary canal, $12 \mathrm{~mm}$.; lateral, $10 \mathrm{~mm}$.

The medullary canal is full. Medullary index, $23 \%$.

Structure.-A horseshoe band of lamellæ, frequently interrupted by complete and crude Haversian systems of the (Ia) differentiation, surrounds the section. It is widest in the anterior wall. The lacunæ are round, oval, long, and narrow.

The central ring, irregular in shape, is composed of well developed Haversian systems and forms the entire thickness of the posterior wall. The lacunæ are oval. The systems are united by many cross canals.

Internal circumferential lamellæ form a narrow ring around the medullary canal with the exception of the posterior wall. In the anterior wall it becomes cancellous.

Type I-III, Ia, C.

LEFT FEMUR OF A WHITE MALE, AGE 40. NO. 1, NEBraska STATE Hospital

PL. 35, Fig. 453. Syn. Tab. XI

Case of idiopathic epilepsy. Patient had 20 convulsions the day of his death.

Antero-posterior diameter of bone, $27 \mathrm{~mm}$; lateral, $22 \mathrm{~mm}$.

Antero-posterior diameter of medullary canal, $24 \mathrm{~mm}$; lateral, $18 \mathrm{~mm}$.

Medullary index, $277 \%$.

General character of the bone.-The femur was small in size. With the exception of a surrounding shell of bone from $1 \mathrm{~mm}$. to $2 \mathrm{~mm}$. thick, the entire medullary portion had suffered an extensive softening and the bone structure had disappeared.

Structure.-The external circumferential lamellæ were fragmentary. Quite large canals penetrated the bone from the periosteum. 
The central ring was composed of large, small, and irregularly shaped Haversian systems and inter-Haversian lamellæ. In some systems the Haversian canals were very large and irregular, and in the others they were normal in size. The lacunæ were oval. In some portions of the section, large, irregularly shaped spaces were present. The internal circumferential lamellæ formed a narrow ring around the medullary canal.

Type III, C.

\section{HISTOLOGICAL EXAMINATION OF TWO ENTIRE HUMAN FEMORA}

1. Left Fenur, 41 Cir. Long, No. 300, Cr. Med. Coli.

This bone was cut into pieces $2.5 \mathrm{~cm}$. in length, and a cross-section of each piece was examined microscopically. The first section was made through the equatorial diameter of the head, the sccond through the middle of the neck, the third through the lesser trochanter, and the following scctions through the shaft and lower extremity.

HEAD

This section was a circle with a diameter of $44 \mathrm{~mm}$. It was surrounded by an enclosing envelope of bone $0.5 \mathrm{~mm}$. in thickness and composed of lamellæ with round and oval lacunæ and rather infrequent canaliculi.

The remainder of the section was made up of cancellous bonc, the meshes of which were filled with marrow. In the central portion of the section the cancellous bone was much heavier than clsewhere. The walls of the meshes were composed of lamellæ with oval and long lacunæ and radiated from the center toward the periphery. No Haversian systems were found.

NECK

Antero-posterior diameter of bone, $33 \mathrm{~mm}$; lateral, $27 \mathrm{~mm}$.

This section was surrounded by an envelope of bone, varying in thickness from $1 \mathrm{~mm}$. in the anterior to $3 \mathrm{~mm}$. in the posterior wall. It was composed of lamellæ with oval lacunæ and bushy canaliculi, interrupted by a few Haversian systems.

The remainder of the section was made up of canccllous bone, heavier in the posterior than it was in the anterior wall, and having a radiating direction from the posterior toward the anterior boundary of the section. The cancellous bone, as a whole, was considerably denser than it was in the head and was composed of lamellæ, interrupted by a few crude Haversian systems. 
Antero-posterior diameter of bone, $37 \mathrm{~mm}$.; lateral, $28 \mathrm{~mm}$.

This section is surrounded by an envelope of bone, ranging in thickness from $1 \mathrm{~mm}$. in the posterior to $4 \mathrm{~mm}$. in the outer, $2.5 \mathrm{~mm}$. in the anterior and $5 \mathrm{~mm}$. in the inner wall.

From the inner wall the calcar femorale, an extension inward of the surrounding envelope, gradually separated into cancellous bone which then merged into that occupying the whole central portion of the section.

Structure.-The envelope was composed of indistinctly lamellated bone with diffusely arranged lacunæ and bushy canaliculi, interrupted by crude Haversian systems. The walls of the cancellous meshes were composed of lamellæ without Haversian systems.

\section{FOURTH SECTION}

Antero-posterior diameter of bone, $33 \mathrm{~mm}$. lateral, $28 \mathrm{~mm}$.

Antero-posterior diameter of medullary canal, $19 \mathrm{~mm}$.; lateral, $19 \mathrm{~mm}$.

Medullary index, $67 \%$.

Structure.-With the exception of the posterior ridge this section was surrounded by a wide horseshoe-shaped background of lamellæ, forming half of the thickness of the entire wall of the bone, and containing many Haversian systems of the (Ia) and (C) differentiations.

The posterior ridge was composed of Haversian systems, between which were lamellæ with many large, oval lacunæ and bushy canaliculi. The central ring was narrow and composed of Haversian systems with some inter-Haversian lamelle. Many of the Haversian systems were senile. A narrow ring of internal circumferential lamellæ surrounded the medullary canal.

\section{FIFTH SECTION}

Antero-posterior diameter of bone, $31 \mathrm{~mm}$; lateral, $31 \mathrm{~mm}$.

Antero-posterior diameter of medullary canal, $15 \mathrm{~mm}$.; lateral, $14 \mathrm{~mm}$.

Medullary index, $28 \%$.

\section{SIXTH SECTION}

Antero-posterior diameter of bone, $28 \mathrm{~mm}$; lateral, $26 \mathrm{~mm}$.

Antero-posterior diameter of medullary canal, $13 \mathrm{~mm}$; lateral, $10 \mathrm{~mm}$.

Medullary index, $22 \%$.

SEVENTH SECTION

Antero-posterior diameter of bone, $28 \mathrm{~mm}$; lateral, $25 \mathrm{~mm}$.

Antero-posterior diameter of medullary canal, $13 \mathrm{~mm}$. lateral, $10 \mathrm{~mm}$.

Medullary index, 23\%. 
EIGHTH SECTION

Antero-posterior diameter of bone, $28 \mathrm{~mm}$; lateral, $26 \mathrm{~mm}$.

Antero-posterior diameter of medullary canal, $13 \mathrm{~mm}$.; lateral, $12 \mathrm{~mm}$.

Medullary index, $27 \%$.

NINTH SECTION

Antero-posterior diameter of bone, $28 \mathrm{~mm}$. ; lateral, $26 \mathrm{~mm}$.

Antero-posterior diameter of medullary canal, $15 \mathrm{~mm}$.; lateral, $14 \mathrm{~mm}$.

Medullary index, $36 \%$.

\section{TENTH SECTION}

Antero-posterior diameter of bone, $28 \mathrm{~mm}$; lateral, $27 \mathrm{~mm}$.

Antero-posterior diameter of medullary canal, $17 \mathrm{~mm}$; lateral, $17 \mathrm{~mm}$.

Medullary index, $62 \%$.

\section{ELEVENTH SECTION}

Antero-posterior diameter of bone, $30 \mathrm{~mm}$; lateral, $28 \mathrm{~mm}$.

Antero-posterior diameter of medullary canal, $21 \mathrm{~mm}$; lateral, $20 \mathrm{~mm}$.

Medullary index, $100 \%$.

\section{TWELFTH SECTION}

Antero-posterior diameter of bone, $31 \mathrm{~mm}$; lateral, $28 \mathrm{~mm}$.

Antero-posterior diameter of medullary canal, $24 \mathrm{~mm}$; lateral, $21 \mathrm{~mm}$.

Medullary index, $140 \%$.

Structure.-The above sections resembled in structure the fourth, a description of which is already given. There was, however, an increasing proportion of the lamellar background from the fourth to the twelfth section. Senile systems were numerous.

\section{THIRTEENTH SECTION}

Antero-posterior diameter of bone, $34 \mathrm{~mm}$; lateral, $30 \mathrm{~mm}$.

Structure.-The section is surrounded by a wide lamellar background in which are variously shaped Haversian systems. 'The remainder' of the section is cancellous.

FOURTEENTH SECTION

Antero-posterior diameter of bone, $30 \mathrm{~mm}$.; lateral, $40 \mathrm{~mm}$.

Structure.-The section is surrounded by lamelle with a few Haversian systems. The remainder of the section is cancellous. 
FIFTEENTH SECTION

Antero-posterior diameter of bone, $31 \mathrm{~mm}$.; lateral, $52 \mathrm{~mm}$.

Structure.-The section is surrounded by lamelle with a few Haversian systems. The remainder is cancellous.

The type of bone of this femur was I-III, C, senile. The characteristic units of structure were lamellæ.

2. Leff Femur of a White Femille, 38 Cm. Long. No. 301, Cr. Med. Coll.

Transverse sections were made at intervals of $2.5 \mathrm{~cm}$. and in the same situations as they were in femur No. 300.

HEAD

Antero-posterior diameter of the equatorial section, $41 \mathrm{~mm}$.; lateral, $41 \mathrm{~mm}$.

Structure.-The section was surrounded by a thin envelope of bone, $0.5 \mathrm{~mm}$. in thickness, and composed of lamellie with a few very crude Haversian systems. The remainder of the section was made up of cancellous bone much more dense in the central portion than elsewhere and composed of lamella. The walls of the meshes radiated from the central portion toward the periphery.

NECK

Antero-posterior diameter, $30 \mathrm{~mm}$. ; lateral, $27 \mathrm{~mm}$.

Structure.-The section was surrounded by an envelope of bone, varying in thickness from $3 \mathrm{~mm}$. in the posterior to $1 \mathrm{~mm}$. in the lateral wall. The enclosing envelope was composed of Haversian systems and some inter-Haversian lamellæ. The remainder of the section was made up of cancellous bone. denser near the posterior wall, and radiating from this location toward the periphery. It was considerably heavier than that of the head, and the walls of the meshes were composed of lamellæ with a few Haversian systems.

SECTION THROUGH THE LESSER TROCHANTER

Antero-posterior diameter, $34 \mathrm{~mm}$; lateral, $33 \mathrm{~mm}$.

Structure.-The section was surrounded by an envelope of bone, varying in thickness from $4 \mathrm{~mm}$. in the posterior to $1 \mathrm{~mm}$. in the lateral wall. It was composed chiefly of Haversian systems, between which were some inter-Havversian lamellæ. The calcar femorale was well marked and composed of lamellæ with many Haversian systems. The remainder of the section was made up of a heavy cancellous bone composed of lamellæ. 
FOURTH SECTION

Antero-posterior diameter of bone, $30 \mathrm{~mm}$; lateral, $27 \mathrm{~mm}$.

Antero-posterior diameter of medullary canal, $22 \mathrm{~mm}$; lateral, $18 \mathrm{~mm}$.

Medullary index, $97 \%$.

FIFTH SECTION

Antero-posterior diameter of bone, $29 \mathrm{~mm}$.; lateral, $25 \mathrm{~mm}$.

Antero-posterior diameter of medullary canal, $20 \mathrm{~mm}$; lateral, $15 \mathrm{~mm}$.

Medullary index, $72 \%$.

SIXTH SECTION

Antero-posterior diameter of bone, $27 \mathrm{~mm}$.; lateral, $24 \mathrm{~mm}$.

Antero-posterior diameter of medullary canal, $18 \mathrm{~mm}$; lateral, $13 \mathrm{~mm}$.

Medullary index, $58 \%$.

SEVENTH SECTION

Antero-posterior diameter of bone, $26 \mathrm{~mm}$; lateral, $24 \mathrm{~mm}$.

Antero-posterior diameter of medullary canal, $16 \mathrm{~mm}$; lateral, $13 \mathrm{~mm}$.

Medullary index, $50 \%$.

\section{EIGHTH SECTION}

Antero-posterior diameter of bone, $27 \mathrm{~mm}$. ; lateral, $24 \mathrm{~mm}$.

Antero-posterior diameter of medullary canal, $17 \mathrm{~mm}$.; lateral, $13 \mathrm{~mm}$.

Medullary index, $87 \%$.

As the foregoing five sections have practically the same minute structure one description will be sufficient for all.

Structure.-These sections were composed of small and large Haversian systems with a small amount of inter-Haversian lamellæ. Some of the systems are senile. The external and internal circumferential lamellæ were fragmentary. The cancellous bone disappeared at the seventh section.

\section{NINTH SECTION}

Antero-posterior diameter of bone, $27 \mathrm{~mm}$. lateral, $25 \mathrm{~mm}$.

Antero-posterior diameter of medullary canal, $17 \mathrm{~mm}$; lateral, $15 \mathrm{~mm}$.

Medullary index, $61 \%$.

\section{TENTH SECTION}

Antero-posterior diameter of bone, $27 \mathrm{~mm}$.; lateral, $25 \mathrm{~mm}$.

Antero-posterior diameter of medullary canal, $18 \mathrm{~mm}$.; lateral, $16 \mathrm{~mm}$.

Medullary index, $75 \%$. 
Antero-posterior diameter of bone, $32 \mathrm{~mm}$.; lateral, $30 \mathrm{~mm}$.

Antero-posterior diameter of medullary canal, $26 \mathrm{~mm}$; lateral, $21 \mathrm{~mm}$.

Medullary index, $69 \%$.

Structure of the ninth, tenth, and eleventh sections.-With the exception of the posterior ridges these sections were composed of an external horseshoeshaped band of lamellæ, which was wide in the anterior and very narrow in the lateral wall. The lamellar band was frequently interrupted by Haversian systems, some of which were senile. The central ring was composed of well devel. oped, small and large Haver'sian systems, some of which were senile. The internal circumferential lamelle were fragmentary.

The principal variations in these sections were seen in the appearance of the band of lamellie and reappearance of the cancellous bone.

TWELFTH SECTION

Antero-posterior diameter of bone, $33 \mathrm{~mm}$. lateral, $28 \mathrm{~mm}$.

Antero-posterior diameter of medullary canal, $20 \mathrm{~mm}$; lateral, $19 \mathrm{~mm}$.

Medullary index, $126 \%$.

\section{THIRTEEN'TH SECTION}

Antero-posterior diameter of bone, $27 \mathrm{~mm}$.; lateral, $36 \mathrm{~mm}$.

Cancellous.

\section{FOURTEENTH SECTION}

Antero-posterior diameter of bone, $28 \mathrm{~mm}$; lateral, $44 \mathrm{~mm}$.

Cancellous.

\section{FIFTEENTH SECTION}

Antero-posterior diameter of bone, $35 \mathrm{~mm}$.; lateral, $70 \mathrm{~mm}$.

Cancellous.

Structure of twelfth, thirteenth, fourteenth, and fifteenth sections.-These were composed of Haversian systems and some inter-Haversian lamellæ. The band of lamellæ was not present. The systems were small and large, and some were senile. The external circumferential lamellw were fragmentary and the internal were cancellous.

The type was III, C, senile. 


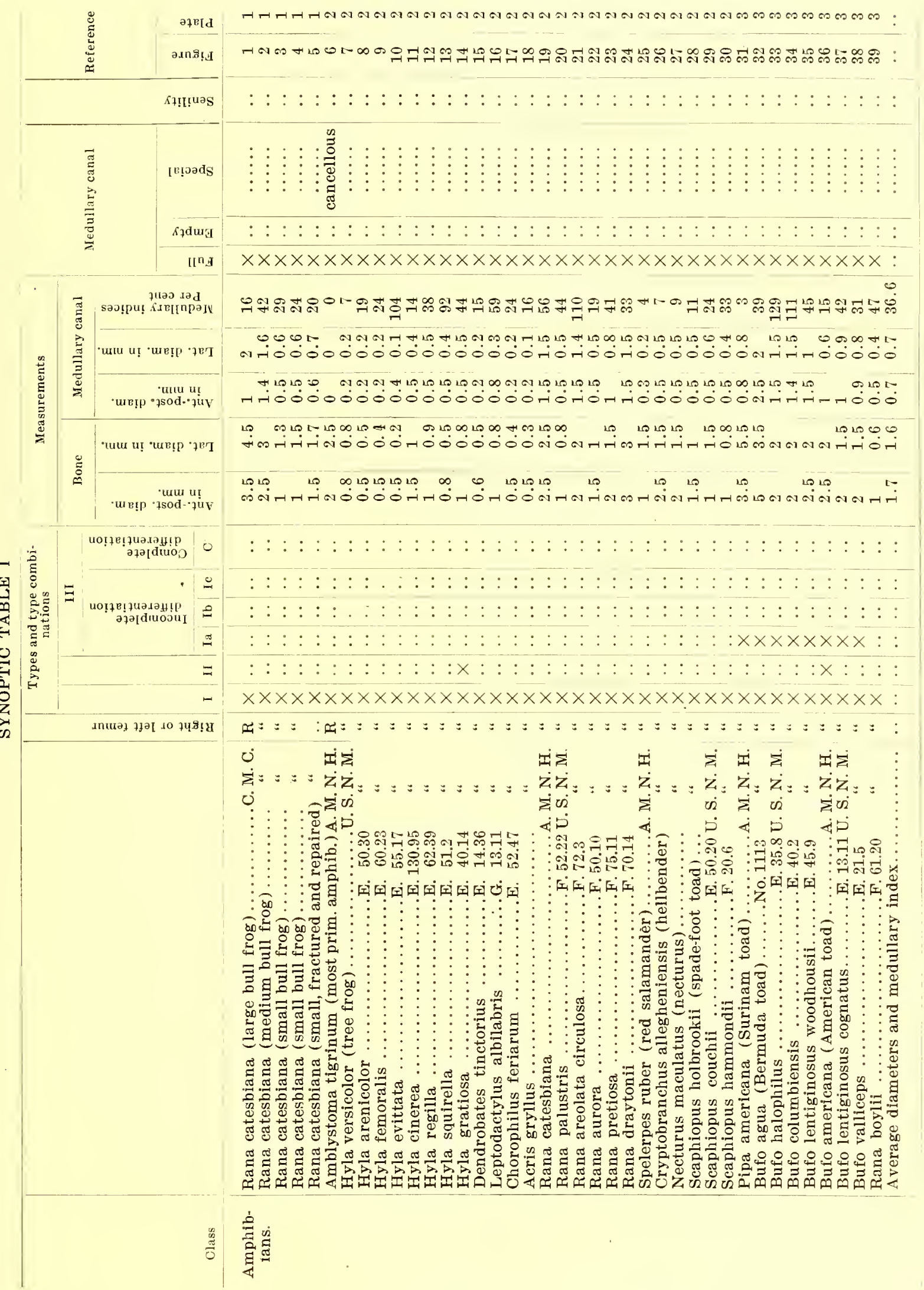




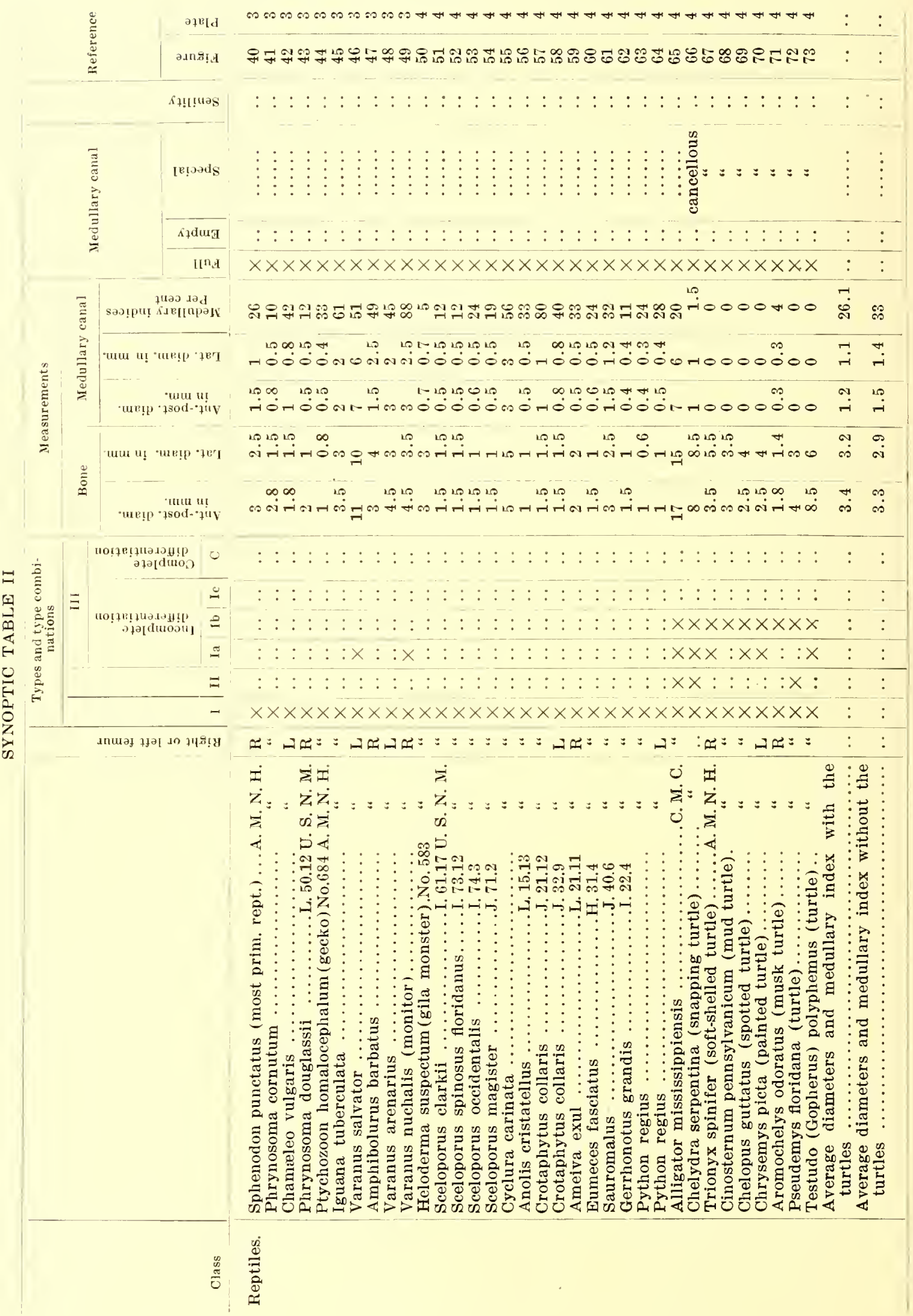


No. 3

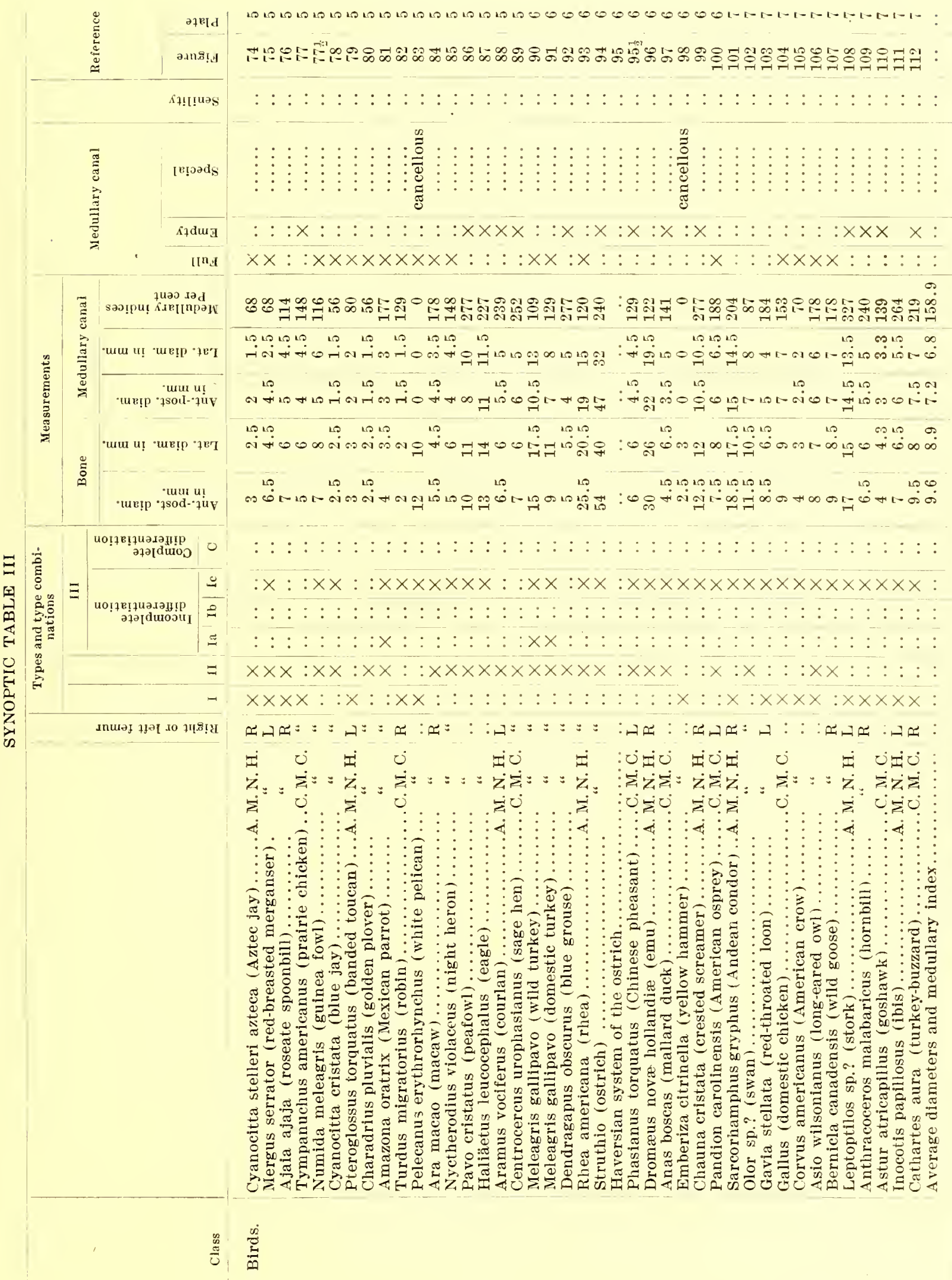

221 


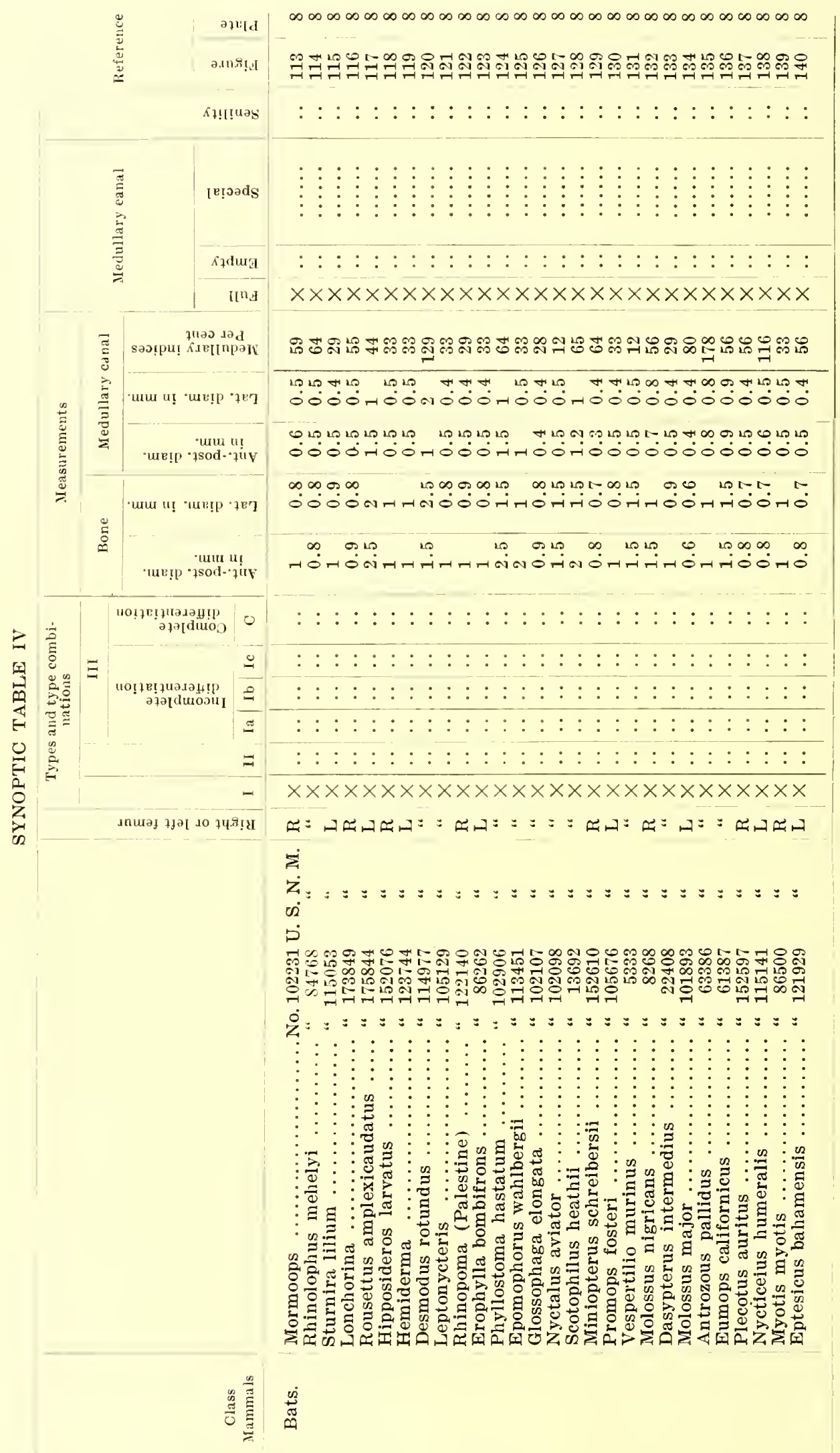




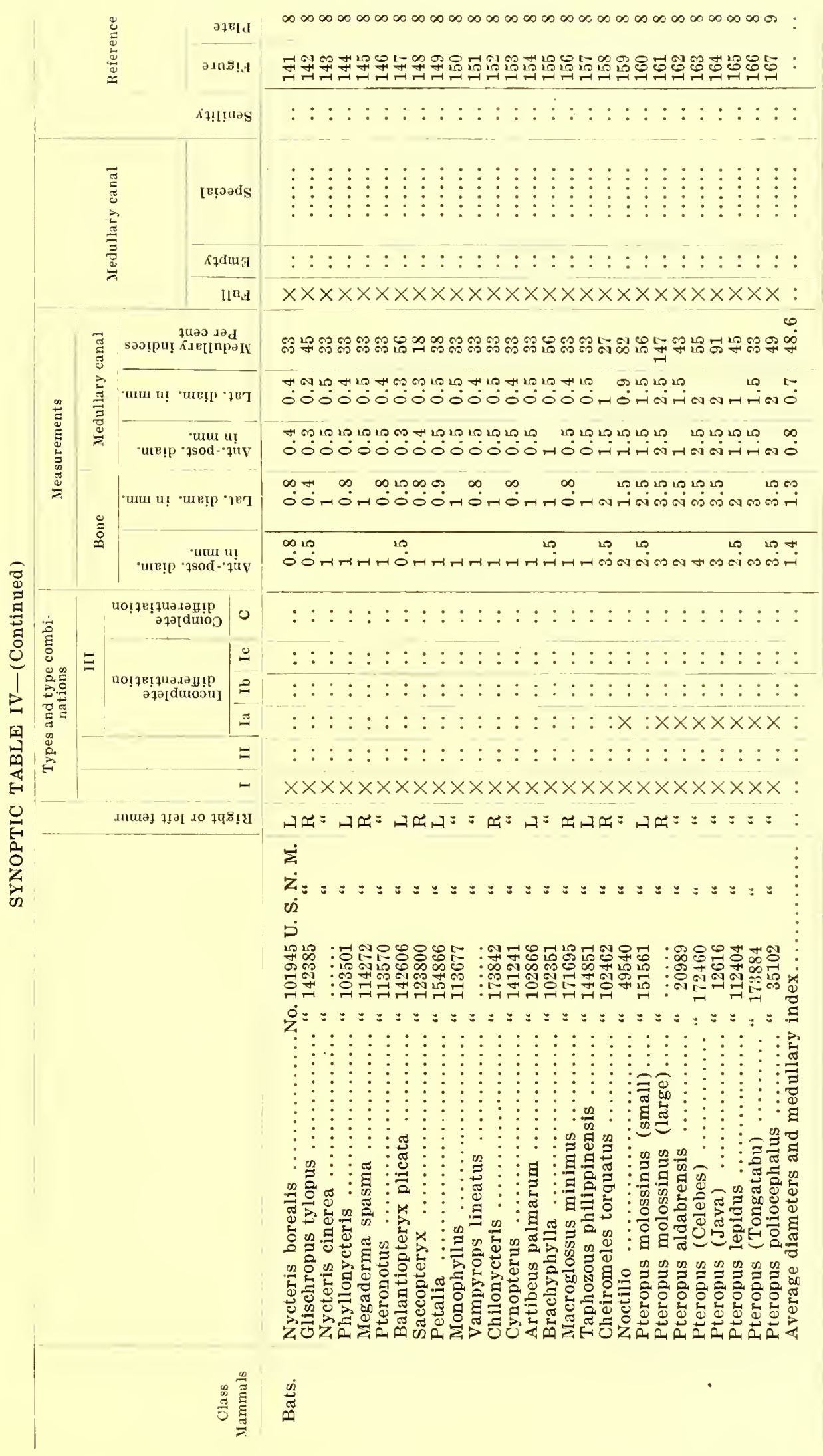




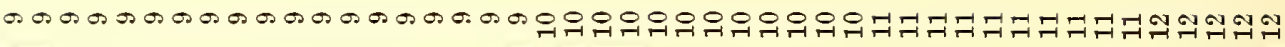

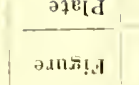

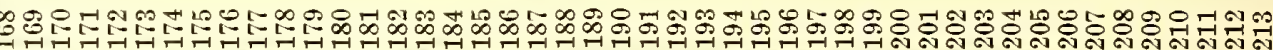

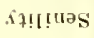

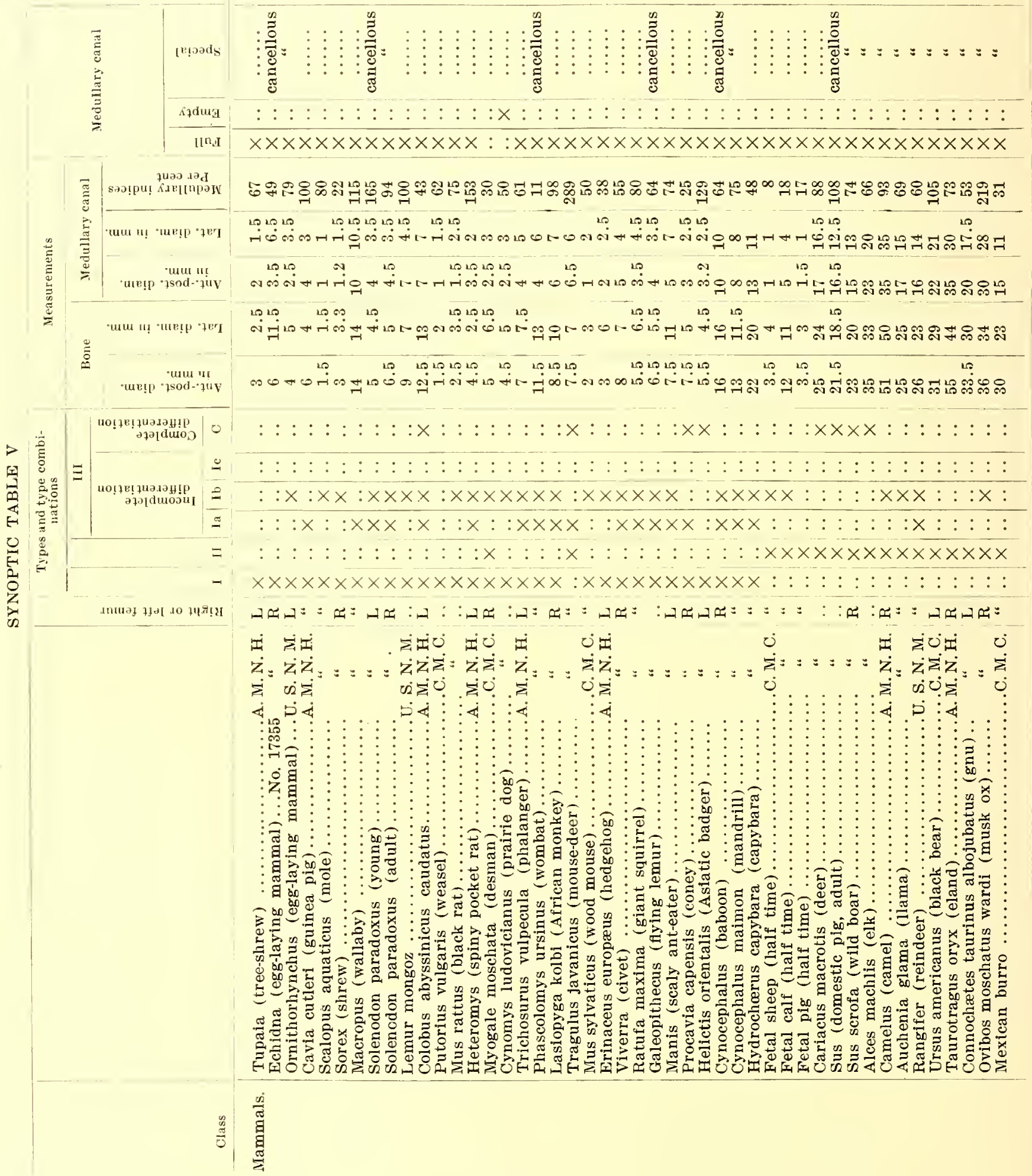


No. 3

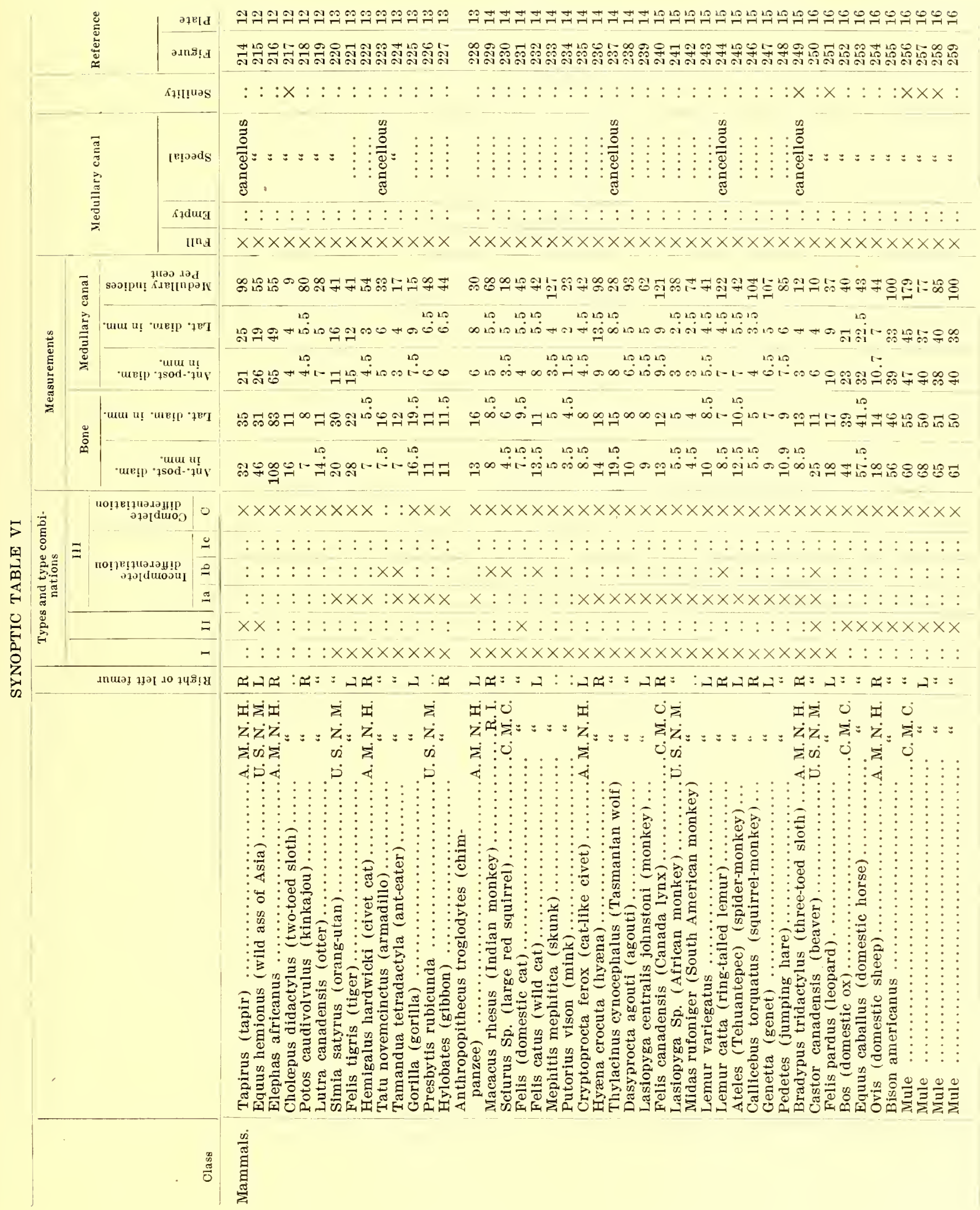




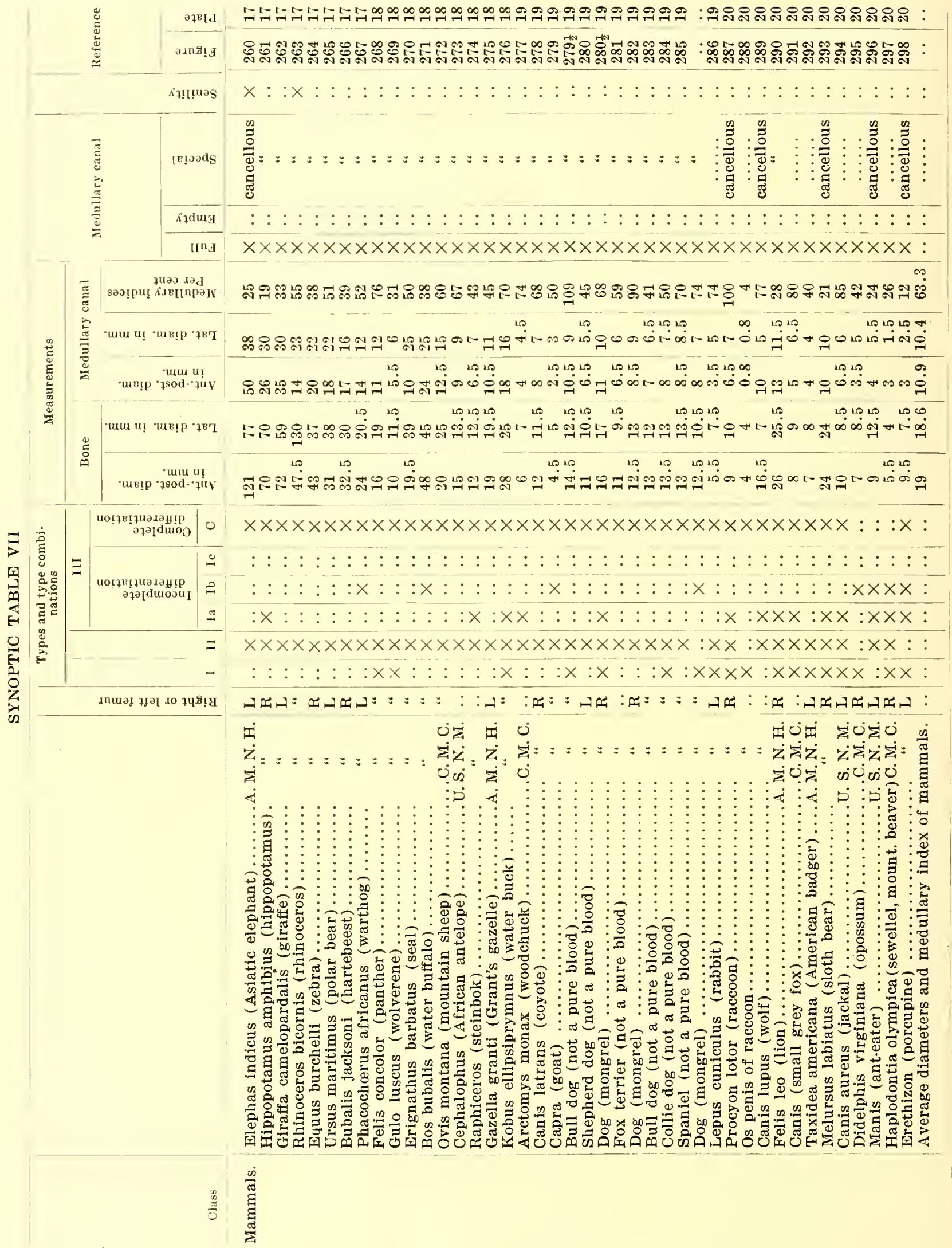


No. 3

COMPARATIVE HISTOLOGY OF FEMUR-FOOTE

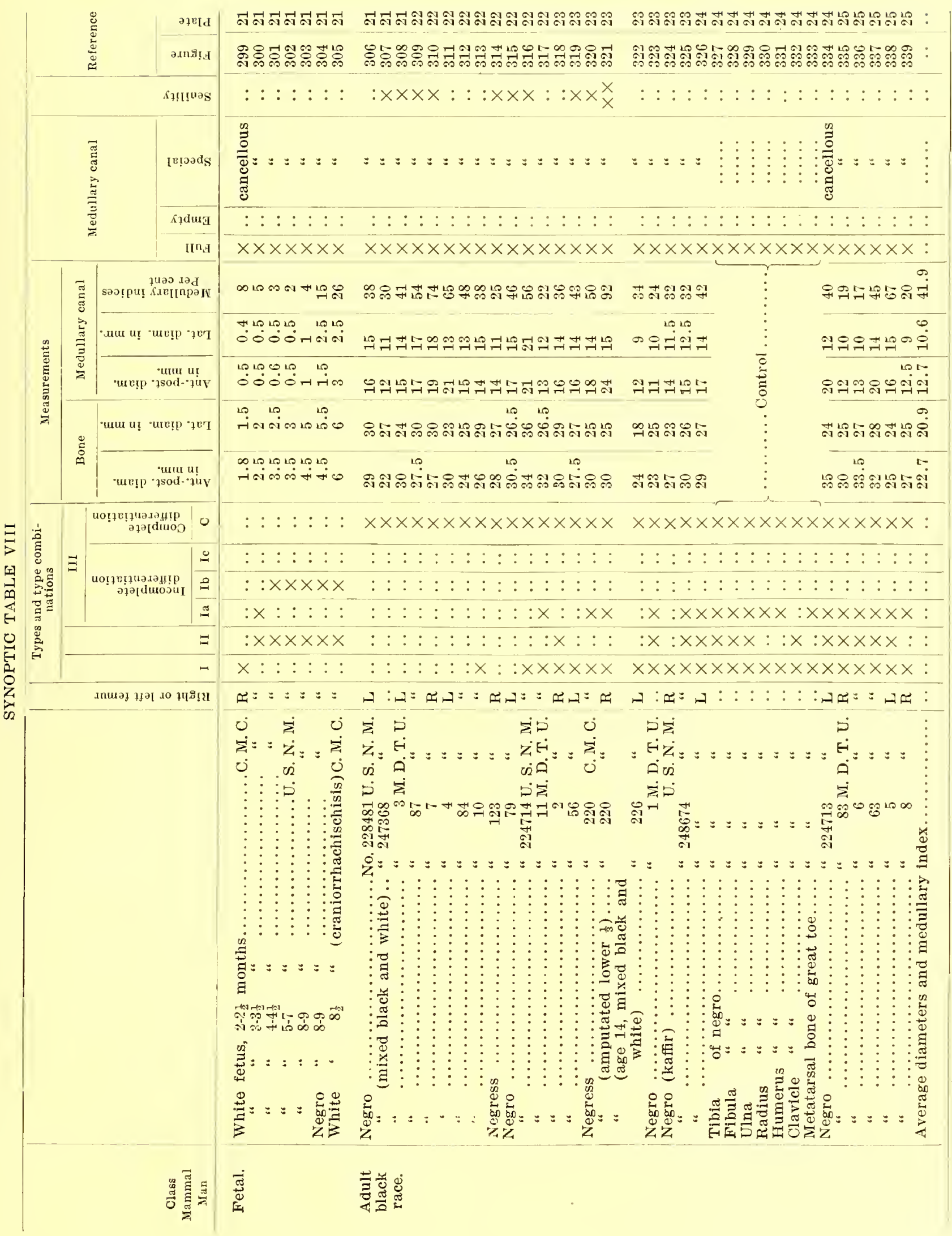




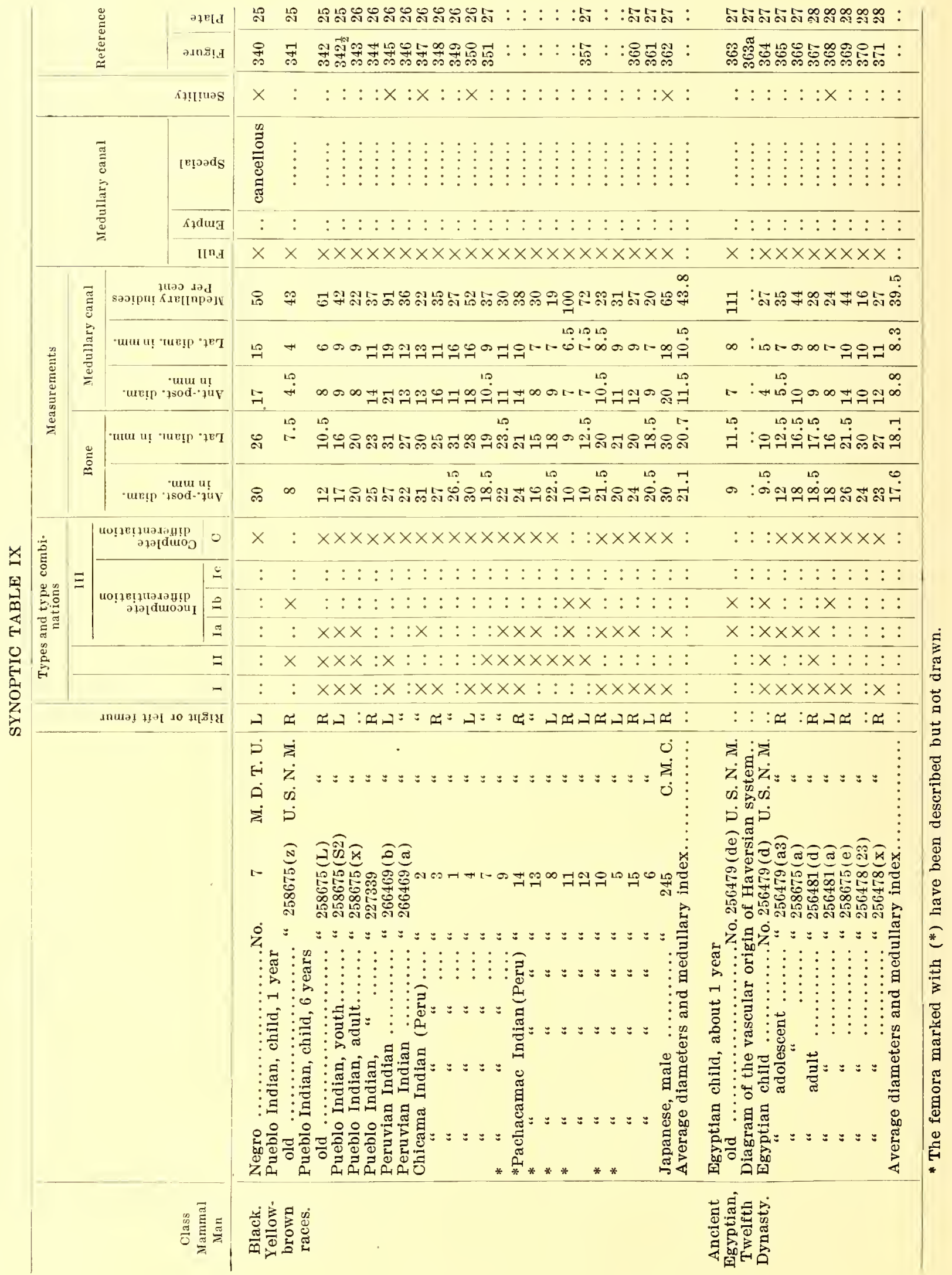




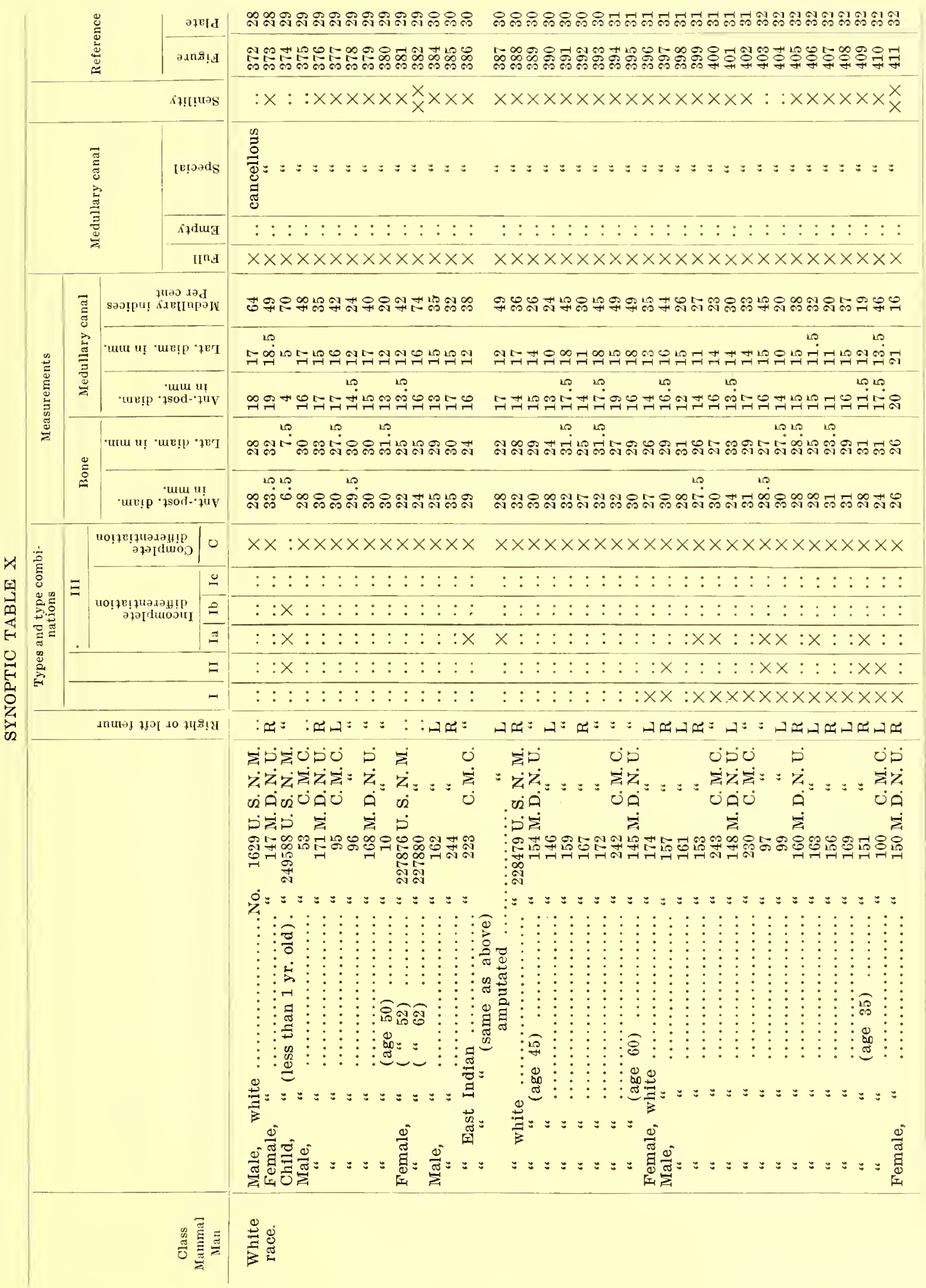




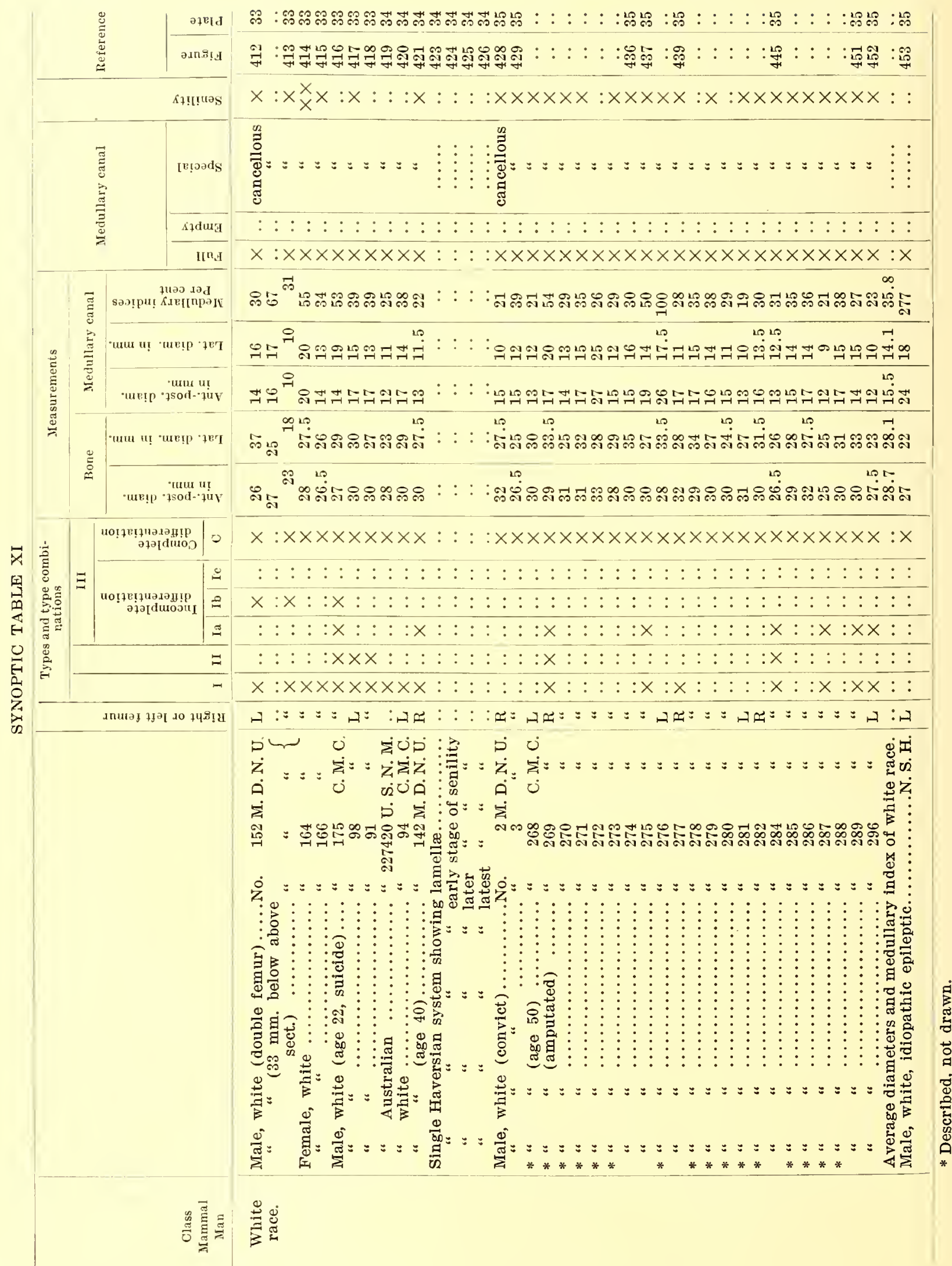




\section{INDEX}

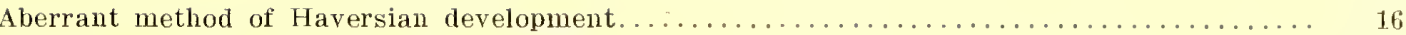

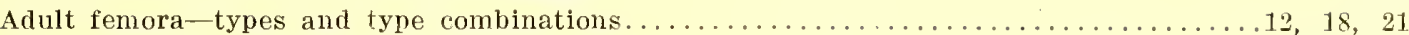

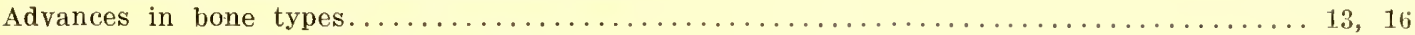

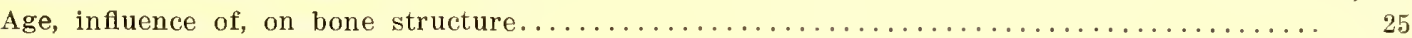

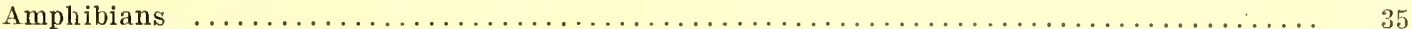

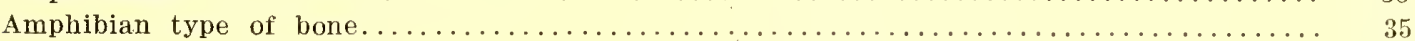

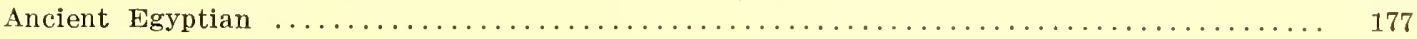

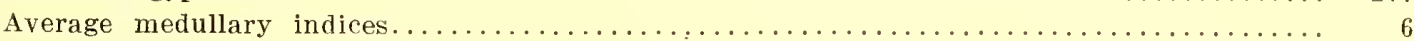

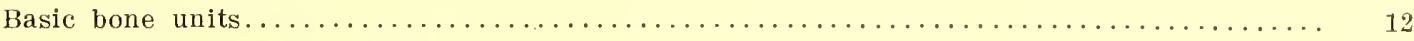

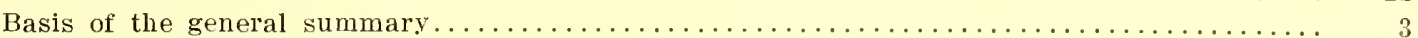

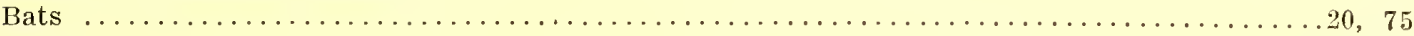

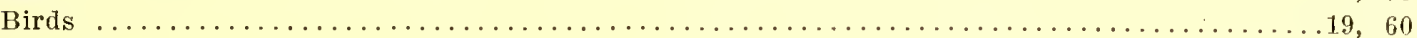

Black race $\ldots \ldots \ldots \ldots \ldots \ldots \ldots \ldots \ldots \ldots \ldots \ldots \ldots \ldots \ldots \ldots \ldots \ldots \ldots \ldots \ldots \ldots \ldots \ldots \ldots \ldots \ldots \ldots \ldots . \ldots \ldots, 35,153$

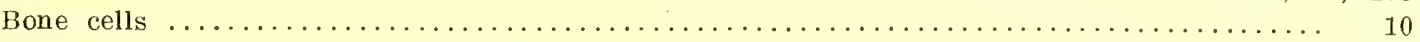

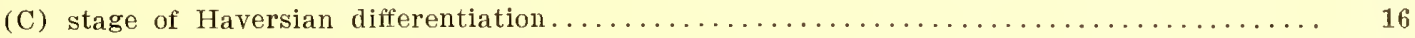

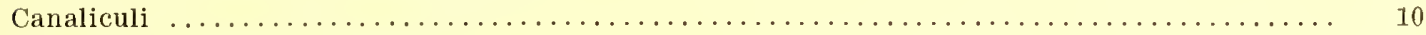

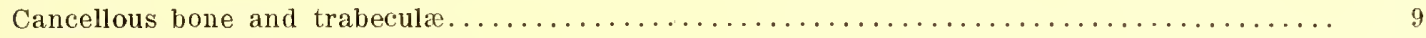

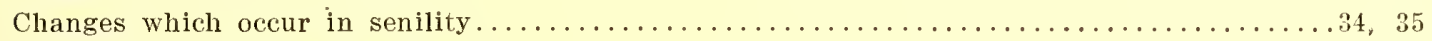

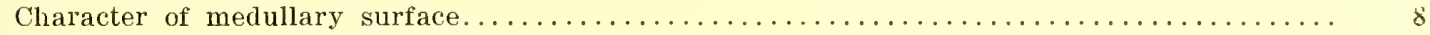

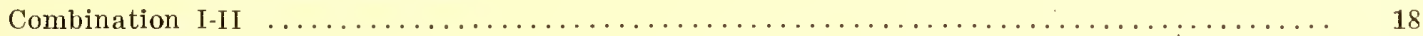

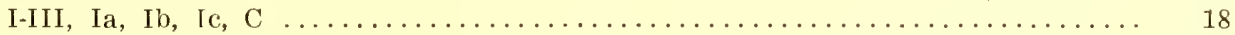

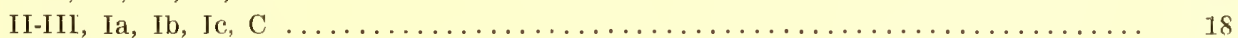

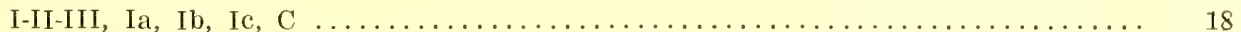

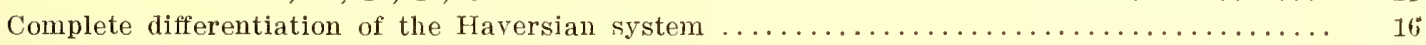

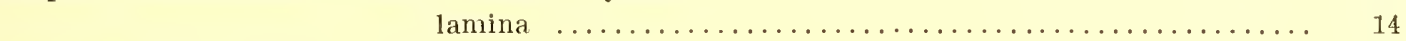

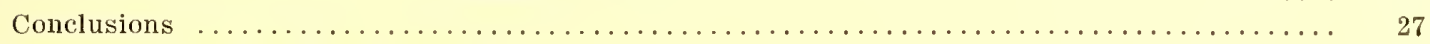

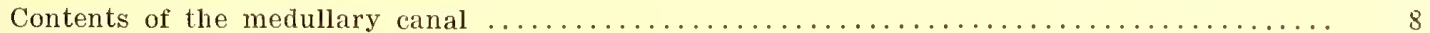

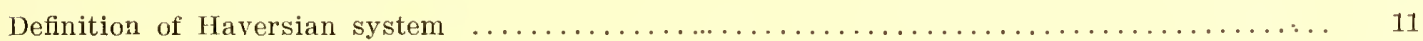

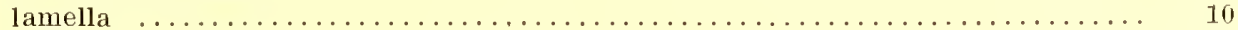

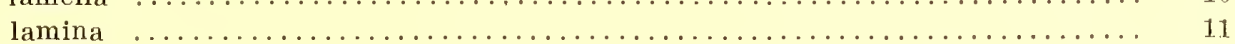

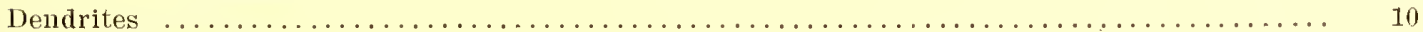

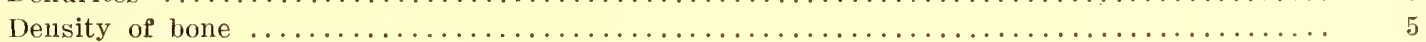

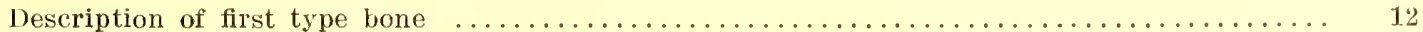

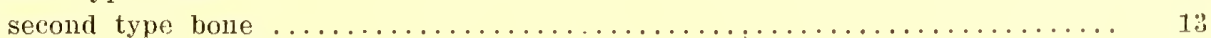

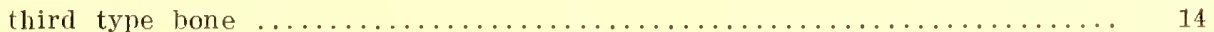

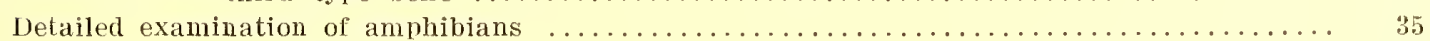

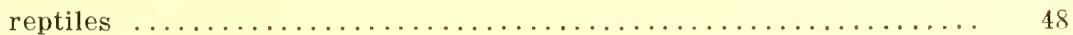

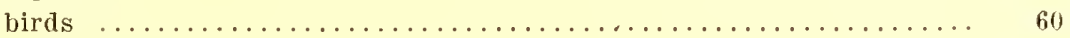

bats $\ldots \ldots \ldots \ldots \ldots$

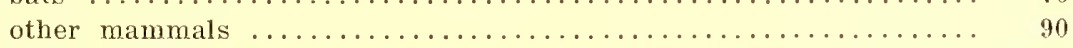

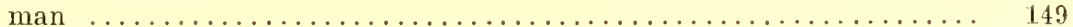

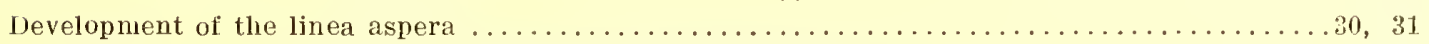

lamellar and laninar horseshoe-shaped rings................. 30

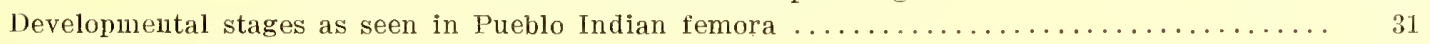

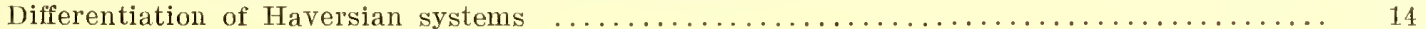

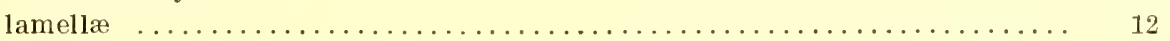

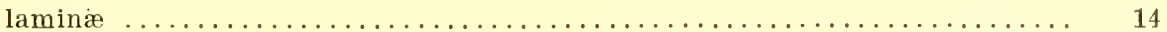

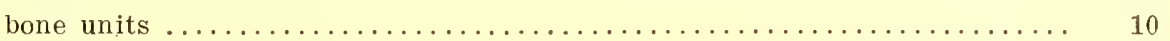

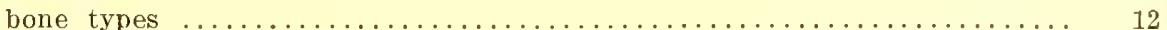

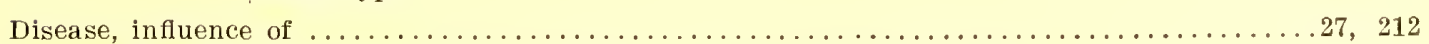

Distribution of the three bone types as they exist in the various femora............... 17

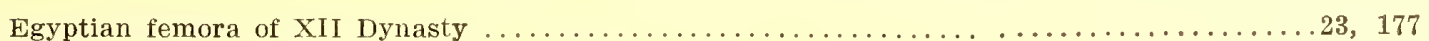




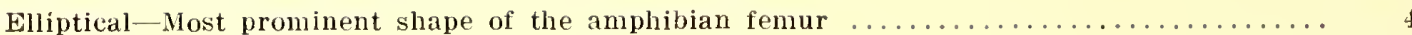

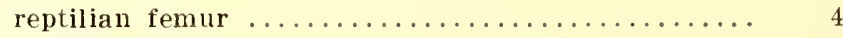

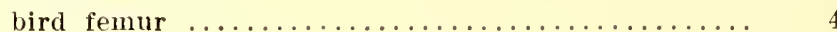

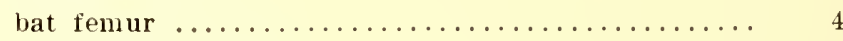

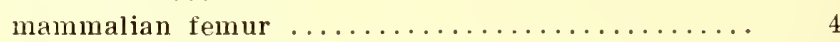
lemur below $\operatorname{man} \ldots \ldots \ldots \ldots \ldots \ldots \ldots \ldots \ldots \ldots \ldots, 4$

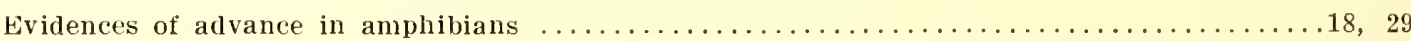

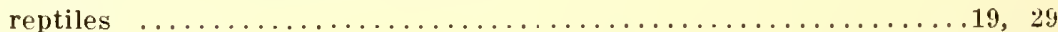

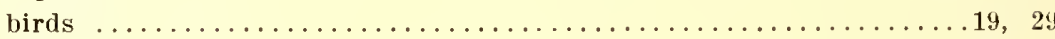

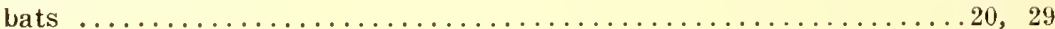

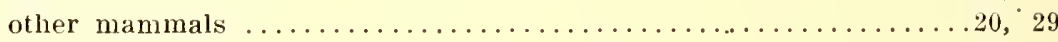

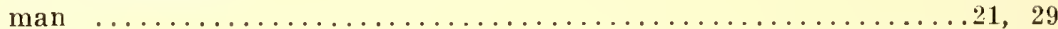

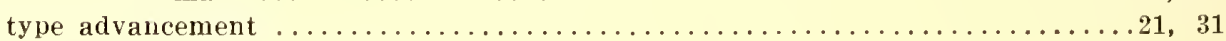

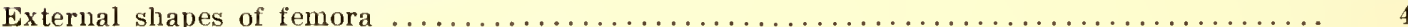

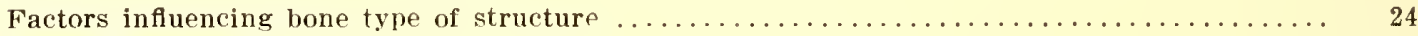

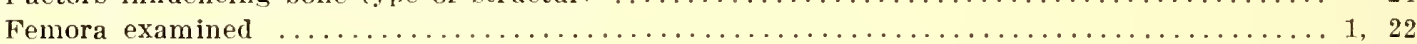

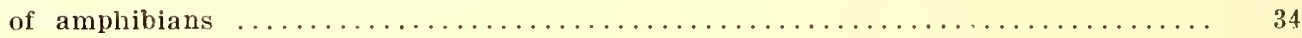

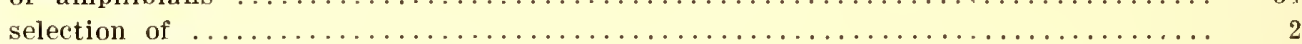

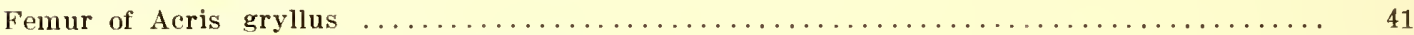

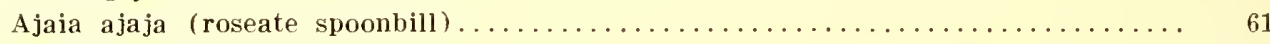

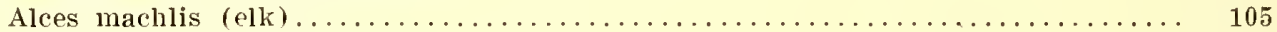

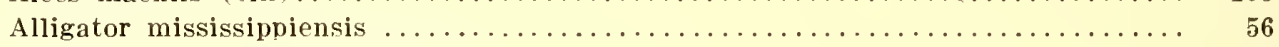

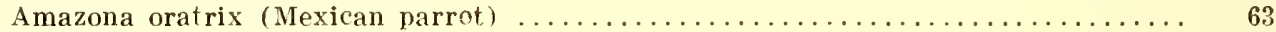

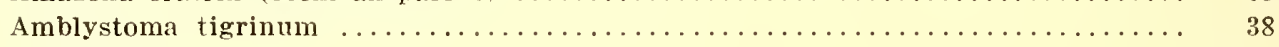

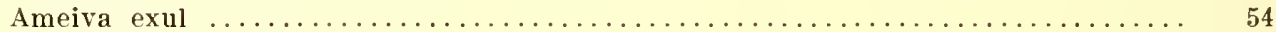

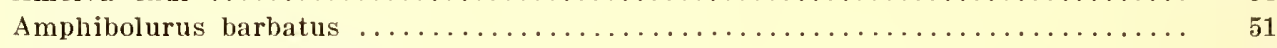

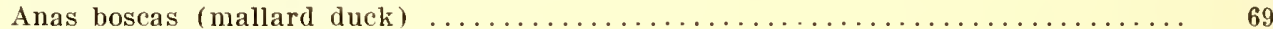

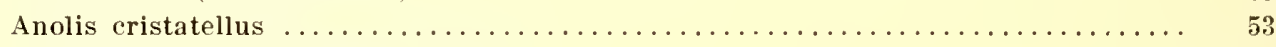

Anthracoceros malabaricus (hornbill) .......................... 74

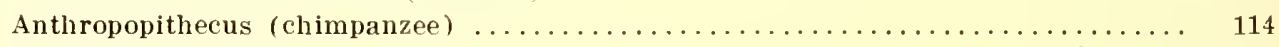

Antrozous pallidus ....................................... 81

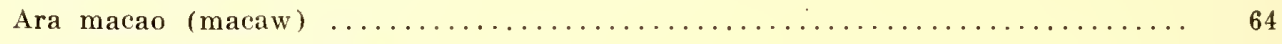

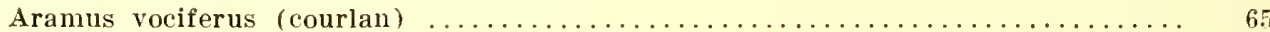

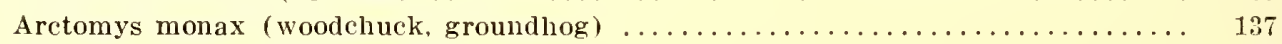

Aromochelys odoratus (musk turtle) .......................... 58

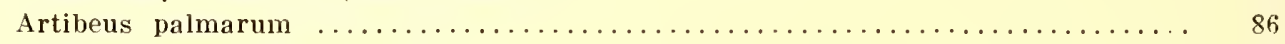

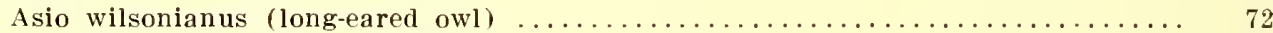

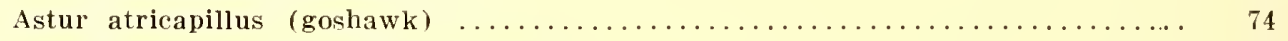

Ateles (spider-monkey) (Tehuantepec) ........................... 122

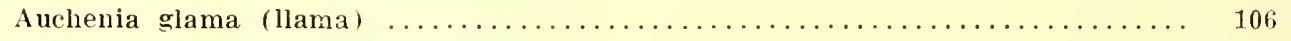

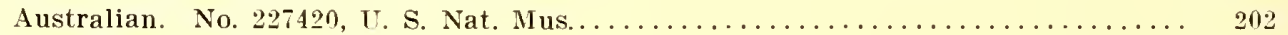

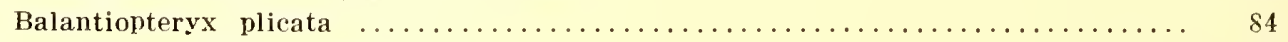

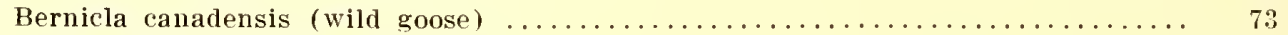

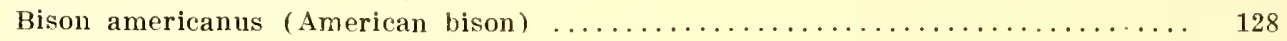

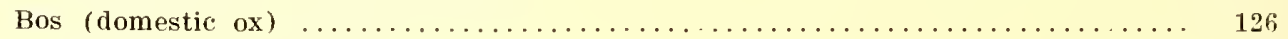

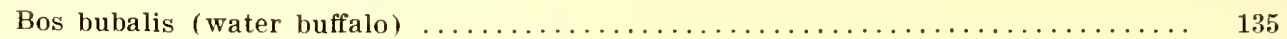

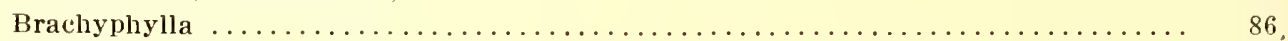

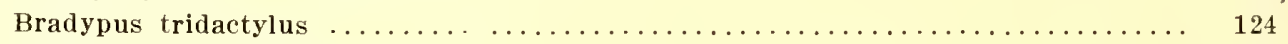

Bubalis jacksoni (la artebeest) $\ldots \ldots \ldots \ldots \ldots \ldots \ldots \ldots \ldots \ldots \ldots \ldots \ldots \ldots \ldots \ldots \ldots \ldots \ldots$

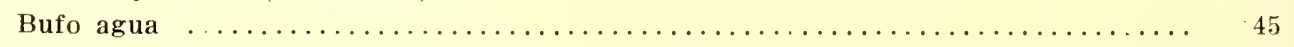

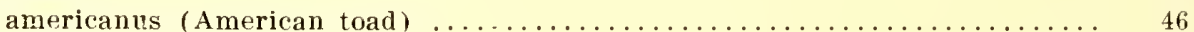

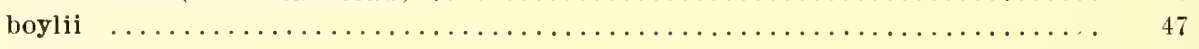

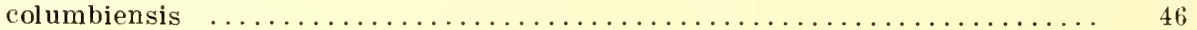

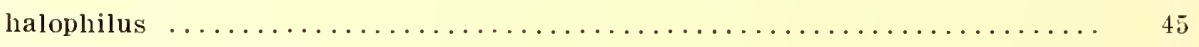

lentiginosus cognatus .............................. 47

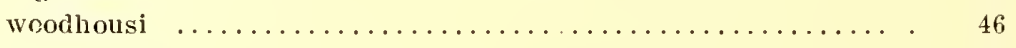

valliceps $\ldots \ldots \ldots \ldots \ldots \ldots \ldots \ldots \ldots \ldots \ldots \ldots \ldots \ldots \ldots \ldots \ldots \ldots \ldots \ldots \ldots \ldots \ldots$

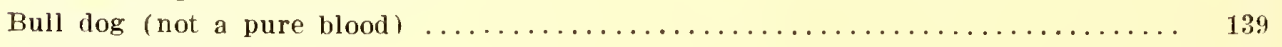

Callicebus torquatus $\ldots \ldots \ldots \ldots \ldots \ldots \ldots \ldots \ldots \ldots \ldots \ldots \ldots \ldots \ldots \ldots \ldots \ldots \ldots \ldots \ldots$ 
Femur of Camelus (camel)

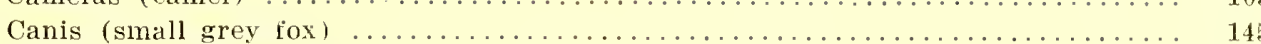

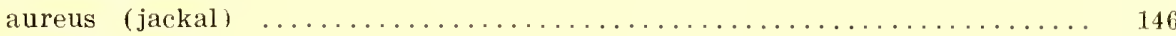

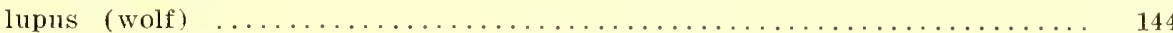

latrans $($ coyote $) \ldots \ldots \ldots \ldots \ldots \ldots \ldots \ldots \ldots \ldots \ldots \ldots \ldots \ldots \ldots \ldots$

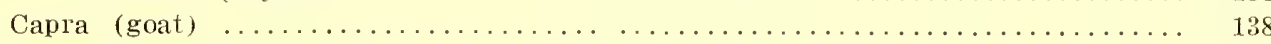

Cariacus macrotis (deer) ................................... 10.

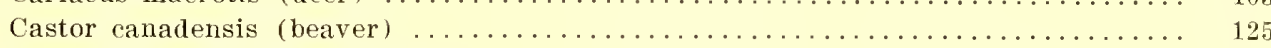

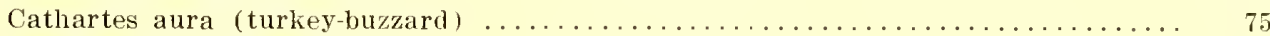

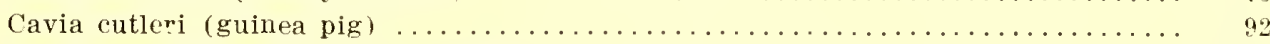

Centrocercus urophasianus (sage hen) $\ldots \ldots \ldots \ldots \ldots \ldots \ldots \ldots \ldots \ldots \ldots \ldots \ldots \ldots \ldots$

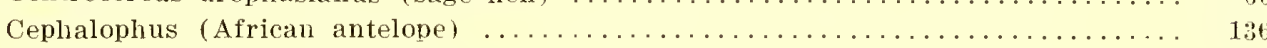

Chamæleo vulgaris (chameleon) ................................ 49

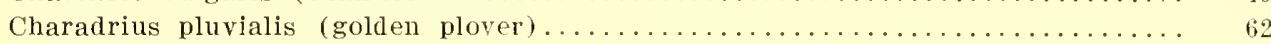

Chauna cristata (crested screamer) ........................... 70

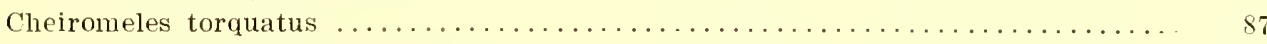

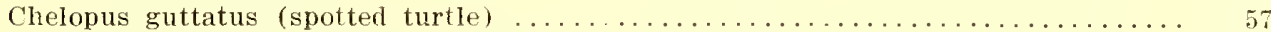

Chelydra serpentina (snapping turtle) $\ldots \ldots \ldots \ldots \ldots \ldots \ldots \ldots \ldots \ldots \ldots \ldots \ldots . \ldots \ldots$

Chicama Indian, No. 2, U. S. Nat. Mus. . . . . . . . . . . . . . . . . . . . . . . . . . 170

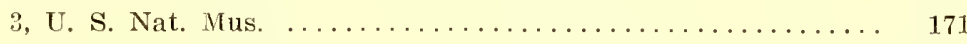

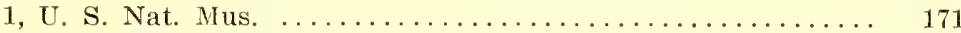

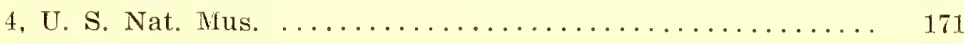

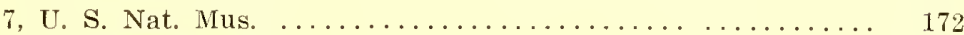

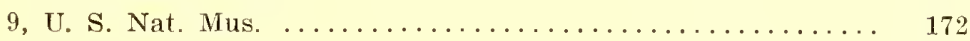

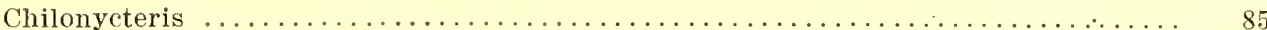

Cholepus didactylus (two-toed sloth) $\ldots \ldots \ldots \ldots \ldots \ldots \ldots \ldots \ldots \ldots \ldots \ldots \ldots \ldots \ldots$

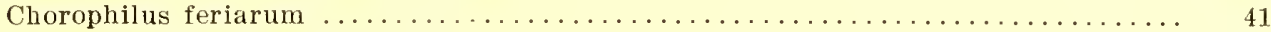

Chrysemys picta (painted turtle) $\ldots \ldots \ldots \ldots \ldots \ldots \ldots \ldots \ldots \ldots \ldots \ldots \ldots \ldots \ldots \ldots$

Cinosternum pennsylvanicum (mud turtle) ....................... 57

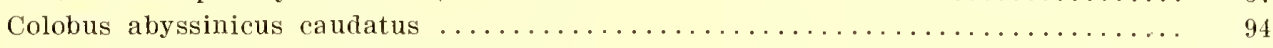

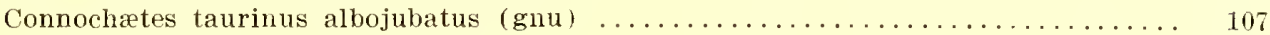

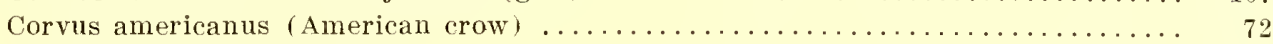

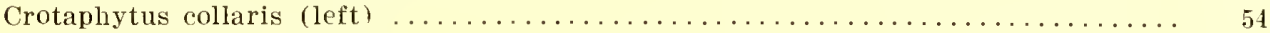

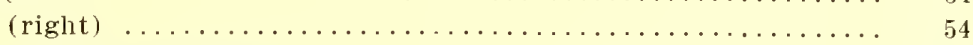

Cryptobranchus allegheniensis (hellbender) ....................... 43

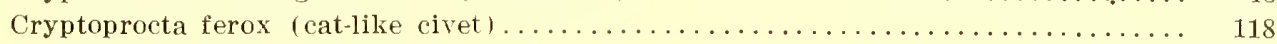

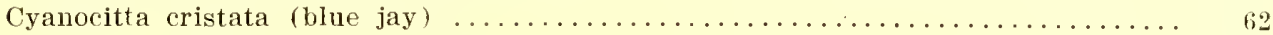

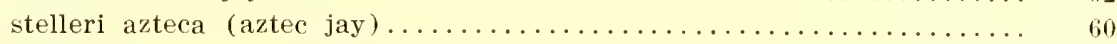

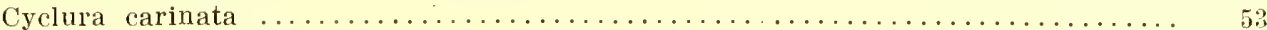

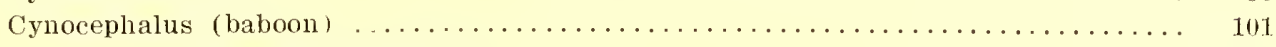

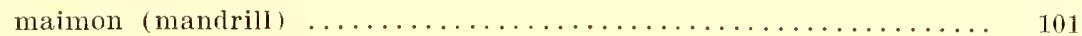

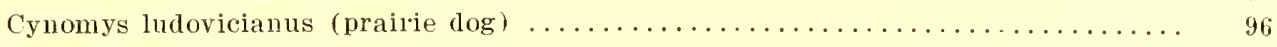

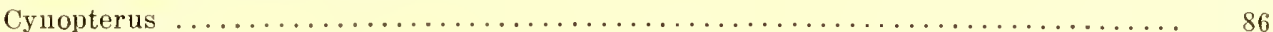

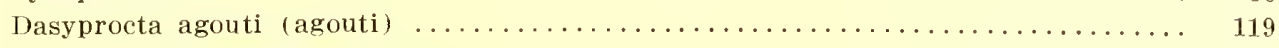

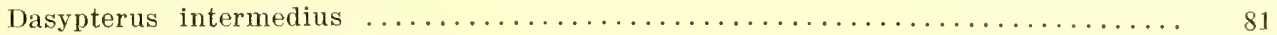

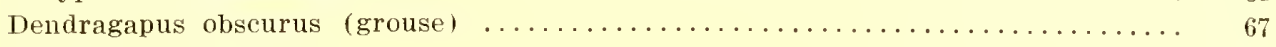

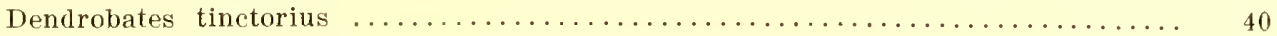

Desmodus rotundus $\ldots \ldots \ldots \ldots \ldots \ldots \ldots \ldots \ldots \ldots \ldots \ldots \ldots \ldots \ldots \ldots \ldots \ldots \ldots \ldots \ldots 77$

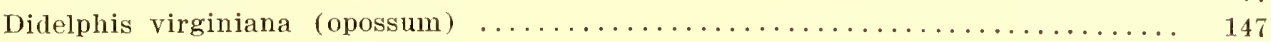

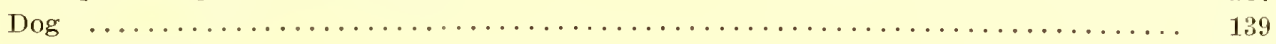

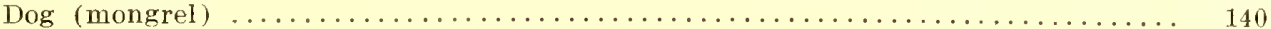

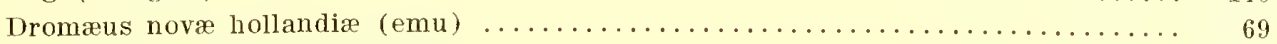

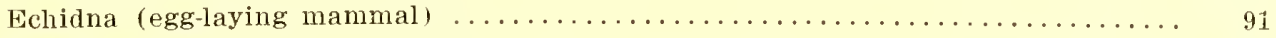

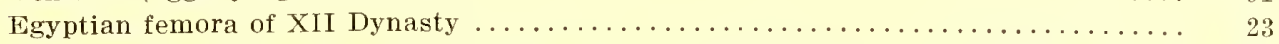

Egyptian child of one year (XII Dynasty), No. 256479 (de), U. S. Nat. Mus. ... 177

256479 (d), U. S. Nat. Mus. ... 178

youth (XII Dynasty), No. 256479 (a3), U. S. Nat. Mus............. 179

adult (XII Dynasty), No. 258675 (a), U. S. Nat. Mus. . . . . . . . . 179

256481 (d), U. S. Nat. Mus. ........... 180

256481 (a), U. S. Nat. Mus. ............ 180 
Femur of Egyptian adult (XII Dynasty), No. 258675 (e), U. S. Nat. Mus. ............. 181 $256478(23)$, U. S. Nat. Mus. . . . . . . . 182

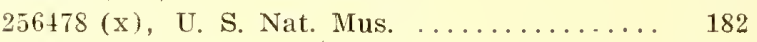

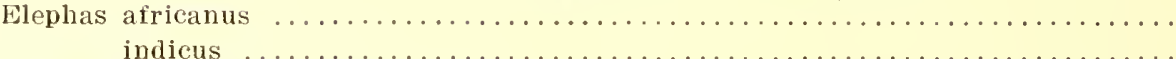

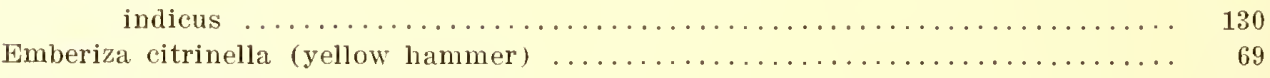
Epileptic idiopathic ................................... 212

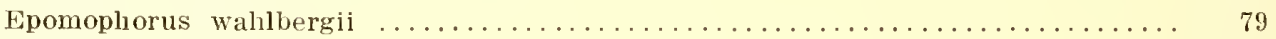

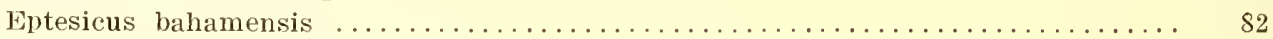

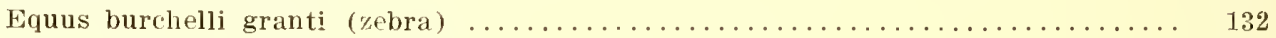

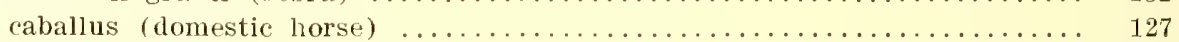
hemionus (wild ass of Asia) ......................... 108

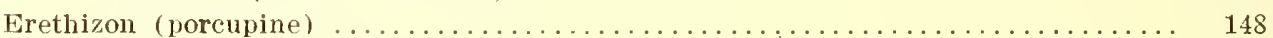

Erignathus barbatus (seal) ............................... 135

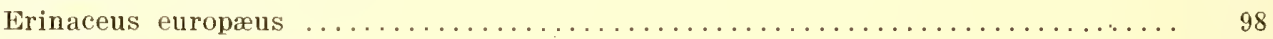

Erophylla bombifrons .................................. 78

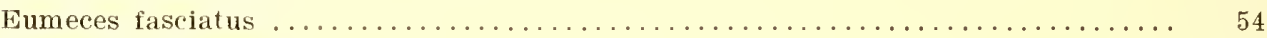

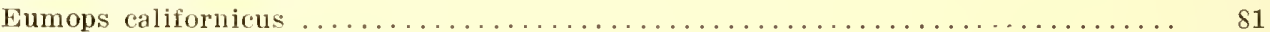

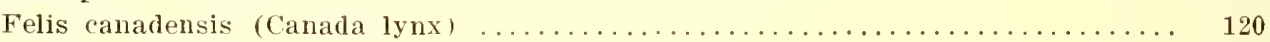

catus (wild cat) ................................... 116

concolor (panther) $\ldots \ldots \ldots \ldots \ldots \ldots \ldots \ldots \ldots \ldots \ldots \ldots \ldots \ldots \ldots \ldots \ldots \ldots \ldots$

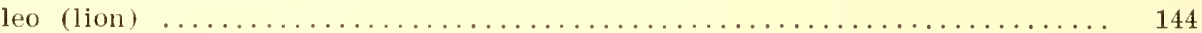

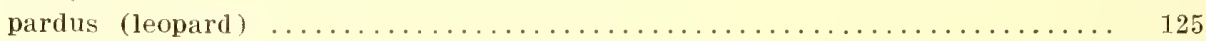

(domestic cat) ..................................... 116

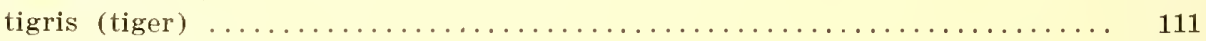

Fetal calt, 18 weeks ...................................... 102

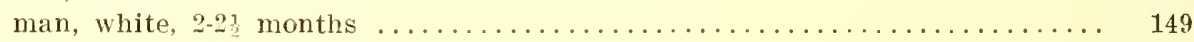

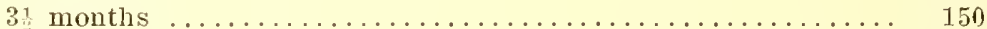

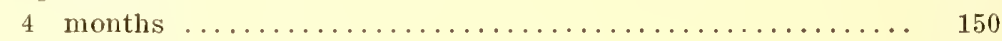

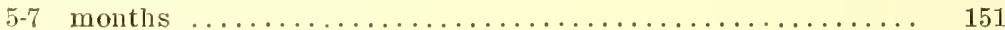

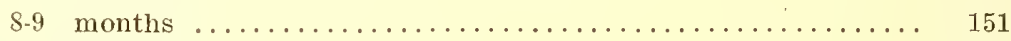

negro, 8-9 months .............................. 152

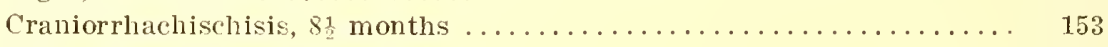

pig, 81 weeks ....................................... 103

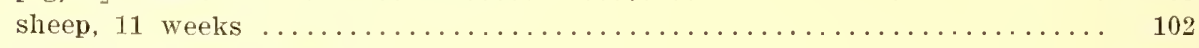

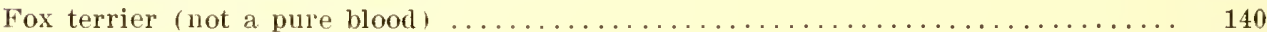

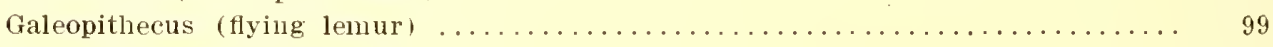

Gallus (domestic chicken) ................................... 72

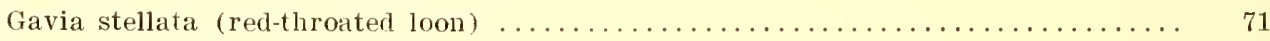

Gazella granti ............................................. 137

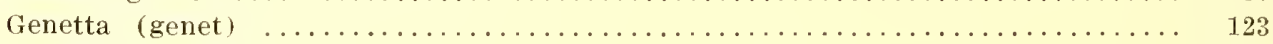

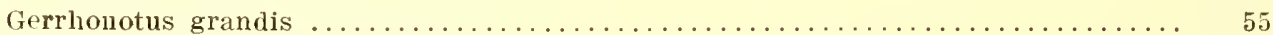

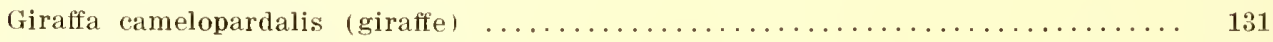

Glischropus tylopus ................................... 89

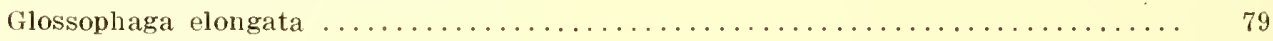

Gorilla (gorilla) ......................................... 112

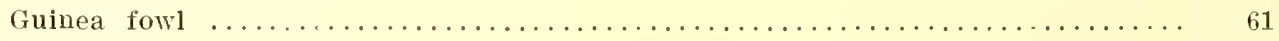

Gulo luscus (wolverine) ,...................................... 134

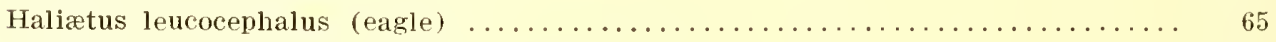

Haplodontia olympica (sewellel, mountain beaver) .................. 148

Helictis orientalis (Asiatic badger) $\ldots \ldots \ldots \ldots \ldots \ldots \ldots \ldots \ldots \ldots \ldots \ldots \ldots \ldots \ldots \ldots \ldots$

Heloderma suspectum (gila monster) ........................ 52

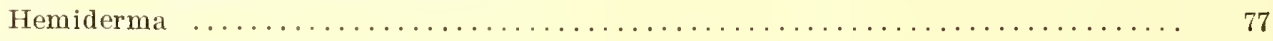

Hemigalus hardwicki (civet cat) $\ldots \ldots \ldots \ldots \ldots \ldots \ldots \ldots \ldots \ldots \ldots \ldots \ldots \ldots \ldots \ldots \ldots \ldots$

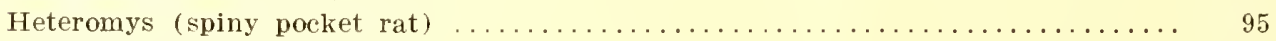

Hippopotamus amphibius ................................. 130

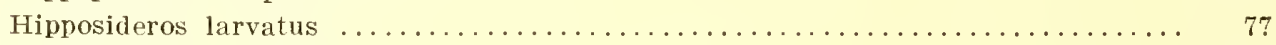

Hydrochœrus capybara .................................. 102

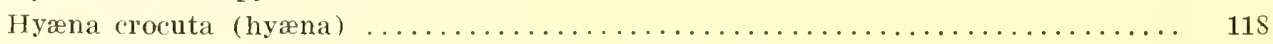




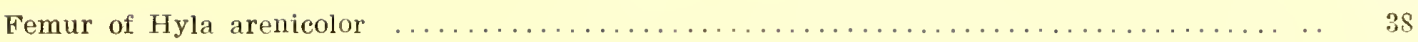

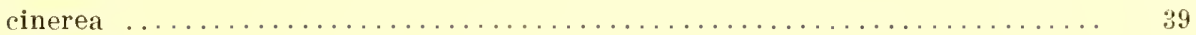

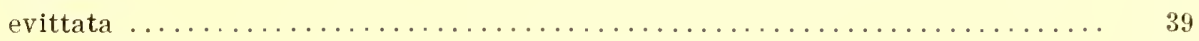

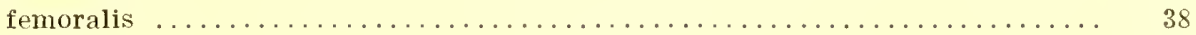

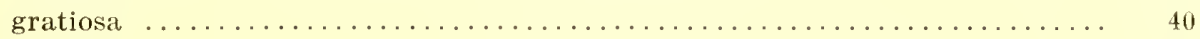

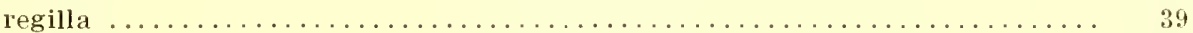

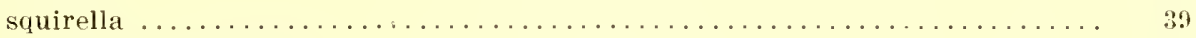

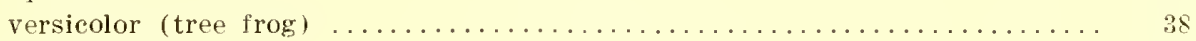

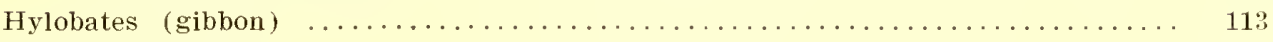

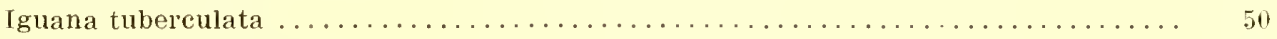

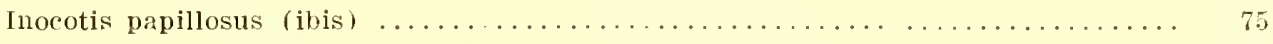

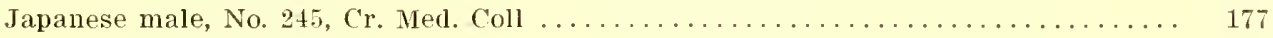

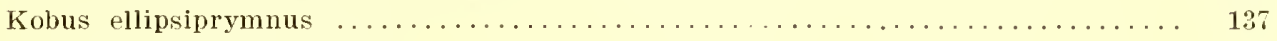

Lasiopyga centralis johnstoni . . . . . . . . . . . . . . . . . . . . . . . 119

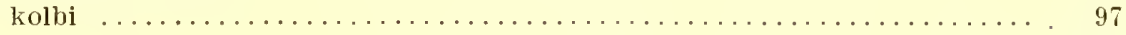

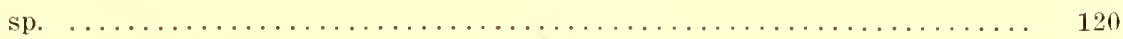

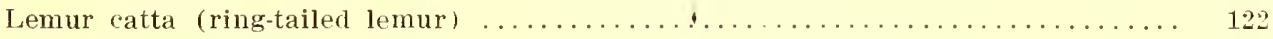

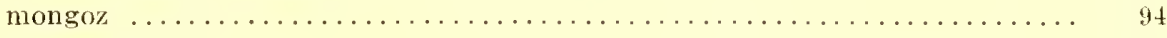

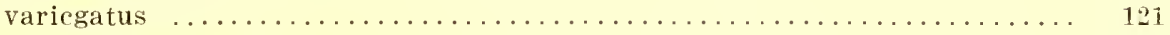

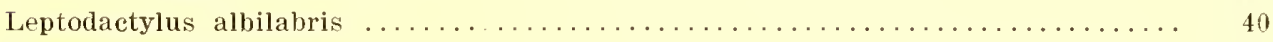

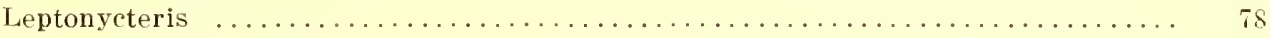

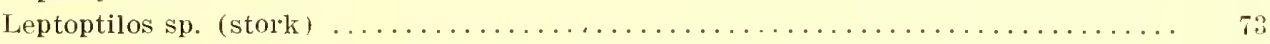

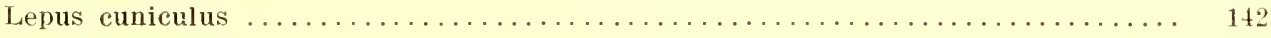

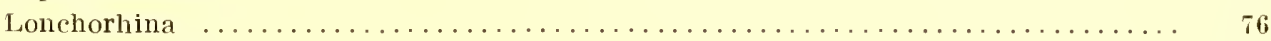

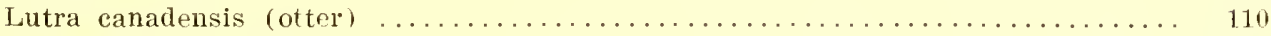

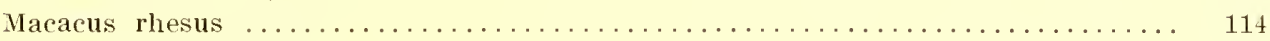

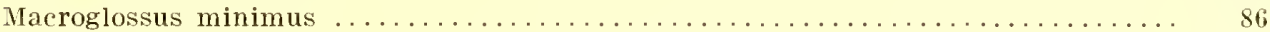

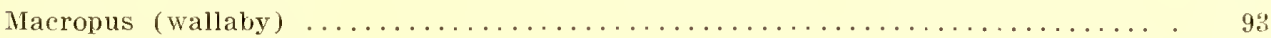

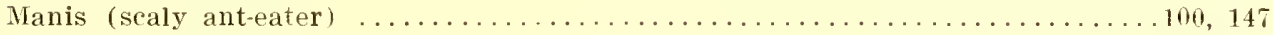

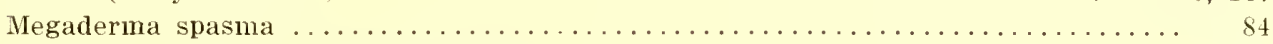

Meleagris gallipavo (domestic turkey) $\ldots \ldots \ldots \ldots \ldots \ldots \ldots \ldots \ldots \ldots \ldots \ldots \ldots \ldots \ldots$

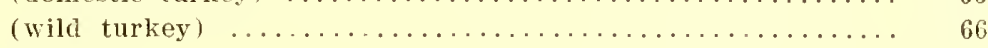

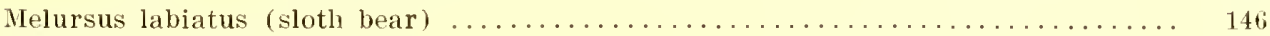

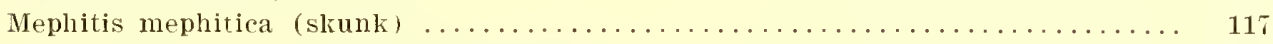

Mergus serrator (red-breasted merganser) .........................

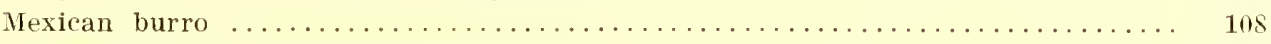

Midas rufoniger. (South American monkey) ........................ 121

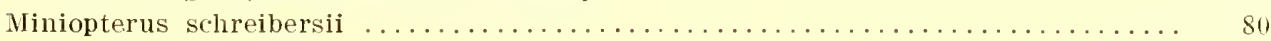

Molossus major ....................................... 81

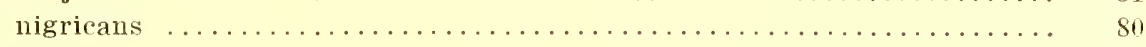

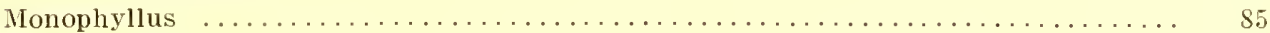

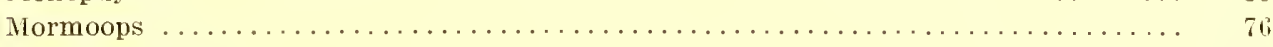

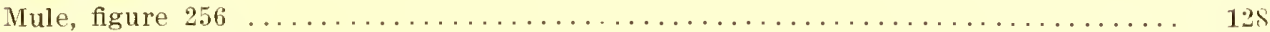

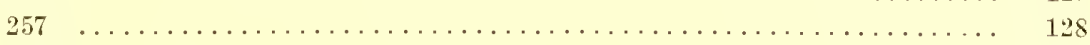

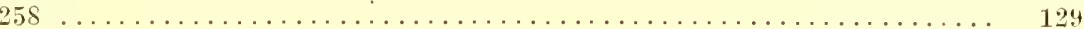

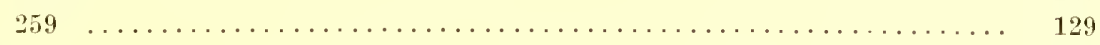

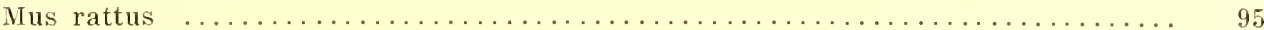

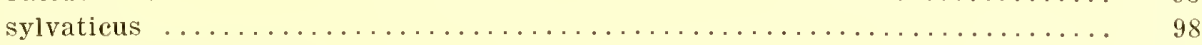

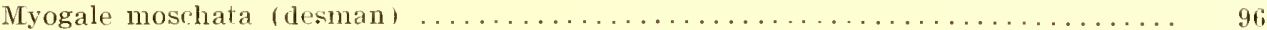

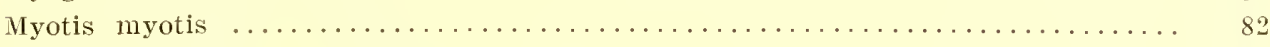

Necturus maculatus (necturus) . . . . . . . . . . . . . . . . . . . . 48

Negro, No. 228481 , U. S. Nat. Mus. . . . . . . . . . . . . . . . . . . . . 158

Negro and white mixed-at least half white ........................ 154

Negro, No. 3, Med. Dept. Tulane Univ. .......................... 154

87, Med. Dept. Tulane Univ. ........................ 155

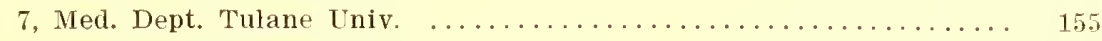

4, Med. Dept. Tulane Univ. ........................ 155

84, Med. Dept. Tulane Univ. . . . . . . . . . . . . . . . . . 155

10, Med. Dept. Tulane Univ. ....................... 15i

Negless, No. 122, Med. Dept. Tulane Univ. ....................... 150 
Femur of Negro, No. 79 , Med. Dept. Tulane Univ $\ldots \ldots \ldots \ldots \ldots \ldots \ldots \ldots$

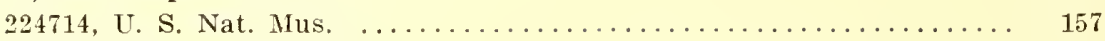

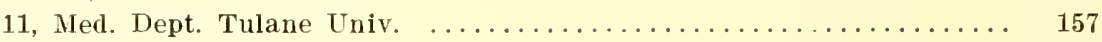

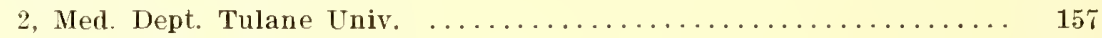

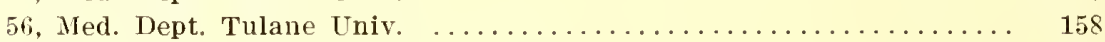

Negress (left), No. 220, Cr. Med. Coll. .................... 158

(right), No. 220, Cr. Med. Coll. (amputated) ............... 158

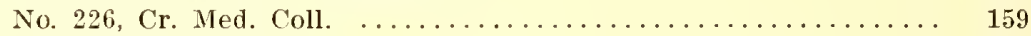

Negro, No. 1, Med. Dept. Tulane Univ. . . . . . . . . . . . . . . . . . . . . 159

Kaffir, No. 263196, U. S. Nat. Mus. ..................... 160

(right), No. 248674, U. S. Nat. Mus. .................... 160

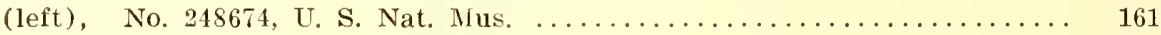

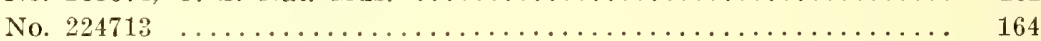

No. 83 , Med. Dept. Tulane Univ. ...................... 164

6 , Med. Dept. Tulane Univ. . . . . . . . . . . . . . . . . . . 165

63, Med. Dept. Tulane Univ. ........................ 165

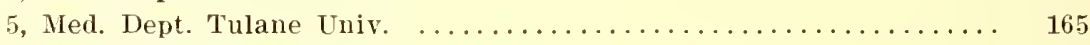

8, Med. Dept. Tulane Univ. ........................ 166

7, Med. Dept. Tulane Univ. ..................... 166

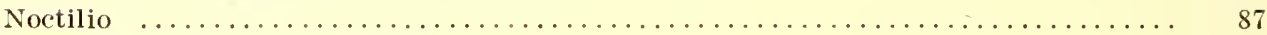

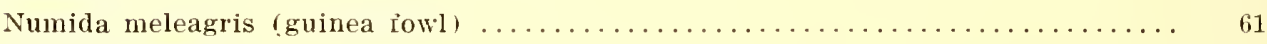

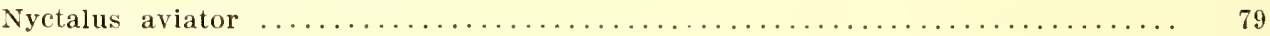

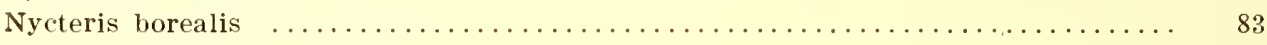

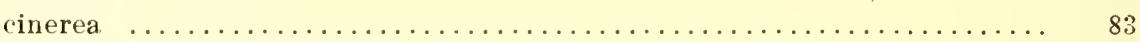

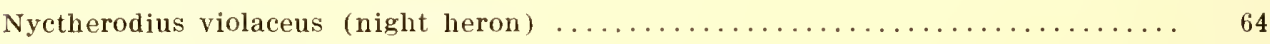

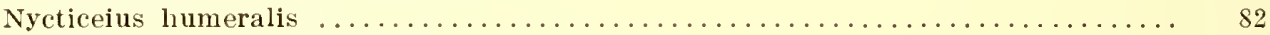

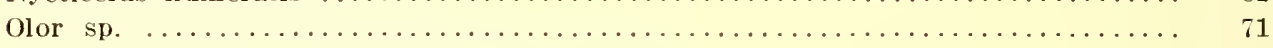

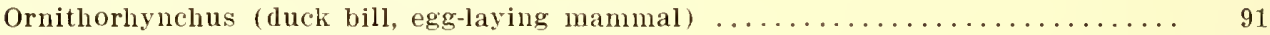

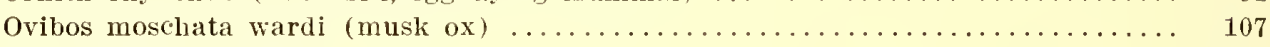

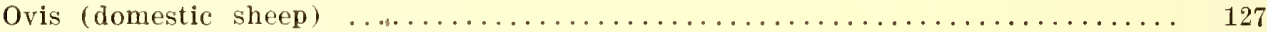

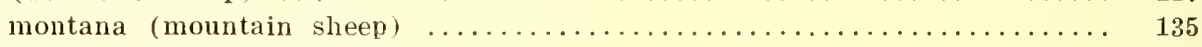

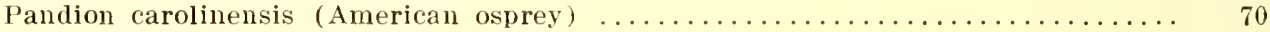

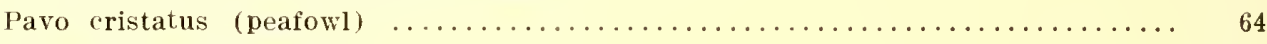

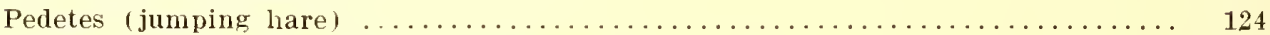

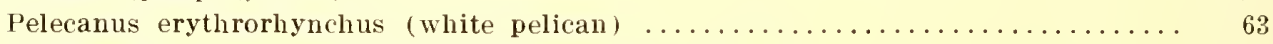

Peruvian Indian, adult, No. 266469 (b), U. S. Nat. Mus. . . . . . . . . . . . 170

266469 (a), U. S. Nat. Mus. . . . . . 170

14, U. S. Nat. Mus, ${ }^{*} \ldots \ldots \ldots \ldots \ldots \ldots \ldots \ldots \ldots \ldots$

13, U. S. Nat. Mus. ${ }^{*} \ldots \ldots \ldots \ldots \ldots \ldots \ldots \ldots \ldots \ldots$

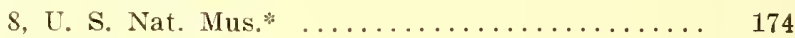

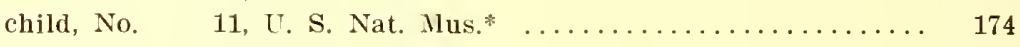

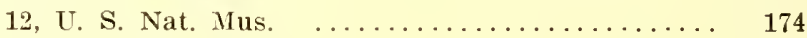

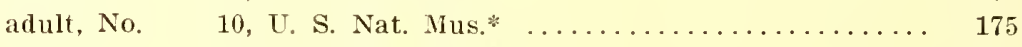

5, U. S. Nat. Mus.* ................. 175

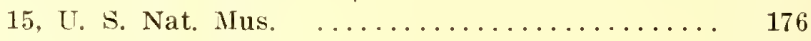

7, U. S. Nat. Mus. _................ 176

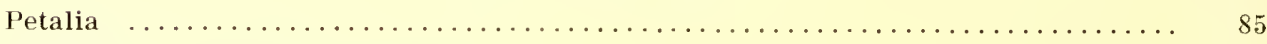

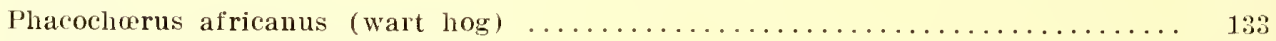

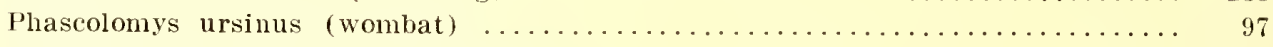

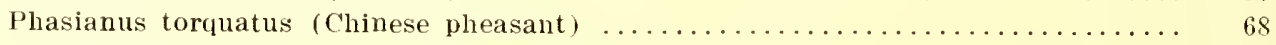

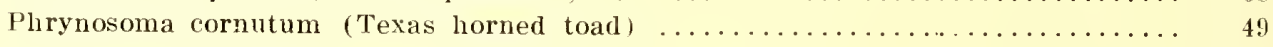

douglasii $\ldots \ldots \ldots \ldots \ldots \ldots \ldots \ldots \ldots \ldots \ldots \ldots \ldots \ldots \ldots \ldots \ldots \ldots \ldots \ldots \ldots \ldots \ldots \ldots \ldots \ldots \ldots \ldots \ldots \ldots \ldots \ldots \ldots \ldots \ldots$
Phyllonycteris $\quad \ldots \ldots \ldots \ldots \ldots \ldots \ldots \ldots \ldots \ldots \ldots$

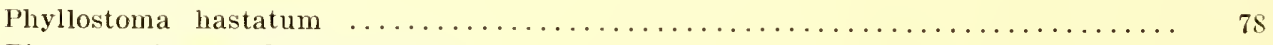

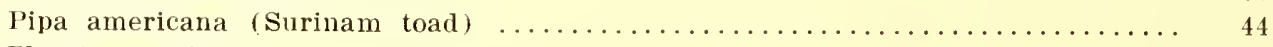

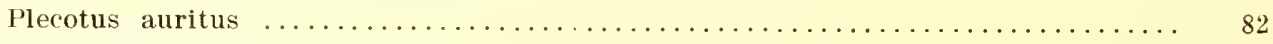

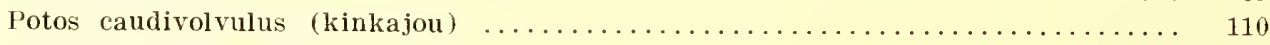

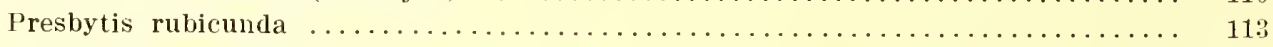

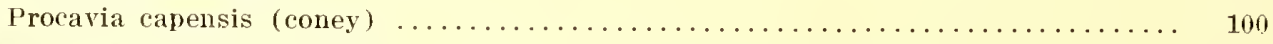

Femora marked with (*) described, but not drawn. 


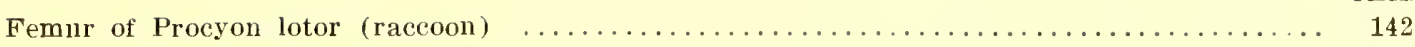

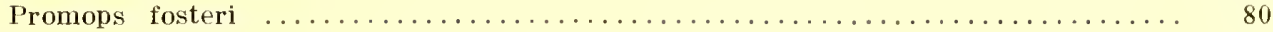

Pseudemys floridana $\ldots \ldots \ldots \ldots \ldots \ldots \ldots \ldots \ldots \ldots \ldots \ldots \ldots \ldots \ldots \ldots \ldots \ldots \ldots \ldots$

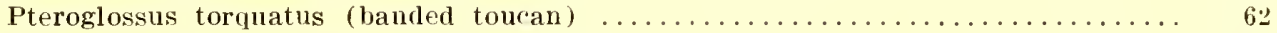

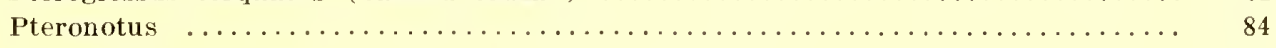

Pteropus aldabrensis $\ldots \ldots \ldots \ldots \ldots \ldots \ldots \ldots \ldots \ldots \ldots \ldots \ldots \ldots \ldots \ldots \ldots \ldots \ldots \ldots$

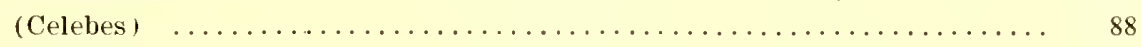

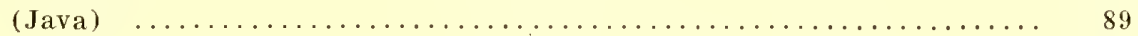

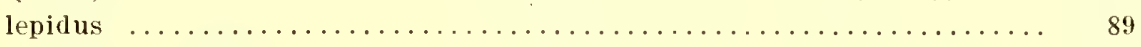

molossinus (small) $\ldots \ldots \ldots \ldots \ldots \ldots \ldots \ldots \ldots \ldots \ldots \ldots \ldots \ldots \ldots \ldots \ldots$

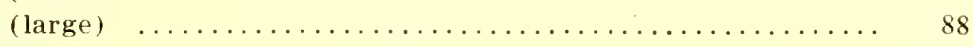

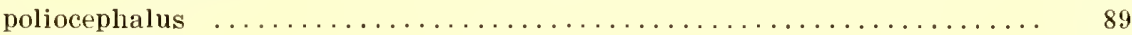

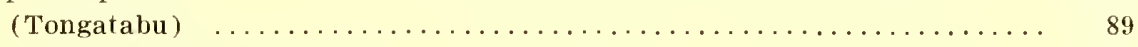

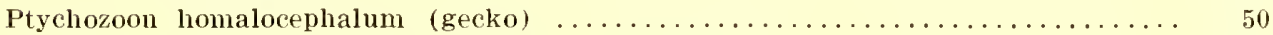

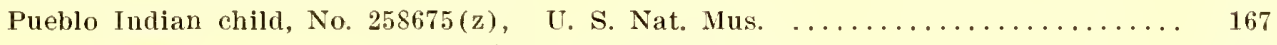

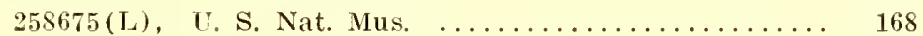

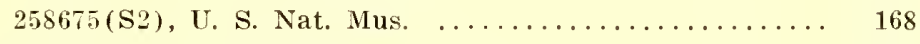

adult, Na. $258675(\mathrm{x})$, U. S. Nat. Mus. ................ 169

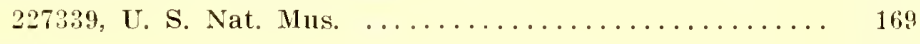

Putorius vulgaris (weasel) $\ldots \ldots \ldots \ldots \ldots \ldots \ldots \ldots \ldots \ldots \ldots \ldots \ldots \ldots \ldots \ldots \ldots . \ldots . \ldots . \ldots \ldots$

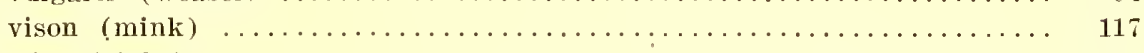

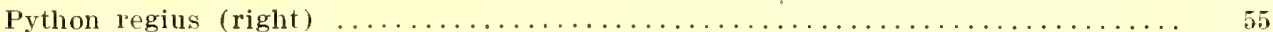

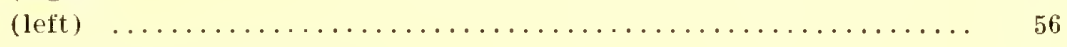

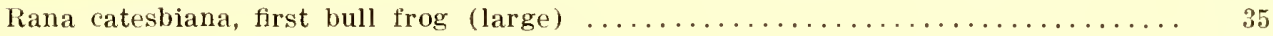

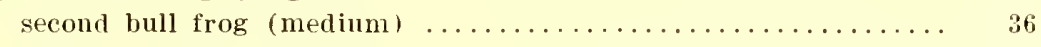

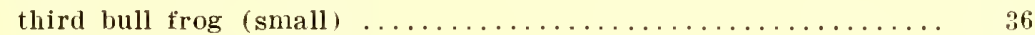

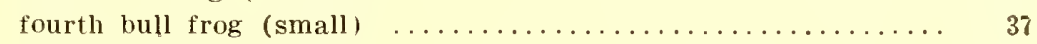

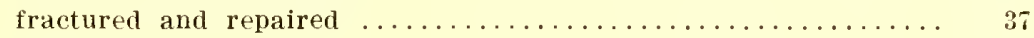

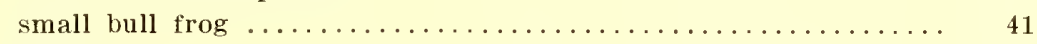

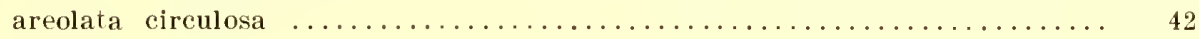

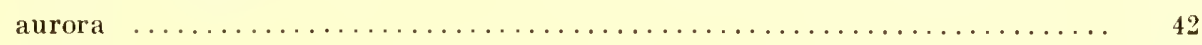

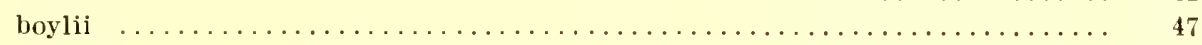

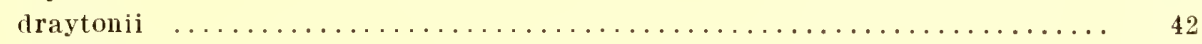

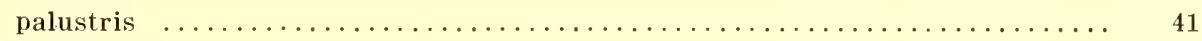

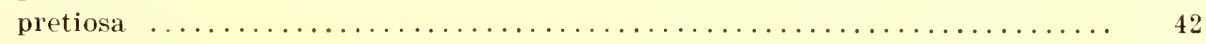

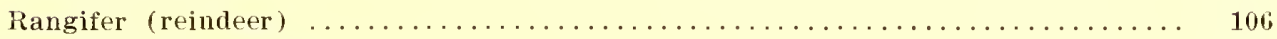

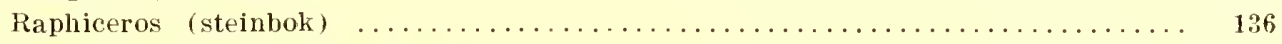

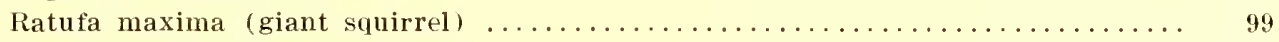

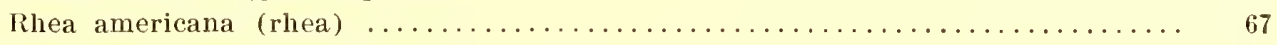

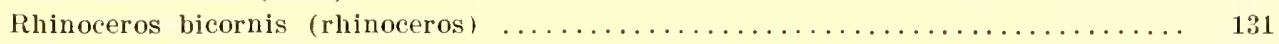

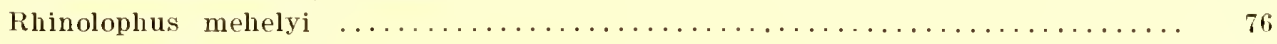

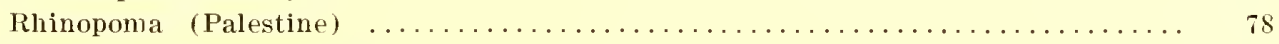

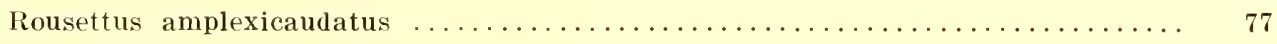

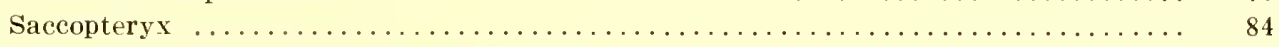

Sarcorhamplus gryphis (Andean condol) $\ldots \ldots \ldots \ldots \ldots \ldots \ldots \ldots \ldots \ldots \ldots \ldots \ldots \ldots \ldots$

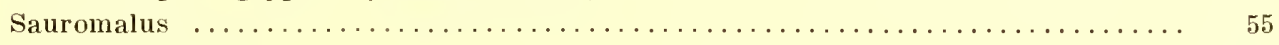

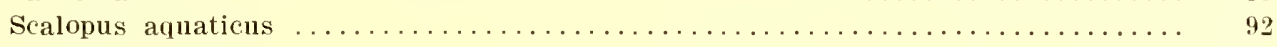

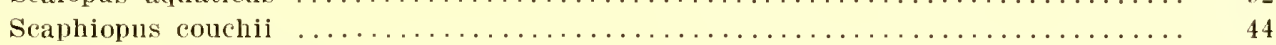

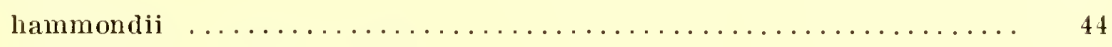

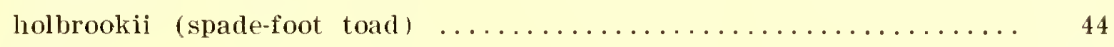

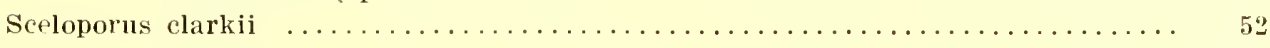

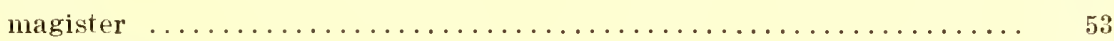

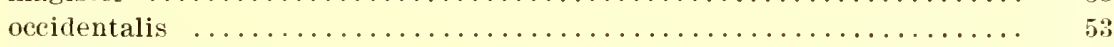

spinosus floridanus $\ldots \ldots \ldots \ldots \ldots \ldots \ldots \ldots \ldots \ldots \ldots \ldots \ldots \ldots \ldots \ldots \ldots \ldots \ldots$

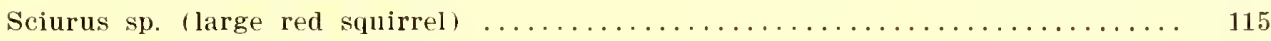

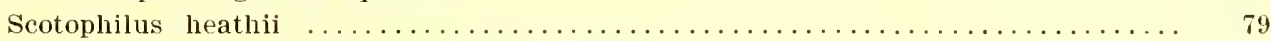

Shepherd $\operatorname{dog}($ not a pure blood). figure $280 \ldots \ldots \ldots \ldots \ldots \ldots \ldots \ldots \ldots \ldots \ldots \ldots$

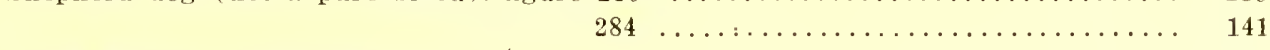

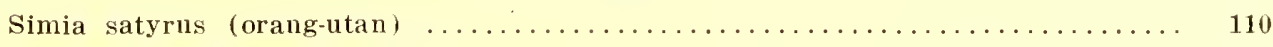

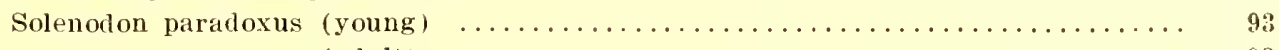

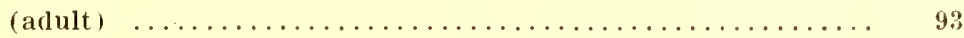




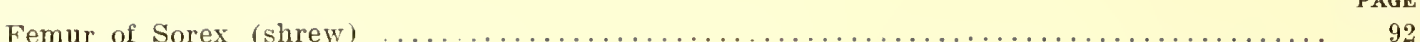

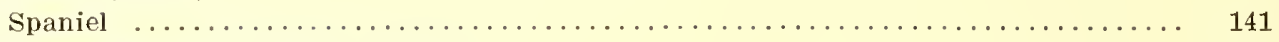

Spelerpes ruber (red salamander) ............................ 43

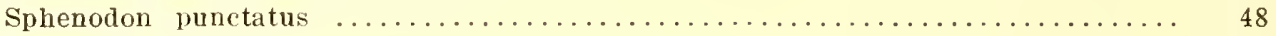

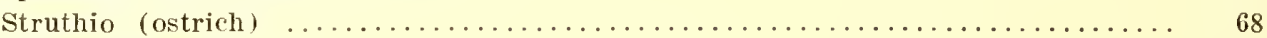

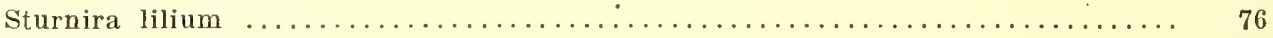

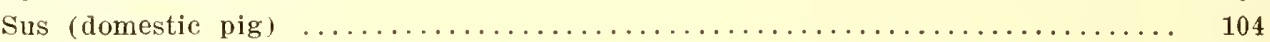

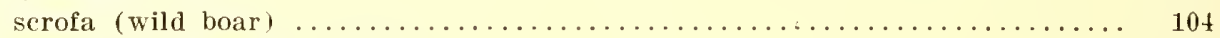

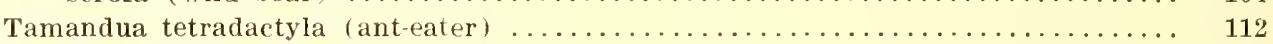

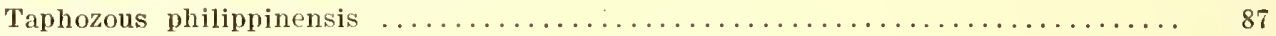

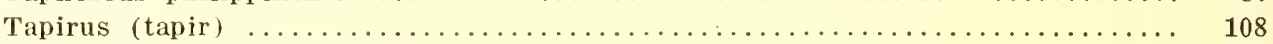

Tatu novemcinctus (armadillo! ............................... 112

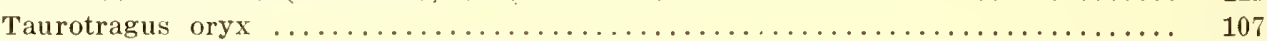

Taxidea americana (American badger) .......................... 145

Testudo (Gopherus) polyphemus ........................... 59

Thylacinus cynocephalus (Tasmanian wolf) ..................... 119

Tragulus javanicus (Java mouse-deer) ......................... 98

Trichosurus vulpecula (phalanger) ................................ 97

Trionyx spinifer (soft-shelled turtle) $\ldots \ldots \ldots \ldots \ldots \ldots \ldots \ldots \ldots \ldots \ldots \ldots \ldots \ldots \ldots . \ldots \ldots$

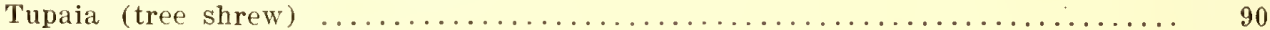

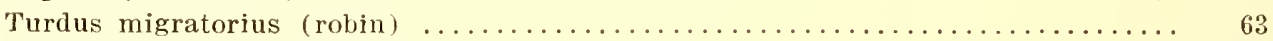

Tympanuchus americanús (prairie rhicken) ...................... 61

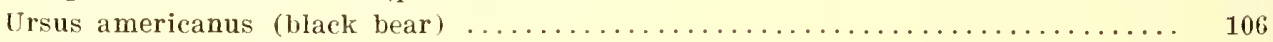

maritimus (polar bear) ............................. 133

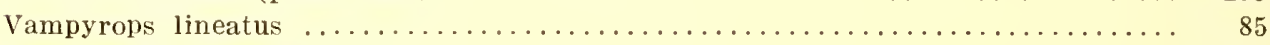

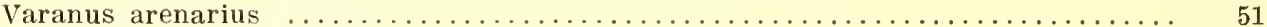

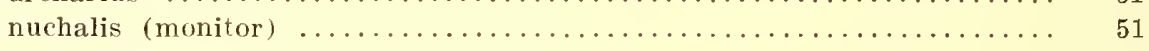

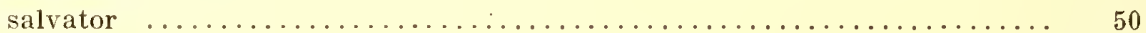

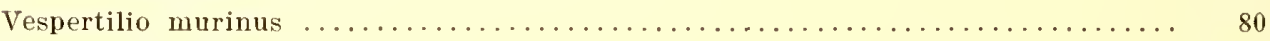

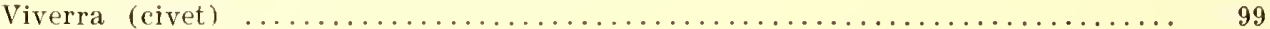

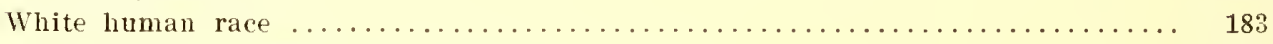

White male, No. 1629 , U. S. Nat. Mus. . . . . . . . . . . . . . . . . . . . . . . . 183

147, Med. Dep. Northwestern Univ. . . . . . . . . . . . 183

child (less than one year), No. 249588, U. S. Nat. Mus. ............... 184

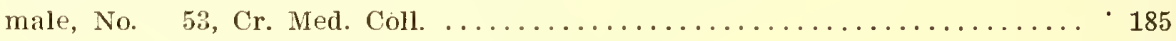

171, Med. Dept. Northwestern Univ.................... 185

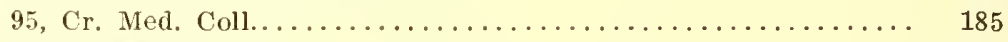

96, Cr. Med. Coll............................ 186

168, Med. Dept. Northwestern Univ................ 186

10, Med. Dept. Northwestern Univ.................. 187

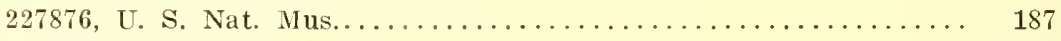

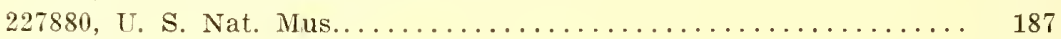

162, Med. Dept. Northwestern Univ ................ 188

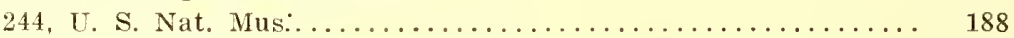

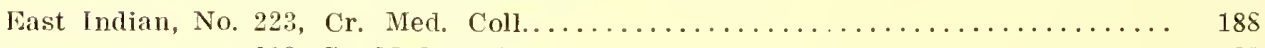

223 , Cr. Med. Coll............................. 189

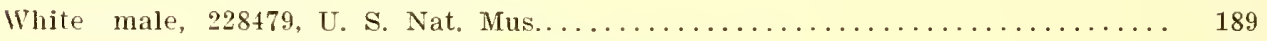

154, Med. Dept. Northwestern Univ.................... 190

146, Med. Dept. Nortliwestern Univ.................. 190

159, Med. Dept. Northwestern Univ..................... 190

167, Med. Dept. Northwestern Univ.................. 191

172, Med. Dept. Northwestern Univ.................... 191

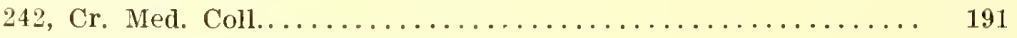

145, Med. Dept. Northwestern Univ..................... 192

174, Med. Dept. Northwestern Univ................... 192

157, Med. Dept. Northwestern Univ..................... 192

161, Med. Dept. Northwestern Univ.................... 193

15s, Med. Dept. Northwestern Univ..................... 193

243, Cr. Med. Coll............................ 193

148, Med. Dept. Northwestern Univ..................... 194

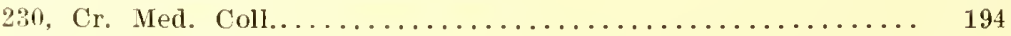

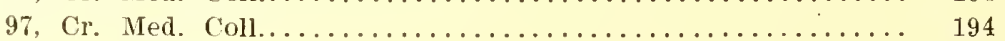


Femur of White male No $99 \mathrm{Cr}$ lled Coll

160, Ned. Dept. Northwestern Univ................... 196

163, Med. Dept. Northwestern Iniv..................... 196

156, Med. Dept. Northwestern Univ.................... 196

169, Med. Dept. Nortluwestern Univ..................... 197

151, Med. Dept. Northwestern Univ.................... 197

100, Cr. Med. Coll.................................... 198

150, Med. Dept. Northwestern Univ.................. 198

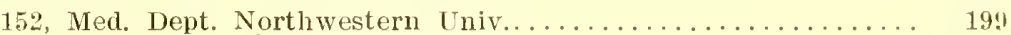

152, Med. Dept. Northwestern Univ.................... 199

164, Med. Dept. Northwestern Univ................... 200

166, Med. Dept. Northwestern Univ................. 200

(suicide), No. 175, Cr. Med. Coll...................... 200

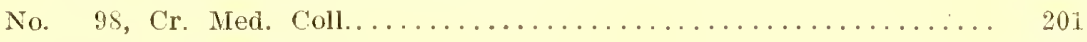

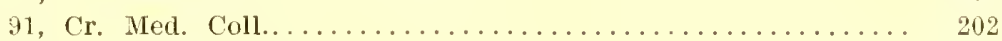

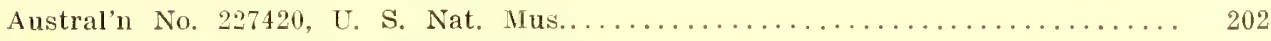

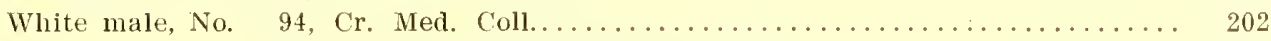

142, Med. Dept. Northwestern Univ.................. 203

(convict), No. 2, Med. Dept. Nebraska Univ................. 204

No. $\quad 3$, Med. Dept. Nebraska Univ...................... 204

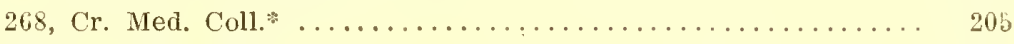

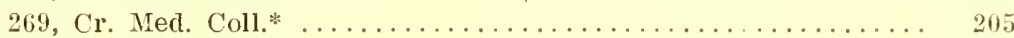

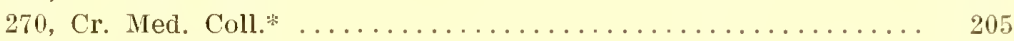

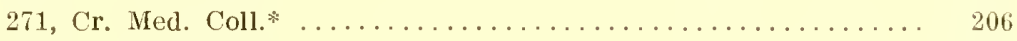

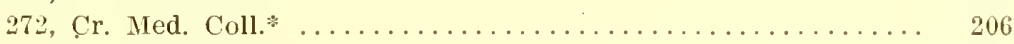

273, Cr. Med. Coll.* ........................ 206

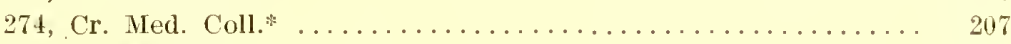

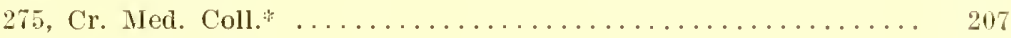

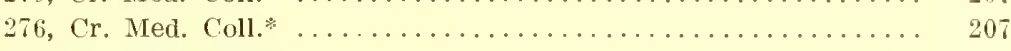

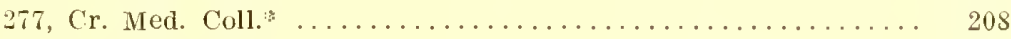

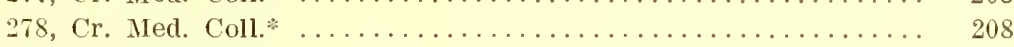

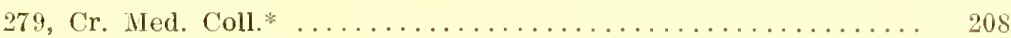

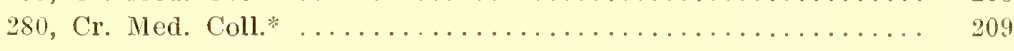

281, Cr. Med. Coll.* ........................ 209

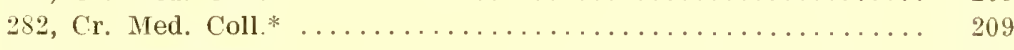

284, Cr. Med. Coll.* ........................ 210

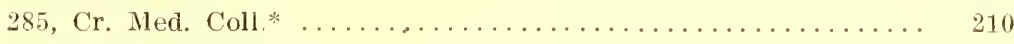

286, Cr. Med. Coll.* ....................... 210

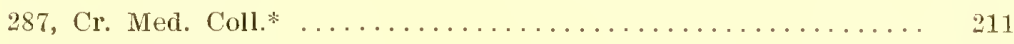

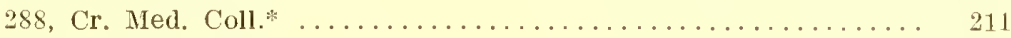

289, Cr. Med. Coll." ........................ 211

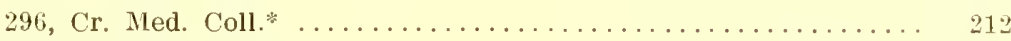

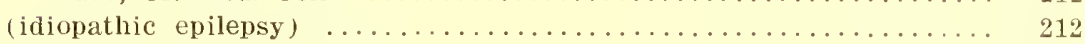

Fetal human femora and their lurther development.........................21, 24

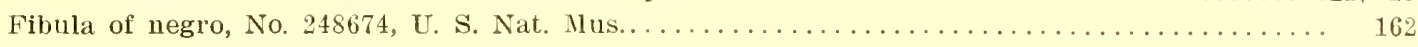

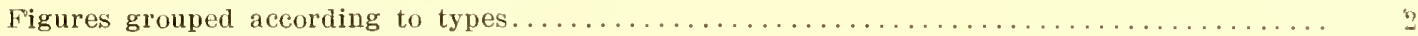

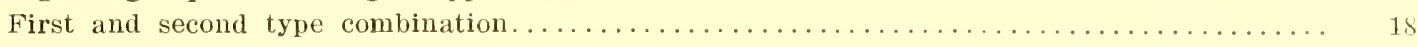

First and third type combination. . . . . . . . . . . . . . . . . . . . . . . .

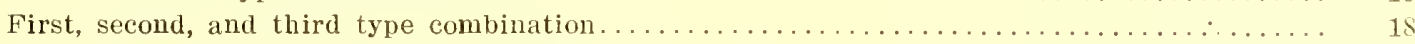

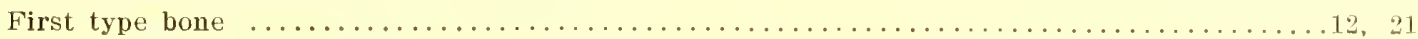

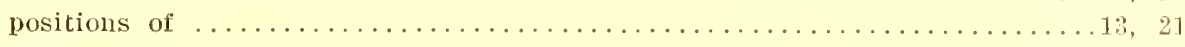

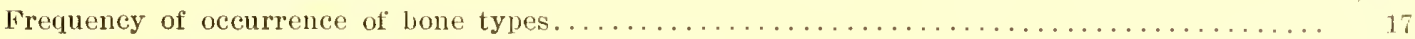

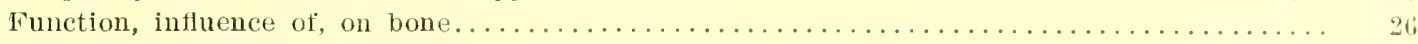

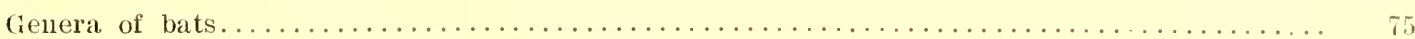

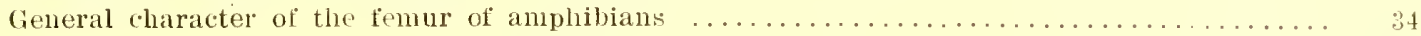

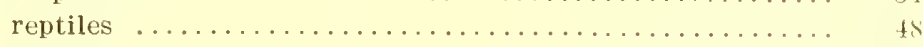

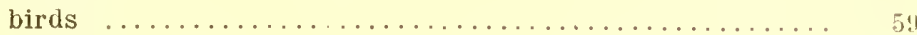

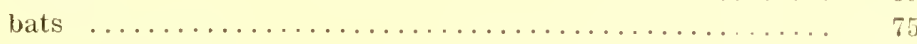

other mammals ........................... 90

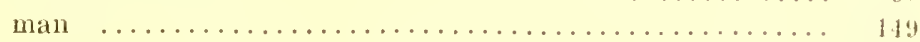




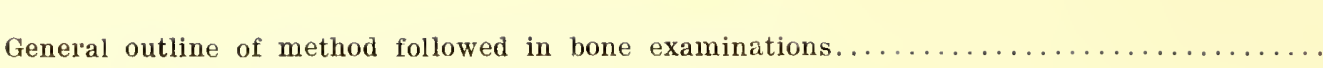

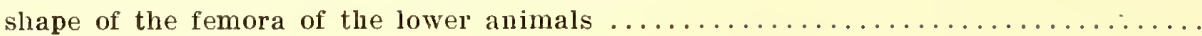

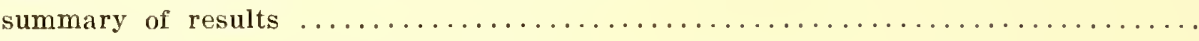

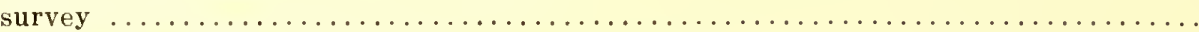

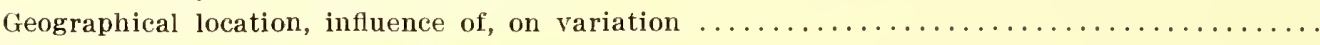
Grade of animals in biological classification

Haversian systems

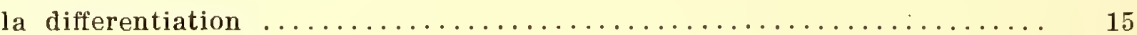

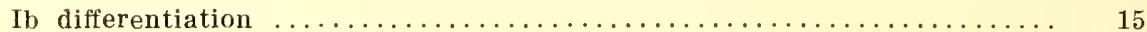

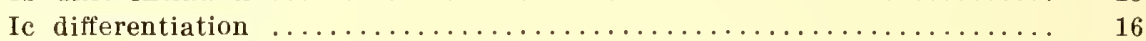

C differentiation $\ldots \ldots \ldots \ldots \ldots \ldots \ldots \ldots \ldots \ldots \ldots \ldots \ldots \ldots \ldots \ldots$

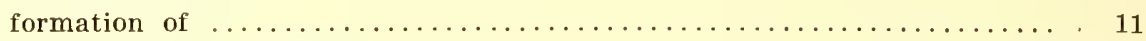

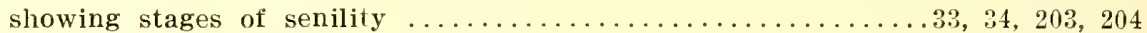

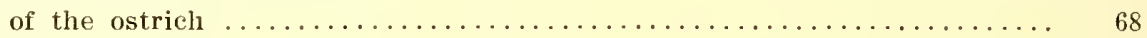

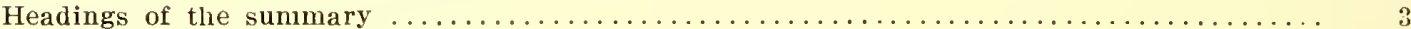

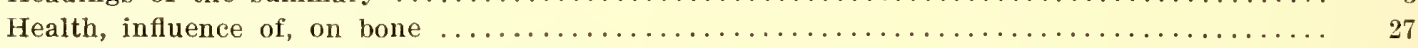

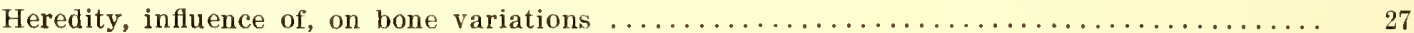

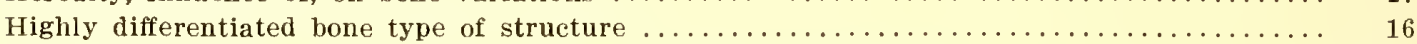

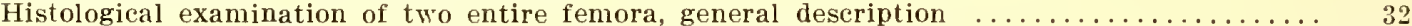

detailed description ................213-218

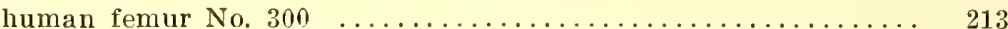

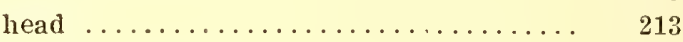

neck ........................... 213

lesser trochanter ................ 214

fourth section .................... 214

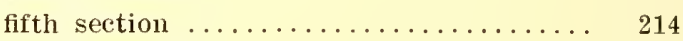

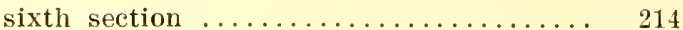

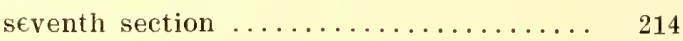

eighth section ................ 215

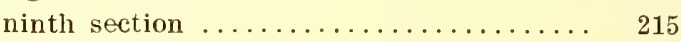

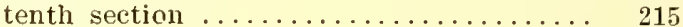

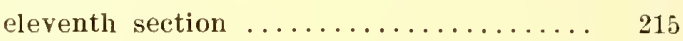

twelfth section .................. 215

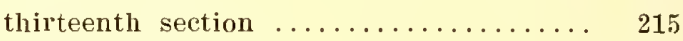

fourteenth section ................ 215

fifteenth section $\ldots \ldots \ldots \ldots \ldots \ldots \ldots \ldots . \ldots \ldots$

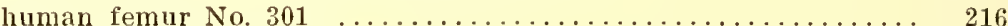

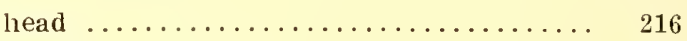

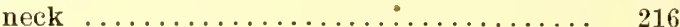

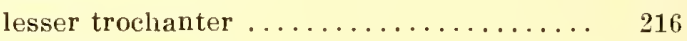

fourth section ................ 217

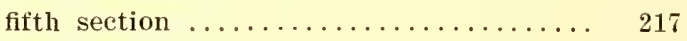

sixth section .................. 217

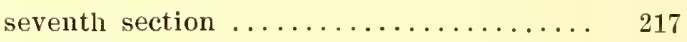

eighth section ................ 217

ninth section ............... 217

tenth section ................. 217

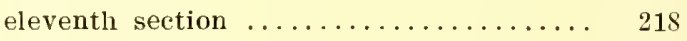

twelfth section ................. 218

thirteenth section .............. 218

fourteenth section .............. 218

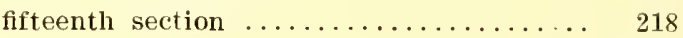

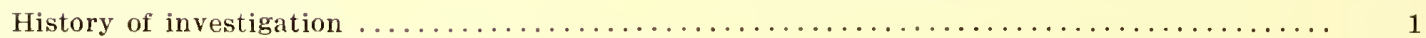

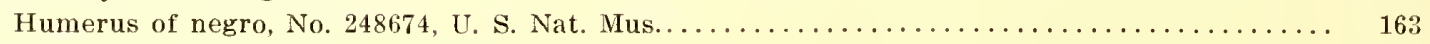

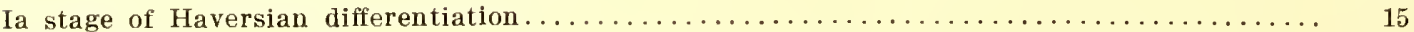

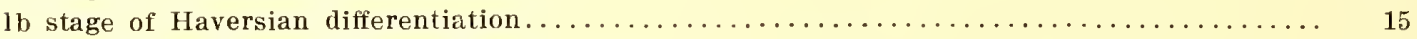

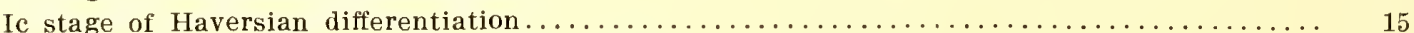

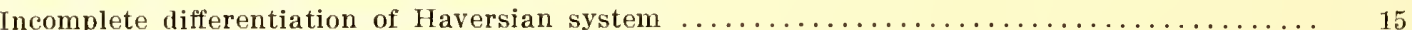

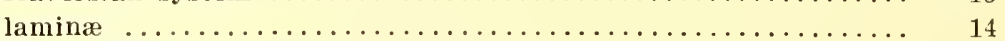

Increase of medullary index from amphibian to bird ........................ 


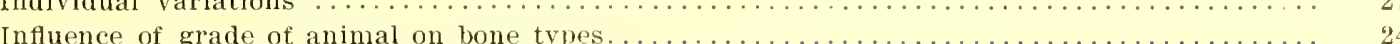

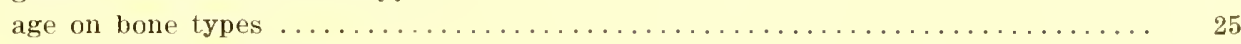

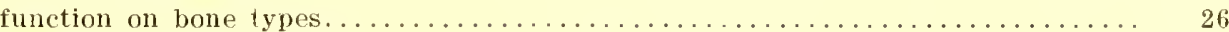

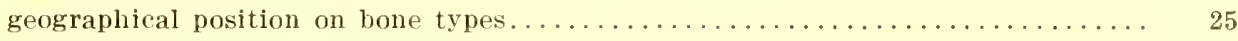

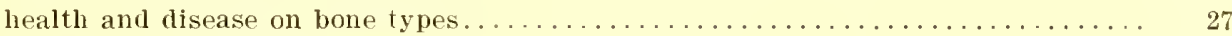

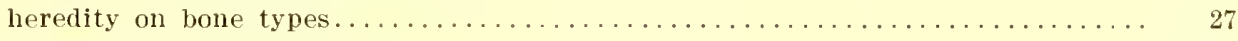

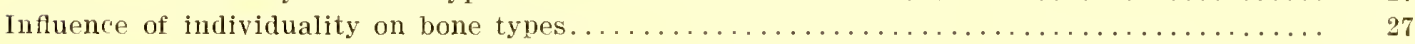

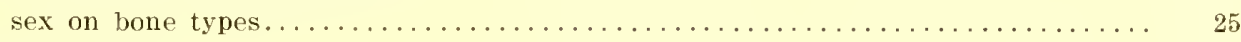

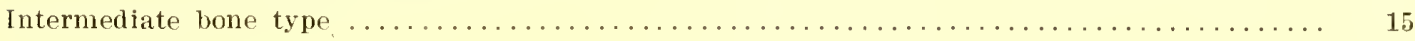

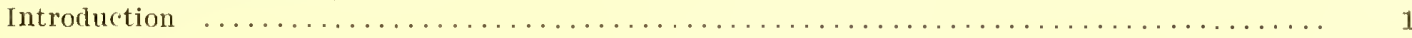

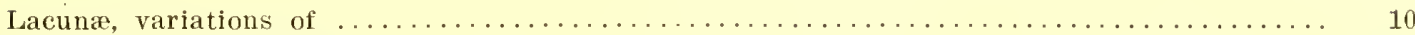

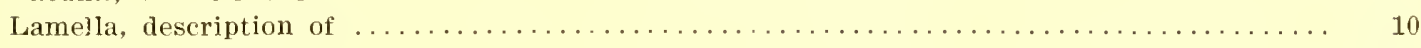

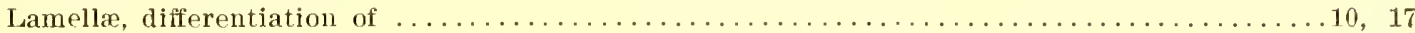

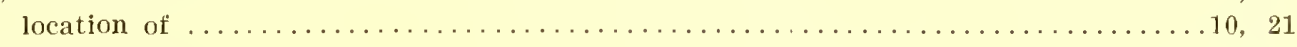

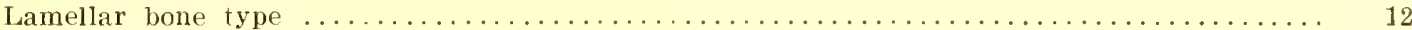

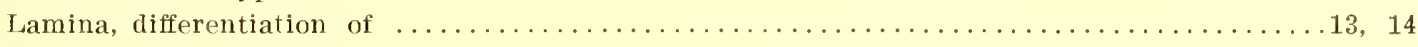

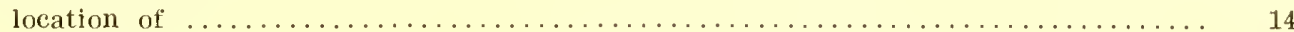

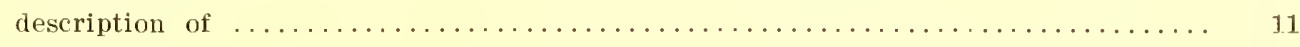

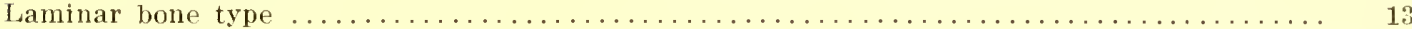

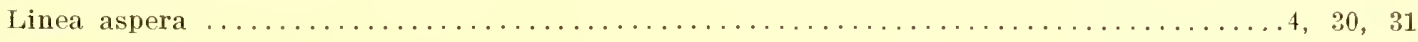

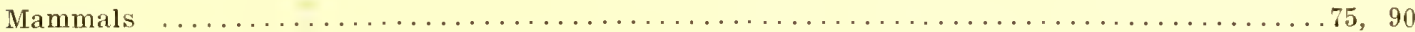

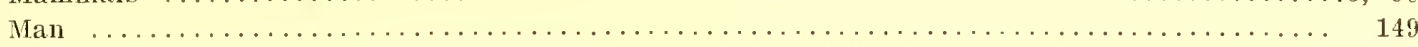

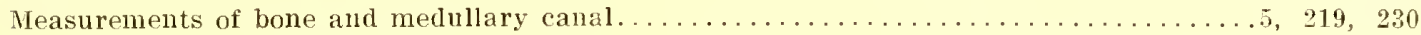

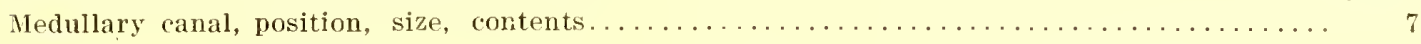

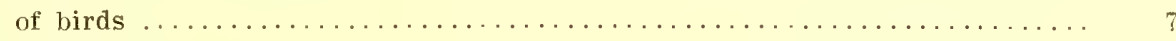

variations of $\ldots \ldots \ldots \ldots \ldots \ldots \ldots \ldots \ldots \ldots \ldots \ldots \ldots \ldots \ldots \ldots \ldots \ldots \ldots \ldots \ldots \ldots$

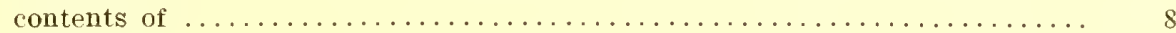

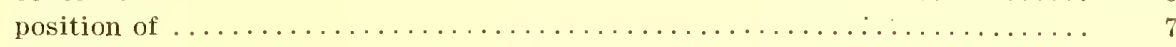

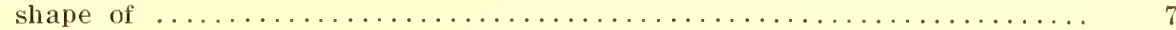

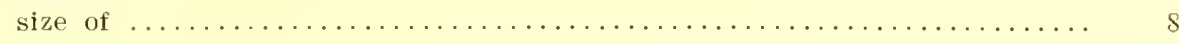

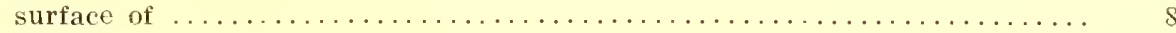

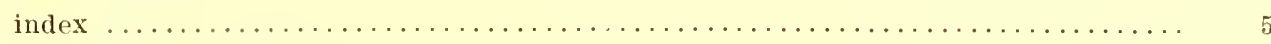

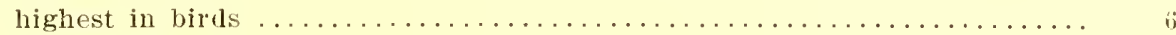

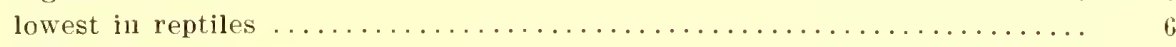

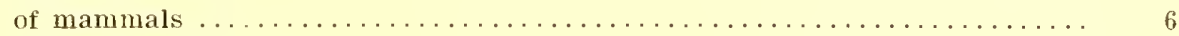

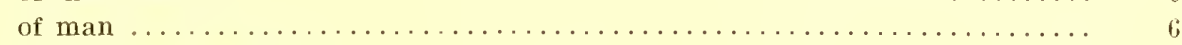

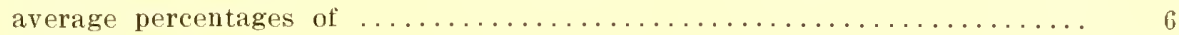

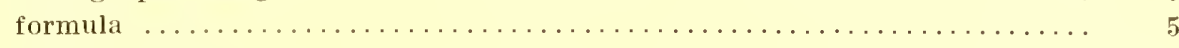

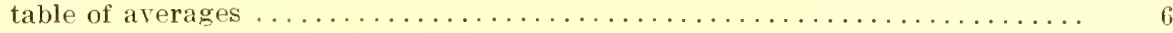

Metatarsal bone of big toe of negro, No. 248674, I. S. Nat Mus..................... 163

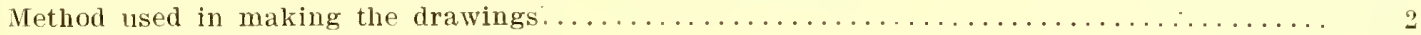

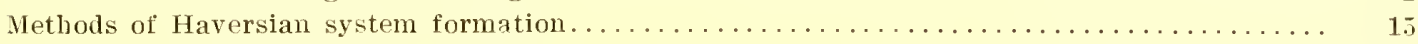

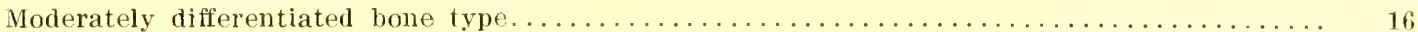

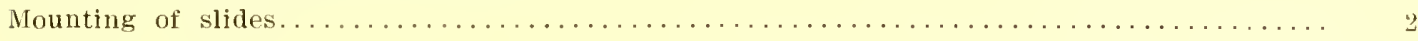

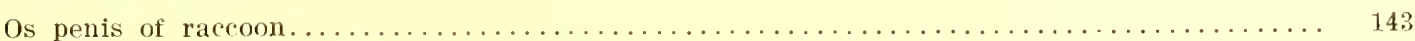

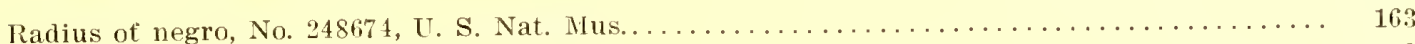

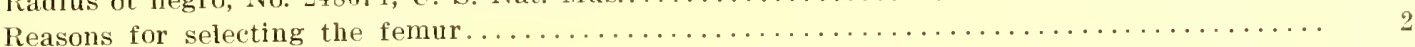

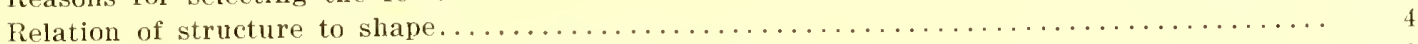

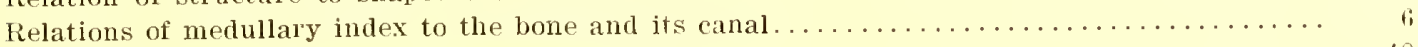

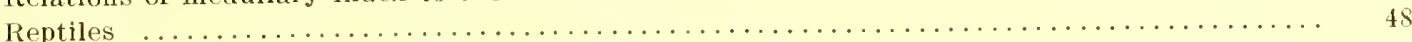

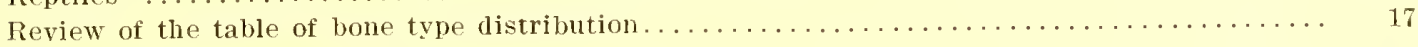

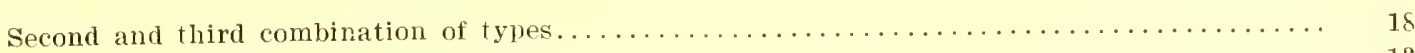

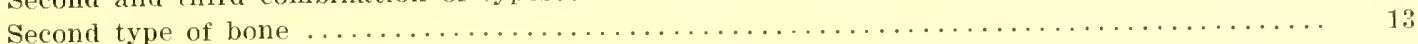

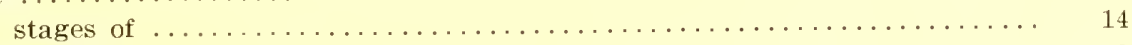

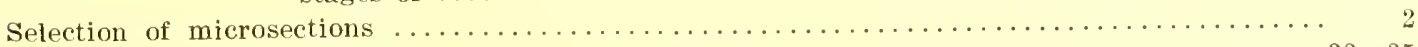

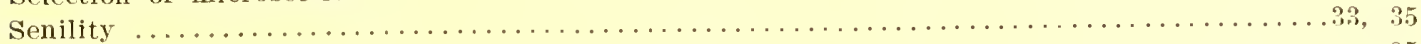

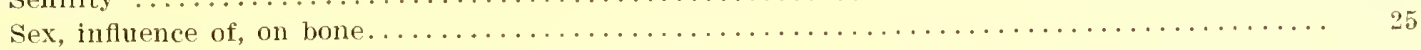




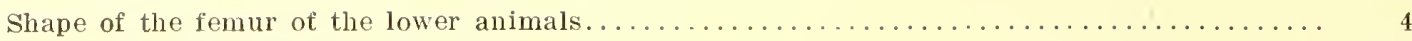

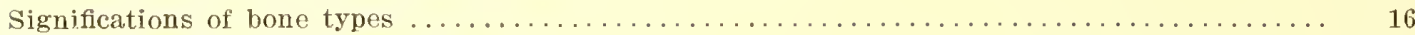

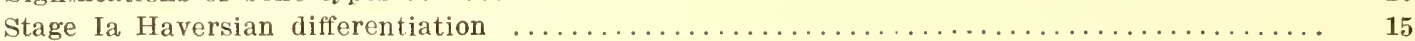

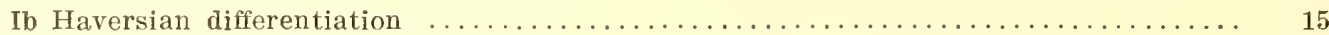

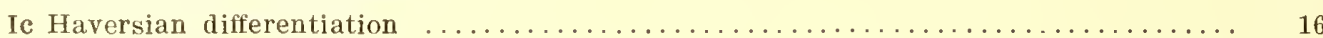

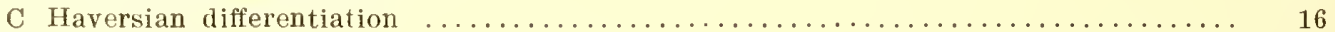

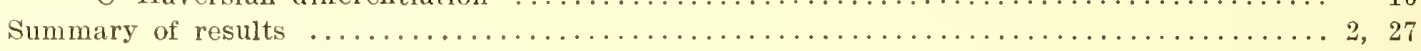

senile changes ........................................ 34

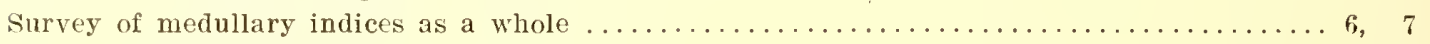

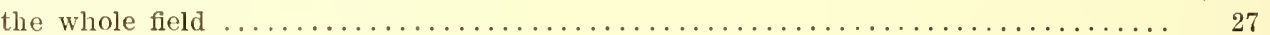

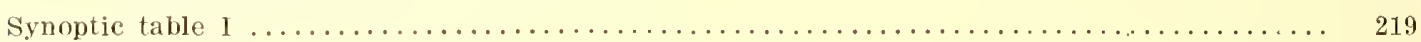

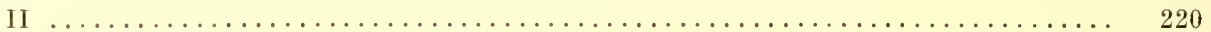

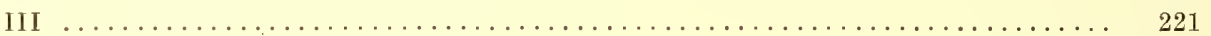

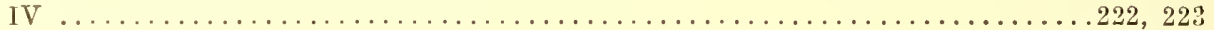

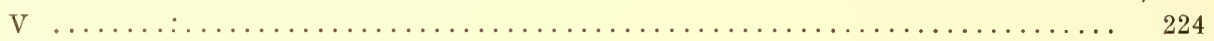

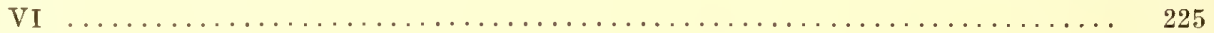

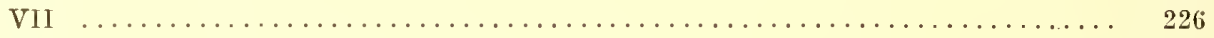

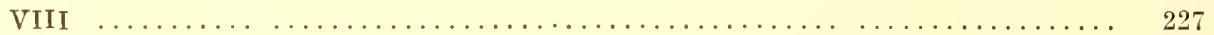

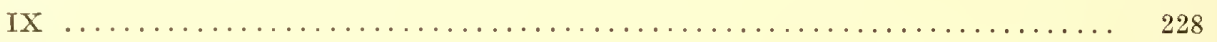

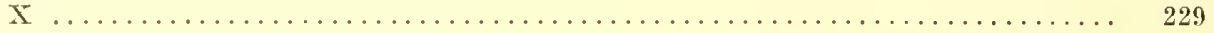

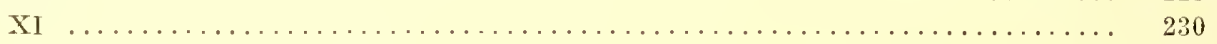

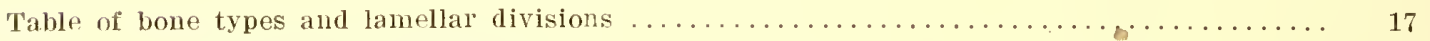

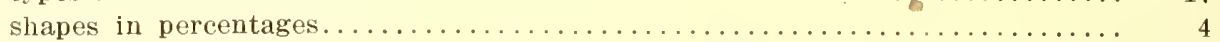

medullary indices $\ldots \ldots \ldots \ldots \ldots \ldots \ldots \ldots \ldots \ldots \ldots \ldots \ldots \ldots \ldots \ldots \ldots \ldots$

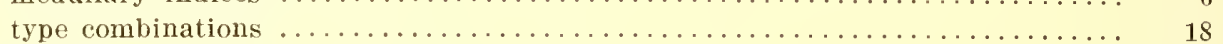

the distribution of the three bone types $\ldots \ldots \ldots \ldots \ldots \ldots \ldots \ldots \ldots \ldots \ldots \ldots \ldots \ldots \ldots \ldots . \ldots 17$

Third conclusion of the survey of averages of medullary indices. . . . . . . . . . . . . . . . . . . .

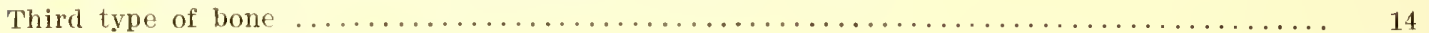

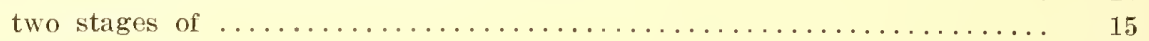

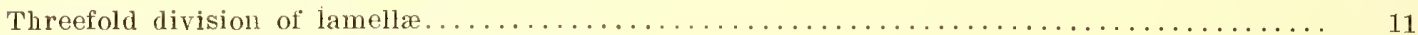

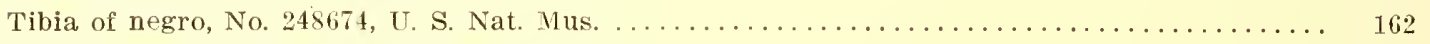

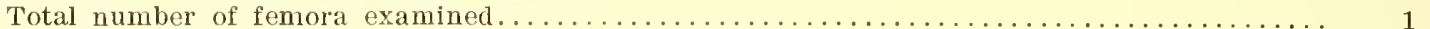

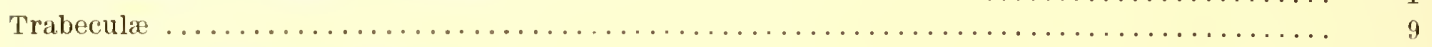

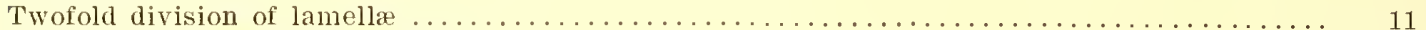

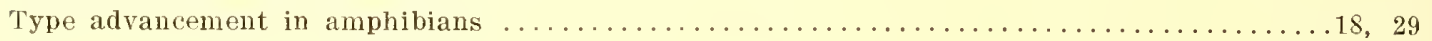

reptiles .....................................19, 29

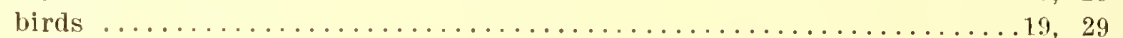

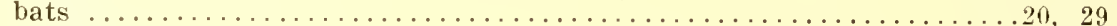

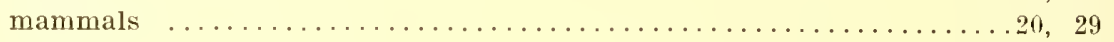

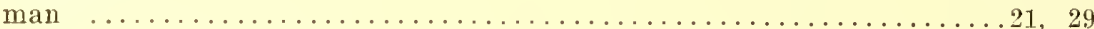

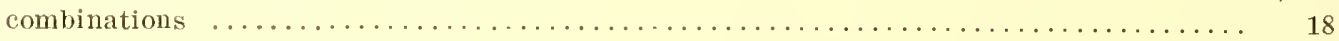

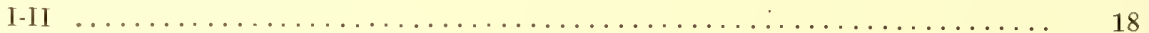

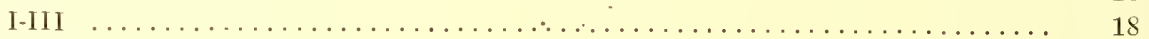

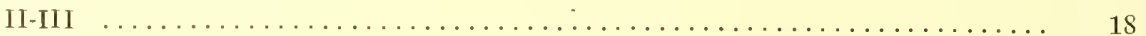

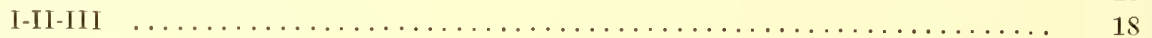

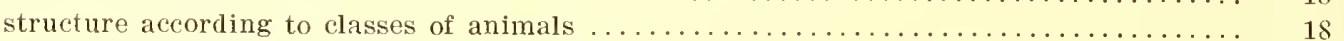

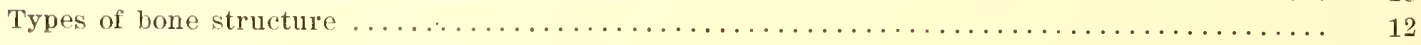

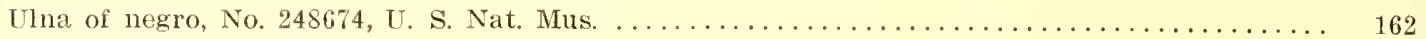

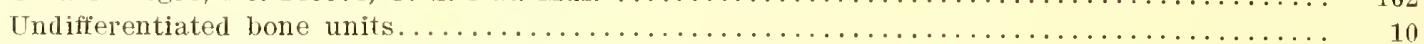

Uniformly lamellated bone structure.................................. 11

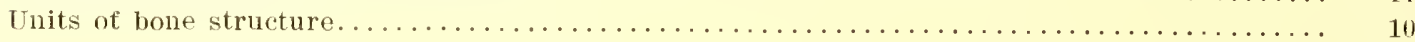

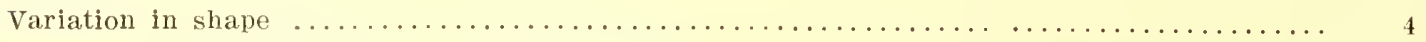

the prominent factor in bone histology $\ldots \ldots \ldots \ldots \ldots \ldots \ldots \ldots \ldots \ldots \ldots \ldots \ldots \ldots \ldots 2,8$

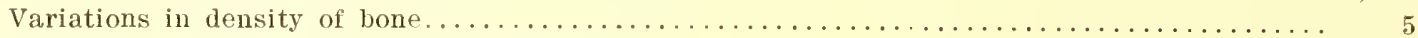

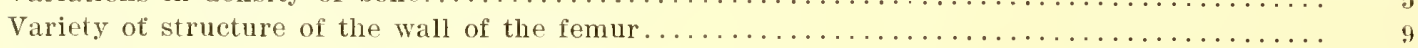

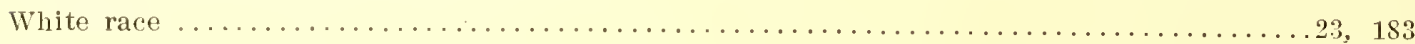

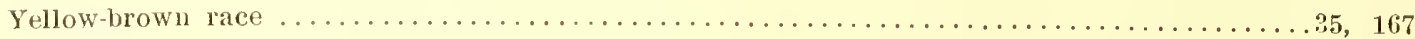




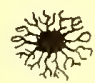

FIG. A
Round Jacuna with short, bushy canaliculi. Eiarly stage

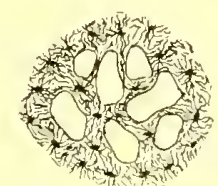

Fig. D

Basic or undifferentiated bone. Amblystoma tigrinum

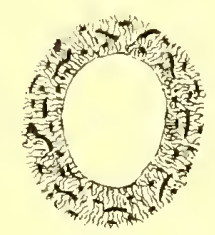

Fif. H
Early stage in the differentiation of laminæ.
Aztec jay

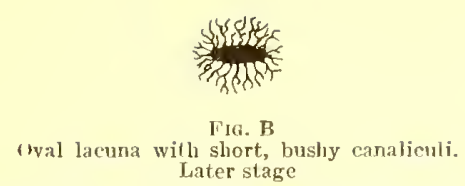

Later stage

TIIREE STAGES IN THE DIFFERENTIATION OF LAGUNA

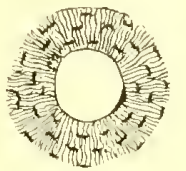

Difrerentiated bone, Frog. Concentrie lacunæe FIRST DIFFERENTIATION

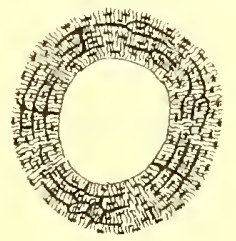
FIG. I
Later stage in the differentiation of laminx.
Chinese pheasant SECOND DIFFERENTIATION

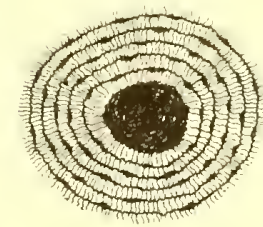

Diferentiated bone. Haversian system of man. Coneentric lamellæ

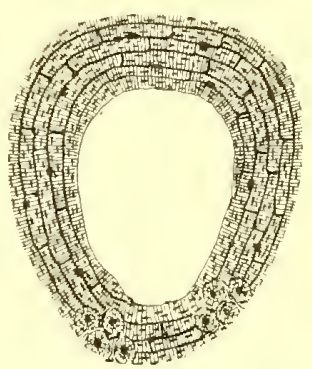

FIG. J
1atest stage in the differentiation of Iaminit:
Pig

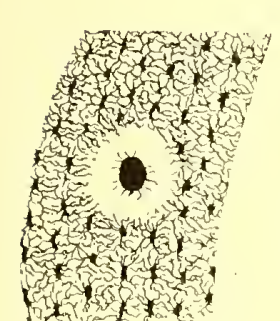

if 1 in

Fig. I
Stage Ja. Amphibian Incomplete differentiation of Havcrsian systems THIRD DIFEERENTIATION

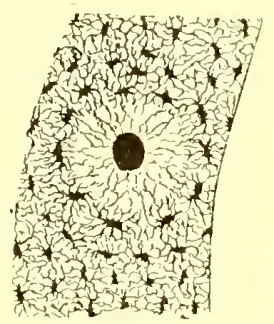

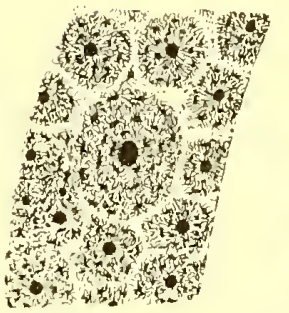

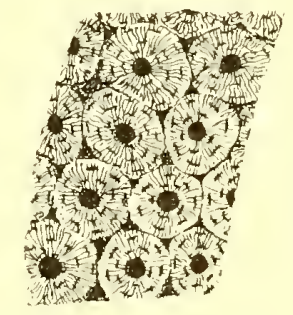

Fig. $\mathrm{N}$

Stage C. Mammal. Man. Haversian systems

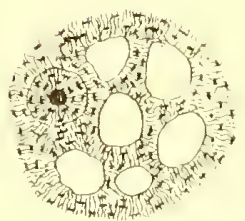

Fig.
Haversian system
formed in the mesh of cancellous bone ABERRANT FORMS

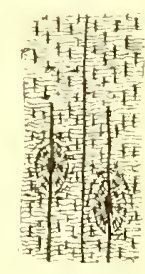

Fig. P

Haversian systrms a seeond type bone

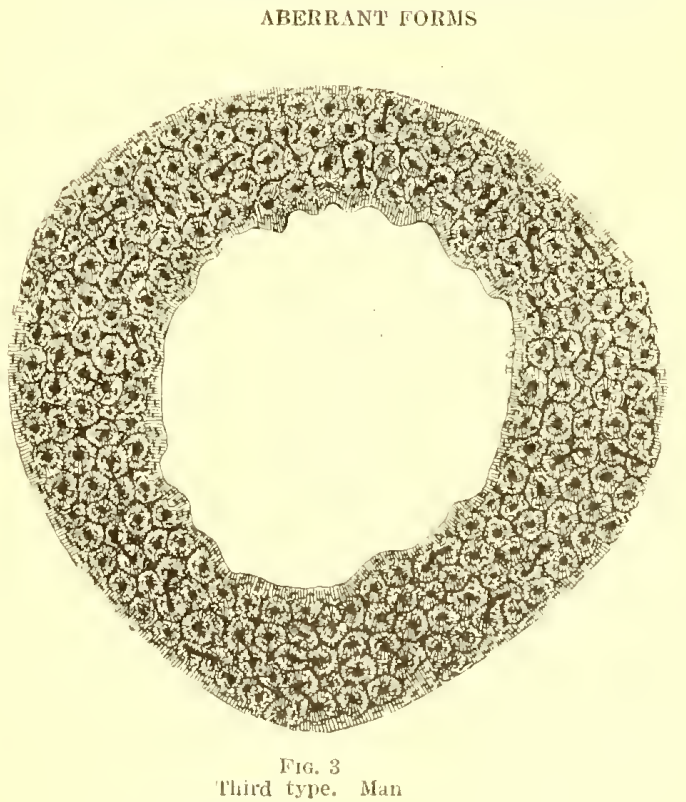



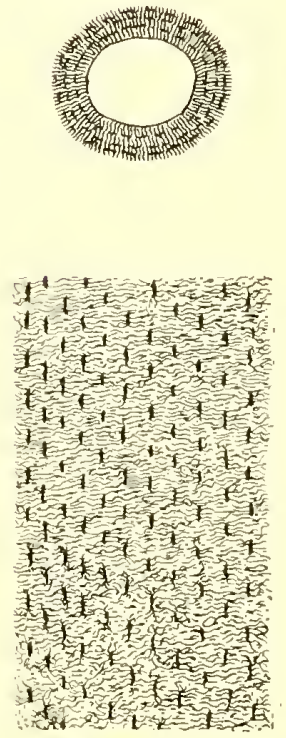

F1G. 1
Cross and longitudinal sections

of a femur of the first type

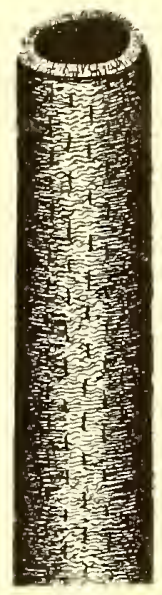

Fif. 4
Diagram illustrating a first type:
femur

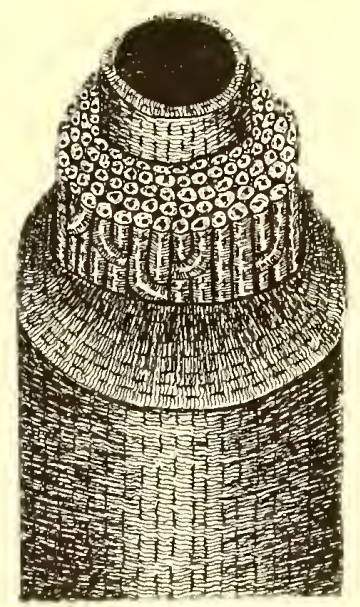

F19. 7

the first and third type
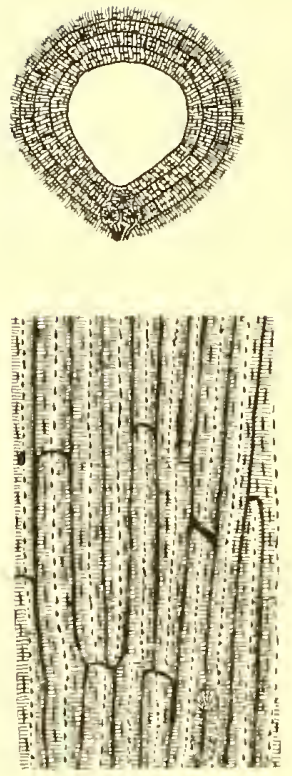

Fig. 2

Cross and longitudinal sections
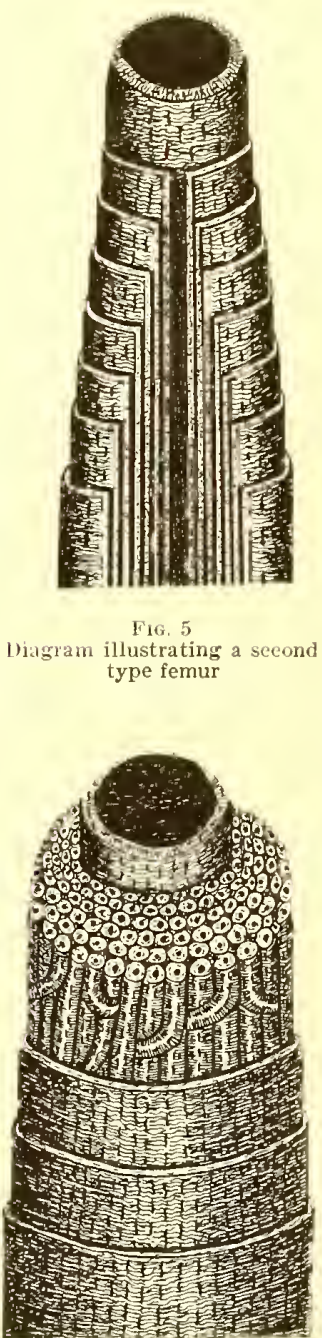

FIG, 8

Diagram illustrating a ten combination
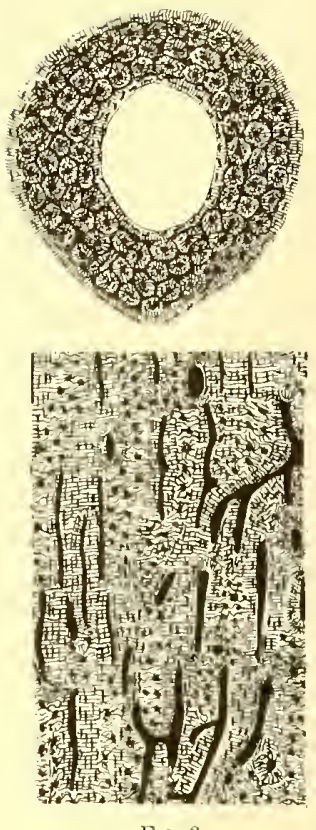

FiG. 3
Cross and longitudinal section of a femur of the third type

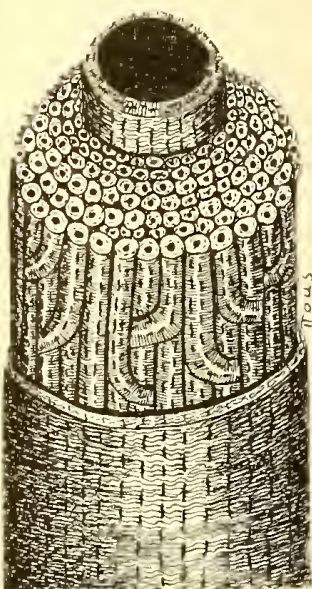

Fig. 6
Diagram illustrating a third

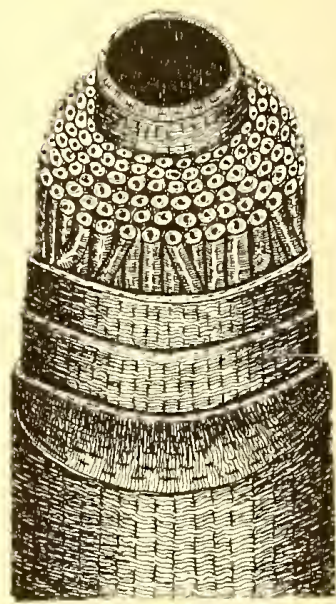

Fis. 9

Fic. 9 a fermur of the first, second and third

CROSS AND IONGITUUINAL SECIIONS OF TYPES OF FEMORA, AND DIAGRAMS ILLUSTRSTING TILE CONSTRUCTION OF FEMORA 


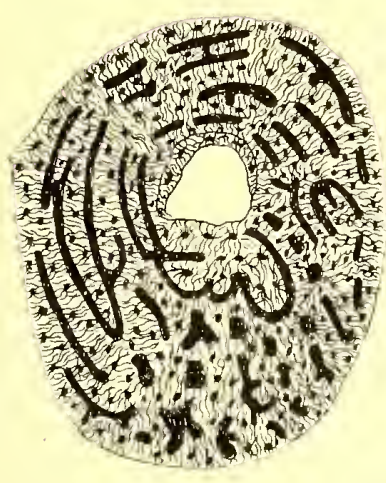

FIg. 1
I-II. Human fetus

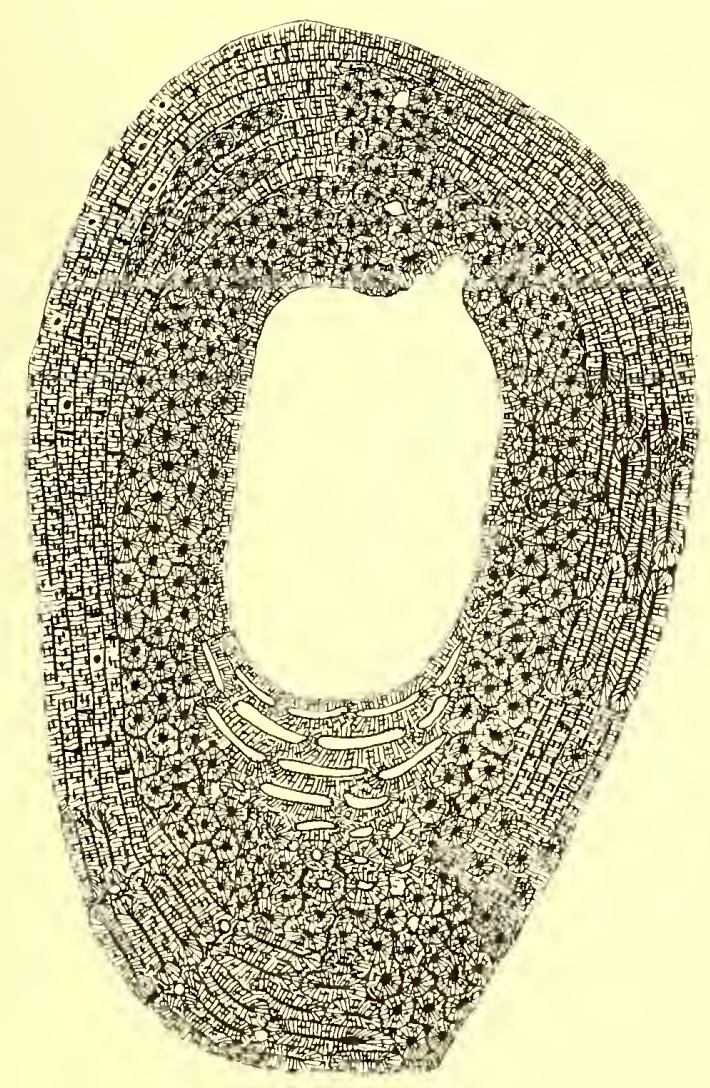

FIG. 3
II-III. EIephas indicus

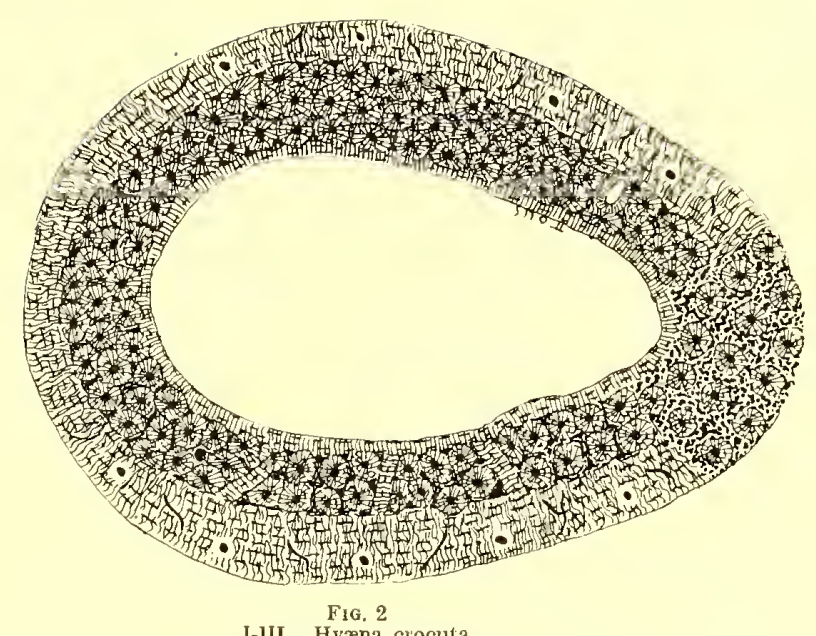

I-1II. Hyena crocuta

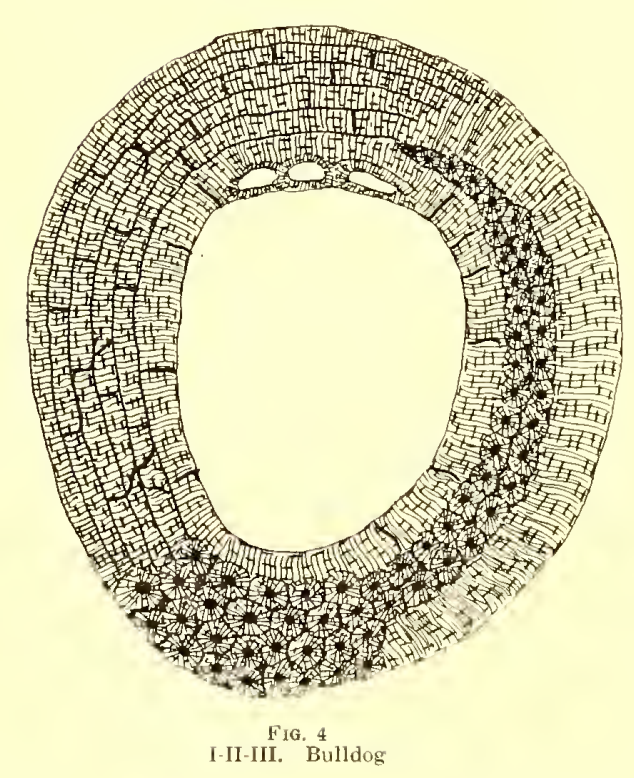

COMBINATIONS OF TYPES 


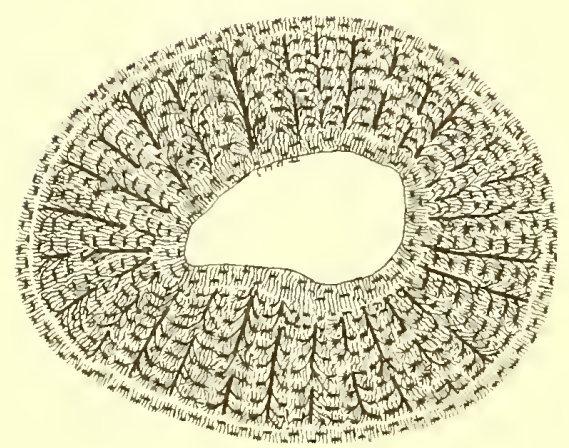

FiG. 1

Right femur of a large bull frog (Rana catesbiana), showing radiating bush-like canals

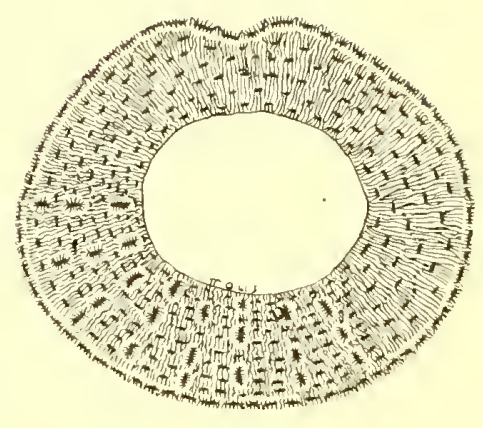

Fig. 2
Right fenuur of a medium-sizcd bull frog (Rana
catesbiana), the radiating canals disappearing

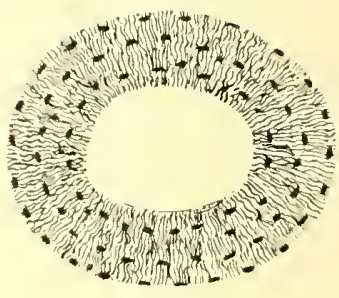

Fig. 3
Right femur of a sinall bull frog (Rana catesbiana), in which radiating canals are displaced by lamellæ

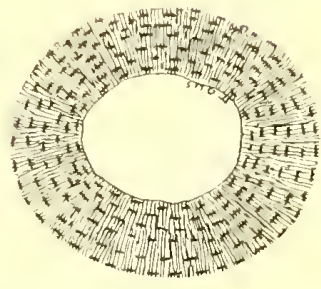

Frg. 4
light femur of a bull frog showing the first type

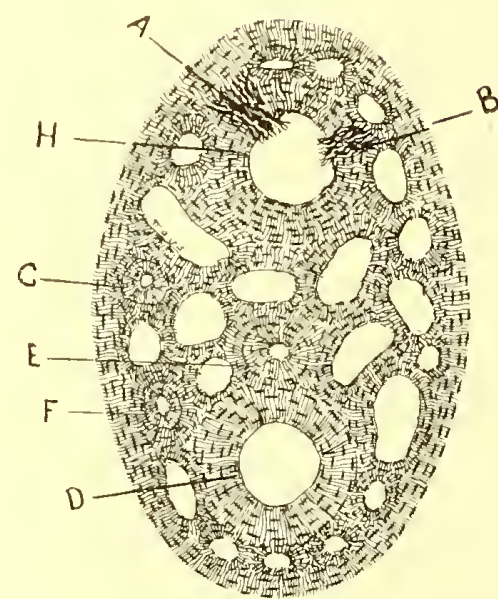

Fig. 5

FIG. 5
Fractured and repaired femur of a bull frog (Rana catesbiana), slowing new cancellous bone of repair 


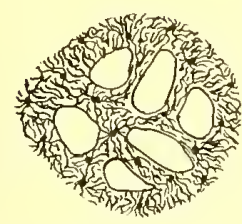

Fıg. 6

Right fenur of (nost primitive amphibian)

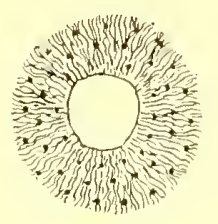

FIG. 7

Right femur of
Hyla versicolor ('ree frog)

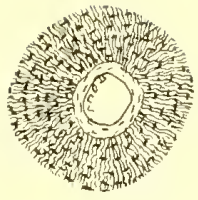
F1G. 8
Right femur of Hyla
arenicolor

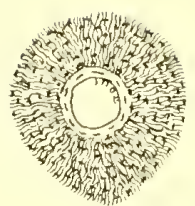
Fig. 9
Right femur of Hyla
femoralis

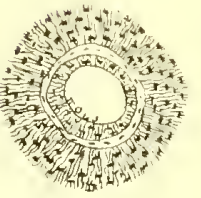

FIG. 14
Right femur of Hyla
gratiosa

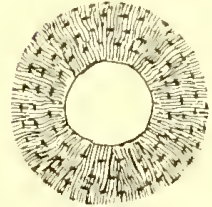

FiG. 19
Right femur of Rana Fig. 15
Right femur of Acris
gryllus
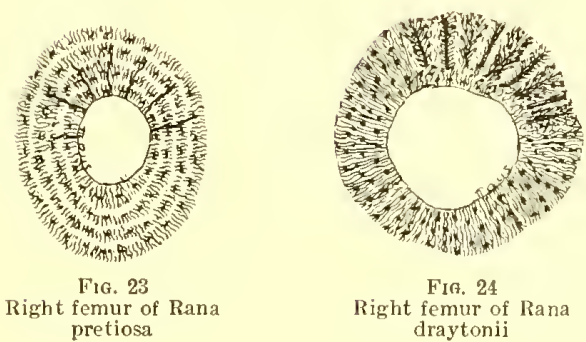

Fig. 28
Right femul of Scaphiopus
holbrookii

AMPIIIBIANS
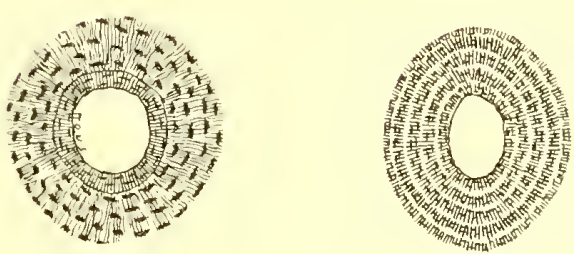

F16. 29 Right femur of Scaphiopus
couchii

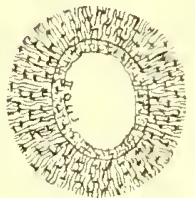

FIG. 10
Right femur of Hyla

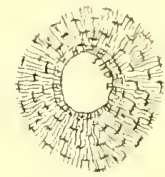

FIG. 15 Right femur of
Dendrobates tinctorius

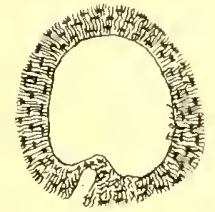
FIG. 21
$\begin{gathered}\text { Right femur of Rana } \\ \text { areolata circulosa }\end{gathered}$

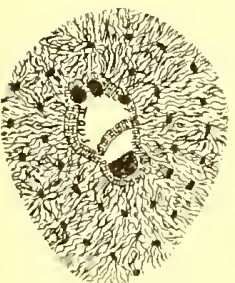

FiG. 26
Right femur of Cryptohranchus alleghenicnsis

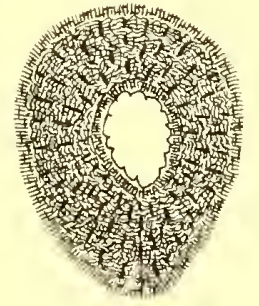

F1G. 27
Right femur of Necturu maculatus

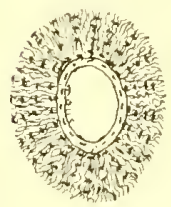

Frg. 20
Right femur of Rana
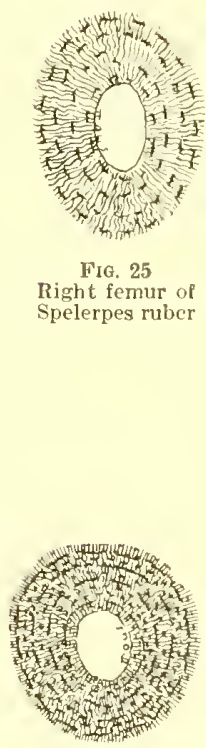

Fig. 30 hamrondii 

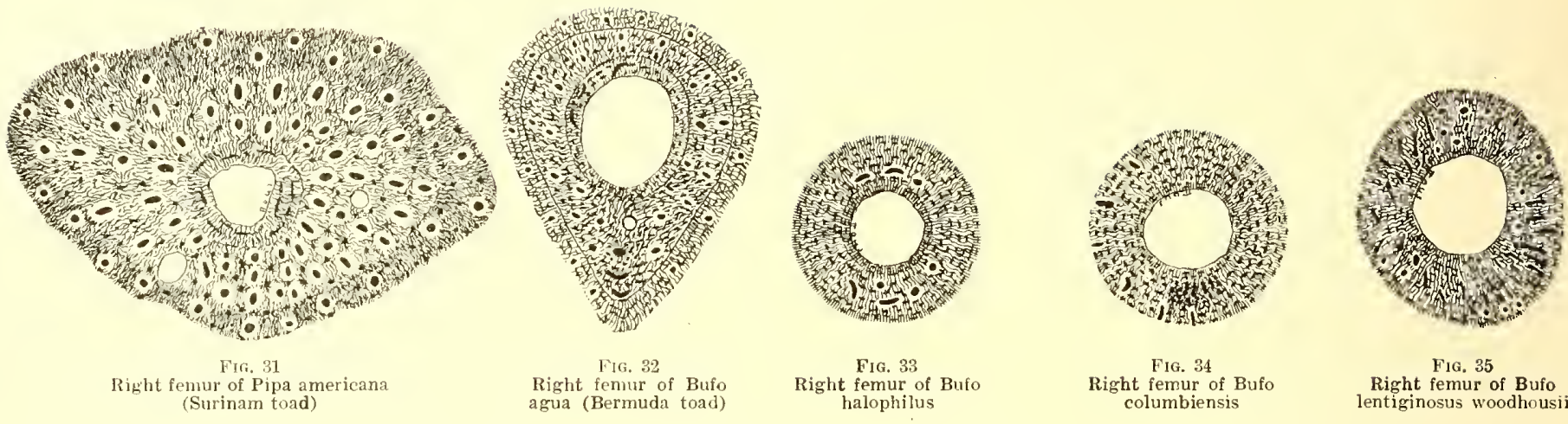

FIG. 33
Right femur of Bufo
halophilus

FIG. 34
Right femur of Bufo
columbiensis

FIG. 35
Right femur of Bufo
lentiginosus woodhousii
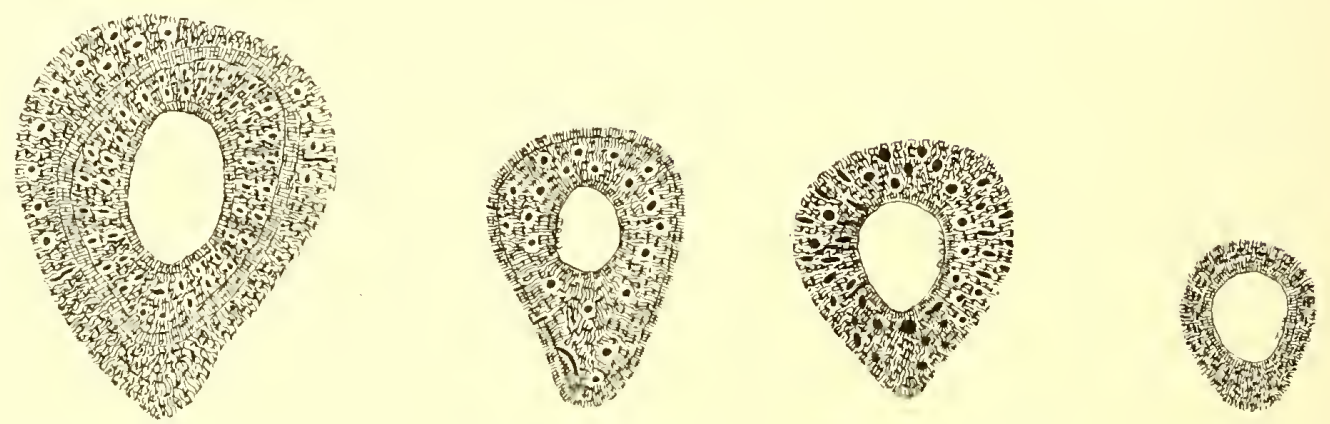

Rlght femur of Bufo americana

Fig. 37
Right femur of Bufo
lentiginosus cognatus

Fici, 38
Right femur of Bufo
valliceps

Fig. 39
Right femur of Rana
boylii

REPTILES

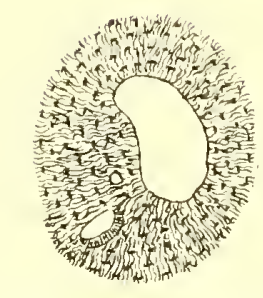

Fig. 40

Right femur of Sphenodon reptile)

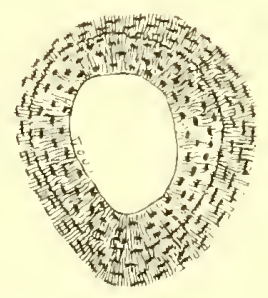

FIG. 41
Right fenur of Phrynosoma cornutum

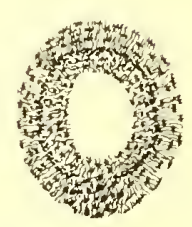

Feft femur of Chainæleo vulgaris

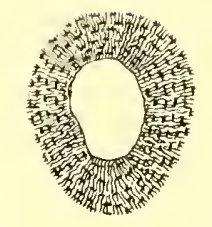

FIG. 43

douglassii

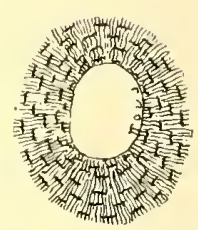
Fia. 44
Right fenur of Ptychozoon
homalocephalum

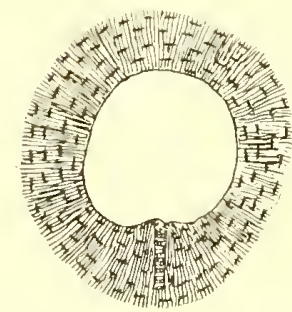

Fig. 45

Right femur of Ig wana
tuberculata

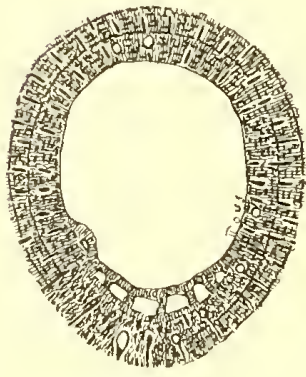

Fig. 46
Left femur of Varanus
salvator

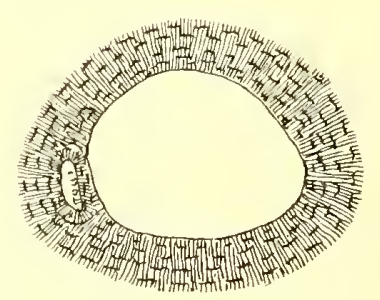

FIG. 47 Amphibolurus barbatus AMPHIBIANS AND REPTILES

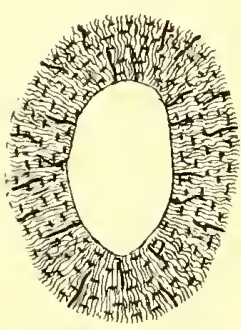

FIG. 48 Garnus
Left femur of Varanus

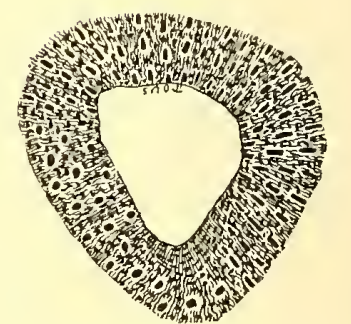

Fig. 49
Right femur of Varanus 


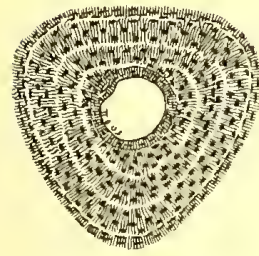

FIG. 50

Right femur of
IIfloderma suspectum

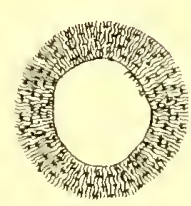

FIG. 51

Right femur of Sceloporu
clarkii

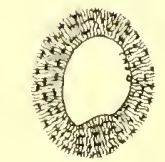

FIG. 52

Right femur of foridanus
flor

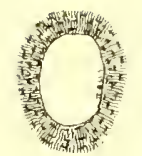

FIG. 53

Right femur o Sceloporils
occidentalis

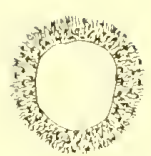

Fig. 54 Sceloporus magister

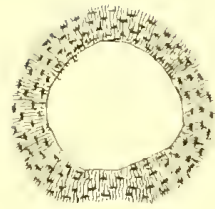

FIG. 55 Right femur of
Cyclura carinata

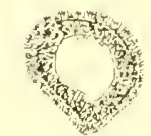

FIG. 56 Anolis cristatellus
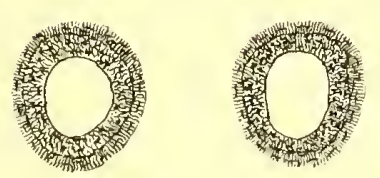

F1G. 57
Right femur

Right femur o
Crotaphytus rotaphytu
collaris

FIG. 58
Left femur of Left femur of
Crotaphytus
collaris

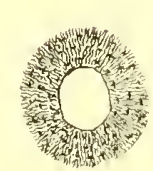
Fig. 59
Right femur of Ameiva exul

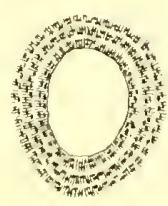

FIG. 60

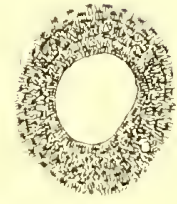

FIG. 61

Right femur of Sauromalus
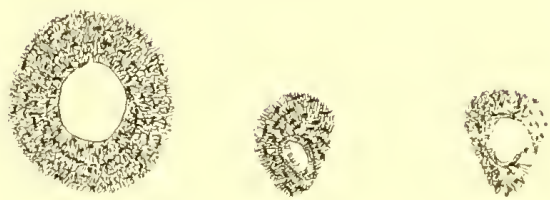

F1G. 62
Right femur of
Gerrhonotus

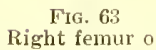

Right femur of
Python regius grandis

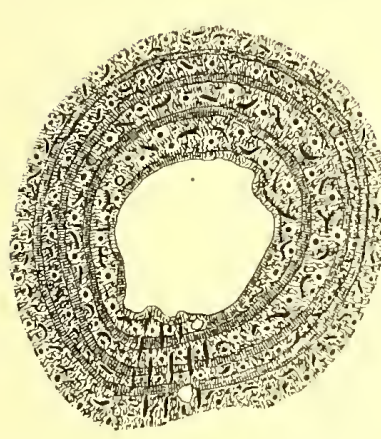

FIG. 65
Left fenuur of Alligator
mississippiensis

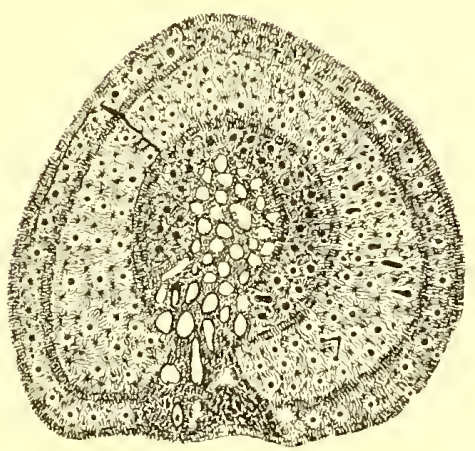

Firi, 66

Femur of Chelydra serpentina

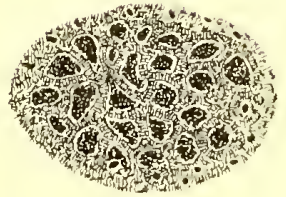

PIG. 67

Right femur of Trionyx

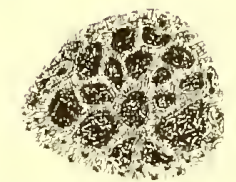

Fia. 68

Right femur of Cinoster num pennsylvanicum

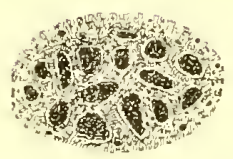

Fig. 69

ight femur of Chelopus turtle)

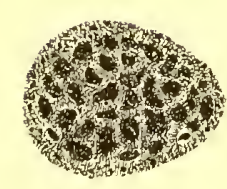

FIG. 70

Left femur of Chrysemys picta

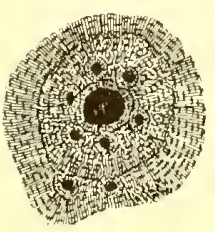

Fig. 71
Right femur of Aromochelys odoratus (musk turtle)

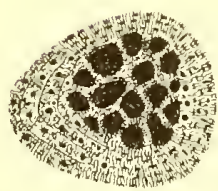

Fig. 72
Right femur of Pseudemys floridana REPTILES

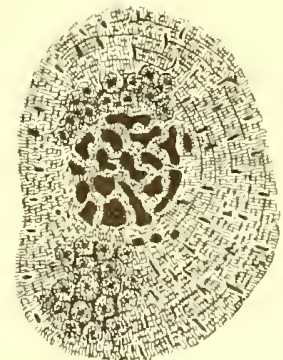
Fig. 73
Right femur of Testudo (Gopherus)
polyphemus 

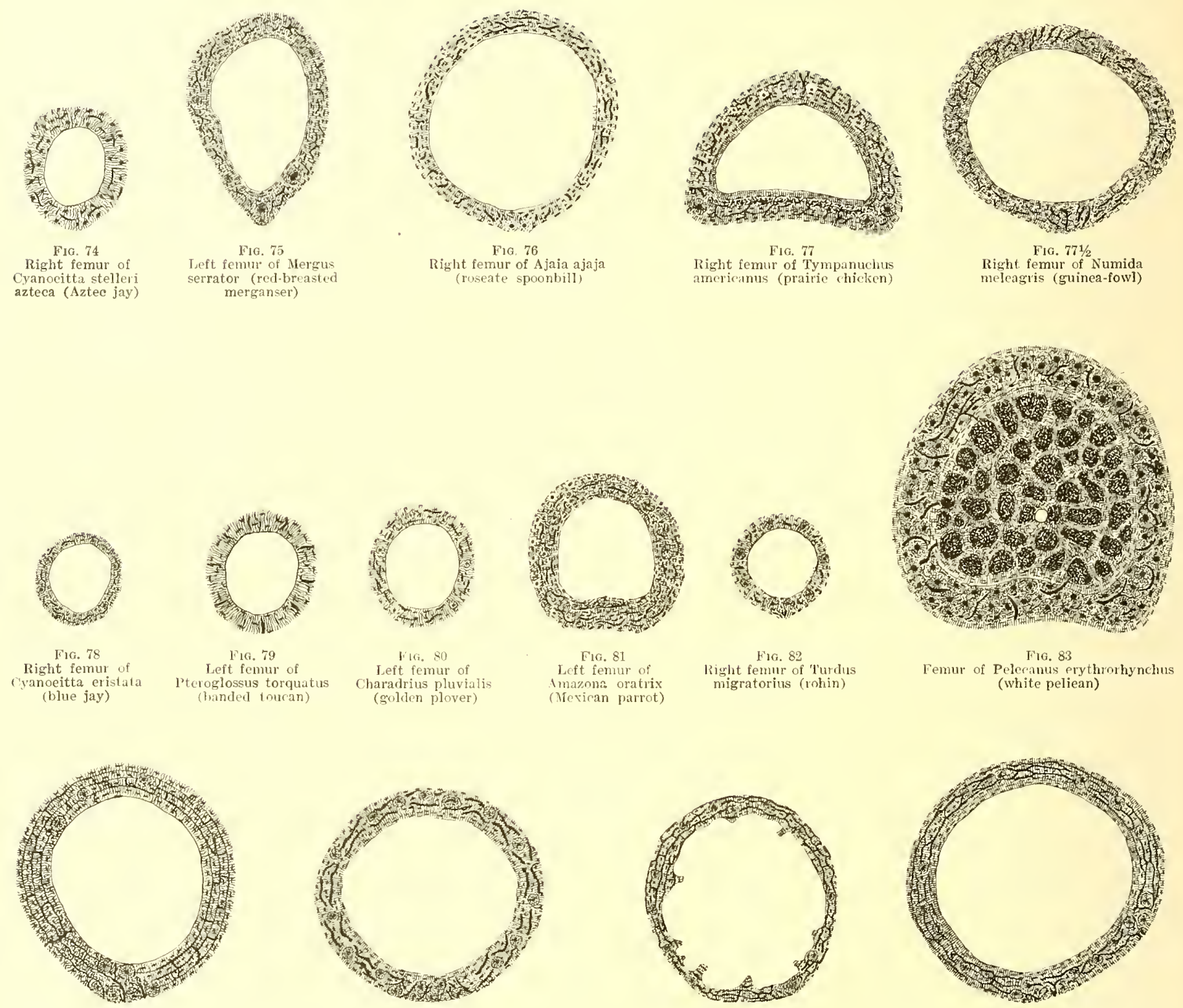

Fig. 84
Right femur of Ara macao (macaw) Fig, 85
Right femur of Nyctherodius violaceus

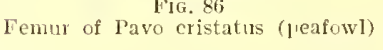

FiG. 83 mazons oratrix migratorius (mhin) Femur of Pavo cristatus (ן eafowl) Fig. 87
Femur of Haliætus leucoeephalins
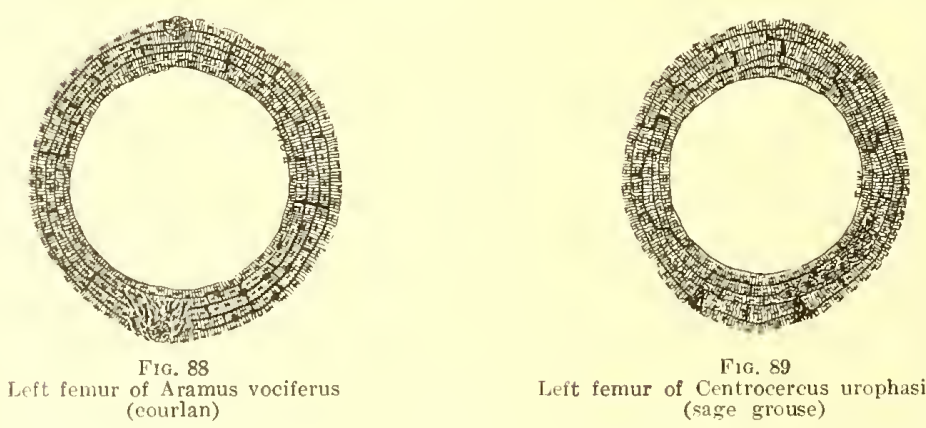

Fig. 89
Left femur of Centrocercus urophasianus

BIRDS 


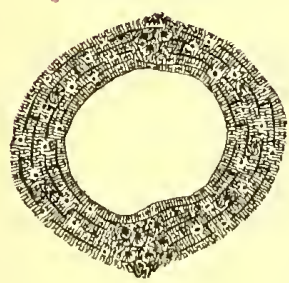
FiG. 90
Left femur of Meleagris gallipavo
(wild turkey)

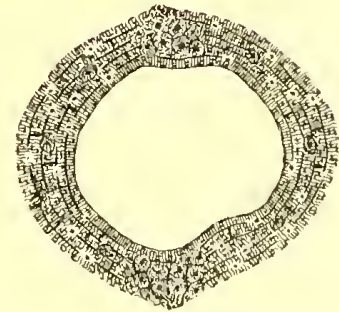

FrG. 91
Left femur of Meleagris gallipavo
(domestic turkey, 16 lbs. weight)

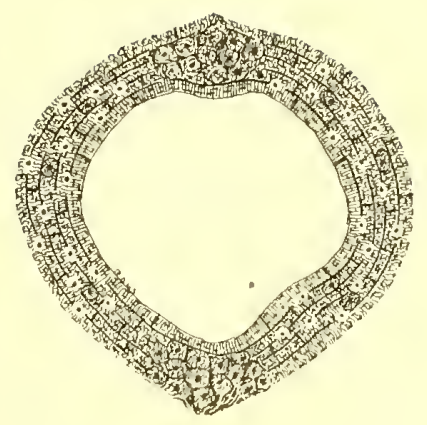

FIG, 911/2

Left femur of Meleagris gallipavo (domestie turkey, 32 lbs. weight)

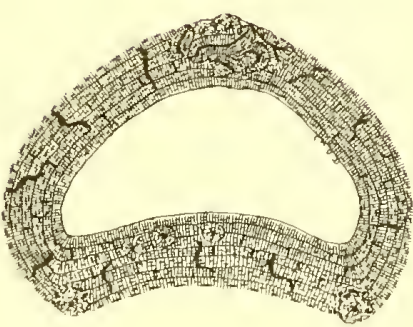

Fig. 92
Left fonur of Dendragapus obseurus
(blue grouse)

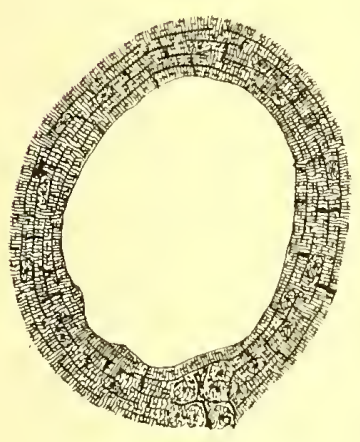

FIG. 93
Left fenur of Rhea americana

(rhea)

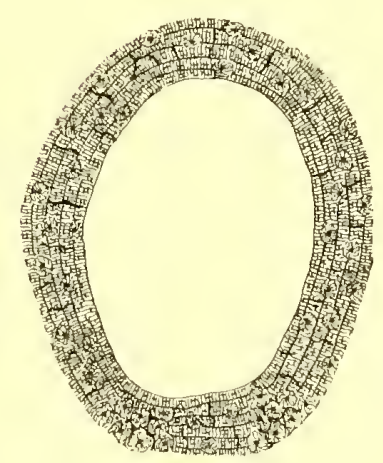

Fig. 94
I.eff femur of Struthio
(ostrieh)

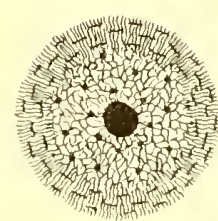

F.1G. 9.5

llaversian system of
Fig. 94, showing early central and late pe

ripheral stages of

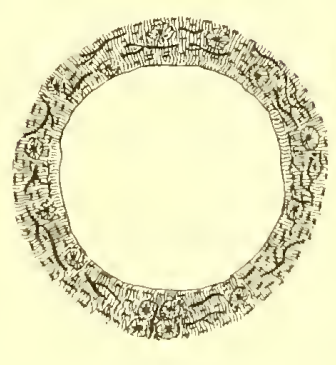

F1G. 951/2

Left femur of Phasianus tor<smiles>C1CCCC1</smiles>

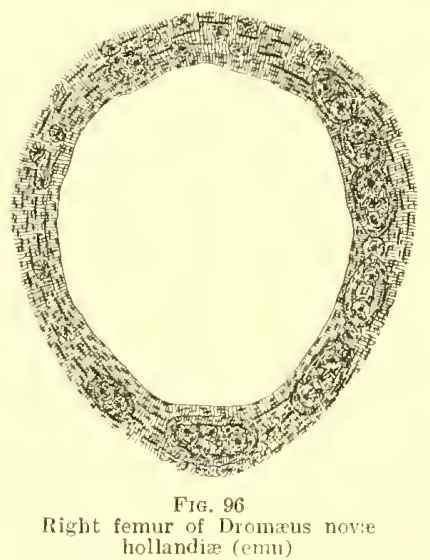

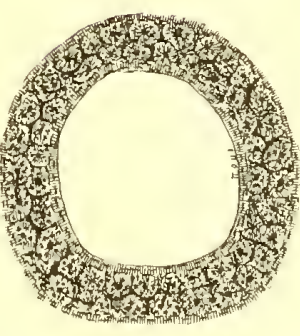

F⿻, 99

Fut 99
Right femur of (Chauna eristata
(crested screamer)
Fifi. 98
Fenur of Emberiza citrinella
(yellow hammer)

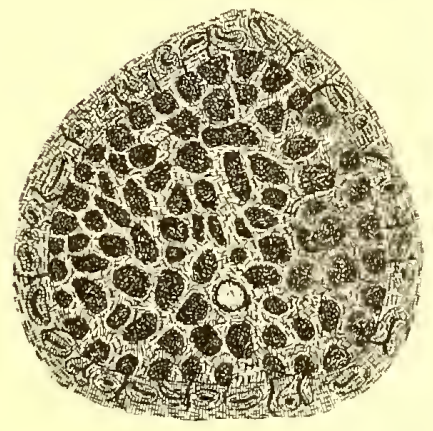

BIRDS

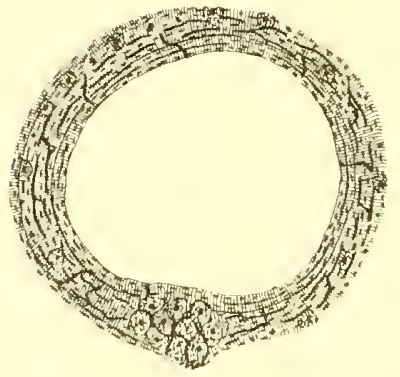

Fig. 100
Left femur of Pandion earolinensis

(Ameriean osprey)

Fif. 97
Femur of Anas boseas (mallard duck) 


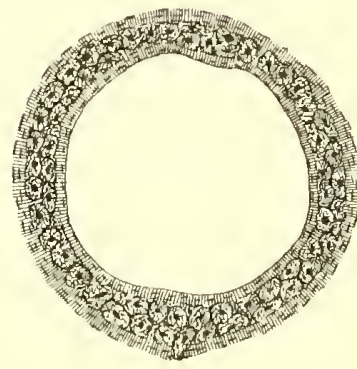

F1G. 101
Right femur of Sarcorhamphus gryphus (Andean condor)

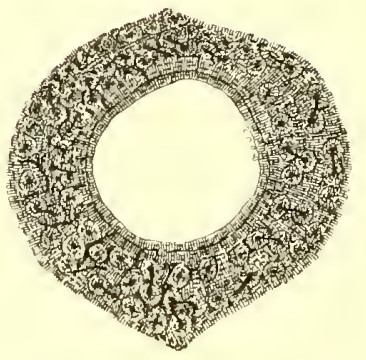
Fig. 102
Right femur of Olor sp. (swan) Right femur of hlor sp. (swan)

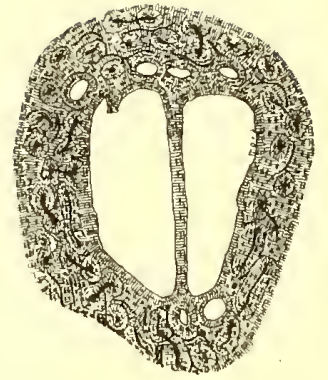

FiG. 103
Left femur of Gavia stellata
(red-throated loon)

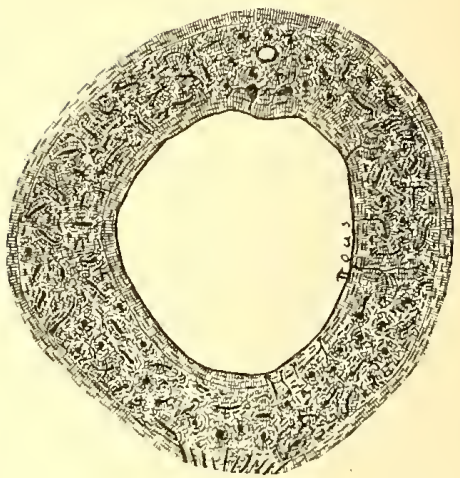

Fig. 104

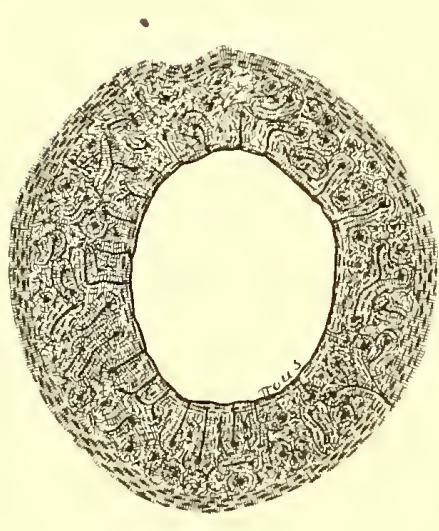

FIG. 105

Femur of Corvus americanus
(American crow)

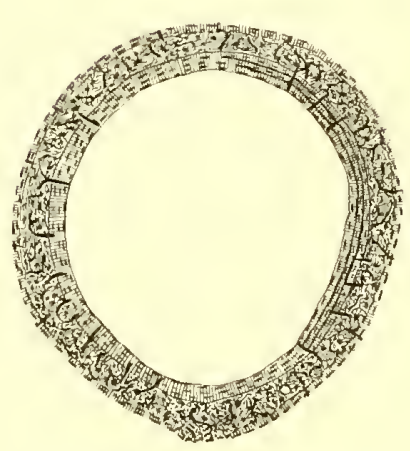

Fia. 106
Femur of Asio wilsonianus (long-
eared owl)

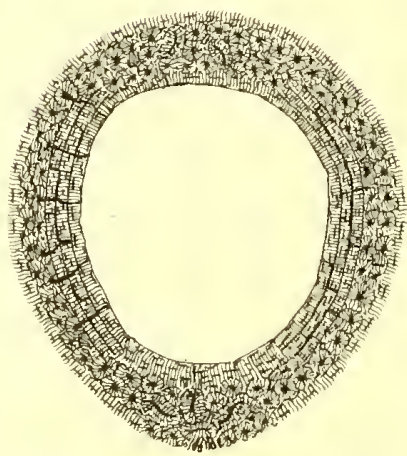

F1G. 107
Right femur of Bernicla canadensis
(wild goose)

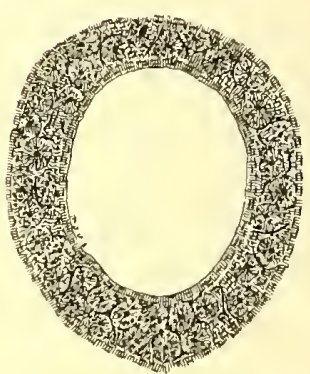

Fig. 108
Left femur. of Leptoptilos sp.
(stork)
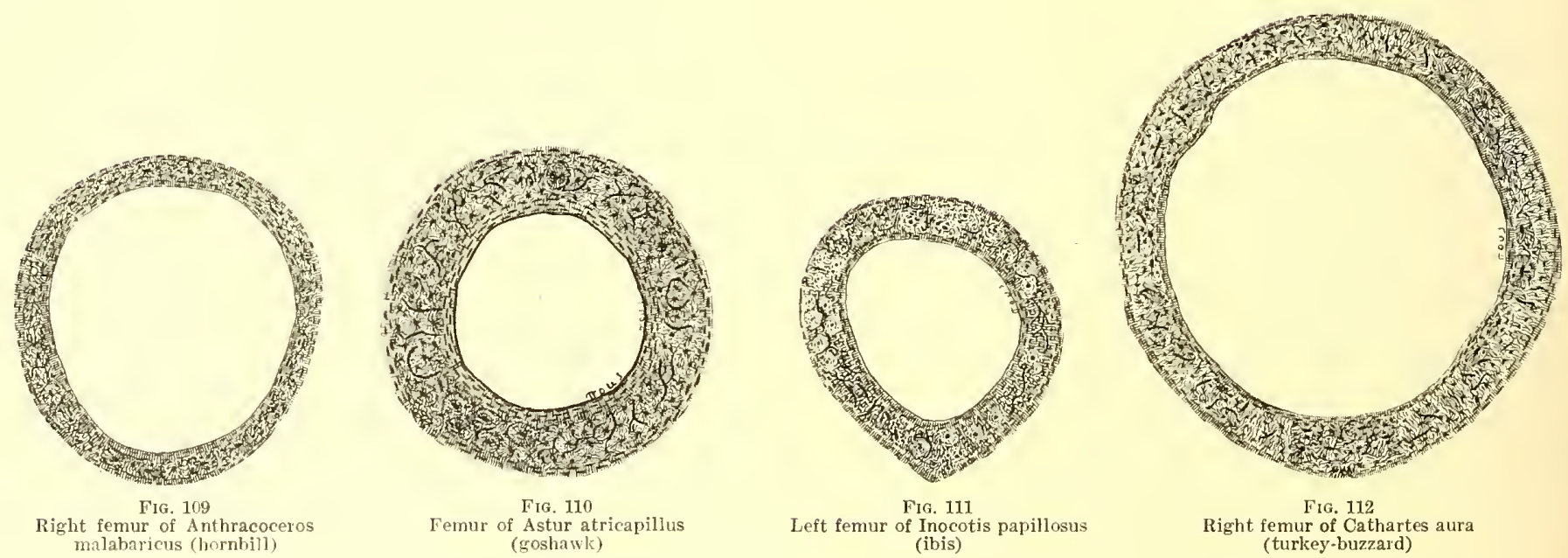


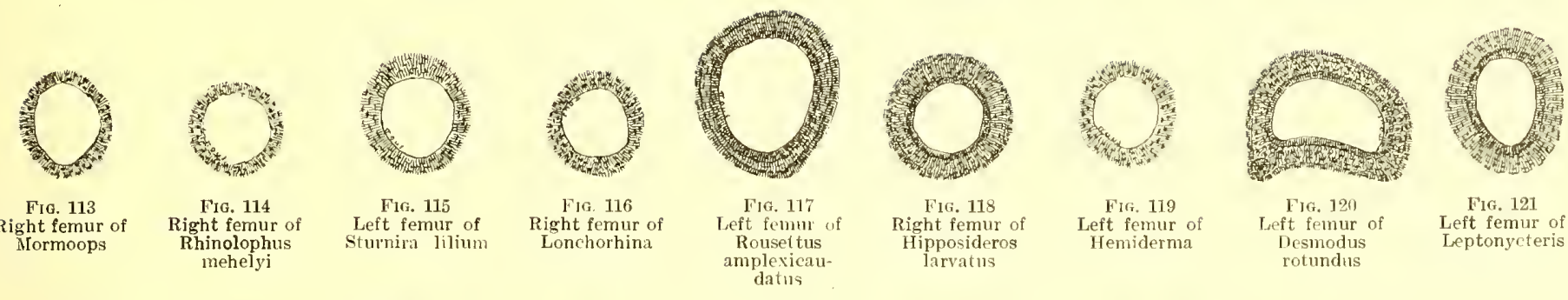

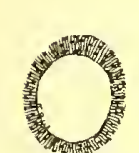
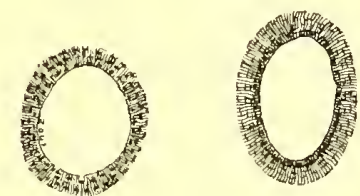

FIG. 124
Left femur of

Phyllostoma

Fig. 123
Left femur

Fig. 122

Rhinopoma

(Palestine)

Erophylla

hastatum

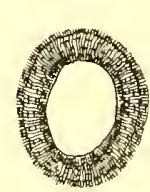

Fig. 125

Left femur of Epomophorus
wahlbergii

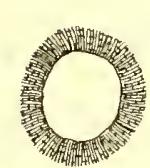

FIG. 126 Left femur of Glossophaga
elongata

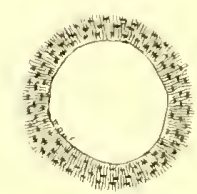

Fig. 127

Left femur of

Nyctalus
aviator
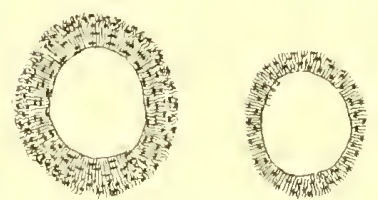

Fici. 128

Left femur of

Scotophilus
heathii

F16. 129

Right femur of

Miniopterus
schreibersii

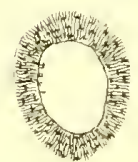

F19. 130

Promops

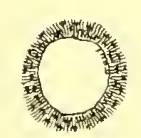

FIG. 131

FIG. 131
Left femur of Vespertilio
nuurinus

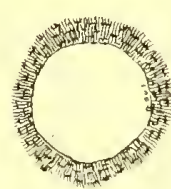

F1G. 132

Fig. 132
Right femur of
Molossus

nigricans
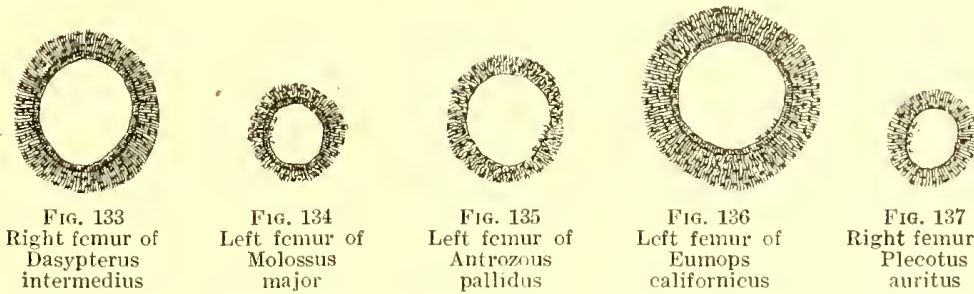

FIG. 135

Antrozous
pallidos

FIG. 136
Left femur

Eumops
californicus

\section{FIG. 137}

Right femur o
Plecotus

auritus

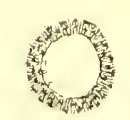

Fנ?. 138

Left femur of
Nycticeins

Nycticeius
humeralis

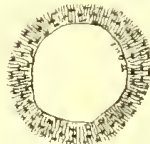

Right femur of inyotis

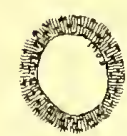

FiG. 140 Left femur of
Eptesicus

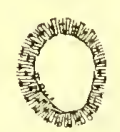

FIG. 141

Left femur of
Nycteris

borealis

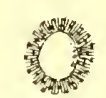

Fic. 142

Fig. 142
Right femur

Glischropus
tylopus

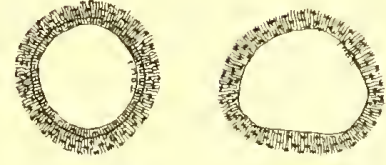

FIG. 144

Left femur of
Phyllonycteris Nycteris
Nyct femur

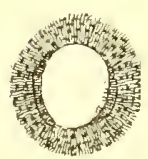

Fig, 145

Right femur o Iegaderma

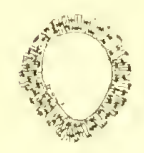

Fig. 146 Right femur of cinerea

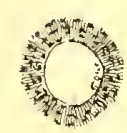

Fig. 149

Left femur o
Petalia

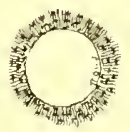

Fig. 150 Left femur of
Monophyllus

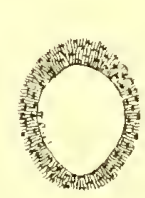

FIG. 151 Left femur of
Vampyrops

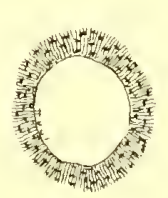

Fic. 152

Right fenuur of
Chilonycteris

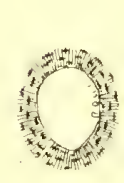

Fig. 153

Right femur o
Cynopterus

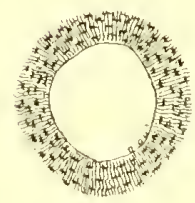

Left femur of

Artibeus
palmarum

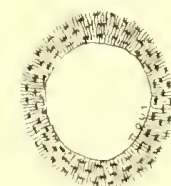

F1G. 155

Left fenur of
Biachyphylla.

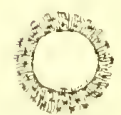

F1G. 147 Left femur of
Balantiopteryx plicata

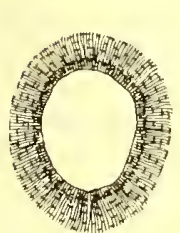

F1G. 158

Right femur of

Cheiromeles

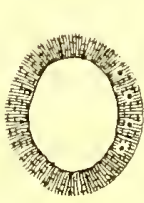

Fia. 159 Right femur of
Noctilio.

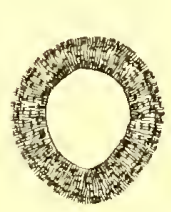

Fif. 160

Left femur of Pteropus
molossinus

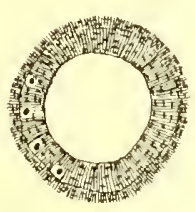

Fic. 161 Right femur
Pteropus
molossinus
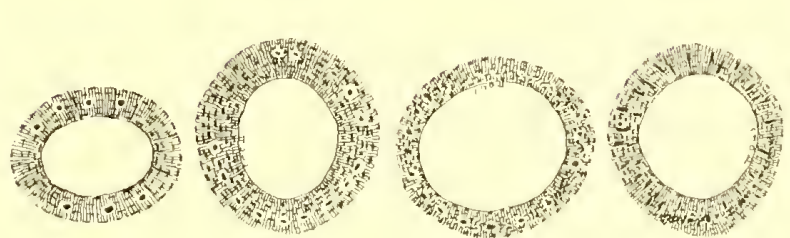

Fif. 162

FiG. 163
Right femur of

Pteropus
(Celelies)
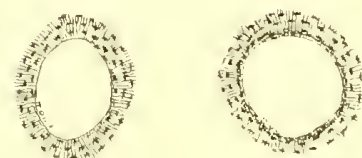

F1G. 156

Right feinur of
Macroglossus minimus
minoglossis

F1G. 157

Left femur of Taphozous
philippinencis

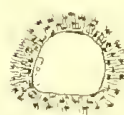

Fis. 148 Saccopteryx

\footnotetext{
FIVTY GENERA OF BATS
} 


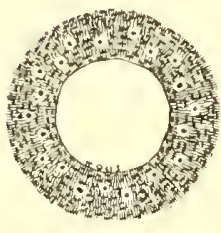

Fig. 167
Right femur of

Pteropus
poliocephalus (fruit-eating bat)

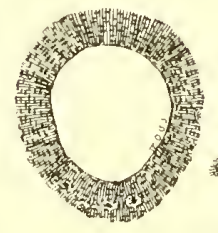

FiG. 168
Left femur of

Tupaia. Tre

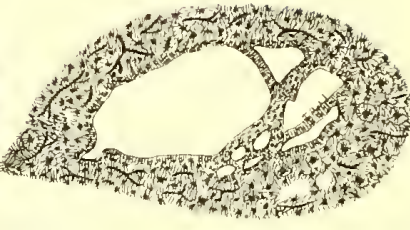

Right femur 169

of Echidn

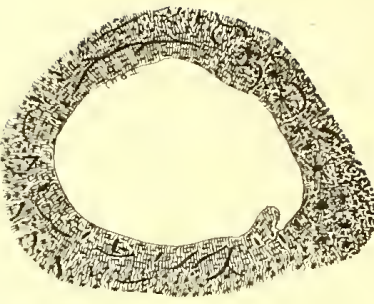

Frg. 170

Left femur of Ornithorhynchus.
(duckbill, egg-laying mammal)

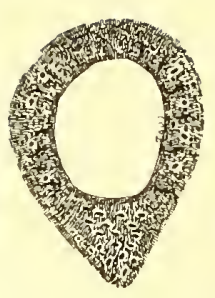

FIG. 171 Left femur of
Cavia cutleri
(guinea-pig)

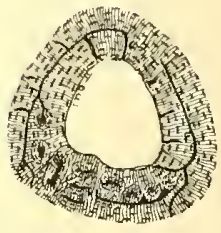

Fig. 172
Left femur

Scalopus aquaticus (mole)

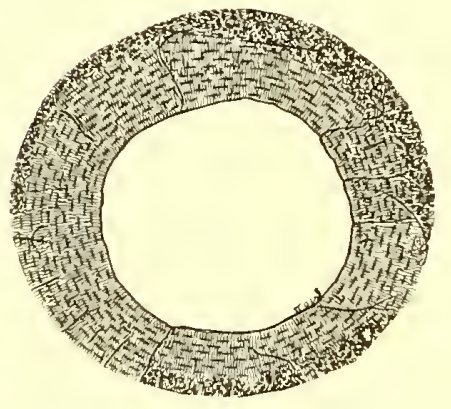

FIG. 179

Femur of Putorius vulgaris (weasel)

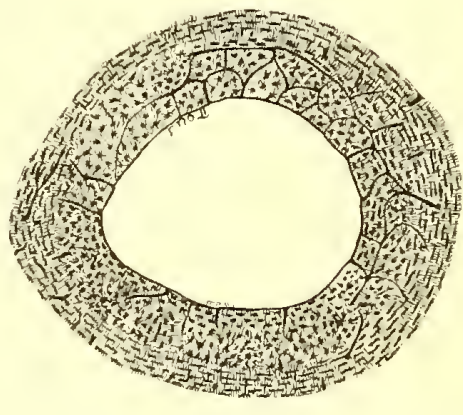

Fig. 180

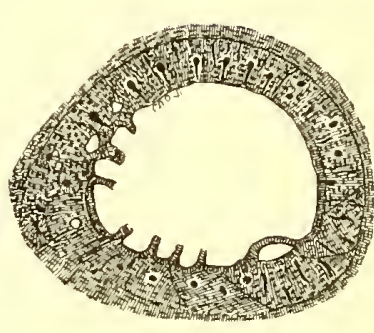

Fig. 176
Right femur of Solenodon paradoxus (adult)

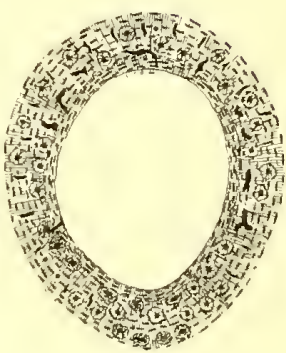

Fig. 177

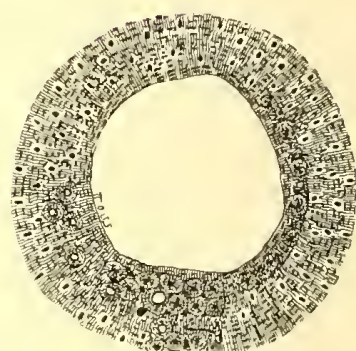

Fig. 178

Left femur of Colobus
abyssinicus caudatus (African monkey) (young)

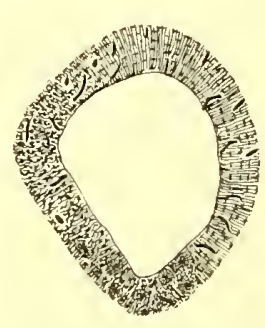

FIG. 181
Left femur of Heteromys
(Spiny pocket rat)

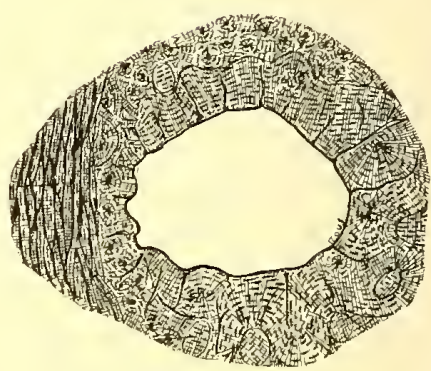

Right femur of Myog (desman)

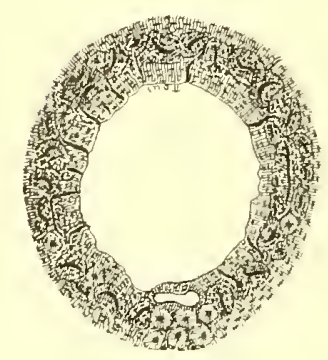

Femur of Cynomys 183 (prairie dog)

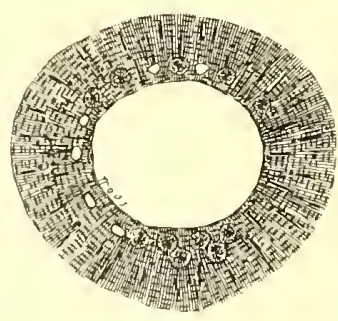

Fig. 184
Left femur of Trichosurus vulpecula
(phalanger)

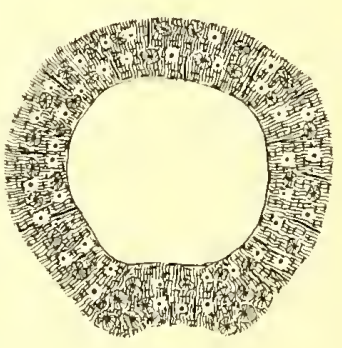

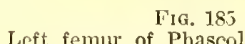

(wombat)

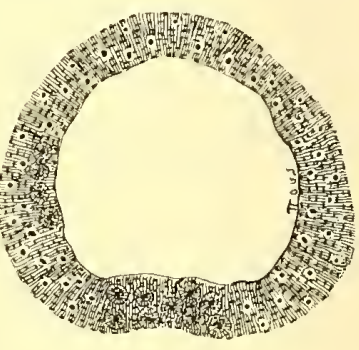

Right FIa. 186 

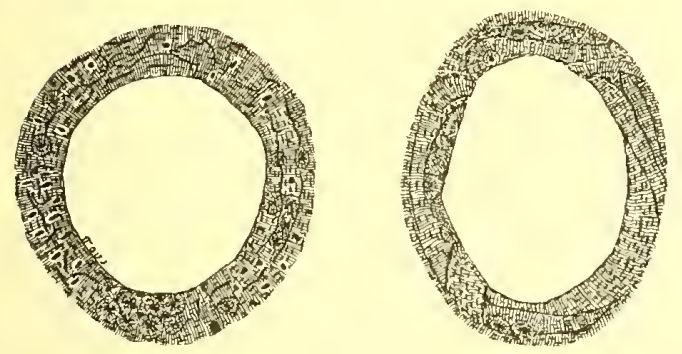

FIG. 188 Right femur of Mus
sylvaticus (wood mouse)

F1G. 187
Right femur of Tragulus
javanicus (mouse-deer) avanicus (mouse-deer)

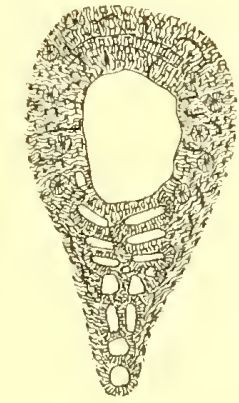

Feft femur of Erinaceus
europæus (hedgehog)

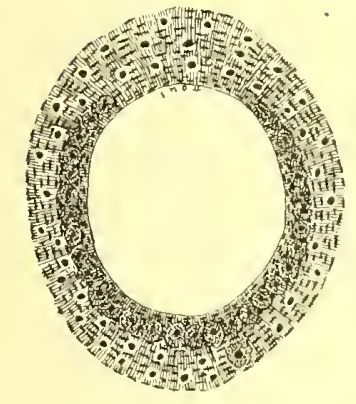

Fic. 192

Femur of Galeopithecus
(flying lemur)

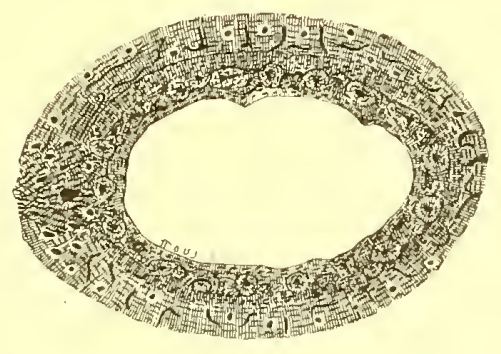

Left femur of Fanis (scaly ant.eater)

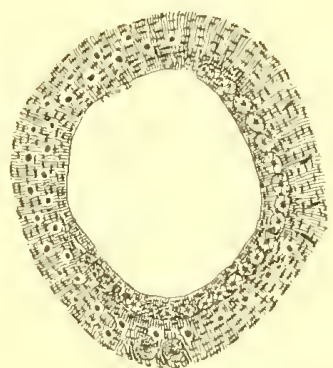

FIG. 190
Right femur of Viverra
Civet

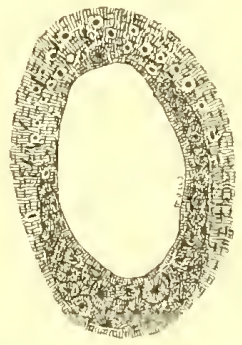

Frg. 194
Right femur of Procavia

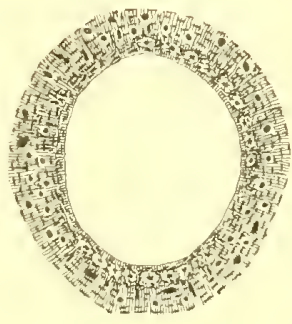

Fig. 191
Right femur of Ratufa
mavima (giant squirrel)

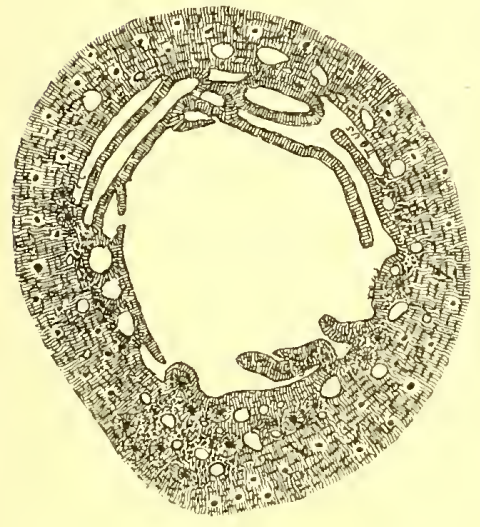

Fig. 190

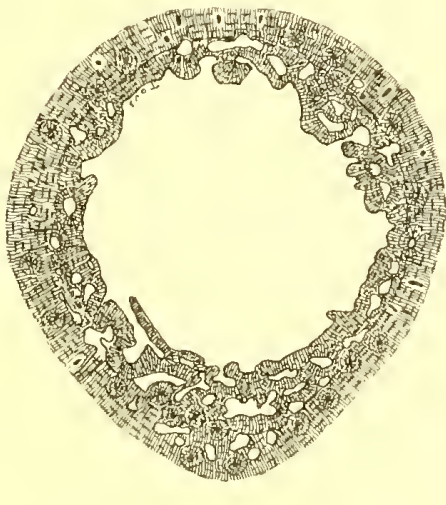

Right femur of 197 (Inandrill)

MAMMALS

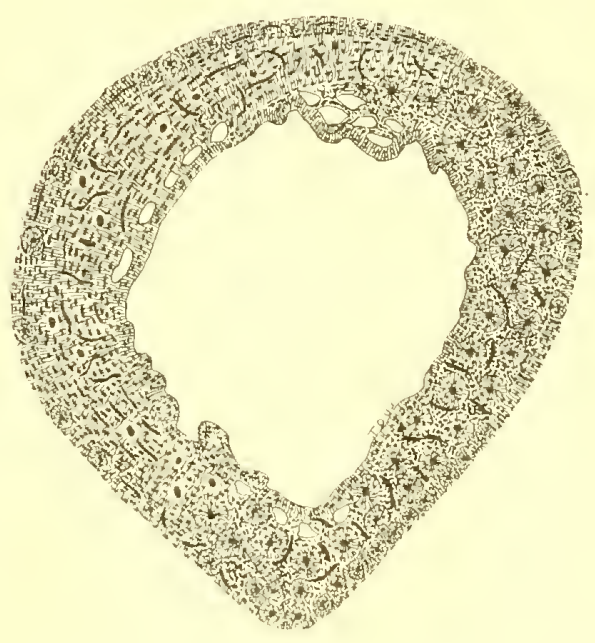

FIG. 198
Right femur of Hydrocherus capybar

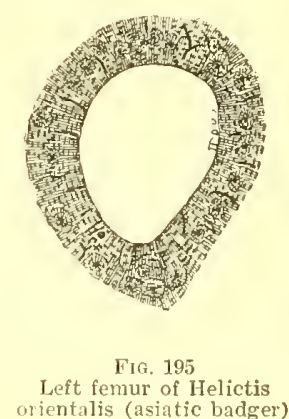




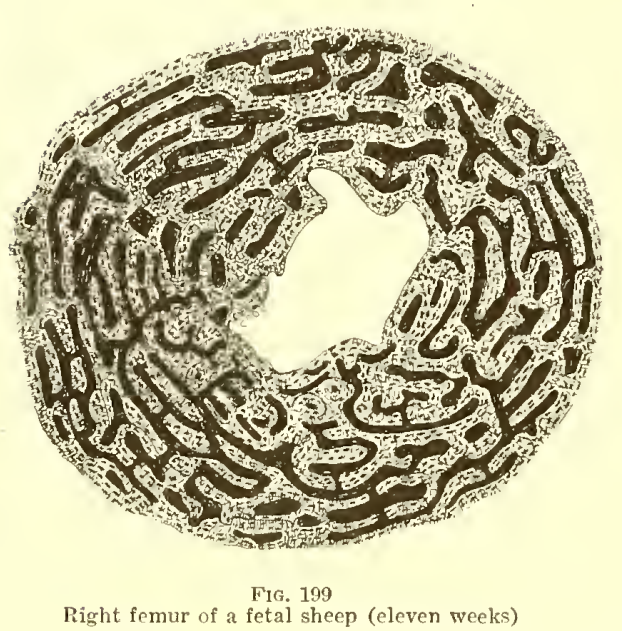

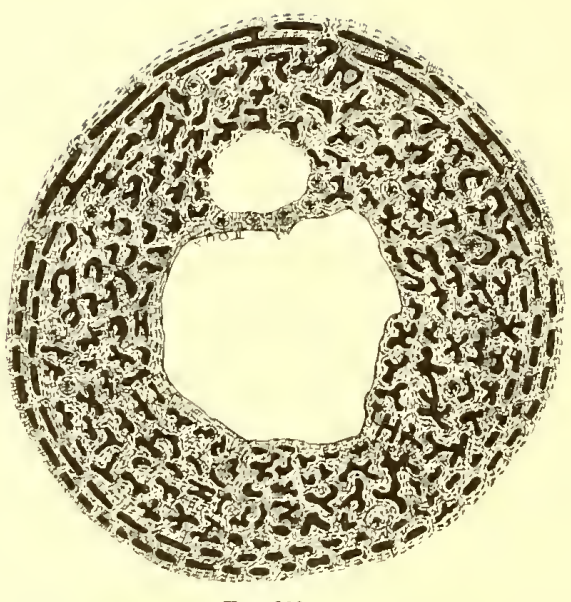

Fig. 200
Right femur of a fetal calf (eighteen weeks)

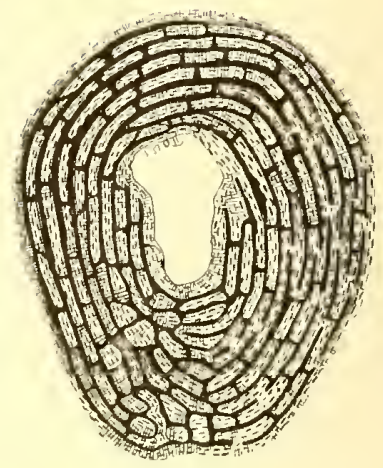

Fig. 201
Right femur of a fetal pig (eight and one-half
weeks)

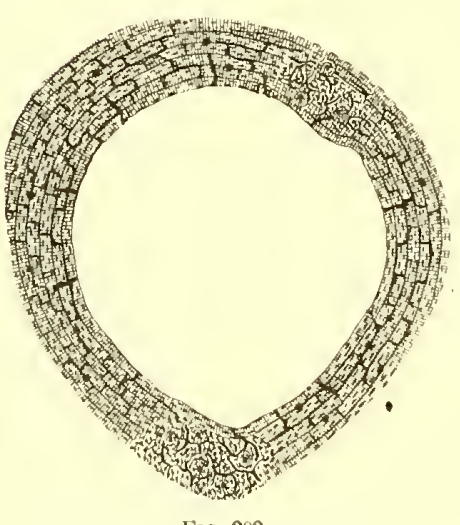

Femur of Cariacus macrotis (deer)

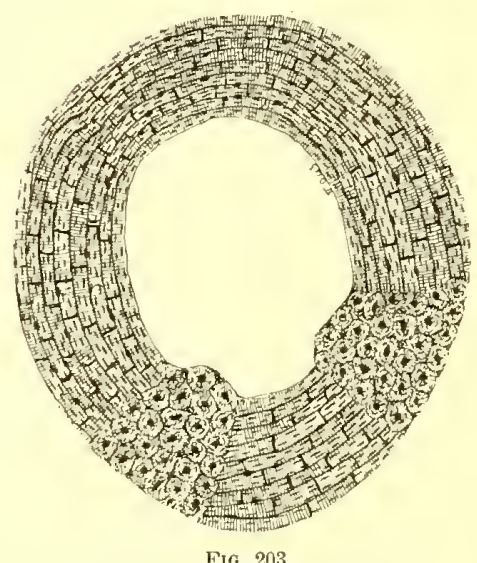

Right femur of Sus (domestic pig)

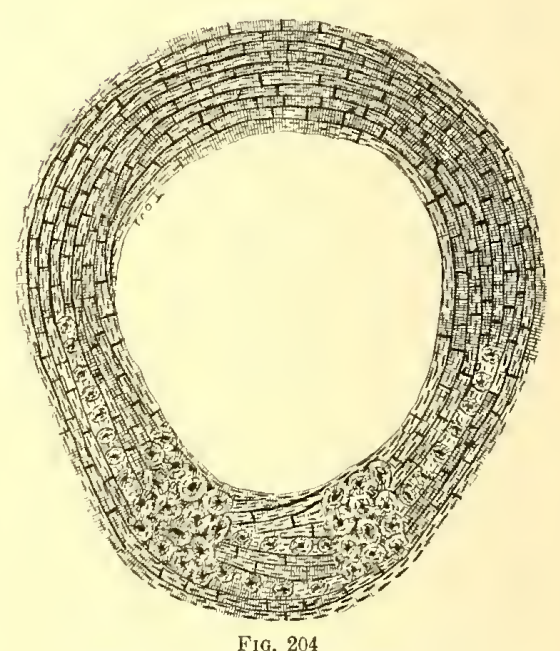

Right femur of Sus scrofa (wild boar)

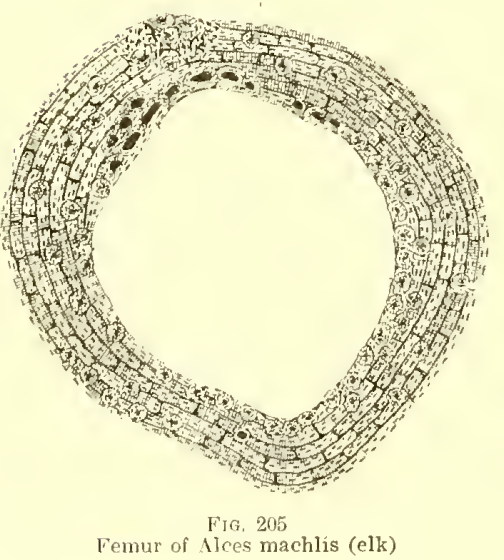

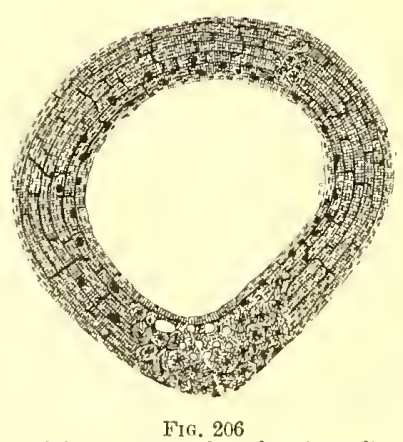

Right femur of Camelus (camel)

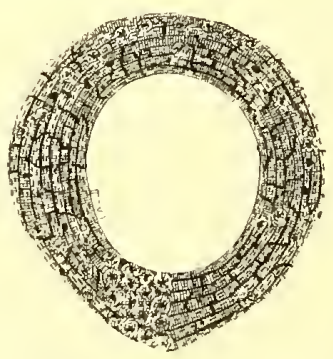

Fig. 207
Right femur of Auchenía glama (llama)

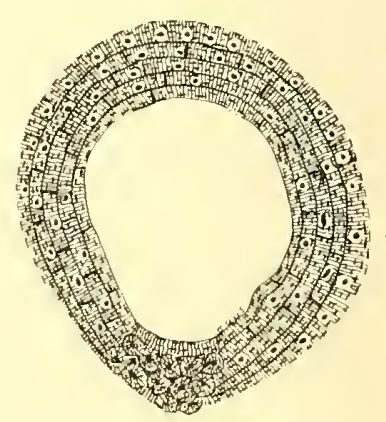

Fig. 208
Right femur of Rangifer (reindeer) 


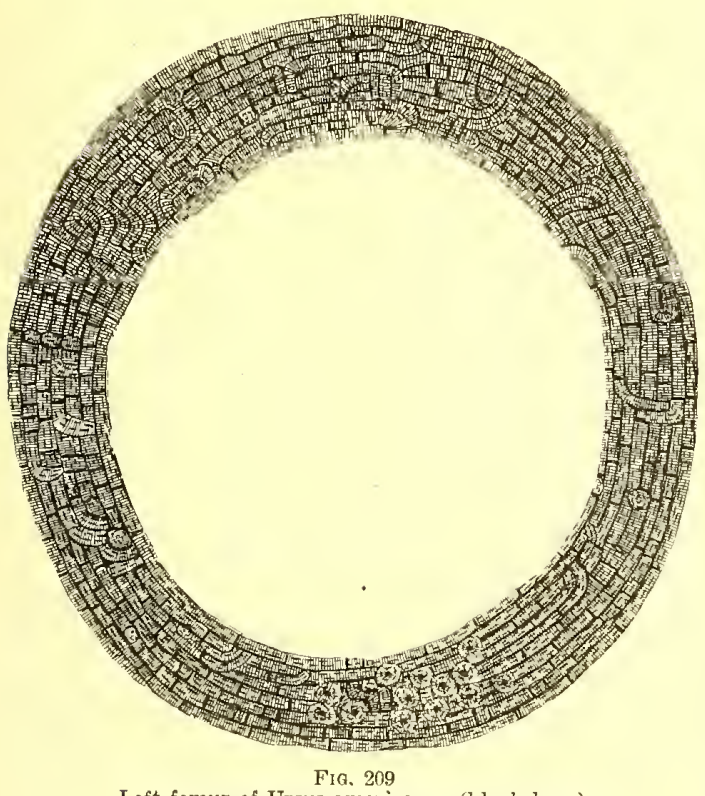

Left femur of Ursus americanus (black bear)

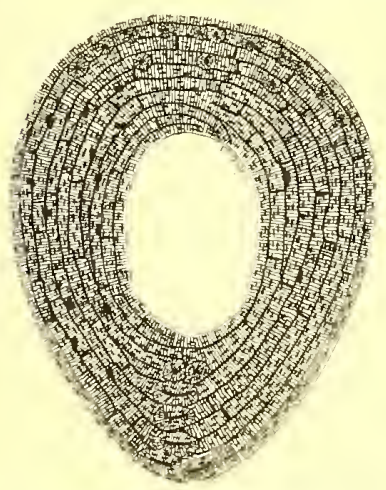

FIG. 213
Right femur of a Mexican burro

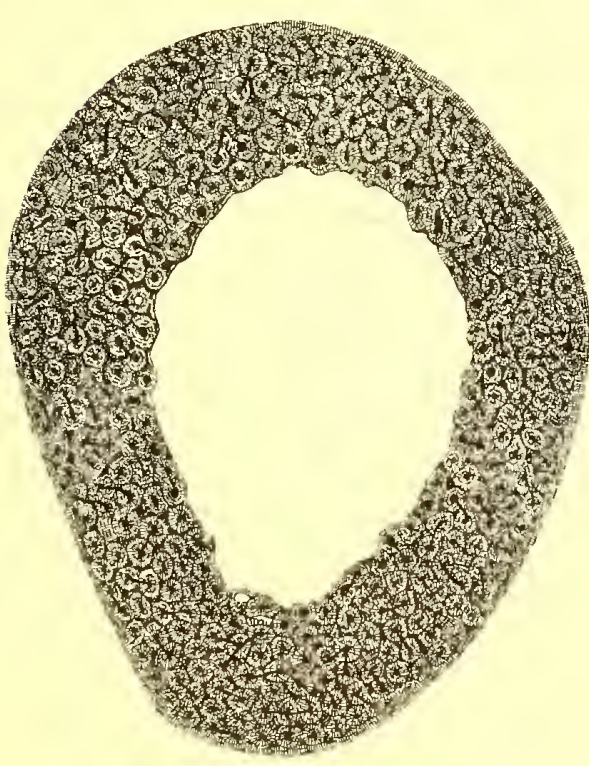

Fig. 216
Right femur of Elephas africanus

(African elephant)
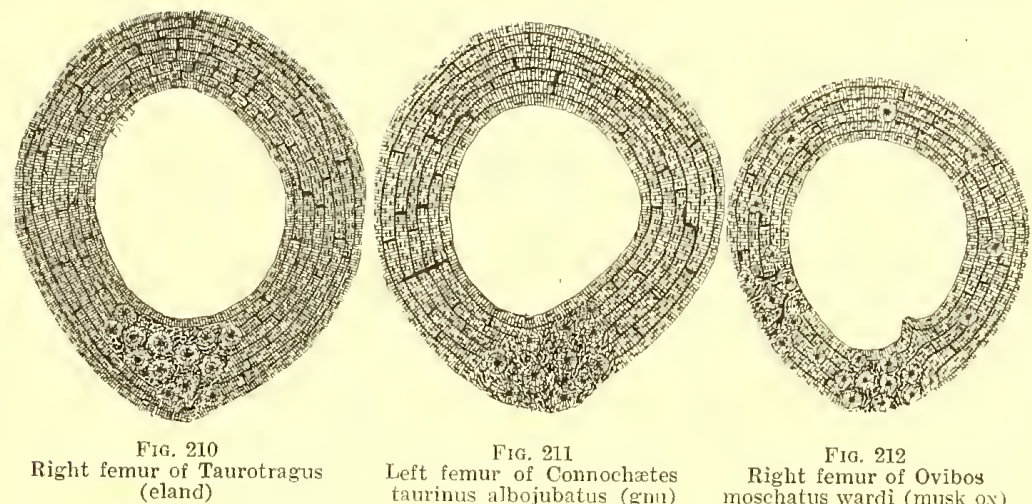

FIG. 211
Left femur of Connochætes
taurinus abojubatus (g*m1) Fia. 212
Right femur of Ovibos
moschatus wardi (musk ox

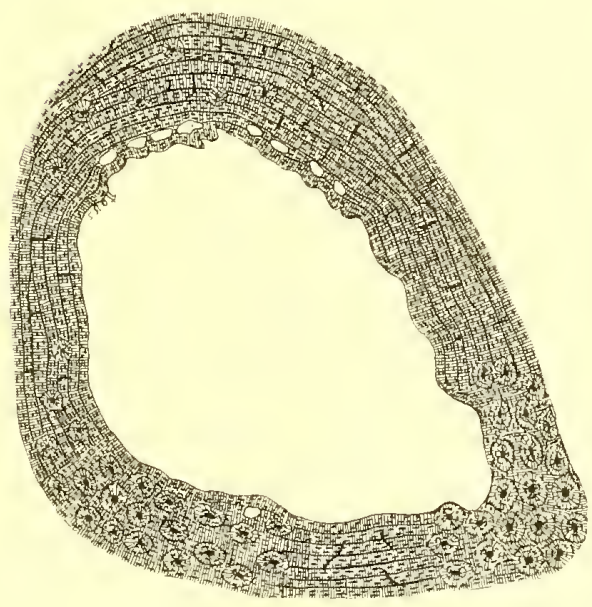

$$
\begin{gathered}
\text { Fig. } 214 \\
\text { Right femur of Tapirus (tapir) }
\end{gathered}
$$

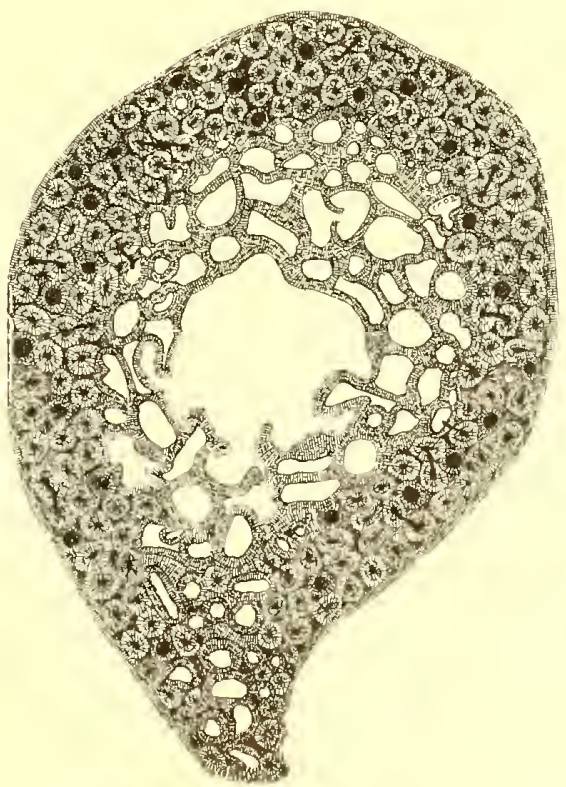

FiG. 217
Femur of Cholœpus didactylus (two-toed sloth)

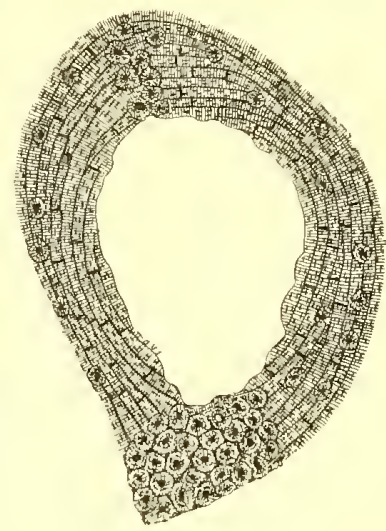

$$
\begin{aligned}
& \text { FIG, } 215 \\
& \text { Right femur of Equus henio- } \\
& \text { nus (wild ass of Asia) }
\end{aligned}
$$
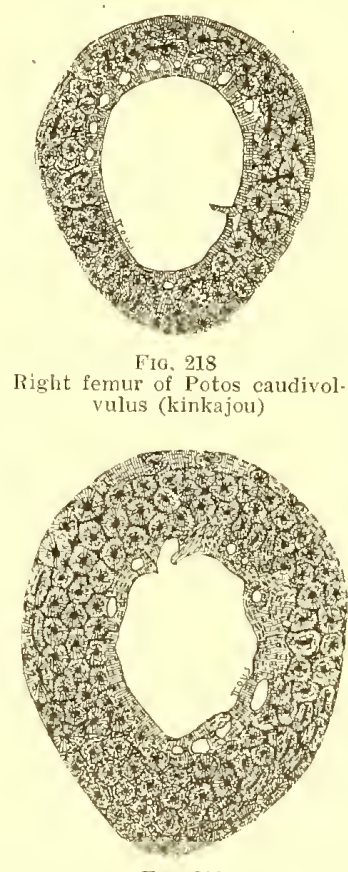

FiG. 219
Right femur of Lutra canaden.
sis (otter) 


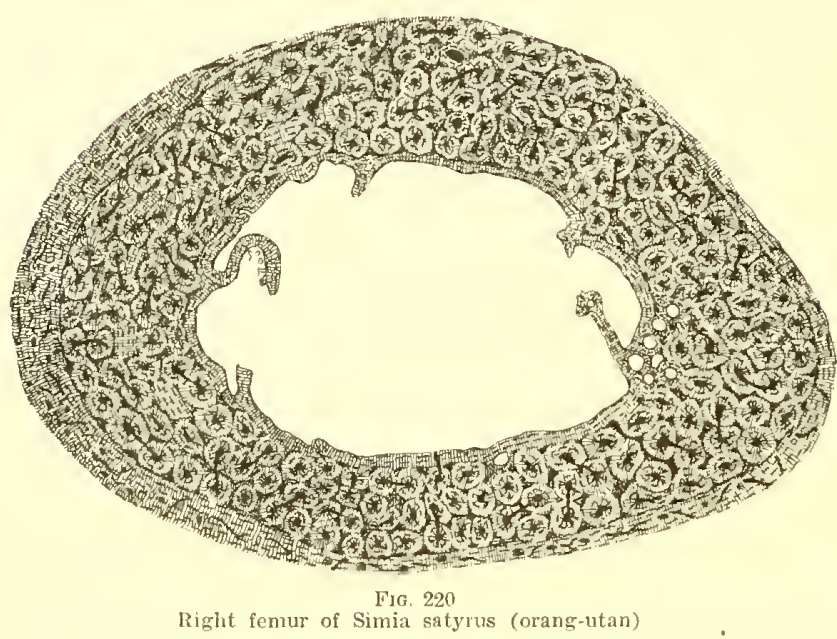

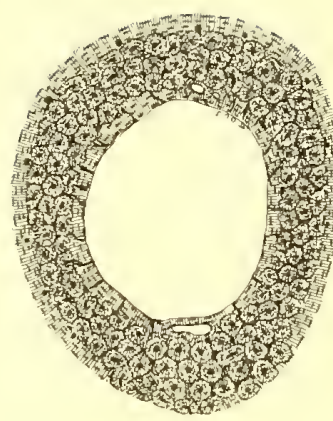
Fig. 221
Left femur of Felis tigris
(tiger)

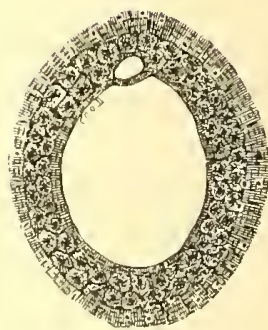

Fig. 222
Right femur of Hemigalus

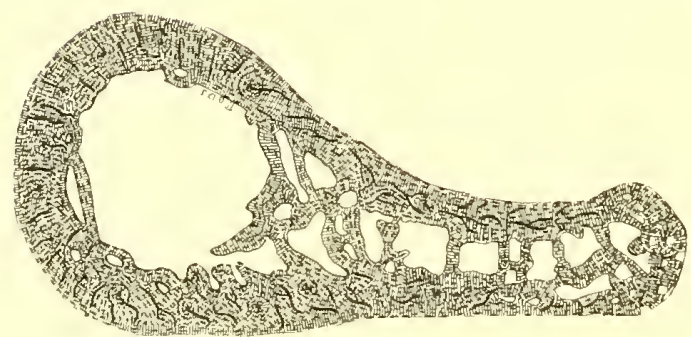

FIG. 223

Right femur of Tatu noremcinctus. Armadillo

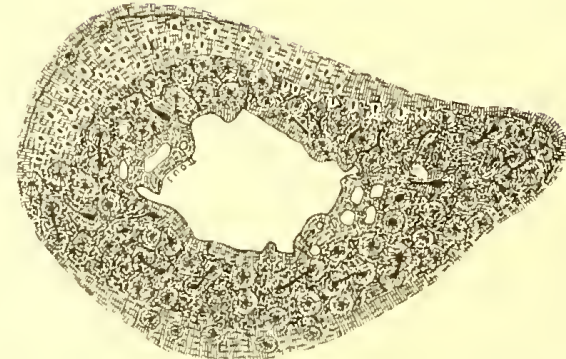

FIG. 224 FIG. 224
Right femur of Tamandua

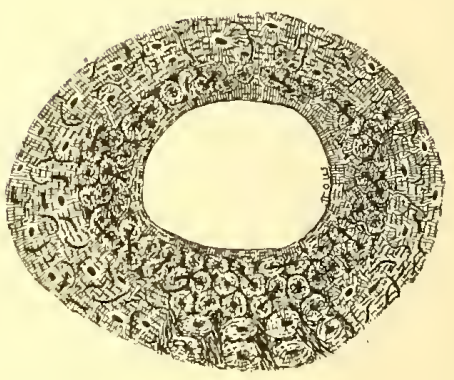

Fig. 225
Left femur of Gorilla (gorilla)

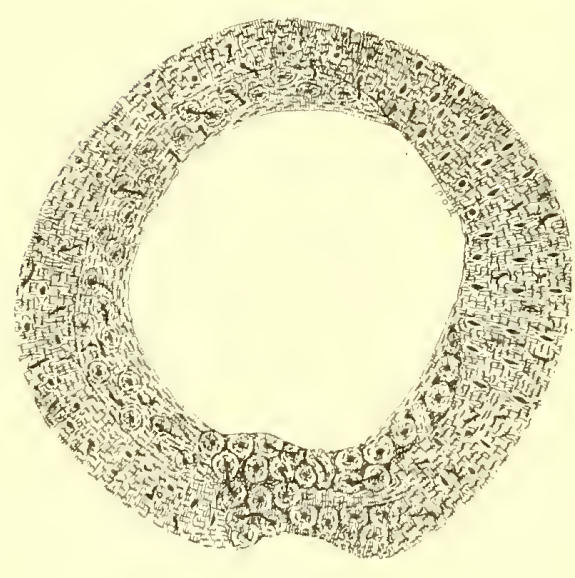

Fig. 226
Femur of Presbytis rubicunda (monker)

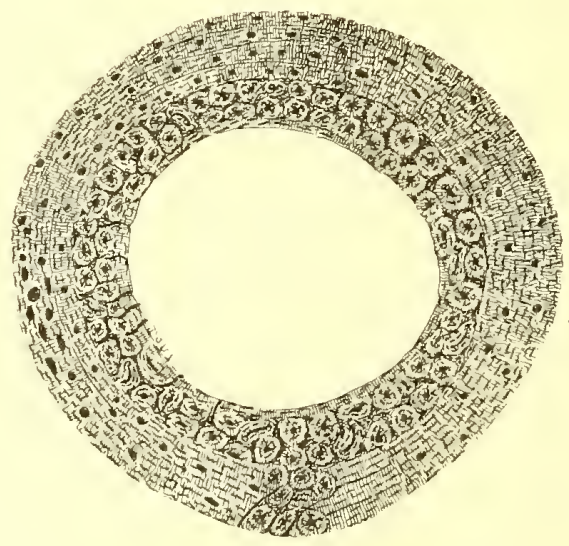

Fig. 227
Right femur of Hylobates (gibbon)

MIMMALS

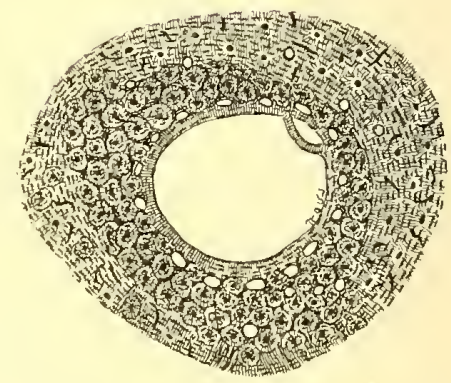

Fig. 228 I eft femur of Anthropopithe-
cus troglodytes (chimpanzee) 


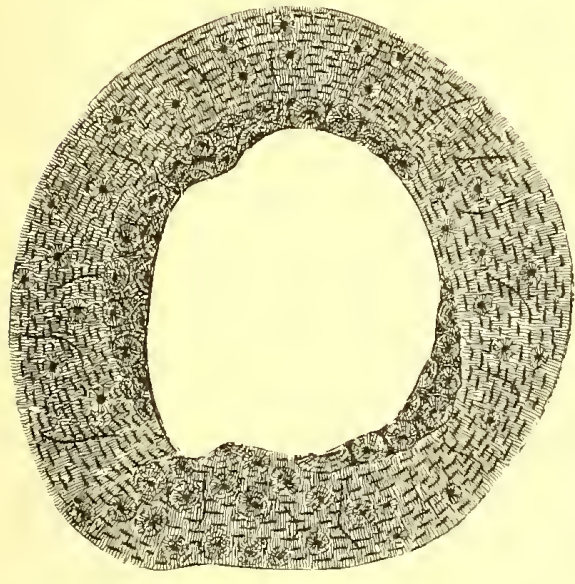

Fig. 229

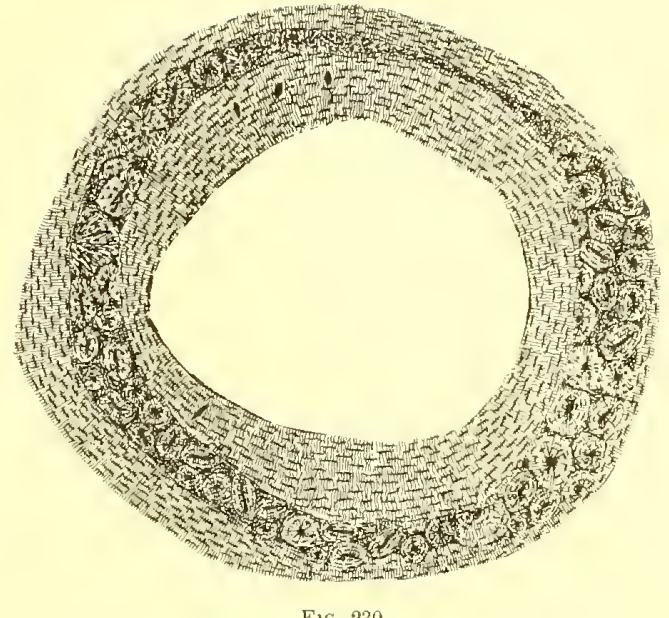

Fig. 230
Right femur of Seiurus sp. (large red squinrel)

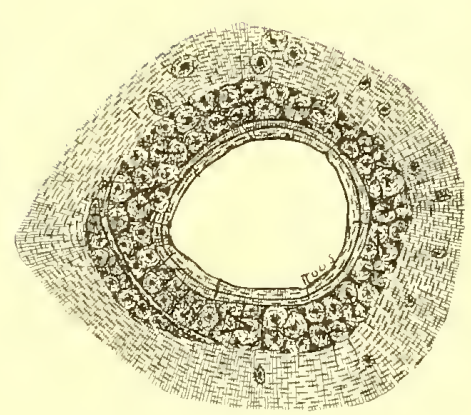

FIG. 231
Right femur of Fclis (domestic cat)

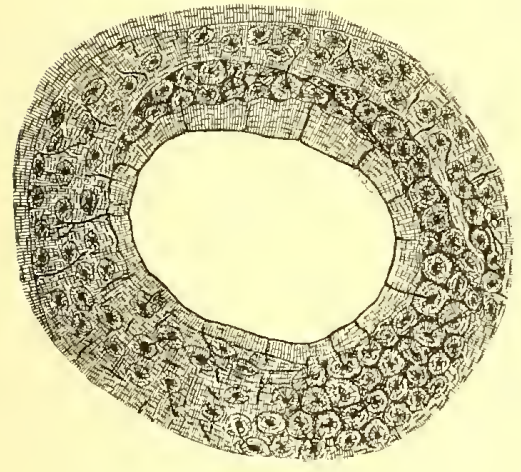

Fic. 232

Fria. 232

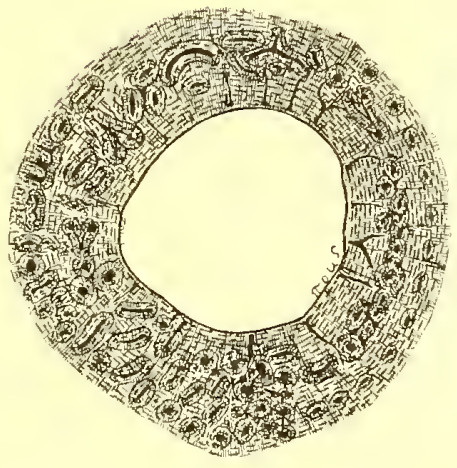

FiG. 233
Femur of Mephitis mephitica (skunk)

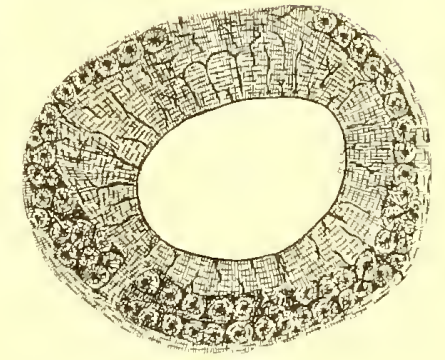

Fig. 234
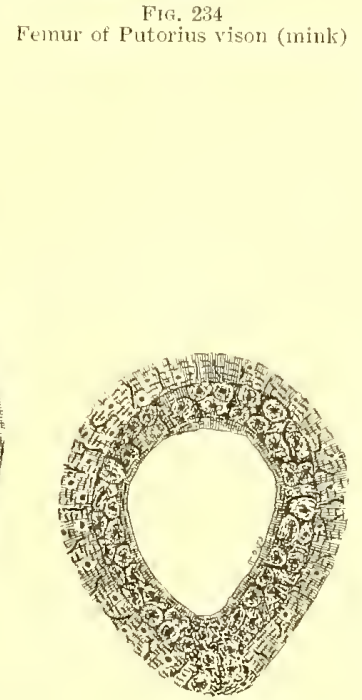
FIG. 238
Right femur of Dasyprocta

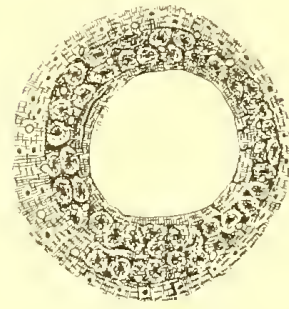

Fif. 235
Left femur of
Cryptoprocta ferox

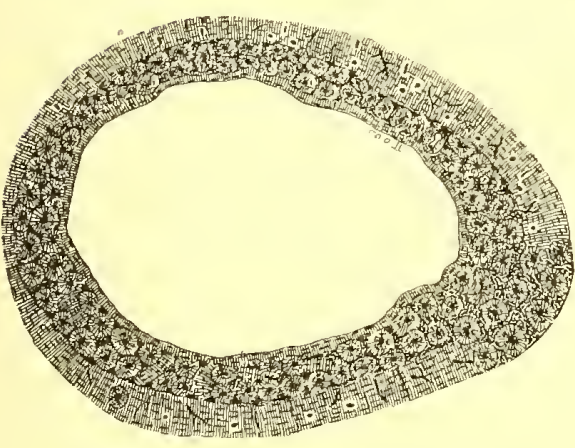

Right fomur of 236

Right femur of Hyæna crocuta (Hyæna)
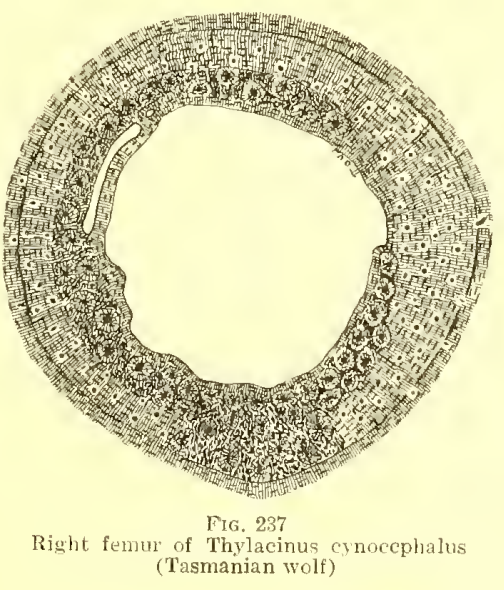

MAMMALS

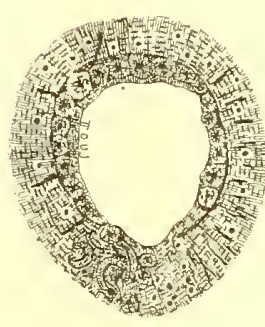
F1G. 239
Left temur of Lasiopyga
centralis johnstoni (monkey) 


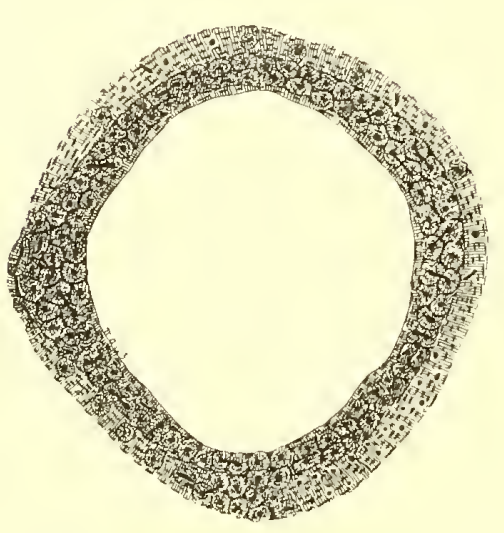

Fig, 240
Right femur of Felis canadensis (Canada lynx)

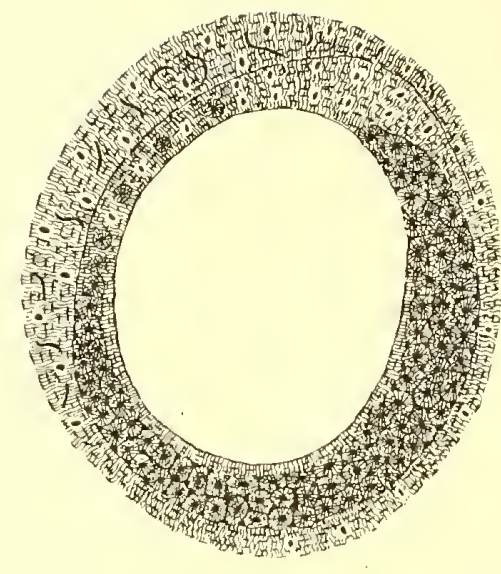

Fia, 241
Riglit femur of Lasiopyga sp. (African

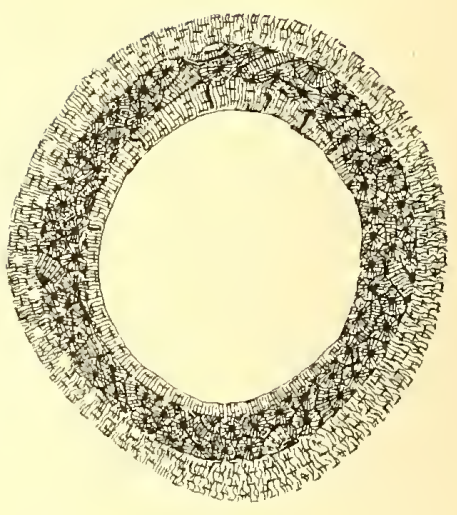

Fig. 242
Right femur of Midas rufoniger (South
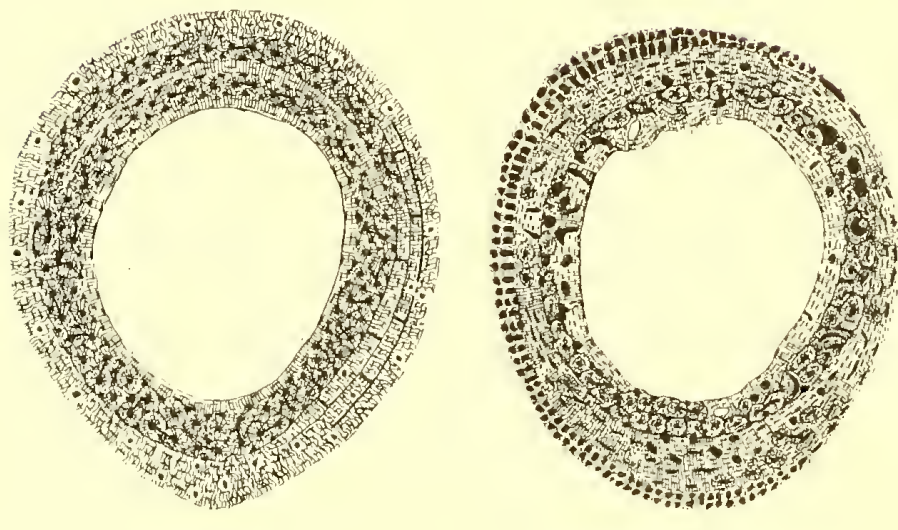

Fig. 244
Right femur of Lemur calta
(ring-tailed lemur)

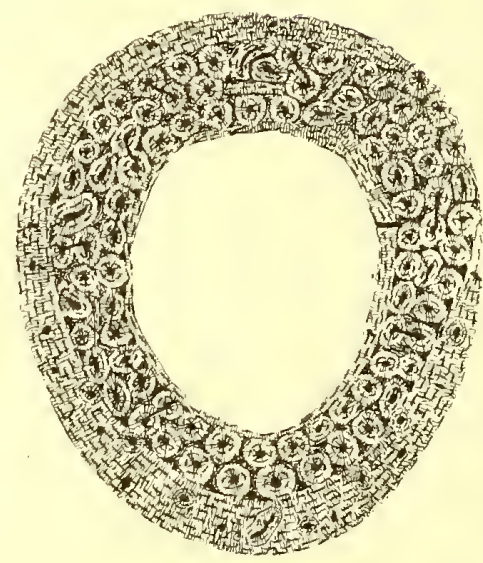

Fig. 245
Left femur of Ateles (spider-

monkey) ('Tehuantepec)

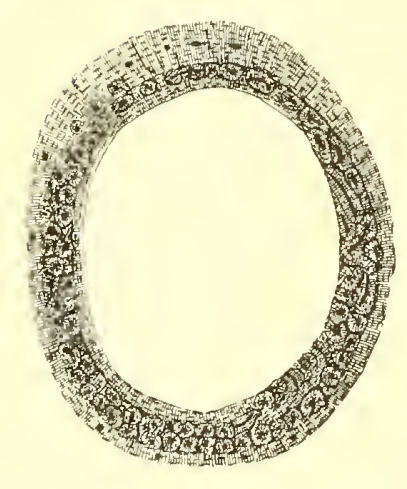

Fig. 247
Left femur of Genetta (genet)

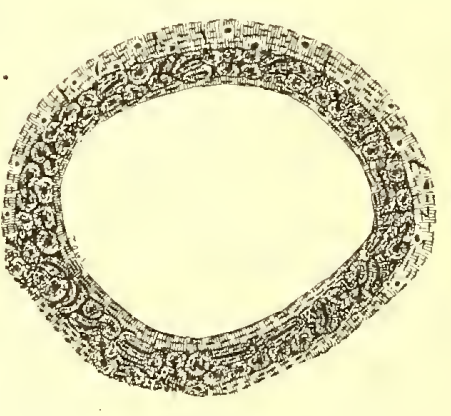

Fig. 248 (jumping hare)
Left femur of Pedetes (jumpla

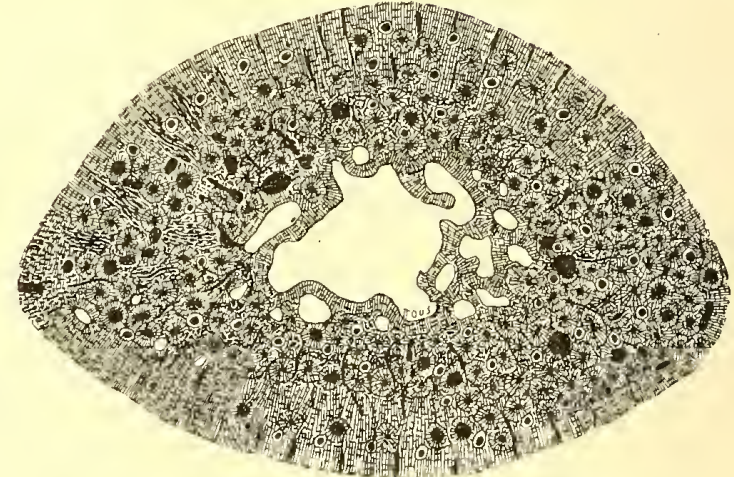

FIG. 249

Right femur of Bradypus tridactylus (three-toed sloth) 


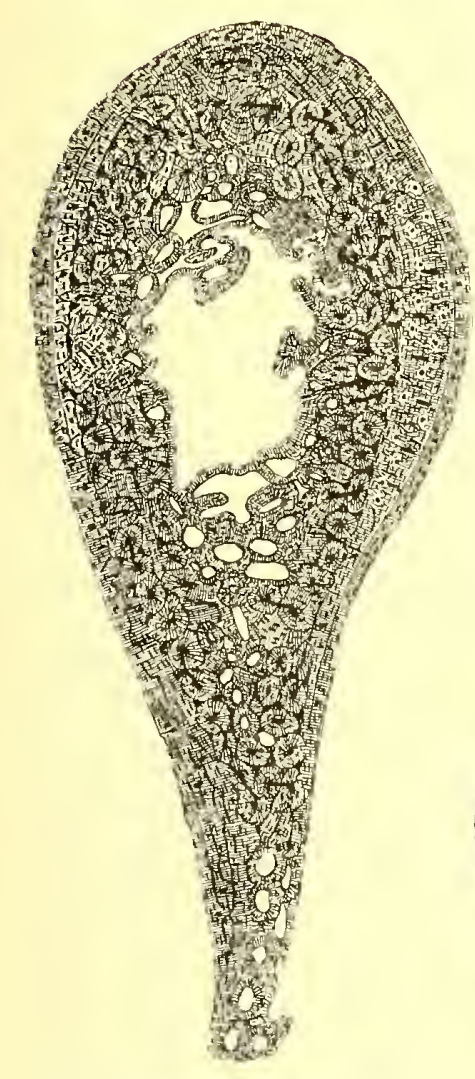

Fig. 250
Right femur of Castor canadensis
(beaver)

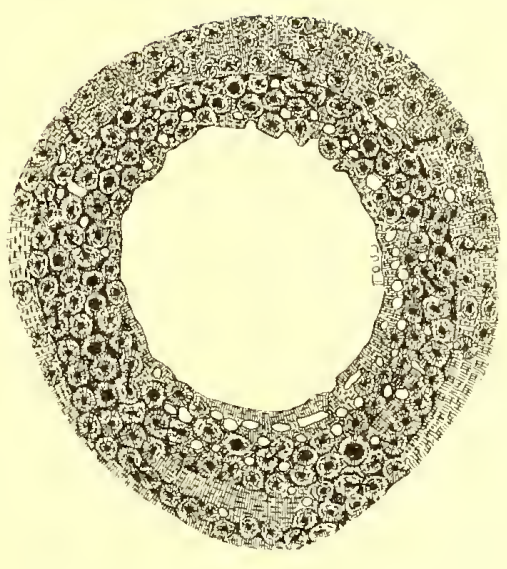

Left femur of Fig. 251 pardus (Ieopard)

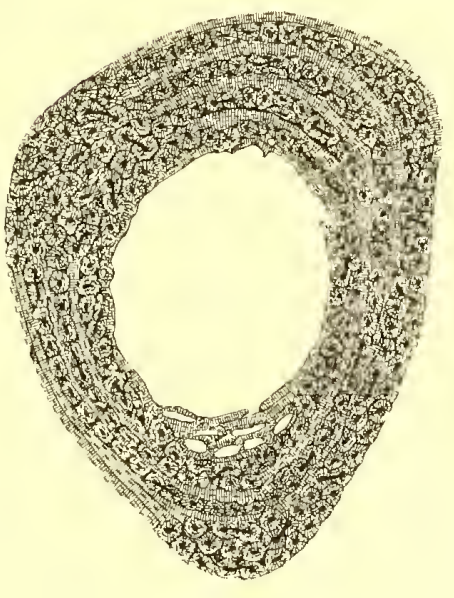

Left femur of Equius caballus (horse)

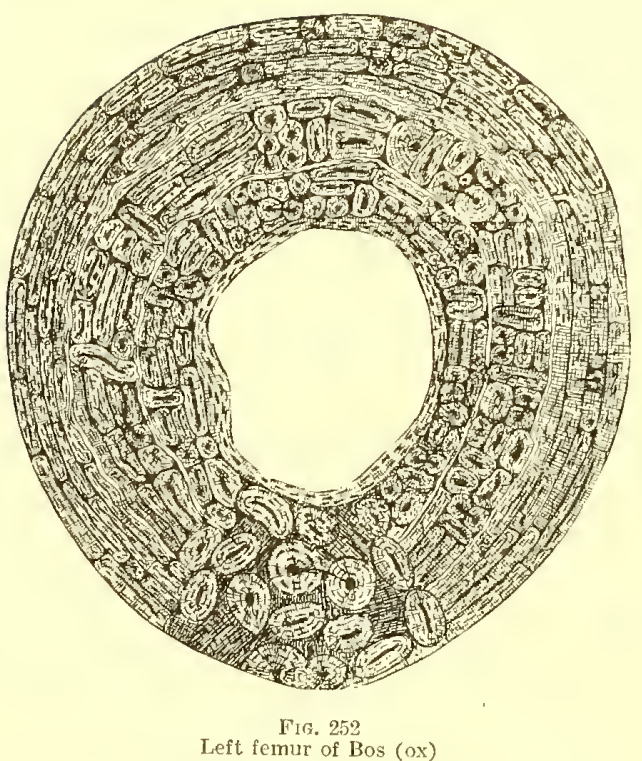

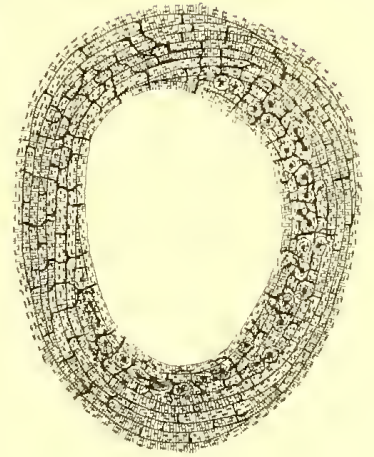

Fifi, 254
Right femur of Ovis (sheep)

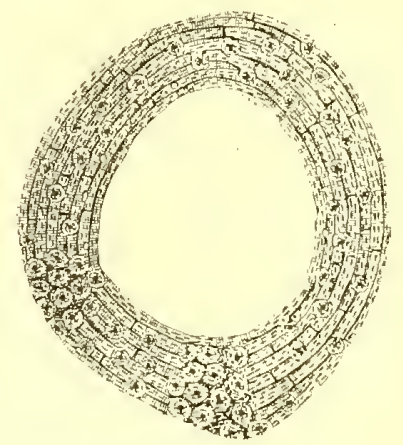

Fig. 255
Right femur of Bison amcri
canus (bison)

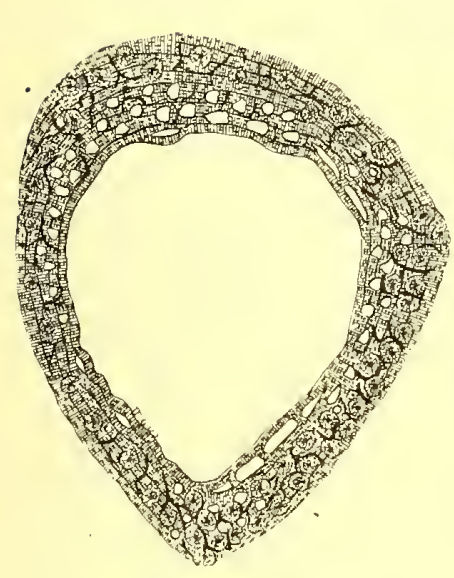

Fig. 256
Right femur of a mule.
No. 227, C. M. C.

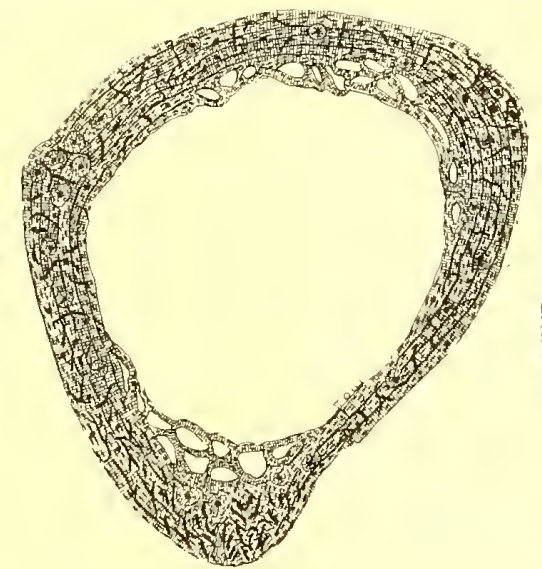

Fig. 257
Left femur of a mule. No. 229

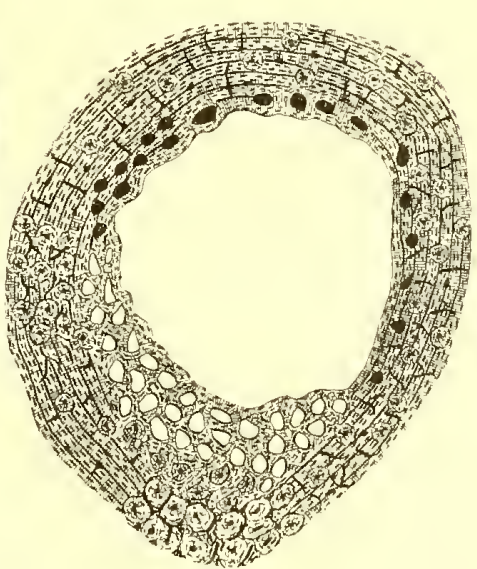

Fig. 258
Left femur of a mule. No. 235,
C. M. C.

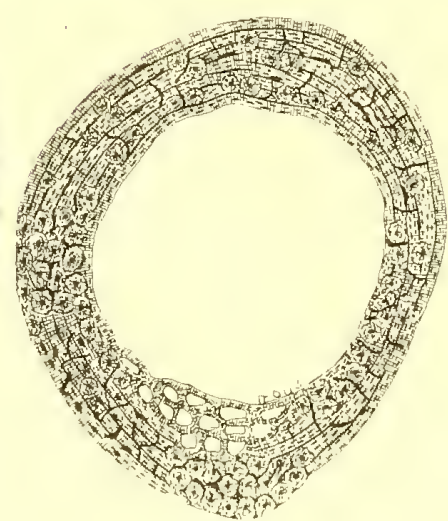

FiG. 259
Left femur of a mule. No. 236 ,
C. M. C. 


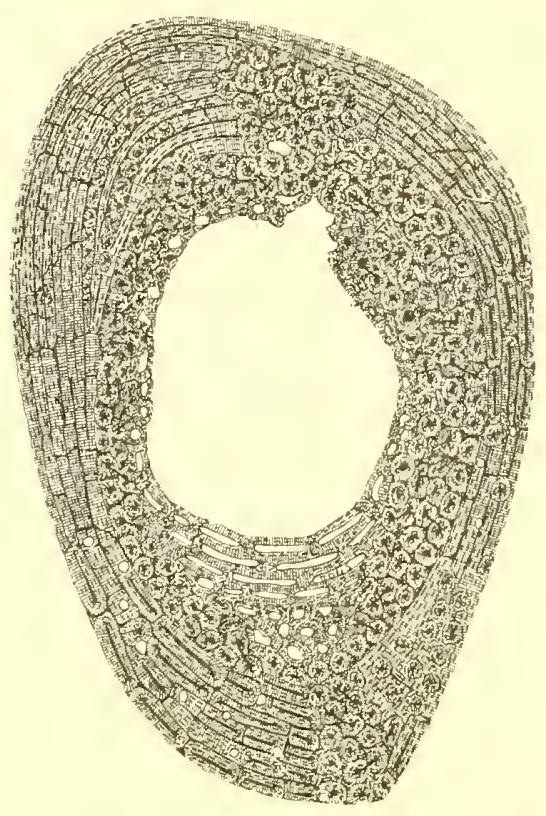

Fig. 260

elephant)

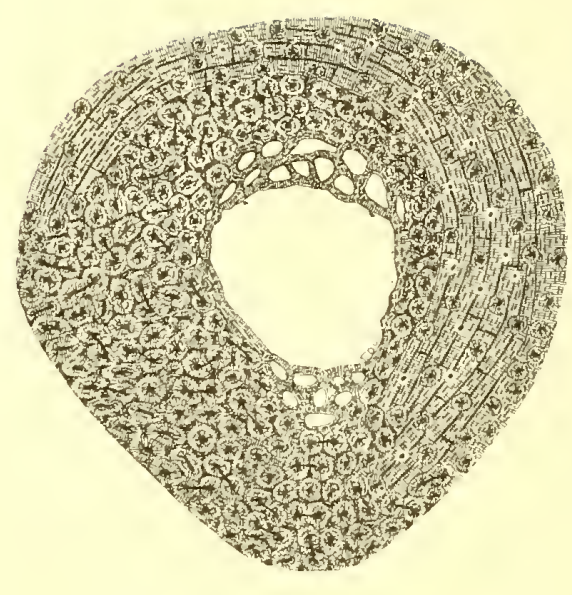

Pig. 261
Right fenur of Hippopotamus amphibius

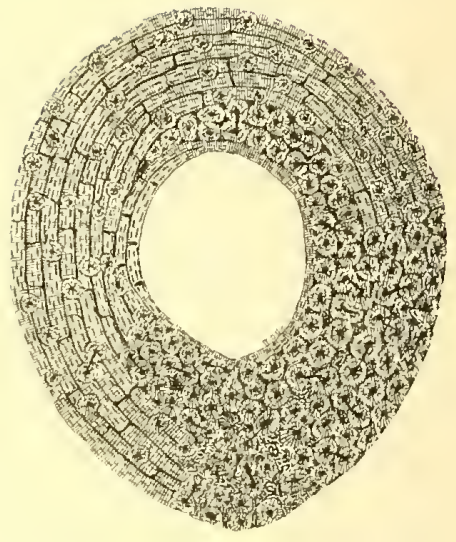

Left femur of Giraffa camelopardalis (giraffe)

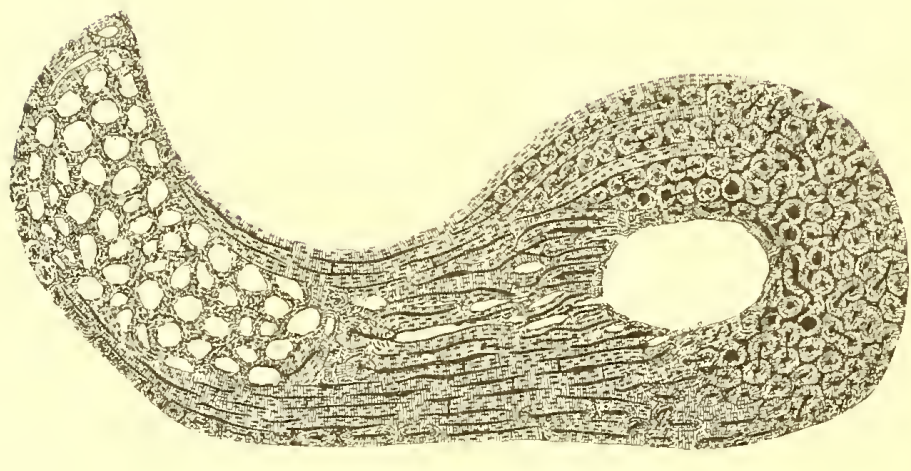

Fig. 263
Left femur of Rhinoceros bicornis (rhinoceros)

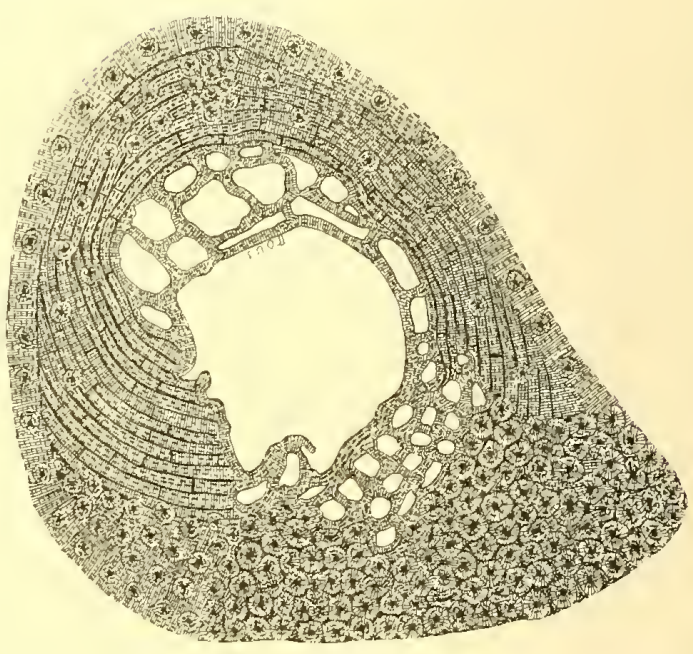

Fig. 264
Right femur of Equus burchelli (zebra)

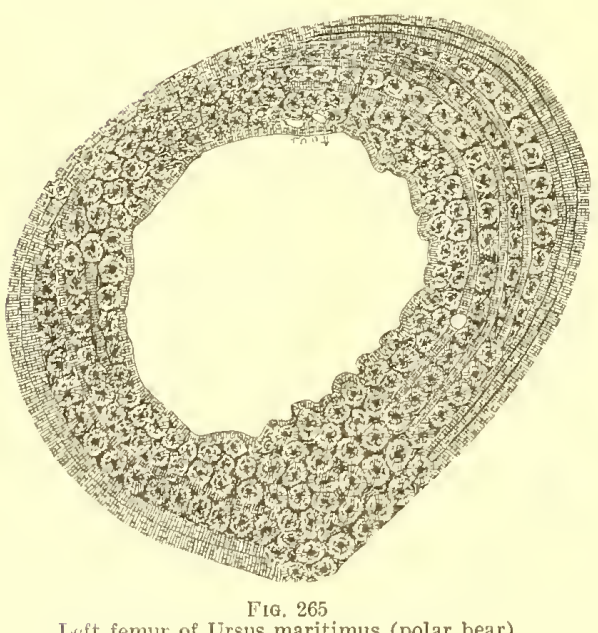

Lcft femur of Ursus maritimus (polar bear)

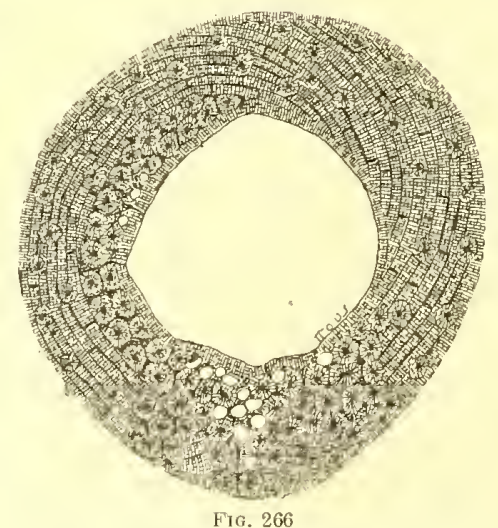

Fig. 266
Right femur of Bubalis jacksoni (Hartebeest)

MAMMALS

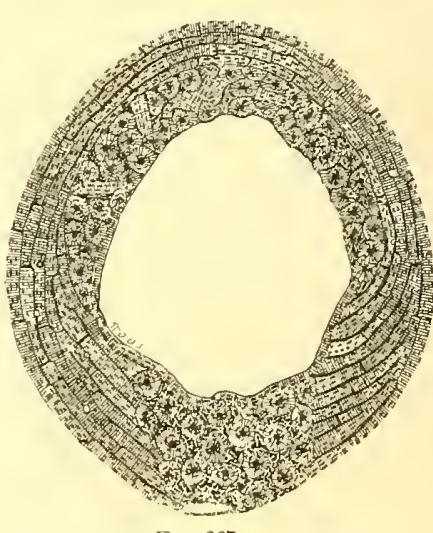

FIG. 267
Left femur of Phacochørus (wart-hog) 


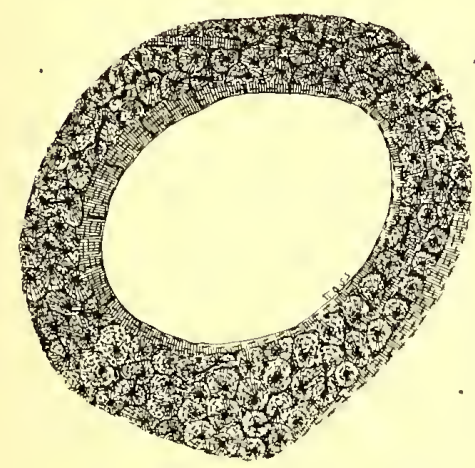

FiG. 268
Left femur of Felis concolor (panther)

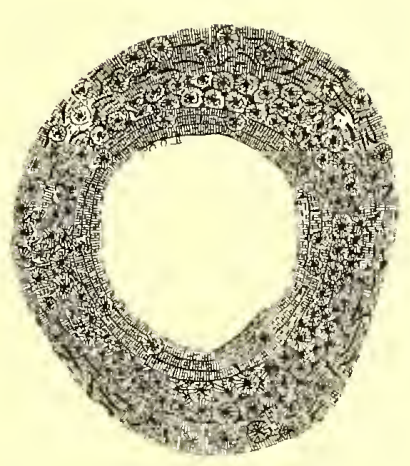

FIG 269
Left femur of Gulo luscus

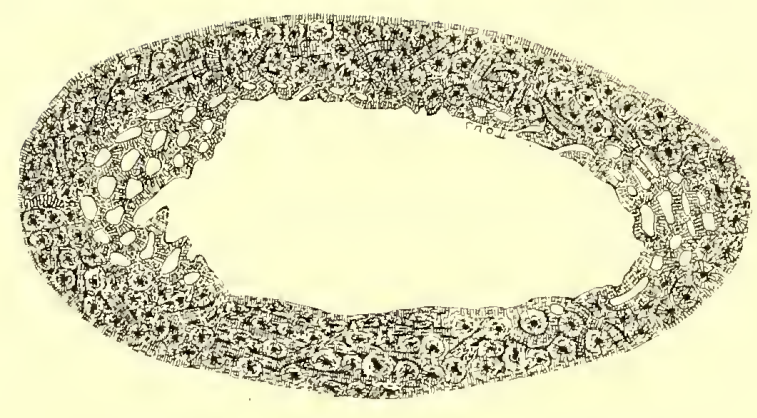

Fig. 270
Left femur of Erignathus barbatus (seal)

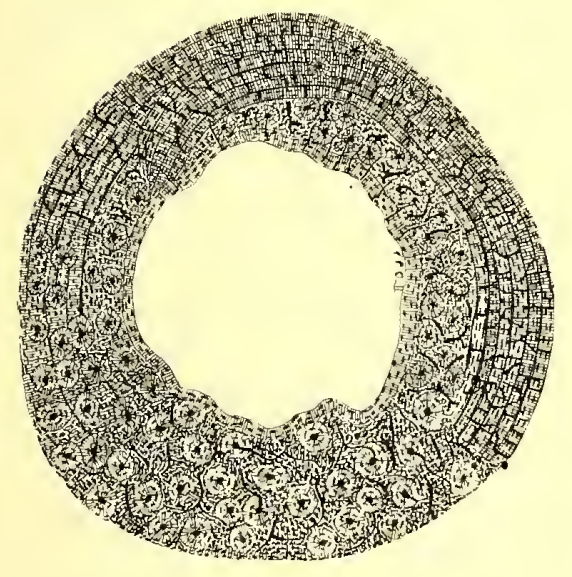

FIG. 271
Left femur of Bos bubalis (water buffalo)

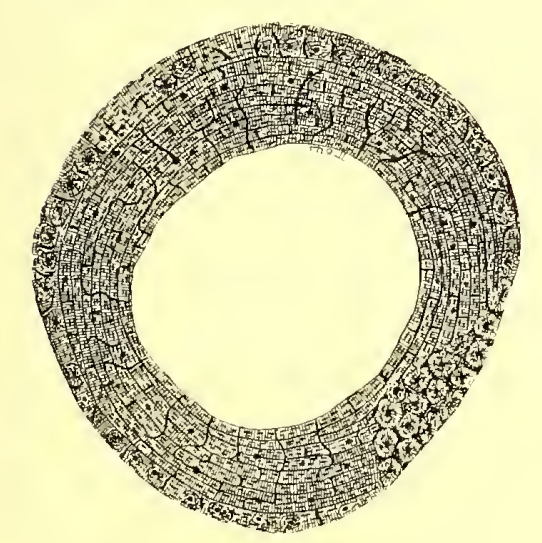

FIG. 274
Femur of Raphiceros (steinbok)

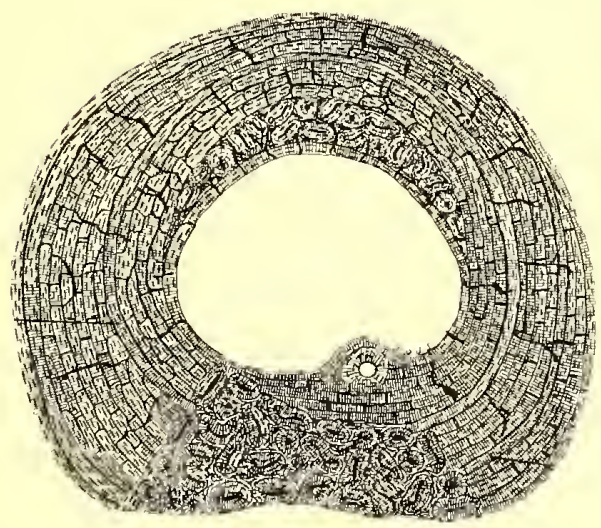

Fig. 272
Left femur of Ovis montana (mountain sheep)

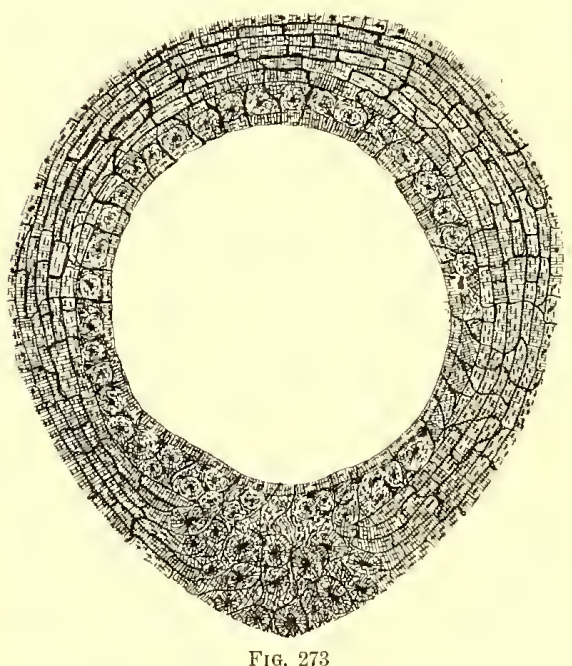

Femur of Cephalophus (African antelope)

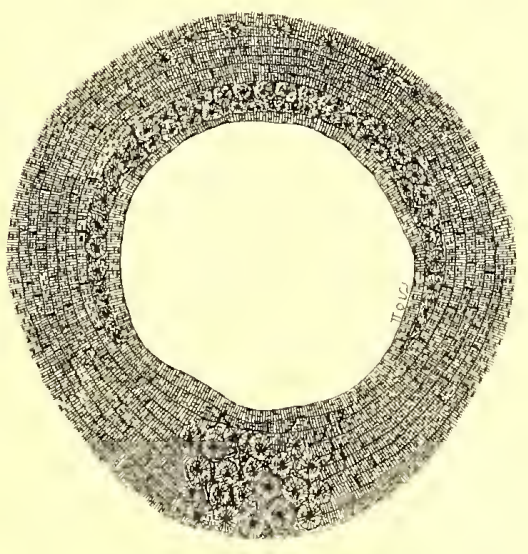

Fig. 275
Left femur of Gazella granti (Grant's gazelle)

MAMMALS

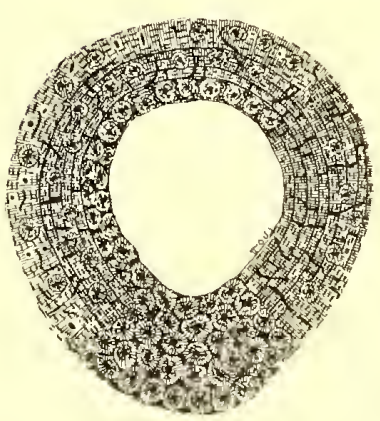

Frg. 276
Left femur of Kobus ellipsiprymnus
(water buck) 


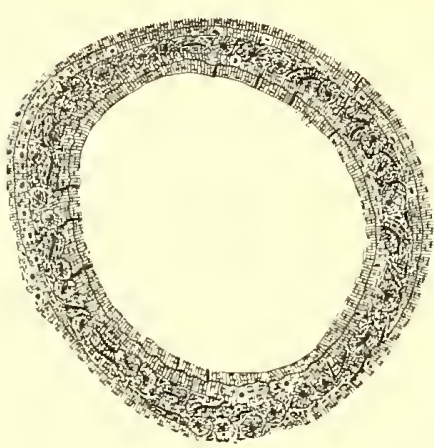

Fig. 277
Right femur of Arctomys monax

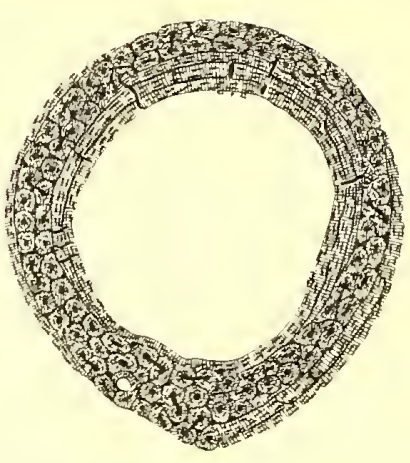

Fig. 278
Right femur of Canis latrans
(coyote)

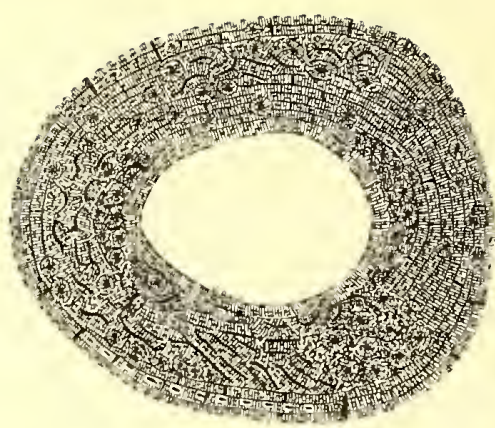

Fig. 279
Right femur of Capra (goat)

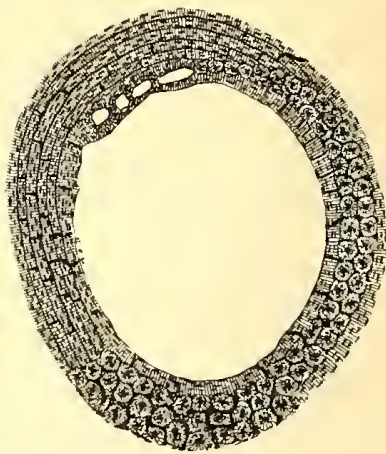

FIG. $2791 / 2$
Right femur of a bull-dog (not a
pure blood)

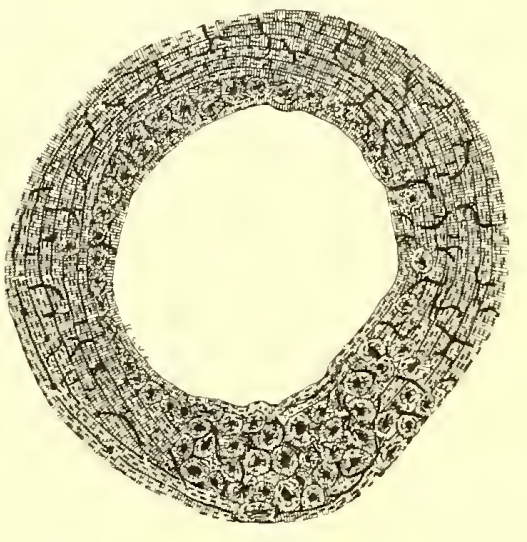

Fig. 280
Left femur of a shepherd dog (not a pure blood)

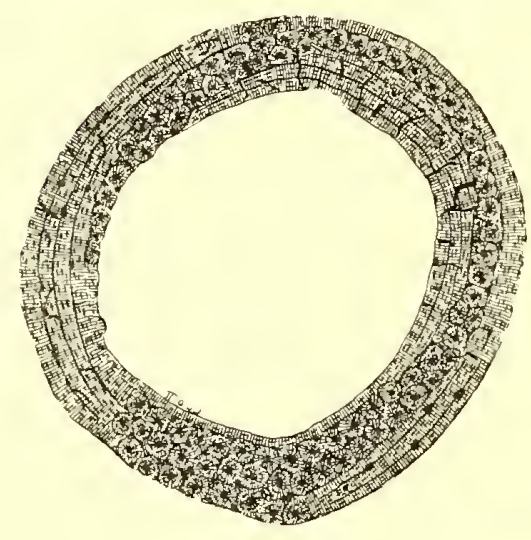

FIG. 282
Right femur of a mongrel dog

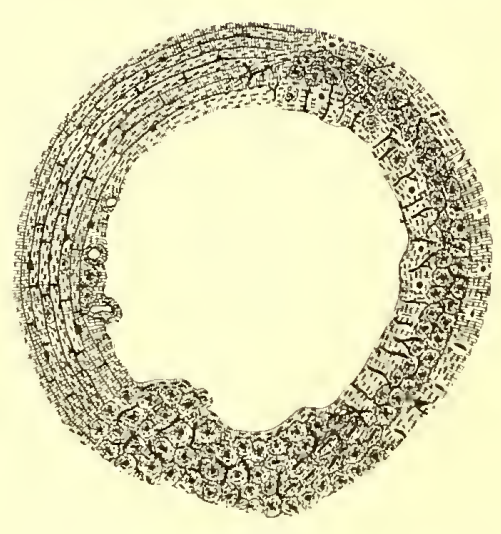

FIG. $2801 / 2$
Right femur of a dog

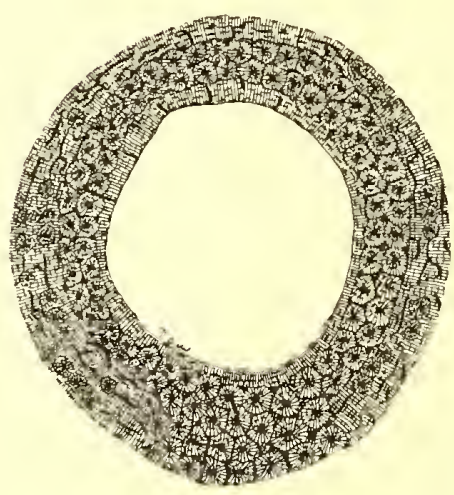

FiG, 283
Right femur of a bull dog (not a pure blood)
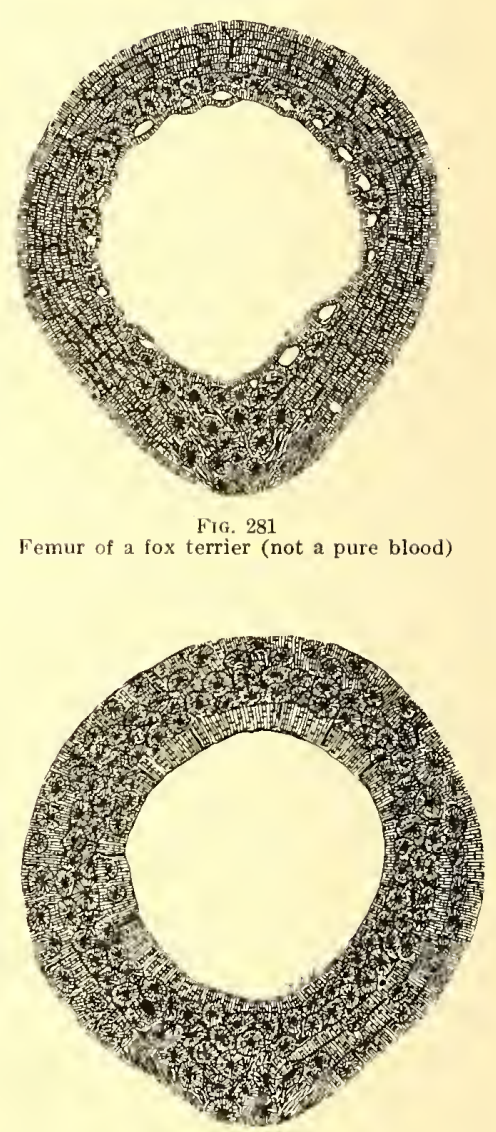

FIG, 284
Right femur of a collie dog (not a pure blocd)
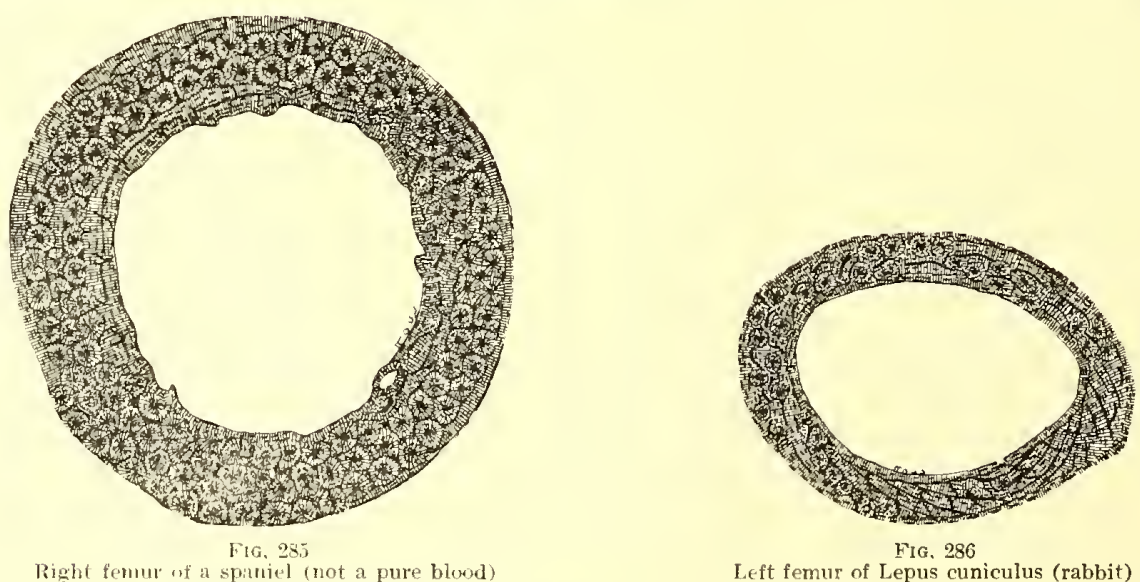

MAMMALS 


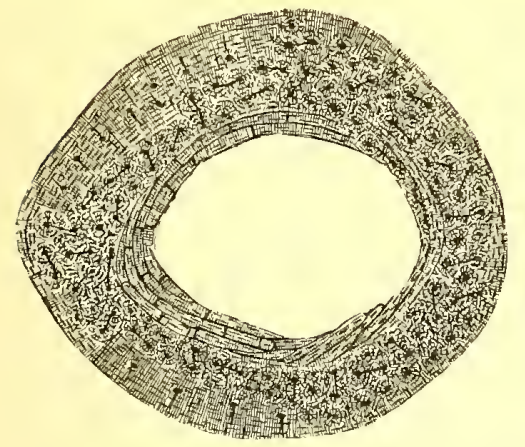

F1G. 287
Right femur of Procyon lotor (raccoon)

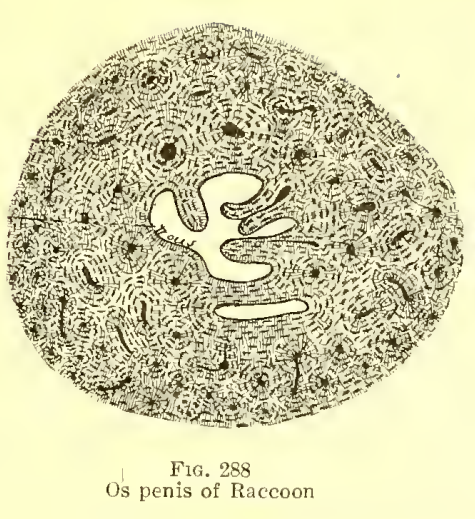

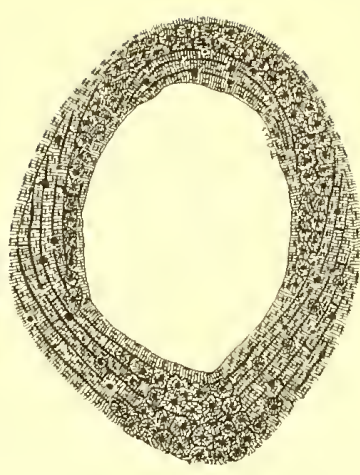

Fig. 289 .

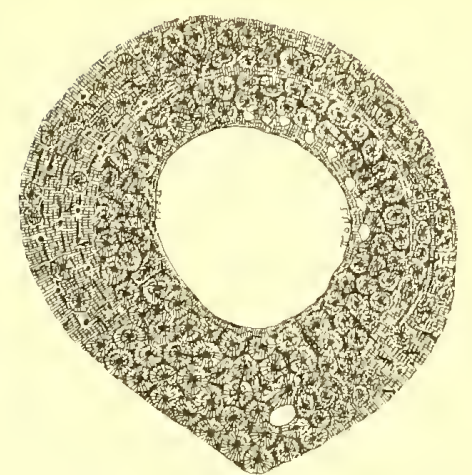

FIG. 290

Right femur of a Felis leo (lion)

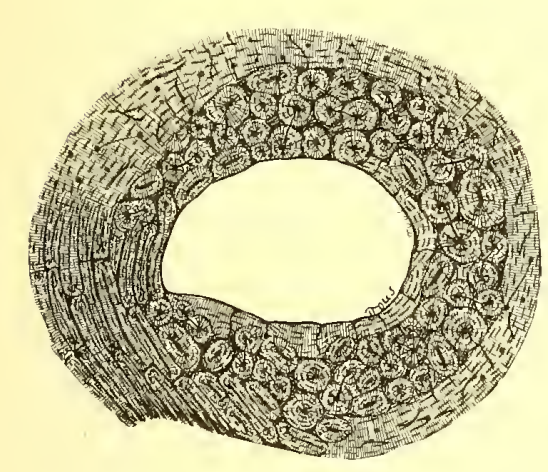

FIG. 291
Right feinur of Canis (small grey fox)

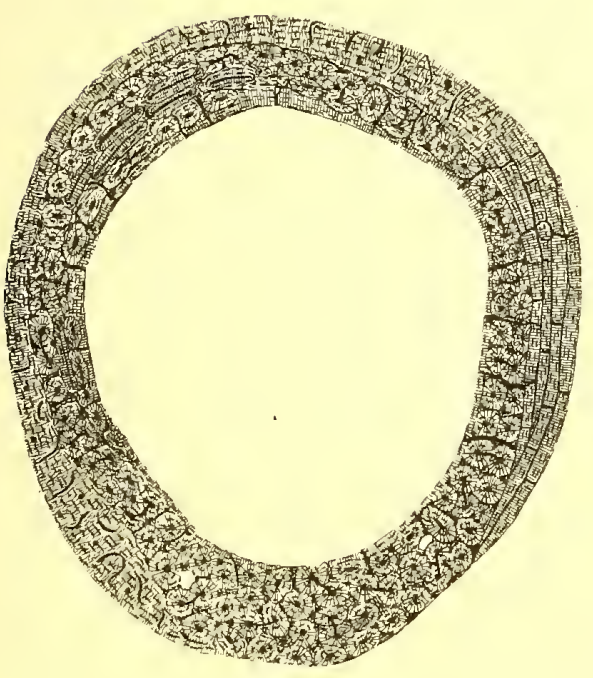

Left femur of Canis. 291

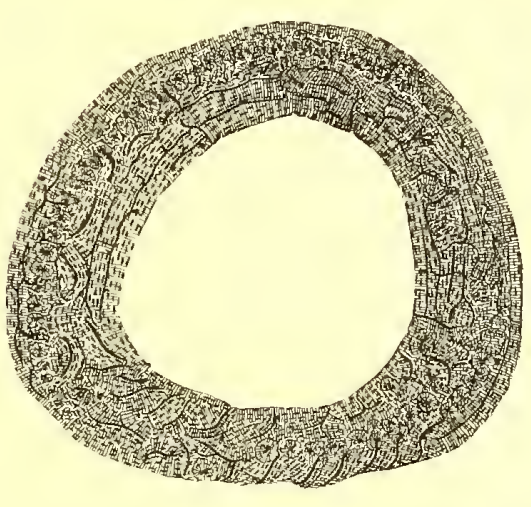

Fig. 292
Left femur of Taxidea an

badger)

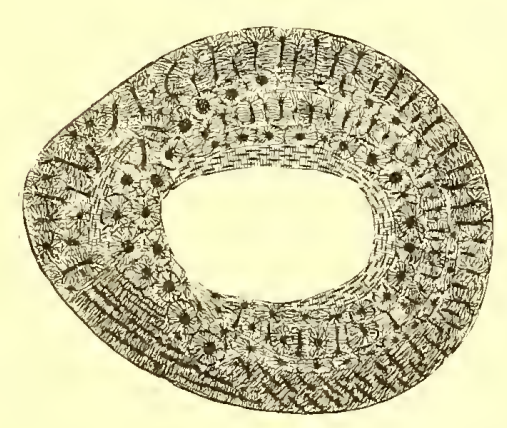

FIG. 295
Right femur of Didelphis virginiana (opossum)

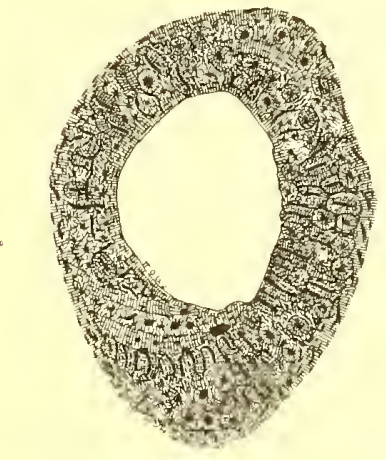

FIG. 297
Right femur of Haplondontia olympica, sewellel (mountain beaver)

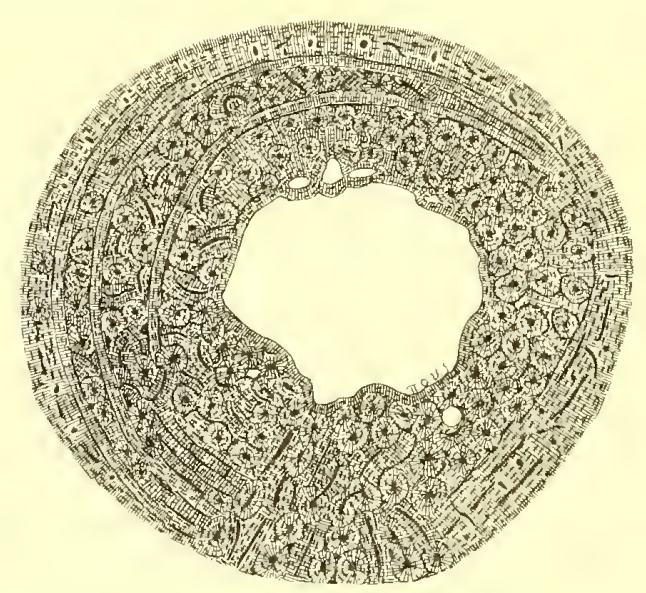

Fig. 293
Right femur of Melursus labiatus (sloth bear)

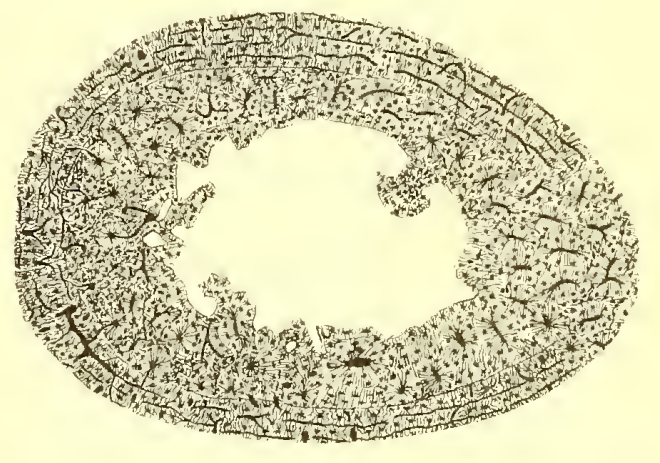

FIG. 296
Left femur of Manis (scaly ant-eater)

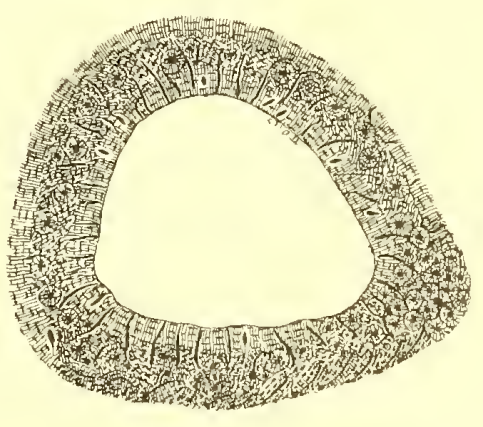

FIG. 298
Left femur of a Erethizon (porcupine)

MAMMALS 


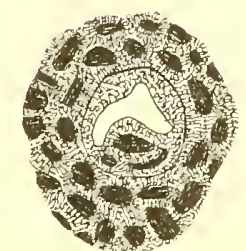

FIG. 299
Right femur of a white Retus of $2 \cdot 2 \frac{1}{2}$ months
fentitis

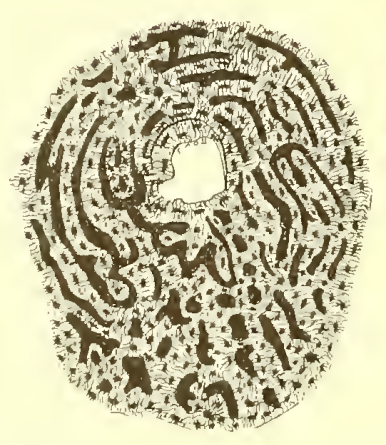

Fig. 300
Right femur of a white fetus

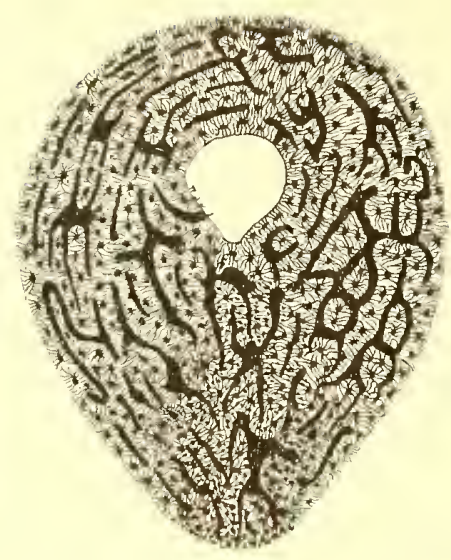

Fig. 301
Right femur of a white fetus of 4 months

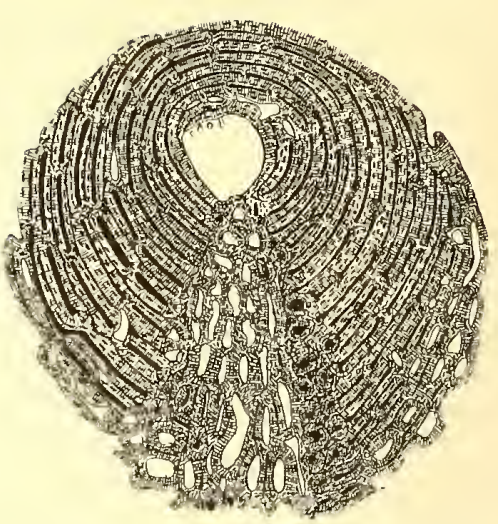

Right femur of a white fetus of 5-7 months

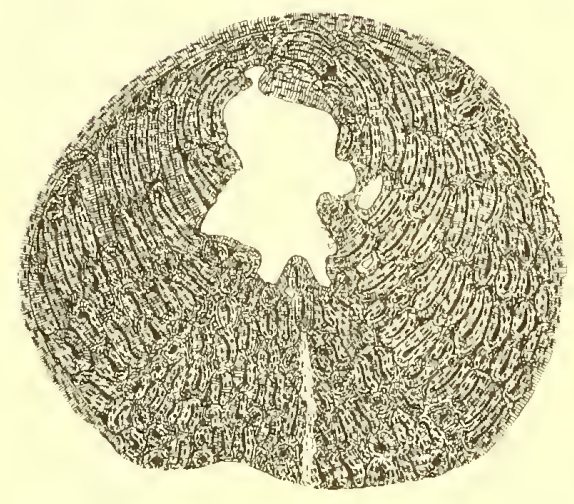

FIG. 303
Right femur of a white fetus of 8-9 months

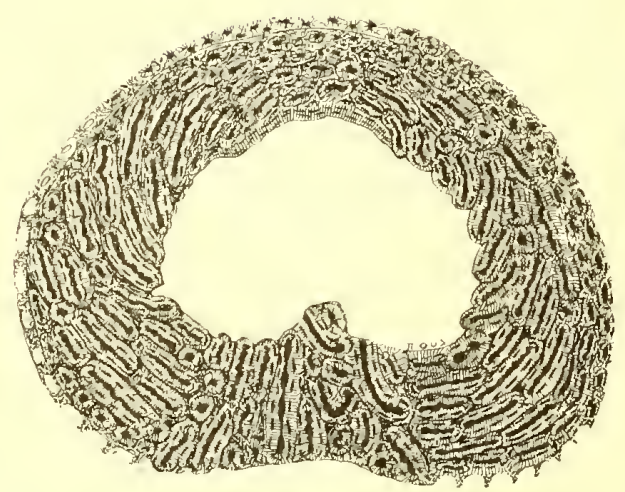

Fig. 304
Right femur of negro fetus of 9 months

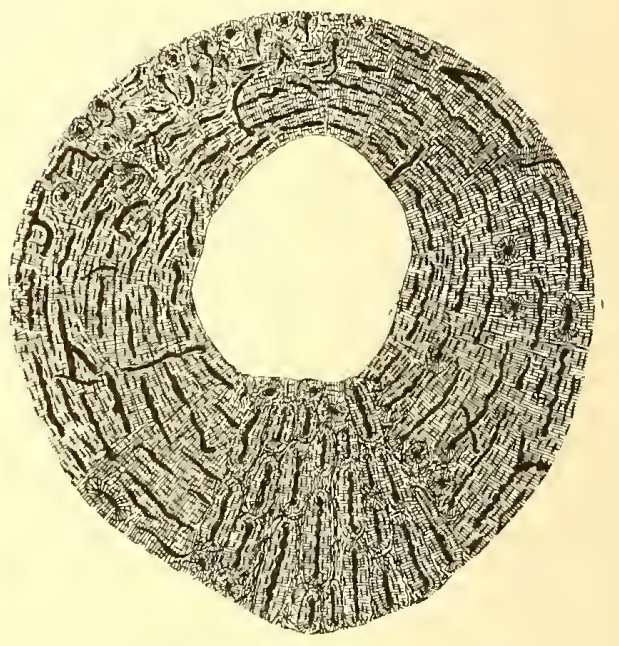

FIG. 305
Right femur of white fetus of $8 \frac{1}{2}$ months (Craniorrhachischisis)

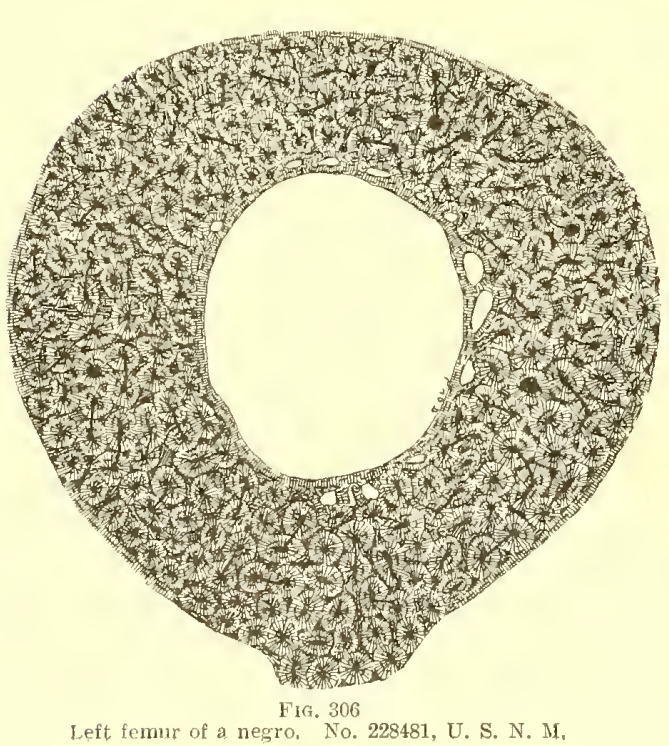

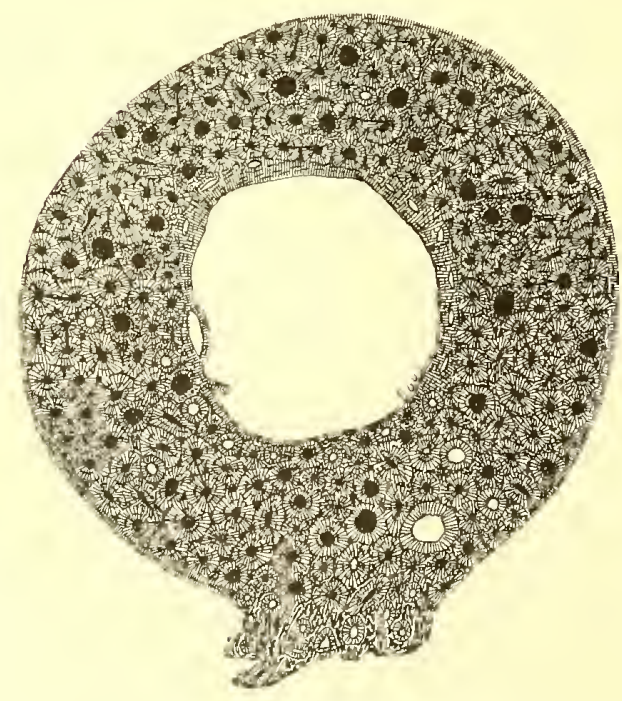

Fifi, 307
Fenur of mixed negro and white (half white). MAN (WHITE, BLACK)

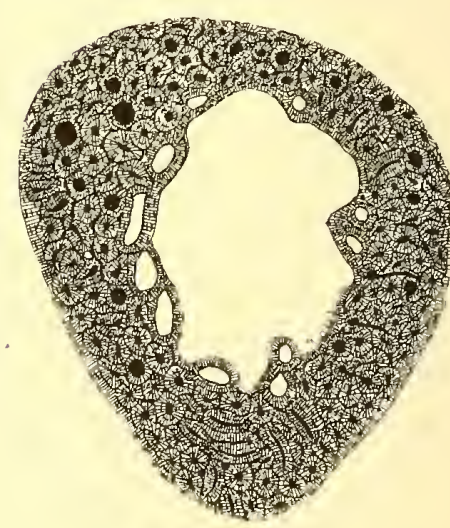

Fia. 308
Left femur of a negro. No, 3, Med. Dept.,
Tulane Univ. 


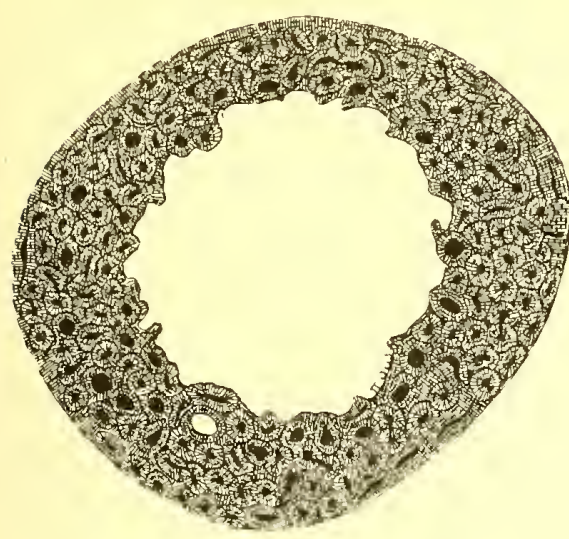

Fig. 309
Left fenur of a negro. No. 87, M. D. T. U.

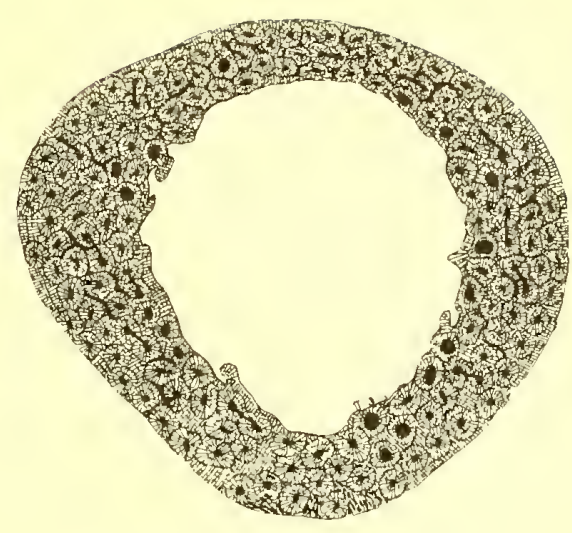

Fic. 310
Right femur of a negro. No. 7, M. D. T. U.

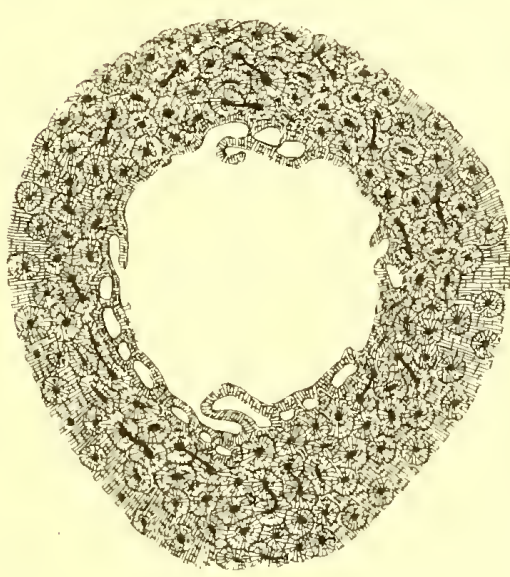

IG. 3 I.

Fig. 312
Right femur of a regro. No. 8 t, M. D. T. I

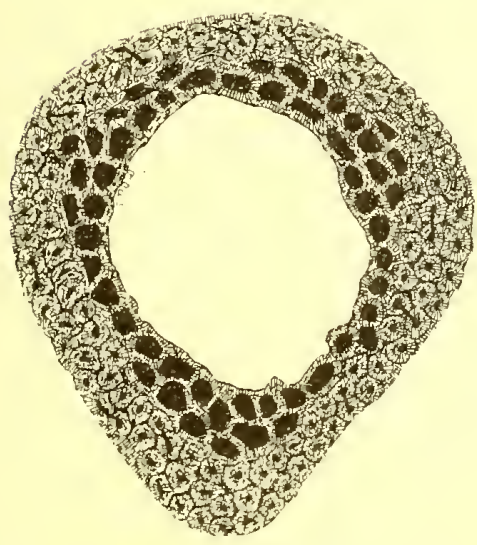

FiG. 315
Left femur of a negro. No. 79, M. D. T. U.

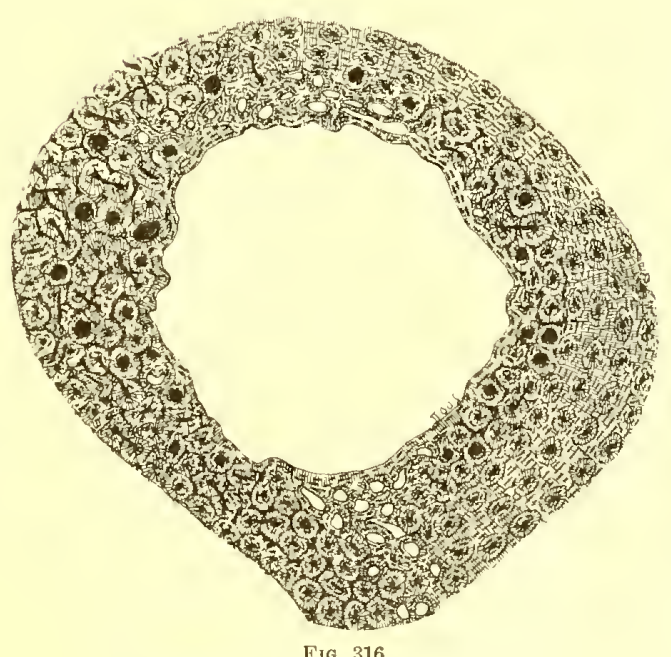

Fia. 316
Left femur of a negro. No. 224714, U, S. N, M.

MAN (BLACK)

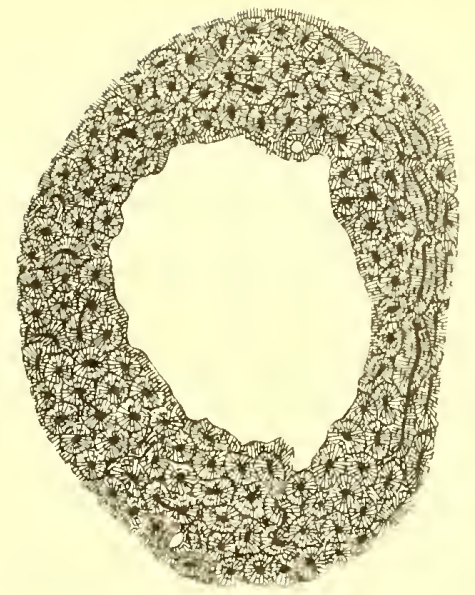

Fig, 311
Left femur of a negro. No. 4, M. D. T. U.

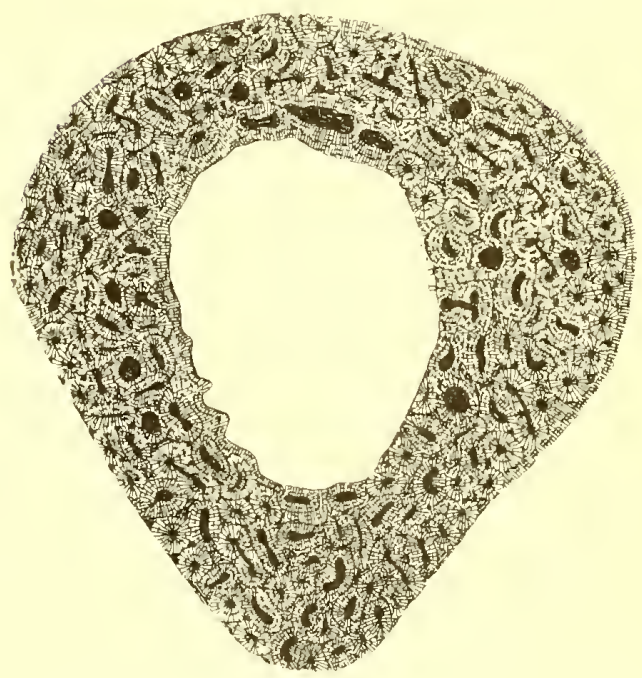

Fig. 314 ,
ligint femur of a negress, age 40. No. 12\%,
M. D. T, U.

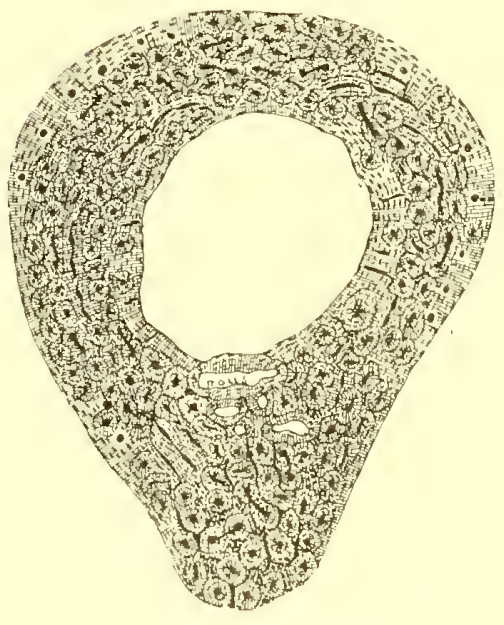

FIG. 317
Left femur of a negro. No. 11, M. D. T. U. 

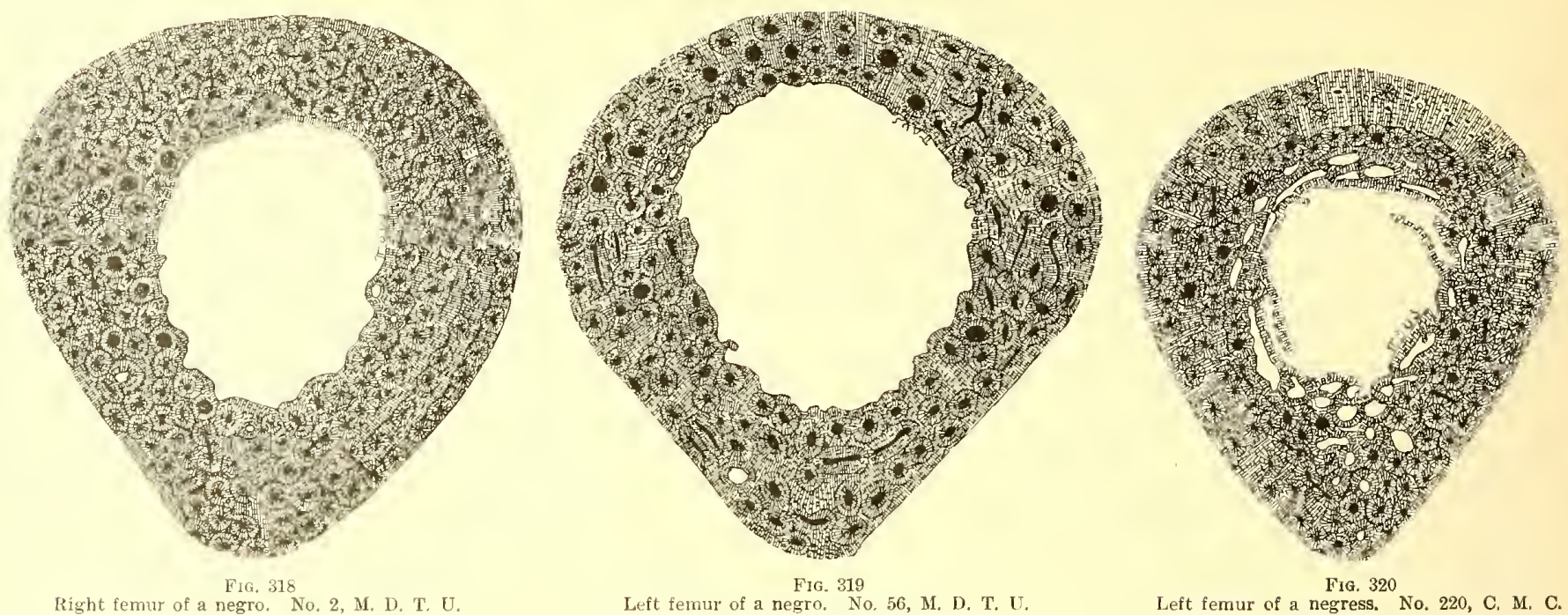

Fig. 320
Left femur of a negress. No. 220 , C. M, C.
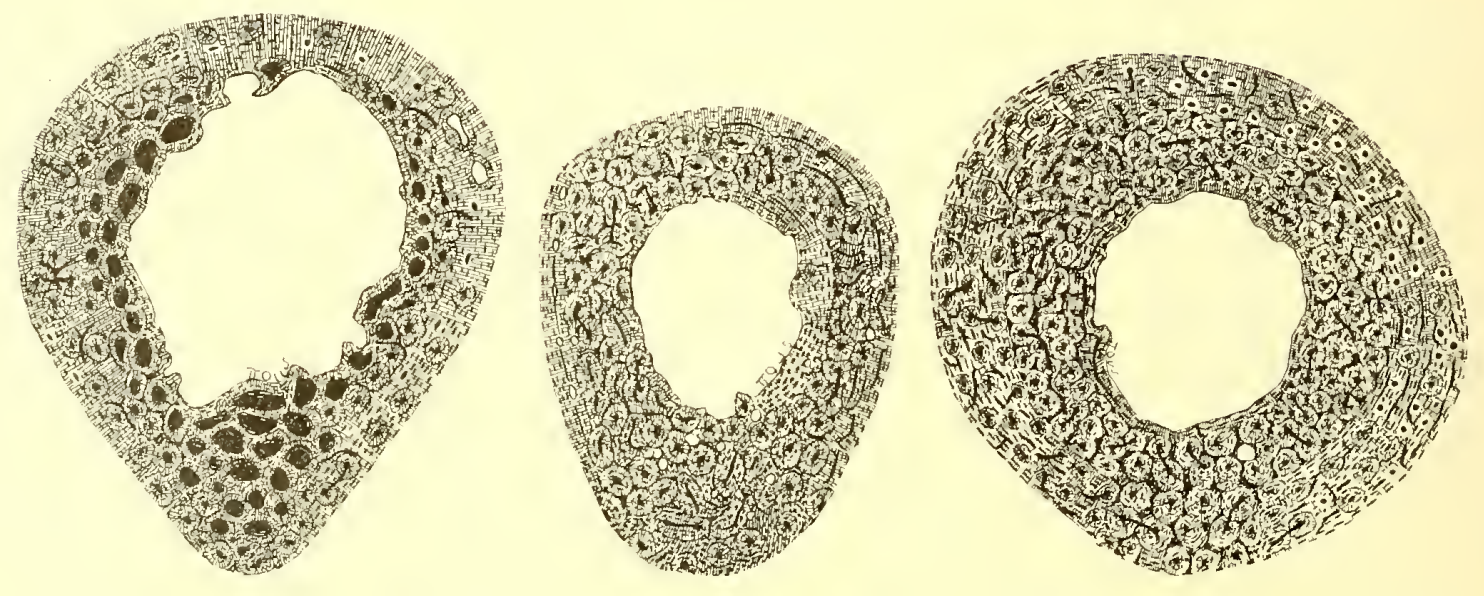

FIG. 321
kight femur of a negress. No. 220, C. M. C.
Anmutated at lower third

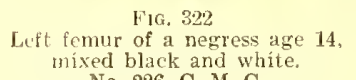

FiG. 323
Femur of a negro. No. 1, M. D. T. U.
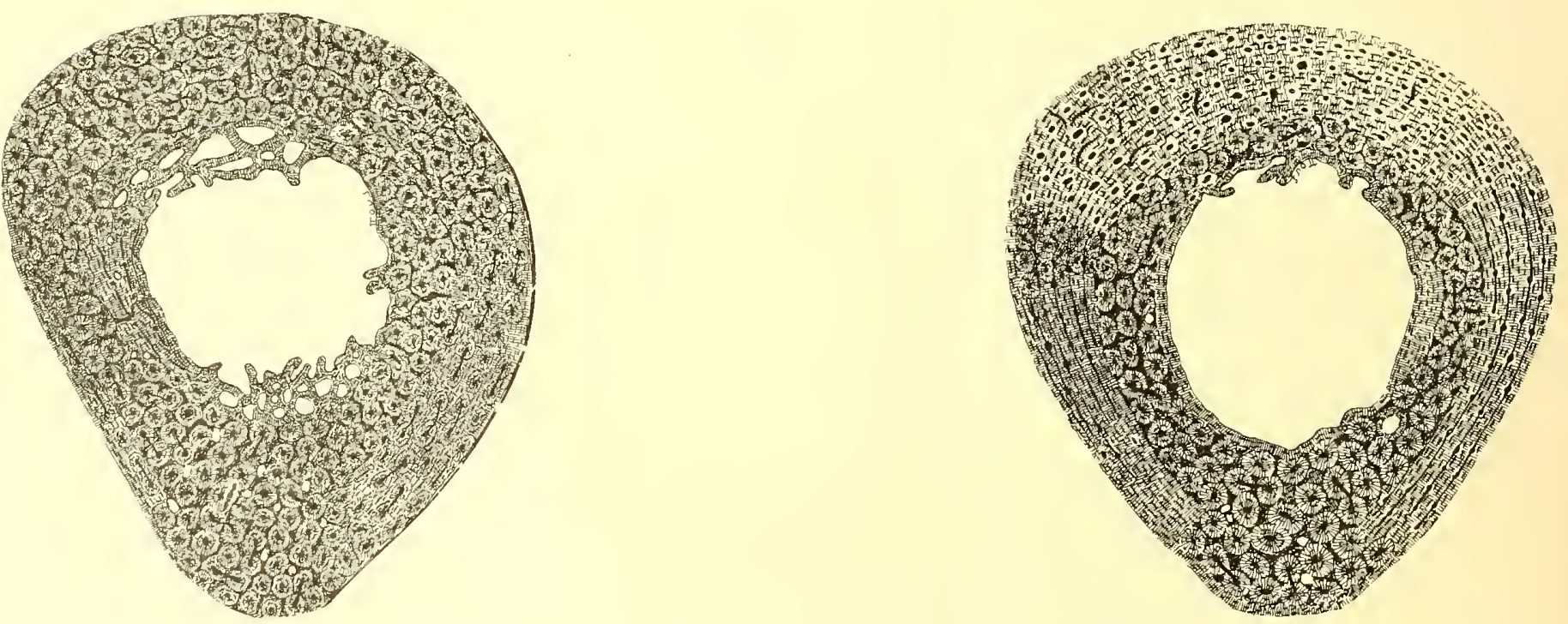

Right femur of a Kafír negro. No. 263196, U, S, N. M. 


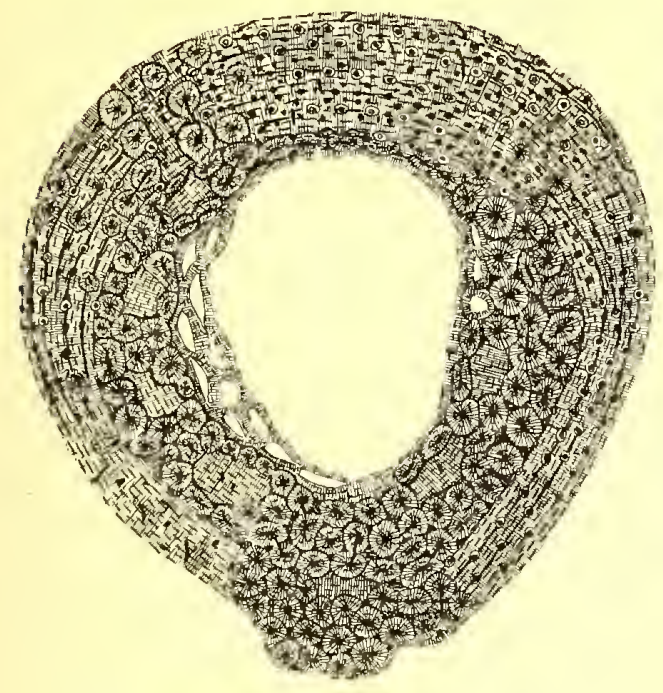

FIG. 326
Left femur of a negro. No, 248674, U, S, N, M.

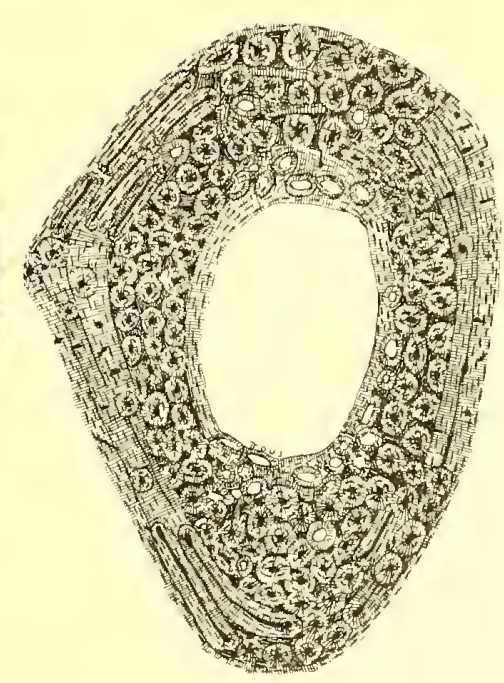

FIG, 327
Tibia of a negro, No, 248074, U, S. N. M.

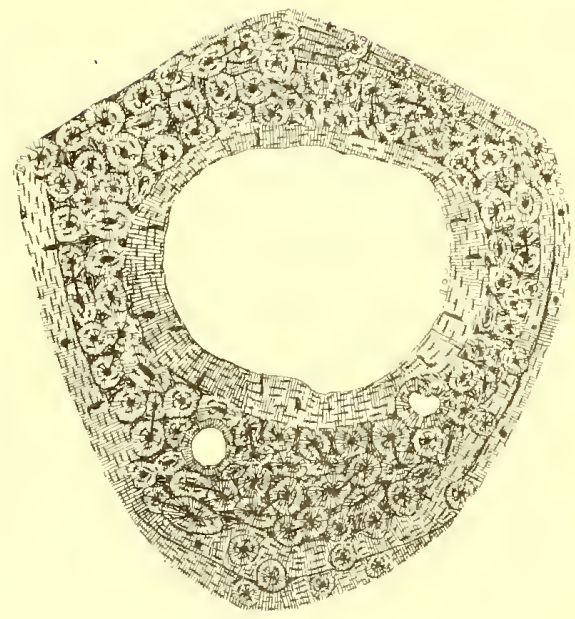

Fig. 328

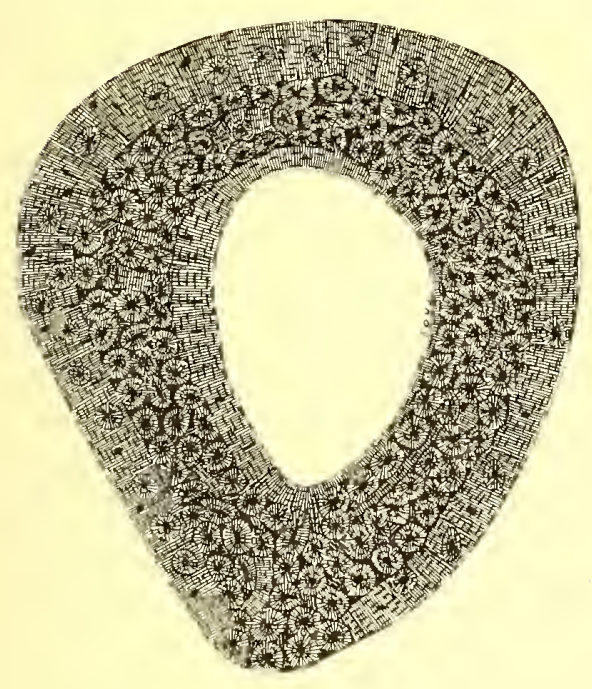

Fia. 329
Ulna of a negro.
No. 248674, U. S. N. M.

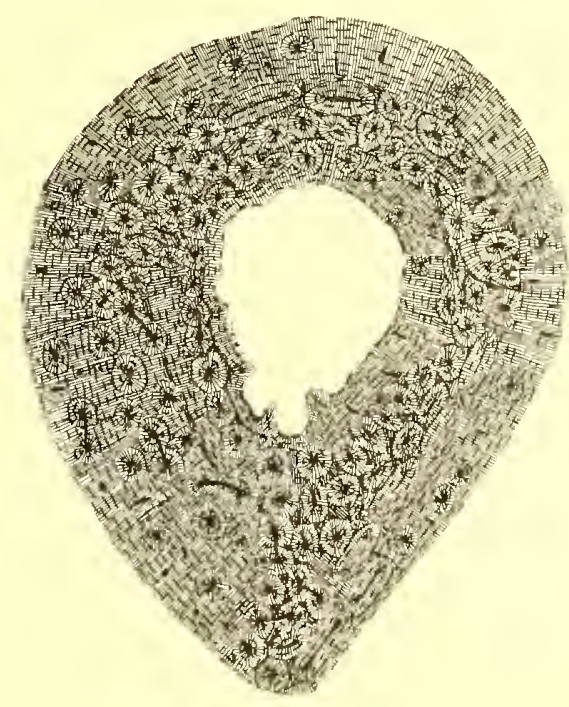

FIG. 330
Radius of a negro. No. 248674 , U. S. N. M.

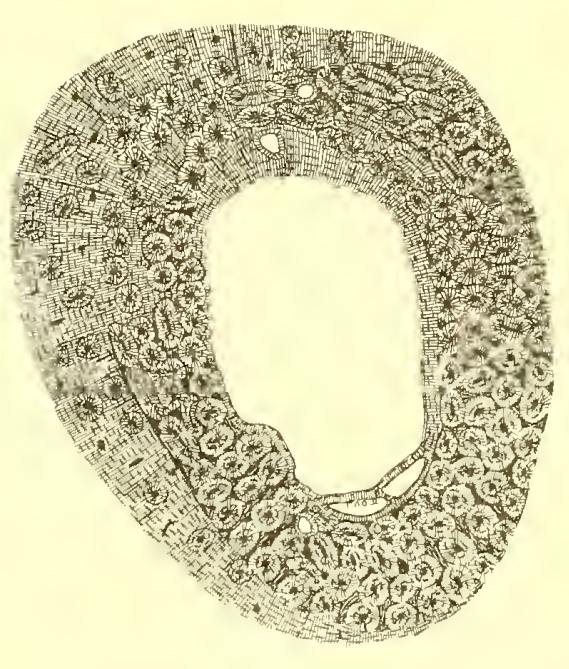

FIG, 331
Humerus of a negro, No, 248674, U、 S. N、 M

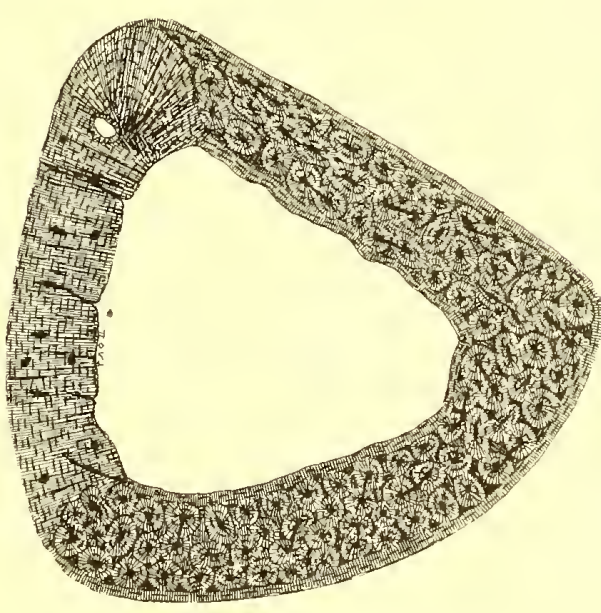

F1G. 333
Metatarsal bone of great toe of negro.
No. 248674, U, S, N, M.

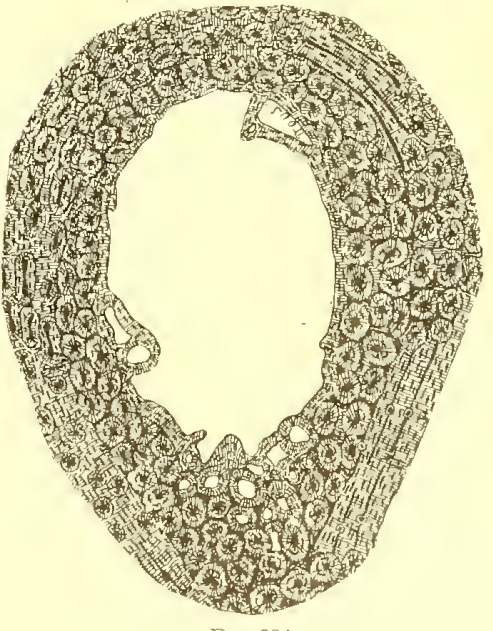

Fig. 334
Left femur of negro. NO. 224713 , U. S. N. M.

MAN (BLACK) 


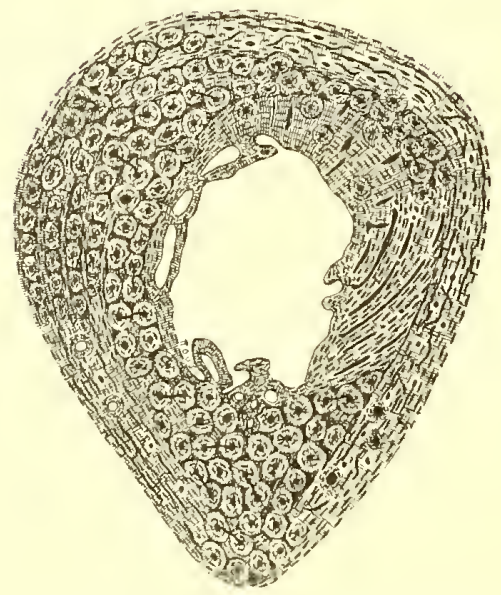

Right femtir of a negro. 335 No, 83 , M. D. T. U.

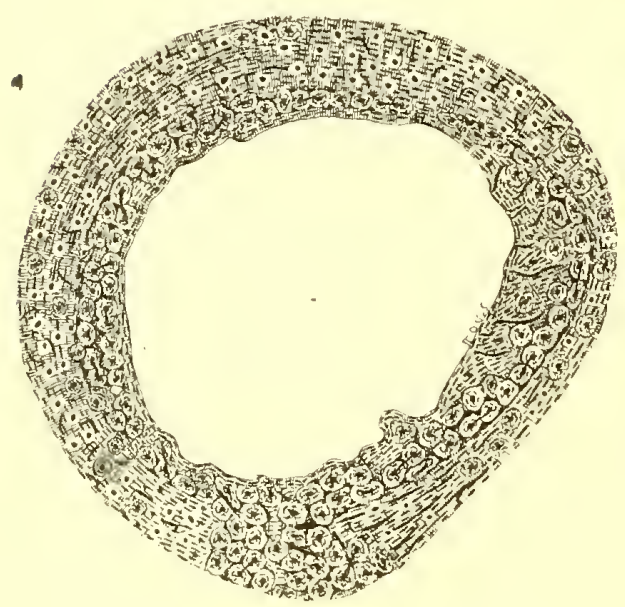

FIG. 338
Left femur of a negro. No, 5, M. D. T. U

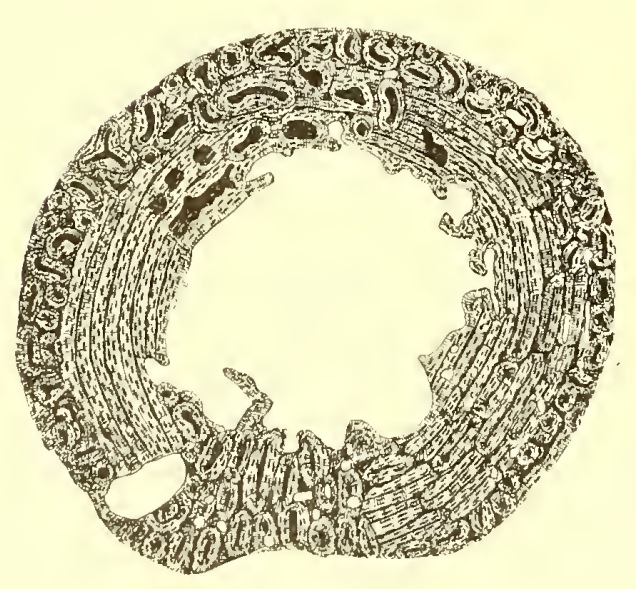

Fir. 341
Right fernur of Pucblo Indian child one year
old. No, $258675(\%)$ U. S. N. M.

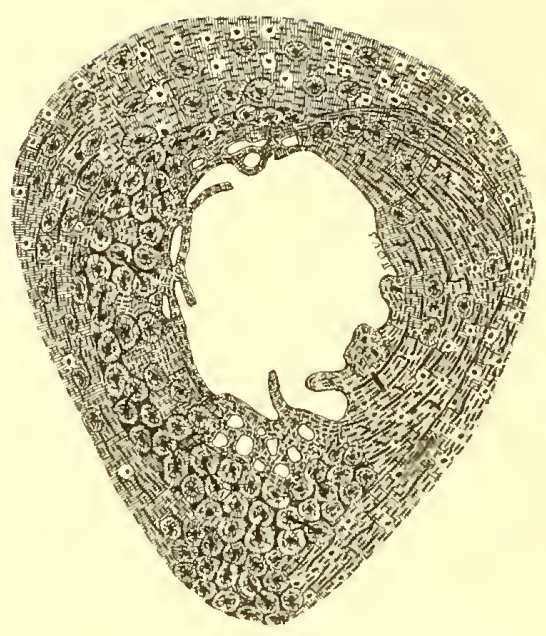

FIG, 336
Right femur of a negro. No, 6, M, D. T. U.

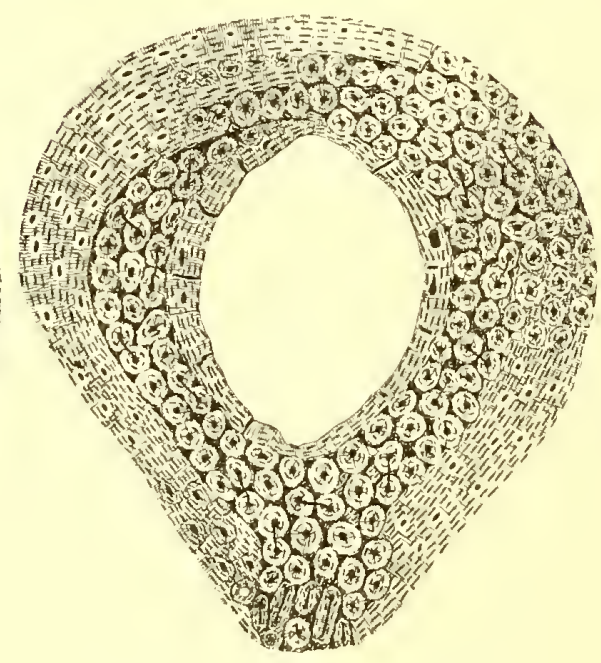

FIG. 339
Right femur of a negro.

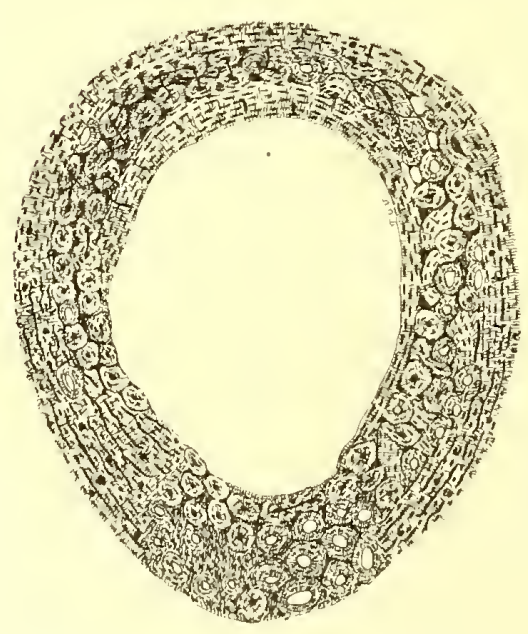

Fra. 342
Left femur of Pueblo Indian chíld six years old.
No. $258675(\mathrm{~L}), \mathrm{U}, \mathrm{S}, \mathrm{N}, \mathrm{N}$.

NEGRO, PUEBLO INDIAN.

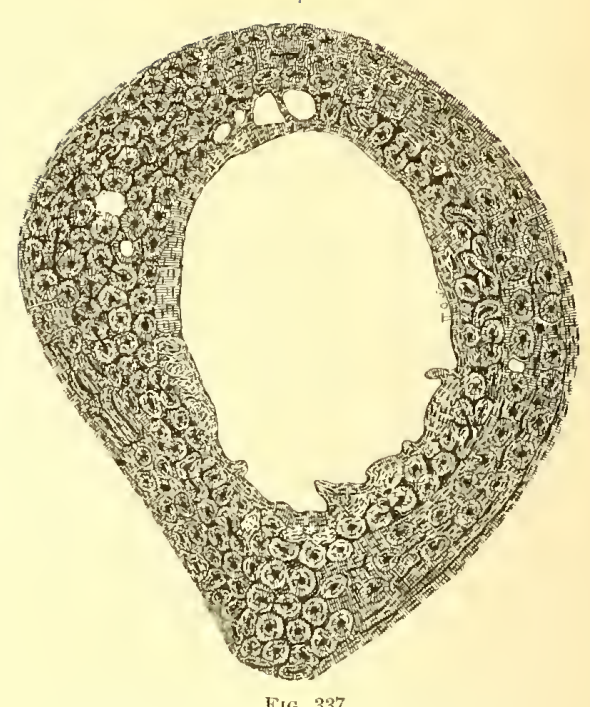

FIG, 337
Right femur of a negro, No, 63, M, D, T. U.

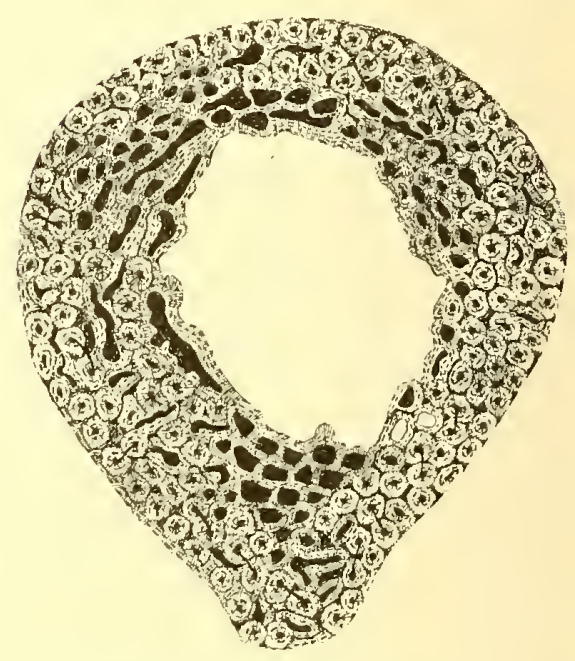

Left femur of a negro. ${ }^{\text {No. }}$ 7, M. D. T. U.

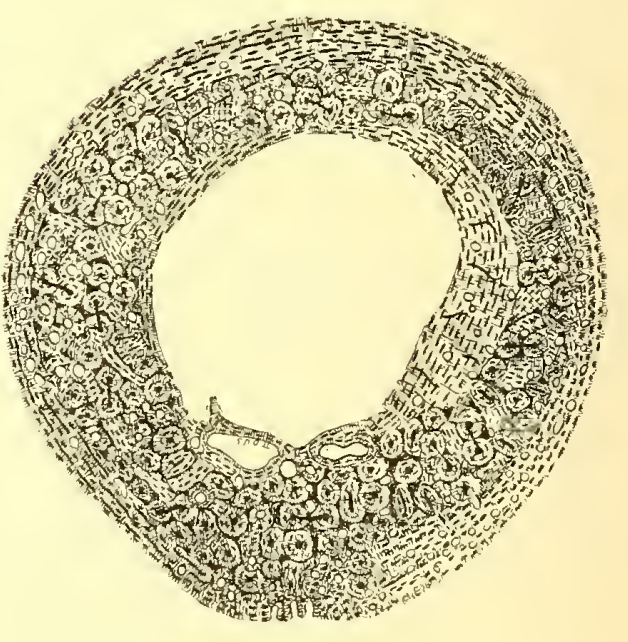

FIG, 3421/2
Left femur of Pueblo Indian youth. No.
258675 (S2), U. S. N. M. 


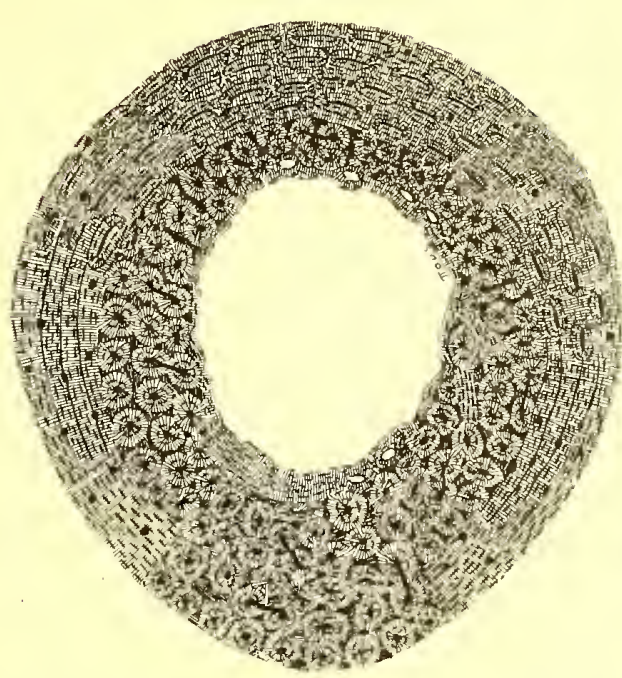

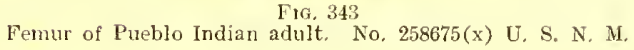

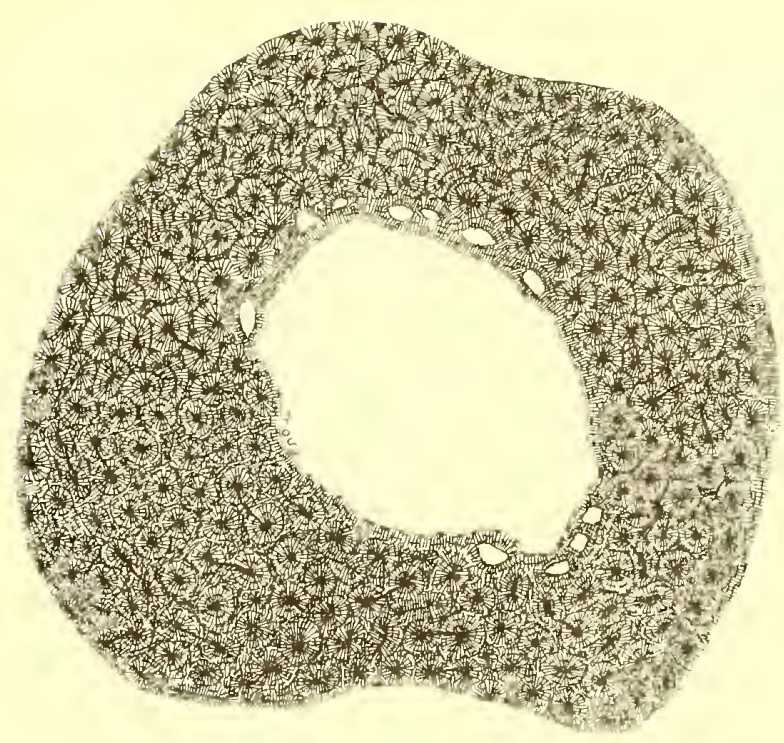

Erg. 344
Right femur of Pueblo Indian adult. No. 227339 ,

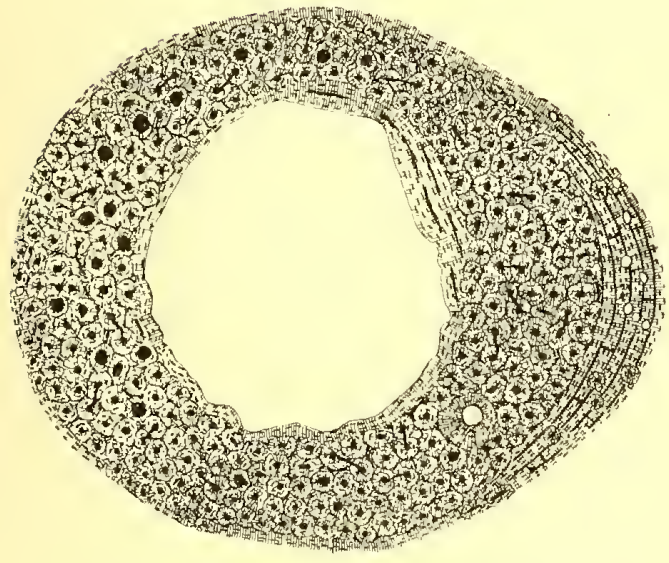

Fig, 345

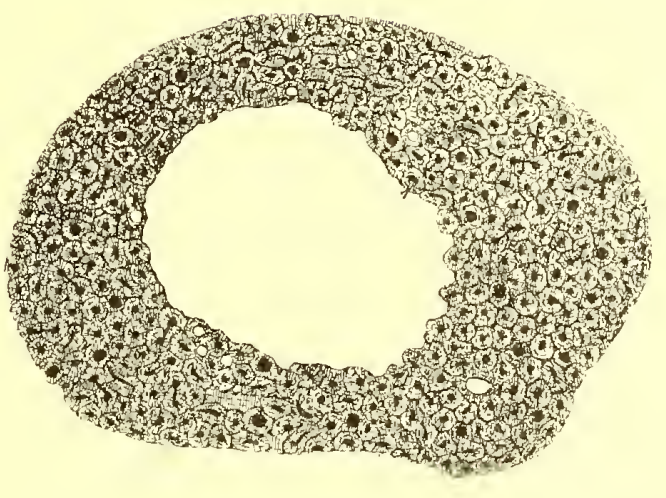

Fify, 346
Left femm of Peruvian Indian, No, 266469(a), L. S. N. M

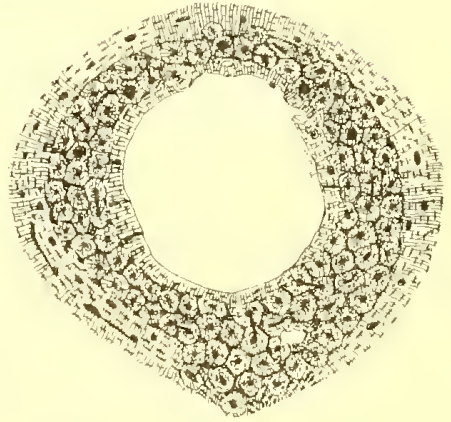

Fig, 347
Left femur of Chicama Indian of Peru.
No. 2, U. S. N. M.

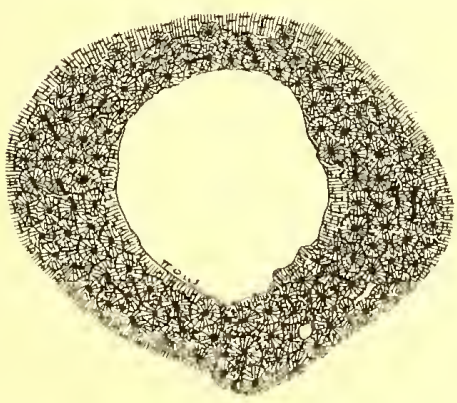

FIG, 348
Right femur of Chicama Indian of Peru
No. 3, U. S. N. M.

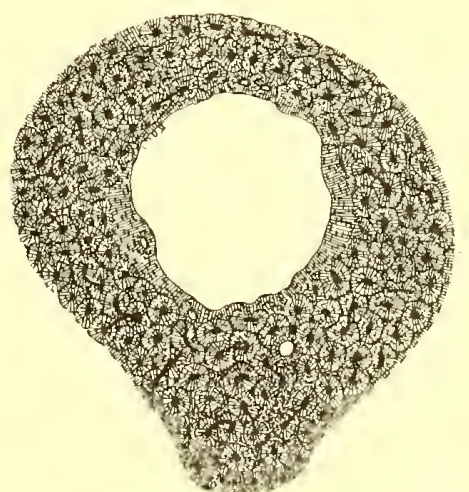

Fig. 349
Right femur of Chicana Indian of Peru.
No, 1, U, S, N, M.

MAN (YELLOW-BROWN)

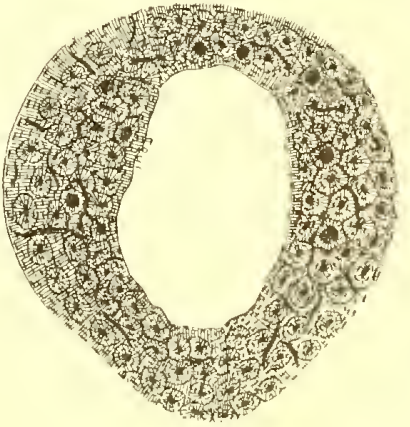

Fig, 350
Left fimur of Chicama Indian of Peru.
No, 4, U, S. N. M. 


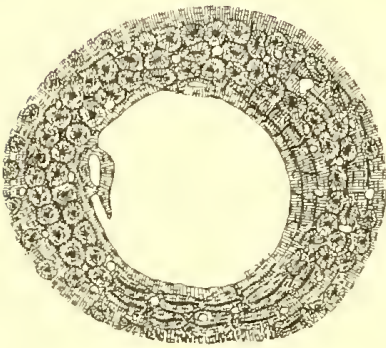

F1G. 351
Left femur of Chicama Indian of

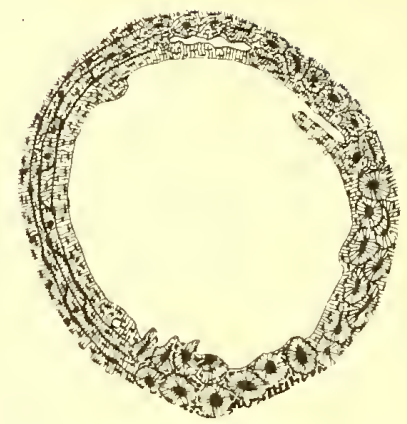

Fig. 357
Iseft femur of Pachacamac Indian of

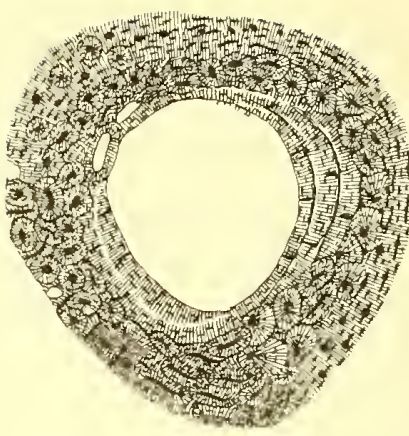

FIG. 360

Right femur of Pachacamac Indian

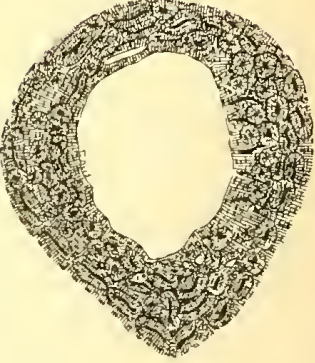

F1G. 361
Left femur of Pachacamac Indian of

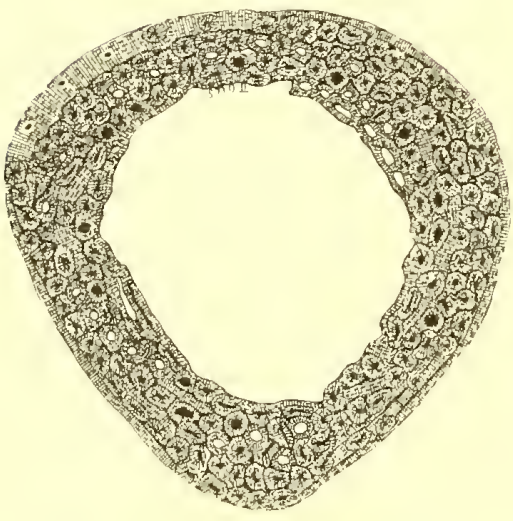

Fig. 362
Right femur of a Japanese male. No. 245 ,
C. M. C.

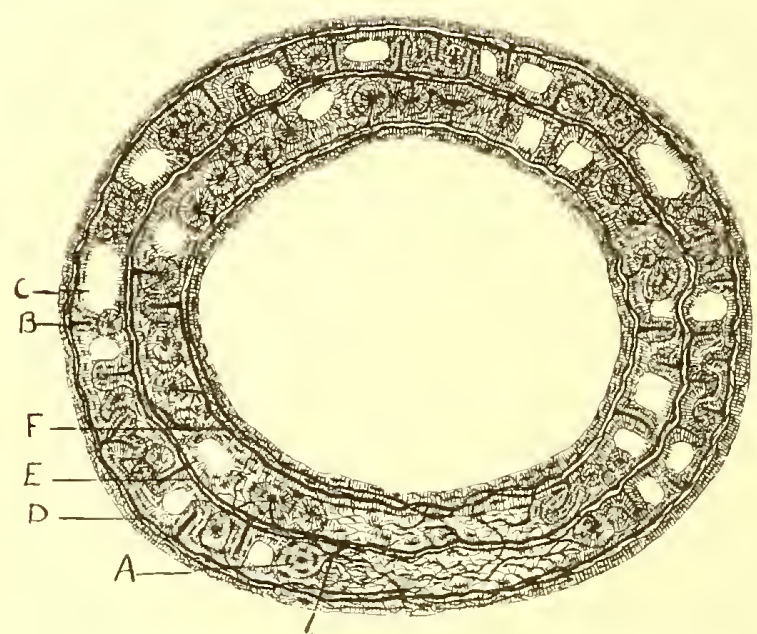

Fig. 363
Femur of Egyptian child of XII Dynasty. No. 256479(de)
U. S. N. M.

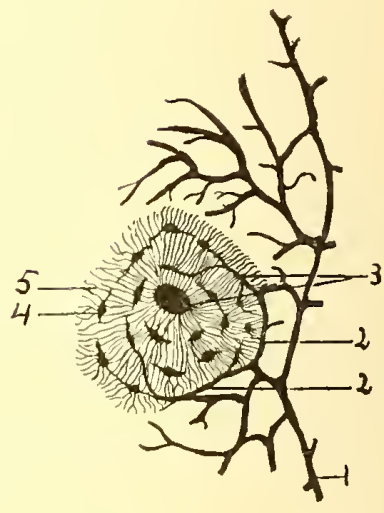

Fia. $363 \mathrm{a}$
Vascular origin of an Haversian
system as seen in Fig. 363 at A

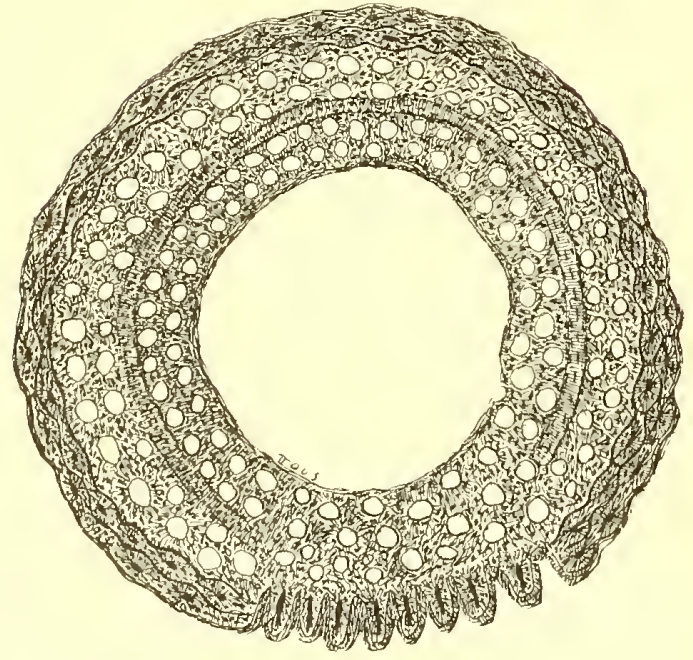

FIG. 364
Femur of Egyptian child of XII

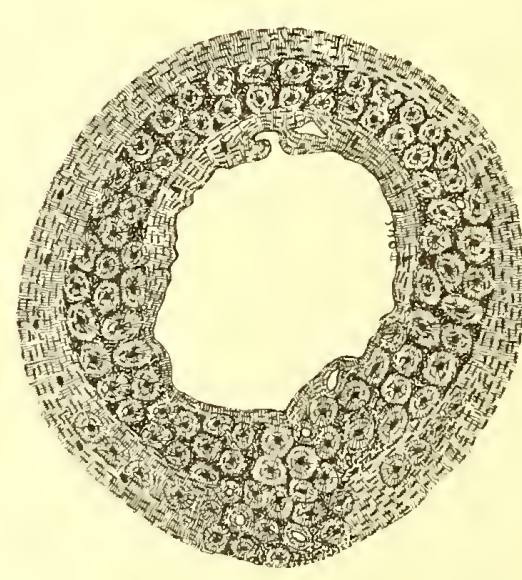

F1G. 365
Right femur of Egyptian clild of XII Dynasty.

No. 256479(a3), U, S. N. M

MIN (PERUVIIN INDIAN AND EGYPTIAN)

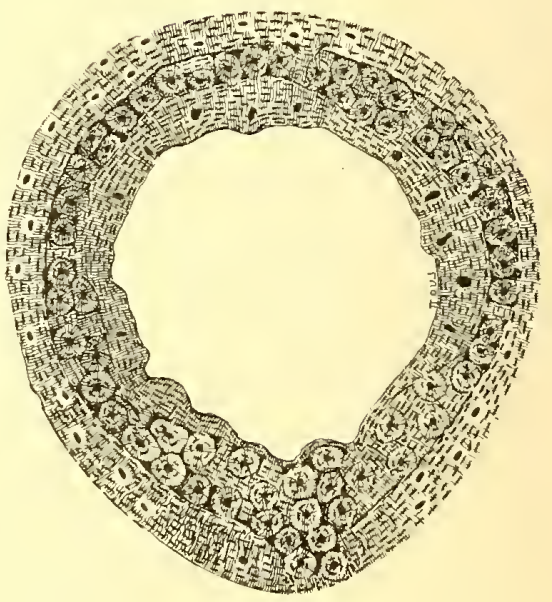

Fia. 366
Femur of Egyptian youth of XII Dynast Egyptian youth of XII
No. 258675 (a) U. S. N. M. 


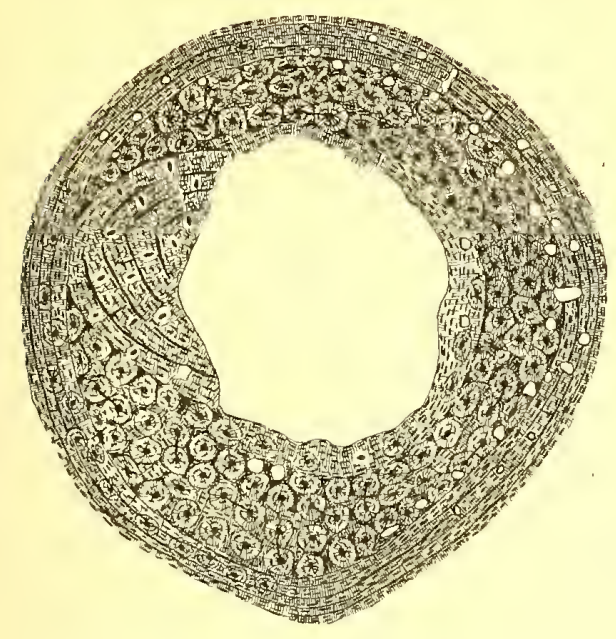

FIG. 367
Right femur of Egyptian adult of XIr Dynasty.

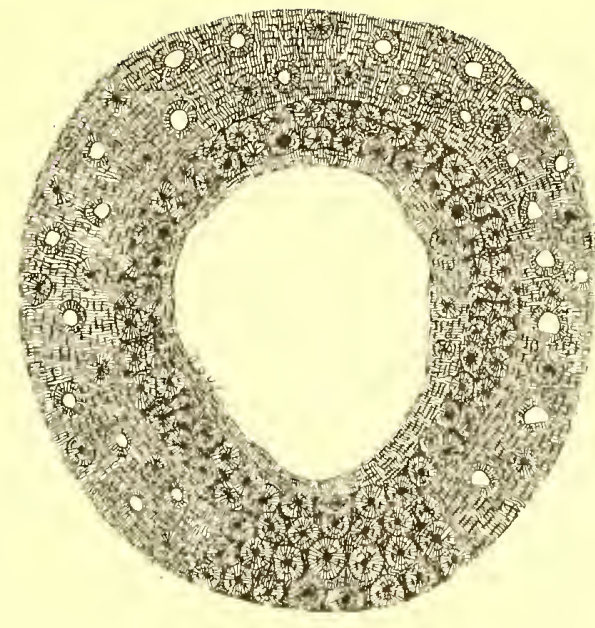

Fia. 368
Left femur of Egyptian adult of XII Dynasty.

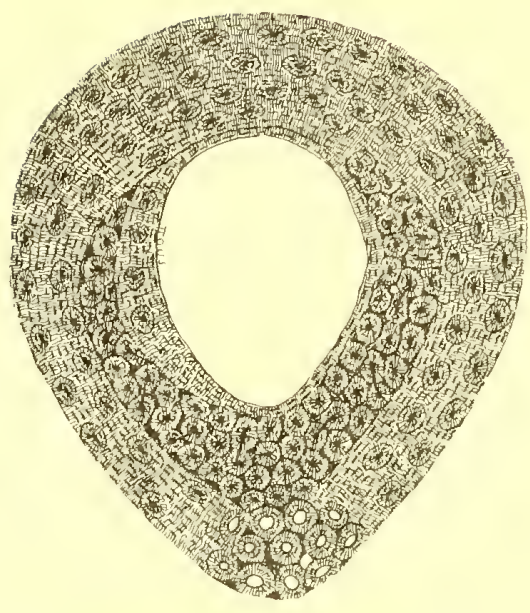
Fic, 369
Right femur of Egyptian adult, XII Dynasty

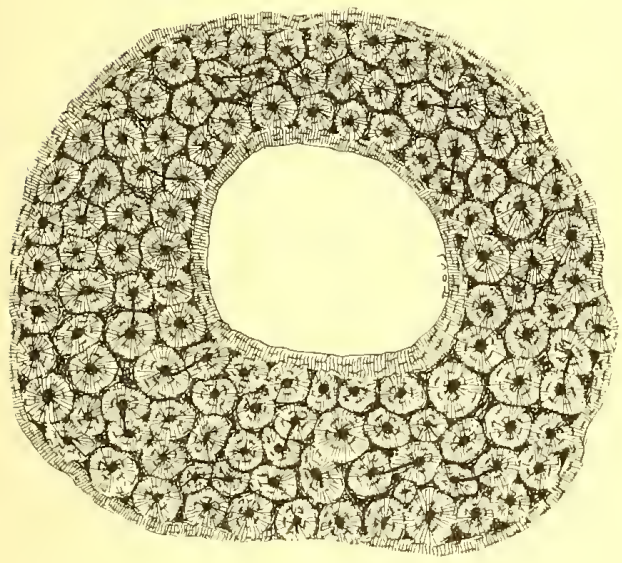

FIG. 370
Femur of Egyptian adult of XII Dynasty
No. $256478(23)$, U. S. N. M.

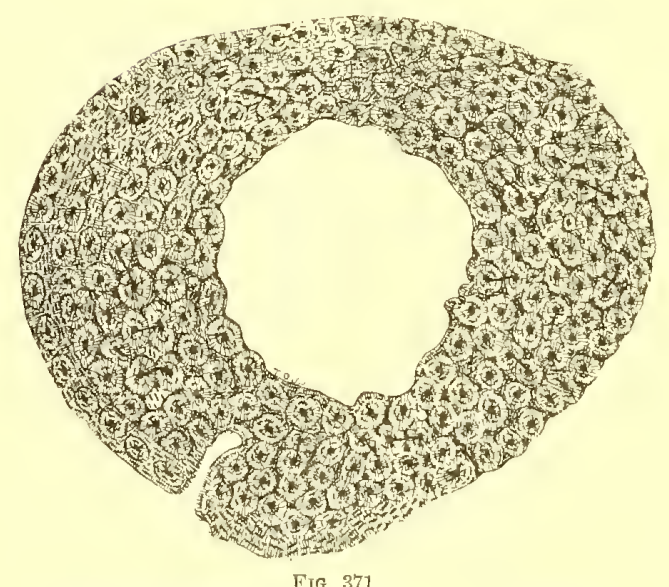

FiG. 371
Right femur of Egyptian adult of XII Dynasty.

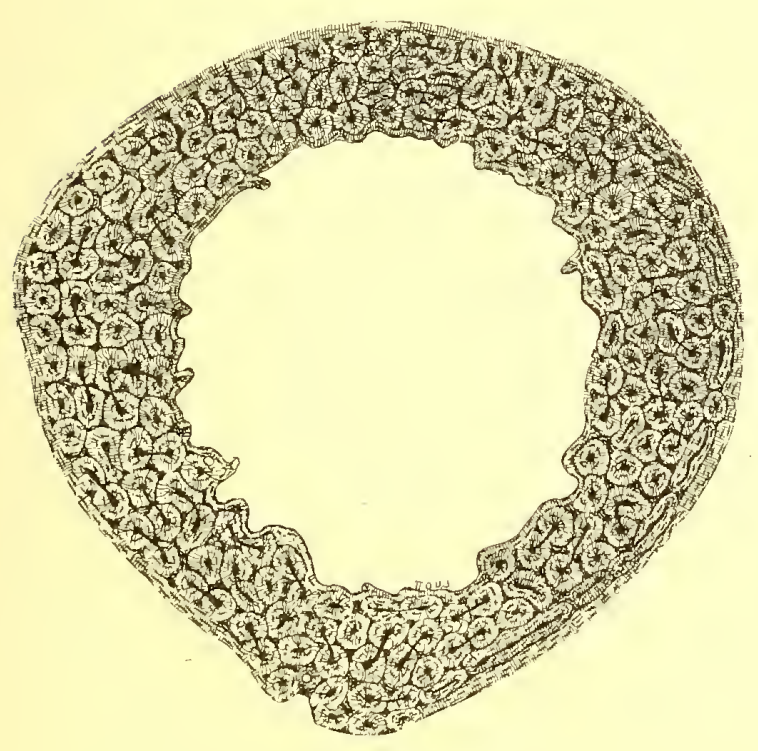

Fia. 372
Femur of a male white. No. 1629, U. S. N. M.

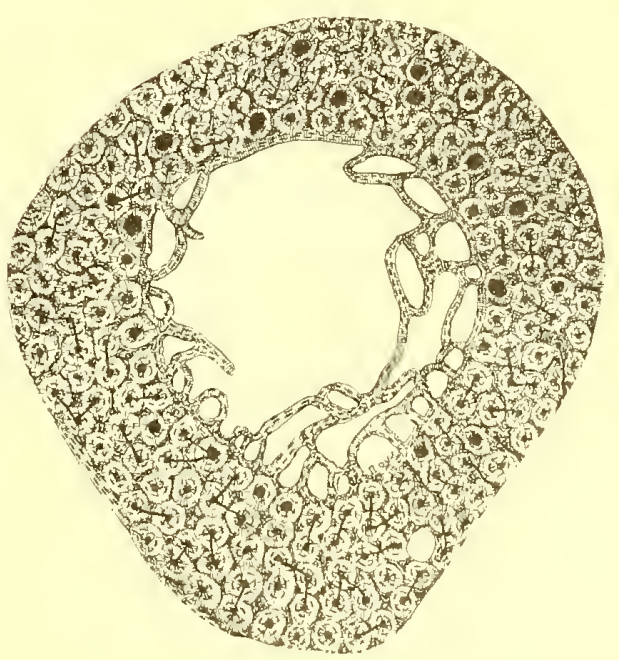

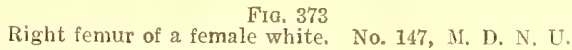




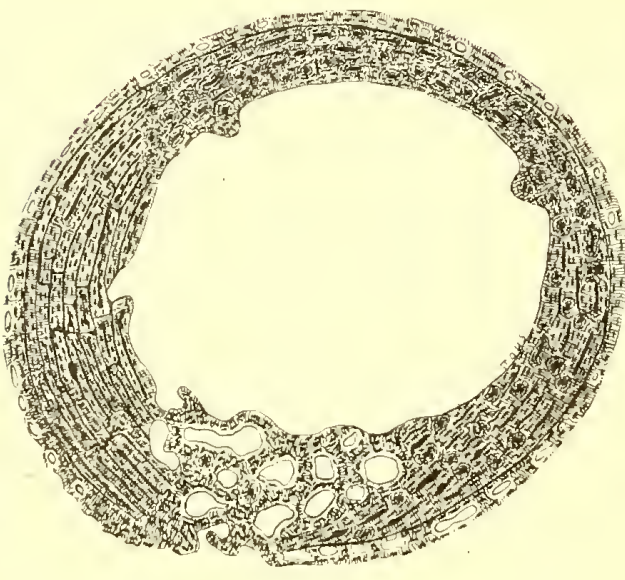

Fia, 374

Right femur of a white child less than one year old No, 249588 , U. S. N. M.

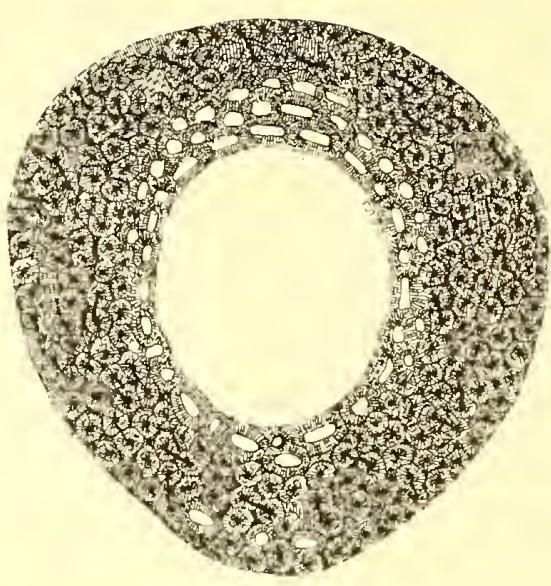

Femur of a male white. 375 No. 53, O. M, C.

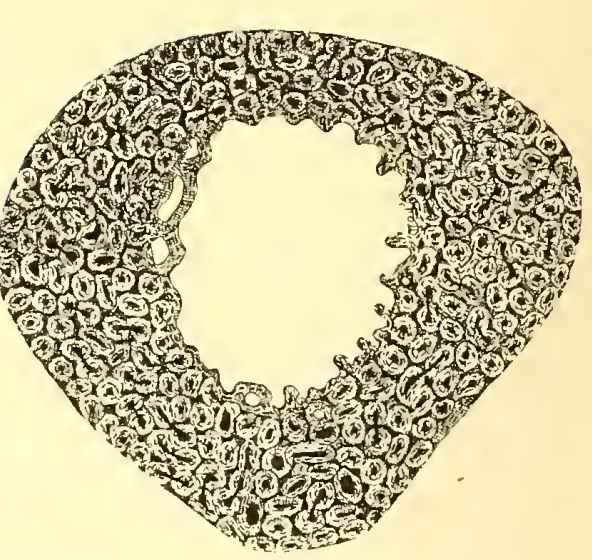

Fig, 376 Night femur of a male white. No, 171, M, D. N. U.

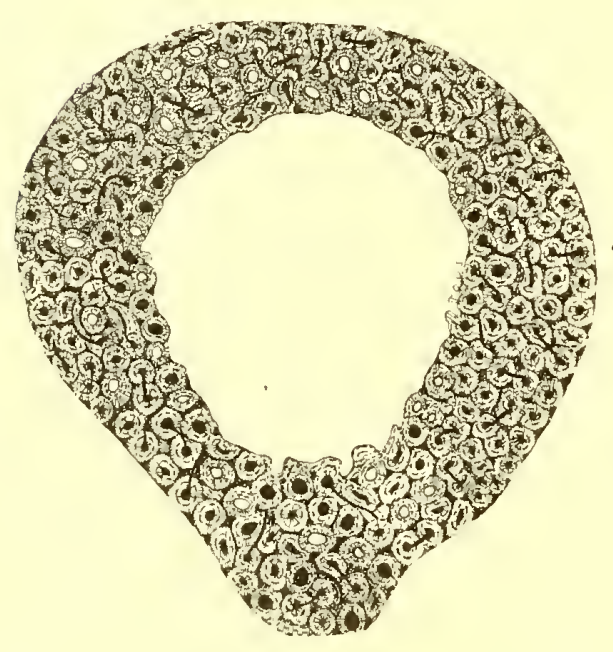

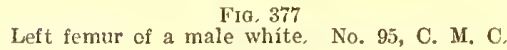

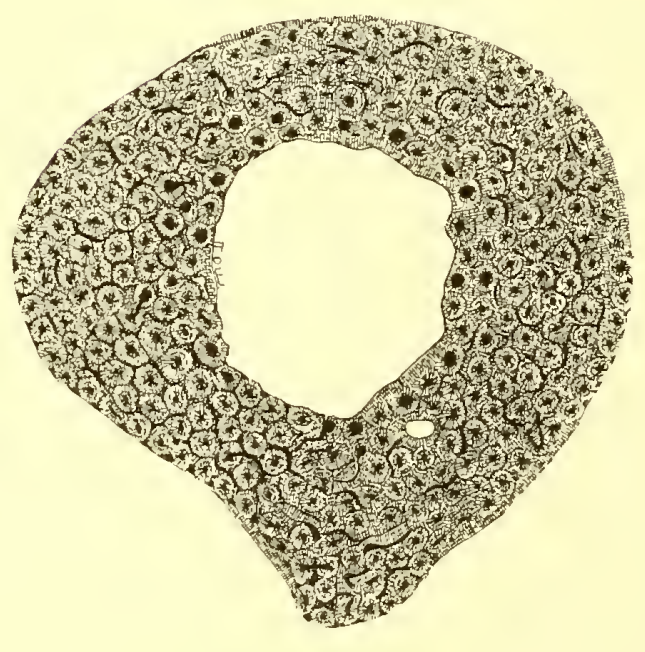

F1G, 378
Left femur of a male white, No, 96, C. M. C,

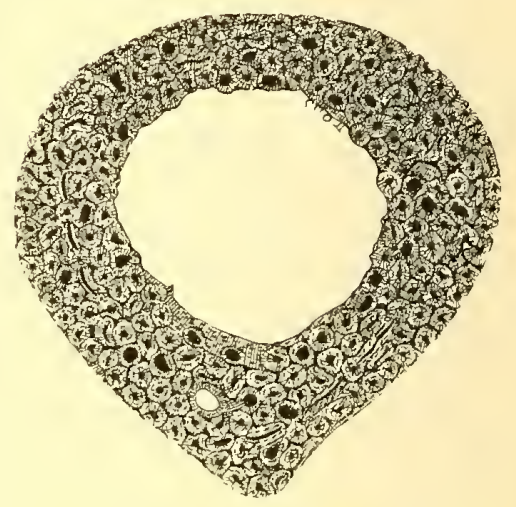

Fig, 379
Left fernur of a male white, age 45. No, 168,
M, D, N, U,

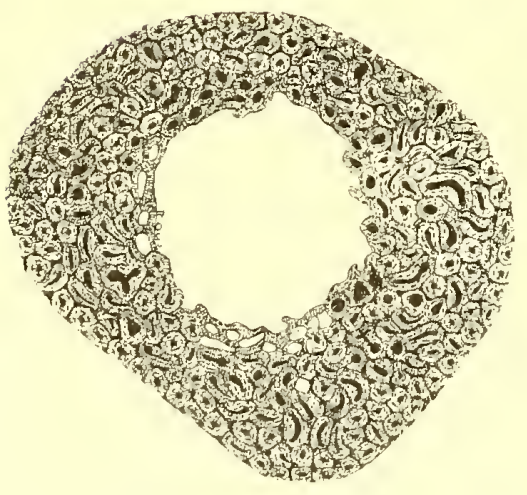

Fig, 380
left femur of a male white, age 50, No, 10 ,
M. D, N, U,

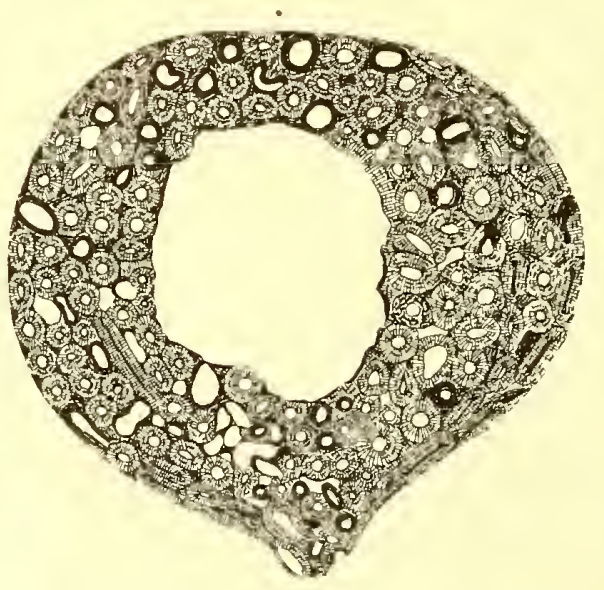

FiG, 381
Femur of a female whíte, age 52, No. 227876,

MAN (WHITE RACE)

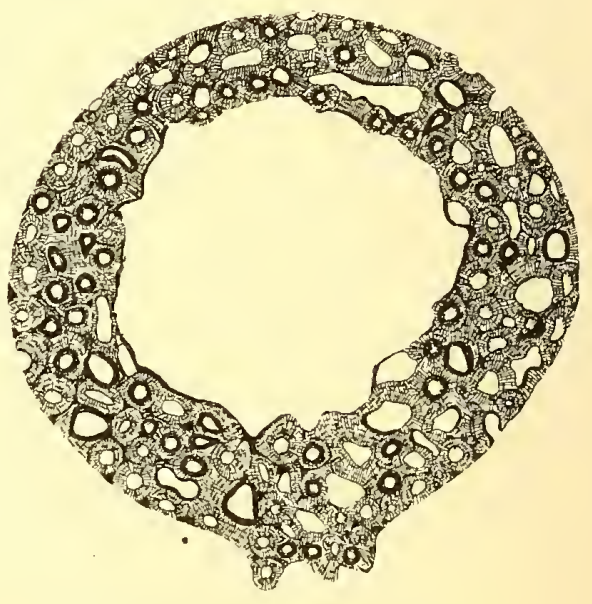

FIG, 382
Femur of a female white, age 60, No. 227880, 

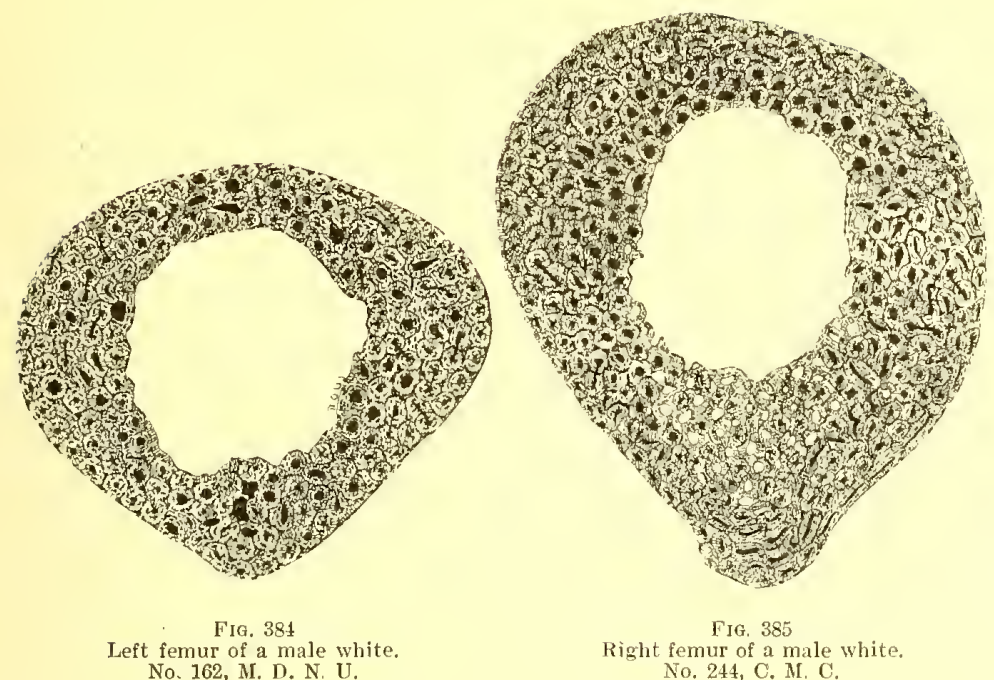

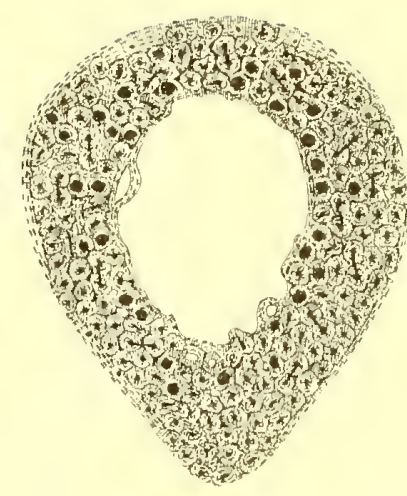

Fifi, 386
Right femur of East Indian male.

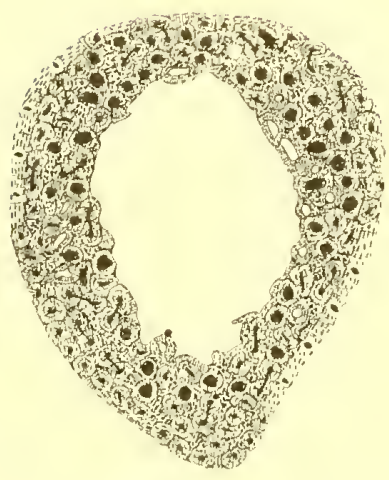

Fig, 387
Left femur of No. 223 C. M. C.

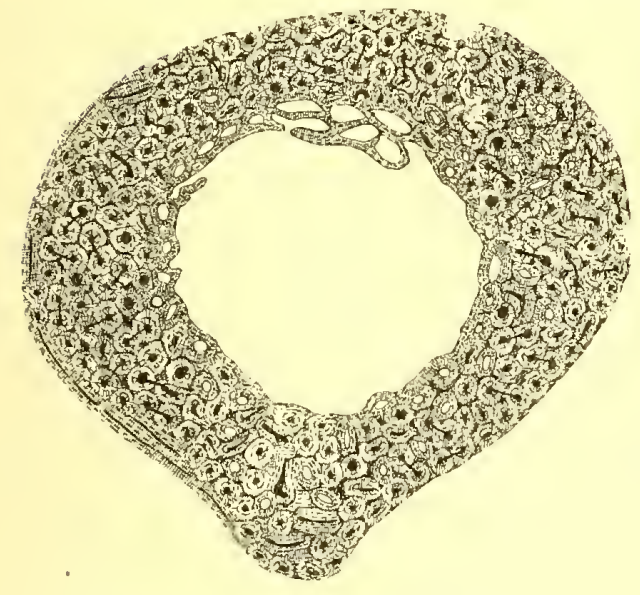

FIG, 388
Right femur of a male white. No. 228479 ,

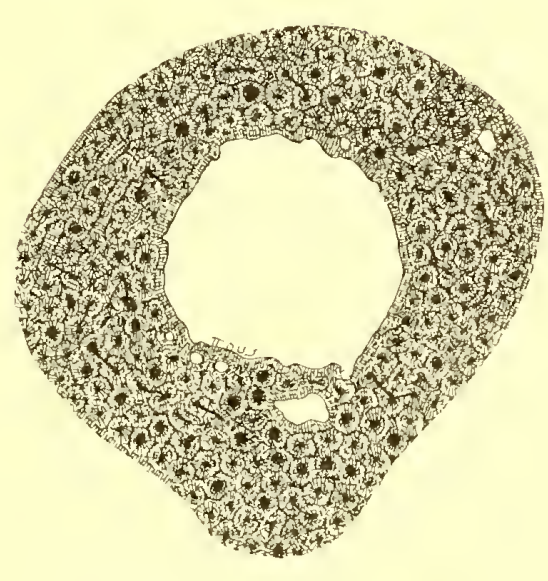

FIG. 389
Right femur of a male white, age 45 . No. 154 ,

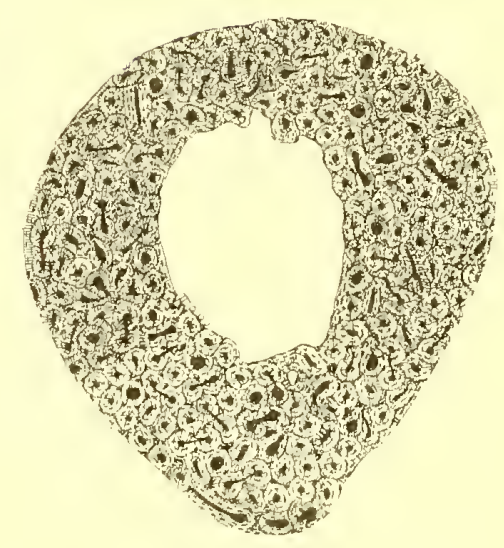

FIG. 390
Left femur of a male white. No. 146,

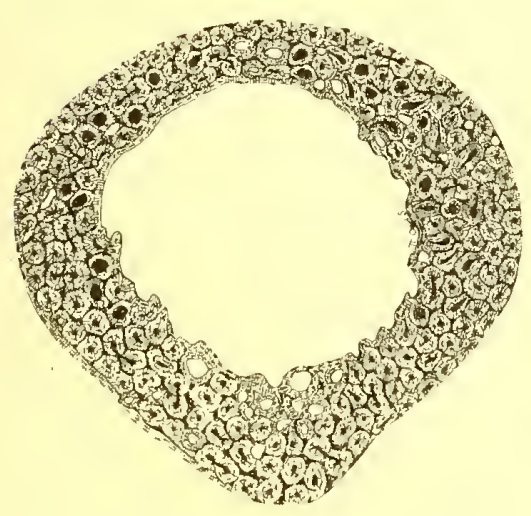

Fro. 391
Left femur of a male whit

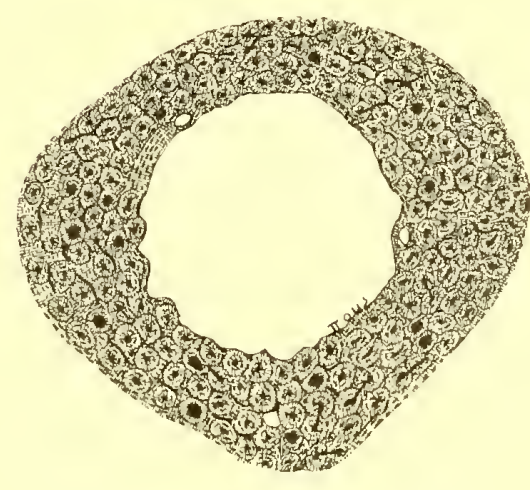

F1G, 392
Right femur of a male white. No. 167,
M. D. N. U.

MAN (WHITE RACE)

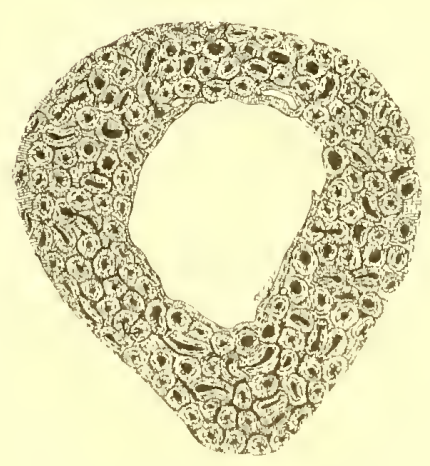

Fri., 393
Right femur of a male white. No. 172,
M. D, N. U. 


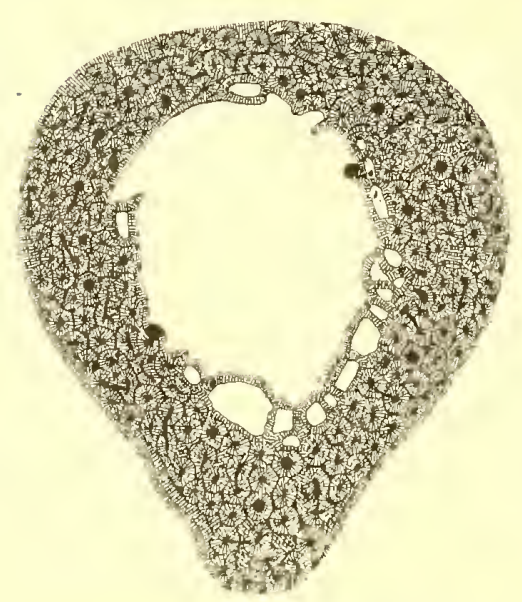

FIG, 394
Right femur of a male white, No. 242 ,
C. M. C.

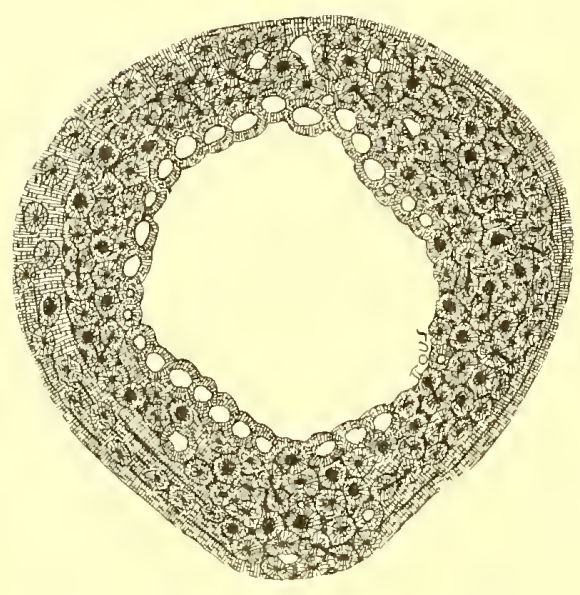

FIG. 397
Right femur of a male white. No. 157,

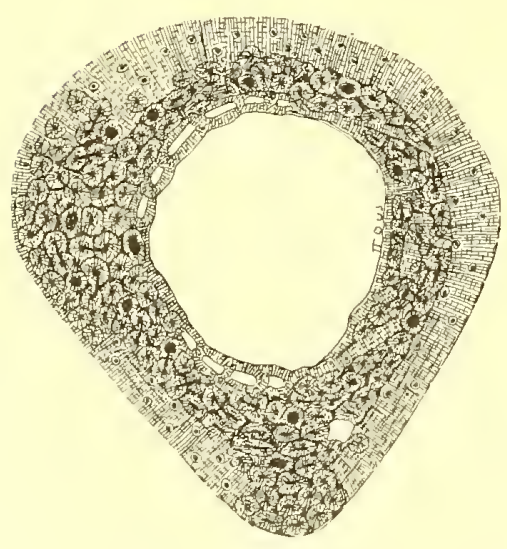

Right femur of male white. No. 243 ,
C. M. C.

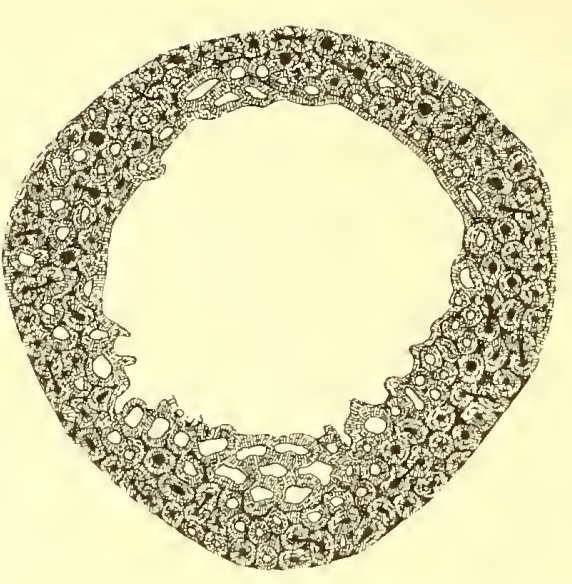

FIG. 395
Right femur of a male white, age 60, No. 145
M. D. N, U.

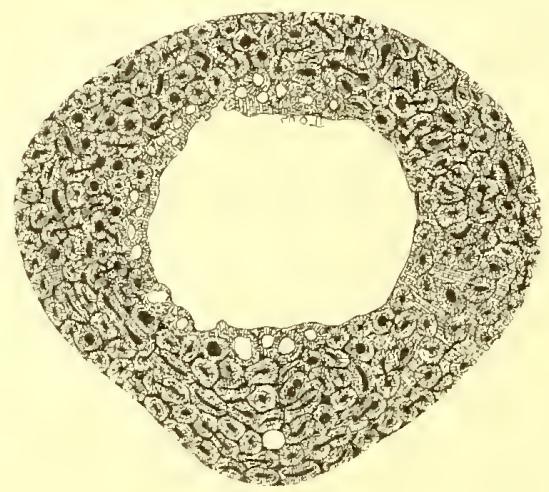

FIG, 398
Left femur of a male white, No. 161,

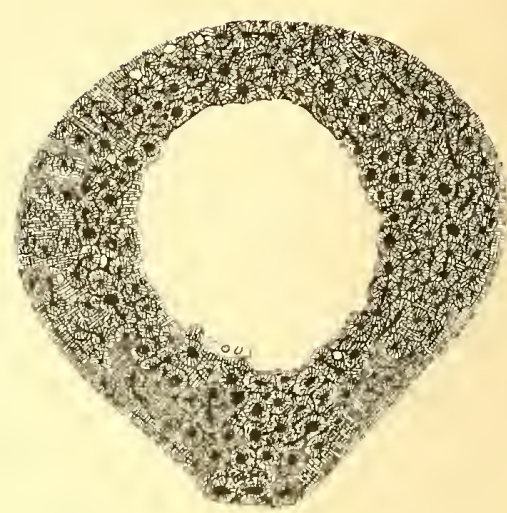

FIG, 396
Left femur of a female white. No, 174,
M. D. N. U.

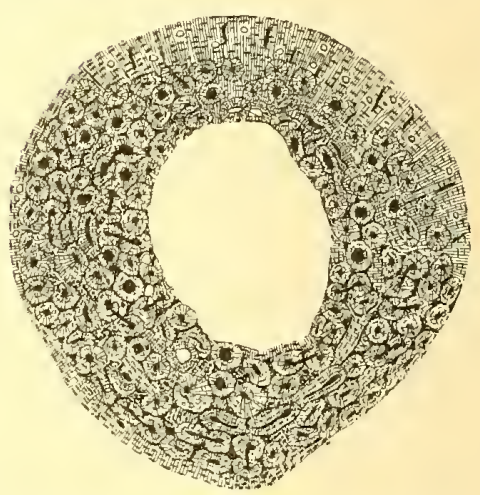

FIG. 399
Right femur of a male white. No. 153,

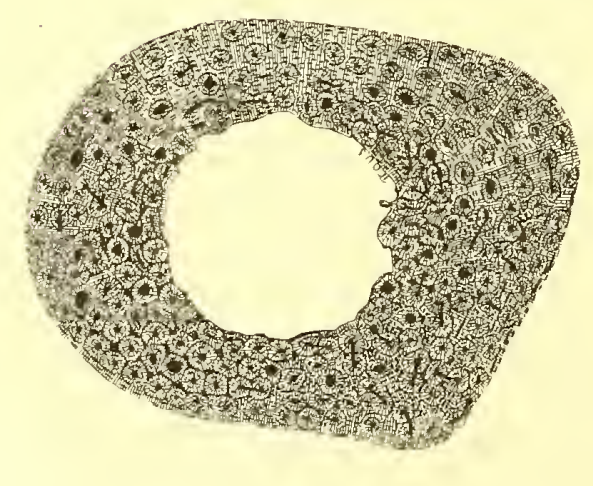

FIG, 401
Left femur of a male white. No. 148,

MAN (WHITE RACE)

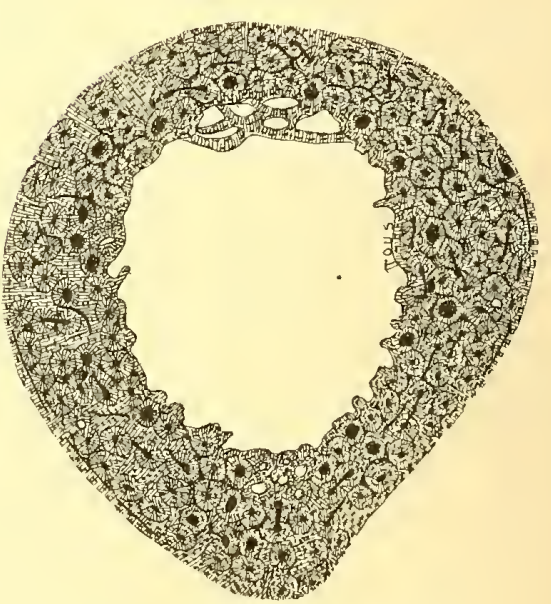

FIG. 402
Left femur of a male whit`. No. 230 , 


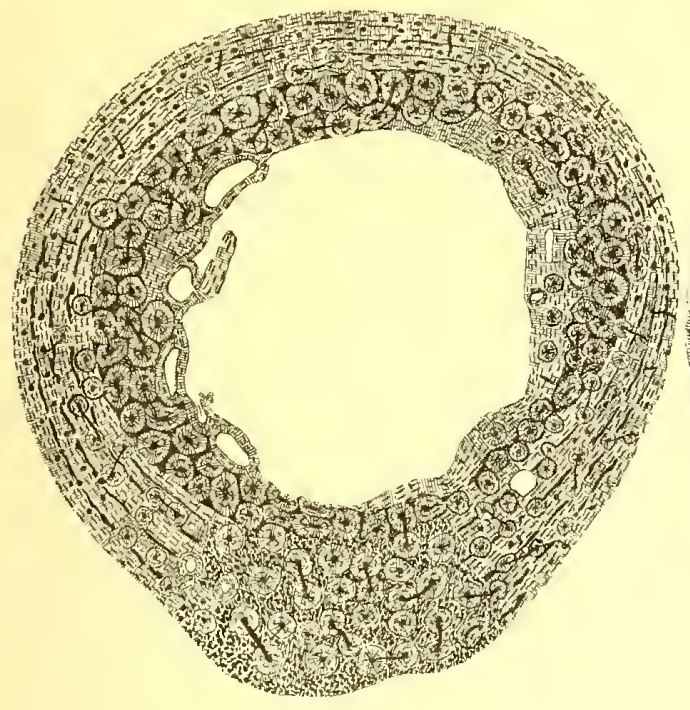

FiG. 403
Left femur of a male white. No. 97, C. M. C.

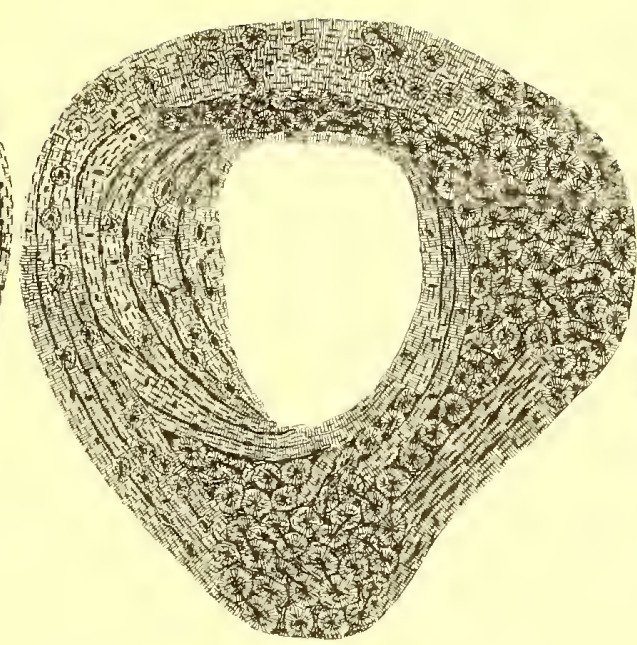

Fig. 404

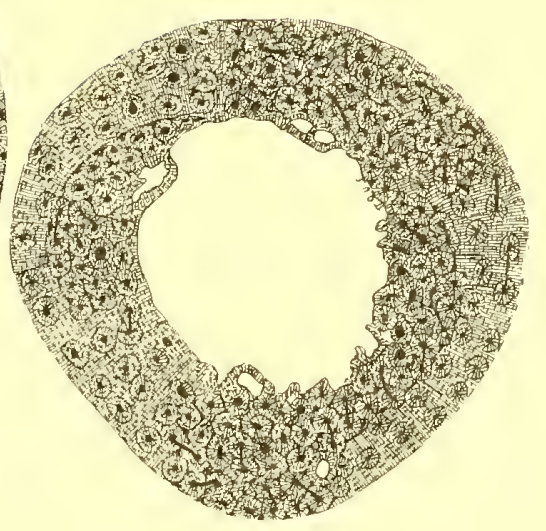

FIG. 405
Right femur of a male white. No. 160,
M. D. N. U.

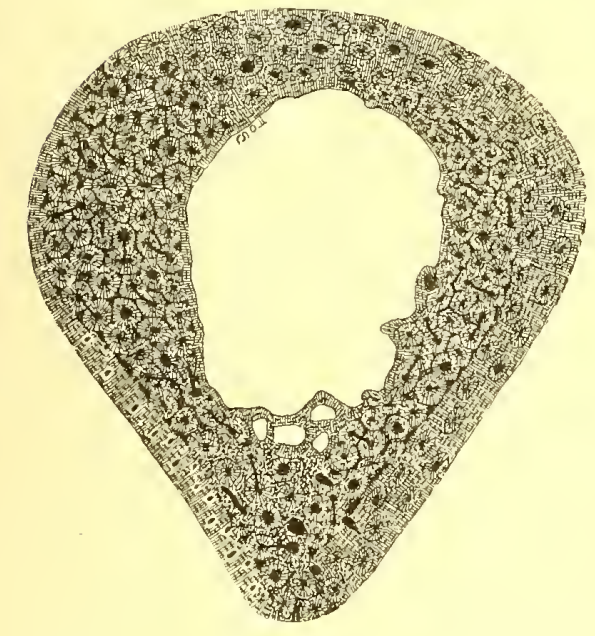

FIG. 406
Left femur of a male white. No. 163, M. D, N. U.

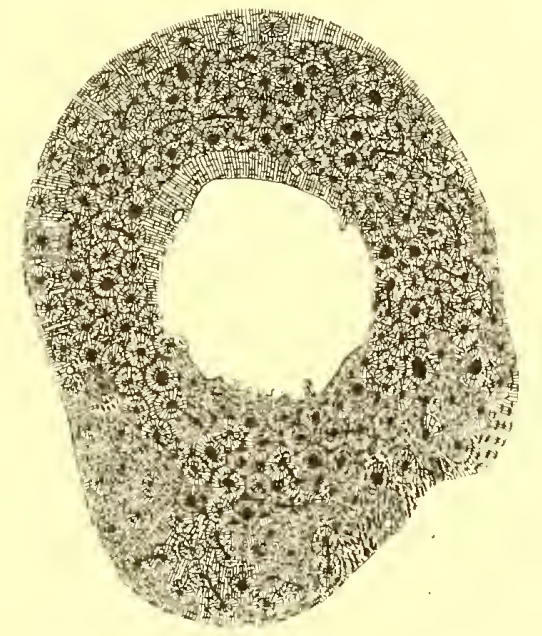

liight femur of a ma. 407

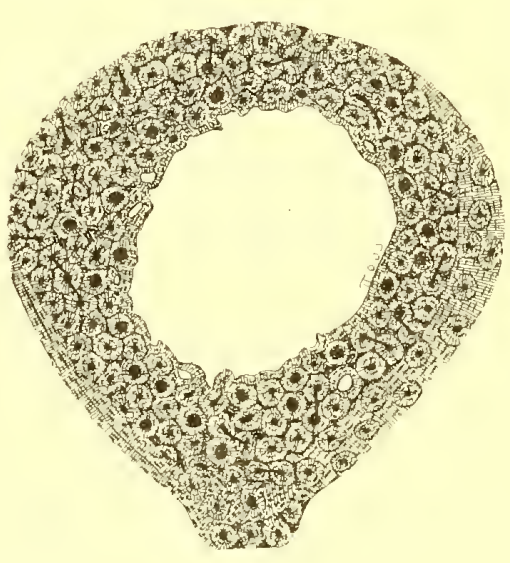

Fyg. 408
Left femur of a male white No. 169,
M. D. N. U.

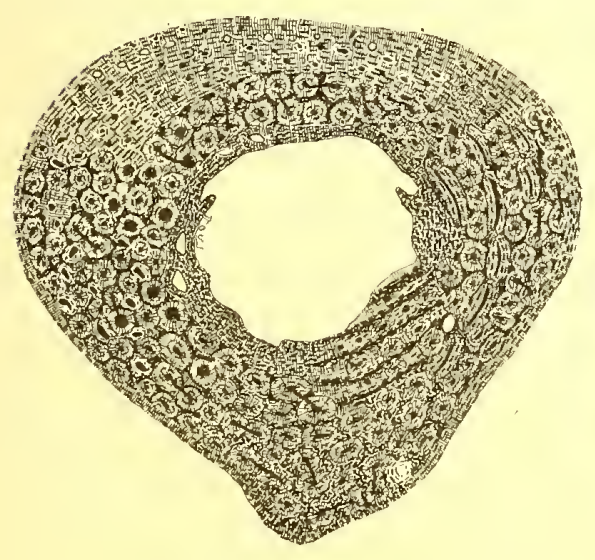

Fir. 409
Right femur of a male white, age 35 . No. 151,
M. D. N. U.

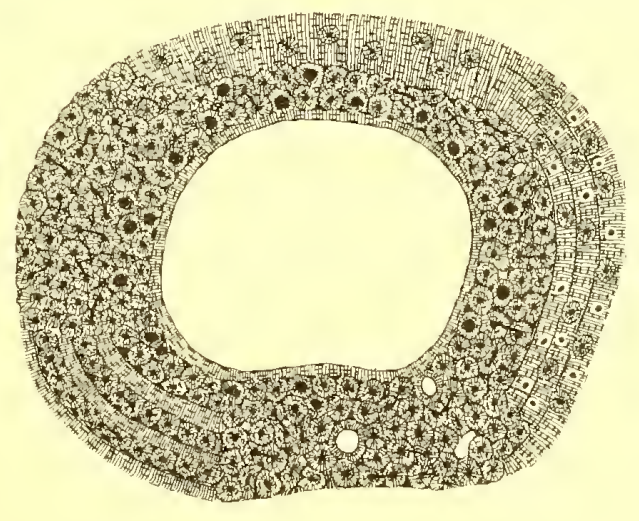

Fig, 410
Left femur of a male white. No. 100, C. M. C. MAN (WHITE RACE)

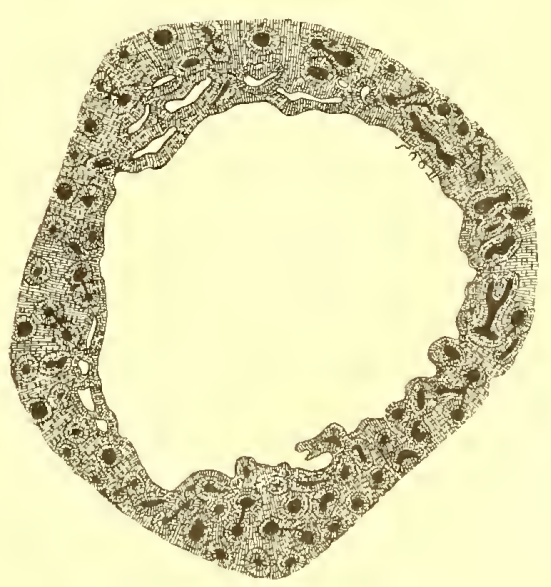

Fig. 411
Right femur of a female white. No, 150 

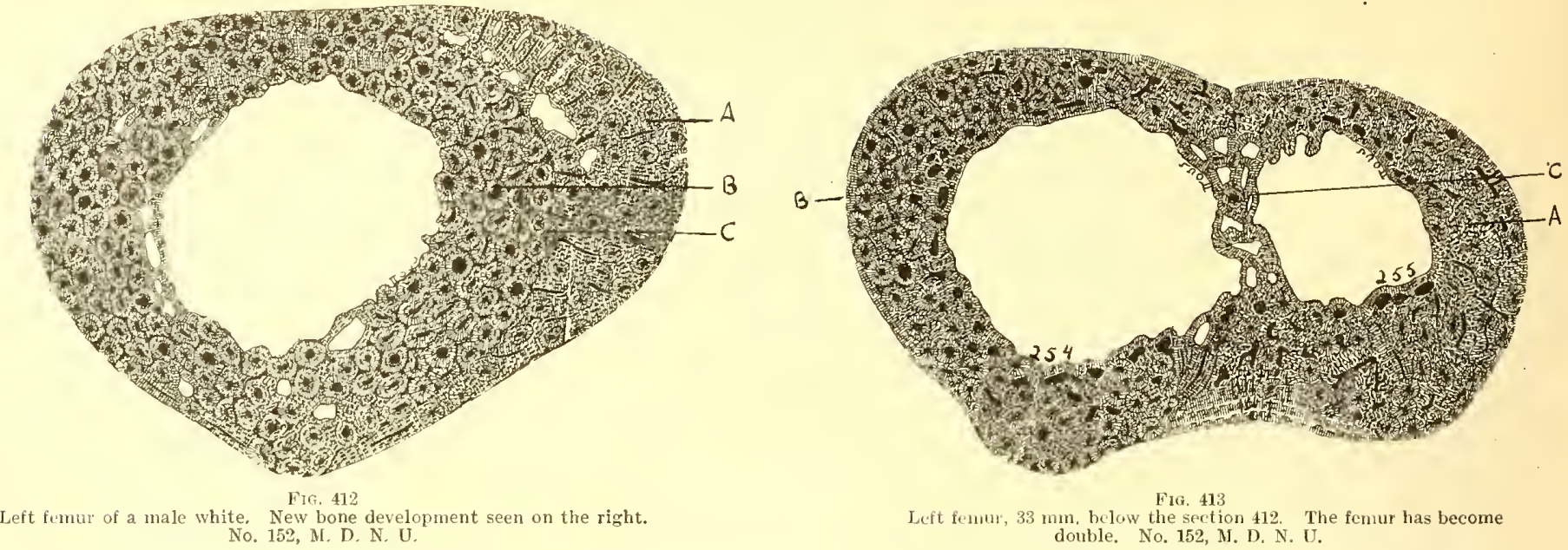
No. 152, M. D. N. U

Fig. 413
Left fenur, 33 min, helow the section 412 . The femur has become
double. No. 152, M. D. N. U.
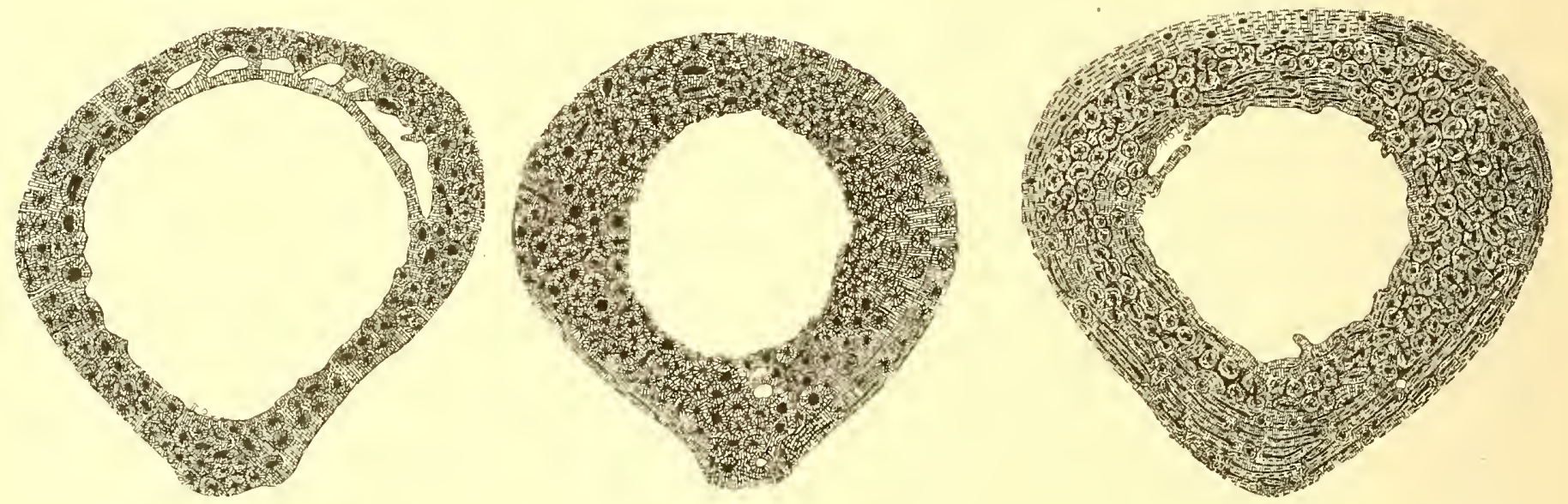

Left femur of a female white. No. 164, M. D. N. U. FIG. 415 22 (suicide). No. 175

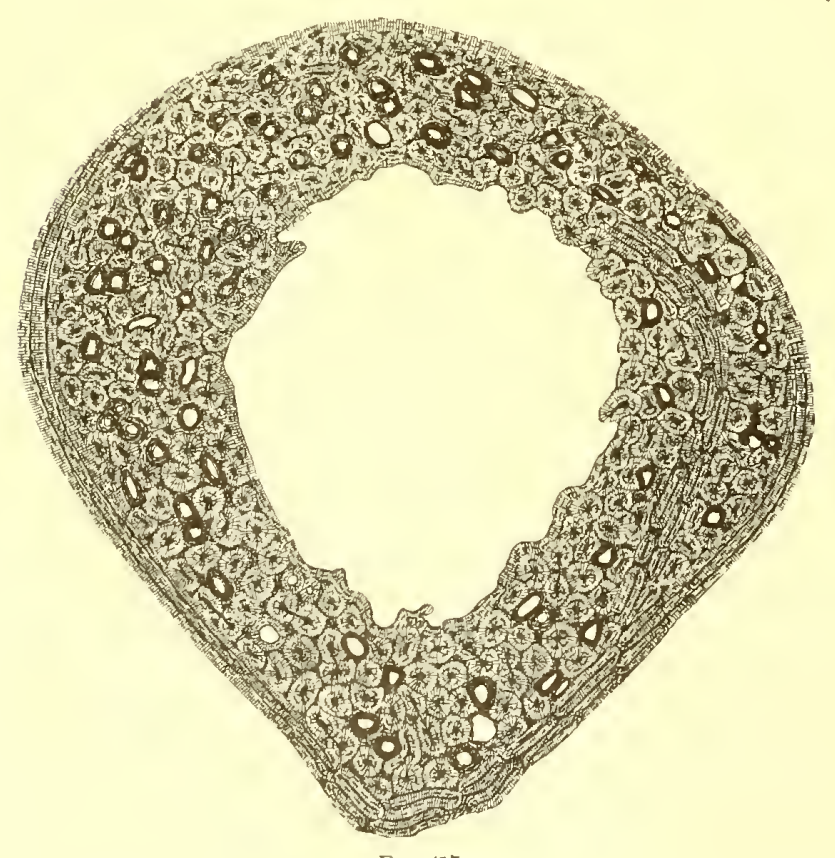

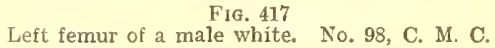

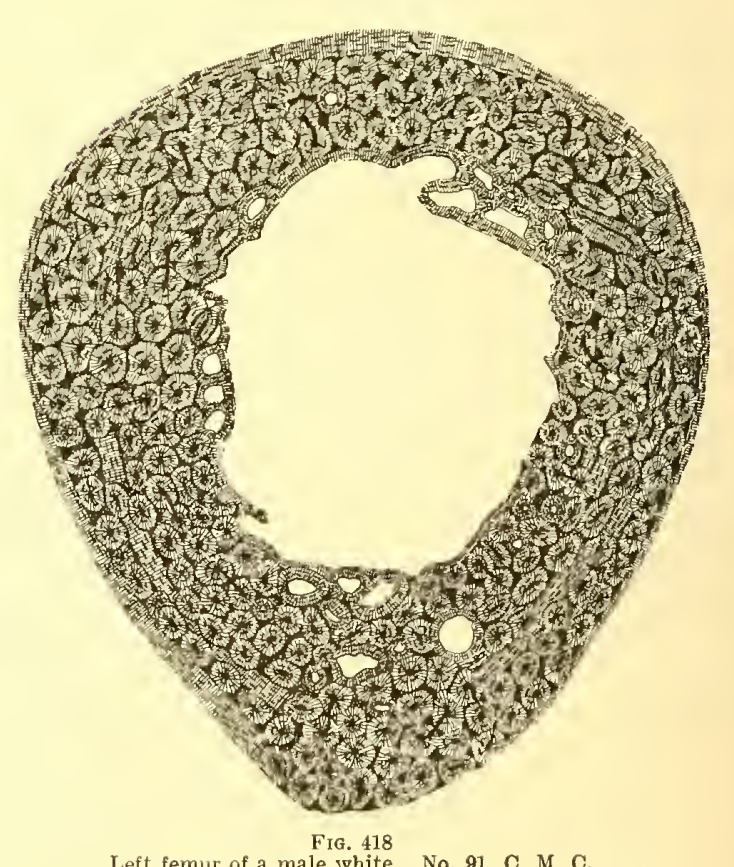

Fig. 418
Left femur of a male 1 vhite. No. 91, C. M. C. 


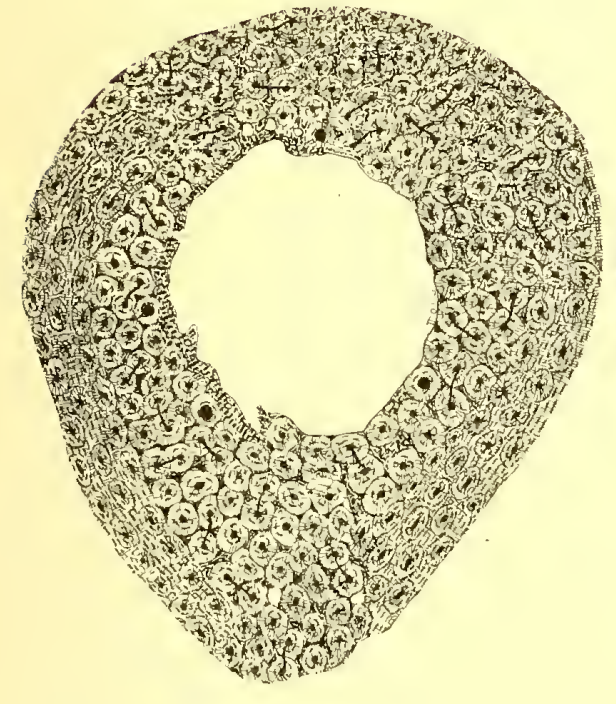

Fic. 419
Femur of an Australian.

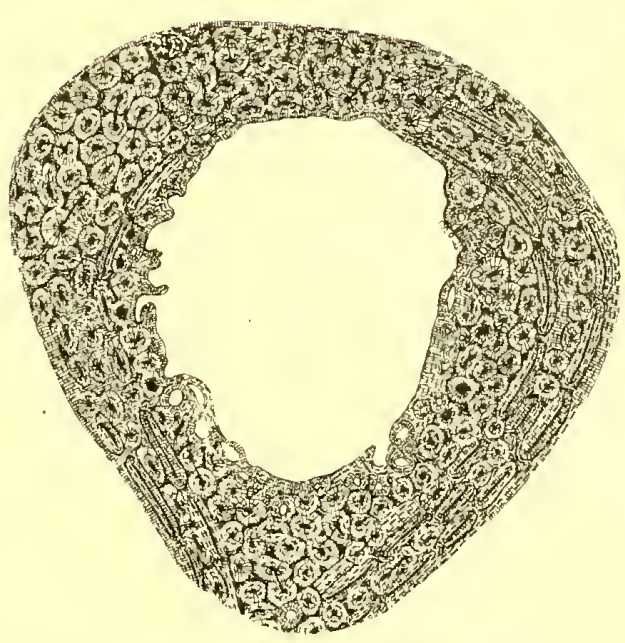

Fig. 420
Left femur of a male white. No. 94, C. M. C.

MAN (AUSTRAIIIN; WIITE RACE)

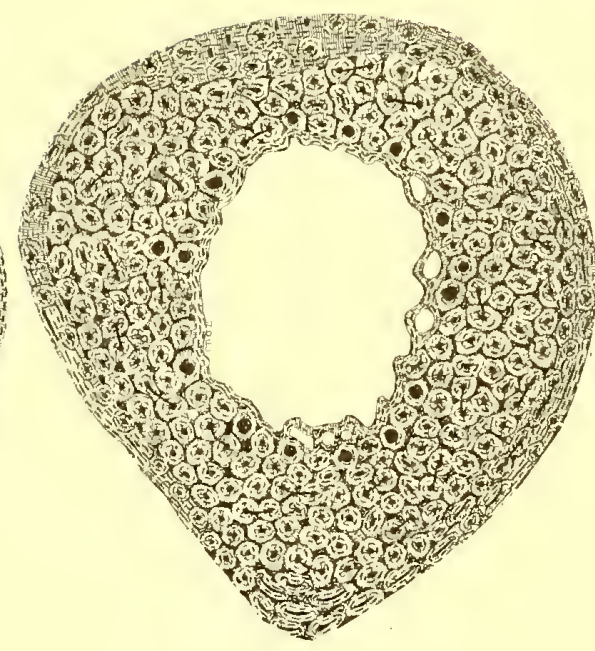

Fig. 421
Right femur of a male white, No. 142, M. D. N. IT.

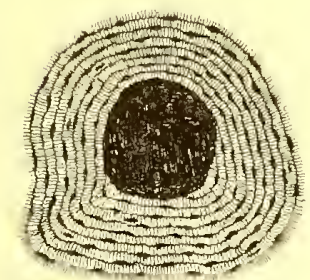

Fig. 423
A single Haversian system
cnlarged showing lamellæ

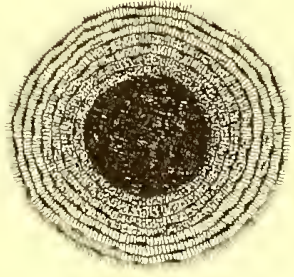
Fig, 424
Ilaversian system showing
early stage of senility

DIAFRAMS SHOWING STAGES OF SENHLTTY

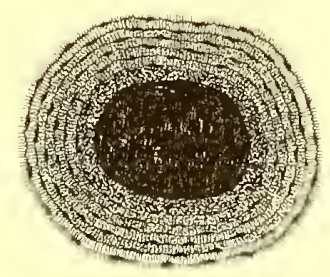
F1G, 425
Haversian system showing
later stage of senility

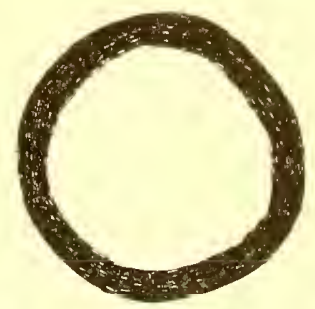

F16. 426

Haversian system showing latest stage of senility 


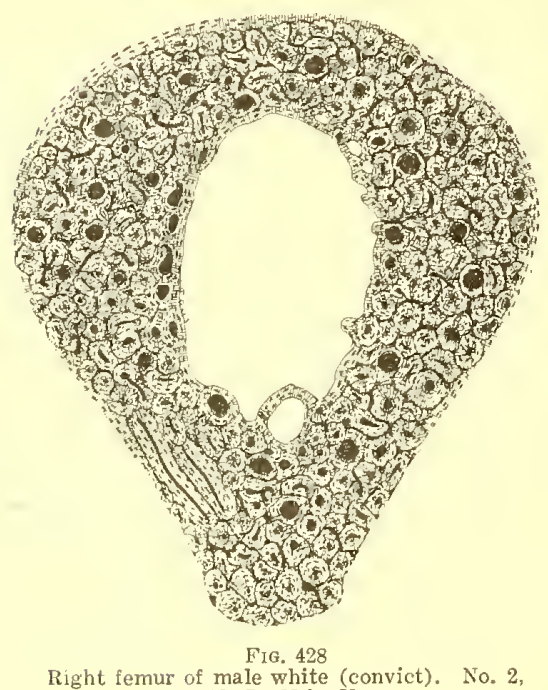

Right femur of male white (co
M. D. Neb. U.

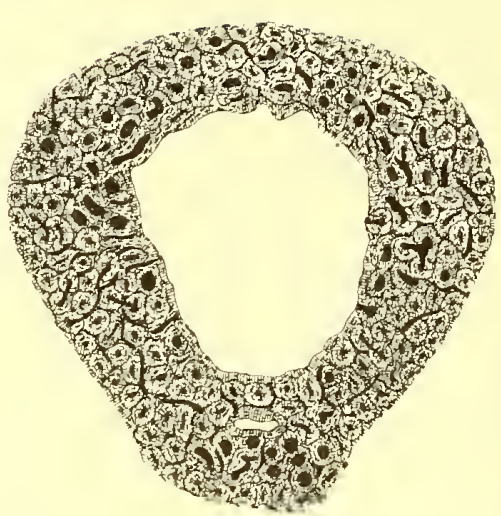

FiG. 429
Right femur of a male white (convict). No. 3,

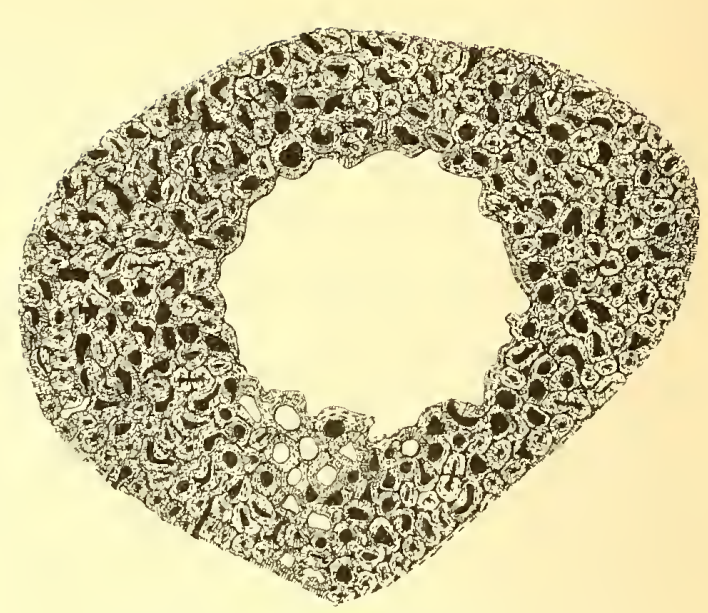

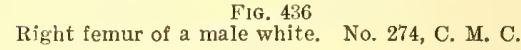

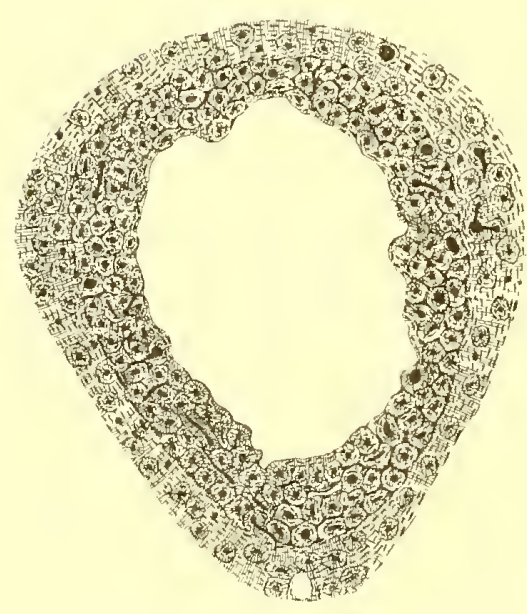

Fig. 437
Right femur of a male white. No. 275, a male whic.

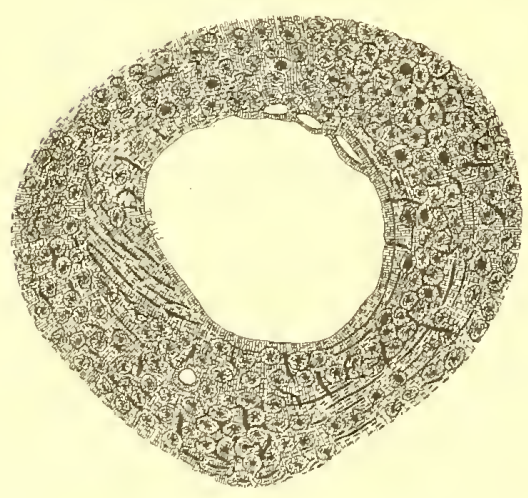

FIG. 451
Right femur of a male white. No. 289,

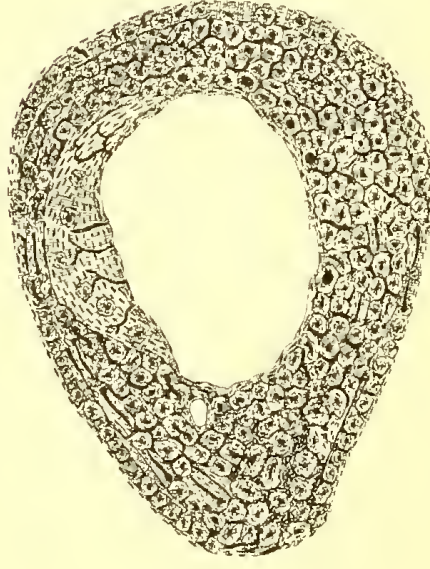

Fig. 439
Right femur of a male whitc. No. 277 ,

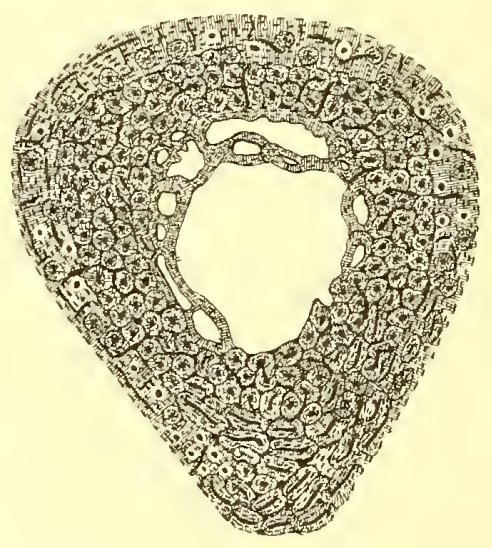

FIG. 452
Left femur of a male white. No. 296,
C. M. C. MAN (WHITE RACE)

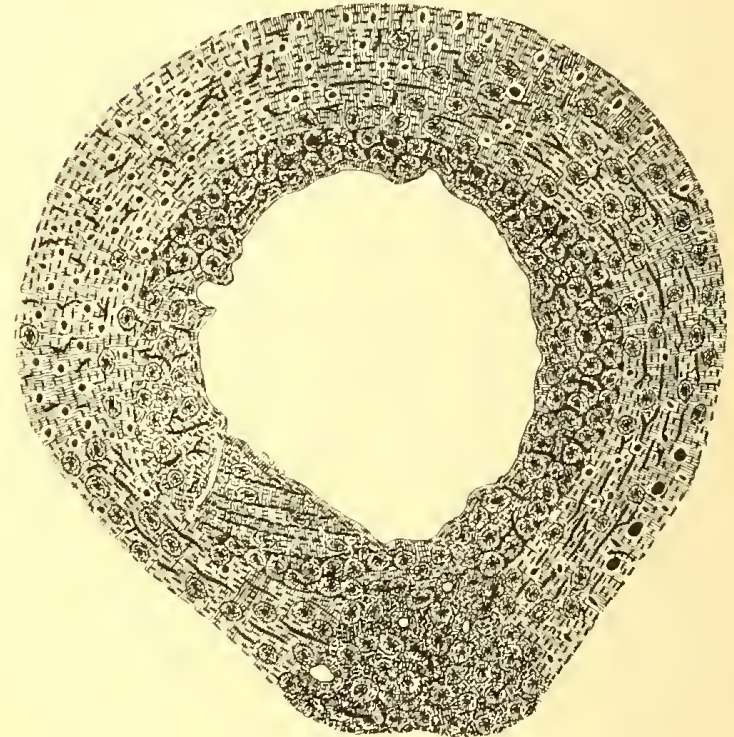

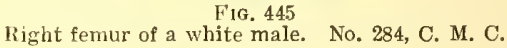

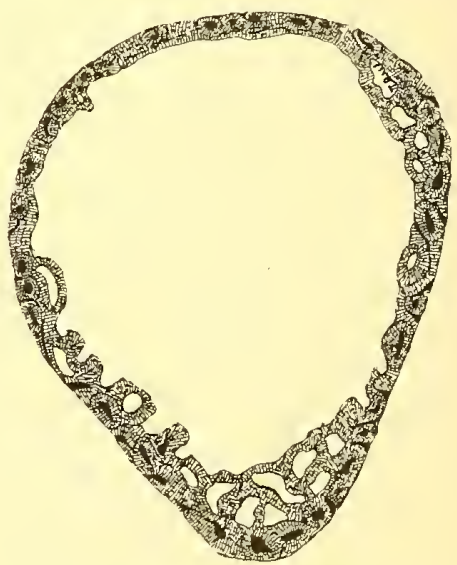

Fig. 453
Left femur of a male white, age 40 (case of diopathic epilepsy).
No. 1 , N. S. H. 




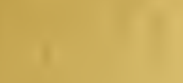

-

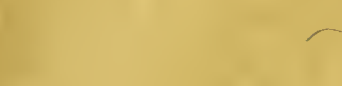

I

I

$=1$

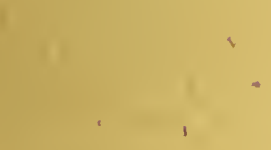

a. -

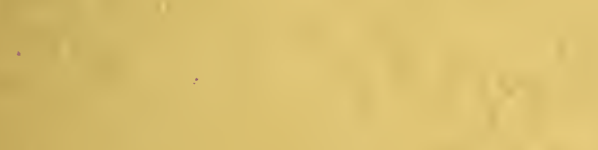





SMITHSONIAN INSTITUTION LIRRARIES

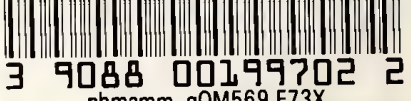
nhmamm gOM569.F73X
. 